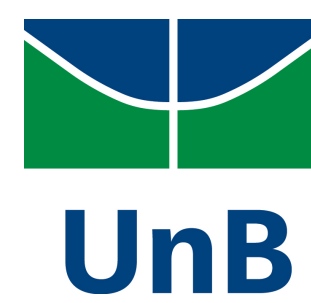

UNIVERSIDADE DE BRASÍLIA

FACULDADE DE COMUNICAÇÃO

PROGRAMA DE PÓS-GRADUAÇÃO EM COMUNICAÇÃO

MAURO GIUNTINI

\title{
A NARRATIVA CINEMATOGRÁFICA DE ALEJANDRO GONZÁLEZ IÑÁRRITU
}





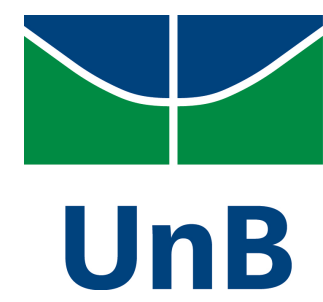

UNIVERSIDADE DE BRASÍLIA

FACULDADE DE COMUNICAÇÃO

PROGRAMA DE PÓS-GRADUAÇÃO EM COMUNICAÇÃO

MAURO GIUNTINI

\section{A NARRATIVA CINEMATOGRÁFICA DE ALEJANDRO GONZÁLEZ IÑÁRRITU}

Tese apresentada ao Programa de Pós-Graduação em Comunicação da Universidade de Brasília (UnB) como requisito parcial para a obtenção do Título de Doutor em Comunicação.

Orientadora: Profa. Dra. Susana Madeira Dobal Jordan 
Ficha catalográfica elaborada pela Biblioteca Central da Universidade de Brasília. Acervo 1020591.

\footnotetext{
G537n A narrativa cinematográfica de Alejandro González Iñárritu / Mauro Giuntini. - - 2015.

$313 \mathrm{f}$. : il. ; $30 \mathrm{~cm}$.

Tese (doutorado) - Universidade de Brasília, Faculdade de Comunicação, Programa de Pós-Graduação em Comunicação, 2015.

Inclui bibliografia.

Orientação: Susana Dobal.

1. González Iñárritu, Alejandro. 2. Cinema - México. I. Dobal, Susana. II. Título.
}

CDU 791.43 


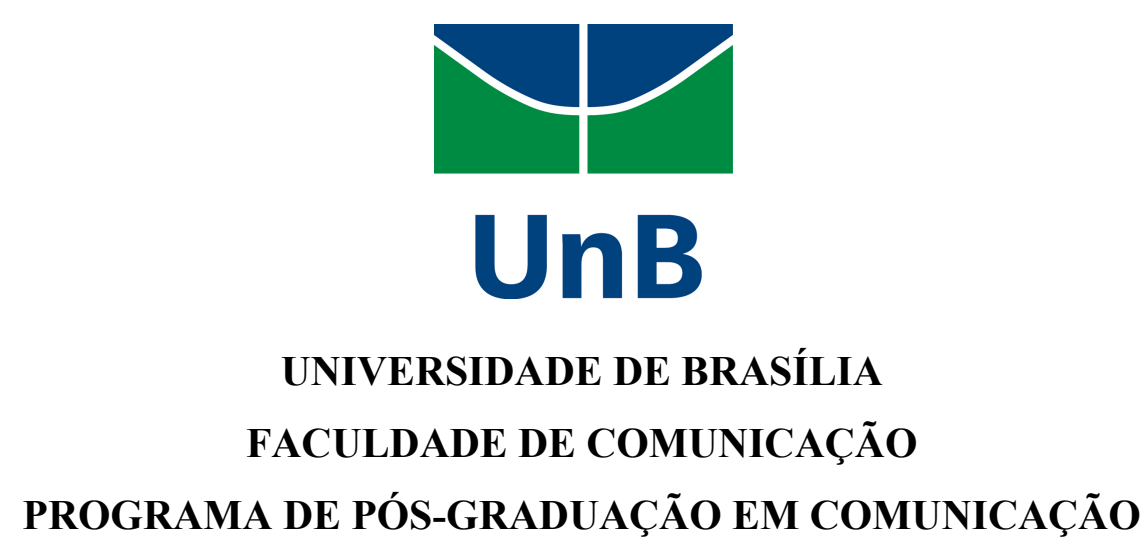

Diretor da Faculdade de Comunicação

Prof. Dr. David Renault

Coordenadora do Programa de Pós-Graduação

Profa. Dra. Taís de Mendonça Jorge 



\title{
BANCA EXAMINADORA
}

\author{
PRESIDENTE DA BANCA
}

Profa. Dra. Susana Madeira Dobal Jordan

Professora Adjunta do Departamento de Audiovisuais e Publicidade Faculdade de Comunicação da Universidade de Brasília - FAC - UnB

\section{TITULARES}

\section{Prof. Dr. João Luis Vieira}

Professor Titular do Departamento de Cinema e Vídeo

Universidade Federal Fluminense - UFF

\section{Prof. Dr. André Luís Gomes}

Professor Adjunto do Departamento de Teoria Literária e Literaturas (TEL) Instituto de Letras da Universidade de Brasília - UnB

\section{Prof. Dr. Sérgio de Sá}

Professor Adjunto do Departamento de Jornalismo Faculdade de Comunicação da Universidade de Brasília - FAC - UnB

\section{Prof. Dr. Paulo Paniago}

Professor Adjunto do Departamento de Jornalismo Faculdade de Comunicação da Universidade de Brasília - FAC - UnB 
SUPLENTE

Profa. Dra. Roberta Kumasaka Matsumoto

Professora Adjunta do Departamento de Artes Cênicas, Instituto de Artes da Universidade de Brasília - IDA-UnB 
Para Lu, Bubu e Dodi, luzes do meu céu. 



\section{AGRADECIMENTOS}

Agradeço:

À minha mulher Luciana Teixeira e aos meus filhos Bruno Giuntini e Diogo Giuntini pelo apoio incondicional.

À minha mãe Therezinha Giuntini por todo o amor e me ter iniciado nas artes.

Ao meu pai Mauro Viana por ter me ensinado a importância do prazer e da liberdade na vida.

À profa. Susana Madeira Dobal Jordan pela paciência, dedicação e rigor crítico na orientação desta investigação.

Aos professores João Luiz Vieira, André Luis Gomes, Paulo Paniago e Sérgio de Sá pelas generosas contribuições à pesquisa aportadas na banca de defesa da tese.

Aos professores Suzete Venturelli e Armando Bulção pelas relevantes contribuições oferecidas durante qualificação da tese.

À prof. Tânia Montoro pela postura de guardiã de limiar e estímulo à superação. dessa jornada.

Ao prof. Gustavo de Castro pelos ensinamentos e ajuda no momento mais escuro

Ao prof. Luis Gonzaga Motta pela indicação de vias férteis para se estudar a narrativa.

Ao mestre e cineasta Vladimir Carvalho pela generosidade das incessantes lições a cada encontro.

Ao prof. Geraldo Moraes pela confiança ao proporcionar minha entrada no meio audiovisual.

Aos meus professores da graduação do Curso de Comunicação Social da UnB pelos primeiros incentivos e votos de confiança, em especial Sérgio Dayrell Porto, Luis Humberto e Célia Ladeira.

À profa. Denise Moraes pela cumplicidade na troca de confidências acadêmicas.

Aos meus colegas do Curso de Comunicação Organizacional da UnB pelo incentivo, especialmente aos professores Liziane Guazina, Tiago Quiroga, Fernanda Martinelli, Ellis Regina, Gabriela Freitas e Samuel Lima.

Aos meus amigos do Curso de Comunicação da Universidade Católica de Brasília pela oportunidade de participar na construção de ambiente acadêmico especial, principalmente aos professores André Luis Carvalho, Ivany Câmara Neiva, Ana Lúcia Galuff, 
João Curvello, Ellen Geraldes, Asdrubal Formiga, Janara Lopes, Duda Bentes e Milton Cabral (in memorian).

Ao prof. Antônio Teixeira pelo exemplo de excelência na pesquisa científica.

À todos os alunos que tive nesses quase 17 anos de docência na Universidade Católica de Brasília e na Universidade de Brasília.

À todos os técnicos e atores com os quais realizei audiovisuais desde 1989.

Aos meus amigos da época da graduação na UnB pela companhia instigante no período no qual me encantei pela comunicação e o audiovisual na gloriosa década de 80 , especialmente Mário Salimon, Dulcídio Siqueira, Cesar Mendes, Fernando Molina, Katia Donida, João Carlos Teixeira, Eliana Carneiro, Andrea Boni e Isabella Lara.

Ao assistente de pesquisa Henrique Laterza pela ajuda providencial na análise sequencial dos filmes e captura de frames para ilustração da tese.

Aos meus irmãos Marcos, Adriana e Maria Teresa por todas as vivências lúdicas e afetivas partilhadas.

À minha belle mère Lúcia Teixeira pelas lições de praticidade.

À profa. Lavina Ribeiro pelas orientações iniciais e por ter acreditado no impulso original desta pesquisa.

À profa. Roberta Kumasaka Matsumoto pela cordialidade na suplência na banca de defesa da tese.

À Maria del Pilar Acosta, pelo esmero na revisão e diagramação. 
"Uma parte de mim é todo mundo

Outra parte é ninguém, fundo sem fundo

Uma parte de mim é multidão

Outra parte estranheza e solidão

Uma parte de mim pesa, pondera Outra parte delira

Uma parte de mim almoça e janta

Outra parte se espanta

Uma parte de mim é permanente

Outra parte se sabe de repente

Uma parte de mim é só vertigem

Outra parte linguagem

Traduzir uma parte na outra parte Que é uma questão de vida e morte Será arte?"

Ferreira Gullar 



\section{RESUMO}

Partindo do princípio que a evolução da narrativa cinematográfica é decorrente de uma transação ininterrupta entre tradição e inovação, a tese propõe o exame da combinação entre duas estratégias que se destacam na renovação do cinema ficcional hegemônico contemporâneo: ordenação temporal não-linear e multiplicidade de narrações - multitramas e multiprotagonismo. Para tanto, foi utilizado método analítico baseado em concepções cognitivistas neoformalistas, principalmente as propostas por David Bordwell, complementado por valiosos aportes de críticos da cultura, tais como: Gilles Lipovetsky, Octavio Paz e Néstor Canclini. Constatou-se que o emprego das estratégias de construção cinematográfica visa incutir na narrativa aspectos de multiplicidade e complexidade presentes na sociedade atual. A escolha do corpus da pesquisa recai sobre a obra do mexicano radicado nos Estados Unidos, Alejandro González Iñárritu, tanto pelas suas características estéticas quanto pelas temáticas abordadas em sua filmografia. Seus quatro primeiros filmes - Amores brutos (Amores perros, 2000), 21 gramas (21 grams, 2003), Babel (2006) e Biutiful (2010) - apresentam uma composição singular de manipulações formais das instâncias do tempo e da narração, assim como também tratam dos principais temas da globalização na atualidade: movimentos populacionais, multiculturalismo, desterritorialização, presença da mídia e da tecnociência no cotidiano. Embora tenha realizado filmes de ampla circulação mundial, tanto em festivais como no circuito comercial, produzidos em diversos países e em associação com empresas midiáticas transnacionais, o diretor foi capaz de manter sua independência autoral e a unidade artística da sua filmografia. Ao tratar de temas banalizados no cinema mainstream, como relações familiares, sexo e violência, oferecendo, porém, uma peculiar abordagem humanista marcada por seu imaginário cultural original, a cinematografia de Iñárritu destaca-se no panorama mundial ao expor contrastes e conflitos universais de um planeta caótico interligado por fluxos de informações e pessoas. Solidão, amor, morte e o impacto do acaso no destino são os temas proeminentes nos filmes estudados e são abordados por um viés que demonstra a influência da identidade cultural mexicana na obra de Iñárritu. As análises fílmicas revelam que o alto grau de ambiguidade e contradição das personagens em seus arcos de transformação imersos em situações críticas e, por vezes, trágicas, exercem tanta influência no desenrolar das tramas como as manipulações temporais e a multiplicidade de narrações. $\mathrm{O}$ exame minucioso das narrativas em questão aponta para a busca de uma harmonia entre forma e conteúdo, na qual questões políticas e sociais cruciais dos dias de hoje são tratadas com densidade sem, contudo, menosprezar a necessidade de encontrar maneiras criativas de contar histórias que despertem e renovem o engajamento do espectador durante a fruição do filme.

Palavras-chave: Narrativa fílmica. Cinema contemporâneo. Globalização. Iñárritu. 



\begin{abstract}
Assuming that the evolution of narrative film is the result of a continuous transaction between tradition and innovation, the thesis proposes the study of the combination of two strategies that stand out in the renewal of contemporary hegemonic fiction cinema: non-linear temporal ordering and multiplicity of narrations - multiplot and multiprotagonism. The use of these strategies aims to instill in the narrative aspects of multiplicity and complexity present in today's society. The choice of the research corpus lies on the work of Mexican settled in the United States, Alejandro González Iñárritu, both for its aesthetic characteristics, as well as the issues addressed in his filmography. The first films of the director - Love's a bitch (Amores perros, 2000), 21 grams (2003), Babel (2006) and Biutiful (2010) - hold together the alignment of formal manipulations of the instances of time and narration, as well as they address key issues of globalization nowadays: population movements, multiculturalism, deterritorialization, and media and techno-science presence in everyday life. Although had made films of broad circulation, at festivals and commercial circuit, produced in various countries and in association with transnational media companies, the director was able to maintain independence and the authorial artistic unity of his filmography. Despite dealing with banal themes of the mainstream cinema, such as family relationships, sex and violence, offering, however, a peculiar humanistic approach noticeable by its original cultural imaginary, the films of Iñárritu stands out exposing universal contrasts and conflicts of a chaotic world interconnected by information and people flows. Loneliness, love, death and the impact of the chance on the destiny are the prominent themes in the studied films and are covered by a bias that demonstrates the influence of Mexican cultural identity in the work of Iñárritu. The film analysis reveals that the high degree of ambiguity and contradiction of the characters in its transformation arches immersed in critical situations, and sometimes tragic, wield so much influence on the conduction of the plots as the time manipulations and the multiplicity of narrations do. Analysis of the narratives in question indicates the search for harmony between form and content, in which currently important political and social issues are treated with density, but without underestimating the need to search for creative ways to tell stories that renew and awaken the viewer's engagement during the fruition of the film. Therefore, it is used analytical method based on neoformalist cognitive conceptions, especially those proposed by David Bordwell, complemented by valuable contributions of culture critics, such as Gilles Lipovetsky, Octavio Paz and Néstor Canclini.
\end{abstract}

Key words: Film narrative. Contemporary cinema. Globalization. Iñárritu. 



\section{SUMÁRIO}

INTRODUÇÃO - IÑÁRRITU E A RENOVAÇÃO DO CINEMA

CAPÍTULO I - ABORdagem da NARRATIVA DE IÑARRITU

1.1 O NARRATIVO E O CINEMATOGRÁFICO 30

1.2 COGNITIVISMO, NARRATIVA E MONTAGEM 35

1.3 DO SIMPLES AO COMPLEXO E A INTEGRAÇÃO DAS VANGUARDAS 43

1.4 MULTIPLICIDADE DE NARRAÇõES E NÃO-LINEARIDADE

1.5 FORMA E CONTEÚDO NA OBRA DE IÑ́́RRITU

1.6 Perspectivas analíticas

CAPÍTULO II - CONEXões HISTÓRICAS E CULTURAIS DA NARRATIVA DE IÑ́́RRITU

2.1 VINCULAÇÕES HISTÓRICAS DAS ESTRATÉGIAS NARRATIVAS DE IÑÁRRITU 73

2.2 O ENLACE HIPERMODERNO ENTRE A GLOBALIZAÇÃO E A MEXICANIDADE 86

2.3 O IMPACTO DA INTERFACE CULTURAL INFORMÁTICA NA NARRATIVA

CAPítulo III - A TEIA de AMores Brutos $\quad 107$

3.1 ANTECIPAÇÃO, FRAGMENTAÇÃO E CONVERGÊNCIA 109

3.2 APRESENTAÇÃo DOS PROTAGONISTAS E ABERTURA COM PLANO DE DETALHE 119

3.3 O LADO CÃo E A FAMÍlIa

3.4 INFLUÊNCIAS E CONEXÕES DA TEIA CANINA

CAPÍTULO IV - 21 GRAMAS: ORdEM EMOCIONAL ENTRE VIDA E MORTE 137

4.1 AS EMOÇÕES DAS PERSONAGENS COMO ORDENADORAS DA TRAMA 141

4.2 O SENTIDO DA TRAMA E A PERDA DE SENTIDO DAS PERSONAGENS

4.3 DA CRISE AO CLÍMAX

4.4 O CICLO DA REDENÇÃO

4.5 APONTAMENTOS SOBRE AMORES BRUTOS E 21 GRAMAS 172

CAPÍtUlo V - Babel: A REDE EXPANDIDA $\quad 177$

$\begin{array}{lll}5.1 & \text { A ORQUESTRAÇ̃̃o Da TRAMA } & 181\end{array}$

5.2 SIGNIFICADOS E SONORIDADE DAS TRANSIÇÕES ENTRE AS HISTÓRIAS

5.3 SUTURA DE DIFERENÇAS CONTRASTANTES

5.4 TESSITURA ENTRE O CONVENCIONAL E O INOVADOR 210

CAPÍTULO VI - BIUTIFUL: OS EXTREMOS DA VIDA

6.1 ENTRELAÇAMENTO DE RAMIFICAÇÕES E PROFUNDIDADE DE PERSONAGENS

6.2 O FIM NO COMEÇO 224

6.3 CONEXÕES DA ANTECIPAÇÃO COM O MEIO E O FIM

6.4 ALTERNATIVAS FORMAIS E APROFUNDAMENTO TEMÁTICO 234 
APÊNDICES - ESTRUTURAS E ESCALETAS DOS FILMES 267 APÊNDICE A 268 APÊNDICE B 270 APÊNDICE C 278

APÊNDICE D 284

APÊNDICE E 291 APÊNDICE F 297 APÊNDICE G 298 APÊNDICE H 299 


\section{INTRODUÇÃo}

\section{IÑÁRRITU E A RENOVAÇÃO DO CINEMA}

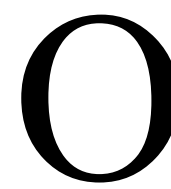

cinema é primordialmente uma arte voltada para grandes audiências e também uma manifestação cultural complexa, suas produções exigem que os filmes tragam alguma novidade, um mínimo de individualidade, que dialoguem com as questões estéticas e morais de seu tempo, mesmo seguindo preceitos de algum gênero ou fórmula mercadológica. Em boa parte de sua manifestação contemporânea, o cinema se mostra alinhado às transformações do capitalismo, do consumo e dos meios de comunicação. A narrativa fílmica está sendo renovada sob forte influência das complexas mudanças político-econômicas suscitadas pela globalização, aliadas ao impacto da tecnologia digital. Uma concentração inédita de alterações significativas em todos os elos de sua cadeia produtiva - da produção ao consumo - dinamiza o audiovisual atualmente, provocando mudanças estéticas, inclusive, no modo de se narrar.

O processo de globalização proporcionou o contato direto entre diferentes culturas e o indireto, por meio da difusão de informações com o desenvolvimento dos meios de comunicação. Esses contatos, por sua vez, provocaram uma interpenetração cada vez mais ampla do imaginário de diferentes países. Se, por um lado, a interpenetração levou à homogeneização e americanização de produtos e culturas, por outro, tornou-se um importante vetor de afirmação da identidade cultural dos países para com o resto do mundo, independentemente do tamanho de suas economias. $\mathrm{O}$ embate dessas forças contrárias produziu uma variedade de produtos culturais cada vez mais mestiçados, transculturais e multiformes.

A breve e mutante história da sétima arte é marcada pela intensa mescla de escolhas estéticas que seguem o padrão com outras mais originais. Acompanhando essa tendência da área, alguns realizadores contemporâneos exploram os limites a que se pode chegar, ao se combinarem algumas estratégias articulatórias utilizadas pelo cinema de vanguarda da modernidade com formas tradicionais do cinema clássico, na busca por narrativas envolventes que expressem a complexidade dos dias atuais. $\mathrm{O}$ resultado dessa combinação gera narrativas fílmicas que tendem a misturar convenções de gêneros ao contar várias histórias simultanea- 
mente embaralhadas no tempo, provocando diluição do encadeamento causal e falta de distinção entre ações principais e secundárias. Filmes com essas características valorizam o sensorial e o emocional na construção das tramas e acabam por engajar o espectador em um esforço de intelecção ainda mais intenso em sua compreensão. No território de experimentação dos limites, alguns cânones da narrativa clássica são subvertidos lançando mão de repertório de desconstrução da narrativa do cinema moderno, sem renunciar à comunicabilidade com um público amplo. Dessa forma, o cinema contemporâneo promove um de seus laboratórios de inovações mais dinâmicos.

Em parte expressiva da cinematografia recente, a clara diferenciação entre a ação principal e as complementares foi estilhaçada em uma narrativa marcada pela dispersão, descontinuidade e fragmentação dos padrões de narração. Uma das principais tendências dessa renovação combina, em sua elaboração, aspectos de multiplicidade e complexidade visando incrementar sua imprevisibilidade e provocar um engajamento mais ativo do espectador na compreensão das histórias apresentadas. Filmes que apresentam essas características foram enquadrados por Gilles Lipovetsky e Jean Serroy (2009) em uma tipologia denominada " $m u l$ tiplex". Essa vertente do cinema é marcada pela incorporação de aspectos característicos da hipermídia, ${ }^{1}$ tais como: fragmentação, hibridização, não-linearidade, excesso de informação e alta velocidade dos fluxos de trocas.

Duas das estratégias mais recorrentemente adotadas pelo cinema multiplex reduzem a previsibilidade da narrativa por meio da associação de multiplicidade de narrações com ordenações temporais não-lineares. A combinação dessas duas estratégias no processo de renovação da linguagem do cinema provoca o afrouxamento da relação de causalidade entre as cenas. $\mathrm{O}$ espectador, ao percorrer o trajeto fragmentado e errático da trama, é demandado a fazer um esforço muito mais intenso para acompanhar a narrativa do que o exigido pelo cinema clássico, tendo que investir mais energia para interpretar os fragmentos espaço-temporais recebidos e ordená-los no processo de inferir a história. A coerência da narrativa é restabelecida pela utilização de elementos estruturantes, fios condutores, que viabilizam a legibilidade e a fruição do discurso audiovisual.

\footnotetext{
${ }^{1}$ A hipermídia é um sistema de registro e exibição de informações informatizadas por meio da interatividade ramificada (estrutura de galhos de árvore), que permite acesso aos materiais que o constituem - textos, imagens estáticas ou em movimento, sons, softwares, etc. - a partir de hiperlinks que acionam outros documentos e assim sucessivamente. A rede mundial de computadores (World Wide Web) é uma das implementações mais populares de hipermídia. Um caso particular de hipermídia, o hipertexto usa apenas um tipo de mídia, texto com interatividade e hiperlinks que conduzem a outros dados.
} 
A proposta deste estudo é analisar filmes ficcionais contemporâneos da indústria cinematográfica hegemônica que apresentem multiplicidade de narrações e não-linearidade, e que abordem questões relacionadas à globalização. Baseado nesse critério, a escolha do corpus da pesquisa recaiu sobre a obra do mexicano radicado nos Estados Unidos, Alejandro González Iñárritu, tanto por suas características estéticas, bem como pelas temáticas abordadas em sua filmografia. Seus quatro primeiros filmes - Amores Brutos (Amores perros, 2000), 21 gramas (21 grams, 2003), Babel (2006) e Biutiful (2010) - apresentam uma combinação singular das manipulações formais de instâncias da narrativa cinematográfica e tratam dos principais temas da globalização na sociedade contemporânea: movimentos populacionais, multiculturalismo, desterritorialização, presença da mídia e da tecnociência no cotidiano.

A investigação pretende examinar, na obra de Iñárritu, variadas combinações entre estratégias de ordenação temporal não-linear e de multiplicidade de narrações, que são utilizadas pelo cinema ficcional contemporâneo para emular, em sua narrativa, aspectos de pluralidade e complexidade presentes na globalização. Os filmes do diretor apresentam multiplicidade em sua narração sob diversos aspectos - multiplot ou multitramas e multiprotagonismo. Esses filmes também apresentam formas distintas de organização temporal não-linear - episódica permeada; errática com ordenação emocional; cíclica com linearidade interna nos enredos e não-linearidade; e com flashforward estruturante.

A forma da organização discursiva da "trilogia da morte" de Iñárritu (Amores brutos, 21 gramas e $\mathrm{Babel}$ ) enquadra-se em um modo narrativo fílmico definido por David Bordwell (2008) como "narrativa de rede" (network narrative), no qual encontros acidentais ao acaso engatilham conexões inesperadas entre personagens não relacionadas, enredando uma teia complexa. Esse modo narrativo é uma marca do cinema transnacional atual. ${ }^{2}$

A análise dos filmes de Iñárritu objetiva integrar forma e conteúdo, abordar a narrativa principalmente como processo e, de maneira complementar, como representação e estrutura. Em um primeiro nível, as análises privilegiam o exame formal com a utilização de instrumental analítico cognitivista-neoformalista. Em certos momentos, foi necessário investigar a narrativa como estrutura e destacar a função das partes na construção do todo. Paralelamente, a narrativa foi abordada como representação e a análise enfocou as conexões do mundo diegético da história com a realidade.

\footnotetext{
${ }^{2}$ Em seu livro Poetics of Cinema, Bordwell (2008, p. 245-250) apresenta uma extensa lista com filmes dos cinco continentes lançados até meados de 2007, que seriam narrativas de rede. A lista contém filmes dirigidos por cineastas famosos como Robert Altman, Michael Haneke, Amos Gitai, Wong-Kar-way, Krzysztof Kieslowiski, Hou Hsiao-hsien, Alain Resnais, Rodrigo Garcia, Claude Lelouche, Otar Iosseliani, Aton Egoyan, entre tantos outros.
} 
Para tanto, a tese organiza-se em seis capítulos: o primeiro capítulo tem, predominantemente, carácter teórico-metodológico; o segundo apresenta uma abordagem histórica da renovação da linguagem em estudo; e os quatro seguintes são analíticos e focalizam cada um dos filmes da obra de Iñárritu, tratando dos filmes na ordem cronológica em que foram realizados.

O Capítulo I, “Abordagem da narrativa de Iñárritu”, apresenta os conceitos teóricos da pesquisa - narratologia, estudos de cinema, cognitivismo e crítica da cultura - e os relaciona com o cinema multiplex do diretor em foco. São expostas as hipóteses de trabalho e os objetivos da pesquisa, bem como sua metodologia, justificativa e definição de recorte. Na sequência, contextualizam-se a forma e a temática da obra do diretor no universo comunicacional da atualidade, com o intuito de relacionar o impacto da globalização no cinema contemporâneo com a multiplicidade de narrações e a não-linearidade na renovação de sua linguagem.

O primeiro capítulo aborda também uma das questões chave do processo de renovação do cinema, que é a absorção de algumas estratégias narrativas utilizadas pelos cinemas de vanguarda da modernidade, que romperam com a transparência do cinema clássico ao evidenciar as marcas da narração do diretor-autor. Examina-se como algumas dessas estratégias narrativas modernistas continuam sendo utilizadas para tratar de temas sociais relevantes da atualidade na obra de Iñárritu, entretanto, com uma conformação que busca se comunicar com uma larga audiência.

O Capítulo II, “Conexões históricas e culturais dos filmes de Iñárritu”, aponta conexões da obra do diretor com modos narrativos do cinema clássico, moderno e contemporâneo, que ajudam a entender como ele foi capaz de desenvolver uma filmografia com unidade estética, manter sua identidade artística e cultural, mesmo produzindo em vários países de diferentes continentes, e, ao mesmo tempo, alcançar audiências em todo planeta.

De início, são apresentadas as noções de cinema contemporâneo e independente adotadas na pesquisa e exposta a posição do diretor na busca de manter sua autonomia autoral ao se associar tanto aos grandes estúdios estadunidenses como às suas subsidiárias alternativas para produzir e distribuir seus filmes. Expõe-se a dinâmica do cinema independente, que surge como negação da produção economicamente dominante, mas interage com as forças atuantes no mercado, conciliando a conveniência em se produzir e distribuir filmes inovadores de baixo orçamento para públicos segmentados, com a necessidade de renovação da indústria por meio da abordagem de temas singulares com estilo impetuoso, agregando a visão particular de um realizador. 
Em seguida, colocam-se as inovações narrativas realizadas por Iñárritu em perspectiva e contextualizam-se suas experimentações na história do cinema mundial relacionando aspectos marcantes de sua obra com algumas estratégias narrativas aplicadas por movimentos cinematográficos vanguardistas da modernidade - o surrealismo, a escola soviética da década de 1920, o neorrealismo italiano e a nouvelle vague francesa. Também analisa-se como a filmografia do diretor mexicano aborda variados aspectos da transnacionalidade da cultura no início do século XXI, oferecendo a perspectiva de se pensarem as conexões dos cinemas nacionais na economia globalizada, com base em noções propostas por Octavio Paz (2014), Arjun Appadurai (1996) e Nestor Canclini (2011, 2008, 1997).

O Capítulo III, “A teia dos Amores brutos”, analisa o filme de estreia de Iñárritu, Amores brutos (Amores perros, 2000), que foi aclamado como um dos mais premiados mundialmente no ano de seu lançamento, consagrando-se como um filme local, em seu interesse imediato, e global, em seu alcance. No filme, a intersecção, ao acaso, dos destinos de três estranhos por meio de uma colisão de automóveis na Cidade do México orquestra manipulações temporais e variações de perspectiva na narração. A estrutura do filme é dividida em três capítulos, com várias inserções de cada história permeando as demais.

É empreendido um esforço para se averiguar como o filme promove engajamento por meio da justaposição de cenas, enfatizando temas como a disputa machista por dominância, o poder do acaso no rumo da vida, a abordagem de embates entre formas de amar, classes sociais e faixas etárias de personagens. Examinam-se as principais estratégias que conformam a macro estrutura da trama: abertura com flashforward de perseguição; fragmentação em capítulos; repetições da colisão de automóveis como ordenadoras temporais da trama; e entrelaçamento dos enredos. Em seguida, são observados temas comuns aos três capítulos do filme, que também colaboram na sutura da narrativa: as relações familiares e a presença canina.

O Capítulo IV, "21 gramas - ordem emocional entre vida e morte” dedica-se ao estudo de estratégias narrativas ainda mais radicais empregadas por Iñárritu na orquestração de seu segundo filme, 21 Gramas. Assim como na prima obra, solidão, relações familiares, violência, morte, redenção e o impacto do acaso no destino sobressaem-se no enredo. 21 gramas apresenta múltiplos protagonistas como Amores brutos, porém oferece apenas um enredo, é falado em inglês e estrelado por atores hollywoodianos famosos - Sean Penn, Naomi Watts e Benício Del Toro.

Novamente, um acidente de carro, mas, desta vez, um atropelamento, conecta três personagens ao acaso, entretanto, diferentemente de em Amores brutos, eles serão levados a partilhar as consequências trágicas desse evento em uma intriga de vingança. Nesse segundo fil- 
me de Iñárritu, a ordenação temporal demanda um empenho mais aguçado do espectador na compreensão de sua estrutura errática, na qual não se consegue identificar um padrão no encadeamento do enredo. Investiga-se como a narração de 21 gramas rompe com o encadeamento causal e cronológico entre cenas consecutivas e adota a emoção como principal fio condutor em uma ordenação aparentemente aleatória. As vinculações são arquitetadas cena a cena por meio de padrões de similaridade e contrastes, com o sentimento de uma personagem ecoando nas demais.

O Capítulo V, “Babel - rede expandida”, investiga as estratégias diferenciadas utilizadas por Iñárritu ao urdir uma narrativa que puxa os limites convencionais do cinema hollywoodiano, sem, contudo, transcendê-los, estabelecendo um diferencial como produto cultural sem comprometer sua comunicabilidade. Após cruzar a fronteira entre México e Estados Unidos na realização de 21 gramas, Iñárritu alça um voo ainda mais amplo para fechar sua trilogia da morte. Ao invés de três linhas narrativas, como nos filmes anteriores, Babel (2006) entrelaça quatro enredos filmados em diferentes locações no Marrocos, Japão, Estados Unidos e México. Trata-se de um filme com sete indicações ao Oscar e grande audiência - a maior bilheteria entre os filmes de Iñárritu, com arrecadação de 135 milhões de dólares, que mistura atores não profissionais com as estrelas internacionais Brad Pitt e Cate Blanchett.

Babel é focado nas relações familiares e, além da multiplicidade de protagonistas, apresenta também diversidade cultural e linguística. Um tiro acidental disparado por um préadolescente entrança uma teia de junções entre três continentes. O filme aborda travessias de fronteiras de diversas ordens - geográficas, políticas, culturais, étnicas, sociais e econômicas -, ressaltando as conexões entre realidades contrastantes, e evidenciando a preservação das identidades nacionais em um mundo globalizado ligado em rede. Estuda-se, neste capítulo, a maneira com que o entrelaçamento dos quatro enredos do filme dá a impressão de simultaneidade entre as histórias, ressaltando as leves discrepâncias temporais explicitadas com sutileza no desenrolar da trama. São examinadas também as transições entre as vinte e quatro sequências da estrutura narrativa de Babel, que funcionam como fronteiras entre os universos de suas histórias, criando uma experiência cognitiva-emocional envolvente por meio de variadas estratégias visuais e sonoras.

Enquanto, em Amores brutos e 21 gramas, havia apenas uma ou duas localidades, em Babel, os espaços físicos são diversificados em amplo espectro, da metrópole Tóquio à aldeia em área rural do Marrocos. Essa variedade espacial díspar recebe tratamento formal inédito na obra de Iñárritu com abundância de planos abertos. Há, ainda, no filme, a abordagem do espaço como fluxo, representado tanto pela migração em busca de melhores condições de vida na 
fronteira entre México e Estados Unidos, como também pelo turismo em Marrocos, traçando a teia de conexões globalizantes de um mundo interligado por movimentos populacionais e pela mídia, onde os pobres movem-se por necessidade e os ricos por prazer.

O Capítulo VI, “Biutiful - os extremos da vida”, analisa o diferencial da tessitura da narrativa do quarto filme de Iñárritu, Biutiful (2010), ambientado em Barcelona, Espanha. Solidão e morte seguem como motes proeminentes e a diversidade se faz presente mais uma vez por meio das etnias, nacionalidades e línguas faladas em uma Europa marcada pelos impactos cruéis das relações de trabalho globalizadas, em meio às interações afetivas entre nativos espanhóis e migrantes ilegais africanos e chineses. O filme inova em suas manipulações nãolineares com a utilização de um flashforward estruturante e a transferência da ênfase de sua experimentação narrativa para o desenvolvimento das personagens e aprofundamento das questões temáticas relacionadas ao impacto das macropolíticas socioeconômicas nas relações interpessoais.

Em Biutiful, a maior disponibilidade de tempo para contar somente uma história com único protagonista permite ao diretor trabalhar as personagens com pluralidade de facetas e em ritmo mais brando que nos filmes anteriores. No andamento geral do filme, a lenta, realista e densa transformação das personagens é mais determinante no desenvolvimento da trama do que as ações. O protagonista do filme, Uxbal (Javier Bardem), é um anti-herói trágico e ambíguo, que vive à margem da sociedade e cativa a audiência por ter qualidades admiráveis, mesmo tendo atividades repugnantes. Depois que Uxbal aceita a iminência da morte, sua movimentação para atingir o objetivo de organizar a vida para que os filhos fiquem bem é desenvolvida como uma jornada ramificada e cheia de percalços, surpresas e decepções. O capítulo também examina a ruptura inédita na filmografia de Iñárritu com o realismo, através de elementos de fantasmagoria e flerte com o surrealismo.

Nas Considerações Finais, veremos como as experimentações da narrativa, nos diversos filmes de Iñárritu, configuram-se com variações diversas, mantendo, no entanto, uma coerência autoral peculiar. Com a visão do conjunto da obra, poderemos verificar até que ponto ela realmente se associa a características de uma parte importante da produção cinematográfica contemporânea, seja nos seus aspectos formais, seja na sua capacidade sensível e crítica de abordar temáticas relacionadas a questões relevantes de um mundo incontornavelmente globalizado.

Esta é a trajetória proposta para o estudo do diálogo criativo que Alejandro González Iñárritu promove entre tradição e inovação no cinema contemporâneo por meio da tessitura de suas narrativas fílmicas. Boa jornada. 


\title{
CAPítulo I
}

\section{ABORDAGEM DA NARRATIVA DE IÑ̃́RRITU}

\begin{abstract}
"O filme deve, cada vez mais, encontrar o seu público, e, acima de tudo, deve tentar, cada vez, uma sintese dificil do padrão e do original: o padrão se beneficia do sucesso passado e o original é a garantia do novo sucesso, mas o já conhecido corre o risco de fatigar enquanto o novo corre o risco de desagradar."
\end{abstract}

(Edgar Morin, in Cultura de Massas no Século XX - o espírito do tempo - Neurose 1987, p. 28)

atividade cinematográfica exige uma consciência do ofício e de suas impli-
cações, que situa o realizador em uma posição diferenciada para explorar
seus mecanismos de construção e motivações de produção. Admitindo-se que "os cineastas herdam, observam, impregnam-se, citam, parodiam, plagiam, desviam, integram as obras que precedem as suas" (VANOYE; e GOLIOT-LÉTÉ, 1994, p. 36), o recorte proposto neste estudo coloca o desafio teórico e metodológico na busca de explicações e interpretações sobre a construção do cinema contemporâneo. A obra de Iñárritu oferece a combinação tanto de elementos formais como também de conteúdos identificados como relevantes de serem analisados por esta pesquisa. Acredito que, justamente pela intensidade proporcionada pela composição desses aspectos, sua filmografia constitui material fértil para se identificar e estudar as transações entre tradição e inovação no cinema contemporâneo. Feitas essas considerações iniciais, pode-se levantar uma pergunta-chave que sintetize o cerne da questão em foco e guie a investigação: Considerando-se as características de multiplicidade e complexidade do cinema contemporâneo, como a combinação de distintas estratégias de multiplicidade de narrações com as de ordenação temporal não-linear renova a narrativa cinematográfica? 
Visando dar início ao desafio teórico-metodológico de responder a questão proposta, o primeiro capítulo deste estudo apresenta os principais referenciais teóricos da investigação: narratologia e estudos do cinema - composto por teoria do cinema, história do cinema e análise fílmica. O capítulo também elucida como esses dois referenciais serão complementados pela crítica da cultura. Em seguida, expõem-se os conceitos e noções fundamentais da abordagem cognitivista-neoformalista adotada pela pesquisa, que serão relacionados com a narrativa e a montagem. Na sequência, trata-se da combinação engendrada pelo cinema contemporâneo entre formas do cinema clássico com estratégias narrativas utilizadas pelos cinemas de vanguarda da modernidade sem comprometer sua comunicação com uma larga audiência. Nas seções seguintes, discorre-se sobre como as estratégias de multiplicidade de narrações e a não-linearidade operam na renovação da linguagem do cinema contemporâneo, contextualizam-se o feitio e o teor da filmografia do diretor no universo comunicacional da atualidade e apresenta-se a metodologia adotada na investigação.

\subsection{O narrativo e o cinematográfico}

Como o problema da pesquisa proposto é multifacetado, faz-se necessário lançar mão de conceitos e teorias de tradições diferentes para buscar iluminar suas faces. Entretanto, como em fotografia, ao lançarmos luz, também projetamos sombras, sendo, pois, preciso dimensionar a potência e variar o ângulo de incidência ao equalizar as diversas fontes para se chegar a um resultado desejável: uma iluminação conceitualmente equilibrada. A analogia entre a aplicação de luz e de teoria a um objeto nos ajuda a entender a dinâmica do processo interativo que será empreendido nesta investigação.

Ao examinar o "estado de conhecimento" da questão em foco - a renovação da narrativa cinematográfica - identifiquei duas disciplinas que oferecem valiosas perspectivas para essa averiguação: estudos de cinema e narratologia. Essas duas disciplinas constituirão os focos de luz de maior intensidade que nos permitirão abordar o objeto da pesquisa e iluminar criticamente o processo de realização artística das narrativas em questão. A luz principal dos estudos de cinema receberá a contraluz ${ }^{1}$ da narratologia para delinearem-se os contornos específicos do cinematográfico e destacá-los do fundo generalizante das narrativas como um

\footnotetext{
${ }^{1}$ Contraluz é o foco de luz que vem de trás e destaca o objeto iluminado do fundo. Esse tipo de luz dá um toque de glamour ao criar um halo em torno do objeto em que incide e precisa ter intensidade maior do que a somatória das luzes frontais para ter efeito.
} 
todo. As perspectivas dos estudos de cinema e narratologia serão complementadas pela filosofia ou crítica da cultura como luz de preenchimento das áreas que permanecerem sombreadas. ${ }^{2}$ Essas disciplinas serão brevemente descritas e relacionadas ao objeto de estudos a seguir.

A narrativa, surgida bem antes do cinema, está presente em todas as sociedades em todos os tempos como destacam diversos estudiosos da matéria como Roland Barthes (2009), Mieke Bal (2009), Joseph Campbell (2007), Paul Ricoeur (1994; 2010) e outros. ${ }^{3}$ A humanidade necessita criar representações da realidade, muitas delas por meio de narrativas, para explicar e entender suas relações com o meio ambiente e organizar suas interações sociais. Luiz Gonzaga Motta, em Análise Crítica da Narrativa (2013), ressalta a amplitude da presença da narrativa em nossas vidas enquanto imaginamos, dialogamos, divertimo-nos, sonhamos, apaixonamo-nos, lembramos, mentimos, estudamos, cremos, jogamos e praguejamos. Sinteticamente, a narrativa pode ser definida como uma cadeia de eventos relacionados por causa e efeito ocorrendo no tempo e no espaço. Ela é apontada por Motta (2013, p. 18) como a principal maneira com que os seres humanos constroem o sentido da realidade. Essas maneiras de dar sentido ao mundo são pesquisadas por uma disciplina que abarca todas as narrativas, chamada narratologia, que estuda as leis gerais da narratividade e suas instâncias constituintes objetivando a compreensão do fato de contar uma história e de suas implicações. Os estudos sobre a narrativa precedem a constituição da narratologia como disciplina independente.

O estudo da narrativa na modernidade é deflagrado pelas investigações dos formalistas russos, com as análises temáticas de Tomachevski (1970) e a morfologia de Propp (1984). ${ }^{4}$ Os formalistas russos foram os primeiros a pensar a analogia entre a linguagem e o cinema e procuraram sistematizar o universo aparentemente caótico dos fenômenos fílmicos. A publicação mais ambiciosa dessa tradição, a antologia Poetika Kino, A poética do cinema (1927), ${ }^{5}$ pretendia oferecer uma sólida fundação ou "poética" para a teoria do cinema, comparável à sua poética da literatura. Os principais pensadores desse movimento (Chklovski, Eikhenbaum e

\footnotetext{
${ }^{2}$ Luz de preenchimento ou fill light é aquela que clareia as sombras projetadas pelos outros focos de iluminação.

${ }^{3}$ Cf. BARTHES, Roland et al. Análise estrutural da narrativa. Petrópolis - RJ: Vozes, 2009; CAMPBELL, Joseph. O herói de mil faces. São Paulo: Pensamento, 2007; BAL, Mieke. 3 ed. Narratology - introduction to the theory of narrative. Toronto: University of Toronto Press Incorporated, 2009; RICOUER, Paul. Tempo e narrativa: tomo I. Campinas: Papirus, 1994; RICOUER, Paul. Tempo e narrativa: a configuração do tempo na narrativa de ficção, v. 2. São Paulo: Martins Fontes, 2010.
}

${ }^{4}$ Cf. PROPP, Vladmir. Morfologia do conto maravilhoso. Rio de Janeiro: Forense, 1984.

${ }^{5}$ CHKLOVSKI, V; EICHEnBAUM, B; TYNiAnOV, I. et al. Poetika Kino (Poética do Cinema). MoscouLeningrado: [s.n], 1927. Os artigos de Tynianov e Eichenbaum foram traduzidos para o francês, Cahiers du cinemá 220-51, 1970. Existem duas traduções recentes para o inglês, uma da Oxford e outra da Ann Arbor, Michigan. 
Tinianov) elaboraram conceitos - "discurso interior", sistemas dinâmicos estruturados em relação a um "dominante" - modelos e tipologias que serviram de base para formulações de correntes teóricas posteriores, tanto a estruturalista como algumas pós-estruturalistas, como a cognitivista, uma das principais referências deste estudo, a qual se filia David Bordwell. ${ }^{6}$ Por resgatarem o legado do formalismo russo, os cognitivistas são também chamados de neoformalistas e essa linha teórica será devidamente apresentada na próxima seção.

A narratologia surge na literatura, proposta por Tzvetan Todorov em $1969,{ }^{7}$ associada às contribuições da corrente estruturalista, ${ }^{8}$ especialmente as teorizações de Gérard Genette (1972; 1980) e as concepções de Christian Metz (2004; 2009) que mesclavam o estudo dos códigos cinematográficos e a narratividade. Genette retomou o termo "narratologia” proposto por Todorov (1969), especificamente no capítulo "Discurso da narrativa”, em seu livro Figuras (GENETTE, 1972), em que propõe o conceito de narratologia modal, em oposição a outra, temática. Essa conceptualização de modal e temática subsidia a distinção entre a narratologia da expressão e a de conteúdo. A narratologia de expressão estaria focada no estudo das formas e níveis de narração, temporalidade, pontos de vista e outros aspectos formais da construção narrativa. E a narratologia temática trataria do conteúdo da história contada, das ações e relações das personagens. ${ }^{9}$ Genette (1980, p. 33-160) também trouxe contribuição

\footnotetext{
${ }^{6}$ No prefácio do primeiro livro de David Bordwell (2008) traduzido no Brasil, Figuras traçadas na luz - a encenação no cinema, Fernão Ramos comenta que talvez ele seja, hoje, o principal pensador de cinema nos Estados Unidos. Esse professor da Universidade de Wisconsin (Madison), fundador e promotor da escola cognitivistaneoformalista de crítica e análise de filmes, empreendeu estudos detalhados sobre o estilo de alguns cineastas (Eisenstein, Ozu e Dreyer), com destacada habilidade em descrever a forma dos filmes relacionando-a com o estado histórico da linguagem cinematográfica. Bordwell $(1985 ; 1997)$ também dedica-se a questões teóricas mais amplas, notadamente relacionadas à narração, a qual propõe estudar a partir de categorias estilísticas historicamente definidas e a noção de estilo.
}

${ }^{7}$ Cf. TODOROV, Tzvetan. As estruturas narrativas. 5 ed. São Paulo: Perspectiva. 2008.

8 "A ideia e a palavra [estruturalismo] surgiram a propósito do estudo das narrativas míticas feito por Claude Lévi-Strauss $(1958,1962)$. Este trabalhou a hipótese de que tais narrativas, complexas e aparentemente irracionais, manifestam, na verdade, uma grande sistematicidade, se forem relacionadas com "estruturas" ocultas que regulam seu desenvolvimento. Essa ideia de uma estrutura invisível, mas sistemática, foi rapidamente referida ao modelo linguístico, tal como deduzido das posições de F. de Saussure. Como a linguística, a análise estrutural recorta enunciados contínuos, para localizar neles 'contrastes' (Lévi Strauss), diferenças, distâncias; essas análises permitem construir grades de interpretação, que permitem, por sua vez, fazer outras análises. (...) Essa herança foi discutida de maneira polêmica por Bordwell - que lhe opõe a lição formalista, na versão renovada que ele propõe dela." (AUMONT; MARIE, 2007, p. 110-111, acréscimos meus).

${ }^{9}$ Um autor que se destacou na teorização da narratologia de conteúdo foi A. J. Greimas. Cf. Elementos para uma teoria da interpretação da narrativa mítica. In: BARTHES, R. et al. Análise estrutural da narrativa. Petrópolis - RJ: Vozes, 2009. p. 63 - 113. 
significativa ao teorizar sobre as relações temporais na narrativa, propondo os conceitos de ordem, duração e frequência que serão utilizados nas análises dos filmes de Iñárritu. ${ }^{10}$

Metz (2004; 2009), apesar de ter criticado os teóricos que comparavam o cinema a uma língua e definiam-no como uma "linguagem sem língua", não consegue fundar a narrativa fílmica devido a sua vinculação com as teorias estruturalistas que reduziam o cinema a um objeto linguístico, independentemente da articulação de materiais de outra natureza, nãolinguísticos. A sintagmática é, para ele, o código cinematográfico por excelência, que organiza a lógica da ação e a mensagem dos filmes em sujeição à narratividade. ${ }^{11}$

A encruzilhada entre o narrativo e o cinematográfico também é estudada mais recentemente por André Gaudreault e François Jost (2009) que pesquisam a especificidade da "narratologia cinematográfica", por meio de estudo comparado com a narrativa literária. Gaudreault e Jost (2009) buscam o entendimento das estruturas que fundamentam o ato audiovisual de contar histórias, esmiuçando como se narra articulando sons e imagens. Para isso, baseiam-se nas instâncias constitutivas da narrativa: o narrador, o tempo, o espaço e a narração. Eles defendem que, apesar de a expressão narrativa cinematográfica só ter se disseminado recentemente, a associação desses termos esteve presente não somente na outrora badalada abordagem estruturalista, como também teve precursores como Jean Mitry ${ }^{12}$ e Albert Laffay. ${ }^{13}$

Gaudreault e Jost (2009) defendem uma mudança de foco em relação a Metz, que estava mais interessado na capacidade da linguagem cinematográfica de significar, e propõem enfatizar sua capacidade de narrar. O livro da dupla, A narrativa cinematográfica (2009), traz aportes conceituais indispensáveis para a compreensão do problema desta pesquisa. Isso, obviamente, não desqualifica, nem exclui as contribuições de Metz (2004; 2009), justamente pela oscilação entre o significar e o narrar.

\footnotetext{
${ }^{10}$ Cf. GENETTE, G. Figuras. São Paulo: Perspectiva, 1972. GENETTE, G. Narrative discourse: an essay in method. Ithaca - EUA: Cornell University Press, 1980. GENETTE, G. Narrative Discourse Revisited. Ithaca EUA: Cornell University Press, 1988.

${ }^{11}$ Cf. METZ, Christian. A significação do cinema. 2 ed. São Paulo: Perspectiva, 2004. METZ, Christian. A grande sintagmática do filme narrativo. In: BARTHES, R. et al. Análise estrutural da narrativa. Petrópolis RJ: Vozes, 2009. p. 210-217

${ }^{12} \mathrm{Cf}$. MITRY, Jean. The aesthetics and psychology of the cinema. Indiana University Press: Bloomington, In - EUA, 1997.

13 "Laffay só publicou um único livro de teoria do cinema, Logique du cinema (1964), coletânea de artigos escritos anteriormente para a revista Les Temps Modernes, entre o fim da década de 1940 e o início da década de 1950. Em sua obra, ele liga a definição de cinema como linguagem à presença da narrativa. (...) Para ele, se o cinema não é a realidade, mas uma representação do real, ele deve isso à narrativa e a sua capacidade de tornar as coisas legíveis, de reorganizá-las e inseri-las em uma composição. No entanto, sendo a estrutura da narrativa discursiva, o cinema, ao se casar com a narrativa, torna-se uma linguagem." (AUMONT; MARIE, 2003, p. 175)
} 
$\mathrm{Na}$ introdução de Narration in the fiction film (1985), Bordwell distingue dois modos mais tradicionais de se estudar a narrativa - como representação e como estrutura - e apresenta outra alternativa - como processo. A abordagem da narrativa como representação caracteriza-se pelo estudo focado na camada de narratividade independente do significante ou da linguagem, ou seja, com ênfase em seu conteúdo considerando o mundo da história, seu retrato da realidade e seus significados mais amplos. A narrativa é investigada como estrutura quando sua análise está voltada para o ato narrativo e para a enunciação, levando em conta a materialidade do significante - icônico-sonoro, no caso dos filmes - e o modo particular com que combina as partes para se chegar a um todo. A abordagem do estudo da narrativa como representação e estrutura descrita por Bordwell (1985) alinha-se à concepção de narrativa temática e modal proposta por Genette (1972), ambas acepções apartam o conteúdo da expressão.

A corrente teórica cognitivista, liderada por Bordwell, propôs uma terceira alternativa de enfoque para a matéria: a narrativa como processo, enquadrada como uma atividade de selecionar e organizar o material da história para se atingir objetivos específicos no espectador. Na óptica cognitivista, a história é resultante do processo de colher pistas, aplicar esquemas, formular e testar hipóteses, e a trama é a articulação e apresentação da história no filme. Para essa corrente teórica, a história nunca é materialmente apresentada na tela, e sim adivinhada por meio de deduções e inferências. A trama constitui um sistema, porque organiza os eventos da história de acordo com princípios específicos. $\mathrm{O}$ exame das relações entre as formas com que a trama apresenta as informações da história revela a tessitura das narrativas. Nessa perspectiva, as análises propostas por esta pesquisa privilegiaram a abordagem cognitivista, a narrativa como processo, mas também a contemplaram como representação e estrutura, estabelecendo relações entre conteúdo e expressão nas narrativas fílmicas em apreciação.

Finalmente, "vamos definir o cinematográfico não como tudo que aparece nos filmes, mas como aquilo que só é suscetível de aparecer no cinema e que, portanto, constitui de maneira específica a linguagem cinematográfica no sentido estrito do termo" (AUMONT, 1995, p. 96). O específico cinematográfico será abordado nesta pesquisa na perspectiva cognitivistaneoformalista, que será apresentada na seção a seguir. 


\subsection{Cognitivismo, narrativa e montagem}

As teorias do cinema são compostas por contribuições oriundas de diversas disciplinas, como a filosofia, a sociologia, a psicologia, a linguística e várias outras. A linha cognitivista analítica na teoria do cinema segue essa tendência transdisciplinar e surgiu nos Estados Unidos em sincronia com o fenômeno pós-moderno, das décadas de 1980 e 1990. Essa linha opõe-se à teoria estruturalista por meio da rejeição de suas bases conceituais na psicanálise e na semiologia linguística, e da adoção da psicologia cognitiva e da estética enraizada no formalismo russo como alicerces de sua abordagem. Devido à valorização da herança do formalismo russo, os cognitivistas também são denominados neoformalistas.

Os cognitivistas-neoformalistas rejeitaram a base filmolinguística, em que o cinema opera de forma semelhante a uma linguagem que pode ser apreendida por meio de uma abordagem linguístico-semiológica. As reflexões mais recentes dessa linha teórica se dedicam ao estudo dos elementos formais do cinema que "coincidem" com as leis da percepção humana. Ao embasar seu pensamento na psicologia cognitiva e no formalismo russo, desenvolveram um instrumental analítico embasado em protocolos do racionalismo científico (inferência, prova, demonstração, indução, dedução, abdução e verificabilidade). Dessa forma, constituiuse um arcabouço teórico marcado pelo rigor analítico apoiado na concretude do material expressivo dos filmes.

Os cognitivistas descartaram a psicanálise e adotaram a psicologia cognitivista como chave da compreensão da experiência fílmica. ${ }^{14}$ Os teóricos dessa linha rejeitam a suposição da "Teoria" de que o espectador esteja em estado regressivo, do sonhar acordado, passivo e tomado como refém pelo movimento das imagens e a fruição da narrativa, num estado de letargia. Eles acreditam que há uma atividade racional, em estado de alerta, na qual o espectador executa a leitura atribuindo sentido por meio de inferências com base nas "pistas" advindas do filme. A mente do espectador estaria constantemente buscando ordem e significado. Trata-se de um processo em que os filmes oferecem indicações aos espectadores, a partir das quais, estes utilizam esquemas interpretativos para construir histórias ordenadas e inteligíveis em suas mentes. Segundo essa visão:

À medida que o espectador assiste a um filme, ela ou ele capta pistas, lembra-se de informações, antecipa o que vem em seguida, e, geralmente, participa da criação da

\footnotetext{
${ }^{14} \mathrm{Cf}$. Bordwell, David. Making meaning: inference and rhetoric in the interpretation of cinema. Cambridge: Harward Univ. Press, 1989.
} 
forma do filme, que molda expectativas particulares congregando curiosidade, suspense e surpresa. (BORDWELL; THOMPSON, 1993, p. 65, tradução nossa) ${ }^{15}$

Além de opor-se à teoria estruturalista por meio da adoção de bases diferenciadas, os cognitivistas se diferenciam ainda mais da corrente anterior pela visão de alcance da teoria nos estudos de cinema. O livro Post-Theory - reconstructing film studies, ${ }^{16}$ organizado por David Bordwell e Noel Carroll, já no seu título, ao grafar teoria com "T" maiúsculo, ataca com ironia o campo unificado da teoria estruturalista. Os vários textos desse livro combatem a unidade da "Teoria" que articula dispositivo técnico, natureza da imagem, psicanálise e política, a partir de uma mesma matriz explicativa. Os cognitivistas propõem como alternativa um conjunto de teorias em pequena escala (piece-meal theory) para tratar de um problema em questão. Além do que, essa abordagem se ajustaria melhor ao fato de que uma única "Teoria" unificante não consegue abarcar as múltiplas dimensões do cinema. A crença cognitivista é de que tal postura gera respostas mais precisas a perguntas menos ambiciosas, como as propostas nesta investigação.

Em Poetics of cinema, David Bordwell (2008, p. 12-17) vincula sua linha teórica à tradição deflagrada pelas fragmentadas notas de aula de Aristóteles em A Poética (século IV a.C.). A poética do cinema proposta por ele é originária da palavra grega poiesis - fazer ativo. A esse respeito, Bordwell (2008, p. 12, tradução nossa) defende que:

A poética de qualquer meio artístico estuda a obra finalizada, como o resultado de um processo de construção - um processo que inclui um componente artesanal (como regras básicas), os princípios mais gerais segundo os quais o trabalho é composto, suas funções, efeitos e usos. Qualquer investigação sobre os princípios fundamentais pelos quais artefatos em qualquer meio de representação são construídos, e os efeitos que decorrem destes princípios, pode cair dentro do domínio da poética. $^{17}$

Bordwell defende, na introdução desse livro, que os ensaios ali reunidos vão além de analisar forma e estilo, eles tentariam explicar como os filmes funcionam e por que, em

\footnotetext{
${ }^{15}$ No original: "As the viewer watches the film, she or he picks up cues, recalls information, anticipates what will follow, and generally participates in the creation of the film's form. The film shapes particular expectations by summoning up curiosity, suspense and surprise". (BORDWELL e THOMPSON, 1993, p. 65).

${ }^{16}$ BORDWELL, David; CARROL, Noël (orgs.). Post-Theory - reconstructing film studies. Madison: The University of Wisconsin Press, 1996.

${ }^{17}$ No original: "The poetics of any artistic medium studies the finished work as the result of a process of construction - a process that includes a craft component (such as rules of thumb), the more general principles according to which the work is composed, and its functions, effects, and uses. Any inquiry into the fundamental principles by which artifacts in any representational medium are constructed, and the effects that flow from those principles, can fall within the domain of poetics." (BORDWELL, 2008, p. 12)
} 
certas circunstâncias, eles acabam assumindo determinadas formas. Suas explanações evocam uma variedade de fatores, como: intenções artísticas, influências sociais, restrições normativas e institucionais, e similaridades interculturais. De acordo com sua concepção, todo projeto de pesquisa em poética envolve três perspectivas: analítica, teórica e histórica. A perspectiva analítica estuda dispositivos específicos em um espectro de obras ou em apenas uma. Já a perspectiva teórica levanta condições para a definição de um gênero ou categoria. E a histórica empreende esforço para compreender como os trabalhos de arte assumem certas formas dentro de um período ou entre períodos diferentes.

Em Narration in the fiction film, Bordwell (1985), além de desenvolver a alternativa cognitiva à semiótica para explicar como os espectadores compreendem os filmes (BORDWELL, 1985, p. 29 a 47), desenvolve também os dois níveis em que a narrativa opera do ponto de vista do filme: a trama e a fábula (BORDWELL, 1985, p. 48 a 62). Algumas das estratégias para romper a linearidade da narrativa no cinema contemporâneo exploram as possibilidades de combinação dos dois tempos da narrativa: o tempo da história (fábula, story) e o tempo da trama (enredo, plot). A fábula é a história toda, articulada pelas relações de causa e efeito e ordenadas cronologicamente. Assim, o tempo na trama pode divergir do tempo da história. São essas discrepâncias entre as linhas de tempo da trama e da história que demandam do espectador um esforço para ordenar cronologicamente os eventos que são gradualmente apresentados. A história quase nunca aparece toda na tela, ela é oferecida pela trama, que é a forma como os eventos da história são apresentados pela obra. No início do século $\mathrm{XX}$, os formalistas já haviam definido e teorizado sobre a distinção entre história ( $f a$ bula) e trama (syuzhet) e sugerido separá-las como procedimento metodológico para desvendar as estratégias narrativas de um roteiro, conforme defendeu Boris Tomachevski (1970, p. 173) em seu antológico texto "Temática". ${ }^{18}$

A parte três do mesmo livro de Bordwell (1985), Historical Modes of Narration, apresenta a maneira como o cinema clássico, o cinema moderno e o cinema de arte estruturam suas narrativas. Ali, são examinados os mecanismos formais que conferem clareza, homoge-

\footnotetext{
${ }^{18}$ O ensaio "Temática" contém bases imprescindíveis para a análise de qualquer narrativa, inclusive a cinematográfica, apesar do interesse original desse autor ter sido a literatura. Tomachevski (1970) distinguiu a fábula da trama da seguinte forma: "Chama-se fábula o conjunto de acontecimentos ligados entre si que nos são comunicados no decorrer da obra. Ela poderia ser exposta de uma maneira pragmática, de acordo com a ordem natural, a saber, a ordem cronológica e causal dos acontecimentos, independentemente da maneira pela qual estão dispostos e introduzidos na obra. A fábula opõe-se à trama, que é constituída pelos mesmos acontecimentos, mas que respeita a ordem de aparição na obra e a sequência de informações que nos destinam.” (TOMACHEVSKI, 1970, p. 173)
} 
neidade, linearidade e coerência à narrativa clássica. $\mathrm{Na}$ análise dos modos de narração do cinema moderno e de arte, Bordwell expõe as estratégias narrativas que alteram ou subvertem os parâmetros de narração clássica sem impossibilitar a legibilidade de seu discurso e promovendo o engajamento do espectador por meio de mecanismos diferenciados. ${ }^{19}$ As análises comparativas entre o modelo clássico e o moderno desenvolvidas por Bordwell oferecem embasamento para a investigação das relações entre narrativa e montagem na articulação da imprevisibilidade do cinema contemporâneo.

Os cognitivistas, com destaque para Bordwell, oferecem, portanto, perspectivas conceituais e instrumental analítico para investigações da narrativa do cinema contemporâneo que se revelam pertinentes para o cinema de Iñárritu, tão baseado na participação do espectador na co-construção da narrativa. Outros teóricos também se dedicaram à análise comparativa do cinema clássico e do moderno, como Gilles Deleuze nos livros A imagemmovimento - Cinema I (1983) e A imagem-tempo - Cinema II (2007). Deleuze, ao construir sua teorização sobre bases filosóficas e semióticas consistentes, propôs explanações oportunas sobre o cinema clássico e o moderno, entretanto, suas teorizações não oferecem instrumental analítico para aplicação no exame de formas e modos narrativos do cinema da contemporaneidade.

Curiosamente, se por um lado, algumas teorizações mais recentes sobre o cinema não proporcionam aportes diretos para esta investigação, por outro, o texto seminal da narratologia de Aristóteles, A Poética (2003), apresenta conceitos proveitosos sobre a relação da trama com as personagens. Aristóteles defende a importância do conceito de unidade na narrativa, no qual a ordem das partes constitui o todo. As partes são ordenadas em conexões tais que, se deslocada ou suprimida uma delas, também se altera o todo. Nada é solto ou gratuito na narrativa, todas as partes e conexões têm uma função no todo. O elemento mais importante da narrativa é a trama dos fatos ordenada conforme a verossimilhança, em que as ações são executadas pelas personagens de acordo com suas características e pensamentos. Os conceitos aristotélicos de forma poética foram formulados examinando o teatro trágico e os poemas épicos, mas oferecem elementos que se aplicam nas análises das relações entre as partes na constituição de uma unidade na narrativa cinematográfica. Alguns desses conceitos, como o

\footnotetext{
${ }^{19} \mathrm{O}$ cognitivista "Murray Smith (Engaging characters: Fiction, emotion, and the cinema. Oxford: Clarendon Press, 1995) substitui o conceito psicanalítico de identificação (desenvolvido por Metz, Mulvey, Heath e muitos outros) pelo de engajamento [engagement]" (STAM, 2006, p. 270, acréscimos nossos). A troca dos termos reflete uma mudança conceitual e se justifica devido ao fato de que os cognitivistas destacam a função ativa do espectador na recepção dos filmes - atividade racional em estado de alerta -, ao contrário da passiva implícita no conceito de identificação - estado regressivo do sonhar acordado.
} 
de "situação trágica por excelência", possuem potencial de elucidar princípios de construção das narrativas em estudo.

Quase todos os personagens principais dos filmes de Iñárritu apresentam, em sua configuração, variações que se encaixam na definição aristotélica da "situação trágica por excelência”. Essa situação é definida como sendo a do homem que não se distingue muito pela virtude e nem pela justiça e cai em infortúnio, não porque seja vil, mas por força de algum erro, que, nas histórias de Iñárritu, estão associados ao acaso. A piedade surge da desgraça do herói que é infeliz sem o merecer. Essa situação trágica fica evidente na construção de personagens como: Octavio (Gael Garcia Bernal), Valeria (Goya Toledo) e El Chivo (Emilio Echerría), em Amores brutos; o casal Richard Jones (Brad Pitt) e Susan (Cate Blanchett) e a empregada Amelia (Adriana Barraza), em Babel; e Uxbal (Javier Barden), em Biutiful. São personagens sem consciência de seus atos, que cometem coisas terríveis por ignorância de suas consequências. Os arcos de transformação desses personagens trágicos de Iñárritu serão analisados nos capítulos III, V e VI.

Já que os gregos foram mencionados, vale trazer à baila também o conceito de Nemesis levantado por Peter F. Parshall ao analisar a trama de Amores brutos em Altman and after (2012, p. 84). Nemesis é uma lei natural na visão grega, na qual se um mortal ou um deus viola um princípio moral, seria como se afastasse um pêndulo que inevitavelmente balançaria para trás, trazendo consequências devastadoras em reparação da violação cometida. Parshall (2012) identifica a Nemesis como um princípio orquestrador da trama de Amores brutos, mas que pode ser evidenciado também nos demais filmes de Iñárritu.

Definido o enfoque teórico cognitivista-neoformalista como norteador desta investigação e citados outros conceitos relevantes, é oportuno aprofundar a compreensão da distinção e dos pontos de contato entre o geral do narrativo e o específico do cinematográfico, à luz do que seria uma teoria realmente "do cinema", que tenha surgido no âmago de sua especificidade. Essa opção nos leva inevitavelmente às reflexões sobre a montagem, que constitui o fundamento mais específico da linguagem fílmica. De acordo com Ismail Xavier (1998; 2008), os autores que mais se destacaram ao abordar a montagem foram o teórico francês André Bazin (2014) e o cineasta russo Sergei Eisenstein (1990), e suas contribuições interessam a esta pesquisa justamente pela oposição de seus postulados. Bazin traduz a impressão de continuidade e de homogeneidade do cinema narrativo clássico com seu conceito da "transparência" da montagem. Eisenstein, por sua vez, em sintonia estética com a ideologia marxista, propõe a "montagem intelectual" com a valorização da fragmentação e do choque 
entre as imagens quando relativiza em seus ensaios que a justaposição de dois fragmentos de filme corresponde mais ao seu produto do que à sua soma.

Os ensaios seminais desses dois autores estabelecem os fundamentos para se compreender tanto a montagem narrativa, que:

consiste em reunir, numa sequência lógica ou cronológica e tendo em vista contar uma história, planos que possuem individualmente um conteúdo factual, e contribui assim para que a ação progrida do ponto de vista dramático (o encadeamento dos elementos da ação segundo uma relação de causalidade) e psicológico (a compreensão da trama pelo espectador). (MARTIN, 2007, p. 132)

Como também, a montagem expressiva:

Baseada na justaposição de planos, cujo objetivo é produzir um efeito direto e preciso pelo choque de duas imagens; neste caso, a montagem busca exprimir por si mesma um sentimento ou uma ideia; já não é mais um meio, mas um fim: longe de ter como ideal apagar-se diante da continuidade, facilitando ao máximo as ligações de um plano a outro, procura, ao contrário, produzir constantemente efeitos de ruptura no pensamento do espectador, fazê-lo saltar intelectualmente para que seja mais viva nele a influência de uma ideia expressa pelo diretor e traduzida pelo confronto de planos. (MARTIN, 2007, p. 132-133)

Repare que, nessas definições de Marcel Martin sobre as duas categorias básicas de montagem, como também em sua síntese de que "a montagem é a organização dos planos de um filme em certas condições de ordem e de duração" (MARTIN, 2007, p. 132), aparecem alguns conceitos-chave de narratologia - sequência lógica e cronológica, contar uma história, relação de causalidade, trama, ordem e duração. Esta constatação não é mera coincidência e evidencia o fato de que, para explicar como a montagem articula significado ou narra, inevitavelmente, faz-se necessário adentrar em outro campo de estudos, o da narrativa. Portanto, em cinema, montagem e narrativa são instâncias indissociáveis que, embora se diferenciem, interpenetram-se.

Este estudo assumirá uma abordagem relacional, ao colocar a montagem e a narrativa como instâncias não preexistentes a um sistema, mas que se definem justamente nas relações que estabelecem entre elas, sem ordem de prioridade ou subordinação. A relação entre a montagem e a narrativa é entendida como um efeito estruturante, uma simbiose que liga a forma do sistema total com o do fenômeno estudado, a renovação da linguagem do cinema. Para isso, elege-se, como visto anteriormente, dois fatores explicativos dentro dessa problemática multiplicidade de narrações e temporalidade não-linear - tanto pelo impacto na articulação da totalidade do sistema quanto pela capacidade desses fatores de estabelecer relações entre as 
outras instâncias constituintes da unidade de seu conjunto, como, por exemplo, as personagens e os temas das histórias.

Após essa explanação sobre os pontos de contato e de distinção entre o narrativo e o cinematográfico, e o entrelaçamento entre narrativa e montagem no cinema, faz-se necessário assinalar as limitações da teoria dominante desta pesquisa - cognitivista-neoformalista - e apresentar alternativa para sua complementação. Apesar de sua consistência, o corpo teórico cognitivista apresenta restrições que precisam ser compensadas, como bem aponta Robert Stam (2006, p. 271):

A teoria cognitivista, ao concentrar-se nos processos mentais, deve trabalhar complementarmente com métodos de maior orientação social e histórica ou, ao contrário, corre o risco de ela própria encarcerar-se, ou seja, de restringir complexos processos históricos à prisão perceptiva monódica da psique individual.

Visando ampliar o potencial analítico da teoria cognitivista com uma visão que desvende as conexões entre o cinema e as esferas social, econômica e histórica nas quais está inserido, propõe-se uma aproximação com autores da chamada "filosofia ou crítica da cultura". Essa corrente teórica é evocada para ampliar o alcance de instrumental analítico cognitivista por meio da contextualização do cinema contemporâneo e da identidade cultural mexicana no panorama da globalização pós e hipermoderno ${ }^{20}$ no Capítulo II e na análise dos filmes. A complementariedade iluminadora dessa corrente teórica à cognitivista esclarece, portanto, aspectos principalmente da relação entre forma e conteúdo do cinema de Iñárritu.

A combinação de saberes da história e teoria do cinema com outros da narratologia permite delimitar a narrativa do cinema multiplex ${ }^{21}$ e identificar as estratégias específicas aplicadas por Iñárritu na articulação de seus filmes. Esses saberes fazem parte da vertente metodológica teórico-histórica deste estudo, que proporciona arcabouço para a contextualização da narrativa de Iñárritu na contemporaneidade. No Capítulo II - “Conexões históricas e culturais dos filmes de Iñárritu" - , essa mesma vertente subsidiará o exame dos atrelamentos que

\footnotetext{
${ }^{20}$ Gilles Lipovetsky questiona a abordagem pós-modernista com o argumento de que não se tratava do fim da modernidade, mas de um novo patamar, uma "modernidade ao quadrado, superlativa", e contrapõe o conceito de hipermodernidade ao de pós-modernidade, como uma "segunda modernidade" (LIPOVETZKY e SERROY, 2009 , p. 49). "O hipercinema se caracteriza por uma fuga para frente supermultiplicada, uma escalada de todos os elementos que compõem seu universo" (LIPOVETSKY e SERROY, 2009, p. 71).

${ }^{21} \mathrm{O}$ multiplex é uma tipologia de narrativa fílmica contemporânea proposta por Gilles Lipovetsky e Jean Serroy (2009, p. 91-120), na qual a clara diferenciação entre a ação principal e as complementares foi fraturada em uma forma marcada pela não-linearidade, descontinuidade e fragmentação dos padrões de narração.
} 
as estratégias narrativas adotadas, nos filmes em questão, estabelecem com aspectos marcantes de alguns dos principais movimentos cinematográficos da história do cinema. O mesmo manancial teórico subsidia tanto o exame dos modos narrativos, que as manipulações temporais e a multiplicidade de narrações engendraram, como também a apreciação de como esses modos narrativos afetam os sentidos de seus espectadores, ao mesmo tempo em que refletem formas contemporâneas de percepção da realidade.

$\mathrm{Na}$ investigação das relações entre formas narrativas contemporâneas e suas temáticas socioeconômicas, a combinação de teoria e história do cinema com narratologia recebe o complemento fundamental dos críticos da cultura. Gilles Lipovetsky (2009) oferece valiosa contribuição para a compreensão da inserção da obra de Iñárritu em seu contexto histórico de produção e exibição. Lipovetsky também fornece conceitos vitais para a delimitação do objeto dessa pesquisa - multiplex, imagem-excesso, hipermodernidade e outros. Ideias, conceitos, noções e análises de críticos da cultura como Octavio Paz (2014), Néstor Garcia Canclini (2011) e Arjun Appadurai (1996) serão adicionados nos próximos capítulos ao se relacionar a temática dos filmes de Iñárritu ao processo de globalização e à cultura mexicana.

Apesar de existir uma produção acadêmica considerável sobre estudos do cinema, uma parcela relativamente reduzida de pesquisadores dedica-se a investigar as especificidades da narrativa do cinema contemporâneo. Uma parte significativa das investigações na área ainda concentra-se em abordagens do cinema clássico e do cinema moderno como modelos em confrontação. Apesar de esses estudos serem importantes, até mesmo indispensáveis para a compreensão do cinema atual, a adoção contemporânea de estratégias híbridas entre o clássico e o moderno quebra paradigmas e requer uma abordagem distinta.

Uma das questões-chave do processo de renovação na narrativa cinematográfica é a absorção de algumas estratégias articulatórias que foram utilizadas pelos cinemas de vanguarda da modernidade, associadas aos conceitos de cinema de arte, nas quais se rompeu a transparência do cinema clássico e evidenciaram-se as marcas da narração do diretor-autor. Algumas das estratégias narrativas das vanguardas modernistas, outrora articuladas, visando, principalmente, contestar o status quo, e direcionadas para um público restrito, continuam podendo ser utilizadas para tratar de temas sociais relevantes da atualidade, entretanto, em uma nova configuração que procura se comunicar com um público mais amplo. A relação entre a narrativa do cinema contemporâneo e algumas estratégias de vanguarda do cinema moderno será analisada a seguir. 


\subsection{Do simples ao complexo e a integração das vanguardas}

A forma dominante da narrativa clássica do cinema se conformou adequadamente a uma lógica de produção industrial em série para divertir as massas de uma sociedade de consumo. O cinema clássico, porém, ganhou novos contornos em Hollywood a partir dos anos 1980. O poder comercial da estrutura simplificada da narrativa clássica, com sua fácil assimilação pelo grande público, foi incrementado por uma gama de efeitos especiais em um ritmo frenético de ação conjugado com uma edição de som hiperenvolvente. Indiana Jones e os caçadores da arca perdida (Indiana Jones, Steven Spielberg, 1981) é o filme marco dessa nova era dos blockbusters. ${ }^{22} \mathrm{O}$ novo arranjo é composto pela alta comunicabilidade da narrativa clássica, a "imagem-simples", intensificada pelo extraordinário tratamento de sons e imagens, a "imagem-excesso", constituindo o "simplex" (LIPOVETSKY; SERROY, 2009, p. 91-92). A simplicidade deixou de ser tão simples e foi potencializada pelo excesso de sensações oferecidas por uma montagem vertiginosa de sons e imagens. Apesar de o cinema ser uma arte que exige grandes investimentos, tendo em vista que capital ser conservador e procurar minimizar os riscos de seus empreendimentos, o cinema lança-se à frente e, até mesmo, os blockbusters permitem-se certas audácias formais, mesmo que comedidas e tangenciando clichês.

Os blockbusters de super-heróis em ação são a parte mais aparente do cinema hipermoderno, com sua assombrosa pirotecnia de alta tecnologia e seu alto impacto em toda a mídia resultante de milionárias campanhas promocionais. Entretanto, essa não é a única manifestação da despadronização e complexificação dos modelos narrativos do audiovisual atualmente. Apesar de preponderantes no mercado do cinema, os filmes de grande orçamento que fazem parte dessa categoria representam apenas cerca de $2 \%$ dos títulos produzidos tanto nos Estados Unidos como em outros centros produtores importantes - França, Inglaterra e Espanha, por exemplo - ou mesmo em países emergentes como o Brasil.

A estrutura narrativa simplificada, no entanto, absorveu interferências resultantes do processo de globalização, que intensificaram o intercâmbio entre diferentes culturas por meio de movimentos migratórios, do turismo, e dos meios de comunicação de massa, principalmente após o progresso da tecnologia digital. Esse intercâmbio, por sua vez, provoca uma

22 "Termo usado em Hollywood para designar qualquer produção de larga escala de grande orçamento. Intolerância (Intolerance, D. W. Griffith, 1916) e E o vento levou (Gone with the wind, Victor Fleming, 1939) foram ambos chamados de 'blockbusters' em seu tempo. O termo, hoje, significa um filme que ganha mais de cem milhões de dólares.” (COOCK, 1990, p. 497, tradução nossa)

No original: "A term traditionally used in Hollywood to designate any large-scale, big-buget production. Intolerance (1916) and Gone with the wind (1939) were both called "blockbusters" in their day. The term now means a film that earns more than 100 million dollars.” (COOCK, 1990, p. 497) 
miscigenação cada vez mais ampla do imaginário de diferentes nações. A miscigenação promove a homogeneização e americanização dos produtos e culturas, mas também abre perspectivas opostas a essa tendência hegemônica, por meio de interações entre diferentes países. Para ilustrar as transações multinacionais de produtos audiovisuais com exemplos próximos à realidade brasileira, vale citar o número expressivo de filmes iranianos e argentinos lançados comercialmente no país nas últimas décadas. ${ }^{23} \mathrm{O}$ embate dessas forças contrárias amplia a diversidade de produtos culturais e promove o entrelaçamento de identidades.

Na hora da globalização, (...) as identidades se misturam, tornam-se voláteis, descompartimentadas e caleidoscópicas. Mesmo se a época testemunha a revitalização dos fundamentalismos religiosos e das identidades étniconacionais, o fato é que os modelos de estabilidade e de homogeneidade cedem o passo aos fluxos discordantes, a processos de cruzamento das identidades tradicionais (LIPOVETSKY; SERROY, 2009, p. 95).

Além do choque das forças antagônicas da homogeneização com o do fortalecimento das identidades culturais, resultantes do processo de globalização, há que se pensar, também, nos reflexos da crescente globalização de capitais sobre o mercado cinematográfico mundial. A esse respeito, cabe ressaltar que o cinema estadunidense continua hegemônico em quase todos os mercados do planeta, mas com participação crescente de capitais internacionais em seu financiamento. ${ }^{24}$ Houve também uma crescente internacionalização dos locais de filmagem. Centros produtores europeus tradicionais como França, Inglaterra e Alemanha, motivados por vantagens financeiras têm filmado, cada vez mais, em países do leste europeu, como na Bulgária, Polônia e Romênia. Até mesmo os grandes estúdios americanos têm atravessado a fronteira com o Canadá, ou cruzado meio mundo para filmar na Austrália e na Nova Zelândia visando melhores condições de realização e, surpreendentemente, redução de custos.

Se o acesso a capitais transnacionais financiou produções de grande vulto, a globalização também permitiu o acesso a novas tecnologias para produção de filmes de baixo orçamento. Assim, o acesso de países periféricos, com pouca tradição de produção cinematográfica, a equipamentos digitais de captação e edição de som e imagem, associado a políticas

\footnotetext{
${ }^{23}$ Aliás, em anos recentes, as cinematografias nacionais do Irã e da Argentina conquistaram o cobiçado Oscar de Melhor Filme Estrangeiro, respectivamente com: A separação (Jodaeiye Nader az Simin, Asghar Farhadi, 2011) e $O$ segredo dos seus olhos (El secreto de tu ojos, Juan José Campanella, 2009).

24 “dos 30 primeiros filmes no box-office de 2001, $32 \%$ eram sustentados por financiamentos internacionais. Os fundos alemães representam de $15 \%$ a $20 \%$ dos 15 bilhões de dólares mobilizados para o financiamento de todos os filmes dos grandes estúdios em Hollywood.” (LIPOVETSKY; SERROY, 2009, p. 24)
} 
públicas de incentivo à produção, tornou possível a participação desses países no mercado cinematográfico.

A complexidade das trocas culturais e econômicas advindas da globalização, com suas consequências sobre a forma, a temática e o modo de produção cinematográficos, trouxe desgastes consideráveis ao cinema hegemônico, o simplex, culminando na evidente perda de interesse por filmes que seguem essa tradição, conforme se verifica em segmentos expressivos de uma audiência cada vez mais diversificada. ${ }^{25}$ Nesse contexto, uma das características apontadas como responsáveis por essa redução de interesse do público é, justamente, a previsibilidade de sua estrutura narrativa.

Sob o transformador impacto das novas tecnologias digitais, não só na produção, ${ }^{26}$ mas também na disseminação de conteúdos audiovisuais, a fórmula discursiva consagrada do cinema clássico, potencializada pelo simplex, tem sido renovada justamente pela incorporação de elementos e estratégias narrativas historicamente mais relacionados ao cinema modernista de vanguarda, multifacetado e não-linear. E é exatamente no aspecto da imprevisibilidade, que esses elementos, originalmente pertencentes a outros sistemas formais, têm contribuído para a revitalização da narrativa audiovisual.

Nesse contexto, o cinema experimenta a passagem do simplex para o chamado "multiplex", categoria conceitual proposta por Lipovetsky e Serroy (2009, p. 67-68) que expressa a fusão entre multiplicidade e complexidade - a "multiplexidade", a "imagem-multiplex" - para abarcar a desregulação e complexificação formal do hipercinema. É verdade que o padrão narrativo simplex - de uma única história contada com início, meio e fim - segue hegemônico, mas tendo que conviver, cada vez mais, com narrativas mais sintonizadas com a multiplicidade e complexidade de nossos dias, até mesmo nas produções hollywoodianas. ${ }^{27}$

Dessa forma, a unidade de ação clássica, que diferia claramente a ação principal das complementares, foi estilhaçada no cinema multiplex e substituída pela narrativa do hiperci-

\footnotetext{
25 “Na era digital, com muitos canais (500 ou mais), o público se fragmentará em um grande número de públicos especializados. Sob essas circunstâncias, as maneiras de contar história também podem ser modificadas para levar em conta o padrão do desejo, pensamento e crença desses subgrupos. Nesse novo ambiente, a oportunidade de afastar-se da forma narrativa linear e experimentar com estilos narrativos é simplesmente um fato da era digital.” (DANCYGER, 2003, p. 413)

${ }^{26}$ Outro aspecto desse impacto é o de que se os produtores e diretores não ousarem experimentar novas formas de narrativas, eles correm o risco de perder parte de seu público para novos realizadores que, devido à acessibilidade das novas tecnologias, podem conseguir se estabelecer com uma produção sintonizada com a sensibilidade dessas novas audiências.

${ }^{27}$ Um exemplo claro dessa afirmação é o filme A origem (Inception, Christopher Nolan, 2010). O filme apresenta um empilhamento de vários níveis narrativos ao representar uma missão de invasão da mente de um poderoso empresário japonês usando uma técnica de espionagem industrial por meio dos sonhos.
} 
nema, marcada pela dispersão, descontinuidade e fragmentação dos padrões de narração. No discurso hipermoderno, o acessório é tão importante quanto o conflito matriz da história principal, favorecendo o caótico. O espectador, ao percorrer o trajeto errático da trama, é demandado a fazer um esforço muito mais árduo para acompanhar a narrativa do que o exigido pelo cinema clássico, tendo que decifrar os fragmentos espaço-temporais recebidos e ordená-los para entender a história.

O propósito da organização narrativa de uma parcela do cinema hipermoderno é distinto do realizado pelos cinemas de autor das décadas de 50 e 60 do século passado. A narrativa reflexiva dos autores desses movimentos de vanguarda reivindicava o status de obra de arte para o cinema em oposição aos meros produtos descartáveis do cinema comercial. Diretores como Jean Luc Godard, Michelangelo Antonioni e Pier Paolo Pasolini expressaram com profundidade questões sociais e existenciais de seu tempo que não eram contempladas pelo cinema clássico, por isso estavam interessados em quebrar tabus e polemizar contra as normas narrativas tradicionais. Eles desejavam diferenciar-se, ao veicular sua mensagem antistatus quo, e isso só era viável por meio de uma forma revolucionária. Os diretores-autores estavam dispostos a assumir até mesmo o prejuízo da fruição em massa de seus filmes por dificuldade de acesso do público às formas narrativas empregadas, em prol de seus ideais políticos e estéticos.

Por sua vez, uma parcela significativa do hipercinema transgride a narrativa clássica com uma abordagem integrativa, apesar de manter ímpetos de questionamento ou, quiçá, provocação ao establishment. Até mesmo o cinema simplex pode lançar mão de algumas estratégias enunciativas que fazem parte do repertório estilístico autoral vanguardista de desconstrução da narrativa clássica. Entretanto, quando o faz, utiliza essas estratégias retirando sua essência contestatória, convertendo-as em recursos para tornar o espetáculo fílmico mais envolvente, apenas um subterfúgio discursivo sedutor adequado à sociedade do hiperconsumo. $^{28}$

Por outro lado, alguns diretores do cinema hipermoderno, sobretudo os pertencentes à categoria multiplex, são ainda mais ousados e assumem o desafio de combinar a inspiração revolucionária engajada dos diretores modernistas com o potencial de comunicação envolvente do ferramental estético e tecnológico do cinema contemporâneo. Apesar da absorção de boa

\footnotetext{
${ }^{28}$ A apropriação e ressignificação de estilo com neutralização de conteúdo cultural contestador é comum na publicidade. Pode-se observar o uso de música de contestação do punk rock da década de 1980 para vender artigos esportivos, telefonia celular e até mesmo Coca-Cola nos dias de hoje.
} 
parte do repertório narrativo e estilístico das vanguardas por cinematografias interessadas em temas sociais e, até mesmo, por filmes com perspectivas comerciais razoavelmente amplas, segue incessante o embate entre formas hegemônicas e emergentes por meio de realizações experimentais que revigoram constantemente os campos mutantes das artes e da comunicação.

Diretores como Iñárritu radicalizam sua narrativa na busca de levar à tela questões complexas e proeminentes da sociedade atual de maneira profunda, mas com uma forma intrigante que seja também compreendida e toque a sensibilidade de um público amplo. Ao se lançarem na realização desse desafio tão arrojado, harmonizando interesses autorais, comerciais e políticos díspares, os cineastas são impelidos a promover uma intensa experimentação inovadora da narrativa cinematográfica que merece ser minuciosamente examinada.

Foi, portanto, por meio da intensificação do ritmo e da ação, bem como pelo excesso de sensações visuais e sonoras no simplex e, posteriormente, com a descontinuidade e fragmentação narrativa no multiplex, que a narrativa cinematográfica reagiu ao atual cenário comunicacional. Essas foram duas das principais estratégias narrativas que o cinema utilizou para se renovar e continuar disputando a atenção de um público cada vez mais saturado de informações e imagens.

No próximo tópico, serão apresentadas as estratégias narrativas de manipulações temporais não-lineares e multiplicidade de narrações utilizadas no cinema multiplex de Iñárritu. Essa apresentação expõe o impacto dessas estratégias no encadeamento causal da trama e procuram evidenciar seu mecanismo para promover um engajamento diferenciado da audiência por meio de uma demanda mais ativa da intelecção. Será também esboçada a conexão dessas estratégias narrativas com os conceitos de história (story, fabula) e trama (enredo, plot, syuzhet).

\subsection{Multiplicidade de narrações e não-linearidade}

Um dos aspectos marcantes das transformações experimentadas pela narrativa contemporânea é o da multiplicidade que, segundo Italo Calvino (1997, p. 117-138), configura-se como um conjunto de "redes de conexões entre os fatos, entre as pessoas, entre as coisas do mundo" (CALVINO, 1997, p. 121). Com muita propriedade, Arlindo Machado (2008, p. 238) 
faz uma conexão sintética da acepção de Calvino com o universo audiovisual dos nossos tempos:

Se for possível reduzir a uma palavra o projeto estético e semiótico que está pressuposto em grande parte da produção audiovisual mais recente, podemos dizer que se trata de uma procura sem tréguas dessa multiplicidade que exprime o modo de conhecimento do homem contemporâneo. O mundo é visto e representado como uma trama de complexidade inextricável, em que cada instante está marcado pela presença simultânea de elementos os mais heterogêneos e tudo isso ocorre num movimento vertiginoso, que torna mutantes e escorregadios todos os eventos, todos os contextos, todas as operações.

A multiplicidade não se atém aos formatos das telas, mas penetra seus limites interiores rompendo a unidade tradicional do quadro audiovisual por meio de múltiplas "janelas" simultâneas. Em uma mesma tela podem ser apresentadas, ao mesmo tempo, uma combinação de várias imagens, múltiplos sons, vozes e textos. Esse material expressivo utilizado é híbrido, tem origens diferentes (desenho, fotografia, vídeo, texto escrito em gerador de caracteres, modelo gerado em computador, etc.), migra de um meio para outro e de uma natureza para outra (pictórica, digital, fotoquímica, eletrônica). A manipulação das imagens pode chegar a um nível tal de radicalismo a ponto de cada plano ser um híbrido de natureza indeterminada, em que:

tamanha é a mistura, a sobreposição e tamanho é o empilhamento de procedimentos diversos, sejam eles antigos ou diversos, sofisticados ou elementares, tecnológicos ou artesanais. O próprio conceito de plano, importado do cinema tradicional, revela-se cada vez mais inadequado para descrever o processo organizativo das novas imagens pois em geral há sempre uma infinidade de "planos" dentro de cada tela, encavalados, superpostos, recortados uns dentro dos outros. (MACHADO, 2008, p. 240)

Essa profusão de sons e imagens, acelerada em permanente fluxo de combinação e recombinação, dissolveu as fronteiras materiais e formais entre suportes e linguagens. Parte dessas figuras mutantes em movimento são, inclusive, reciclagens de material proveniente dos meios de comunicação de massa, cujas origens se perdem na composição desse tecido discursivo complexo. Trata-se de uma estética marcada pela saturação, pelo excesso, com máxima concentração de informação em um mínimo de espaço-tempo. Lipovetsky e Serroy (2009) defendem que a "imagem-movimento" 29 e a "imagem-tempo", ${ }^{30}$ propostas por Gilles Deleuze

\footnotetext{
${ }^{29}$ Quando surgiu o cinema, a qualidade que diferenciava sua imagem das demais era o movimento. Gilles Deleuze (1983) considerou a imagem-movimento uma das duas grandes modalidades de cinema e distinguiu suas variações no cinema clássico.
} 
(1983; 2007), já não conseguem abarcar algumas das principais tendências do audiovisual contemporâneo e propõem acrescentar à taxonomia de Deleuze uma nova categoria: a "imagem-excesso", que busca fazer o espectador balançar em um fluxo de imagens-sensação e que não enfatiza seu engajamento por meio de um encadeamento racional.

Se é possível falar de hipercinema é porque ele é o do nunca bastante e do nunca demais, do sempre mais de tudo: ritmo, sexo, violência, velocidade, busca de todos os extremos, e também na multiplicação dos planos, montagem-corte, prolongamento dos filmes e saturação da faixa sonora. (LIPOVETSKY e SERROY, 2009, p. 67)

Os excessos estéticos do hipercinema relativizam um dos princípios fundantes da narrativa cinematográfica clássica que é o encadeamento de cenas em uma relação de causalidade. A justaposição das cenas de um filme orientada por princípio causal intervém na configuração das principais instâncias constitutivas da narrativa: o tempo, o espaço, as personagens e a narração. Em geral, o público está habituado com narrativas que têm uma construção linear e sente satisfação ao acompanhar o desenrolar progressivo das tramas. $\mathrm{O}$ espectador sente-se parte das histórias ao entender o que contam.

Quando um filme rompe a ordenação causal esperada e dificulta, ou, até mesmo, impede, que a audiência usufrua da "hospitalidade" que essa experiência narrativa oferece, a tendência inicial é o estranhamento. Essa reação é frequente em filmes de David Lynch como A estrada perdida (Lost highway, 1997) e Cidade dos sonhos (Mulholand drive, 2001), nos quais o diretor rompe a relação de causa e efeito entre as cenas, minando a trama ou, ainda, radicalizando as circunvoluções, a ponto de o espectador ter uma experiência quase hipnótica em sua desorientação, como, especialmente, em Império dos sonhos (Inland empire, 2006). Para esse arquiteto de labirintos, "é o mistério que faz sentido, não o sentido que faz o mistério” (LIPOVETSKY; SERROY, 2009, p. 101).

Em uma parcela crescente de filmes contemporâneos, a compreensão clara da história deixou de ser uma exigência e de significar eficiência narrativa. Até mesmo a disseminação em grande escala da cultura do divertimento do cinema de ação, com suas imagens-excesso e sua preponderância do sensorial-emocional sobre a intelecção, trouxe um estímulo involuntário às experimentações narrativas. $\mathrm{O}$ simplex cultivou no público uma sensibilidade receptiva a construções menos comprometidas em seguir o encadeamento causal. Abriram-se possibili-

\footnotetext{
${ }^{30}$ Termo proposto por Gilles Deleuze (2007) para designar a imagem do cinema pós-guerra, principalmente as relacionadas ao neorrealismo italiano e à nouvelle vague francesa, marcada por uma "ruptura dos vínculos sensório-motores", desvinculando o tempo na noção de movimento do cinema clássico.
} 
dades de se testar outros padrões narrativos que procurassem levar o espectador a vibrar para além do que está sendo narrado, como assinalam Lipovetsky e Serroy (2009, p. 101), ao comentar o cenário do audiovisual na hipermodernidade: "Não mais a direção linear da narrativa, mas uma rede complexa e multicultural na qual as pessoas se perdem numa trama feita de flashs descontínuos e impressões sucessivas”.

Alguns realizadores contemporâneos exploram os limites a que se pode chegar, ao assimilarem estratégias narrativas avessas ao cinema clássico, tais como: minar o encadeamento causal, como já citado, enevoar a distinção entre ações principais e secundárias, misturar as convenções dos gêneros, contar várias histórias simultaneamente embaralhadas no tempo e, mesmo assim, ser capaz de urdir uma narrativa envolvente e apta a expressar a complexidade da atualidade. Nessa exploração de possibilidades narrativas menos acomodadas às normas convencionais e mais ousadas na valorização de conexões sensoriais e emocionais, o cinema, de certa maneira, aproxima-se da música, que é uma arte tradicionalmente mais afeita a levar a audiência a vibrar além do sentido do que é narrado em suas composições. A valorização do sensorial e do emocional na construção das tramas acaba por engajar o espectador em um esforço de intelecção ainda mais intenso em sua compreensão.

Da problematização do objeto da pesquisa, podemos deduzir que duas das principais estratégias alternativas levantadas para revigorar a narrativa cinematográfica contemporânea estão associadas a duas instâncias: à narração, a maneira de contar a história com multiplicidade de enunciações; e ao tempo narrativo, em que ordem os acontecimentos história são apresentados pela trama. A multiplicidade faz-se presente nas narrativas contemporâneas por meio da narração de mais de uma história em um mesmo filme (multiplot) ou de histórias com vários personagens principais (multiprotagonistas), mas, também, por variações na ordenação temporal na trama. E chega-se a representações complexas da realidade por meio da combinação dessas pluralidades de narrações e multiplicidades temporais.

Vários diretores têm experimentado formas alternativas de combinar os tempos da trama e da história. Quentin Tarantino dinamizou bastante a relação entre o público e o filme quando concebeu uma noção de tempo não-linear em Pulp fiction-tempo de violência (Pulp Fiction, 1994). Outros realizadores ousaram estruturar filmes na ordem cronológica inversa, em que a trama apresenta a fábula começando com seu último evento e segue na "contramão" da linha do tempo, até o encerramento com o seu primeiro acontecimento, como em Amnésia (Amnesia, Christopher Nolan, 2000) e Irreversivel (Irreversible, Gaspar Noé, 2002). Iñárritu optou por exigir ainda mais do espectador quando montou 21 gramas (21 grams, 2003) com 
os eventos encadeados por um critério emocional de forma tão embaralhada no tempo que não se consegue detectar um padrão de ordenação das cenas, o que será analisado no Capítulo IV.

Outra variação de ruptura da linearidade por meio de manipulação temporal é a utilização do flashforward, um salto repentino à frente. O flashforward também opera nas discrepâncias advindas da dupla temporalidade da narrativa. A antecipação tem caráter provocador ao "deixar-nos vislumbrar o desfecho antes de nós captarmos todas as cadeias causais que levam a ele" (BORDWELL, 1985, p. 79, tradução nossa). ${ }^{31}$ Dessa forma, suscita a curiosidade e engaja o público no esforço de relacionar o trecho antecipado com os outros eventos da trama e ordená-lo na busca do entendimento da fábula.

Recentemente, nota-se um aumento na utilização de flashforward logo na abertura dos filmes, apresentando, de início, uma cena marcante sem, contudo, explicá-la. Um exemplo da utilização desse recurso, pertencente ao universo cultural brasileiro, é o fuzilamento do carro do Capitão Nascimento no início do filme Tropa de elite 2 - inimigo agora é outro (José Padilha, 2010). Nesse caso, em vez de mostrar uma cena inteira, antecipam-se apenas alguns planos rápidos fora de contexto.

Iñárritu abre Amores brutos com um flashforward da colisão de automóveis que é o entroncamento do filme, a única cena na qual os três protagonistas se encontram no mesmo tempo e espaço. Esse evento repete-se quatro vezes no filme, permitindo ao espectador elucidar as relações temporais das três tramas que compõem a narrativa, conforme será examinado em detalhe no Capítulo III, "A teia dos amores caninos". O procedimento de antecipação na abertura do filme pode adquirir valor ainda mais dominante na estruturação da narrativa, como fez Iñárritu em Biutiful, conforme será analisado à frente, no Capítulo VI, “Biutiful - os extremos da vida".

Nesses dois capítulos, III e VI, será aprofundada a reflexão sobre a antecipação na narrativa cinematográfica. Serão examinadas as relações que se estabelecem entre as posições dos acontecimentos na trama (plot) e seu lugar na fábula (story), baseados nas categorias de ordem, duração e frequência proposta por Gérard Genette (1980, p. 33-85) e investigadas suas conexões com outras partes e instâncias da narrativa cinematográfica. O objetivo, ao analisar a estratégia de ruptura da temporalidade e da causalidade linear por meio de uma antecipação (flashforward), é contribuir para a compreensão do potencial dinamizador da narrativa que as

\footnotetext{
${ }^{31}$ No original: "it lets us glimpse the outcome before we have grasped all the causal chains that lead up to it." (BORDWELL, 1985, p. 79)
} 
antecipações produzem ao engajar o espectador no desafio de ordenar os acontecimentos para compreender a história.

Na narrativa clássica do cinema, a aparição de um evento antes do seu lugar normal na cronologia, o flashforward, é bem menos comum do que o retorno ao passado, flashback. Gérard Genette (1980) chamou esse procedimento narrativo inverso de analepse (ana - depois -, e lepse - tornar), que tem como duas de suas funções mais frequentes a complementação de uma lacuna da intriga ou do caráter de um personagem, ou também a criação de suspense, ao atrasar a realização de certos acontecimentos. Genette (1980) propôs os termos prolepse e analepse para distinguir a terminologia da narratologia daquela empregada na análise fílmica, que utiliza as palavras flashforward e flashback.

Essencialmente, o flashback e o flashforward são igualmente constituídos por uma discrepância entre a ordem dos eventos na história e no enredo, mas desempenham funções diferentes, com impactos distintos na estrutura fílmica. O flashback, apesar de poder gerar suspense por meio do retardamento na realização de acontecimentos, tem, basicamente a função de complementar informações sobre a intriga ou os personagens. Volta-se no tempo para oferecer uma nova leitura, explicar. Por sua vez, o flashforward desempenha a função de provocar a curiosidade do espectador. Projeta-se no futuro para suscitar questionamentos de como um personagem chegou àquela situação ou o que significam aquelas imagens que não fazem sentido. Portanto, o flashback e o flashforward têm funções quase opostas: enquanto um explica e responde, o outro questiona e provoca.

O flashback foi bem mais utilizado no cinema clássico e parte do moderno, por se tratar de uma estratégia narrativa que pode ser ancorada na subjetividade dos personagens. Dessa forma, conecta-se internamente na trama, mantendo o ilusionismo da onipresença e onisciência do espectador. Por outro lado, o flashforward é um recurso que explicita uma intervenção externa direta do autor na narração e, por isso mesmo, é mais utilizado no cinema de arte moderno e contemporâneo, os quais permitem, e, até mesmo, valorizam, a intrusão autoral para "esquentar" a interação do espectador com o filme em contraposição ao realismo buscado pelo cinema clássico.

Outras estratégias, bastante utilizadas nos últimos anos para se incrementar a imprevisibilidade da narrativa, não atuam na instância temporal, mas na da narração. A que está mais em voga é a da multitrama, em que múltiplos enredos (multiplot) são abordados com o mesmo peso narrativo. Dessa forma, esses filmes contam duas, três ou mais histórias entrecruzando personagens com diferentes graus de ligação ou, mesmo, nenhuma conexão. $\mathrm{O}$ filme marco dessa tendência é Short Cuts - cenas da vida (Short Cuts, de Robert Altman, 1993), em que 
um grupo diversificado de moradores de Los Angeles se cruzam ao acaso. Apesar de o mesmo diretor já ter realizado um filme de estrutura similar quase vinte anos antes, Nashville (Nashville, Robert Altman, 1975). Entretanto, Nashville não teve o reconhecimento merecido na época de seu lançamento por ser um filme esteticamente à frente de seu tempo. Short Cuts ganhou notoriedade por estar mais sincronizado com a percepção da sociedade no momento que surgiu.

A composição em mosaico dos filmes multiplots pode oferecer uma representação multifocal de uma rua, como em Magnólia (Magnólia, de Paul Anderson, 1999); de uma cidade, ${ }^{32}$ a Cidade do México de Amores Brutos de Iñárritu; ou até mesmo de todo o planeta como em Babel, também de Iñárritu. "São filmes que traduzem a fragmentação e as novas segmentações do mundo através da heterogeneização estrutural da narrativa" (LIPOVETSKY; SERROY, 2009, p. 98). Alguns cineastas apresentaram seus filmes com múltiplas tramas de uma forma mais ousada dividindo a tela e projetando histórias diferentes simultaneamente, como em Time Code (Time Code, Mike Figgis, 2010) que repartiu a tela em quatro para exibir suas quatro tramas.

Outra variação bastante interessante da estratégia de imprimir multiplicidade à narração é, em vez de mostrar várias histórias simultâneas, apresentar apenas um enredo, só que, por diferentes pontos de vista de várias personagens principais com o mesmo peso narrativo, constituindo o multiprotagonismo. Foi como fez, por exemplo, Ang Lee (1997) ao revelar as relações afetivas entre pais e filhos de duas famílias vizinhas convivendo com o adultério em Tempestade de Gelo. Iñárritu, em 21 Gramas, também contemplou com o mesmo peso narrativo as três personagens envolvidas em uma história de vingança relacionada com um transplante de coração - o receptor do órgão, a viúva do doador e o responsável pela morte do doador - , o que será examinado detalhadamente no Capítulo IV, "21 gramas - ordem emocional entre vida e morte".

Se elementos que sustentam a legibilidade da narrativa - encadeamento causal e ordenação temporal linear - são alterados, relativizados, ou tornam-se muito complexos, como acontece com a narrativa multiplex, faz-se necessário compensar de alguma forma essas lacunas e excessos para que o espectador continue acompanhando o fluxo do discurso audiovisual. Se não há mais um único protagonista para se acompanhar da crise à resolução da trama e a relação de causa e efeito entre as cenas ficou nebulosa ou mesmo desapareceu, outros recur-

\footnotetext{
${ }^{32}$ Os exemplos são muitos: temos Los Angeles, em Crash - no limite (Crash, Paul Haggis, 2005), ganhador do Oscar de Melhor Filme em 2005; Londres, em Wonderland (Michael Winterbotton, 1999); Belo Horizonte em $O$ céu sobre os ombros (Sérgio Borges, 2009); e, Brasília, em Simples Mortais (Mauro Giuntini, 2007).
} 
sos precisam ser aplicados para manter a unidade da narrativa. O primeiro desafio é conseguir estabelecer coerência, apesar do afrouxamento ou rompimento da causalidade. A solução estruturante mais utilizada é estabelecer fios condutores - os "fios de Ariadne" do labirinto da narrativa cinematográfica multiplex - que permitam ao espectador fazer conexões e orientarse no trajeto da narrativa. ${ }^{33}$

Os fios condutores podem ter naturezas bem diferentes e origens em todas as instâncias constitutivas da narrativa. Um fio condutor pode estar relacionado com uma ação, ser um evento; pode estar ancorado no espaço, ser um lugar; ou pode ser deflagrado no tempo, pelo compartilhamento de um momento. A amarração pode se dar também pela combinação de fios condutores de naturezas distintas, ou, mesmo, ser constituído por elementos mais sutis. Como exemplo já citado no tópico anterior, Iñárritu usa a repetição de um acidente de carro como um dos principais fios condutores para orientar a fruição da narrativa em Amores Brutos, permitindo que o espectador relacione o tempo das três tramas do filme. Além desse fio condutor da batida, o Capítulo III também examina outros elementos que participam ativamente na sutura de sua narrativa.

David Bordwell (2006, p. 77-78) destaca a relevância da repetição como princípio geral para garantir a inteligibilidade na experimentação em Hollywood: "quão mais complexos são os dispositivos, mais redundante a narrativa precisa ser" 34 A repetição coloca-se como recurso indispensável no preenchimento das lacunas abertas pela flexibilização do encadeamento causal e oferece informações para que o espectador seja capaz de estabelecer as conexões necessárias para a compreensão das histórias dos filmes. A recorrência mais comum verificada é a de ações que revelam novos aspectos e perspectivas em cada reapresentação, facilitando o entendimento da narrativa como um todo. Também é usual o emprego de repetição de materiais narrativos de outra natureza, como os temas - solidão, incomunicabilidade, conflito de classes, etc. - na amarração dos vários enredos. Além da repetição, outra força aglutinadora da narrativa multiplex é o magnetismo do paralelo entre as múltiplas tramas que estimula o espectador a, constantemente, buscar associações entre personagens, objetos, situações e ideias.

\footnotetext{
${ }^{33}$ Apesar de não ter sido formulado como um conceito teórico, essa noção de "fíos condutores" é lançada por Ken Dancyger (2003). O autor afirma que "a carreira de assassinatos de Mickey e Mallory é o fio condutor de Assassinos por natureza (Natural born killers, Oliver Stone, 1994); a batalha de Guadalcanal é o fio condutor de Além da linha vermelha (The thin red line, Terrence Malick, 1998); a crise de identidade é o fio condutor de Pulp fiction - tempo de violência (1994)" (DANCYGER, 2003, p. 420).

${ }^{34}$ No original: "The more complex the devices, the more redundant the storytelling needs to be." (BORDWELL, 2006, 77-78) Tradução do autor.
} 
Acredito que, na arte, forma é conteúdo, no sentido de que sua unidade e seu significado são determinados pela intricada combinação entre feitio e teor. "O conteúdo e a expressão formam um todo. Apenas sua combinação íntima é capaz de gerar a significação" (VANOYE; GOLIOT-LÉTÉ, 1992, p. 42). Bordwell (1993) também rejeita o entendimento do conceito de forma em oposição ao de conteúdo, como se um poema, uma música ou um filme fosse um jarro (“jug”), uma forma externa que contém algo, um conteúdo. Para ele, a forma do cinema é um sistema interno que governa as relações entre as partes, não tem interior e exterior (BORDWELL; THOMPSON, 1993, p. 43).

Por sua vez, Iñárritu crê que cada história precisa encontrar sua própria forma de ser contada, sintetizando, em entrevista, a relação entre forma e essência - conteúdo - por meio de uma comparação com a maneira de servir a bebida típica de seu país:

É como outra coisa qualquer: Tequila você deve servir em um copo pequeno, porque o gosto é diferente se você servir em um copo alto; ou whisky ou champanhe: eles têm sua própria forma. E penso que, muitas vezes, a forma é intrínseca à essência da coisa. ${ }^{35}$ (IÑÁRRITU, apud LITTGER, 2006, p. 188 , informação oral, tradução nossa)

A relevância do exame minucioso da obra de Iñárritu não reside apenas na consistência com que articula algumas das estratégias narrativas mais inovadoras adotadas no cinema ficcional, mas também no fato de criar representações sobre aspectos cruciais da complexidade da sociedade atual. Em sua filmografia, destacam-se as influências do sistema econômico sobre as interações pessoais, como, por exemplo, o impacto das relações de trabalho globalizadas na existência de indivíduos comuns. Partindo do pressuposto de que o cinema é constituído por uma práxis - prática acompanhada de reflexão -, existe a oportunidade de analisar as relações entre o modo de se contar histórias no cinema e o contexto socioeconômico da contemporaneidade, que estimulam esta investigação sobre o funcionamento narrativo dos filmes em foco. Nesse sentido, visando integrar a maneira de se narrar com seu teor, a seção seguinte versa sobre o relacionamento entre forma e conteúdo nos filmes de Iñárritu, com destaque para temáticas atreladas à globalização.

\footnotetext{
${ }^{35}$ No original: "It's like everything else: Tequila you have to serve in a small glass, because the flavor is different if you serve it in a tall glass; or whiskey or champagne: they have their own form. And I think sometimes form is intrinsic to the essence of the thing." (IÑÁRRITU, apud LITTGER, 2006, p. 188, informação oral)
} 


\subsection{Forma e conteúdo na obra de Iñárritu}

Além das categorias formais apontadas anteriormente como renovadoras da linguagem do cinema, a vertente do cinema contemporâneo em exame é marcada pela incorporação de aspectos característicos do fenômeno socioeconômico da globalização, tais como: fragmentação, hibridização e fluxos de trocas transnacionais. Este estudo interessa-se também em contemplar filmes cujas temáticas associam o macro universo das transações socioeconômicas com o micro das relações afetivas entre as pessoas na atualidade. Outro aspecto levado em consideração no recorte do universo deste estudo foi a combinação de relevância artística com amplitude de receptividade dos filmes pelo público.

Acredito que, para uma apreensão perspicaz das inovações narrativas do cinema ficcional contemporâneo hegemônico, seja relevante focar uma produção que concilie interesses estéticos e temáticos, muitas vezes, considerados divergentes entre o público e a crítica. $\mathrm{O}$ cinema atual em seu "modernismo ao quadrado", parece mais afeito à conciliação entre experimentação estética com boa comunicabilidade com a audiência. Por isso, o interesse em uma parcela distinta de filmes que consegue a proeza de ser aclamada pela crítica internacional em festivais e também atinge um público amplo, mais especificamente na que se enquadra na tipologia proposta por Bordwell em seu site oficial, no artigo Lessons from Babel (2006), como "filmes de prestígio" (prestige pictures). Essa tipologia inclui títulos que, além de perseguirem o sucesso comercial dos filmes de gênero, aspiram possuir as marcas autorais notáveis dos filmes direcionados para acontecerem nos festivais internacionais, os chamados "filmes de festival" (festival films).

Baseado nesses critérios, a escolha do corpus da pesquisa recai sobre a obra do mexicano radicado nos Estados Unidos, Alejandro González Iñárritu, tanto por suas características estéticas, bem como pelas temáticas abordadas em sua filmografia e a receptividade alcançada junto à crítica especializada e ao espectador de cinema. Seus quatro primeiros filmes lançados no circuito exibidor global - Amores Brutos (2000), 21 gramas (2003), Babel (2006) e Biutiful (2010) - apresentam uma combinação singular das manipulações formais das instâncias de narração e temporais da narrativa cinematográfica, além de tratarem criticamente dos principais temas da globalização na sociedade atual: multiculturalismo, movimentos populacionais, desterritorialização e presença da mídia e da tecnociência no cotidiano; com especial sensibilidade para com a perspectiva humana das personagens que encontram-se à margem do poder instituído e mais vulneráveis nesse processo civilizatório. 
Iñárritu tece seu painel nada apologético da globalização focado nas desventuras de famílias menos favorecidas, cujos membros se encarregam de trabalhos ilícitos ou informais, como o jovem Octavio (Gael Garcia Bernal) de Amores brutos, que encontra, na rinha de cães, possibilidades de ganhos financeiros significativos. No mesmo filme, El Chivo (Emilio Echeverria), um ex-guerrilheiro revolucionário, tem como ocupação mais rentável assassinar por encomenda na megalópole Cidade do México. Em 21 gramas, Jack (Benicio Del Toro), um ex-presidiário latino, convertido e pregador, desestrutura-se ao matar acidentalmente um pai e duas filhas, perde a fé, afasta-se de sua família e retorna aos trabalhos forçados dos condenados. Imerso em uma África arcaica, uma criança pastora de cabras dá um tiro desatinado em uma turista americana, deflagrando conexões em quatro países - Marrocos, Estados Unidos, México e Japão - em Babel. O incidente do disparo leva à extradição, dos Estados Unidos, de uma empregada doméstica mexicana, Amelia (Adriana Barraza), por ter atravessado ilegalmente a fronteira com o México para assistir ao casamento de seu filho, levando consigo o casal de crianças de seus patrões americanos. Em Biutiful, o até bem intencionado Uxbal (Javier Barden) ganha seu sustento explorando africanos no comércio e intermediando trabalho escravo de chineses em Barcelona.

Apesar das similaridades na utilização de multiplicidade de protagonistas e enredos e manipulações temporais em sua obra, cada um dos filmes possui sua maneira específica de ser contado. Os três primeiros filmes de Iñárritu (Amores brutos, 21 Gramas e Babel) são estruturados em torno de um evento acidental, cujos efeitos se ramificam em direções diferentes ao tecer uma tapeçaria humana de vidas independentes, mas interligadas. Celestino Deleyto e María del Mar Azcona (2010, p. 20, tradução nossa) destacam que :

$\mathrm{O}$ acaso se caracteriza não apenas como um dispositivo deflagrador que faz vidas separadas afetarem umas às outras de formas inesperadas, mas também como um elemento temático importante que paira sobre os padrões da narrativa fragmentada dos filmes. Em vez de simplesmente um receptáculo para a história, a forma torna-se uma parte intrínseca dela. ${ }^{36}$

A trilogia inicial de Iñárritu (Amores brutos, 21 Gramas e Babel) enquadra-se no modo narrativo definido por Bordwell $(2006 ; 2008)$ como "narrativa de rede" (network narrative), que engloba filmes nos quais encontros acidentais de diferentes tipos, ao acaso, engatilham conexões inesperadas entre personagens não relacionadas conformando uma rede

\footnotetext{
${ }^{36}$ No original: "Random chance features in them not only as a triggering device that makes separate lives affect one another in unexpected ways but as a major thematic element looming over the film's fragmented narrative patern. Rather than simply a vessel for the story, the form becomes an intrinsic part of it." (DELEYTO; AZCONA, 2010, p. 20)
} 
complexa de relações diretas e indiretas (2008, p. 189-250; 2006, p. 72-103). "Em todos os filmes de Iñárritu, essas conexões são estabelecidas por meio da violência, sugerindo como ela permeia a cultura humana, com ações descuidadas de uma pessoa impactando muitas outras" (PARSHAL, 2012, p. 73, tradução nossa.). ${ }^{37}$ Intersecções ao acaso - acidentes de carro em Amores brutos e 21 Gramas, e um tiro em Babel - possuem muita relevância na estruturação das tramas e evidenciam a proeminência da narração ao orquestrar manipulações temporais e variações na perspectiva das personagens. A narração dos filmes em análise enfatiza a centralidade do acaso na construção dessas narrativas de rede que se ambientam em grandes cidades como lugares privilegiados para enredar suas múltiplas tramas.

Inárritu é o cineasta que imprimiu com mais consistência na tela diversos aspectos e impactos da globalização na sociedade. Babel apresenta um amplo mosaico que revela as ligações sociais, políticas, econômicas e afetivas da nossa "aldeia global" (MCLUHAN; FIORE, 1968). Em sua textura rizomática, um tiro detona atrelamentos em três continentes África, América e Ásia. Uma turista americana é alvejada acidentalmente por uma criança de Marrocos, com um arma presenteada por um japonês e tem seus filhos levados pela empregada mexicana a cruzar a fronteira entre os Estados Unidos e seu país natal.

Embora Babel seja o filme mais emblemático da presença da globalização na obra de Iñárritu, outros aspectos desse amplo fenômeno também estão presentes em todas as suas outras películas. O mundo cão dos bairros pobres da Cidade do México, onde vagam Octavio e El Chivo em Amores brutos, choca-se literalmente em uma batida de carros com o "mundinho" efêmero e descartável da moda e das celebridades midiáticas da modelo espanhola Valeria e de seu amante Daniel, editor de uma grande revista. O contraste entre o universo de pobreza e violência de dois dos três enredos do filme com um terceiro, marcado pela riqueza e frivolidade, espelha as desigualdades marcantes nos grandes centros urbanos globalizados, onde esses extremos interagem caoticamente. O acesso ao consumo de bens e serviços de luxo não garante a segurança dos afortunados que usufruem de suas benesses, e tudo pode se perder a qualquer instante em um lance do acaso ou a intervenção de alguma ação criminosa.

Em Biutiful, Iñárritu aborda a problemática da ilegalidade do trabalho gerada pelos fluxos migratórios de populações em busca de melhores condições de vida na Europa. Seu personagem principal, Uxbal, um nativo espanhol, ganha o sustento intermediando o trabalho escravo de chineses e explorando africanos no comércio informal em Barcelona, Espanha. Nessa megalópole europeia, os contrários também convivem lado a lado, com trocas violentas

\footnotetext{
${ }^{37}$ No original: "In all Iñárritu's films this connection is established through violence, suggesting how it permeates human culture, with careless actions by one person impacting many others.” (PARSHAL, 2012, p. 73)
} 
como na Cidade do México de Amores brutos. Entretanto, em Biutiful, Iñárritu mostra que, apesar dos conflitos que existem entre os mais bem afortunados e os marginalizados do poder econômico, há uma interdependência cruel entre eles, uns precisam dos outros.

Por sua vez, 21 gramas urde uma imbricada trama de vingança na qual dois personagens em melhor posição na escala social - a viúva de classe média alta Cristina (Naomi Watts) e seu amante, o professor universitário Paul (Sean Penn) que vive com o coração transplantado do ex-marido de Cristina - unem-se para matar o pobre coitado Jack (Benício del Toro) que desgraçou a própria vida ao atropelar e matar as filhas e marido de Cristina. Essa história inusitada e saturada do excesso retórico do cinema mexicano tem como pano de fundo um tema muito valorizado na contemporaneidade globalizada: a interferência da tecnociência na existência humana. A trama mostra dilemas sobre a vida e a morte gerados pelas possibilidades intervencionistas da medicina atual. O filme explora, além do enredo de vingança, as consequências afetivas e questões morais e éticas relacionadas com o transplante de coração, a inseminação artificial e a postergação da morte por meio da medicina. O próprio título do filme não deixa de ser um irônico questionamento da capacidade da ciência na compreensão da existência.

Distingo Iñárritu como principal autor dos filmes em análise, por ser um diretor que se coloca como força vital proeminente, ao deixar evidente suas marcas autorais e estabelecer unidade nos e entre os filmes que realizou. Entretanto, é preciso apontar as relevantes contribuições artísticas e coautorais de seus habituais colaboradores: o diretor de fotografia Rodrigo Prieto, o compositor musical Gustavo Santaolalla, o técnico de som Martín Hernández, a produtora Brigitte Broch, e o montador Stephen Mirrione. É imperativo destacar como fundamental a colaboração do roteirista Guillermo Arriaga no desenvolvimento da narrativa de sua trilogia inicial (Amores brutos, 21 gramas e Babel). Apesar de Arriaga ter entrado em litígio e rompido sua relação de trabalho com Iñárritu justamente por pleitear assinar como coautor dos filmes que fizeram juntos, o que não foi admitido por Iñárritu, levando o roteirista a tornar-se também diretor. ${ }^{38}$ Por sua vez, Iñárritu assina o roteiro de seu quarto filme, Biuti$f u l$, junto com Armando Bo e Nicolás Giacobone e, apesar de algumas diferenças formais e estruturais em relação aos três primeiros títulos, mantém clara unidade da obra como um todo. Embora seja acentuado o aporte coautoral de seus parceiros, a pesquisa apenas se referirá a

\footnotetext{
${ }^{38}$ Depois do rompimento com Iñárritu, Arriaga assinou o roteiro junto com o diretor em $O$ búfalo da noite (El búfalo de la noche, Jorge Hernandez Adana, 2007); escreveu e dirigiu Vidas que se cruzam (The burning plain, 2008); escreveu e dirigiu episódios em dois filmes coletivos (Words with gods, episódio La sangre de dios, 2014) e (Rio eu te amo, episódio Texas, 2014); e escreveu e dirigiu dois curtas, Broken night (2013) e El pozo (2010).
} 
Iñárritu como autor da obra em questão posto que, devido aos objetivos do estudo, não acrescenta explorar especificamente o processo de colaboração entre eles e o diretor na tessitura da narrativa dos filmes.

Até aqui, procurou-se contextualizar as principais características formais e temáticas da obra de Iñárritu na contemporaneidade e justificar a pertinência de sua análise para compreensão da renovação do cinema contemporâneo principalmente por meio da vertente teórico-histórica deste estudo. A próxima seção focaliza, então, outra perspectiva conceitual que integra esta investigação: a empírico-analítica, na qual definem-se as abordagens aplicadas nas análises das narrativas cinematográficas em questão e expõem-se os procedimentos metodológicos que serão utilizados.

É importante ressaltar que essas duas vertentes metodológicas - teórico-histórica e empírico-analítica - não são abordadas de maneira estanque e se interpenetram no decorrer da investigação. Apesar da predominância da abordagem teórico-histórica de estratégias narrativas e temas da contemporaneidade na fundamentação teórica do estudo, o empírico-analítico fez-se presente no exame de sequências e estruturas dos filmes em foco. No Capítulo II, envida-se um esforço de historicização dos principais aspectos da narrativa cinematográfica em questão e as análises fílmicas serão permeadas com teorias do cinema e conceitos da crítica da cultura. Nos Capítulos III, IV, V e VI, ao se tratar das estratégias da narrativa dos filmes de Iñárritu e se examinarem as conexões do mundo diegético ${ }^{39}$ da história com a contemporaneidade, também entrelaçaram-se as abordagens empírico-analítica e teórico-histórica. $\mathrm{O}$ entrelaçamento dessas duas perspectivas metodológicas possibilita a investigação, em seu desenvolvimento e conclusão, bem como, permite relacionar a multiplicidade, fragmentação e complexidade das narrativas cinematográficas de Iñarritu com elementos da globalização e traços da cultura mexicana.

\subsection{Perspectivas analíticas}

A vertente empírico-analítica desta investigação adota a análise fílmica como seu principal aporte metodológico, na busca da compreensão da organização dos materiais narra-

\footnotetext{
39 “Para Étienne Souriau, os 'fatos diegéticos' são aqueles relativos à história representada na tela, relativos à apresentação em projeção diante dos espectadores. É diegético tudo o que supostamente se passa conforme a ficção que o filme apresenta, tudo o que essa ficção implicaria se fosse supostamente verdadeira." (AUMONT, MARIE, 2003, p. 77
} 
tivos nos quatro filmes de Iñárritu lançados comercialmente no Brasil até dezembro de 2014: Amores Brutos (2000), 21 gramas (2003), Babel (2006) e Biutiful (2010). As análises não se limitaram ao discurso fílmico e abrangem elementos anteriores ou posteriores à difusão dos filmes, tais como, making of, entrevistas, críticas ou quaisquer outras informações extrafílmicas que trouxessem contribuições relevantes para os objetivos do estudo. A investigação contempla tanto a forma como o conteúdo das narrativas visando a apreensão do estado histórico de sua linguagem cinematográfica.

Não existe uma metodologia única para se fazer análise fílmica. Todavia, é possível estabelecer conceitualmente as fundações desse processo analítico que consiste na desconstrução descritiva e na reconstrução interpretativa. Estabelecidas essas fundações, torna-se viável conceber análises em diferentes níveis - forma, conteúdo e relação de sons e imagens para contemplar a narrativa cinematográfica como processo, representação e estrutura.

Os teóricos cognitivistas-neoformalistas, em vez de proporem uma metodologia geral e universal para a análise fílmica, defendem que se deve "inventar" um método adequado para cada estudo proposto. Nessa "invenção", analisar um filme é procurar sua dominante estilística, no fundo, interpretá-lo relacionando aspectos formais e temáticos. Os adeptos dessa corrente acreditam que o conjunto dos conceitos formalistas ligados à história dos estilos preserva suas análises da arbitrariedade.

A proposta metodológica aqui desenvolvida é a de executar os mesmos procedimentos analíticos nos quatro filmes de Iñárritu, entretanto, respeitando, identificando e ressaltando suas especificidades estéticas, temáticas e narrativas. O método adotado visa evidenciar, e não dissimular, as variantes narrativas presentes nos filmes em estudo. Esse posicionamento baseia-se na convicção de que as variações são tão elucidativas para os objetivos pactuados no projeto quanto suas semelhanças. Se por um lado, as semelhanças estruturais e estilísticas nas narrativas dos filmes de Iñárritu, com multiplicidade de narrações e manipulações temporais, constituem marcas autorais reconhecíveis; por outro, suas variações configuram um repertório diversificado que não compromete a coerência de sua obra como um todo.

Os quatro filmes em análise apresentam ordenação temporal não-linear, mas cada um organizado a sua maneira: fragmentação em episódios permeáveis em Amores brutos; ordenação emocional errática em 21 gramas; falsa simultaneidade em Babel; e valorização do flashforward na estruturação de Biutiful. Observa-se nesse conjunto de filmes a ocorrência de três padrões de multiplicidade de narrações e personagens: vários enredos com similar relevância na narrativa (multiplot) - Amores Brutos e Babel; um único enredo com múltiplos personagens principais (multiprotagonismo) - 21 Gramas; e um único enredo com apenas um 
protagonista com múltiplos subplots - Biutiful. A multiplicidade de narrações dos filmes é associada com distintas ordenações temporais não-lineares ao enredar a complexidade das relações sociais e existenciais da contemporaneidade globalizada.

O processo analítico dos filmes foi efetuado em três níveis: o formal, o temático e o relacional; e aborda suas narrativas como processo, representação e estrutura. A narrativa foi predominantemente abordada como processo, em que a atividade de selecionar, arranjar e apresentar o material da história, visa atingir efeitos específicos no receptor, conforme concepção proposta por David Bordwell (1985, introdução p. xi). De acordo com essa visão, a história quase nunca é toda apresentada na tela materialmente, e sim adivinhada, por meio de deduções e inferências. A história é resultante do processo de pegar pistas, aplicar esquemas, formular e testar hipóteses.

Em um primeiro estágio, as análises privilegiaram o exame formal da combinação de estratégias que operam sobre as instâncias narrativas das personagens, da narração, e do tempo: multiplicidade de enredos (multiplot) e de protagonistas de mesmo peso dramático (multiprotagonismo), e ordenação temporal não-linear. Para tanto, foi utilizado instrumental analítico cognitivista-neoformalista conjugado com as categorias propostas por Gérard Genette (1980, p. 33-160), ao mapear como as relações temporais podem ser representadas na narrativa - ordem, duração e frequência.

Como em todas as produções de significado, não é possível dissociar forma de conteúdo. Bordwell e Thompson (1993, p. 43, tradução nossa) propõem uma relação integrativa entre esses "materiais" narrativos e ressaltam a relevância de se analisarem os assuntos abordados respeitando seu significado dentro dos limites da obra:

temática e ideias abstratas entram no sistema total das obras de arte. Elas podem despertar certas expectativas ou traçar inferências. O observador relaciona esses elementos entre si e faz com que interajam dinamicamente. Consequentemente, os temas e ideias se tornam algo diferente do que podem ser fora da obra." $" 40$

A abordagem analítica, inicialmente focada na expressão, em um segundo movimento, foi complementada por outra, que ressalta o conteúdo, designada como temática. Um dos principais temas que perpassa toda a obra de Iñárritu é o impacto da globalização nas rela-

\footnotetext{
${ }^{40}$ No original: "subject matter and abstract ideas all enter into the total system of artwork. They may cue us to certain expectations or draw inferences. The perceiver relates such elements to one another and makes them interact dynamically. Consequently, subject matter and ideas become somewhat different from what they might be outside the work." (BORDWELL e THOMPSON, 1993, p. 43)
} 
ções humanas na atualidade, que teve seus elementos constitutivos identificados e relacionados com a maneira com que são narrados. Para cobrir esse campo, foi evocada a contribuição dos chamados críticos ou filósofos da cultura - Lipovetsky (2009), Appadurai (1996), Canclini (2011), Paz (2014), entre outros. Isso, com o objetivo de efetuar-se a decomposição e explanação sócio-histórica das temáticas das narrações em estudo, tais como: as conexões entre as relações socioeconômicas globalizadas e as interações pessoais; presença da mídia e da tecnociência no cotidiano; movimentos populacionais entre países em busca de melhores condições de vida; e o papel do acaso na trajetória social e existencial das pessoas.

Durante a pesquisa, ocasionalmente foi também necessário acercar-se da narrativa como estrutura e analisar a função das partes na construção do todo. Analisar, na acepção científica do termo, significa decompor um objeto em seus elementos constitutivos. Analisar um filme, portanto:

É despedaçar, descosturar, desunir, extrair, separar, destacar e denominar materiais que não se percebem isoladamente 'a olho nu', uma vez que o filme é tomado pela totalidade. Parte-se portanto, do texto fílmico para "desconstruí-lo" e obter um conjunto de elementos distintivos do próprio filme. (VANOYE e GOLIOT-LÉTÉ, 2008, p. 15)

A fase de desconstrução caracteriza-se pela descrição das partes que compõem os filmes e transposição do filme para a palavra escrita. Jaques Aumont e Michel Marie, em $A$ Análise do Filme (2009), defendem que o grau de detalhamento da desconstrução dos filmes no processo de análise depende das necessidades e objetivos da investigação. Neste estudo, como a análise esmiuça os elementos constitutivos da multiplicidade das narrações e da ordenação temporal, a descrição dos filmes teve, majoritariamente, de se ater à segmentação e, esporadicamente, chegar à planificação - decomposição que desce ao nível do plano, unidade mínima da narrativa cinematográfica. A decomposição dos filmes até unidades com funções dramáticas, sequências ou cenas, atendeu às necessidades gerais da averiguação da macroestrutura das narrativas.

Apenas em fragmentos selecionados dos filmes, como exceção justificada, foi necessário chegar a uma desconstrução plano a plano e examinar a micro estrutura das cenas. A planificação se justifica quando foi inevitável operar no nível relacional das articulações entre sons e imagens, para se remeter aos conceitos e categorias mais amplas da narrativa cinematográfica em exame. Para não tornar as análises intermináveis, esse recurso foi utilizado com parcimônia nos casos em que foi indispensável a análise da microestruturação de cenas para o entendimento das relações que estabelecem com a macrocomposição da narrativa, a articula- 
ção entre cenas e sequências na construção do todo. Como, por exemplo, na análise das relações entre sons e imagens nas cenas de abertura em flashforward de Amores brutos (ver Capítulo III) e Biutiful (ver Capítulo VI) e as conexões que estabelecem na orquestração da narrativa como um todo.

Em um primeiro momento, a investigação enfoca a organização formal ao destrinchar a complexidade das narrativas fílmicas em exame operando em três movimentos distintos: (i) exame da multiplicidade de personagens e enredos, (ii) investigação da organização temporal, para, em seguida, (iii) conjugar análises de três das instâncias narrativas envolvidas - personagens, narrações e tempo. A quarta instância da narrativa, o espaço, também é abordado nas análises, mas de forma complementar, pois tem menor peso na conformação da dominante estilística dos filmes em estudo. Para tanto, os filmes foram segmentados em cenas e sequências para se traçar a estrutura narrativa de cada um deles, por meio de um esquema e revelar a diversidade narrativa de Iñárritu. Estas segmentações foram vitais para compreensão das formas dos filmes em estudo e são apresentadas como escaletas e esquemas nos apêndices.

Delineadas as estruturas sequenciais das narrativas dos filmes, fez-se necessário analisar a ordenação temporal não-linear dos mesmos. Para tanto, recorreu-se ao conceito da dupla temporalidade da narrativa. Há o tempo da história (fabula, story) dos acontecimentos relatados, e o tempo da trama (syuzhet, plot), que advém do próprio ato de contar. Nesse contexto, a enunciação da história, a trama (plot), tem uma temporalidade específica, distinta da temporalidade da própria história (story), constituindo uma anacronia (do grego, ana, contra, e cronos, tempo).

Embora esses dois eixos, história (story) e trama (plot), dificilmente coincidam, é possível relacioná-los por meio das seguintes categorias: ordem, que confronta a sucessão dos acontecimentos supostos pela diegese à ordem de aparição da narrativa; duração, que compara o tempo que esses acontecimentos supostamente deveriam ter na diegese e o tempo que leva para contá-los; e frequência, em que se observa o número de vezes que um determinado acontecimento é evocado pela narrativa, em relação ao número de vezes em que deveria intervir na diegese. ${ }^{41}$ Em que pese a relevância da ordenação temporal na compreensão do sentido da obra em exame, recorremos também às categorias de duração e frequência quando foi necessário complementar a análise, o que será exemplificado pelos filmes em seguida.

Em Amores Brutos, três histórias compartilham um mesmo evento, uma batida de carros. Os enredos são apresentados em capítulos identificados com subtítulos em caracteres e

\footnotetext{
${ }^{41}$ Estas categorias de ordem, duração e frequência foram propostas por Genette (1980, p. 33-160).
} 
demarcados por pontuações de escurecimento da tela (fade in e fade out) em seus inícios e finais. As repetições do acidente nos três capítulos, associadas a eventuais intromissões de um enredo nos demais, oferecem indícios para a ordenação temporal da história como um todo. Por apresentar as características descritas acima, denominei a ordenação temporal desse filme como episódica devido à preponderância da repetição de um episódio em sua definição. $\mathrm{Na}$ análise de Amores brutos (Capítulo III), ao se examinar o evento chave que permite ao espectador compreender a ordenação temporal de suas histórias - a batida de automóveis que envolve seus três protagonistas -, é imperativo se recorrer também às categorias da frequência e duração posto que a colisão é repetida quatro vezes no filme com montagens bem diferenciadas, inclusive quanto ao tempo em que a cena fica em tela.

21 Gramas apresenta a cronologia não-linear mais radical do universo em estudo. $\mathrm{O}$ filme narra seu único enredo (uniplot), oscilando entre as ações de seus três personagens principais com o mesmo peso dramatúrgico (multiprotagonismo). A ordenação temporal da trama embaralha os acontecimentos erraticamente, estilhaçando o encadeamento causal, de acordo com um critério subjetivo do diretor de amarrar os fragmentos das histórias, conforme suas cargas emocionais. Apesar de seu alto grau de imprevisibilidade, a organização da narrativa permite ao espectador presumir razoavelmente sua ordenação temporal, embora não seja possível definir um padrão de sua arrumação temporal durante a fruição do filme. Somente uma análise minuciosa é capaz de desvendar e delinear a "arquitetura" dessa organização temporal tão complexa, o que foi empreendido no Capítulo IV.

Por sua vez, em Babel, um tiro deflagra conexões em quatro pontos diferentes da Terra. Os quatro enredos do filme são expostos alternadamente, sem as delimitações de episódios presentes em Amores Brutos. A narração alterna-se ciclicamente entre os quatro dramas: do marido que tenta salvar a esposa que foi alvejada enquanto faziam turismo no Marrocos; da perseguição e morte do irmão da criança pastora de cabras que atirou no ônibus turístico; da travessia atrapalhada da fronteira entre os Estados Unidos e o México cometida pela empregada acompanhada pelos filhos do casal americano vítima do disparo; e do policial, no Japão, que averigua um caçador viúvo que teria fornecido a arma do crime aos pastores do Marrocos, e acaba se envolvendo com a filha adolescente do viúvo que é surda e traumatizada pelo suicídio da mãe. Nomeei o padrão da organização narrativa desse filme como cíclico, porque intercala blocos de sequências de suas histórias como ciclos, conforme será investigado no capítulo V.

Em Biutiful, a sequência final é antecipada na abertura do filme em flashforward, um salto repentino, brusco, à frente. Esse recurso tem um impacto tão forte na disposição da nar- 
rativa que chamei de flashforward estruturante. Entre a abertura antecipada e sua reapresentação justamente no encerramento do filme, a narrativa transcorre linearmente. O Capítulo VI deste trabalho apresenta a análise desse filme levando em consideração principalmente o impacto dessa forma de narrar no universo do diretor em estudo.

Biutiful oferece apenas um enredo com um único protagonista ao tratar da degradação da família, da solidão e da morte. Apesar da ausência de multiplicidade de enredos e protagonistas no filme, justifica-se sua manutenção no recorte a ser analisado devido à multiplicidade de subplots e ao seu diferencial sui generis na ordenação temporal, que utiliza o flashforward estruturante. Além disso, o filme também agrega valor à averiguação por encampar entre seus temas as relações humanas advindas do movimento de populações em busca de melhores condições de trabalho no contexto da globalização. Ao retratar esse tipo de migração, o filme amplia as perspectivas humanistas na abordagem de um dos temas mais relevantes na obra de Iñárritu: as interferências das relações socioeconômicas nas interações pessoais. O quarto filme de Iñárritu também leva o efeito avassalador da nemesis e o desenvolvimento do arco de transformação do herói trágico aristotélico a novos territórios ao incluir representações imagéticas de espíritos e ações de personagens após suas mortes.

Depois da fase de desconstrução, fez-se preciso percorrer o trajeto no sentido inverso, reconstituir o filme por meio da especulação de como esses elementos que foram isolados e identificados se conectam e se articulam para fazer surgir um todo significante. A reconstrução analítica corresponde à interpretação, um movimento de retorno à unidade do filme e não uma extrapolação com relação a ele.

Como camada analítica adicional dessa metodologia proposta, e nem por isso menos relevante no cômputo geral da pesquisa, almeja-se identificar e apurar a dinâmica de seus fios condutores. Trata-se dos fios estruturantes, as linhas invisíveis de sutura que restauram a coerência e asseguram a legibilidade dessa tipologia de cinema marcada pelo afrouxamento da causalidade devido à fragmentação da multiplicidade e ao entrelaçamento da não-linearidade.

As análises fílmicas contemporâneas tendem a não distinguir explicitamente as fases de desconstrução e reconstrução. Normalmente, alterna-se entre elas, tendo em vista que são complementares e o texto fica mais dinâmico com a combinação de trechos descritivos intercalados com interpretativos. Essa tendência mista foi adotada no trabalho objetivando explicar o funcionamento narrativo próprio de cada filme. Procurei, nos Capítulos de III a VI, combinar harmonicamente a análise da forma com a temática dos filmes visando uma compreensão mais ampla do estado histórico da linguagem cinematográfica em questão. 
Antes, porém, as principais inovações narrativas urdidas na filmografia em foco foram colocadas em perspectiva no Capítulo II, "Conexões históricas e culturais da obra e Iñárritu”, em que é empreendido um esforço em relacionar sua obra com: o afrouxamento da causalidade experimentado por diversos movimentos cinematográficos da modernidade; a utilização de estruturas com multiplicidade de narrações em diferentes momentos do cinema mundial e mexicano; e com a influência da interface cultural informática na narrativa audiovisual. A proposta é de contextualizar a filmografia de Iñárritu em uma linha evolutiva da linguagem do cinema visando ressaltar as conexões que se estabelecem com os modos narrativos do cinema clássico, moderno e contemporâneo. 


\title{
Capítulo II
}

\section{CONEXõES HISTÓRICAS E CULTURAIS \\ DA NARRATIVA DE IÑÁRRITU}

\begin{abstract}
$\mathrm{O}$ estudo proposto coloca o desafio da análise de artifícios narrativos em uma filmografia contemporânea que foi experimentada como presente social, cultural e cinematográfico. A proximidade com o objeto de pesquisa, a pro-
\end{abstract} dução de um cineasta realizada na primeira década do século XXI, requer um esforço de sistematização e afastamento crítico no processo investigativo que permita uma ampliação e um aprofundamento da vivência e do conhecimento já experimentados. O primeiro passo indispensável nesse sentido foi definir o período histórico em que se insere a obra de Iñárritu, o cinema contemporâneo. Para tanto, não se adota um filme como marco histórico inaugural desse período da história do cinema. Em lugar dessa abordagem pontual, opto por acompanhar a definição mais abrangente proposta por Mauro Baptista e Fernando Mascarello (2011) em Cinema Mundial Contemporâneo, na qual os autores localizam as balizas históricas fundadoras do cinema contemporâneo em fenômenos coincidentes que ocorrem em fins da década de 1970 e na de 1980 :

a diluição das cinematografias modernas dos anos 1960 e 1970; a emergência dos cinemas pós-modernos e maneiristas (por exemplo, Almodovar [...]) e dos pós-clássicos ${ }^{43}$ (Cameron, Eastwood); o surgimento de uma 'Nova Hollywood', ${ }^{44}$ fundada no filme blockbuster high concept; ${ }^{45}$ e a reinvenção

\footnotetext{
${ }^{43}$ Pós-clássico seria uma ultrapassagem do classicismo cinematográfico americano.

44 “O termo "Nova Hollywood" foi inicialmente relacionado ao American Art Film do final dos anos 1960 e início dos anos 1970, movimento de cineastas dos Estados Unidos que se afastaram do cinema clássico e aproximaram-se das propostas estéticas dos modernistas europeus, tais como Robert Altman, Martin Scorsese, Francis Ford Coppola e outros. Em um segundo momento, o termo passa a designar a produção mainstream pós-1975 marcada por blockbusters como Tubarão (Jaw, Steven Spielberg, 1975) e Guerra nas estrelas (Star wars, George Lucas, 1977), caracterizando o esvaziamento do cinema de arte americano, o abandono da narrativa típica do filme hollywoodiano praticada até a década de 1960 e por assumir uma posição de destaque na integrada cadeia de produção e consumo midiática.” (MASCARELLO, 2006, p. 336)
} 
do legado dos cinemas modernos e a perda das fronteiras entre o moderno e o clássico, presentes no cinema contemporâneo de autores como Ken Loach, Mike Leigh, Lucrecia Martel, Wong Kar Wai [...] Zhang Yimou, Jia Zhangke, Eduardo Coutinho, Michel Haneke, Lars Von Trier, Abbas Kiarostami, Quentin Tarantino e David Lynch. (BAPTISTA; MASCARELLO, 2011, p. 14)

Exposta a definição de cinema contemporâneo adotada nesta pesquisa, o passo seguinte requer a abordagem de outro conceito relevante para a investigação proposta, o de cinema independente americano. Apesar de Babel, por exemplo, ter sido distribuído em territórios de língua inglesa por um dos maiores estúdios norte-americanos, Paramount, Iñárritu não se considera parte do cinema hollywoodiano, mas se coloca como integrante do cinema independente. O diretor mexicano radicado nos Estados Unidos justifica sua inserção nessa categoria alegando que desenvolveu seus projetos com total liberdade e buscou formas variadas de financiamento, inclusive com vendas antecipadas para diversos países, e que essa diversificação teria contribuído para a manutenção do controle sobre sua produção. Do ponto de vista de Iñárritu, a ideia de independência no cinema advém do processo de realização:

Eu concebi, escrevi ou desenvolvi cada um dos meus roteiros por um par de anos sem ninguém por perto e depois custeei a pesquisa, chequei as locações, e escolhi o elenco dos filmes. Em seguida, apresentava o projeto a diversos potenciais investidores dizendo, 'Esse é o roteiro, esse é o elenco e esse são os custos... Vocês estão interessados?' Nem uma palavra pode ser alterada por contrato e tenho controle sobre o corte final desde meu primeiro filme. ${ }^{46}$ (IÑÁRRITU, 2009, apud DELEYTO; ASCONA, 2010, p. 123, informação oral, tradução nossa)

Os filmes de Iñárritu foram realizados em associação com grandes corporações midiáticas - Amores brutos, com Altavista Films; 21 gramas, com Focus Features; Babel, com Paramount; e Biutiful, com Focus Features e Universal Pictures $-{ }^{47}$ com as quais ele reafirma

\footnotetext{
45 “High concept é o termo adotado para definir a formatação dos filmes que se submetem às pressões do econômico sobre o estético, rompendo com o cinema clássico e assimilando modificações de estilo, narrativa e tratamento temático visando contemplar as demandas das novas estratégias de marketing e venda ao longo de uma cadeia midiática integrada horizontalmente do circuito exibidor das salas de cinema até o dos negócios conexos (jogos eletrônicos, parques temáticos, brinquedos, etc.)”. (MASCARELLO, 2006, 336-337)

${ }^{46}$ No original: "I've conceived, written, or developed each of my scripts for a couple of years with no one around, and then I've financed the research, scouted the locations, and cast the films by myself. Then I would present it to different possible backers saying, 'This is the script, this is the cast, this is the cost... Are you interest?' Not a word can be changed by contract, and I had final cut since my first film." (IÑÁRRITU, 2009, apud DELEYTO; ASCONA, 2010, p. 123).

${ }^{47}$ A Altavista é uma empresa mexicana que se iniciou na atividade cinematográfica como distribuidora e passou a fazer produções e coproduções com outros países. Amores brutos foi sua primeira e mais bem sucedida produção. Outro filme da Altavista que alcançou boa circulação foi a comédia Nicotina (Hugo Rodríguez, 2003), coprodução entre México, Argentina e Espanha. A Focus Features é uma divisão de cinema da NBC e Universal
} 
sua posição de autonomia da seguinte maneira: "Considero-me um cineasta independente e, quando eu trabalho com uma empresa, gosto de trabalhar com, não para, isso porque, dessa forma, o único beneficiado é o próprio filme" (IÑÁRRITU, 2003, apud WOOD, 2006, p. 123, informação oral, tradução nossa). ${ }^{48}$

Dada a ambiguidade quase contraditória entre o posicionamento de Iñárritu e suas associações com as majors - os grandes estúdios com produções de alcance global -, é oportuno clarear o conceito de cinema independente e sua aplicação na atualidade. O cinema independente, ou indie, era geralmente conceituado como antítese do cinema das majors (Warner Bros., Paramount, Sony-Disney, Columbia, 20th Century Fox, United Artists, Metro Goldwin Mayer - MGM - e Universal). Originalmente, estava implícito no termo cinema independente que se tratava de uma prática cinematográfica que, de algum modo, colocava-se como alternativa, ou até mesmo em oposição, ao cinema dominante ou mainstream. O conceito, que surgiu como antítese e negação do cinema economicamente dominante, foi flexibilizado em manobra de adaptação ao mercado visando acomodar principalmente dois interesses distintos: usufruir de vantagens em se produzir e distribuir filmes inovadores de baixo orçamento para nichos específicos; e oxigenar a indústria abordando temas inusitados com estilo arrojado e agregando a visão pessoal de um diretor.

Os grandes estúdios criaram divisões ou subsidiárias tais como Miramax, Fox Searchlight e Focus Features, que promovem o esmaecimento da fronteira entre Hollywood e o cinema independente, otimizando a gestão em paralelo desses modelos produtivos de cinema explorando a complementaridade entre eles. ${ }^{49}$ Essa adaptação das grandes corporações da cadeia produtiva do cinema às práticas produtivas inicialmente antagônicas - mainstream versus

Studios, que atua como produtora e o distribuidora de seus próprios filmes e agente de vendas internacional. O maior sucesso da Focus é O segredo de Brokeback Mountain (Brokeback mountain, Ang Lee, 2005). A empresa também produziu e distribuiu filmes transnacionais dos diretores brasileiros Walter Salles (Diários de motocicleta, 2004) e Fernando Meirelles (O jardineiro fiel, The constant gardener, 2005). A Paramount e a Universal Pictures são dois dos principais estúdios de cinema dos Estados Unidos.

${ }^{48}$ No original: "I regard myself as an independent filmmaker and when I work with a company I like to work with, not for, them because in that way the only beneficiary is the film itself." (IÑÁRRITU, apud WOOD, 2006, p. 145)

${ }^{49}$ A Miramax começou como produtora e distribuidora independente, foi comprada pela Walt Disney Company na década de 1990 e vendida para um empresário da construção civil em 2010. A empresa produziu e distribuiu filmes de diretores famosos como: Pulp fiction: tempo de violência (Pulp fiction, 1994) e Kill Bill: volumes 1 e 2 (2003 e 2004) de Tarantino; Onde os fracos não têm vez (No country for the old man, 2007), dos irmãos Ethan e Joel Cohen; Poderosa Afrodite (Mighty Aphrodity, 1995) de Woody Allen e Gangues de Nova York (Gangs of New York, 2002) de Martin Scorsese. A Fox Searchlight é uma divisão da Fox e da 20th Century Fox que produziu e lançou filmes de muito sucesso de público e alguns vencedores de Oscars como: Quem quer ser um milionário (Slumdog millionaire, Danny Boyle; Loveleen Tanda, 2008), Juno (Jason Reitman, 2007), Pequena miss sunshine (Little miss sunhine, Jonathan Dayton; Valerie Faris, 2006), Sideways - entre umas e outras (Sideways, Alexander Payne, 2004). A companhia é a distribuidora, nos Estados Unidos, do novo lançamento de Iñárritu, Birdman (2014). 
independente - exemplifica a institucionalização das negociações que ocorrem entre inovação e tradição no bojo da indústria cinematográfica. Iñárritu produziu e distribuiu seus filmes associado tanto aos grandes estúdios - Paramount e Universal - como às subsidiárias voltadas para empreendimentos alternativos - Focus Features - preservando sua concepção de independência por meio do controle criativo no desenvolvimento dos projetos e domínio do corte final.

Apresentadas as definições fundamentais de cinema contemporâneo e de cinema independente americano, que delimitam campos em que se inserem a obra em estudo, pode-se avançar na busca de uma apreensão mais apurada das especificidades dos mosaicos humanos e manipulações temporais marcantes na obra de Iñárritu, bem como na identificação de quais contribuições estéticas e temáticas acrescenta ao cinema mainstream. Para isso, faz-se necessário contextualizar as experimentações com multiplicidade de personagens e linhas narrativas combinadas com o embaralhamento do tempo linear desses filmes na transição entre os séculos XX e XXI e estabelecer conexões com outros momentos da história do cinema, em que esses artifícios narrativos também foram utilizados.

A narrativa dos filmes de Iñárritu, constituída por quebras da ordenação cronológica, câmera instável, enorme quantidade de cortes e intensidade dramática, deixou de ser um padrão alternativo de contar histórias e tornou-se um modo próprio de narrar no cinema independente da contemporaneidade com seus interesses temáticos e convenções visuais particulares. Apesar da originalidade de sua combinação, a estrutura e o estilo dos filmes de Iñárritu estão relacionados não só com características da narrativa cinematográfica do seu tempo sob forte influência da hipermídia, como também de outros períodos históricos da evolução da linguagem do cinema. As vinculações entre a filmografia em estudo com características narrativas contemporâneas e antecedentes precisam ser explicitadas para melhor compreensão da inovação que esse cineasta promove ao dialogar com esse legado.

\subsection{Vinculações históricas das estratégias narrativas de Iñárritu}

Como produto cultural pertencente a uma determinada época, a obra de Iñárritu, além de receber influências do modo de vida de seu tempo, absorve também contribuições narrativas de variados movimentos cinematográficos. A esse respeito, o cineasta assume um amplo espectro de admiração por cineastas clássicos e contemporâneos: 
Há diversos diretores que eu admiro. Os clássicos, como Bergman, Fellini, Buñuel, Tarkovsky, Leone, Scorsese, Cassavetes - amo Cassavetes. Eu sou um cara bastante eclético nesse sentido. Mas, ultimamente, as pessoas que realmente me abalam são Lars von Trier, Wong Kar-wai e Ang Lee - eles estão abordando filmes de novas maneiras. ${ }^{50}$ (IÑÁRRITU, apud, CRAWFORD, 2001, informação oral, tradução nossa)

Ele admite, com humildade, que a organização narrativa de seus filmes reutiliza estratégias de diretores anteriores a ele: "Não há nada novo no que eu faço, Rashomon, ${ }^{51} 60$ anos atrás, jogou com estrutura e tempo" (PHILBIN, 2007). ${ }^{52}$ Alguns críticos, por sua vez, insistiram em relacionar Amores brutos com Pulp Fiction (Pulp Fiction, Quentin Tarantino, 1995) pela estruturação em episódios e articulação do tempo fílmico, associação essa questionada pelo cineasta:

Essa coisa de Tarantino [associação com seu estilo] é engraçada. Acho que as pessoas têm creditado Tarantino pela invenção da estrutura de três histórias, mas o que dizer de Faulkner e García Márquez? E tem havido tantos filmes que também usaram-na, mas de repente Tarantino recebe o crédito por isso. Eu não tenho nada a ver com Tarantino, exceto talvez a abordagem da violência mais do que a estrutura. ${ }^{53}$ (IÑÁRRITU, CRAWFORD, 2001, informação oral, tradução e acréscimos nossos)

As semelhanças e diferenças entre a estruturação da narrativa e a temática da violência nos filmes de Iñárritu e Tarantino serão examinadas com mais profundidade no Capítulo III durante a análise de Amores brutos. Porém, a obra de Iñárritu não pode ser delineada apenas a partir de aspectos da produção estadunidense. Características marcantes do imaginário e da cultura latino-americana e mexicana estão diretamente associados com componentes estruturais dos filmes em questão. O multiprotagonismo, por exemplo, é proeminente nos murais de Diego Rivera, um dos mais representativos artistas pictóricos da tradição iconográfica mexi-

\footnotetext{
${ }^{50}$ No original: "I have a lot of directors that I admire. The classics, like Bergman, Fellini, Buñuel, Tarkovsky, Leone, Scorsese, Cassavetes - I love Cassavetes. I'm a pretty eclectic guy in that sense. But lately, the people that really shake me are Lars von Trier, Wong Kar-wai and Ang Lee - they are approaching films in new ways." (IÑ̃́RRITU, apud CRAWFORD, 2001)

${ }^{51}$ Rashomon (Akira Kursawa, 1950) conta de forma fragmentada e não-linear a história de um suposto assassinato de um samurai e o estupro de sua mulher em quatro perspectivas diferentes e contraditórias por meio de relatos de testemunhas, do estuprador e do próprio morto, por meio de um médium, restando ao espectador concluir o que realmente teria acontecido.

${ }^{52}$ No original: "This is nothing new, what I do, Rashomon, sixty years ago, played with structure and time." (IÑARRITU, apud PHILBIN, 2007, s. p.).

${ }^{53}$ No original: "The Tarantino thing is funny - I think people have credited Tarantino with the invention of the three-story structure, but what about Faulkner and García Márquez? And there have been so many films that have used it too, but suddenly Tarantino gets the credit for that. I don't have anything to do with Tarantino, except for maybe the approach to violence more than the structure." (IÑÁRRITU, apud CRAWFORD, 2001)
} 
cana, bem como também é recorrente na literatura latino-americana de Julio Cortázar, Jorge Luis Borges e Ernesto Sábato. Outra influência inegável é a das telenovelas, uma das formas mais populares de entretenimento na história daquele país - assim como do Brasil - caracterizadas por melodramas com proliferação de personagens, linhas narrativas e pontos de vista.

Críticos e analistas têm comparado a obra de Iñárritu com esse gênero popular televisivo em termos de narrativa e valores ideológicos (SMITH, 2003, p. 39) e, frequentemente, depreciado a obra do cineasta por causa dessas similaridades (DENBY, 2007, p. 85). Muitas vezes, tem sido questionado, por exemplo, que se não fosse por sua estrutura narrativa não ortodoxa, 21 gramas, seria apenas um melodrama convencional e não o produto de arte que pretende ser (DENBY, 2007, p. 84). Concordo parcialmente com as críticas colocadas acima. Os filmes de Iñárritu têm em comum com as telenovelas o multiprotagonismo e a temática das relações afetivas, principalmente entre pais e filhos. Entretanto, a abordagem das interações familiares nos filmes do diretor diferenciam-se pela profundidade e ambiguidade do arco de transformação das personagens e as conexões que estabelecem com um universo políticosocial mais amplo e contraditório. Além do mais, não se pode abstrair a forma peculiar com que as narrativas de Iñárritu são urdidas e conformam uma percepção diferenciada de conteúdos compartilhados por outros tipos de narrações.

Antes de se aprofundar na análise das conexões entre a obra de Iñárritu e a cultura de seu país de origem no terço final desta seção e na próxima, há que se considerar que a história do próprio cinema é repleta de exemplos de fragmentação cronológica e proliferação de pontos de vista, ${ }^{54}$ que oferecem as bases sobre as quais o diretor deriva suas contribuições à renovação da narrativa cinematográfica. O embasamento dessa renovação é resultante da herança de alguns movimentos cinematográficos vanguardistas da modernidade. Essas escolas cinematográficas exploraram elementos de ruptura da narrativa clássica usando estratégias que visavam incrementar a imprevisibilidade das tramas por meio do afrouxamento do encadeamento causal das cenas e da ordenação temporal não-linear.

Ainda ao final da era do cinema mudo, emergiu um movimento que estruturava seu discurso cinematográfico baseado em recursos articulatórios opostos ao cinema clássico: a montagem soviética da década de 1920. Uma legião de cineastas russos, com destaque para Sergei Eisenstein, Vezevolod Pudovkin, Aleksander Dovzhenko e Dziga Vertov, patrocinada por um governante - Lênin - consciente do poder de propaganda ideológica que pode ser

\footnotetext{
${ }^{54}$ Alguns destaques: Orson Welles com Cidadão Kane (Citizen Kane, 1941); Stanley Kubrick com O Grande Golpe (The killing, 1956); e Alain Resnais com Hiroshima mon amour (1959), Muriel (Muriel ou le temps d'un retour, 1963), Smoking e No smoking (Smoking/Non-smoking, 1993).
} 
exercido pelo cinema, empreendeu um investimento que produziu uma cinematografia pujante, implodindo alguns dos pilares de sustentação da narrativa linear. Em sintonia com os princípios marxistas, os diretores russos desse movimento escolheram trabalhar com personagens coletivos movidos por forças sociais, em vez de personagens individuais movidos por objetivos psicológicos. Abandonaram a suavidade na passagem de um plano para outro, por meio das regras convencionais de continuidade e exploraram o potencial expressivo do choque entre as imagens na criação de novos significados, valorizando o conflito entre planos.

Os surrealistas Luis Buñuel e Salvador Dalí abriram os olhos do cinema clássico, literalmente à navalha, para outras maneiras de ordenar os eventos da trama, ao estabelecerem o marco fundador da não-linearidade no cinema com seu filme manifesto, $O$ cão andaluz (1929). Nessa obra prima, o encadeamento de cenas instigantes assemelha-se a um sonho impossível de ser contado. Adotou-se uma estrutura em que as cenas são apresentadas sem relacionamento de causa e efeito entre elas, em que não há uma trama que dê unidade à história e, por isso, fica quase impossível ao espectador estabelecer expectativas realizáveis sobre seu desenvolvimento. Os personagens são expostos de maneira tão errática que não permitem ao público sequer formar um esboço turvo deles, inviabilizando qualquer possibilidade de identificação ou mesmo de simpatia. A trama linear é substituída por uma composição que "cultiva as rupturas, o onirismo, as imagens mentais, a confusão entre objetividade e subjetividade, as visões provocantes" (VANOYE; GOLIOT-LÉTÉ, 1994, p. 32). É plausível relacionar alguns conceitos do cinema surrealista, como o encadeamento onírico e a mistura entre objetividade e subjetividade, com as cenas de abertura e encerramento de Biutiful que representam a passagem da vida para além da morte, nas quais um filho encontra o pai que nunca conheceu e há uma espantosa aberração entre suas idades - o pai está mais novo que o filho.

O neorrealismo italiano, ${ }^{55}$ na década de 1940 , permitiu-se flexibilizar um pouco a cadeia de causa e efeito das cenas e incluiu ações mais soltas, sem contribuição direta para o desenvolvimento da trama, que arejavam o ritmo da narrativa. Em um cenário de pós-guerra, “a intriga importa menos do que a descrição da realidade" (DELEUZE, 2007, p. 11). Os seus realizadores argumentaram que, afinal de contas, como a vida real não é tão linear e concatenada, uma representação realista da vida como ela é deveria comportar uma certa dispersão de eventos e tempos mortos para guardar mais semelhança com ela. Em Amores brutos, por

\footnotetext{
${ }^{55}$ Filmes marcantes do neorealismo italiano, como Roma cidade aberta (Roma, cittá aperta, Roberto Rosellini, 1945), Obsessão (Ossessione, Luchino Visconti, 1943), Ladrões de bicicleta (Ladri di biciclette, Vittorio de Sica, 1948) e Arroz amargo (Riso amaro, Giuseppe De Santis, 1949), têm em comum com as obras de Iñárritu a densidade humanista ao retratar os impactos socioeconômicos do seu tempo nas relações interpessoais.
} 
exemplo, as andanças pela Cidade do México de El Chivo - misto de assassino de aluguel e catador de lixo -, em vários momentos, mostram tempos mortos que não contribuem para o desenrolar da trama, mas dão profundidade aos dramas do filme por meio da ambientação na realidade daquela metrópole.

A nouvelle vague francesa dos anos 1960, considerada a primeira vanguarda propriamente cinematográfica, adotou alguns artifícios dos movimentos cinematográficos soviéticos e dos italianos acima citados, adequou-os às suas necessidades estéticas e lançou películas que contavam histórias, mas que, ao mesmo tempo, questionavam sua própria narrativa, como fez Jean-Luc Godard em Acossado (’̀ bout de souffle, 1960). O enredo é mostrado de maneira anárquica, cravejado de cenas sem relação de causa e efeito e repleto de desvios - em meio a uma ação, um personagem pode simplesmente entrar em um bar para comprar um maço de cigarros, sem que isso ajude em quase nada a evolução da história. E, para espanto de alguns espectadores, um personagem pode romper inesperadamente a objetividade da cena e se dirigir diretamente a ele, lembrando-o que se está assistindo a um filme, numa estratégia antiilusionista. Os cortes também ficam evidenciados pelo uso abundante de jump cuts (cortes com pulo), em que, para usar um termo caro a esse movimento, o auteur (autor) assume para o espectador as fraturas da sua articulação da narrativa e, ao invés de dissimular, explicita a manipulação do tempo e do espaço. Essa seria justamente uma das marcas autorais mais evidentes na obra de Iñárritu e motivo para a eloquência de sua narração na manipulação de multiplicidades temporais, de personagens e enredos.

As rupturas estilísticas de quebra da linearidade por meio de distensões e fragmentações propostas pelos cinemas revolucionário soviético, surrealista, neorrealista e a nouvellevague influenciaram o cinema clássico, mas com moderação. Por outro lado, suas estratégias discursivas forneceram subsídios estruturantes para os movimentos das décadas de 1950, 1960 e 1970 que transformaram radicalmente a narrativa cinematográfica. O mundo, no pósguerra, estava mudado e era preciso encontrar uma outra forma para falar dele. As novas gerações de realizadores experimentaram caminhos alternativos ao cinema clássico.

Orson Welles institui o cinema moderno com múltiplos enunciadores intra e extradiegéticos em Cidadão Kane (Citzen Kane, 1941), no coração do sistema, Hollywood, variando a narração entre a locução em off do documentário News on the march no início do filme e os pontos de vista de diversas personagens - a investigação do jornalista em busca do significado de Rosebud, e relatos do tutor da infância e da ex-mulher. Surgem também diversos movimentos de novos cinemas contestadores tanto na Europa ocidental e oriental - free cinema na Inglaterra, novo cinema na Alemanha - mas também no, então, chamado terceiro mundo - 
Cinema Novo no Brasil. Essa fase de efervescência do cinema culmina na década de 1970 com a ascensão da geração do "sexo, drogas e rock'n'roll" em Hollywood, onde figuram cineastas como Martin Scorsese, Steven Spielberg, George Lucas, Francis Ford Coppola, Robert Altman, entre outros.

O período de três décadas de rebeldia e contestação no cinema (1970, 1980 e 1990) é marcado por uma nova forma de narrar que busca livrar-se da ditadura do roteiro excessivamente concatenado por causa e efeito. Os realizadores preferem filmar em locação em vez de estúdio e procuram evitar os artificialismos das interpretações das estrelas, em prol da naturalidade de novos atores ou até mesmo de atores não profissionais.

É evidente um incremento do interesse em experimentar com estruturas temporais e multiplicidade de personagens e enredos desde o começo da década de 1980, e a audiência familiarizou-se novamente com essas manipulações, como nas décadas de 1950, 1960 e $1970 .^{56}$ Os filmes de Iñárritu, por sua vez, também mostram que o tempo afeta as personagens e suas relações ao revelar a fragilidade da existência. Iñárritu lança mão da racionalização da ordenação temporal para potencializar a emoção: contando três histórias simultâneas narradas sucessivamente em três segmentos demarcados por subtítulos, ao invés de entrecortá-las (cortá-las transversalmente), como em Amores brutos; movendo-se livremente entre presente, passado e futuro, como em 21 Gramas; ou, como em Babel, imprimindo um falso senso de simultaneidade entre diferentes histórias.

Ironicamente, a multiplicidade de enredos em um mesmo filme foi experimentada, ainda nos primórdios do cinema, justamente pelo diretor que instituiu as bases do cinema clássico, D.W. Griffith, em seu segundo filme de longa metragem, Intolerância (Intolerance, 1916). No início da década de 1910, Griffith compreendeu a lógica entre os pontos de vista específicos da câmera e da personagem e aprendeu a implicar o espectador na trama por meio da autonomia de se estabelecer o ângulo, a distância, a duração e a escala dos planos. É justamente na passagem da montagem paralela para a articulação de campo/contracampo que Arlindo Machado aponta o nascimento do narrador no cinema ao emular uma presença dinâmica do espectador dentro da cena.

\footnotetext{
${ }^{56}$ Com o objetivo de exemplificar a amplitude e diversidade de experimentações temporais e com multiplicidade de personagens desse período (1950 a 1970), cito três exemplos oriundos de várias nações que contêm propostas cinematográficas bem diferentes: Rio 40 Graus (Nelson Pereira dos Santos, 1955) apresenta uma profusão de personagens da favela e da zona sul carioca interagindo em uma trama semi-documental; $O$ ano passado em Marienbad (L'Année dernière à Marienbad, 1961) oblitera o tempo ao contar a história de um estranho tentando seduzir uma mulher casada a fugir com ele de um hotel luxuoso, mas ela mal se lembra do caso que tiveram lá um ano antes; por sua vez, Sem destino (Easy rider, Dennis Hoper, 1969) apresenta flashforwards recorrentes antecipando planos de cenas futuras como se fossem efeitos alucinógenos vinculados aos encontros aleatórios da viagem de dois amigos motoqueiros em direção ao Mardis Gras.
} 
Por meio da hábil seleção das durações, dos campos e dos ângulos de visão, o narrador torna possível ao espectador, num certo sentido, 'entrar' no universo diegético e circular dentro dele como um observador privilegiado, que vê sem ser visto. [...] Essa sensação de onividência produzida por essa espécie de 'deus' interno à narrativa constitui a célebre ubiquidade que marca a experiência do espectador no cinema clássico. (MACHADO, 2008, p. 146)

É justamente nesse momento, quando o cinema começa a cortar dentro de uma mesma cena superando assim o desafio de articular, com continuidade, fragmentos sucessivos de espaço e tempo em sincronismo, que se estabelece uma forma inédita de narrar. Essa nova maneira de representar a realidade provocará alterações na percepção do mundo e influenciará a narrativa de outras artes e meios de comunicação.

Griffith aplicou seu refinamento da montagem paralela em Intolerância (1916), em que são narradas paralelamente quatro histórias: a tomada de Babilônia por Ciro, a Paixão de Cristo, o massacre de São Bartolomeu e um drama dos EUA no início do século XX, em que um inocente é injustamente acusado. Trata-se do primeiro filme de longa metragem multiplot da história do cinema. Nesse filme, pode-se observar o uso da articulação campo/contracampo de forma mais elaborada, com o posicionamento oblíquo da câmera, na cena do julgamento de um inocente em um drama nos Estados Unidos. No início do cinema, alternar entre ações que ocorriam em espaços diferentes era conveniente porque evitava as rupturas temporais e espaciais.

Apesar da precocidade da experimentação com multiplicidade de enredos quando o cinema clássico estava ainda incipiente, essa tendência foi deixada de lado por décadas em prol da consolidação de um modo narrativo alinhado com a lógica de uma arte de consumo de massa. ${ }^{57} \mathrm{~A}$ narrativa do cinema clássico tem como objetivo atingir um grande público sem distinção de classe econômica ou nível cultural, de sexo ou de idade, de crença religiosa, ou mesmo de nacionalidade. Seu espectador alvo é o indivíduo médio, do qual não se espera nenhuma referência cultural específica ou erudita. Esse cinema é claramente democrático e ambiciona simplesmente divertir, dar prazer, propiciar evasão fácil e acessível a todos. Para atingir seus objetivos de massificação, sua organização discursiva é orientada pela facilidade de acesso, configurando um sistema narrativo claro, contínuo, que provoca a participação imediata do espectador pela verossimilhança. O acesso a obra é viabilizado pela legibilidade fácil

\footnotetext{
${ }^{57}$ Somente na década de 1930, tem-se registro de que um grande estúdio, a Metro Goldwin Mayer (MGM), realizou filmes com multiplicidade de enredos e personagens, reunindo uma grande coleção de estrelas em ambientes semifechados: Grande hotel (Grand hotel, Edmund Goulding, 1932), Jantar às oito (Dinner at eight, George Cukor, 1933) e As mulheres (The women, George Cukor, 1939). (DELYTO e AZCONA, 2010, p. 20)
} 
na apresentação de todas as instâncias constitutivas da narrativa: narração, personagens, tempo e espaço.

O cinema clássico compreende um período que vai do início dos anos 1930 até a década de 1950. É a época de ouro dos estúdios, do cinema das estrelas, que valoriza o roteiro e torna-se o principal entretenimento dos americanos, e o lazer popular, por excelência, em boa parte do mundo. Esse desenvolvimento e expansão só foram possíveis graças aos avanços narrativos proporcionados pela primeira grande mudança tecnológica no cinema - a entrada do som - ao final dos anos 1920, e pelo amplo desenvolvimento dos gêneros cinematográficos - Western, musicais, policial e tantos outros - nas décadas seguintes.

O filme clássico respeita o padrão canônico de estabelecimento de um estado inicial de coisas que é violado e deve ser reestabelecido. São histórias quase sempre estruturadas em três atos, nas quais se apresentam os personagens e se estabelece o conflito matriz no primeiro, desenvolve-se o conflito no segundo e conclui-se a trama no terceiro. A transição entre um ato e outro é, normalmente, marcada por um turning point (ponto de virada). A intriga é urdida de modo a fazer com que os personagens ajam e comportem-se para a produção e reiteração de dados fundamentais para a história.

A narratividade do cinema clássico é caracterizada estruturalmente pela presença de um protagonista, principal objeto de identificação com o público, orientado por forças psicológicas e envolvido em uma trama que evolui linearmente, ao longo de cadeia de cenas relacionadas por causa e efeito. Esses personagens estão empenhados em resolver um problema evidente ou atingir objetivos específicos. São, normalmente, tipos fáceis de serem identificados porque são delineados por um conjunto evidente de traços, qualidades e comportamentos. Em sua trajetória, esses personagens entram em conflito com outros personagens ou com circunstâncias externas. A história termina com a resolução do problema e a clara consecução ou não consecução dos objetivos.

A narrativa do cinema moderno, por sua vez, abre espaço para personagens menos focadas em objetivos e mais sujeitos a imprevistos e tempos mortos. As personagens modernas são, geralmente, mais ambíguas e susceptíveis a se envolverem em eventos que desviem a progressão da história. A falta de objetividade dessas personagens torna a narrativa menos orientada, possibilitando finais menos fechados, sem resolução do conflito matriz da história.

A narração clássica trata a técnica cinematográfica como um veículo para a transmissão de informações sobre a história (fábula) pela trama (enredo). A causalidade é o princípio unificador do discurso e qualquer paralelismo é subordinado ao movimento de causa e efeito. A trama apresenta a ordem, frequência e duração dos eventos da fábula, revelando suas rela- 
ções causais. Nada é mostrado por acaso e nem deve parecer supérfluo na busca da maior clareza possível. O estilo dessa narração estimula o espectador a construir um tempo e um espaço da ação da fábula que seja o mais coerente e consistente possível. A compreensão do filme é guiada por um ponto de vista único e onisciente. "A história deve parecer contada por si mesma, numa cronologia linear que liga as diversas ações a uma intriga principal. $O$ filme se organiza segundo um desenrolar lógico ou progressivo que exclui a ambiguidade em função de uma narração transparente" (LIPOVETSKY; SERROY, 2009, p. 19).

O cinema moderno viola esses fundamentos da narrativa clássica minimizando a relevância da lógica e da clareza na estruturação dos filmes por meio de diversas estratégias narrativas: flexibilização do encadeamento causal dos eventos; diversificação dos pontos de vista; rompimento da linearidade da cronologia; e a maior exposição da autoria na narração das histórias.

O filme clássico tende a produzir a onisciência narrativa por meio da onipresença espacial. Tanto os cortes internos na cena assim como a montagem em paralelo entre vários locais diferentes destacam a onipresença da narração. O corte no interior, de acordo com A. Lindsley Lane, "estimula, através da escolha correta de seu objeto e posicionamentos, a sensação no receptor 'de estar presente à porção mais vital da experiência - no ponto mais vantajoso de percepção' ao longo de todo o filme" (LANE, apud BORDWELL, 2005, p. 288). A onipresença clássica estabelece um esquema em que o espectador, por meio da câmera, é alçado a uma posição de observador invisível, "um olhar sem corpo" (XAVIER, 2003, p. 37), que, apesar de livre das contingências de tempo e espaço, está discretamente confinado a padrões de codificação, em nome da fácil compreensão da história.

O cinema moderno explora uma presença mais autoral da câmera na leitura da cena, em que a expressividade subjetiva prevalece sobre a exposição objetiva do espaço e da trama. Diretores como Luis Buñuel, Federico Fellini e John Cassavetes, por exemplo, consagraramse pelo poder de decupar as cenas de seus filmes, imprimindo uma ambiência de sensações, emoções e ideias que vai bem além de simplesmente registrar com clareza as relações espaçotemporais das ações em quadro. Iñárritu busca essa expressividade intensificada alcançada por outros diretores à sua maneira, desenvolvendo estilo próprio ao combinar predominantemente câmera na mão com montagem fragmentada e interpretações viscerais de personagens ambíguos em situações extremas.

A narração clássica, além de ser onisciente e de ter alto grau de comunicabilidade, é moderadamente autoconsciente - com baixo grau de reconhecimento, pela narração, de sua veiculação ao espectador. A narração sabe mais que qualquer um dos personagens, ou que 
todos juntos, e, quase nunca, reconhece que está se dirigindo ao público. A onisciência, a comunicabilidade e a autoconsciência são intensificadas nas aberturas e finais dos filmes. A comunicabilidade não permite que informações significativas sejam mantidas desconhecidas e não deixa lacunas, como lapsos temporais e omissões causais. A narração moderna, ao contrário, assume e expõe as marcas das suturas da trama sem pudores de dissimular sua tessitura e é mais permeada de lacunas, lapsos e omissões de informações sobre o desenvolvimento do enredo.

Outra característica muito importante da narrativa clássica é sua baixa ambiguidade. Ela apresenta uma separação clara entre a realidade diegética objetiva, os estados mentais dos personagens e os comentários inseridos pela narração. Os planos subjetivos são ancorados em contexto objetivo. Um plano-ponto-de-vista, por exemplo, é motivado e associado a planos objetivos que o precederam ou o sucederão. $\mathrm{O}$ cinema moderno se permite ser mais ambíguo e tira proveito expressivo da indefinição entre planos objetivos e subjetivos, estimulando uma postura mais ativa e aberta do espectador na decodificação de suas relações.

A trama clássica, normalmente, apresenta duas linhas de enredo: em primeiro plano, um romance heterossexual e, em segundo, uma esfera de contextualização associada ao trabalho, a uma missão ou a uma busca. Cada linha possui objetivos, obstáculos e clímax próprios. Esse modelo simplista ganha mais complexidade na narrativa do cinema moderno com a multiplicidade de enredos e dispersão da importância entre eles.

Em que pesem as influências do novo cenário comunicacional, boa parte dos audiovisuais narrativos disponíveis nas salas de cinema, televisão ou mesmo circulando na internet contam suas histórias baseados nos elementos estruturantes codificados pelo cinema clássico. Ainda podemos identificar, nos filmes exibidos em variadas plataformas, a predominância de protagonistas orientados por forças psicológicas, envolvidos em tramas que evoluem ao longo da cadeia de cenas relacionadas por causa e efeito, apesar da absorção de algumas influências do cinema moderno na renovação de sua forma de narrar.

Em sua essência, a narrativa linear do cinema clássico está associada a uma experiência pré-determinada, por meio de sua lógica de articulação de fragmentos de tempo e espaço, na qual o público segue o fluxo, pactuando com o encadeamento, para se chegar a uma resolução, que confirma ou frustra suas expectativas. A narrativa linear baseia-se na trama e no envolvimento do espectador com o personagem principal, que visa emocionar a audiência. Ao público, é reservada a função de dar sentido a esse discurso. Essa vivência é quase sempre satisfatória e, muitas vezes, até excitante, mas é construída com parâmetros previsíveis. Visando dar novas perspectivas para a previsibilidade do cinema clássico e criar representações 
da realidade em sintonia com os desejos e necessidades da audiência atual, o cinema contemporâneo resgatou alguns artifícios pertencentes ao legado de movimentos cinematográfícos modernistas e experimentou novas formas narrativas nas últimas décadas.

Uma das estratégias narrativas mais eficientes do cinema contemporâneo para se ampliar a imprevisibilidade e complexidade das relações entre as personagens nas tramas é a utilização de múltiplos protagonistas. Narrativas multiprotagonistas marcaram os filmes de desastre da década de 1970 e fizeram de Robert Altman, com seu inaugural Nashville (1975), o primeiro diretor que tornou essa característica em sua marca autoral. Ao entrelaçar o universo das campanhas eleitorais com os negócios da música country em Nashville, Altman estruturou a trama com elementos que se tornariam característicos desse gênero e de sua filmografia. Apesar da quantidade excessiva de personagens, vinte e quatro, a duração do tempo da história é curta, cinco dias, e um acontecimento final congrega todas as personagens. O multiprotagonismo ficou popular na década de 1980 com filmes que construíram suas histórias em torno de agrupamentos de personagens com semelhante importância, normalmente amigos ou membros de família, mas também grupos conectados de forma mais aleatória, oferecendo variedade de pontos de vista e perspicazes explorações da interação humana e de dinâmica de grupos. $^{58}$

Na década de 1990 essa tendência ficou mais sofisticada e variada. Grupos ligados espacialmente foram substituídos por coleções de personagens mais isolados em cidades, cujos caminhos se cruzavam de forma acidental ou aleatória. $\mathrm{O}$ arrefecimento dos laços conectivos entre as múltiplas personagens favoreceu o incremento da multiplicidade de enredos. ${ }^{59}$ Nos anos 2000, as narrativas de rede, como são conhecidas as histórias nas quais encontros acidentais ao acaso engatilham conexões inesperadas entre personagens não relacionadas, conquistaram reconhecimento em Hollywood. Antes da "trilogia da morte" de Iñárritu o modo narrativo destacou-se, por exemplo, com Traffic - ninguém sai limpo (Traffic, Steven Soderberg, 2000). ${ }^{60}$ Traffic aborda a questão do tráfico de drogas entre Estados Unidos e México, trazen-

\footnotetext{
${ }^{58}$ São exemplos de filmes multiprotagonistas dessa época que tiveram bom público nas salas de cinema do Brasil: Sonhos eróticos de uma noite de verão (A midsummer night's sex comedy, Woody Allen, 1980), O primeiro ano do resto de nossas vidas (St. Elmo's fire, Joel Shumacher, 1985), Hannah e suas irmãs (Hannah and her sisters, Woody Allen, 1986) e Faça a coisa certa (Do the right thing, Spike Lee, 1989).

${ }^{59}$ Os filmes multiprotagonistas da década de 1990 que mais me marcaram e despertaram meu interesse foram: Grand Canyon - ansiedade de uma geração (Grand Canyon, Lawrence Kasdan, 1991), Short Cuts - cenas da vida (Short Cuts, Robert Altman, 1993), Antes da chuva (Before de Rain, Milcho Manchevisk, 1994), Felicidade (Happiness, Todd Sodondz, 1998) e Magnólia (Magnolia, Paul Thomas Anderson, 1999).

${ }^{60}$ Traffic (SODERBERG, 2000)foi indicado para cinco categorias do Oscar e ganhou em quatro: melhor diretor, melhor roteiro adaptado, melhor ator coadjuvante (Benício Del Toro) e melhor montagem para Stephen Mirrio-
} 
do a problemática das transações financeiras, políticas, sociais e culturais da fronteira entre os dois países.

Crash - no limite (Crash, Paul Haggis, 2004) foi ainda mais alto e atingiu o patamar máximo do prestígio na indústria cinematográfica ao sagrar-se vencedor do Oscar de Melhor Filme. ${ }^{61}$ Crash também trata de temas relevantes e polêmicos da atualidade: as relações, contradições e conflitos entre grupos sociais de diversas etnias com níveis econômicos diferentes, convivendo em uma Los Angeles fragmentada e à beira de uma convulsão social. As premiações de Traffic e Crash deram um selo de autoridade de larga audiência às narrativas estruturadas com multiplicidade de protagonistas e enredos e atestaram sua capacidade em lidar com questões sociais contemporâneas desafiando propostas estéticas de menor complexidade. $\mathrm{O}$ sucesso dos filmes multiplex, porém, não se restringiu ao cinema americano e tornou-se um fenômeno transcultural.

Deleyto e Azcona (2010, p. 21-23) observaram que o multiprotagonismo já havia sido empregado na estruturação de filmes mexicanos mais antigos como em Os esquecidos (Los olvidados, Luis Buñuel, 1950), Reportaje (Emilio Fernández, 1953) e Mecánica Nacional (Luis Alcoriza, 1971). Os autores apontaram que o artifício narrativo de multiplicidade proliferou na filmografia do México, a partir da década de 1990, ao tecerem-se representações de diversas situações: uma remota rua da Cidade do México em O beco dos milagres (El callejón de los milagros, Jorge Fons, 1995); um grande edifício em Corazones rotos (Rafael Montero, 2001); a experiência da imigração, em uma variedade de perspectivas, em El jardin del Edén (María Novaro, 1994), em que a vida de três mulheres se cruzam em Tijuana; ou fábulas agridoces de vidas solitárias que se atravessam em uma grande cidade, em Coisas insignificantes (Cosas insignificantes, Andrea Martínez, 2008).

Carl J. Mora (2012, p. 187-250) detecta uma mudança interna no financiamento dos filmes mexicanos como indutor de sua capacidade de atravessar fronteiras e atingir maiores audiências. O declínio da subvenção estatal para os cinemas nacionais em países como o México - onde, antes, o financiamento oficial constituía a espinha dorsal de sucessivas ondas de cinema de arte - estimulou a busca por financiamento privado e global de filmes. Amores brutos é um exemplo eloquente dessa estratégia alternativa de levantar recursos para a realização e distribuição de filmes que repercutiu tanto no sucesso do filme no exterior como no México.

ne. Mirrione, depois, tornou-se um dos colaboradores recorrentes de Iñárritu, com quem trabalhou em 21 gramas, Babel (montagem premiada em Cannes e indicada ao Oscar 2006) e Biutiful.

${ }^{61}$ Crash (HAGGIS, 2004) foi indicado ao Oscar em seis categorias e, além de Melhor filme, ganhou melhor roteiro original e melhor montagem. 
Amores brutos foi financiado pelas mexicanas Altavista e $\mathrm{Nu}$ Vision e comercializado nos cinco continentes por uma miríade de empresas em contratos específicos por janelas de distribuição (salas de cinema, TVs, homevideo, etc.). ${ }^{62}$ Iñárritu, Afonso Cuarón e Guillermo del Toro fizeram filmes atrativos não só para o espectador local, mas também internacional, não se limitaram ao circuito dos festivais e atingiram um público mais amplo. Diferente das gerações anteriores, eles encontraram o financiamento estatal em declínio e buscaram recursos em fontes privadas nacionais e transnacionais diversificadas. Associaram-se ocasionalmente aos grandes estúdios ou a suas subsidiárias voltadas para produções independentes e de televisões praticando vendas, por vezes antecipadas, de direitos de distribuição em vários países, ocasionando consequências estéticas e mercadológicas em suas realizações.

A geração de cineastas anterior à de Iñárritu - Arturo Ripstein como figura proeminente, ${ }^{63}$ acompanhado por Jorge Fons, Paul Ledúc, Felipe Cazals e Jaime Humberto Hermosillo, ${ }^{64}$ entre outros - surgiu durante o governo de Luis Hecheverría Álvarez (1970-76) e revitalizou o cinema mexicano, que se encontrava em uma profunda crise na década de 1960, com a produção de um conjunto de obras sob influência do chamado "cinema de autor" da época. O cinema desses realizadores caracteriza-se pela constante busca por uma forma que expressar-se o que era particular da experiência do país, contribuindo para a redefinição do conceito de mexicanidad (MORA, 2005, p. 118-139). Os filmes do membro mais conhecido desse grupo, Ripstein, participaram de festivais e circuitos de cinemas de arte na Europa (Cannes, Veneza e San Sebastián), nos Estados Unidos (Sundance, São Francisco e San Diego) e até mesmo no Brasil (Gramado e Rio de Janeiro), mas não obtiveram penetração em públicos mais amplos. Quando os financiamentos estatais minguaram, Ripstein conseguiu continuar fazendo seus filmes, mas a maioria dos outros realizadores de sua geração enfrentou sérias

\footnotetext{
${ }^{62}$ Para citar alguns exemplos, o filme foi distribuído pela Lions Gate (salas de cinema e DVDs legendados) no mercado dos Estados Unidos, pela Nu Vision no México, pela Warner na Alemanha e na Suíça e pela Imagem Filmes no Brasil. Em alguns países, como na Argentina e Espanha, diferentes companhias se encarregaram da comercialização nas diferentes janelas de distribuição.

${ }^{63}$ Arturo Ripstein entrou para o cinema como assistente de direção em $O$ anjo exterminador (El ángel exterminador, Luis Buñuel, 1962) e assina a direção de cinquenta e seis títulos entre curtas, documentários e filmes de longa metragem de ficção. Concorreu à Palma de Ouro de Cannes com três filmes: a adaptação do romance do Prêmio Nobel de Literatura Gabriel García Marquez, Ninguém escreve ao coronel (El coronel no tiene quien le escriba, 1999); La reina de la noche (1994); e El santo oficio (1974). Em festivais no Brasil ganhou duas vezes o Kikito de Melhor Filme Latino Americano no Festival de Gramado: em 1994, com La reina de la noche e, em 2000, com A perdição dos homens (La perdición de los hombres); ganhou o Redentor de Melhor Filme Latino Americano no Festival do Rio com La virgem de la luxuria em 2002.

${ }^{64}$ Os filmes mais premiados e conhecidos desses diretores são: Beco dos milagres (El calderon de los milagros, Jorge Fons, 1995), Frida naturaleza viva (Paul Ledúc, 1983), Cobrador - in God we trust (Paul Leduc, 2006); De noche vienes, Esmeralda (Jaime Humberto Hermosillo, 1997), Canoa (Felipe Cazals, 1977) e Las vueltas del citrillo (Felipe Cazals, 2006).
} 
dificuldades. O cinema mexicano vivia, assim, uma profunda crise no início da década de 1990.

Um dos mais celebrados filmes dessa geração, O beco dos milagres (de Jorge Fons, 1995), marca a passagem para uma nova era. Apesar de o filme ter sido majoritariamente patrocinado pelo Estado, apresenta a vida sórdida e obscura dos habitantes de uma rua pobre da Cidade do México e revela suas ansiedades e frustrações. Os críticos apontam esse título como representativo tanto formal como tematicamente de sua geração. A película é multiprotagonista e lançou a atriz Salma Hayek, ${ }^{65}$ que também destacou-se em A balada do pistoleiro (Desperado, Robert Rodriguez, 1995) e Traffic, alçando-a ao estrelato hollywoodiano e abrindo passagem para que outros realizadores também fizessem a travessia da fronteira rumo à opulenta indústria do vizinho ao Norte.

Ao representar na tela transposições de fronteiras nos quatro cantos do mundo; sejam elas físicas, políticas ou metafóricas, o conjunto de filmes realizados por Iñárritu oferece fértil material para uma reflexão sobre as negociações que se estabelecem entre o nacional e transnacional da produção cinematográfica em tempos de globalização. Amores Brutos é uma produção mexicana, já 21 gramas é americana, os dois filmes seguintes são coproduções: Babel é estadunidense-francesa-mexicana e Biutiful mexicana-espanhola. Não só o financiamento e distribuição dos filmes é transnacional, mas também suas filmagens acontecem em várias nações, absorvendo traços de suas realidades.

Situar a produção desse diretor latino-americano na história do cinema contemporâneo é examinar sua habilidade em transcender os parâmetros nacionais, imerso na necessidade da própria indústria cinematográfica em promover novas combinações entre a tradição e a inovação. A atuação eficiente de Iñárritu como protagonista do cinema transnacional está ligada com a bagagem cultural peculiar de sua pátria e sua sensibilidade pessoal em perceber e representar relações universais de poder e seus impactos existenciais, especialmente nas pessoas menos privilegiadas da sociedade como nas trajetórias de Octavio e El Chivo em Amores brutos; de Jack em 21 gramas; dos garotos pastores e da empregada Amelia em Babel; e de Uxbal e os trabalhadores ilegais africanos e chineses em Biutiful.

Esta seção procurou relacionar aspectos marcantes da obra de Iñárritu - multiplicidade de protagonistas e de enredos e não-linearidade - com o surgimento e propagação desses arti-

\footnotetext{
${ }^{65}$ Salma Hayek é a personalidade mexicana mais conhecida internacionalmente e a primeira a conseguir destaque em Hollywood desde Dolores del Río, em 1920, e Lupe Vélez, nas décadas de 1930 e 1940. Salma usou seu prestígio para produzir e estrelar em Hollywood Frida (Julie Taymor, 2002) interpretando a famosa pintora surrealista Frida Kahlo.
} 
fícios narrativos na história do cinema mundial e mexicano. A análise de componentes nacionais e transnacionais nos filmes de Iñárritu proporciona a oportunidade de se pensar a identidade nacional na primeira década desse século e ilustra as contradições e conexões dos cinemas nacionais na economia globalizada e do nacional como conceito cultural. A próxima seção pretende estabelecer algumas conexões que permitam compreender como esse diretor mexicano foi capaz de desenvolver uma filmografia com unidade estética em sua narrativa, manter sua identidade artística e cultural, mesmo filmando em vários países de diferentes continentes, e, ao mesmo tempo, alcançar audiências em todo planeta.

\subsection{O enlace hipermoderno entre a globalização e a mexicanidade}

A obra de Iñárritu emerge não apenas de um contexto industrial específico, mas também cultural, em que a busca pela essência da identidade nacional continua a ser uma parte importante. A análise desses filmes revela, portanto, atrelamentos entre o local e o global na produção cinematográfica contemporânea, mesmo quando o território do México não está materialmente em quadro. A mexicanidade acompanha Iñárritu onde quer que ele vá filmar e se entranha em suas obras. A identidade cultural do diretor influencia sua escolha temática, o ponto de vista de sua mirada e o estilo narrativo que desenvolve em seus filmes.

O primeiro filme de Iñárritu, Amores Brutos (2000), filmado na Cidade do México, obteve destacado êxito de bilheteria em seu país e foi distribuído internacionalmente apesar da sua temática e estética marcadamente locais. O filme foi também um dos mais premiados em festivais pelo mundo, sendo indicado ao Oscar de melhor filme estrangeiro. O segundo, 21 Gramas (2003), constitui um interessante caso de estudo de transnacionalidade, pois seu roteiro foi escrito pelo roteirista mexicano Guillermo Arriaga em espanhol, para ser realizado no México com atores de seu país natal em sua língua mãe, mas cruzou a fronteira norte e foi filmado nos EUA em inglês com estrelas hollywoodianas (Naomi Watts, Sean Penn e Benício del Toro). O terceiro filme, Babel (2006), trata diretamente de travessias de fronteiras e aborda os contrastes e as conexões, que se estabelecem entre habitantes de quatro países de três continentes diferentes deflagradas por um tiro acidental. Em seu quarto filme, Biutiful (2010), Iñárritu apresenta um complexo e cruel mural das relações de trabalho em que migrantes africanos e chineses lutam pela sobrevivência em uma Barcelona muito diferente do cartão postal de cidade modelo europeia. Observa-se claramente, portanto, a forte presença de temática relacionada à globalização e suas consequências em seus filmes. 
A ascendência da globalização econômica nas décadas de 1980 e 1990 está diretamente relacionada com o declínio das utopias, dos projetos revolucionários e das vanguardas, tanto nos países centrais como nos periféricos. O pós-modernismo coloca-se como um discurso nesse momento de remapeamento das possibilidades culturais e políticas, e traz para o primeiro plano a natureza fragmentada e heterogênea da identidade social contemporânea formatada pela mídia. Nessa conjuntura, a produção de signos e informações ganha importância e a distinção entre arte erudita e popular entra em colapso. Nas abordagens de Jameson (1995; 1996), Lyotard (1998) e Baudrillard (2005), ${ }^{66}$ o neologismo "pós-moderno" significa o fim, a superação da modernidade, e ressalta os aspectos mais sombrios dessa travessia da rebeldia (utopias) para o conformismo econômico e político (democracia-individualista). Uma das contribuições mais importantes desses autores é a constatação de que quase todas as lutas políticas contemporâneas são disputadas no campo de batalha simbólico da mídia.

Em um segundo momento, alguns filósofos e críticos da cultura, como Gilles Lipovetsky e Sébastien Charles (2004), ${ }^{67}$ questionaram a abordagem pós-modernista com o argumento de que não se tratava do fim da modernidade, mas de um novo patamar, uma "modernidade ao quadrado, superlativa", e contrapuseram o conceito de hipermodernidade ao de pósmodernidade, como uma "segunda modernidade", na qual:

Tecnologias genéticas, digitalização, ciberespaço, fluxos financeiros, megalópoles, mas também pornografia, condutas de risco, esportes radicais, performances, happenings, obesidade, dependência de drogas: tudo aumenta, tudo se extremiza e se torna vertiginoso, 'sem limite'. É como uma imensa fuga para a frente, uma engrenagem sem fim, uma modernização exagerada, que se apresenta à segunda modernidade. (LIPOVETZKY; SERROY, 2009, p. 49)

A abordagem diferenciada e menos pessimista oferecida pelo conceito de hipermoderno parece mais sintonizada com as características da sociedade complexa do início do século XXI, especialmente no campo do cinema conforme ressalta o livro A Tela Global - mídias culturais e cinema na era hipermoderna de Lipovetsky e Serroy (2009). Entretanto, o termo pós-moderno remete a um conceito já bem difundido que abrange questões também pertinentes e que não pode ser descartado assim tão facilmente. Os conceitos de pós-moderno e hipermoderno referem-se a momentos e aspectos diferentes do mesmo processo social, político,

\footnotetext{
${ }^{66}$ Cf. JAMESON, Fredric. As marcas do visível. Rio de Janeiro: Graal, 1995. JAMESON, Frederic. Pósmodernismo, a lógica cultural do capitalismo tardio. São Paulo: Ática, 1996. LYOTARD, Jean-François. A condição pós-moderna. Rio de Janeiro: José Olympio, 1998. BAUDRILLARD, Jean. Tela total: mito-ironias da era do virtual e da imagem. Porto Alegre: Sulina, 2005.
}

${ }^{67}$ Cf. LIPOVETSKY, Gilles; CHARLES, Sébastien. Os tempos hipermodernos. São Paulo: Barcarolla, 2004. 
econômico e cultural. Portanto, os termos pós e hipermoderno e as conceitualizações que evocam podem ser abordados não como excludentes, mas como complementares e, assim, serão tratados nesse estudo.

O cinema contemporâneo está inserido nessa dinâmica pós e hipermoderna. Os estudos dos filósofos ou críticos da cultura estabelecem conexões teóricas que permitem o entendimento das relações entre economia, política, tecnologia e narrativa no atual cenário marcado pela fragmentação e pelo fluxo exagerado e acelerado de trocas culturais mediatizadas. ${ }^{68} \mathrm{Se}$, por um lado, esse conhecimento leva a um diagnóstico ambicioso do atual processo civilizatório, por outro, ao pensar o cinema inserido nessa conjuntura, os filmes tendem a figurar como mera confirmação dos grandes esquemas traçados por esses teóricos. Os diálogos dos estudos de cinema com as teorias do pós e do hipermoderno oferecem perspectivas de mapeamento do cenário em que o cinema contemporâneo está inserido. Trata-se de uma valiosa contextualização teórica para a compreensão do ambiente socioeconômico que conforma a tipologia do cinema em estudo.

O conceito de cinema nacional em sua origem era aparentemente simples e pretendia abarcar apenas "filmes realizados por determinado país no interior do seu território" (CROFTS, apud BAPTISTA; MASCARELLO, 2011, p. 28). Entretanto, o cinema, desde seus primórdios, mostrou-se vocacionado a transpor as fronteiras dos estados nacionais. Tanto Thomas Edison, bem como os irmãos Lumière adaptaram suas câmeras para funcionarem também como projetores e enviaram operadores para filmarem e projetarem pontos turísticos famosos espalhados pelo mundo - Torre Eiffel, Cataratas do Niágara, Muralhas da China - oferecendo, dessa forma, um protogênero cinematográfico, conhecido como "vistas" (views). ${ }^{69}$ À medida que se foi acumulando essa produção e que foram circulando essas vistas entre os países, combinadas com registros do cotidiano, personalidades e excentricidades (aborígenes, contorcionistas, etc.), surgiu o primeiro esboço de uma rede de produção e distribuição global de filmes. O cinema, no início dos anos 1910, já havia se tornado narrativo. Sua exibição tinha deixado de ser uma compilação de filmes de curta metragem variados e instituído o padrão de

\footnotetext{
${ }^{68}$ Cf. CANCLINI, Néstor García. Culturas híbridas: estratégias para entrar e sair da modernidade. São Paulo: Ed USP, 2011. CANCLINI, Néstor García. Leitores, espectadores e internautas. São Paulo: Iluminuras, 2008. SANTOS, Milton: Por uma outra globalização: do pensamento único à consciência universal. 19 ed. Rio de Janeiro: Record, 2010, BAUMAN, Zigmunt. Globalização. Rio de janeiro: Zahar, 1999. BAUMAN, Zigmunt. Modernidade Líquida. Rio de janeiro: Zahar, 2001.

${ }^{69}$ As "vistas" cinematográficas têm origem na tradição das expedições de documentar imageticamente seus achados, principalmente nas colônias distantes e em lugares exóticos. A representação imagética das explorações era produzida inicialmente por meio da pintura e da ilustração e passou a contar com o aporte da fotografia na segunda metade do século XIX, obtendo grande sucesso comercial. O cinema acrescentou o movimento a essas vistas e contribuiu para intensificar a circulação desse tipo de imagens.
} 
espetáculo do filme de longa metragem, cujo marco é $O$ nascimento de uma nação (The birth of a nation, D.W. Griffith, 1915).

Com a Primeira Grande Guerra Mundial, a produção de filmes em diversos países europeus entrou em colapso devido ao fato de o conflito ter se realizado em seus territórios e a produção estadunidense passou a ser hegemônica em quase todo o planeta. $\mathrm{O}$ abalo da produção cinematográfica das potências europeias depara-se com a ascensão da produção estadunidense não apenas como uma adversária nacional dominante, mas como elemento cultural multinacional portador de uma linguagem transparente com pretensão de universalidade. Diversas outras nações percebem a importância do cinema como o mais poderoso meio de comunicação da época, e também como aparelho de propaganda ideológica, difusor de modos de comportamento e padrões de consumo. Essa conjuntura provoca medo da americanização da cultura e ameaça de deterioração das identidades nacionais pelo produto hollywoodiano, estimulando a criação de proteções e subsídios a suas cinematografias. "A noção de cinema nacional somente vai surgir, portanto, durante a década de 1920, em resposta à consolidação do predomínio mundial de Hollywood ocorrida na época" (DYER; VICENDEAU 1992, p. 8 ; DANAN, 2006, p. 174, apud MASCARELLO 2008, p. 40).

Travessias do nacional para o transnacional fazem parte da história do cinema mundial desde seus primórdios, não são incomuns dentro da Europa e também acontecem entre outros continentes e a América. Apesar de a maioria dos diretores se manter vinculada ao seu país de origem, uma pequena parcela, porém expressiva, atravessa fronteiras e filma em outras línguas. Essas travessias dos cineastas que se tornam internacionais podem ser transitórias, como nos notórios casos do italiano Bernardo Bertolucci, do polonês Roman Polansky e do alemão Wim Wenders; ou definitiva, quando se estabelecem em outras nações, como fizeram no passado o alemão Fritz Lang e o judeu-austríaco Billy Wilder, ou mais recentemente o holandês Paul Verhoeven e o chinês John Woo, todos nos Estados Unidos.

É importante destacar que Iñárritu não é o único diretor mexicano a fazer sucesso além das fronteiras de seu país. Em 2007, foi emblemático o fato de que ele junto com Guillermo del Toro, Alfonso Cuarón e seus filmes - Babel (2006), O labirinto do fauno (El labirinto del fauno, 2006) e Filhos da esperança (Children of men, 2006), respectivamente - receberam nada menos do que quatorze indicações ao Oscar, incluindo melhor filme (Babel), direção (Iñárritu foi o primeiro mexicano indicado nessa categoria), fotografia, montagem e direção de arte. Essas indicações chamam a atenção por se tratar de um grupo nacional representado em tantas categorias principais da prestigiosa premiação da indústria cinematográfica hegemônica e não apenas na categoria de melhor filme estrangeiro. Iñárritu com seus colegas Cua- 
rón, del Toro e os atores Gael García Bernal e Salma Hayek são os principais destaques da vitalidade e força do cinema mexicano contemporâneo.

Alfonso Cuarón e Guillermo del Toro desenvolveram suas carreiras baseadas no tipo mais comercial dos filmes transnacionais: os filmes de gênero (genre movies). Cuarón apresenta um espectro amplo de variedades de gêneros em sua trajetória. Depois de um pequeno sucesso local com uma comédia romântica de financiamento estatal, Sólo com tu pareja (1991), Cuarón realizou, já em Hollywood, o filme infantil A princezinha (The little princess, 1995) e a livre adaptação de Grandes esperanças (Great Expectations, 1998), com Robert de Niro e Gwyneth Paltrow. Depois ele retornou ao México e fez o filme de estrada (roadmovie) E sua mãe também (Y tu mamá también, 2001); de volta aos EUA, dirigiu a fantasia blockbuster Harry Potter e o prisioneiro de Azkaban (Harry Potter and the prisoner of Azkaban 2004) e a ficção científica Filhos da esperança (Children of men, 2006), com Julianne Moore e Clive Owen. Em 2014, Cuarón consagrou-se como o primeiro cineasta latino-americano a ganhar o Oscar de Melhor Diretor por seu trabalho em Gravidade (Gravity, 2013). Observando a filmografia de Cuarón, tanto nas películas mexicanas como nos filmes em língua inglesa, não se percebe uma permanência de características temáticas ou estilísticas que lhe confira uma identidade autoral particular e fica evidente sua flexibilidade e eficiência em transitar entre diversos gêneros - comédia, fantasia infantil, road movie e ficção científica.

Guillermo del Toro percorre uma, também profícua, trajetória, similar a de Cuarón, porém mais focada nos gêneros ficção científica, horror e fantasia. Del Toro despontou no seu país com Cronos (1993) e foi, imediatamente, dirigir Mira Sorvino em Mutação (Mimic, 1997) no país vizinho. Em seguida engatou filmes de ficção científica de alto orçamento, Blade II - o caçador de vampiros (Blade II, 2002), Hellboy (2004) e Hellboy II - o exército dourado (Hellboy II - the golden army, 2008); e duas coproduções mexicano-espanholas, $A$ espinha do diabo (El espinazo del diablo, 2001) e O labirinto do fauno (El labirinto del fauno, 2006), nas quais introduziu o contexto histórico da guerra civil espanhola.

Cuarón e del Toro se engajaram em filmes de alto orçamento, almejando o faturamento, mas que também buscavam ser atraentes para audiências mais exigentes e críticas, que viam alguns de seus filmes como cinema de arte, como E sua mãe também, Filhos da esperança e O labirinto do fauno. A carreira de Iñárritu tem semelhanças com as de seus conterrâneos, entretanto, destacou-se porque obteve um reconhecimento um pouco diferenciado. Os filmes de Iñárritu foram aclamados por parte da crítica como um outro tipo de filme transnacional, o de "filme de prestígio" (prestige pictures), tipologia proposta por Bordwell (2013) que concilia sucesso comercial com a autoria dos "filmes de festival" (festival films). Amores 
brutos e o filme de Cuarón, Sua mãe também (2001), junto com outros filmes da mesma época, revolvem a crise da especificidade nacional no cinema mundial comercial e questionam a neutralização de tópicos culturais específicos de produtos culturais globalizados.

Arjun Apadurai (1996, p.19) prognosticou, ao final do século passado, que o nacional não estaria saindo de cena, mas estaria sendo reconstituído pelas mudanças contemporâneas da subjetividade provocadas principalmente pela mídia e diferentes formas de migração. No caso do México, essas mudanças globais adquiriram significados particulares em função de um aspecto peculiar do senso de identidade étnico-nacional desse país apontado por Octavio Paz (2014, p. 86): “O mexicano não quer ser índio nem espanhol. Também não quer descender deles. Nega os dois. E não se afirma como mestiço, mas como abstração: é um homem. Torna-se filho do nada. Começa em si mesmo".

O México é um país étnico e culturalmente híbrido como todos os outros povos latinoamericanos. Entretanto, essa postura de negação de suas origens e inclinação para uma abordagem mais incerta de sua identidade coloca o México em uma posição peculiar e abre perspectivas para enlaces diferenciados entre processos sócio-econômicos-culturais nacionais e globais. Apesar de Paz (2014) afirmar que os mexicanos normalmente neguem sua origem mestiça, ${ }^{70}$ sociólogos como Natividad Gutiérres (apud DELEYTO; AZCONA, 2010, p. 12, 88) consideram a hibridização o aspecto mais saliente da mexicanidad (mistura racial, fusão de culturas, tradições e estilos). A negação da mestiçagem, um aspecto tão vital na constituição do povo mexicano, associada à ambiguidade com que concebe sua própria identidade pode ser sugestiva na compreensão da capacidade de Iñárritu e outros cineastas daquele país em transpor barreiras nacionais e se inserirem em uma dinâmica global.

Dados os objetivos desta pesquisa, outro aspecto relevante a ser considerado nas transações entre o cinema mexicano e a globalização é sua proximidade conflituosa com a potência hegemônica do audiovisual, os Estados Unidos. A longa e traumática história do país à sombra do vizinho ao Norte fez com que o senso de soberania mexicano tenha sido determinado por dois acordos em 150 anos: o tratado de Guadalupe-Hidalgo, a resolução legal da guerra imperialista travada pelos Estados Unidos contra o México em 1848, em que o México foi despojado de metade de seu território; e os entendimentos do North American Free Trade Agreement (NAFTA), em 1994, que é um tratado de livre comércio entre Estados Unidos, Canadá e México, tendo o Chile como associado.

\footnotetext{
${ }^{70}$ Octavio Paz (2014,p. 85), em seu livro, O labirinto da solidão, relaciona a rejeição dos mexicanos à mestiçagem com a aversão à imagem de la Malinche, a nativa que traiu o povo Asteca ao se oferecer voluntariamente como amante do conquistador espanhol Cortés, um dos arquétipos nacionais mais poderosos.
} 
O principal objetivo do NAFTA é incrementar a circulação de mercadorias e serviços entre os países integrantes, principalmente por meio da suspensão de barreiras alfandegárias e acordos de cooperação. Desde que esse tratado foi firmado, tem sido difícil analisar seus efeitos macroeconômicos, devido ao grande número de outros fatores na economia global, principalmente a crise mundial dos últimos anos. Entretanto, estudos de economia têm indicado que o NAFTA, em vez de aumentar o comércio, causou uma concentração, na qual os signatários do tratado passaram a importar mais uns dos outros em detrimento de transações com outras nações. Alguns economistas argumentam que o NAFTA aumentou a concentração de renda tanto no México como nos EUA.

Houve um incremento dramático da imigração ilegal de mexicanos para os Estados Unidos desde que o tratado passou a vigorar (MORA, 2005, p. 188-191; DELEYTO; AZCONA, 2010, p. 5-6 e 18). Uma parte considerável desses imigrantes seria constituída de pequenos fazendeiros e trabalhadores rurais expulsos de suas terras por falência devido à concorrência desleal com os subsídios dos produtos agrícolas estadunidenses. A mexicanidade foi traumaticamente afetada pelo tratado de Guadalupe-Hidalgo e diluída pela intensificação de transações materiais e simbólicas agenciadas pelo NAFTA.

Ao mesmo tempo, o contexto geopolítico, de certa forma, colocou o México em uma posição favorável para assimilar os recentes desenvolvimentos culturais em que o nacional está sendo redefinido pelo global e transnacional. A busca pela identidade mexicana foi sempre marcada por resistência e incorporação, facilitando o entendimento de por que Iñárritu e outros expoentes da geração de cineastas mexicanos, menos obsessivos com traumas históricos e formas tradicionais de identidade, estejam mais prontos para incorporar o transnacional ao nacional. O contexto, a validade e a porosidade do conceito de cinema nacional mexicano estão diretamente vinculados ao de identidade nacional e aos efeitos dos processos de globalização sobre ele.

Ann Marie Stock (1997, p. 161) defende uma crítica de cinema que compreenda as práticas fílmicas pós-nacionais que não privilegiam origem, pureza e cerceamento. Outros autores, como Apadurai (1996), Lipovetsky (2009) e Canclini (2011), afirmam que os desenvolvimentos recentes assinalam que o nacional e o transnacional não são necessariamente incompatíveis. Mora (2012, p. 255) argumenta que os jovens cineastas mexicanos dos anos 1990 parecem estar à vontade quanto à manutenção de sua identidade cultural e nacional, apesar de esse senso de identidade ter se tornado mais complexo e sofisticado. Questionado por rodar 21 Gramas nos EUA, Iñárritu (apud Wood, p. 142, informação oral, tradução nossa) 
expressou seu sentimento de identidade mexicana e defendeu seu direito de filmar em outros países:

Tenho muito orgulho de ser mexicano e me sinto ainda mais mexicano quanto mais longe vou do meu país [...] É muito importante para um artista viajar, porque isso dá uma melhor perspectiva de você mesmo e de seu país. Para se conhecer é preciso explorar outras culturas. [...] Eu acho que um país não é um pedaço de terra ou uma bandeira. Um país é uma ideia que pode ser expressa por meio de imagens, palavras e muitas outras formas de expressão. Tenho muito orgulho de fazer parte da comunidade do cinema mundial e poder contar a história que eu quero, em qualquer país. ${ }^{71}$

A posição de Iñárritu é veementemente apoiada por seus compatriotas, também diretores transnacionais, que não veem contradição entre suas identidades nacionais e a nacionalidade dos seus filmes. Guillermo del Toro (2003, apud Wood, 2006, p. 154, informação oral, tradução nossa) considera racista a crítica aos diretores mexicanos que produzem em outros países:

Eu trabalho onde me é permitido - seja na Espanha, em Praga, ou nos EUA. Onde quer que eu vá, no entanto, eu sou um cineasta mexicano e esse é o fato que as pessoas que fazem essas críticas perdem. Eles acreditam - o que é uma forma extrema de racismo - que se você sai do país, então não é mais "um de nós" e não vai voltar. ${ }^{72}$

Alfonso Cuarón (2002, apud Wood, p. 97, informação oral, tradução minha) chega a minimizar a importância de se filmar em Hollywood:

Eu nunca realmente tive a intenção de ir para Hollywood, e eu não considero-a como a Meca do cinema. Para muitos diretores, mexicanos ou outros, é uma meta; para mim, é apenas parte de uma jornada. Para mim, pessoalmente, foi a última. Eu quero fazer filmes em outros lugares e em todos os lugares. ${ }^{73}$

\footnotetext{
${ }^{71}$ No original: "I am a very proud Mexican and I feel even more Mexican the further I go from my country. It is a great thing for an artist to travel, because it gives an even greater perspective of oneself and one's country. In order to know yourself you have to explore other cultures. [...] I think that a country is not a piece of land or flag. A country is an idea that can be expressed through images, words and many other forms of expression. I feel very proud to be part of the world cinema and to tell whatever story I want to tell in whatever country." (IÑNÁRRITU, apud Wood, 2006, p. 142)

${ }^{72}$ No original: "I work where I am allowed to - be that Spain, Prague, or the US. Wherever I go, however, I am a Mexican filmmaker, and that is the fact that gets lost on the people who make these criticisms. They believe - in what is a form of ultimate racism - that if you leave then you are no longer 'one of us' and you're not going to come back." (DEL TORO, 2003, apud Wood, 2006, p. 154)

${ }^{73}$ No original: "I never really intended to go to Hollywood, and I don't regard it as the Mecca of cinema. For many directors, Mexican or others, it's a goal; for me it is just part of a journey. For me, personally, it is the latter. I want to do films elsewhere and everywhere. (CUARÓN, 2002, apud Wood, 2006, p. 97)
} 
Travessias de fronteiras são características do cinema transnacional e os filmes desses três realizadores mexicanos são exemplos eloquentes dessa tendência. É significativo, portanto, que Iñárritu, Cuarón e Del Toro, os três diretores de maior destaque do cinema mexicano no século atual, trabalhem mais intensamente fora do seu país.

García Canclini (2011), após investigar o que se mantém da identidade nacional em tempos de globalização, interculturalismo, coprodução multicultural, tratados de livre comércio e integração regional, concluiu que a identidade hoje também é coprodução. Canclini (2011, p. 255-256) não identifica risco de desaparecimento de nações e etnias nesse processo. Em vez disso, propõe abordar a questão e tentar compreender como as formas tradicionais de identidade serão reconstituídas no processo de hibridização intercultural. Deleyto e Ascona (2010, p. 10) defendem que a busca pela essência imaginária da identidade nacional mexicana não tornou-se uma coprodução; “de fato, sempre foi".

De acordo com Octavio Paz (2014, p. 31), o traço mais importante da identidade mexicana é a solidão. "O mexicano sempre está longe, longe do mundo e dos outros. Longe também de si mesmo". Tanto em sua incessante procura por sua origem, quanto na negação da sua linhagem histórica, os mexicanos estão, normalmente, trancados neles mesmos, fechados até mesmo para com seus conterrâneos por medo de verem seus reflexos projetados neles (PAZ, 2014, p. 155). Paz defende que o mexicano e a mexicanidade se definem como ruptura e negação, mas também como procura e vontade de transcender. Ele chama a atenção quanto à dualidade da solidão que envolve ruptura com um mundo e tentativa de criar outro:

O homem é nostalgia e busca de comunhão. Por isso, toda vez que sente a si mesmo, sente-se como carência de outro, como solidão. [...] estamos condenados a viver sozinhos, mas também estamos condenados a atravessar a nossa solidão e a refazer os laços que num passado paradisíaco nos unia à vida. Todos os nossos esforços visam a abolir a solidão. Assim sentir-nos sós tem um duplo significado: consiste por um lado, em ter consciência de si mesmo; por outro, em um desejo de sair de si. A solidão, que é a própria condição da nossa vida, se apresenta como prova e purgação, ao final da qual a angústia e a instabilidade desaparecerão. A plenitude, a reunião, que é o repouso e felicidade, concórdia com o mundo, nos esperam no final do labirinto da solidão. (PAZ, 2014, p. 189)

O desejo de sair de si e obter redenção e plenitude encontra vazão por meio da experiência quase inacessível do ato "mais humano", o amor:

\footnotetext{
${ }^{74}$ Ramírez Berg define o cinema mexicano de 1967 a 1983 como cinema de solidão, uma filmografia repleta de personagens imersos em suas solidões, como metáforas de um país cujo centro sociopolítico não se instituiu, deixando seus cidadãos isolados e abandonados. (Apud DELEYTO; AZCONA, 2010, p. 11)
} 
E pedimos ao amor - que sendo desejo, é fome de comunhão, fome de cair e morrer tanto como de renascer - que nos dê um pedaço de vida verdadeira, de morte verdadeira. Não pedimos a felicidade nem o repouso, pedimos um instante, só um instante, de vida plena, em que os contrários se fundem e vida e morte, tempo e eternidade, se conciliem. Sabemos obscuramente que vida e morte são dois movimentos, antagônicos mas complementares, de uma mesma realidade. Criação e destruição se fundem no ato amoroso; e durante uma fração de segundo o homem vislumbra um estado mais perfeito. (PAZ, 2014, p. 190-191)

A solidão é proeminente no estado de espírito dos principais personagens dos filmes de Iñárritu como em Cristina, Paul e Jack em 21 gramas; Uxbal em Biutiful; Chieko e Amelia em Babel; e El Chivo, Octavio, Valeria e Daniel em Amores brutos (Ver Figuras 2.1, 2.2, 2.3, e 2.4). ${ }^{75}$ Os protagonistas dos filmes imprimem uma forte sensação de isolamento em relação ao mundo que os cerca, moram sozinhos ou em lares onde algum membro da família, pais ou filhos, está ausente e são mostrados vagando pelas cidades ou isolados em suas casas.

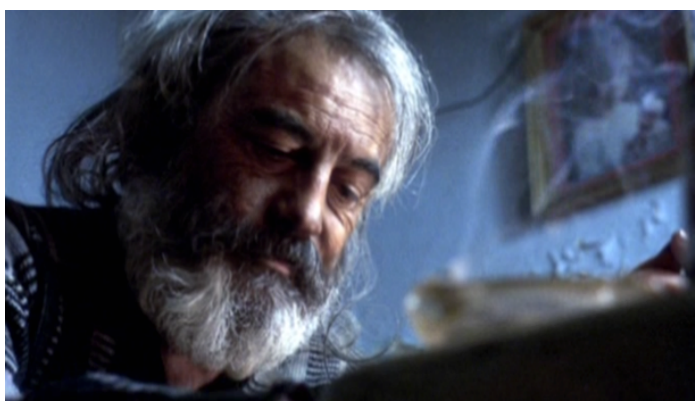

Figura 2.1 - El Chivo é um ex-guerrilheiro que se afastou da família e vive isolado como matador de aluguel em Amores perros

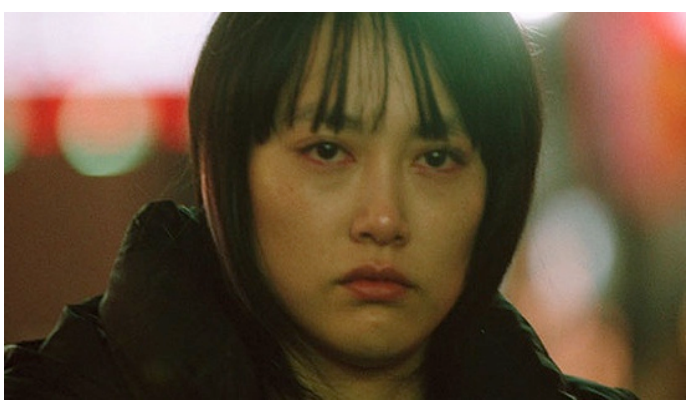

Figura 2.3 - Chieko vaga sozinha pelas ruas de Tóquio transtornada por questões afetivas em episódio de Babel

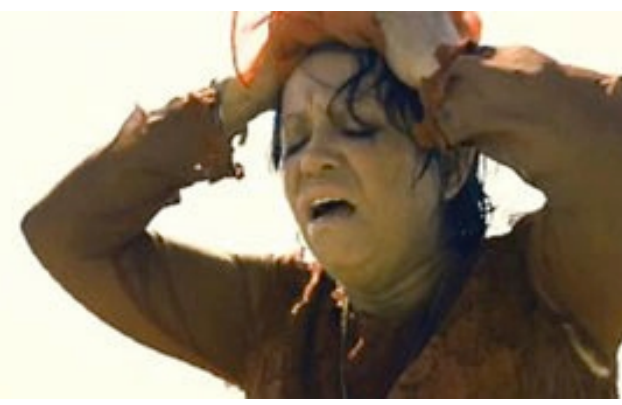

Figura 2.2 - Amelia desespera-se perdida em deserto na fronteira entre Estados Unidos e México em Babel

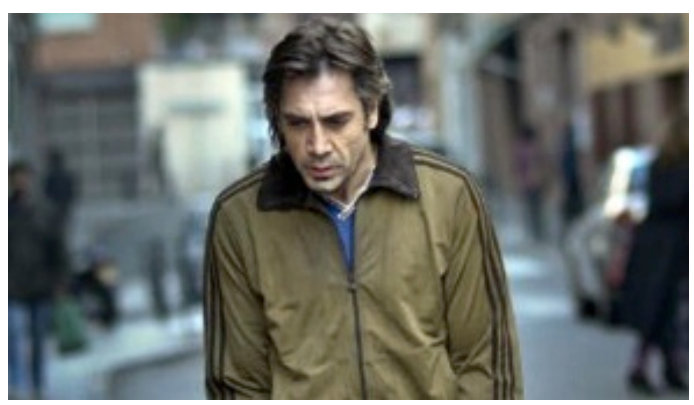

Figura 2.4 - Uxbal busca acomodação para seus filhos em Barcelona no filme Biutiful

\footnotetext{
${ }^{75}$ Todas as figuras que foram inseridas nesta tese são frames dos filmes analisados selecionados por mim. As referências integrais dos filmes constam ao final do documento.
} 
Uma parte considerável dos enredos dos filmes de Iñárritu abordam rupturas com a solidão e tentativas de criação de novos mundos por meio de relações amorosas. Em Amores brutos, o objetivo maior de Octavio é fugir com sua cunhada e começar vida nova em outra cidade; Daniel separa-se de sua esposa e filhas para viver com a amante Valeria; e El Chivo suspende sua carreira de matador de aluguel e tenta reaproximar-se da filha que o tem como morto. Em 21 gramas, Paul também larga sua mulher e entrega-se à paixão por Cristina, viúva do doador de seu coração transplantado. Em Biutiful, Uxbal está morrendo de câncer, rompe com sua mulher bipolar e tenta convencer uma mãe africana a cuidar de seus filhos.

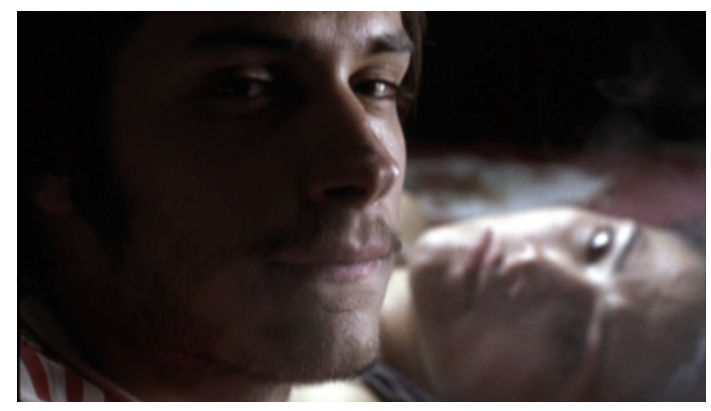

Figura 2.5 - Octavio quer fugir com a cunhada e começar uma vida nova em outra cidade no filme Amores brutos

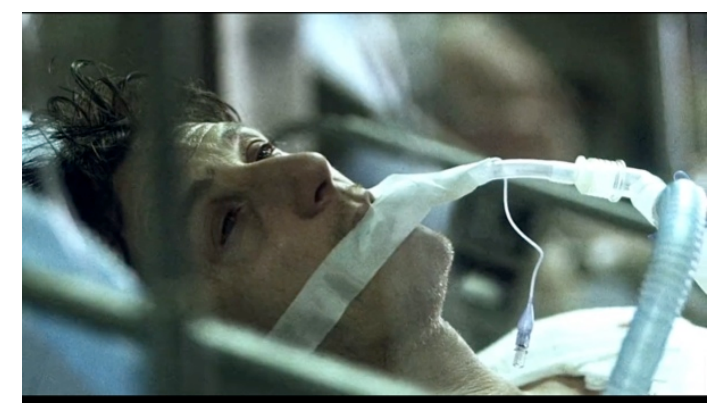

Figura 2.6 - Paul larga a mulher para viver paixão pela viúva do doador de seu coração transplantado em 21 gramas

Entretanto, diferentemente da narrativa do cinema clássico, o objetivo desses personagens de criar novos mundos não será plenamente alcançado pois encontrarão obstáculos que os impelirão a alterar suas trajetórias. A jornada de seus personagens cobra-lhes resistência e incorporação de imprevistos e acasos. É corriqueiro também, nas histórias de Iñárritu, que a aspiração de construção de um novo mundo (vida) leve à destruição (morte): o desejo de Octavio em fugir com a cunhada leva à morte de seu irmão e à destruição de sua família; a amante com a qual Daniel vai viver sofre um acidente de carro e perde uma perna; ao se lançar em sua paixão por Cristina, Paul é seduzido a assassinar o homem que matou o marido e as filhas dela em um acidente. Pelo exposto nos últimos parágrafos, fica evidente que traços marcantes da mexicanidade - ruptura/transcendência e resistência/incorporação - também fazem-se presentes na narrativa cinematográfica de Iñárritu, conforme será melhor examinado na análise fílmica de sua filmografia nos capítulos seguintes.

Obviamente, a representação de extrema solidão por si só não é uma exclusividade do cinema mexicano, mas possui relevo característico nessa cultura e que acaba por embrenharse em suas produções artísticas. Isolamento, solidão e incomunicabilidade estão presentes em várias tradições cinematográficas. Michelangelo Antonioni consagrou-se por sua abordagem 
dessa temática aplicada ao homem moderno na trilogia $A$ aventura (L'avventura, 1960), $A$ noite (La notte, 1961) e Eclipse (L'eclisse, 1962). A solidão e outros estados de espírito associados são recorrentes no cinema independente americano contemporâneo, no qual é representada por meio de longos planos estáticos com atuação minimalista em espaços vazios não amigáveis ou em vizinhanças alienantes (BORDWELL, 2006 p. 84-89; 2008, p. 200-203). Essa sensação paradoxal de isolamento em meio a um mundo em crescente intercomunicação está presente, não apenas nos filmes de uma determinada cinematografia nacional, mas perpassa fronteiras representando muito mais uma percepção existencial vinculada aos tempos atuais do que relacionada com uma realidade localizada. No caso dos filmes de Iñárritu, o que ocorre é uma composição impactante entre a solidão como traço da contemporaneidade conjugada com nuances específicas da cultura mexicana.

Octavio Paz (2014, p. 50-53) estabelece uma conexão intrigante entre a solidão e outros aspectos muito marcantes das tradições culturais mexicanas, também presentes nos filmes de Iñárritu: os excessos retóricos, a violência e a morte. Para Paz, o apreço dos mexicanos por festas e celebrações não é incompatível, mas uma consequência da solidão. Quando os reservados mexicanos se abrem, o fazem com certo grau de exagero e violência que é difícil de ser compreendida por outros povos. É uma expressão da máscara permanentemente usada e sempre ameaçada de ser rasgada por uma súbita explosão de intimidade. Paz, portanto, encontra, no caráter essencial de solidão nacional, a fonte do que é percebido de fora como um culto ao excesso que permeia todos os tipos de manifestações sociais e culturais. A história do cinema desse país é uma das manifestações caracterizadas por essa retórica do excesso. $\mathrm{Na}$ análise de Babel, no Capítulo V, essa temática será aprofundada no exame da festa de casamento do filho de Amelia que a leva a cruzar a fronteira entre os Estados Unidos e o México.

A morte é outro tema muito presente na cultura mexicana e de muito peso na dramaturgia de Iñárritu, levando inclusive seus três primeiros filmes a serem denominados de "trilogia da morte”. Em Amores brutos, além do extermínio de vários cães de briga e da matilha de vira-latas que são a "família" de El Chivo, há também o falecimento violento de seres humanos em batida de automóveis, tiros e facadas. A morte é o tema central em 21 gramas com o perecimento do doente cardíaco Paul (Sean Penn) e do atropelamento fatal de um pai e duas filhas. Babel mostra a polícia assassinando brutalmente o filho inocente diante de seu pai que não consegue evitar a tragédia. Biutiful apresenta o longo padecimento de Uxbal (Javier Barden) vitimado por câncer, sua comunicação com os espíritos dos que já se foram, alusão à morte de seu pai por doença e o falecimento de dezenas de chineses clandestinos por asfixia. 
Segundo Paz, as culturas indígena mexicana e hispânica encaram a morte com uma naturalidade um pouco diferente da maioria das outras culturas. Para os Astecas, a vida e a morte são meros prolongamentos uma da outra. Apesar de essa crença ter se arrefecido parcialmente decorridos séculos de colonização, ela continua permeando e sobrevive na cultura mexicana contemporânea, como pode ser notada em festas populares como o dia dos mortos ou como um dos brinquedos mais populares das crianças em forma de bonecos-esqueleto. Enquanto em outras culturas é comum um pudor acentuado em relação à morte, em alguns casos não ousam nem mencionar seu nome, os mexicanos parecem um pouco indiferentes a ela. Paz (2014, p. 57 e 58) acredita que os mexicanos temem a morte como qualquer outro povo, mas não se escondem do inevitável .

Quer acolhamos ou não as especulações de Paz e outros críticos da cultura sobre a personalidade nacional mexicana, são incontestáveis os excessos na abordagem de alguns temas por Iñárritu, notadamente nas representações de desejo e violência. Os filmes de outro compatriota aclamado em festivais mundo afora, Arturo Ripstein, são famosos por seu tratamento de paixões extremas e a criação de ambientações mórbidas e grotescas. Como em A perdição dos homens (La perdición de los hombres, 2000) em que o corpo de um homem assassinado por dois amigos fica em quadro boa parte do filme enquanto os assassinos conversam calmamente sobre o que vão fazer com ele. Várias formas de excesso e violência também são encontradas nos filmes mexicanos de Luis Buñuel. Alguns deles são atribuídos ao alinhamento do diretor com os preceitos do surrealismo, outros, presentes em Os esquecidos (Los olvidados, 1950), O alucinado (Él, 1953), O bruto (El Bruto, 1952) e Ensaio de um crime (Ensaio de um crimen, 1955), são reconhecidos como influências mexicanas.

Quando Amores brutos foi lançado e consagrou-se como a imagem do México de maior repercussão no exterior, a insistência de Iñárritu em sustentar momentos de intensa emoção e extrema violência abismava plateias mundo afora, enquanto era recebida com naturalidade e identificação pelos mexicanos. Deleyto e Azcona (2010, p. 16) ressaltam que "a familiaridade e a proximidade com a morte, a violência chocante e a relutância em refratar representações de experimentação intensa não são características que marcam apenas a originalidade de Iñárritu, mas de sua origem cultural”.

A violência é um mote muito presente no cinema contemporâneo simplex, principalmente nos filmes de ação, quase sempre tratada de forma banalizada. A representação da violência na obra de Iñárritu transcende o apelo fácil da espetacularização recorrente do tema, acrescentando realismo e densidade humanista vinculada à cultura mexicana. Parte da crítica, principalmente a estadunidense, associou sua forma de retratar a violência com a de Quentin 
Tarantino. Um exame mais cuidadoso levou os analistas a compararem a abordagem da violência de sua prima obra com as dos filmes de Buñuel e Ripstein, dos quais o diretor estreante teria apreendido como representar o fatalismo e a violência visceral. As conexões entre o estilo de Iñárritu e os de Tarantino, Buñuel e Ripstein na narrativa de Amores brutos serão consideradas no próximo capítulo.

O cinema, principalmente o hollywoodiano, sempre teve uma vocação transnacional. A história do cinema latino-americano está repleta de casos de travessias de fronteiras e cruzamentos de influências. Na América Latina e demais lugares, essa tendência se intensificou recentemente pelas mudanças culturais e práticas industriais. Como água para chocolate (A1fonso Arau, 1992), o grande sucesso do cinema mexicano do final do século XX, ofereceu uma história de amor eterno em uma atmosfera de realismo fantástico que mostrou que o México poderia fazer filmes atraentes para seu público interno e cujas especificidades poderiam ser bem recebidas por uma audiência internacional. O sucesso de 21 Gramas, além do circuito de arte, que já havia acolhido filmes de vários diretores mexicanos, como Ripstein e seus contemporâneos, revelou o potencial transnacional do cinema mexicano, até então, pouco explorado.

Apesar de Iñárritu e seu roteirista, Guillermo Arriaga, terem rejeitado em entrevistas os modelos cinematográficos mexicanos anteriores, seus filmes não estabelecem uma ruptura clara com o passado e nem necessariamente seguem os passos dos seus predecessores mais respeitáveis, mas encontram um equilíbrio inédito entre tradição e renovação ao representarem uma sociedade tensionada pela violência e permeada de excessos: colisões de automóveis, tiros, brigas de cachorros, assaltos, sequestros, embates fraticidas, assassinatos, muitos corpos ensanguentados e mortes.

Após a contextualização das estratégias narrativas de Iñárritu na história do cinema mundial e analisadas suas conexões com a cultura mexicana, faz-se necessário refletir sobre a ligação que existe entre os aspectos marcantes da filmografia em estudo com o ambiente tecnológico comunicacional atual. Visando compreender melhor o cenário da comunicação contemporânea, em que as mentes estariam mais preparadas para lidar com várias histórias simultâneas e fora da ordem cronológica, o tópico a seguir apresenta ponderações sobre como as novidades advindas da tecnologia informática afetaram as formas de se narrar e qual foi seu impacto no cinema contemporâneo com base na teoria do digital e das novas mídias. 


\subsection{O impacto da interface cultural informática na narrativa}

A tela grande, na qual o cinema projetou a vida em movimento e imprimiu os sonhos e desejos das massas na modernidade, multiplicou-se em incontáveis formas e dimensões na contemporaneidade. Presentes em espaços privados (lares, bares, restaurantes); públicos (aeroportos, rodoviárias) ou em trânsito (carros, aviões, no computador portátil e no telefone celular), as telas brilham em todos os lugares e a todo momento. A passagem do século do cinema, século XX, para o atual, está ambientada em uma "ecranosfera", que Gilles Lipovestsky e Jean Serroy (2009, p. 23) chamaram de “tela global”. Em menos de cinquenta anos, passamos da tela-espetáculo - a grande tela na sala escura reunindo multidões - à telacomunicação - multiforme, interativa, presente em diversos ambientes e móvel. No início do século XXI, a tela multiforme está onipresente midiaticamente em todo o planeta. "Estamos no tempo da tela-mundo, do tudo-tela, contemporâneo da rede das redes, mas também das telas de vigilância, das telas de informação, das telas lúdicas, das telas de ambiente”.

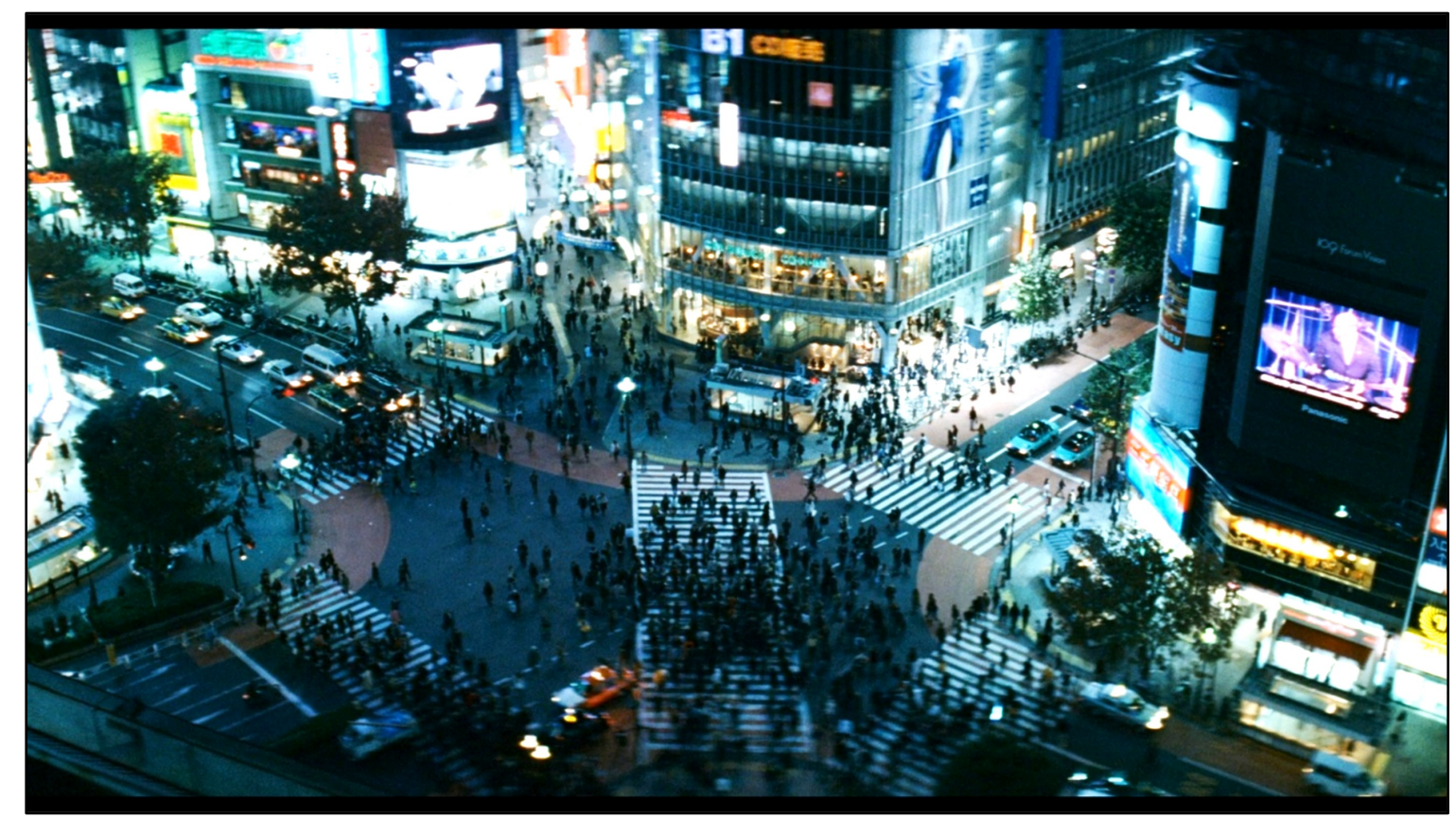

Figura 2.7 - Noite de Tóquio em Babel com telas fixas e móveis por todos os lados na história de Chieko

As telas, além de terem se multiplicado em dimensões e formatos, também não cessam de convergir e se interconectar. As relações com o mundo estão cada vez mais midiatizadas por meio de interfaces com telas que, pela conectividade, perpassam o cotidiano com diversas camadas de interação. São muitas janelas abertas simultaneamente e quase incontrolavelmen- 
te. As mensagens eletrônicas (e-mails, torpedos, tuítes, etc.), sites de relacionamento, portais de notícias não se restringem em pulular na tela do computador e passam a nos acompanhar por onde quer que formos. E não apenas na forma portátil e pessoal do laptop, mas também tocando e vibrando em nossos bolsos e bolsas materializados em telas táteis (touchscreens) de telefones celulares e tablets, permitindo acessar a rede mundial de computadores por meio de sutis toques na tela.

Fluxos de informação trafegam em alta velocidade rompendo limites de tempo e espaço, proporcionando a vivência de níveis de realidade e de narrativas simultâneos. Nunca a aldeia foi tão global e a frase célebre de Marshall MacLuhan (1968) - "o meio é a mensagem”- fez tanto sentido. O presença incessante das múltiplas telas na vida atual fica explícito em Babel na rotina da adolescente surda-muda Chieko. Esse episódio do filme mostra que o fato de a personagem ter o sentido da audição comprometido não a priva da fruição de vídeos em múltiplas telas para compreender e interagir com o universo complexo que a cerca.

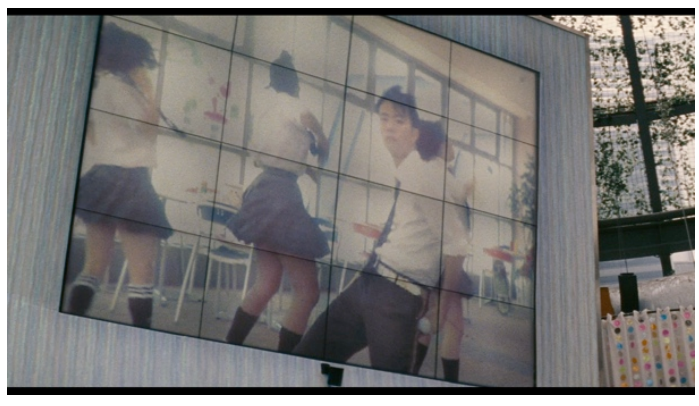

Figura 2.8 - Videowall no trajeto de Chieko com conteúdo infanto-juvenil de dança

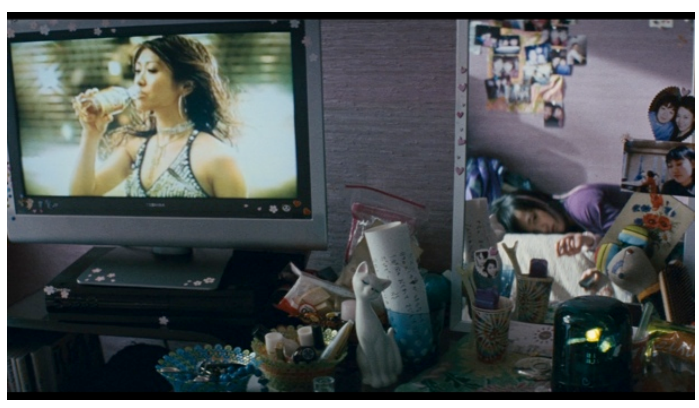

Figura 2.10 - Chieko zapeia TV do seu quarto enquanto espera amiga

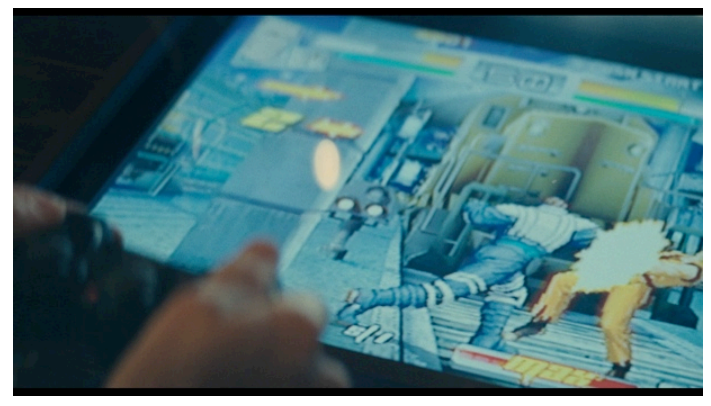

Figura 2.9 - Chieko joga videogame com amigas

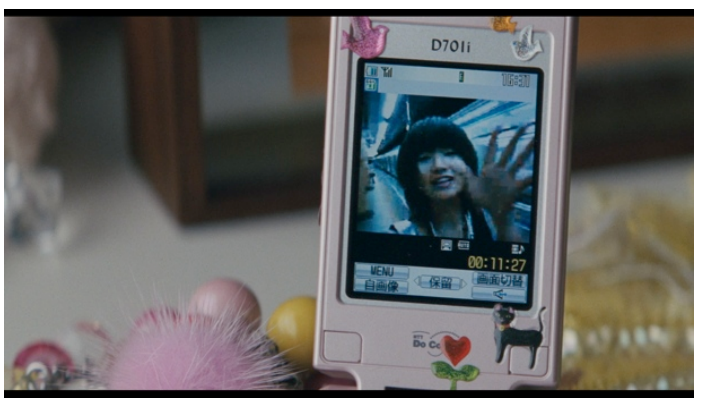

Figura 2.11 - A tela do celular de Chieko é fundamental na comunicação da adolescente surdamuda com o mundo

$\mathrm{Na}$ atualidade, a percepção da vida é fortemente influenciada pelas mídias digitais, que se caracterizam pela multiplicidade e a imprevisibilidade de suas representações da realidade 
complexa. As narrativas produzidas e difundidas nesse universo cultural híbrido e turbulento refletem essas características no ciberespaço. Até mesmo as narrativas de escritura e leitura linear, como o cinema convencional, apresentam transformações formais motivadas pelas labirínticas experiências midiáticas vivenciadas no dia-a-dia. Como a narrativa cinematográfica adaptou-se a esse novo cenário comunicacional? Que estratégias narrativas o cinema adotou em sua renovação para continuar merecedor da atenção de um público saturado de informações e imagens?

Com a chegada da internet e a consolidação da tecnologia digital, a partir da década de 1980, os meios de comunicação passaram a ocupar posição central na esfera cultural e nas interações sociais. “A informatização da cultura não apenas leva ao surgimento de novas formas culturais como os jogos de computador e os mundos virtuais, mas também redefinem as já existentes como o cinema e a fotografia" (MANOVICH, 2002, p. 35). ${ }^{76}$ As tecnologias informáticas, por sua vez, disponibilizam a capacidade de armazenar uma grande quantidade de dados - imagens, sons, textos, etc. - em alta definição e a possibilidade de acessá-la rapidamente de maneira não-linear ou até mesmo aleatória. O espectador passa a ser um leitoroperador - "interator" (MACHADO, 2007, p. 144), que pode acessar o dispositivo discursivo a partir de qualquer ponto, em qualquer direção e no ritmo que lhe apetecer. O processo de exploração do material disponibilizado requer uma postura mais ativa do espectador que pode agir de maneira autônoma e imprevisível ao criar seu percurso. Nesse contexto hipermidiático, o autor não oferece uma obra fechada, com uma única forma de arranjo do material discursivo, mas disponibiliza seus elementos para o interator acessá-lo com infinitas possibilidades. A estrutura discursiva interativa da hipermídia apresenta-se muito mais adequada para representar situações complexas, polissêmicas e paradoxais da sociedade contemporânea do que a escritura sequencial e ordenada linearmente.

Na década de 1990, o computador deixou de ser apenas um instrumento de produção de material cultural e passou a ser a máquina universal de mídia, que, além de criar, também armazena, distribui e acessa todas as mídias. Além do impacto econômico e político na sociedade, a tecnologia digital provocou mudanças nas formas de se perceber e representar a realidade, bem como propagou uma nova forma de interface com a cultura. De acordo com Robert Stam (2006, p. 349), essas inovações tecnológicas trouxeram novos

\footnotetext{
${ }^{76}$ No original: "The computerization of culture not only leads to the emergence of new cultural forms such as computer games and virtual worlds; it redefines existing ones such as photography and cinema."
} 
questionamentos aos temas centrais da teoria do cinema: a especificidade, a autoria, a teoria do dispositivo, a espectatorialidade, o realismo e a estética.

Lev Manovich em The language of New Media (2002), desenvolve uma longa reflexão sobre como a estética das novas mídias foram moldadas pelas tradições culturais mais antigas, principalmente as advindas do texto escrito e do cinema, e como as características intrínsecas do digital oferecem novas perspectivas formais para a organização e exposição de material audiovisual.

Manovich expande o conceito de interface homem-computador (humam-computer interface - HCI), o modo com que o usuário se relaciona com o computador, para o de "interface cultural", para descrever a interconexão entre homem-computador-cultura. Dessa forma, ele evidencia o modo como a informática apresenta e nos permite interagir com informações de qualquer "objeto cultural", sejam elas texto, desenhos, fotos, vídeos ou filmes. Essa interface cultural informática é empregada na arquitetura de informação e navegação de sites da Web, CD-ROMs e DVDs, videogames, bem como, nos jornais, revistas e enciclopédias on-line.

A nova interface informática é caracterizada pela manipulação direta de objetos na tela, sobreposição de imagens, representação icônica, uso de menus dinâmicos de estrutura ramificada e acesso randômico às informações. Tais características configuram uma organização discursiva, na qual "o sentido pode ser produzido não pelo impulso e determinação do desejo individual contido em uma narrativa linear, mas, em vez disso, por um entrelaçamento de camadas reciprocamente relativizadoras de som, imagem e linguagem" (STAM, 2006, p. 354). Esse entrelaçamento, Arlindo Machado (2008) chama de "hibridização de alternativas".

Apesar dessa interface informática ser bem mais recente do que a do texto escrito e a do cinema, Manovich as coloca lado a lado com "tradições que desenvolveram modos únicos de como a informação é organizada, como ela é apresentada ao usuário, como espaço e tempo são correlacionados um ao outro, como a experiência humana é estruturada no processo de acessar informação" (2002, p. 82, tradução minha) ${ }^{77} \mathrm{O}$ autor destaca que a interface informática tem o propósito de ser uma ferramenta capaz de manipular qualquer tipo de informação, enquanto a palavra escrita e o cinema são menos abrangentes nesse sen-

\footnotetext{
${ }^{77}$ No original: "traditions that have developed its own unique ways of how information is organized, how it is presented to the user, how space and time are correlated with each other, how human experience is being structured in the process of accessing information." (MANOVICH, 2002, p. 82)
} 
tido. Manovich (2002, p. 86, tradução e acréscimos nossos) aponta a transformação oferecida por essa nova interface que se relaciona diretamente com o objeto desse estudo:

Em contraste com os meios de armazenamento mais antigos do filme, livro, e fita magnética, nos quais os dados são organizados sequencial e linearmente, sugerindo a presença de uma narrativa ou uma trajetória retórica, a RAM [memória de acesso randômico] 'nivela' os dados. Em vez de seduzir o usuário por meio do arranjo cuidadoso de argumentos e exemplos, pontos e contrapontos, ritmos de mudança da apresentação [...], ou simular caminhos falsos e apresentar dramaticamente avanços conceituais, interfaces culturais, como o próprio RAM, bombardeiam os usuários com todos os dados de uma só vez. ${ }^{78}$

As mídias informatizadas, ao substituírem o armazenamento sequencial pelo acesso randômico e adotarem uma hierarquia organizacional com elementos nivelados, como no hipertexto, estabeleceram e difundiram uma forma de narrar em que o espectador-operador tem uma função mais ativa no encadeamento das partes do discurso. A interface cultural informática promoveu uma transmissão de relevância entre duas instâncias constitutivas da narrativa, privilegiando o espaço em detrimento do tempo na estruturação do material expressivo. Como sintetizou Manovich (2002, p. 86-87, tradução nossa):

Em suma, o tempo torna-se uma imagem plana ou uma paisagem, algo para olhar, ou navegar. Se houver uma nova retórica ou estética que seja possível aqui, ela deve ter menos a ver com a ordenação do tempo por um escritor ou um orador, e mais com um vagar espacial. ${ }^{79}$

Ao leitor, agora também operador, é cobrada uma posição muito mais ativa ao ter que exercer sua liberdade de decidir o trajeto a cumprir em um site ou jogo interativo, bem como a duração em que se deterá em cada item ou nível. A informatização da cultura proporcionou a popularização de uma forma de experiência narrativa diferenciada da oferecida pelas mídias lineares, como o cinema.

\footnotetext{
${ }^{78}$ No original: "In contrast to the older storage media of book, film, and magnetic tape, where data is organized sequentially and linearly, thus suggesting the presence of a narrative or a rhetorical trajectory, RAM "flattens" the data. Rather than seducing the user through the careful arrangement of arguments and examples, points and counterpoints, changing rhythms of presentation [...], simulated false paths and dramatically presented conceptual breakthroughs, cultural interfaces, like RAM itself, bombards the users with all the data at once." (MANOVICH, 2002, p. 86)

${ }^{79}$ No original: "In short, time becomes a flat image or a landscape, something to look at or navigate through. If there is a new rhetoric or aesthetic which is possible here, it may have less to do with the ordering of time by a writer or an orator, and more with spatial wandering." (idem, p. 86-87)
} 
O espectador do cinema convencional em uma sala de projeção também tem uma participação ativa ao inferir a história (fabula) a partir das informações captadas da trama apresentada na tela. Entretanto, a ordem e a duração com que os fragmentos de tempo e espaço serão acessados já estão demarcados no próprio filme e não podem ser alterados pelo espectador.

Robert Stam (2006, p. 352) resumiu o impacto das novas tecnologias sobre a espectatorialidade da seguinte forma:

Se o cinema clássico era uma máquina bem azeitada para a produção de emoções, que obrigava o espectador a acompanhar uma estrutura linear que promovia um conjunto sequencial de emoções, os novos meios interativos possibilitam ao participante - a palavra espectador soa demasiada passiva construir uma temporalidade e modelar uma emoção mais pessoais. A tela é transformada em um 'centro de atividades', um cronótopo cibernético onde tanto o espaço como o tempo são modificados.

Em um período de pouco mais de vinte anos, na virada do século XX para o XXI, a vivência dessa nova interface cultural informática proporcionada pela hipermídia vem ganhando cada vez mais importância na forma como as pessoas se informam, divertem-se e se relacionam. À medida que essa interface informática ocupa papel proeminente na sociedade como mediadora da cultura, algumas de suas características estéticas passam a influenciar a forma discursiva de outras interfaces culturais, como a do texto escrito e a linguagem do cinema.

Conforme Manovich (2002) e Stam (2006), a interface cultural informática caracteriza-se por uma ênfase na "espacialização do tempo", já que a duração que o espectadornavegador - interator - vai dedicar a um evento não é mais determinada por um narrador. Por sua vez, a influência dessa interface informática na linguagem cinematográfica tem impacto de maior vigor justamente na instância temporal de sua narrativa. Esse impacto se expressa por meio da ordenação não-linear, que foi uma das principais formas, junto com a multiplicidade de narrações, que o cinema encontrou para "emular", em uma mídia linear, o "nivelamento" das informações promovido pelo acesso randômico digital.

Pelo exposto, mostrou-se que o estudo dos aspectos constitutivos da interface cultural informática é proveitoso para a compreensão de como as instâncias narrativas são articuladas na hipermídia e de que maneira influenciam o cinema contemporâneo na utilização de multiplicidade de narrações e ordenação temporal não-linear.

Compreendidas as influências do ambiente comunicacional digital na narrativa cinematográfica pode-se avançar na investigação proposta. Os capítulos seguintes examinam 
os quatro filmes de Iñárritu visando aprofundar e interagir com as abordagens da história e da teoria do cinema apresentadas anteriormente, contemplando os aspectos estéticos e temáticos de suas narrativas. 


\section{CAPítulo III}

\section{A TEIA DE AMORES BRUTOS}

"Se quer fazer Deus rir, conte-lhe seus planos.",62

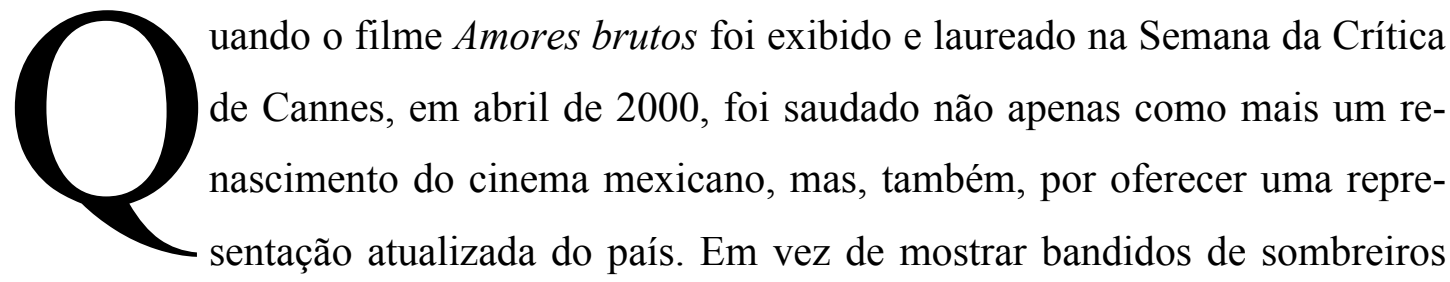
tomando tequila em cenários com cactos ao som de mariachis, a película expõe cenas de muita violência urbana contemporânea. São apresentadas na tela situações do submundo do crime, como assassinatos por encomenda mediados pela polícia, brigas de cachorros, assaltos e sequestros. Essas situações de marginalidade são contrastadas com representações de frivolidades, como: programa de TV com entrevistas de celebridades midiáticas, propagandas de perfume em outdoors e peludos cachorrinhos de companhia.

Não era exatamente uma imagem confortável para se exportar a realidade mexicana como foi, por exemplo, o grande sucesso daquele país a ganhar o mundo na década de 1990, Como água para chocolate (Como agua para chocolate, Alfonso Aral, 1992). Por sua vez, Amores brutos revelava um país ansioso para expor alguns de seus aspectos mais contraditórios para uma audiência internacional que, embora encontrasse especificidades nacionais na obra, podia também reconhecer alguns dos conflitos, questões sociais e ansiedades individuais presentes em realidades cada vez mais globalizadas.

\footnotetext{
${ }^{62}$ No original: "Si quieres hacer reír a Dios, cuéntale tus planes." Ditado popular usado pelo pai de Iñárritu e que pode sintetizar a força do acaso em sua obra. Esse ditado é citado em Amores brutos na cena do funeral de Ramiro, irmão de Octavio, pela viúva, Susana, quando ele, inapropriadamente, aborda a cunhada insistindo em seu plano para que vivam juntos em outra cidade.
} 
Depois de seu êxito em Cannes, o filme de estreia de Iñárritu foi lançado com estrondoso sucesso comercial no México, ${ }^{63}$ apenas duas semanas antes de o partido político no poder, Partido Revolucionário Institucional (PRI), perder as eleições gerais pela primeira vez em mais de setenta anos. O sucesso comercial do filme está vinculado ao momento político e econômico em que foi concebido, realizado e exibido. É desconcertante notar que Amores brutos traz, desde sua origem, uma ambiguidade quase contraditória. Por um lado, a própria existência da obra pode ser atribuída como uma decorrência da implementação dos acordos da NAFTA (North American Free Trade Agreement) nos anos 1990 que estimulou a circulação de capitais, bens e serviços entre Estados Unidos e México. Por outro, o filme não se intimida em representar algumas das consequências sociais do novo regime econômico que transformou negativamente vários aspectos da vida no país em poucos anos.

Entre essas consequências negativas, destaca-se o aumento da pressão demográfica na capital causado pela imigração massiva das áreas rurais empobrecidas devido à concorrência desleal com a produção agrícola subsidiada estadunidense (DELEYTO; AZCONA, 2010, p. 18). A película aborda alguns dos temas sociais mais urgentes naquela ocasião - pobreza, corrupção e violência - e foi imediatamente recebida como em sintonia com a ânsia por mudanças da sociedade mexicana. O sucesso de bilheteria, em seu país de origem, deve-se, em boa parte, ao fato de o filme ter conseguido capturar o estado de espírito do México naquele momento.

Amores brutos não parecia destinado ao sucesso de público devido ao seu tempo de duração, intensos 153 minutos, ser mais longo do que o adotado como padrão no mercado (entre 80 e 120 minutos). Outro aspecto de forte potencial de rejeição da audiência seriam as sangrentas brigas de cachorros presentes no enredo (ver Figuras 3.1e 3.2). ${ }^{64}$ Apesar dessas supostas inadequações da obra ao circuito comercial e de suas características temática e estética serem marcadamente locais, Amores brutos obteve retumbante êxito de bilheteria em seu país de origem e cruzou fronteiras. A produção foi distribuída em várias nações, o filme foi aclamado como um dos mais premiados mundialmente no ano de seu lançamento e indicado

\footnotetext{
${ }^{63} \mathrm{O}$ filme foi lançado pela $\mathrm{Nu}$ Visión, em agosto de 2000, com 215 cópias e arrecadou U\$8.8 milhões no mercado exibidor mexicano. Essa é a quarta maior bilheteria de um filme mexicano no seu próprio país em todos os tempos (WOOD, 2006, p. 86). Segundo Smith (2003, p. 12-13), a performance do filme teria sido ainda melhor: maior bilheteria no México em 2000 e a segunda maior arrecadação no mercado mexicano em todos os tempos, dez milhões de dólares; arrecadação de cinco milhões de dólares nos Estados Unidos e vinte milhões mundo afora.

${ }^{64}$ Todas as Figuras deste capítulo são frames do filme Amores brutos.
}

Fonte: AMORES perros. Direção: Alejandro Gonzales Iñárritu, México: Altavista/Europa Filmes, 2000.1 DVD (153 min). 
ao Oscar de melhor filme estrangeiro, ${ }^{65}$ consagrando-se, dessa forma, como um filme local em seu interesse imediato, e global em seu alcance, tanto nacional como transnacional. A estrondosa repercussão do filme foi decorrente, também, de eficazes táticas de divulgação e promoção. Entretanto, tais táticas só surtiram efeito tão amplo devido às qualidades artísticas da obra ao promover um inovador diálogo estético com a tradição da narrativa cinematográfica, o qual examinaremos minuciosamente a seguir.

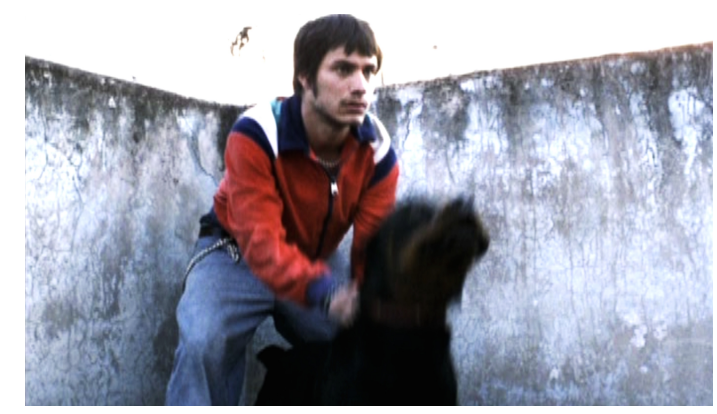

Figura 3.1 - Octavio (Gael Garcia Bernal) atiça seu cachorro Cofi antes de luta

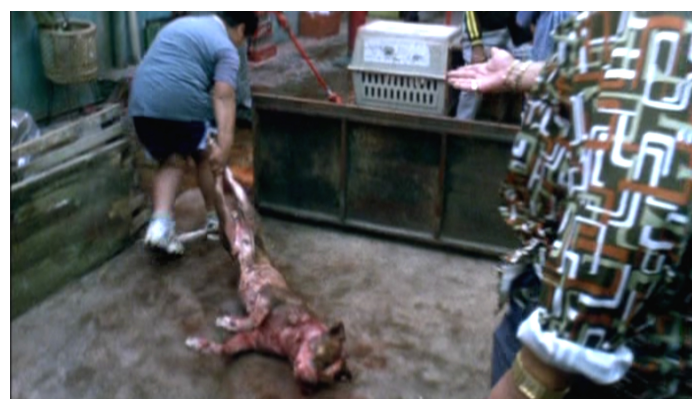

Figura 3.2 - Apesar das cenas de embate entre cães serem muito realistas, os produtores garantem que nenhum animal sofreu durante as filmagens

\subsection{Antecipação, fragmentação e convergência}

Este capítulo analisa as relações entre história (fabula) e enredo (syuzhet) que Iñárritu tece com os temas de seu primeiro filme. $\mathrm{O}$ diretor apresenta uma narrativa com múltiplos enredos (multiplot), na qual uma batida acidental de automóveis na Cidade do México promove o cruzamento da vida de três estranhos - Octavio, Valeria e El Chivo. Iñárritu urde com arrojo e destreza sua primeira narrativa de rede, tipologia que vai distinguir não apenas sua "trilogia da morte" (Amores brutos, 21 gramas e Babel), mas, tornar-se uma marca do cinema contemporâneo transnacional.

Em Amores brutos, assim como em suas outras narrativas de rede, Iñárritu estabelece conexões inusitadas entre personagens por meio da violência, ressaltando sua relevância na sociedade atual e revelando o impacto de ações descuidadas de uma pessoa sobre outras. No

\footnotetext{
${ }^{65}$ Amores Brutos ganhou mais de 30 prêmios internacionais, incluindo o Prêmio da Crítica no Festival de Cannes, um BAFTA e o prêmio de Melhor Diretor no Festival de Edinburgh para Iñárritu. Além do Oscar de melhor filme estrangeiro, o filme também foi indicado também ao Globo de Ouro na mesma categoria. (KEER, 2010, p. 43)
} 
filme, a intersecção ao acaso das trajetórias dos protagonistas em um acidente de carro carrega uma parte considerável do seu peso narrativo ancorando manipulações temporais e gerando variações de perspectiva na narração das histórias.

Nas narrativas de rede, destacam-se determinadas instâncias constitutivas da narrativa, como as personagens e o tempo. A narração, em Amores Brutos, valoriza a exposição autoconsciente de informações sobre a história ao longo do enredo. Iñárritu lança mão de uma combinação de estratégias narrativas na condução da trama, que evidenciam o peso da narração para o espectador. Algumas dessas estratégias atuam na macroestruturação da trama, enquanto outras agem na microestrutura da narrativa.

A estrutura do filme é dividida em três capítulos com durações diferentes, ${ }^{66}$ cada um deles introduzido por um intertítulo com os nomes das personagens principais de cada parte "Octavio y Susana"; "Daniel y Valeria" e "El Chivo y Maru" -, sendo que a narração favorece apenas um dos membros dos casais dos capítulos. As histórias são mais porosas do que a marcada divisão tripla sugere, com várias inserções de cada história permeando as demais (ver esquema com a estrutura do filme no Apêndice A e a escaleta no Apêndice B). O primeiro capítulo, Octavio e Susana, é o mais entrecortado pelos demais. Ele conta com sete inserções da história de El Chivo e quatro de Valeria. O segundo capítulo, "Daniel e Valeria", é o mais homogêneo e sofre apenas duas inserções de cenas de El Chivo. O terceiro capítulo, El Chivo e Maru, conta com três intromissões da história de Octavio e uma menção à de Valeria, seu outdoor de propaganda de perfume sendo retirado de um prédio enquanto El Chivo passa em um carro roubado.

A fragmentação entrelaçada das tramas de Amores brutos cultiva o principal estímulo ao envolvimento do público nas narrativas de rede que é a expectativa de que personagens, ações e situações tendam a estabelecer conexões entre si. Essas conexões vêm, de certa maneira, preencher as lacunas deixadas pelo afrouxamento da causalidade no encadeamento do filme marcado pela imprevisibilidade do acaso. A forma com a qual Iñárritu urde a tessitura de sua narrativa induz a comparações que estimulam o espectador a reparar nas afinidades e diferenças que lhe são apresentadas entre as personagens e situações dos três capítulos.

O ponto forte de atração das narrativas de rede, sua capacidade de promover arrebatamento por meio da justaposição de cenas, enfatizando temas, é proeminente na trama do filme

\footnotetext{
${ }^{66}$ O primeiro capítulo, "Octavio e Susana", tem 57 minutos e vinte segundos de duração; o segundo, "Daniel e Valeria", é o mais curto, com apenas 36 minutos e 43 segundos; e o terceiro, "El Chivo e Maru", é o mais longo e passa um pouco de uma hora, sessenta minutos e 26 segundos. No cálculo das durações dos capítulos não se descontaram as inserções de uma história entrelaçada nas outras.
} 
quando aborda, por exemplo: o poder do acaso no rumo da vida e a disputa machista por dominância. Amores brutos apresenta também comparações contrastantes ao abordar as diferenças entre formas de amar, classes sociais e faixa etária de personagens.

A análise fílmica de Amores brutos pretendeu investigar como as estratégias narrativas utilizadas, tanto na macroestruturação da trama como na microorganização das cenas, realçam sua narração, estimulando e, constantemente, renovando o interesse do espectador. Examinouse como a narração organiza e distribui informações sobre a história (fabula, story) por meio do enredo, trama (syuzhet, plot), instituindo a ordenação temporal não-linear dos acontecimentos, expondo e desenvolvendo seus múltiplos personagens. Por meio dessa análise, foi possível elucidar os atrelamentos e impactos das opções de narração em outras instâncias da narrativa, como na ordenação temporal e no arco de transformação das personagens.

Primeiramente, foram investigadas as principais estratégias que conformam a macroestrutura da trama: abertura em flashforward, fragmentação em capítulos, repetição da colisão de automóveis, entrelaçamento dos enredos, e retardamento da apresentação dos protagonistas. Em seguida, foram examinados dois recursos narrativos que operam na microcomposição das cenas: predomínio da câmera na mão e abertura com plano de detalhe. A partir dessas análises, foi examinada a maneira com que as temáticas do filme são plasmadas pelas opções narrativas adotadas.Amores brutos já começa intenso com um flashforward repleto de elementos típicos do excesso retórico marcante no cinema mexicano, com tiros em meio a uma perseguição de carros, um cão ensanguentado, Cofi, e um rapaz, Jorge (Humberto Busto), que pergunta desesperadamente ao motorista Octavio (Gael García Bernal): “O que você fez, seu idiota"? (“Que hiciste cabrón?”). O ritmo da montagem é acelerado, em menos de dois minutos e meio ( 2 minutos e 18 segundos), o espectador é bombardeado com 71 planos, estabelecendo uma média de duração de menos de dois segundos por plano. A câmera muda de ângulo constantemente, alternando planos internos e externos de perseguidores e perseguidos, com enquadramentos fechados que enfatizam o medo dos garotos caçados.

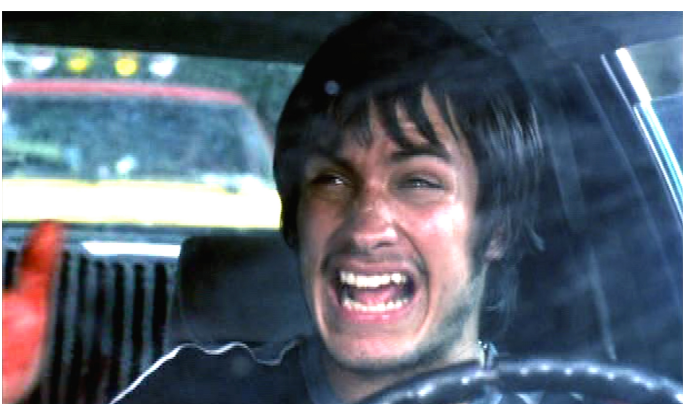

Figura 3.3 - Octavio dirige desesperadamente tentando fugir de perseguidores que atiram

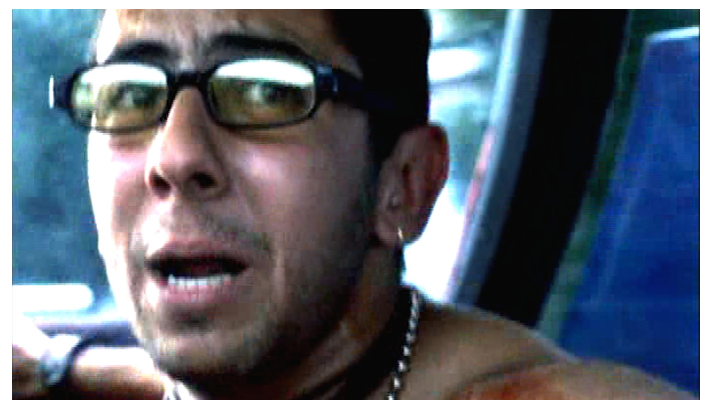

Figura 3.4 - Julio compartilha a agonia de seu amigo Octavio no banco de passageiro 


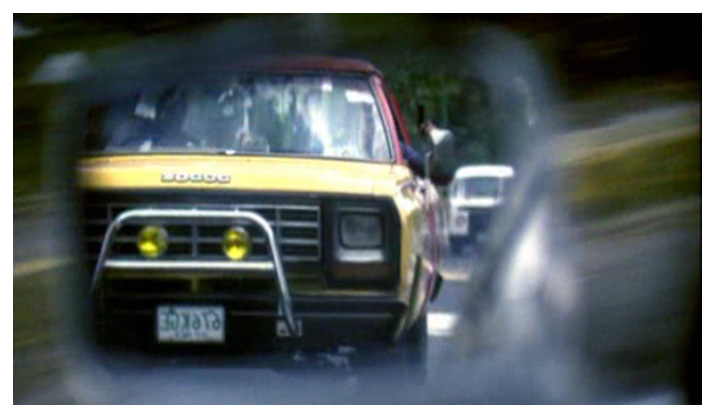

Figura 3.5 - Plano rápido dos perseguidores no ponto de vista de Octavio

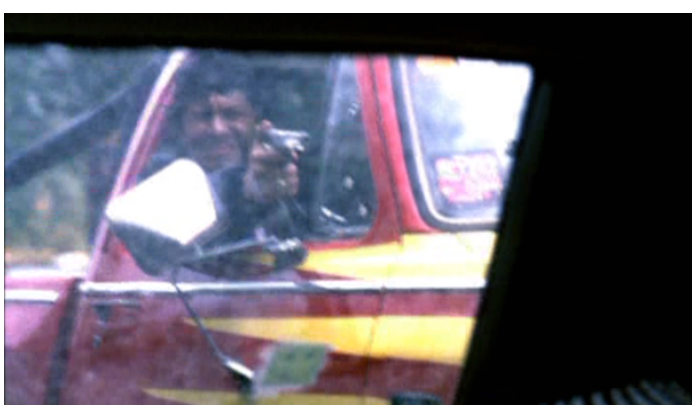

Figura 3.6 - Plano rápido dos perseguidores no ponto de vista de Jorge

A montagem da cena dificulta a orientação do espectador que fica impossibilitado de estabelecer uma compreensão clara da ação. As imagens ganham efeito ainda mais dramático pela utilização do processo de bleach-bypass ${ }^{67}$ que aumenta o contraste intensificando pretos, brancos e os tons de vermelho do sangue (ver Figura 3.7). O senso de desorientação espacial é intensificado pela banda sonora do filme, que acrescenta tons de desespero ao combinar múltiplas camadas de sons de pneus cantando, motores roncando, gritos, tiros e buzinas.

O carro perseguido parece escapar após a camionete amarela que está em seu encalço frear bruscamente para evitar o choque com um ônibus escolar. Apesar da eufórica vibração de alívio dos garotos, a camionete retoma o ataque atirando. $\mathrm{O}$ carro dos garotos atravessa um sinal vermelho e choca-se violentamente contra outro que vem da esquerda (ver Figura 3.8). A tela escurece (fade in) surge o título do primeiro dos três capítulos do filme: "Octavio e Susana".

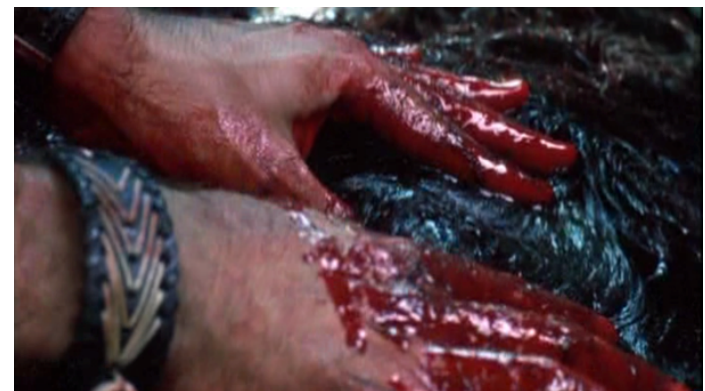

Figura 3.7 - O tom de vermelho do sangue do cachorro é intensificado pelo bleach-bypass

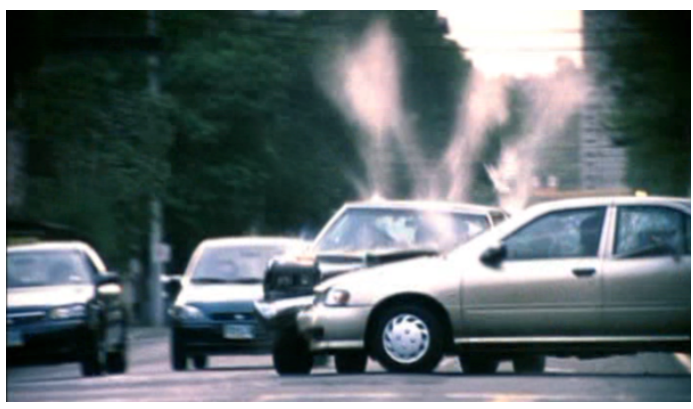

Figura 3.8 - Primeira apresentação da batida de carro no filme

\footnotetext{
${ }^{67} \mathrm{O}$ bleach-bypass é um procedimento realizado durante a revelação de emulsões coloridas que consiste na retenção da prata. O efeito final dá a impressão de haver uma imagem preto-e-branco sobreposta sobre uma colorida com contraste e granulação intensificadas. Digitalmente também é possível obter efeitos semelhantes aos alcançados opticamente.
} 
Como os espectadores não conhecem as personagens envolvidas nessa perseguição inicial desenfreada e nem sabem o que a motivou, a cena é instigante ritmicamente, levanta muitas perguntas, mas explica pouco sobre a história e as personagens. Trata-se de uma estratégia alternativa à narração clássica no início de um filme, que, normalmente, apresenta as personagens principais no trabalho ou em casa, e estabelece o conflito matriz, com objetivo de facilitar a entrada do espectador no mundo da história e em sua cadeia causal.

A abertura do filme em flashforward com a sequência de perseguição e batida de carros configura uma antecipação, dado que se trata da ocorrência de um evento antes de seu lugar normal na história. $\mathrm{O}$ artifício narrativo da antecipação possui caráter provocador ao permitir que o espectador vislumbre o resultado antes de ser exposto a toda cadeia causal que leva até àquele ponto da história. Tal procedimento tem a função de anunciar um acontecimento, visando suscitar a curiosidade do espectador. Projeta-se essa colisão no futuro para gerar questionamentos sobre quem são as personagens envolvidas nessa caçada tão desesperada e como chegaram a essa situação.

O flashforward opera nas discrepâncias advindas da dupla temporalidade da narrativa e explora as diferenças entre a ordem em que os acontecimentos aparecem na trama (syuzhet) e seu lugar na história (fabula). A antecipação rompe a linearidade temporal e causal da história, potencializando o engajamento do espectador no desafio de ordenar os acontecimentos que serão, gradualmente, apresentados para possibilitar a compreensão da história por meio de inferências, deduções e hipóteses.

Por outro lado, o flashforward é um recurso que explicita uma intervenção externa direta do autor na narração para "esquentar" a interação do espectador com o filme. Trata-se de uma abertura intensa em fluxo de sons e imagens, instigante na aliciação do espectador. O emprego do flashforward na abertura de um filme estabelece uma estratégia desafiadora que incita a imersão do espectador de uma maneira mais ativa na narrativa. Trata-se de um recurso narrativo muito utilizado no cinema contemporâneo e sua aplicação por meio de uma cena de perseguição levanta questões específicas. ${ }^{68}$

As perseguições exercem um fascínio quase irresistível por proporcionar uma vivência mediada que foi primordial à sobrevivência humana, perseguir e ser perseguido, ser caça ou caçador. Essa situação dramática já era valorizada na mitologia e na literatura e encontrou no cinema, desde seus primórdios, uma arte que a potencializa ao representá-la com movimento,

\footnotetext{
${ }^{68}$ Vale lembrar de outro filme latino-americano que começa com um flashforward de cena de perseguição que também obteve grande sucesso em festivais e bilheteria dentro e fora de seu país de origem: o brasileiro Cidade de Deus (Fernando Meirelles, 2001).
} 
e depois com as possibilidades estimulantes dos sentidos amplificadas pela inclusão do som. Começar a apresentar a história com uma perseguição é uma escolha narrativa ousada por apresentar uma cena que normalmente constitui o clímax da narrativa clássica, principalmente nos filmes de ação, e que, tradicionalmente, localiza-se na passagem do segundo para o terceiro ato da narrativa, no quarto final dos filmes. Essa opção é cada vez mais recorrente no cinema e também em seriados para a televisão objetivando um início arrebatador em alta voltagem para prender o espectador e incitá-lo a acompanhar todo o desenrolar da cadeia causal que leva até àquele ápice entregue de entrada. ${ }^{69}$

Cristopher Vogler (1998) ao estudar a narrativa dos filmes americanos com ênfase nos sucessos de bilheteria em A jornada do escritor - estruturas míticas para escritores, incorporou ao seu livro os estágios da jornada do herói propostas por Joseph Campbell (2007) em $O$ herói de mil faces. Em suas análises, Vogler constatou a recorrente presença de cenas de perseguição no décimo estágio da jornada do herói, que nomeou de "Caminho de volta", e marca a transição de retorno do herói do "mundo especial" para o "mundo comum". O Caminho de volta é um estágio posterior aos da "Provação", no qual o herói enfrenta o seu maior desafio e escapa da morte, e ao da "Recompensa", no qual assimila as lições e colhe os benefícios, consegue o seu "santo graal", por ter superado seu pior medo na "caverna mais escura". No estágio da Recompensa existe uma tendência de queda da energia da história que a ação de perseguição tende a incrementar. A perseguição surge normalmente como uma retaliação, um contragolpe do vilão ou seus associados que foram vencidos na "Provação". Essa força vingadora que executa a perseguição é capaz de dar um golpe muito duro na sorte do herói, ferindo-o ou matando as pessoas mais chegadas a ele.

No filme em análise, um de seus protagonistas, Octavio, vai se ferir gravemente ao final da perseguição. Com essa motivação, as cenas de perseguição estão, quase sempre, presentes como clímax máximo de filmes de ação e de fantasia. Entretanto, no filme em questão, a perseguição assume outra função alternativa na estruturação da narrativa. Em Amores brutos a batida de carros é o clímax antecipado apenas da primeira história, de Octavio; estabelece o conflito matriz da segunda história, de Valeria; e transfere um elemento da história de Otavio que deflagrará um ponto de virada (turning point) na terceira, de El Chivo.

Depois da instigante alusão ao futuro na cena de perseguição da abertura, há um recuo no tempo e a adoção de um escoamento linear em seu primeiro capítulo, que apresenta o con-

\footnotetext{
${ }^{69}$ São exemplos recentes o francês Intocáveis (Intouchables, de Olivier Nkache e Eric Toledano, 2011) e os seriados para a televisão - Breaking bad - a química do mal (Breaking bad, TV series 2008/13) e Amores roubados (Rede Globo, 2014).
} 
vívio conflituoso de uma família de classe média baixa composta pela mãe, seus filhos jovens adultos Octavio (Gael Garcia Bernal) e Ramiro (Marco Péres), a esposa quase adolescente de Ramiro, Susana (Vanessa Bauche), e o bebê deles. Ramiro é violento dentro e fora de casa, bate em Susana, briga com Octavio e também pratica assaltos a mão armada para complementar seu salário de caixa de supermercado. Octavio tenta proteger sua cunhada Susana dos assédios e agressões de Ramiro, mas acaba seduzindo-a. Para agravar mais ainda a situação, Susana está grávida novamente de Ramiro. Octavio tenta convencê-la a largar seu irmão, fugir com ele e começar uma nova vida com o dinheiro que ganha na rinha de cachorros com Cofi, o Rottweiler que era de Ramiro. Susana acaba cedendo ao assédio de Octavio e aceita fugir com ele, mas, ao invés disso, parte com Ramiro e o bebê após uma surra que Octavio encomenda para o irmão para que ele entre na linha. Em sua derradeira luta, Cofi leva um tiro, Octavio esfaqueia o autor do disparo, seu rival de rinha, El Jarocho (Sánches Parra). Nesse ponto, chega-se novamente à perseguição de carro ensandecida da abertura do filme que provoca a batida do carro de Octavio em fuga, dessa vez, posicionada em seu lugar natural tanto temporalmente como na cadeia de causa e efeito desse primeiro capítulo.

No segundo capítulo, intitulado "Daniel e Valeria", uma famosa modelo espanhola, Valeria (Goya Toledo), vai viver em um novo apartamento com Daniel (Álvaro Guerrero), um bem sucedido editor de uma grande revista, que larga a mulher e duas filhas para ficar com sua amante. ${ }^{70}$ Valeria sai acompanhada de seu cachorrinho, Richie, para comprar uma garrafa de vinho para a primeira refeição do casal na nova moradia quando seu carro é violentamente abaulado pelo de Octavio em fuga da gangue de El Jarocho. Valeria tem uma das pernas gravemente quebrada, o que a coloca em uma cadeira de rodas. Enquanto Valeria figura triunfante em outdoors do perfume Enchant por toda a cidade, ela tem sua recuperação atormentada pela entrada do seu cãozinho Richie em um buraco no piso da sala de estar do recém constituído apartamento do casal. Os dias passam e Daniel não consegue retirar o cachorrinho debaixo do piso. Valeria tenta desesperadamente resgatar seu bichinho do buraco, fere novamente a mesma perna imobilizada com pinos que acaba sendo amputada. Ao final, vemos o casal olhando pela janela do apartamento a parede do edifício onde, antes, havia o outdoor com Valeria exibindo suas belas pernas, anunciando o perfume, e, nesse momento, vê-se o anúncio de aluguel daquele espaço publicitário.

\footnotetext{
${ }^{70} \mathrm{O}$ fato de Valeria ser espanhola e o motivo da separação de Daniel, levou Deleyto e Azcona (2010, p. 18) a relacionarem a construção dessa personagem com fantasmas do passado da dominação hispânica e o mito de $L a$ Malinche, a nativa que traiu o povo Asteca e tornou-se amante de Cortés.
} 
O terceiro e último capítulo, "El Chivo e Maru", conta a história de um velho desleixado que vaga pela cidade puxando um carrinho cheio de coisas velhas encontradas pelas ruas, acompanhado por uma matilha de vira-latas. Gradativamente, ficamos sabendo que El Chivo (Emilio Echevarría), literalmente "o Bode", é um ex-professor que abandonou sua família para viver como um revolucionário, esteve preso e trabalha ocasionalmente como matador de aluguel. Quando El Chivo fica sabendo da morte de sua ex-mulher, procura se aproximar de sua única filha, Maru (Lourdes Echevarría), que acredita que seu pai estivesse morto.

Mediado por um policial corrupto, Leonardo (José Sefami), El Chivo é contratado por um jovem executivo, Gustavo (Rodrigo Murray), para matar seu sócio Luis (Jorge Salinas). El Chivo presencia a batida de carro entre Octavio e Valeria, resgata Cofi do veículo de Octavio e cuida dele. O Rottweiler, quando restabelecido, trucida todos os outros cachorros da matilha de El Chivo, enquanto ele está perseguindo sua vítima encomendada, Luis. Esse evento provoca uma reviravolta na vida de El Chivo, que resolve parar de matar e muda sua aparência corta cabelo, barba e unhas. Ele descobre que Gustavo e Luis são meio irmãos, rouba-lhes dinheiro, celulares e os carros e os coloca em confrontação para que resolvam suas questões. Ao final, El Chivo deixa dinheiro e uma mensagem para sua filha Maru e caminha a esmo na esperança de uma futura conciliação com ela.

A concepção da personagem de El Chivo, um ex-terrorista que se transformou em assassino de aluguel associado à corrupção policial, expressa um sentimento de desencantamento com os ideais revolucionários que foram traídos também por aqueles que assumiram o poder no México. Esse sentimento de desencantamento político encarnado nesse personagem está alinhado com a perda da esperança utópica que marca a pós-modernidade não apenas na América Latina, como também em diversos países nos cinco continentes.

A batida de carros entre Octavio e Valeria, testemunhada por El Chivo e apresentada quatro vezes no filme (cenas 1, 41, 45 e 82), opera como o elemento convergente que elucida as relações temporais entre os três capítulos e acrescenta novos pontos de vista cada vez que vem à tela. A repetição do acidente oferece um fio de Ariadne que permite ao espectador estabelecer conexões e orientar-se na fruição da complexidade da narrativa. Cada vez que esse evento é reapresentado, uma camada adicional é acrescentada àquele momento fatídico, ampliando a compreensão do acidente e das vidas que colidiram naquele tempo e espaço específicos. Esse acidente ao acaso é central na orquestração dessa narrativa com múltiplos protagonistas que apresenta uma estrutura alternativa, substituindo, assim, o princípio organizacional clássico dos filmes de enredo em progressão (forward-moving). A reprise de frações de um 
evento sob diferentes perspectivas é um recurso que evidencia o peso da narração ao ordenar três enredos sobrepostos e fora da ordem cronológica.

O acidente de carro em Amores brutos é o entroncamento do filme, o único momento em que as três histórias coincidem no mesmo tempo e espaço. De acordo com Bordwell (2008, p. 204, tradução nossa), "a convergência mais comum baseada no acaso, tão convencional quanto um tiroteio na rua principal de um Western, é um acidente de carro". ${ }^{71}$ O teórico americano justifica o uso recorrente de colisão de automóveis como ponto de convergência em narrativas de rede devido à sua plausibilidade no universo da história e por ser o mais óbvio encontro ao acaso que pode trazer graves consequências aos envolvidos, principalmente em grandes centros urbanos. Iñárritu valoriza esse elemento de convergência do acidente de carros por meio de repetições para estruturar o entrelaçamento das histórias e desempenhar a função de ordenador temporal da trama para o espectador.

$\mathrm{Na}$ cena de perseguição lançada na abertura do filme em flashforward, o espectador não dispõe de elementos suficientes para fazer maiores conjecturas sobre seu significado e função na narrativa. Só será possível compreender melhor a cena quando ela for reapresentada em sua posição cronológica e causal natural ao final do capítulo de Octavio. Entretanto, a parte final da perseguição, a batida de automóveis, surge mais duas vezes na trama, somando quatro aparições ao todo. As reapresentações da batida acrescentam pontos de vista à ação. Em cada retorno ao acidente, diferentes perspectivas trazem novas informações, estabelecem novas ligações e ampliam a compreensão da trama como um todo.

A primeira vez que o acidente é mostrado na abertura (0min:51seg, indicação da posição inicial em hora, minutos e segundos), só vemos dois rapazes ansiosos em fuga, com um cachorro ferido no banco de trás, batendo no carro de numa mulher anônima (cena 1). Na segunda aparição da batida (57min:20seg), são expostas as razões da correria de Octavio e seu amigo Jorge (cena 41). Quando o filme retorna pela terceira vez ao acidente (1h:01min:53seg), é para nos contar quem é a mulher no carro, Valeria, e que circunstâncias a levaram a dirigir por aquela intersecção naquele momento (cena 45). Na quarta vez que a batida vem à tela (1h:45min:25seg), a cena é mostrada sob o ponto de vista de uma testemunha, El Chivo, e revela o que acontece depois da batida (cena 82). Pela primeira vez, vemos El Chivo participando furtivamente no atendimento das vítimas, roubando o dinheiro de Octavio que está indefeso, ferido, e levando com ele Cofi, o Rottweiler baleado. Em termos de estrutura da narrativa, a batida de automóveis tem posições e funções diferentes em cada uma das

\footnotetext{
${ }^{71}$ No original: "The most common chance-based convergence, as conventional as a main street shootout in a Western, is the traffic accident." (BORDWELL, 2008, p. 204)
} 
três histórias do filme: é o clímax da primeira; o incidente que estabelece a situação do conflito matriz da segunda; e transfere um elemento da história de Otavio para a de El Chivo, o Rottweiler Cofi, que deflagrará um ponto de virada (turning point) na terceira.

A mudança de acesso à história por meio da alternância entre os protagonistas obriga a narração a manipular o tempo. A repetição da batida de carros, além de expandir a compreensão da história por meio das relações causais que estabelece e revelações de perspectivas diferentes para cada protagonista, também opera como um marco cronológico que permite ao espectador ordenar temporalmente os eventos apresentados. Trata-se de uma estrutura temporal de certa complexidade, com irregularidades e assimetrias cuidadosamente equilibradas. Há uma distribuição irregular de elementos anteriores e posteriores ao acidente nos capítulos. No filme, assim como em quase todas as narrativas em rede, a duração do tempo da história é bem restrito, algumas semanas. Enquanto a história de Octavio e Susana, primeiro capítulo, aborda eventos que acontecem antes do acidente, a de Daniel e Valeria, segundo capítulo, trata das consequências da batida. Por sua vez, a história de El Chivo e Maru, terceiro capítulo, revela-se nos dois momentos, mostrando a vida desse protagonista tanto antes como depois da colisão.

Em Amores brutos, após o acidente, não se estabelecem vinculações entre as personagens para uni-los em relações diretas ou indiretas. As vidas dos personagens principais só se entrecruzam uma vez e cada personagem lida com as consequências em total ignorância do destino das outras pessoas envolvidas no acidente. A ausência de interação entre os protagonistas das três histórias do filme amplifica a percepção de suas solidões e estimula o espectador a desempenhar um papel ainda mais ativo na busca de conexões entre os dramas que vivem. Nesse aspecto, Amores brutos difere-se dos dois filmes seguintes de Iñárritu - 21 gramas e Babel-, nos quais as personagens descuidadas que provocaram o infortúnio de outras tomam conhecimento de seus destinos, conforme será analisado nos capítulos seguintes.

Após o exame da proeminência da narração na macroestrutura da narrativa de Amores brutos - por meio da abertura em flashforward e da fragmentação entrelaçada das histórias em capítulos - serão destacadas, a seguir, duas outras estratégias que se somam a elas na tessitura da trama: o retardamento na apresentação dos protagonistas, que também opera no nível macroestrutural; e a abertura com plano de detalhe, que age na microestrutura das cenas. $\mathrm{O}$ objetivo dessa nova camada analítica é examinar como o adiamento da apresentação das personagens principais embaralhando-as com as secundárias e o início de cenas com planos de detalhe se articulam com as demais estratégias narrativas do filme e promovem a renovação do interesse do espectador. 


\subsection{Apresentação dos protagonistas e abertura com plano de detalhe}

Em filmes multiprotagonistas, a apresentação das personagens na trama é normalmente mais distribuída e demanda mais tempo para ser finalizada em relação às narrativas clássicas com apenas uma ou duas personagens principais. Isso se dá simplesmente devido ao maior número de agentes envolvidos na história. Em Amores brutos, além do número de protagonistas já ser mais elevado do que o convencional, as suas apresentações além de entrelaçadas são retardadas pela opção deliberada de apresentá-los após personagens secundários. A narração de Iñárritu, no filme, prefere também não revelar as características básicas dos protagonistas e nem elucidar suas ligações com as personagens secundárias na primeira oportunidade. Ao invés disso, opta por oferecer alguns traços vagos, outros ambíguos e até pistas falsas da configuração dos protagonistas para que o espectador vá retendo essas noções para, gradualmente, conceber uma visão multifacetada de seu todo.

Essa opção por ir delineando gradativa e tortuosamente os protagonistas, associada com a introdução de personagens secundárias antes das principais, aguça ainda mais a curiosidade do espectador. A combinação dessas opções de apresentação das personagens incita a plateia a fazer um esforço extra para diferenciar os protagonistas dos coadjuvantes e elucubrar sobre suas relações. O modo de apresentação de personagens fica evidente no exame do primeiro capítulo do filme, "Octavio e Susana", o mais permeado por inserções de trechos dos outros dois capítulos.

A apresentação do protagonista Octavio não se faz logo depois do intertítulo de sua história. Ao som de latidos, a primeira imagem que surge é a de um cachorro grande conduzido por El Jarocho, entrando na rinha de Mauricio (Gerardo Campbell), passando por outro cão morto sendo arrastado na direção contrária e deixando um rastro de sangue, vê-se também outros animais enjaulados e ensanguentados (cena 2). O amigo de Octavio que estava com ele no carro perseguido que bateu, Jorge (Humberto Busto), está na rinha e ouve El Jarocho e Mauricio acertando o valor das apostas na luta que está prestes a começar. Mauricio medeia e recolhe as apostas, El Jarocho e o dono do oponente provocam seus bichos que partem um ao ataque do outro assim que liberados. Como Jorge está tanto na cena da batida de carros em flashforward como na primeira cena da rinha de cachorros, essa dupla presença em cenas iniciais tão próximas induz a uma valorização excessiva de seu peso na trama. Ainda mais, levando-se em conta que, na época da produção e lançamento do filme, Gael García Bernal (Octavio) estava em seu primeiro papel de protagonista no cinema e era desconhecido do grande público. 
A cena seguinte mostra a fachada de uma casa modesta como fundo para a entrada em quadro de uma adolescente, Susana, usando um típico uniforme estudantil com mini saia e meia três-quartos, que abre a porta e permite que um enorme cachorro, Cofi, fuja (cena 3). Susana entra em casa e pega seu filho bebê que está em uma cadeirinha enquanto sua sogra (Adriana Barraza) está cozinhando. Susana pede à sogra para cuidar do netinho no dia seguinte também porque ela tem uma prova; a sogra responde que não pode e que ela já criou seus filhos e que Susana deve cuidar do dela.

Nesse ponto, quase aos seis minutos do filme, El Chivo, o protagonista do terceiro capítulo, aparece pela primeira vez em uma cena de trinta segundos de duração (cena 4). Ele cata uma armação de ferro do lixo, guarda em seu carrinho e empurra-o ao lado de uma pista acompanhado por um bando de cães. São sete planos em teleobjetiva, com construções desfocadas ao fundo e carros passando em alta velocidade em primeiro plano preenchendo toda a tela em alguns momentos, facilitando os cortes (Figura 3.9). O último plano da cena é o único feito com uma lente grande angular que desvenda a inserção de El Chivo em um amplo ambiente de periferia de grande cidade.

El Chivo é, inicialmente, apresentado como um catador de lixo, quando, de fato, sua atividade de maior peso econômico e dramático é a de matador de aluguel, o que só será desvendado mais à frente. Novamente, a narração opta por privilegiar uma informação secundária em detrimento de outra mais relevante na narração da história, enredando o espectador no processo de analisar pistas e fazer inferências de maneira mais dinâmica, tendo que rever constantemente suas expectativas.

Somente aos onze minutos, revela-se El Chivo em seu quarto decadente, sentado na cama rodeado de cachorros, olhando a foto de um homem de paletó e gravata com anotações no verso e pondo balas no pente de uma pistola, notam-se suas unhas longas e sujas (cena 9). A história de Octavio vai se desenrolando e, aos quinze minutos (cena 12), El Chivo assassina a tiros, em um sofisticado restaurante japonês, o homem da foto que manipulava na inserção anterior (ver Figura 3.10). 


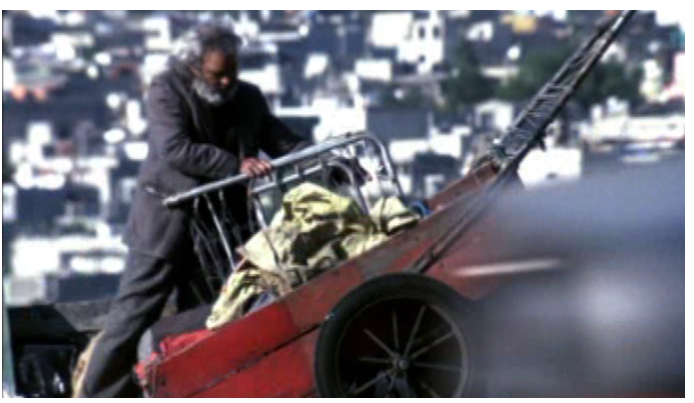

Figura 3.9 - El Chivo é apresentado como catador de lixo

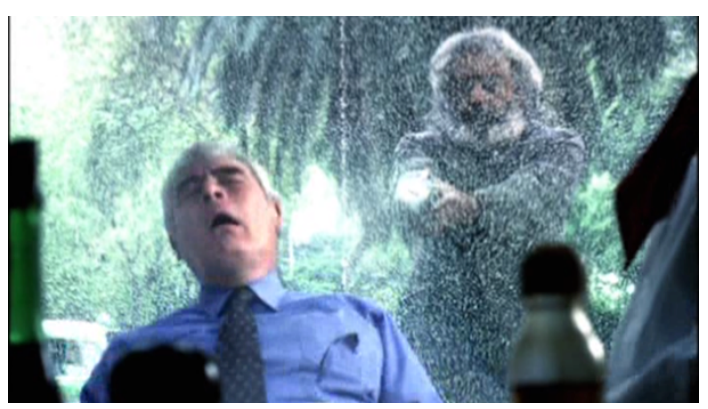

Figura 3.10 - A principal ocupação de El Chivo é a de matador de aluguel

Da rápida apresentação inicial de El Chivo catando lixo, corta-se de volta para a luta de cachorros e estampam-se as reações dos apostadores à vitória do animal de El Jarocho (cena 5). Só em seguida, após três minutos e meio do intertítulo desse capítulo e as aparições de cinco personagens coadjuvantes e de apoio desse núcleo dramático - El Jarocho, Júlio, Maurício, Susana, a mãe de Octávio e do cão Cofi - além do protagonista de outro capítulo - El Chivo -, finalmente, Octavio entra em quadro na cozinha de sua casa (cena 6) e começamos a entender suas relações com sua mãe, sua cunhada Susana, o bebê e seu irmão Ramiro (ver Figuras 3.11 a 3.16).

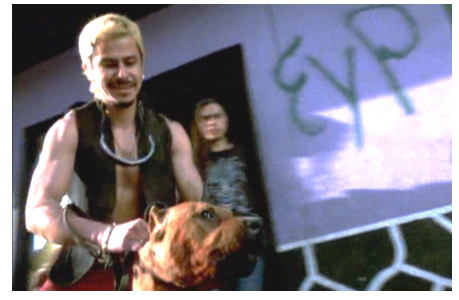

Figura 3.11 - El Jarocho, rival de Octavio nas rinhas de cães

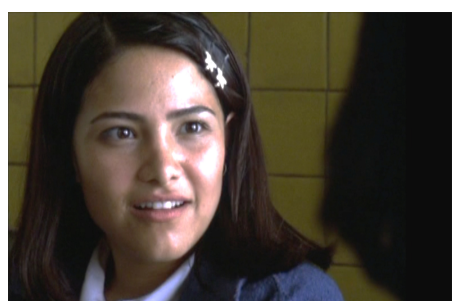

Figura 3.14 - Susana, cunhada de Octavio

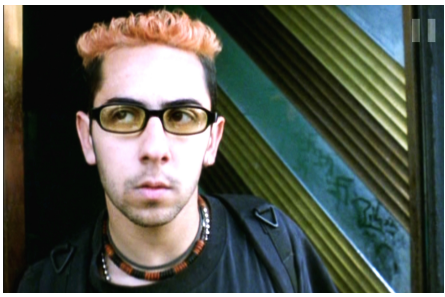

Figura 3.12 - Jorge, amigo de Octavio

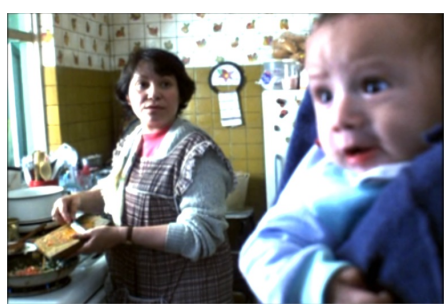

Figura 3.15 - Mãe de Octavio e filho de Susana

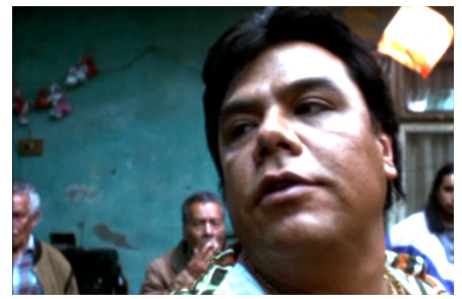

Figura 3.13 - Maurício, dono de rinha de cães

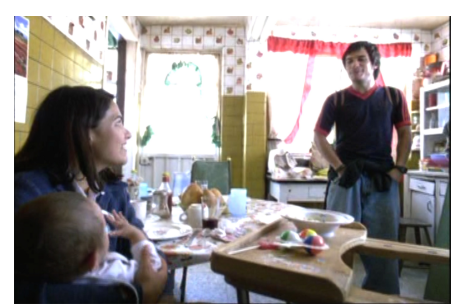

Figura 3.16 - Octavio entra em cena após coadjuvantes

Octavio é simpático e amável com sua cunhada, enquanto seu irmão é ríspido e opressor para com ela. Ramiro repreende Susana porque ela manchou seu uniforme de trabalho na lavagem e porque deixou Cofi escapar. Octavio intervém em defesa da garota, Ramiro diz 
para ele não se meter na conversa dele com sua mulher. A mãe dos rapazes manifesta-se a favor de Ramiro e contra a intervenção de Octavio. Após a saída de Ramiro da cozinha, Octavio e Susana olham-se e sorriem com cumplicidade. É bem tradicional a apresentação de uma personagem em casa para expor suas relações familiares e a cena avança na exposição da tensão e do potencial conflito entre os irmãos em função do interesse incestuoso de Octavio pela cunhada.

Dessa forma, Iñárritu energiza a narração convencional por meio do retardamento da entrada dessa cena mais tradicional, em combinação com o ordenamento mais intrincado do tempo da história e da manipulação da relevância na apresentação das personagens na trama. A importância das relações familiares no filme e nas narrativas de rede será aprofundada no próximo tópico.

Na sequência, após receber uma bolada pela vitória de seu animal, El Jarocho sai da rinha instigado a deixar seu cão brigar com outros animais na rua para se acalmar. Quando El Jarocho, seus comparsas e seu cachorro se aproximam de um bando de vira-latas no beco em frente, El Chivo entra no caminho deles com facão em punho em defesa de seus bichos (cena 7). Essa segunda, das sete intervenções da história de El Chivo no capítulo de Octavio, já planta indícios de seu lado violento (ver Figuras 3.17 a 3. 19). Um dos comparsas assobia e mostra Cofi do outro lado da rua. O bando dá as costas aos vira-latas e El Chivo, e sai em perseguição do Rottweiler. Júlio é testemunha do surpreendente triunfo de Cofi e morte de seu oponente e, mais tarde, conta o sucedido para seu amigo Octavio, quando El Jarocho coloca o corpo do cachorro morto na porta da casa dele. Ao acaso, descobre-se a vocação de Cofi para as lutas, o que terá profundo impacto no desenvolvimento desse capítulo.

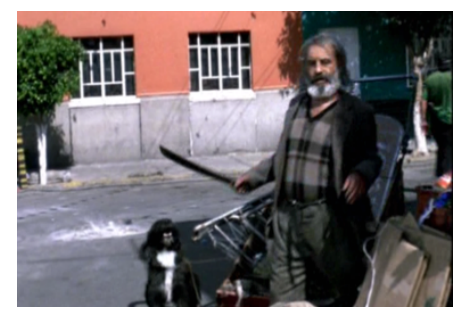

Figura 3.17 - El Chivo puxa o facão para proteger sua matilha

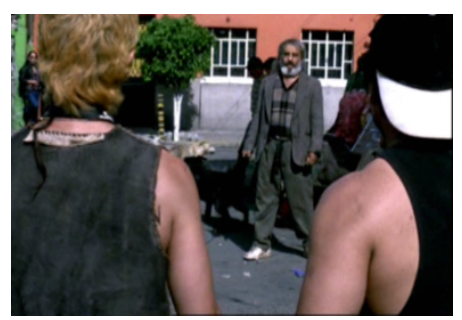

Figura 3.18 - El Chivo encara El Jarocho e seus capangas

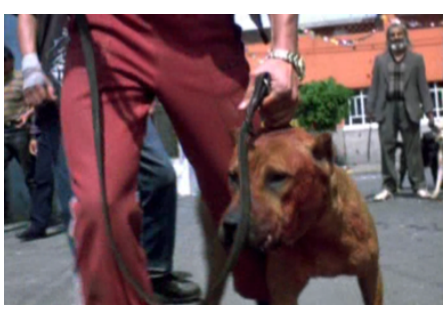

Figura 3.19 - El Jarocho parte em busca de outra presa

Essa segunda aparição de El Chivo no começo do filme, dessa vez cruzando o universo de Octavio por meio de seu amigo Jorge e do bando de El Jarocho, planta uma pista de que as trajetórias desses dois protagonistas vão se fundir, quando, de fato, apenas se tangenciam. Iñárritu emprega pistas falsas para enredar suas personagens na trama, usufruindo do poder da 
narrativa de rede em aguçar a sensibilidade da audiência em estabelecer conexões e inferir desdobramentos nas relações, o que potencializa seu envolvimento na fruição da narrativa.

Somente aos dezesseis minutos de filme (cena 13), ocorre a primeira das quatro intervenções dos protagonistas da segunda história do filme, "Daniel e Valeria", no primeiro capítulo de "Octavio e Susana". A apresentação desse núcleo dramático do filme é ainda mais tardia que a de El Chivo, que é o protagonista da terceira história, e utiliza outras variantes de entrelaçamento de exposição de informação primordial e secundária na tessitura da trama. A inserção dessa história começa com o surgimento de um carro em movimento, no qual uma mulher, que até então não havia aparecido, repreende as filhas que discutem no banco de trás enquanto seu marido, Daniel, inaugura sua participação no filme dirigindo entediado. O carro para em um sinal e Daniel contempla o outdoor de propaganda do perfume Enchant onde Valeria finalmente desponta imponente e sensual exibindo suas pernas.

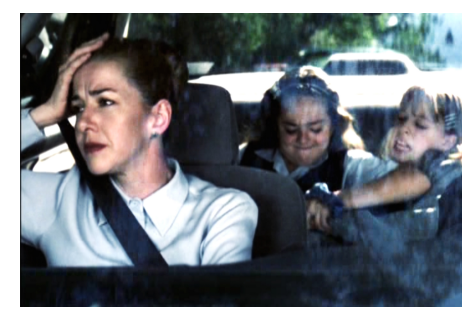

Figura 3.20 - Esposa de Daniel com filhas

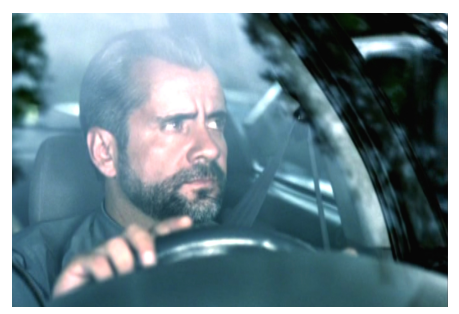

Figura 3.21 - Daniel entediado

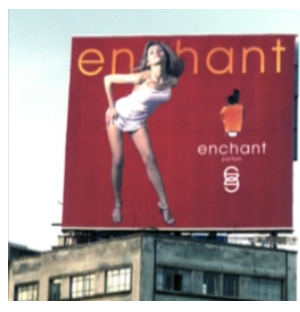

Figura 3.22 - Outdoor apresentando Valeria no filme

Não apenas na estrutura geral da narrativa, como também na microcomposição dessa cena inaugural da história de Daniel e Valeria, há um retardamento na aparição dos protagonistas com a antecipação das presenças secundárias da mulher e das filhas de Daniel. Em seguida, a família de Daniel chega em casa enquanto o telefone toca, mas ninguém responde quando sua filha atende. O telefone toca outra vez, a esposa atende, e, novamente, ninguém fala do outro lado, o que a leva a fazer comentários irônicos que deixam claro sua desconfiança de que seja outra mulher ligando para seu marido.

Nas outras duas inserções de Daniel que irrompem a história de Octavio, Valeria segue oculta ou ausente e utiliza-se a estratégia recorrente no filme de abrir cenas com um plano de detalhe para, só depois, justapor um plano aberto que revela onde aquele detalhe se encaixa. Essa estratégia narrativa operando na microestrutura das cenas será examinada com mais profundidade na parte final desta seção.

$\mathrm{Na}$ aparição seguinte de Daniel (30min:36seg), ele recebe outra ligação telefônica enquanto está na cama com sua esposa, assistindo na televisão um filme no qual aparecem dois 
japoneses conversando (cena 24). Quando esse plano dos japoneses bate na tela provoca um choque porque não tem nenhuma relação com a cadeia causal ou o imaginário apresentado até então. Daniel despista a mulher, sai do quarto para marcar um encontro com sua amante, que, novamente, não aparece na tela. A demora em se revelar quem é a amante de Daniel, Valeria, gera suspense.

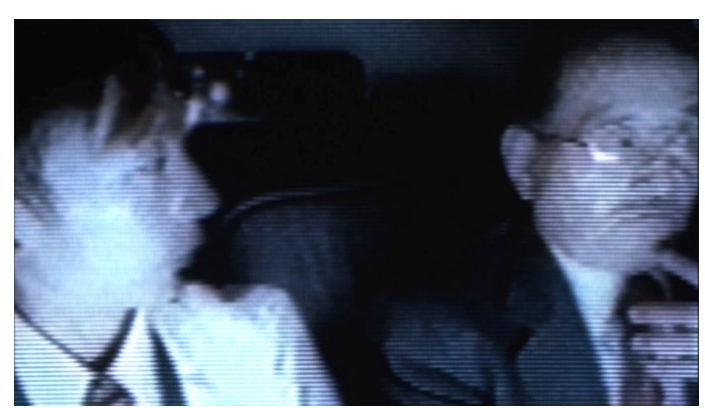

Figura 3.23 - Tela de TV com japoneses

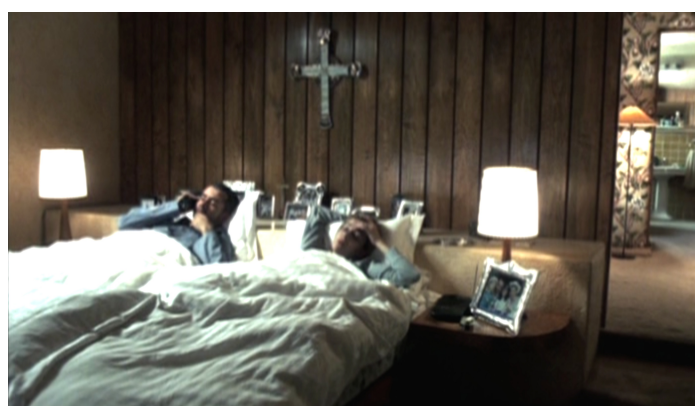

Figura 3.24 - Quarto de Daniel e sua esposa

$\mathrm{Na}$ aparição seguinte de Daniel (cena 34, 42min:52seg), mostra-se, primeiramente, um detalhe da luminária do quarto das filhas de Daniel, ele cobre-as enquanto dormem em suas camas, beija-as e desliga a luz (ver Figuras 3.25 e 3.26). Só mais tarde, no segundo capítulo do filme, quando Daniel se encontra com Valeria no novo apartamento do casal, revela-se que Valeria é sua amante, ele conta que largou a mulher e entende-se que Daniel estava se despedindo silenciosamente das filhas quando cobriu-as e beijou-as. Essas informações, espaçadamente entrelaçadas na trama, oferecem pistas que serão lembradas e processadas pelo espectador na compreensão das histórias gerando uma sensação de gratificação por participar ativamente do jogo narrativo. Apesar de a história de Daniel e Valeria apresentar um equilíbrio maior entre o peso de suas personagens principais, existe uma ligeira predominância de Valeria, que é justamente a figura dramática menos exposta nas cenas introdutórias.

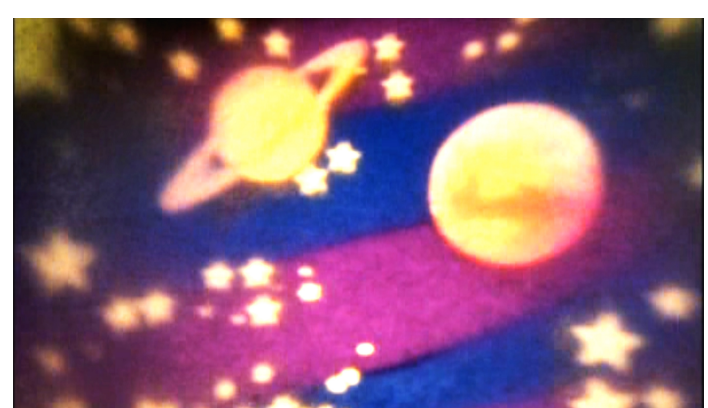

Figura 3.25 - Detalhe de luminária do quarto das filhas de Daniel

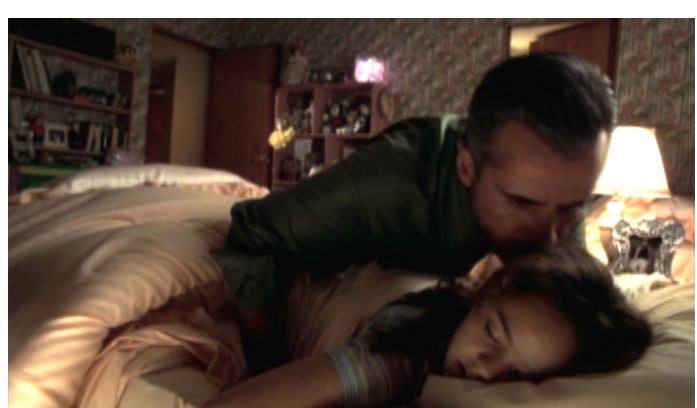

Figura 3.26 - Daniel despede-se de suas filhas com luminária ao fundo 
Na quarta inserção da história de Valeria e Daniel no primeiro capítulo (cena 40, 51min:32seg), Valeria aparece em entrevista no programa de celebridades "Gente de Hoy", assistida por Jorge na televisão do quarto de Octavio. A primeira imagem de Valeria no filme é em uma fotografia publicitária em um outdoor e a segunda em um talk show, que constitui uma forma alternativa de ligar protagonistas por meio da mídia sem precisar colocá-los frente a frente. A entrevista da TV, na qual Valeria apresenta seu falso namorado Andrés Salgado (Ricardo Dalmacci) e seu "filhinho", o cachorro Richie, é entrecortada com imagens de Daniel e Jorge contando dinheiro e se preparando para a última luta de Cofi. A montagem conecta esses dois universos díspares, ao mesmo tempo em que ressalta o contraste social entre eles, principalmente pelas diferenças entre o cão de companhia, Richie, e o de luta, Cofi.

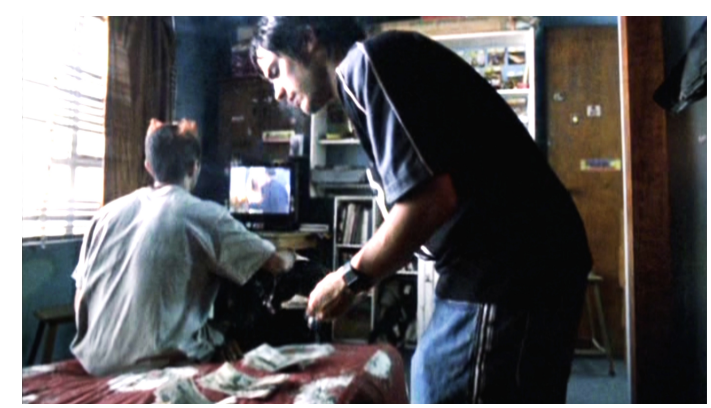

Figura 3.27 - Octavio conta dinheiro, enquanto Jorge assiste Valeria na TV

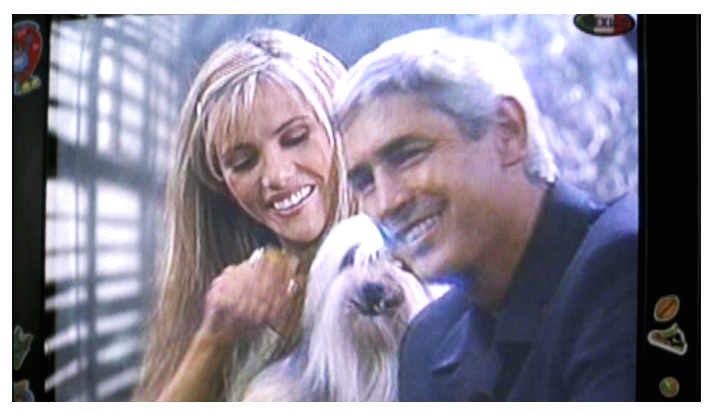

Figura 3.28 - Valeria com seu cachorrinho Richie e o namorado de fachada, Andrés, em programa de TV

Ao final do primeiro capítulo do filme, "Octavio e Susana”, após sua derradeira luta, Cofi é baleado em combate por El Jarocho, que, por sua vez, é esfaqueado por Octavio (cena 41). Esse esfaqueamento deflagra a fuga de Octavio, seu amigo Jorge e Cofi, ensanguentado no banco de trás do carro, perseguidos pelos capangas de El Jarocho. A cena de perseguição e batida antecipada na abertura do filme, agora, aparece em sua posição cronológica natural e o espectador conhece toda a cadeia de causa e efeito que levou Octavio e Jorge até aquele ponto da história. Entretanto, a cena é reapresentada de forma diferenciada. Nessa segunda aparição da batida (56min:30seg), a montagem apresenta um áudio distorcido, com planos sem sincronismo labial e inserções de música alta, conformando uma atmosfera ainda mais excessiva e perturbadora do que a primeira representação das ações de perseguição e colisão. Essa segunda versão da perseguição é mais sensorial, amplifica a sensação de terror e desespero a que Octavio está submetido, mas não acrescenta nenhuma nova informação à trama. 
Nesse ponto de transição entre o primeiro e o segundo capítulos (57min:14seg), a trama oferece uma série de surpresas. A primeira é que, em vez de apresentar a cartela com o intertítulo do segundo capítulo do filme, surge na tela, o apresentador do programa de "Gent de Hoy" em preto e branco do ponto de vista do visor da câmera do estúdio de televisão (cena 42). No filme, existe um predomínio de câmera na mão, esse é um dos raros planos que utilizam um travelling em um carrinho. Em seguida, aparecem os bastidores do encerramento do programa, no qual Andrés convida Valeria para almoçar. Ela desconfia e questiona suas intenções e, desse diálogo, infere-se que ele é apenas um namorado de fachada. Eles param em uma rua com restaurante na esquina, mas Andrés chama Vitoria para conhecer um apartamento que está montando em frente e tem vista para outro outdoor de Valeria na propaganda do perfume.

Ao chegar ao apartamento (cena 43), Valeria quase surta ao perceber que seu sofá e alguns outros de seus pertences estão nesse apartamento, quando é surpreendida por Daniel que surge da cozinha com avental e anuncia que largou a mulher e as filhas e que aquele é o apartamento no qual vão viver juntos. Andrés despede-se e Daniel confirma que ele estará na próxima capa da revista da qual é editor. Essa conversa de despedida leva a entender que esse foi o preço pago por Daniel para que Andrés se passasse por namorado de Valeria no programa de entrevistas "Gente de Hoy".

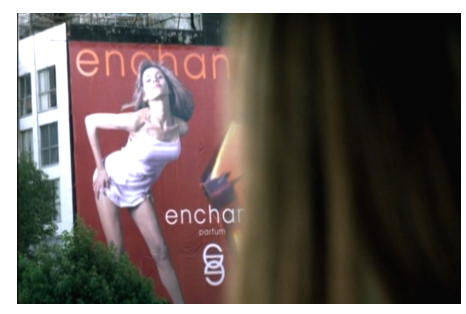

Figura 3.29 - Valeria olha seu outdoor do apartamento

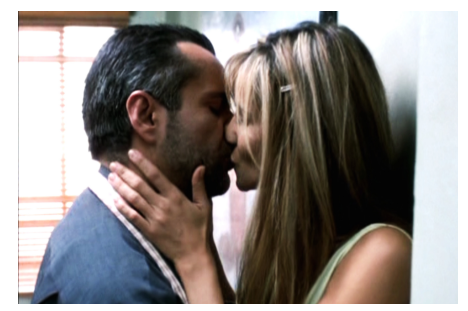

Figura 3.32 - Daniel beija Valeria na nova morada

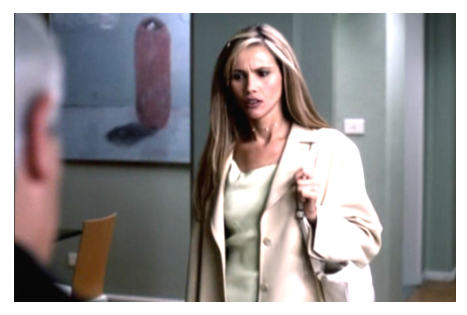

Figura 3.30 - Valeria irrita-se com Andrés

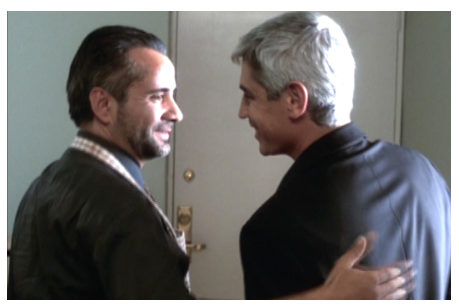

Figura 3.33 - Daniel agradece Andrés

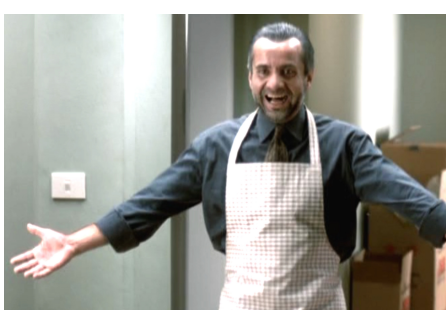

Figura 3.31 - Daniel aparece e revela a surpresa.

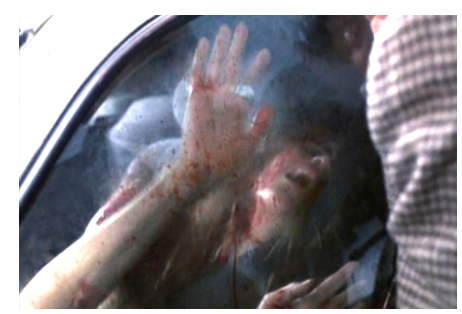

Figura 3.34 - Valeria fica presa nas ferragens do carro

Andrés vai embora, Daniel percebe que se esqueceu de comprar vinho para o almoço que preparou para inaugurar o apartamento do novo casal, Valeria se voluntaria para comprar 
a bebida, pega seu cachorrinho e sai. Valeria coloca uma música do seu agrado no carro e cantarola de felicidade. Ela passa por El Chivo que caminha com sua charretinha e matilha de vira-latas. Valeria para seu carro em um sinal vermelho e aproveita para passar batom. A batida é mostrada pela terceira vez no filme e, dessa vez, adiciona várias informações e novas perspectivas ao evento (cena 45). Mostra-se que El Chivo é testemunha do acidente e revelase a identidade de quem estava no outro carro que colidiu com o de Octavio, Valeria e o seu cachorrinho Richie. Só então, aparece a cartela do segundo capítulo do filme, "Daniel e Valeria" - apesar de, a rigor, já estarmos dentro da história dessa parte desde a cena do estúdio de TV, cinco minutos e meio antes na narrativa. Portanto, houve mais um retardamento de informação, a entrada desse intertítulo, destacando mais uma vez o peso da narração de Iñárritu na apresentação de dados da história na trama. Outro aspecto que chama a atenção nessa transição entre capítulos é a proximidade entre a segunda e a terceira reapresentações da colisão dos carros, separadas por apenas quatro minutos e meio.

A história de Octavio não tem nenhuma entrada durante o segundo capítulo, "Daniel e Valeria", que é o menos poroso e recebe apenas duas participações de El Chivo. A história de Octavio só retorna com três aparições no terceiro capítulo, com cenas que correspondem ao terceiro ato de sua história que mostra a vida de sua família após o acidente (cenas 86, 89 e 100). A terceira história, de El Chivo e Maru, é a mais porosa e, além das sete inserções no primeiro capítulo, conta com mais duas no episódio de Valeria (cenas 52 e 56).

Até aqui nesta seção, procurou-se esmiuçar o entrelaçamento das três histórias de Amores brutos e a forma como Iñárritu retarda a apresentação das personagens principais embaralhando-os com os secundários. No exame da maneira pela qual o diretor vai municiando o espectador com informações vagas e ambíguas sobre as personagens e as histórias, buscou-se explicar como essa forma de narrar estimula o espectador a aguçar sua atenção para apreender as pistas dadas e conjecturar suas conexões. Após o exame do adiamento na apresentação dos protagonistas embaralhando-os com as personagens secundárias, será investigada a seguir outra estratégia que se soma as anteriormente analisadas - abertura em flashforward e entrelaçamento das tramas - só que operando na microestrutura das cenas: a já mencionada abertura com plano de detalhe.

A intensidade emocional e a representação visceral da violência marcantes no filme de estreia de Iñárritu, bem como nos demais, é moldada por meio de uma montagem repleta de cortes e do predomínio da utilização da câmera na mão. Inárritu demonstra uma convicção quase dogmática a respeito das vantagens naturalistas dessa alternativa de filmagem: 
Eu acho que câmera na mão é o mais próximo que você pode chegar da forma como o ser humano experimenta o mundo. Vemos através de uma câmera na mão. Quando eu me movo por aí, não é como um dolly ou uma grua. Como o tripé, essas são maneiras antinaturais de experimentar o mundo. (IÑÁRRITU, 2009, apud DELEYTO; ASCONA, 2010, p. 134, informação oral, tradução nossa) $)^{72}$

Essa convicção leva o diretor a privilegiar a opção de captação despojada de imagens em detrimento de outras mais convencionais, que raramente aparecem em suas tomadas. A câmera é o artefato mediador do diretor ao narrar visualmente as histórias plano a plano e a instabilidade inerente de sua utilização na mão torna mais vívida sua presença, o que evidencia a narração visual do diretor.

Esse efeito enaltecedor da narração visual conferido pela câmera na mão em Amores brutos é potencializado pelo uso recorrente de abertura de cenas com planos de detalhe, conforme mostrado em duas cenas de Daniel na seção anterior (ver Figuras 3.25 e 3.26). Essa opção de decupagem-montagem surge, pela primeira vez, no filme no episódio de Octavio (10min:10seg), na cena que mostra uma tela de televisão repleta de decalques em sua moldura, na qual se vê um filme preto e branco antigo do corcunda de Notre Dame (cena 8, ver Figuras 3.35 e 3.36). Essa imagem não pertence ao beco no qual Cofi vence a briga com o cão da cena anterior, de forma que o espectador não sabe onde pode estar essa tela de TV. Só depois, quando corta-se para uma enquadramento mais aberto, revela-se que se trata do quarto de Octavio, onde Susana vai para agradecer pelo apoio em discussão anterior na cozinha.

Octavio percebe que ela está com a orelha sangrando, ele pergunta a ela se foi Ramiro quem a feriu, mas ela diz que foi sem querer e senta-se na cama dele. A recorrente inserção de imagens de telas de televisão no filme são utilizadas tanto para causar o choque da descontextualização com a cena anterior quanto para estabelecer relações entre o seu conteúdo e a ambiência em que a imagem se introduz. Nesse caso específico, pode-se, sem forçar na interpretação, associar o conhecido amor impossível do Corcunda de Notre Dame com o de Octavio pela cunhada e até relacionar a "monstruosidade" dos planos de Octavio com a aparência do deformado da história francesa.

\footnotetext{
${ }^{72}$ No original: "I think that handheld camera is the closest you can get to the way the human being experiences the world. We see through a handheld câmera. When I move around, I don't dolly or crane. Like de tripod, those are antinatural ways of expirience the world.” (DELEYTO; AZCONA, 2010, p. 134)
} 


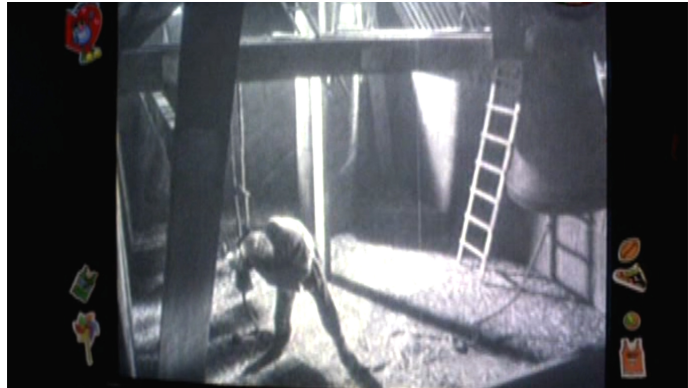

Figura 3.35 - Tela de TV com o filme Corcunda de Notre Dame

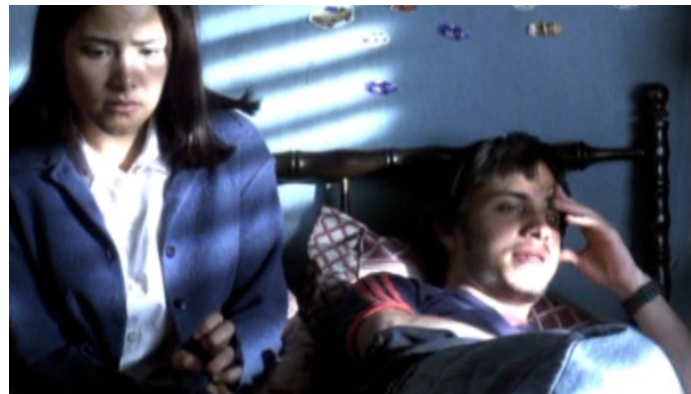

Figura 3.36 - Susana assiste à TV no quarto de Octavio

Essa opção de seleção e ordenamento de um plano de detalhe tem um efeito contrário à tradicional abertura descritiva de cena com um plano aberto, o qual, imediatamente, possibilita ao expectador saber onde a cena se passa, quem são as personagens envolvidas, como estão dispostas em relação umas as outras e ao cenário. Quando um plano de detalhe bate na tela no início de uma cena, em vez de explicar, provoca, desafia o espectador a decifrar o encaixe desse fragmento com dimensões amplificadas no espaço fílmico no qual está inserido. Esse fragmento provoca um choque ao não se encaixar no espaço no qual estava inserido na cena anterior e se coloca como um pequeno enigma a ser decifrado quando o enquadramento se abre e oferece condições de se inventariar as possibilidades de inserção daquele fragmento de proporções alteradas dentro do novo contexto.

A utilização de um enquadramento muito fechado, plano de detalhe, no início de uma nova cena é recorrente em Amores brutos e constitui uma estratégia de decupagem-montagem que também cobra uma postura mais ativa do espectador na compreensão da trama do filme e chama a atenção para a narração do filme na microestrutura da cena.

Tanto a utilização de câmera na mão como a abertura de cenas com plano de detalhe constituem estratégias narrativas que operam no interior das cenas em consonância com as utilizadas na macroestrutura da trama. Essa sobreposição de estratégias narrativas que operam em diferentes níveis - micro e macro -, cujos efeitos convergem na mesma direção, confere maior unidade e consistência à narração. Após a análise da complementariedade entres as estratégias macro e micro ordenadoras da disponibilização de informações da história pelo enredo, serão examinados dois temas comuns aos três capítulos do filme, que também colaboram na sutura da narrativa: as relações familiares e presença canina. 


\subsection{O lado cão e a família}

Apesar da porosidade da narrativa por meio da fragmentação em três núcleos dramáticos e das alternâncias entre eles, é possível detectar que os protagonistas das três histórias mantêm uma vinculação básica com o cinema clássico por serem, ao menos relativamente, orientados por um objetivo. Octavio quer roubar a mulher de seu irmão e começar uma nova vida em outra cidade. Daniel quer ser feliz em sua nova união. El Chivo tem uma grande virada quando Cofi, recuperado de ferimento a bala, trucida toda sua família canina. Esse evento desencadeia uma tomada de decisão na qual El Chivo para de matar e tenta voltar para o convívio da civilização, representado pela mudança em seu visual - corta cabelos e unhas e tira a barba - e a aproximação com a filha abandonada no passado.

A estrutura do filme apresenta mais ênfase na evolução das personagens (character driven) do que ao progresso do enredo (plot driven) ao tecer sua representação da sociedade, na qual os extratos sociais de menor poder aquisitivo têm a função de realizarem o serviço sujo ligado a atividades econômicas ilegais ou informais. A dinâmica entre enredo e personagem na estruturação da narrativa é incrementada pelo ingresso de um objeto circulante, o cachorro Cofi, que deixa de ser de Octavio e passa para El Chivo, proporcionando uma amarração adicional dessas histórias. Existe, ainda, outro cachorro relevante na trama, o peludinho Richie, na história de Valeria e Daniel.

Essa presença canina, destacada em todos os capítulos do filme, estabelece esses animais também como elementos que auxiliam na unificação das histórias e enfatiza traços semelhantes com seus donos: Cofi, apesar de sua procedência inofensiva de cão de família, tem alto potencial de violência assim como Octavio e é um matador em série como El Chivo; Ritchie apresenta a beleza socialmente valorizada e a fragilidade de Valeria. As rinhas de cachorros fazem uma alusão às disputas entre homens para se estabelecerem como machos dominantes, tanto nas brigas entre irmãos - Octavio X Ramiro e Gustavo X Luis - como na atitude de Daniel, ao deixar a família para viver com a fêmea nova. Para Peter F. Parshall (2012, p. 73), "todas as três histórias ilustram como o machismo, o lado cão (perros) da natureza humana, leva três homens a cortar seus laços familiares (amores), uma decisão da qual cada um deles vai se arrepender."73

\footnotetext{
${ }^{73}$ No original: "all three stories illustrate how machism - the dog side of human nature (perros) - causes two men to cast aside the ties of family (amores), a decision each comes to regret." (PARSHALL, 2012, p. 73).
} 
$\mathrm{O}$ arrependimento é decorrente das consequências de infringirem uma lei natural, que os gregos denominavam Nemesis: "se um mortal ou um deus viola um princípio moral, seria como se afastasse um pêndulo - inevitavelmente o pêndulo balançaria para trás" 74 (PARSHALL (2012, p. 84). A Nemesis funcionaria como um princípio norteador do arco de transformação dos protagonistas e da evolução do enredo. Octavio perde sua beleza e saúde no acidente, assim como todo o dinheiro que ganhou ilicitamente e termina vagando sozinho e sem destino por ter se envolvido amorosamente com sua cunhada. Valeria, modelo famosa, que teria levado seu amante Daniel a largar sua esposa mais velha e filhas para viver com ela, termina sem uma perna e condenada ao ostracismo. El Chivo estava marginalizado vivendo a barbárie de assassinatos por encomenda por ter abandonado a família em nome de ideais revolucionários.

Analisando a trama sob essa óptica, percebe-se a ligação entre esse princípio mitológico e dramatúrgico grego com a influência da moral mexicana, predominantemente católica, na qual as noções de pecado e de culpa explicam o preço a ser pago por se seguir impulsos contrários às normas éticas vigentes na sociedade. No filme, essas violações de princípios morais com consequências terríveis destroem as famílias dos protagonistas.

Os filmes de Iñárritu têm como principal tema as relações familiares, mais especificamente entre pais e filhos. Segundo Bordwell (2009), famílias, costumeiramente, fornecem a base para narrativas de rede. Na construção de um mundo diegético baseado nas relações entre estranhos, são geradas lacunas e algumas junções mostram-se um pouco soltas. Esses vazios e inconsistências são, normalmente, preenchidos e complementados pelos laços familiares das personagens.

O mundo da história é preenchido com pessoas ligadas por laços de sangue, amor, desejo, ou lugar comum de trabalho, assim como o mundo que conhecemos. Se a exposição sinaliza imediatamente essas filiações com clareza, podemos ir em frente para rastrear a rede mais complexa de ligações que o filme estabelece. ${ }^{75}$ (BORDWELL, 2009, p. 201)

A família tem forte presença em Amores brutos, que traça um painel de arranjos bem distintos em cada um de seus capítulos, sendo que todos têm em comum pais ausentes. $\mathrm{Na}$ família de Octavio, seu pai nunca aparece e não há nenhuma menção que explique sua ausên-

\footnotetext{
${ }^{74}$ No original: "if a mortal or a God violated a moral principle, it was like pushing a pendulum away - inevitably, the pendulum would swing back. (PARSHALL, 2012, p. 73, p. 84)

${ }^{75}$ No original: "The story world is populated with people bound by blood, love, desire, or common place of work - just like the world we know. If the exposition signals these clear-cut affiliations immediately, we can go on to track the more complex network of links that the film build up." (BORDWELL, 2009, p. 201)
} 
cia. O irmão de Octavio, Ramiro, também é um pai pouco presente, que raramente fica com sua mulher e negligencia prover as necessidades de seu filho bebê, como mantimentos e fraldas. Daniel mostra-se entediado e alienado na companhia de sua mulher e filhas. Logo as abandona para começar vida nova com Valeria, sua amante, que se fere gravemente ao sair de casa para comprar vinho na primeira refeição que vão fazer no novo lar. Mesmo com Valeria muito ferida na perna e confinada a uma cadeira de rodas, Daniel a deixa sozinha o dia todo e segue com sua rotina no trabalho todos os dias até tarde da noite.

No caso de El Chivo, a ausência paterna ganha mais amplitude e complexidade. No início do filme a única família que tem é a matilha de vira-latas que mora com ele e o acompanha quando coleta lixo pela cidade. Por acaso, ao conferir, em um jornal, a matéria sobre um assassinato que cometeu, El Chivo se depara com o anúncio do enterro de sua ex-mulher. O passado de El Chivo é revelado por meio de um diálogo de Leonardo, o policial corrupto que intermedeia a contratação de El Chivo para assassinatos, com um novo cliente, Gustavo.

El Chivo é um ex-guerrilheiro que abandonou a família por motivos revolucionários, foi preso e sua filha acredita que esteja morto. El Chivo, que nunca participou da criação de sua filha, Maru, vai disfarçado ao enterro da ex-mulher e contempla-a de longe. Esse reencontro visual acende a centelha do desejo de reaproximação do pai com a filha. El Chivo começa a observar Maru, entra em sua casa e rouba uma foto dela de formatura na qual outra figura masculina, provavelmente seu padrasto, aparece ao lado da filha e de sua ex-mulher. Ao final do filme, El Chivo retorna furtivamente à casa da filha e devolve a foto na qual ele substituiu o rosto do padrasto por uma foto sua e deixa uma mensagem bastante emocionada na secretária eletrônica revelando que está vivo e confessando que se arrepende de não ter convivido com ela.

A história de Octavio e Susana dá mais ênfase ao processo de violação de um princípio moral, adultério com a cunhada, do que às suas decorrências. $\mathrm{O}$ preço que Octavio paga por ter se envolvido com Susana é apresentado sinteticamente, no que seria o terceiro ato desse capítulo, em três cenas enxertadas no último capítulo de El Chivo, nas quais Octavio figura destituído de saúde, beleza e riqueza. A segunda história de adultério, Daniel e Valeria, dedica-se muito mais aos resultados da transgressão. Nos dois capítulos iniciais, seus protagonistas, Octavio e Valeria, são os condutores dos carros envolvidos na batida. Esse encontro ao acaso simboliza o pêndulo da Nemesis em seu retorno avassalador cobrando o ônus dos princípios morais violados. 
Por sua vez, na terceira história, de El Chivo e Maru, tanto a colisão dos carros como o pêndulo da Nemesis têm funções e significados distintos dos proporcionados nas duas primeiras histórias. El Chivo é testemunha e não condutor dos carros que se chocam. A colisão entroncamento da narrativa - provoca muitos ferimentos graves em Octavio e Valeria e fornece para El Chivo o elemento que vai deflagrar uma guinada em sua trajetória, um ponto de virada, o cão Cofi. O animal funciona como objeto circulante que migra de uma história para outra, fortalecendo a sutura do entrelaçamento entre elas e, por meio de um excesso de violência, provoca um enfraquecimento da mesma violência como opção de vida de El Chivo. Curioso notar que tanto Cofi como El Chivo começaram a matar por força de contingências acima de suas vontades - o ataque do cão de El Jarocho e o contexto da luta revolucionária, respectivamente. Depois disso, continuam matando induzidos por outras pessoas e destituídos de seus papéis originais de cachorro de família e pai de família.

Octavio e Daniel estão atentando contra a integridade de suas famílias no presente da narração, enquanto El Chivo abandonou sua família no passado, há, aproximadamente, duas décadas. E ele não desagregou sua família motivado por um adultério, mas por uma ideia utópica, uma causa revolucionária. El Chivo já sofreu os efeitos do retorno do pêndulo de Nemesis de seu dolo vivendo na solidão e na marginalidade e seu capítulo se dedica à sua tomada de consciência disso, sua ruptura com o purgatório onde esteve condenado durante anos, preso, catando restos pela cidade e matando pessoas por dinheiro. $\mathrm{O}$ arco de transformação dos protagonistas das primeiras histórias, Octavio e Valeria, enfatiza a queda em tentação e purgação por infringir um princípio moral. Já a trajetória de El Chivo expõe um momento posterior desse processo, de libertação e recomeço, no qual ele abandona a barbárie e move-se na tentativa de reconciliação com o que sobrou de sua família, sua filha.

Após a análise de como os temas das relações familiares e da presença canina participam da tessitura da narrativa em interação com as estratégias macro e micro ordenadoras da disponibilização de informações da história pelo enredo, faz-se necessário relacionar Amores brutos com algumas de suas principais influências culturais e fílmicas para melhor compreensão das conexões articulatórias dessa narrativa de rede.

\subsection{Influências e conexões da teia canina}

Uma parte significativa da crítica de cinema associou a representação visceral da violência e o fatalismo impressos por Iñárritu em sua prima obra com a filmografia de Arthuro 
Ripstein e Luis Buñuel (DELEYTO; ASCONA, 2010, p. 15). Aliás, visceral seria a síntese do filme de acordo com seu diretor, "um grito de duas horas". Esse aspecto seria coerente com sua propensão de não interromper quando cenas de intensa violência ou emoção estão na tela. Por sua vez, o roteirista Guillermo Arriaga menciona William Faulkner como sua principal referência na forma de narrar de Amores brutos. Já Iñárritu, prefere citar como suas influências fílmicas Rashomon (Rashômon, Akira Kurosawa, 1950), Short cuts - cenas da vida (Short cuts, Robert Altman, 1993), Antes da chuva (Before the rain, Milcho Manchevski, 1994) e Smoke - Fumo (Smoke, Wayne Wang, 1995) e lembra que navegar entre histórias paralelas é muito comum na literatura latino-americana (DELEYTO; ASCONA, 2010, p. 129). Além da literatura a forte presença do multiprotagonismo em outras áreas da arte e da cultura mexicana como nos emblemáticos murais de Diego Rivera e nas populares telenovelas, conforme já comentado na seção 2.1. Iñárritu também vê uma conexão direta entre a multiplicidade de enredos e o abandono da narrativa linear com as características intrínsecas do ambiente tecnológico da contemporaneidade (DELEYTO; ASCONA, 2010, p. 23), questão desenvolvida também no Capítulo II, seção 2.3.

Apesar da resistência de Iñárritu e Arriaga em admitirem a influência de Pulp fiction tempos de violência (Pulp fiction, Quentin Tarantino, 1994) em Amores brutos, não é difícil notar que existem pontos estruturais em comum entre esses dois filmes: três enredos sobrepostos, apresentados fora da ordem temporal com diferentes pontos de vista e o uso de elementos repetitivos para proporcionar a amarração que incrementa a legibilidade de tramas fragmentadas e entrelaçadas. Bordwell (2008, p. 197, tradução nossa) acredita que Pulp fiction "ofereceu um pacote de dispositivos que seria reformulado posteriormente por outros cineastas: cenas repetidas, títulos que dividem o filme em capítulos, e um secreto reordenamento do tempo que faz a audiência arfar quando vê as histórias emaranhadas." ${ }^{, 76} \mathrm{O}$ rearranjo da cadeia de eventos agenciado pelo enredo desses dois filmes visando fortalecer paralelismos e contrastes entre as histórias e renovar o interesse do público constitui um traço marcante das narrativas de rede e evidencia a narração autoconsciente orientada para o espectador.

De maneira similar com que Tarantino ancora a compreensão da complexidade e multiplicidade de sua narrativa por meio de repetições de trechos de alguns eventos vistos sob perspectivas diferentes - o final da conversa dos ladrões amantes na cabine da lanchonete e o assassinato de colegiais cometido por Vincent e Jules em Pulp Fiction -, Iñárritu vale-se da

\footnotetext{
${ }^{76}$ No original: "offered a package of devices that later filmmakers would retool: repeated scenes, titles that split the film into chapters, and a covert reordering of time that makes the audience gasp when they see the stories mesh.” (BORDWELL, 2008, p. 197)
} 
batida de carros. Entretanto, a reapresentação de elementos na sutura da intriga não se limita à repetição de trechos da ação de alguns eventos. Em Amores brutos, além da colisão de automóveis há também temáticas em comum, como a presença de cães e a ausência de pais nas famílias de todos os seus três capítulos. O compartilhamento de ações e temáticas é combinado com estratégias articulatórias que operam em diferentes níveis narrativos, proporcionando unidade e compreensão à trama.

O próprio modo narrativo de Amores brutos e Pulp fiction, narrativa de rede, já oferece a primeira força aglutinadora de sua multiplicidade fragmentada: a expectativa de que personagens, ações e situações tendam ao paralelismo entre elas. O paralelismo estimula o espectador a estabelecer conexões que preenchem algumas lacunas deixadas pelo afrouxamento da causalidade no encadeamento das narrativas de rede marcadas pela imprevisibilidade do acaso. Conforme verificou-se na análise acima, o magnetismo aglutinador do paralelismo do filme em questão é dinamizado pela combinação tanto de estratégias narrativas que conformam a macroestrutura da trama - abertura em flashforward; fragmentação em capítulos; convergência na colisão de automóveis; entrelaçamento dos enredos; e retardamento da apresentação dos protagonistas. Assim como também se caracteriza por recursos narrativos que operam na microcomposição das cenas - predomínio da câmera na mão e abertura com plano de deta1he. Embora essas estratégias discursivas operem em amplitudes diferentes da estrutura narrativa, micro e macro, elas compõem um arranjo em que seus efeitos se sobrepõem e se potencializam.

Abrir uma cena em plano de detalhe, assim como começar o filme com um flashforward, são estratégias narrativas provocadoras, que levantam perguntas, ao invés de prover informações explicativas, incitando uma postura mais ativa da audiência. Essas estratégias também operam em consonância com a de postergar a apresentação das personagens principais, já que estimula o espectador a fazer inferências, elaborar e testar hipóteses no esforço de apreender quem são os protagonistas e como se relacionam com as personagens secundárias, sendo que, enquanto o flashforward e os retardamentos na apresentação de personagens principais são estratégias que operam entre as cenas, na macroestrutura da narrativa, a abertura de cenas em planos de detalhe atua no interior da cena, em sua microestrutura.

A teia de Amores brutos é urdida por meio do paralelismo e das estratégias narrativas que dispõe informações e estabelecem relações entre história (fabula) e enredo (syuzhet). A tessitura da narrativa do filme explicita a predominância da narração sobre as outras instâncias constitutivas da narrativa como as personagens e o tempo. Essa predominância da narra- 
ção fica evidente na exposição autoconsciente de informações sobre a história, por meio do enredo, tanto na macro como na microestrutura dessa narrativa de rede.

A análise das estratégias articulatórias de Amores brutos expôs a dinâmica da narrativa de rede e evidenciou a eloquência da narração sobre outras instâncias nesse modo de narrar. Procurou-se demonstrar como a narração, ao estabelecer a ordenação temporal não-linear e traçar um arco múltiplo de desenvolvimento de personagens, potencializou o engajamento e a renovação do interesse do espectador na conformação da história. Os recursos narrativos utilizados na trama ressaltam as conexões do compartilhamento temático entre os amores caninos de seus capítulos.

No próximo capítulo, serão analisadas estratégias narrativas ainda mais radicais empregadas por Iñárritu na orquestração de seu segundo filme, 21 Gramas. Novamente, existe um acidente de carros, conectando três personagens ao acaso, entretanto, diferentemente de Amores brutos, eles serão levados a partilhar as consequências trágicas desse evento em uma intriga de vingança. Também há o uso de um objeto circulante na amarração das três histórias e a escolha recai sobre algo ainda mais instigante, um coração humano. Nesse segundo filme, o entrelaçamento das histórias é ainda mais complexo do que a segmentação em capítulos permeáveis do primeiro filme da trilogia. A ordenação temporal de 21 gramas demanda um empenho mais aguçado do espectador na compreensão de sua estrutura errática, na qual não se consegue identificar um padrão no encadeamento do enredo. 


\title{
Capítulo IV
}

\author{
21 GRAMAS -
}

\section{ORDEM EMOCIONAL ENTRE VIDA E MORTE}

\author{
Quantas vidas a gente vive? Quantas vezes a gente \\ morre? \\ Dizem que todos perdemos 21 gramas no momento \\ exato de nossa morte, todos. \\ Quanto cabe em 21 gramas? Quanto se perde quando \\ perdemos 21 gramas? \\ Quanto se vai com elas? Quanto é ganho? 21 gramas. \\ O peso de cinco moedas e cinco centavos, o peso de \\ um beija-flor, uma barra de chocolate. Quanto pesam \\ 21 gramas? ${ }^{77}$
}

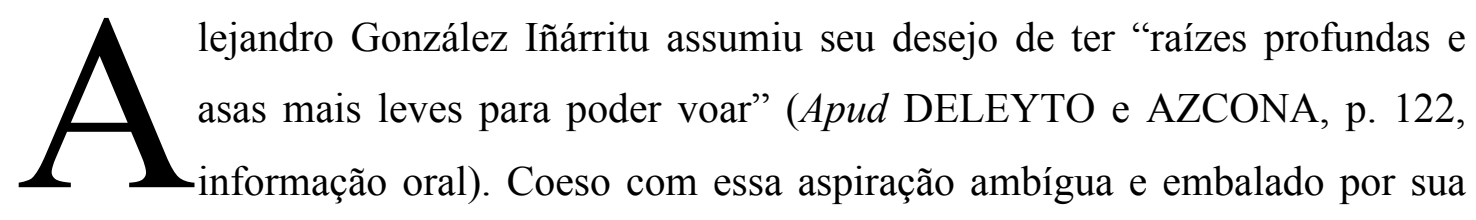
retumbante estreia no mundo do cinema com Amores brutos (Amores perros, 2000), o diretor mexicano atravessa a desafiadora fronteira ao Norte seguido de seus colaboradores mais expressivos - o roteirista Guillermo Arriaga, o diretor de fotografia Rodrigo Prieto e o músico Gustavo Santaolalla -, para realizar seu segundo filme, 21 gramas (21 grams, 2003) ${ }^{78}$ no

\footnotetext{
${ }^{77}$ Fala em off (monólogo interior) de Paul no leito de morte ao final do filme (cenas 106 a 116).

${ }^{78} \mathrm{O}$ título de 21 gramas faz alusão à misteriosa perda de peso no corpo humano na hora da morte, mencionada na epígrafe acima. O significado do título só é revelado ao final do filme, atiçando a curiosidade do espectador em desvendá-lo durante todo o transcorrer da trama.
} 
cerne do cinema independente saxão norte-americano. ${ }^{79}$ Ele faz essa passagem não apenas para trabalhar, mas também para viver com sua família em Los Angeles, Califórnia. ${ }^{80}$

Ironicamente, o voo do diretor o leva a se estabelecer justamente em um dos estados americanos que já fizeram integralmente parte do território mexicano. Além de seus entes mais queridos, Iñárritu leva consigo outras preciosidades: sua bagagem cultural e visão de mundo. O diretor mexicano carrega na alma a cosmologia profunda e antiga do seu povo outrora Azteca, Maia e híbrido espanhol-árabe - disposto a renascer como migrante. Assim como todo desterrado que voa para longe de casa, que precisa experimentar uma espécie de morte para renascer, fazendo sentido em uma nova cultura, a arte narrativa de Iñárritu se transmuta, mas mantém seu imaginário enraizado em sua civilização de origem. O resultado cinematográfico dessa travessia é ainda mais radical do que o alcançado em seu batismo de fogo.

O migrante leva também para seu novo domicílio a muda de seu segundo filme, um roteiro escrito em espanhol em mais uma colaboração com Arriaga. Inicialmente, concebido para ser realizado no México, 21 gramas aborda a relação entre vida e morte em uma trama que expõe o embate entre a racionalização do amor e sua explosão irracional. A percepção de Iñárritu do sentido da vida e da morte e seus atrelamentos é abalizada por sua cultura original, na qual: "para os antigos mexicanos, a oposição entre a morte e a vida não era tão absoluta quanto para nós. A vida se prolongava na morte e vice-versa. A morte não era o fim natural da vida, mas fase de um ciclo infinito" (PAZ, 2014, p. 55). Essa perspectiva do sentido da vida entranhada na mexicanidade de Iñárritu vai influenciar a construção das narrativas de seus filmes, ficando especialmente evidente em sua segunda realização.

O enredo de 21 gramas rompe com o encadeamento causal e cronológico entre cenas consecutivas e adota a emoção como principal fio condutor em uma ordenação aparentemente aleatória. A combinação inovadora da segunda narrativa de rede de Iñárritu mistura multiprotagonismo com rupturas de convenções narrativas do cinema clássico, típicas do cinema de arte, e outras mais tradicionais, como as do melodrama, e, até mesmo, alguns lampejos de

\footnotetext{
${ }^{79} 21$ gramas foi produzido por This and That, a produtora de Ted Hope e distribuído pela Focus Features, dirigida por James Schamus. Hope e Schamus co-fundaram a Good Machine no início dos anos 1990 e, rapidamente, tornaram-se um dos principais players do cenário independente. A empresa foi adquirida pela Universal Pictures, cujo novo ramo "independente" foi renomeado Focus Features. Ver no início do Capítulo II o conceito de cinema independente adotado no estudo.

${ }^{80}$ Iñárritu alega que uma de suas motivações ao migrar para os Estados Unidos (quatro dias antes do nove de setembro) foi a segurança da própria família, principalmente do seu casal de filhos. O pai dele havia sofrido um sequestro relâmpago e a mãe, um assalto, após o lançamento de Amores brutos. (IÑÁRRITU, 2003, apud, WOOD, 2006, p. 144, informação oral)
} 
comédia romântica. A proposta é ousada ao congregar uma temática universal e existencialista com uma forma que exige um engajamento ainda mais ativo do espectador do que em Amores brutos na apuração da história por meio de uma trama com encadeamento causal e cronológico fragmentado e misturado. A muda de 21 gramas germinada no México ganha força e aspectos diferenciados ao ser transplantada para florescer nos Estados Unidos. O filme muda de língua para o inglês e ganha a poderosa adesão de atores hollywoodianos reconhecidamente competentes - Sean Penn, Naomi Watts e Benicio Del Toro - ampliando suas possibilidades de alcance da audiência. Estilística e narrativamente, o filme é facilmente reconhecido como um filme independente americano do início do século XXI.

Os dois primeiros filmes de Iñárritu têm entre eles algumas semelhanças e muitas diferenças, tanto em termos temáticos como formais. Novamente, solidão, relações familiares, violência, morte e redenção sobressaem-se no enredo, assim como o impacto de fatores externos ao acaso no destino das personagens. Ambos os filmes são multiprotagonistas, entretanto, 21 gramas apresenta apenas um enredo, enquanto Amores brutos conta com três, sendo também multiplot. Acidentes de automóvel - batida no primeiro e atropelamento no segundo entrelaçam a vida de três personagens que não se conheciam. Se, no primeiro filme, as personagens não tomam conhecimento do que acontece com os outros envolvidos no acidente, no segundo as consequências do desastre move-as até a tentativa de vingança. Assim como em Amores brutos, essa produção seguinte também narra não-linearmente a cronologia da história e rompe o encadeamento causal das cenas, entretanto, valendo-se de estratégias narrativas bastante diferenciadas e ainda mais ousadas que serão analisadas em detalhe neste capítulo.

A história (fabula) do filme em sua ordem causal e temporal seria resumidamente a seguinte (ver Apêndice D): Paul Rivers (Sean Penn) é um professor de matemática que sofre do coração e precisa de um transplante para sobreviver. Paul vive um casamento fracassado com a inglesa Mary (Charlotte Gainsbourg) que está querendo obsessivamente engravidar de seu marido apesar de seu estado de saúde precário. Cristina Peck (Naomi Watts) é uma exviciada em drogas que conseguiu se reabilitar graças à estável vida em família de classe média proporcionada por seu marido Michael (Danny Huston) e o afeto pelas duas filhas do casal. Jack Jordan (Benicio Del Toro) é um ex-presidiário de classe baixa, alcoólatra, renascido em Cristo no cárcere, que está tentando levar a vida com sua mulher e casal de filhos seguindo com fervor exagerado os preceitos religiosos evangélicos.

Jack atropela acidentalmente e mata o marido de Cristina e suas filhas e foge sem prestar socorro. O coração de Michael é transplantado para Paul proporcionando-lhe momentaneamente uma nova vida. Jack deixa a família e se entrega para a polícia para pagar pelo 
crime que cometeu. Sozinha e desamparada, Cristina volta a se drogar. Paul fica obsessivo em saber a identidade do doador do coração e contrata um investigador privado que descobre que Michael foi o doador. Paul segue Cristina e, depois de várias tentativas de estabelecer contato, acaba conseguindo ir almoçar com ela. De volta à cadeia, Jack perde sua fé, tenta suicidar-se, mas fracassa. Cristina, inicialmente, resiste à sedução de Paul, mas acaba cedendo ao chamado dessa louca paixão, mesmo tendo Paul revelado a ela que vive com o coração de seu exconsorte. Paul abandona sua esposa Mary por uns dias, consumando sua paixão por Cristina.

Marianne (Melissa Leo), mulher de Jack, contrata um advogado e o tira da prisão. O coração transplantado de Paul sofre rejeição e ele é orientado pelo médico que o operou a se hospitalizar para esperar por um outro coração e evitar uma morte horrível por asfixia. A despeito do prognóstico que seu coração deve parar a qualquer momento, Paul opta por viver o pouco tempo que lhe resta fora do hospital. Jack não consegue conviver com a família devido à sua culpa pela morte de inocentes e se afasta em uma atitude de autopunição. O trabalho braçal em outro estado é o martírio escolhido por Jack. Mary vai embora da casa de Paul insistindo que, mesmo contra a vontade dele, vai engravidar com o sêmen que ele tinha autorizado o uso. Cristina não consegue se conformar com o fato de Jack estar livre após ter dizimado sua família e conclama seu amante Paul a matá-lo.

Paul e Cristina viajam para assassinar Jack. Paul chega a ter Jack dominado sob sua mira, mas atira para o lado. Mais tarde, Jack invade o quarto de motel onde Cristina e Paul estão. Os três se engalfinham e no meio da confusão Paul atenta contra a própria vida atirando em seu peito. Cristina e Jack saem em disparada de carro levando Paul a um hospital. Jack tenta assumir a autoria do disparo em Paul, mas é desmentido pela investigação policial. Cristina descobre que está grávida de Paul e perdoa Jack. Paul morre. Jack, redimido pelo absolvição de Cristina, volta para seu lar. Cristina vai começar vida nova com um filho de Paul em seu ventre.

Entretanto, a história é contada de uma forma bem diferente, rompendo totalmente com a causalidade e a temporalidade como princípios ordenadores da trama (ver Apêndice $\mathrm{C}$ - Escaleta de 21 gramas conforme apresentado pela trama). As diversas estratégias narrativas adotadas visando dar uma amarração à história para que o espectador chegue a sua compreensão plena ao final do filme serão minuciosamente examinadas a seguir. 


\subsection{As emoções das personagens como ordenadoras da trama}

Iñárritu revela em entrevista que, desde a leitura da primeira versão do argumento de vinte páginas proposto por Arriaga para 21 gramas, apresentando a história de maneira completamente linear, notou que seria necessário contá-la de maneira não convencional:

Tudo parecia bastante previsível. Eu imediatamente percebi que a história se beneficiaria com uma estrutura narrativa embaralhada, porque, dessa forma, previsibilidade se tornaria inevitabilidade. E inevitabilidade, em oposição à previsibilidade, pode ser muito interessante ao se contar uma história. ${ }^{81}$ (IÑÁRRITU, 2009, apud DELEYTO; AZCONA, 2010, p. 130, informação oral, tradução minha)

Além da previsibilidade, ${ }^{82}$ o diretor também identificou outra característica no argumento original que reiterava o imperativo da procura de uma estrutura alternativa para contar aquela história:

21 gramas tinha um problema radioativo em potencial: lida com elementos melodramáticos puros que podem ser encontrados, de uma forma ou outra, no mundo das novelas. Eu sabia que estava tratando de algo que precisava de uma abordagem e execução radicalmente diferentes. A estrutura foi crucial para o filme, para não mencionar o registro e as performances. ${ }^{83}$ (IÑÁRRITU, 2009, apud DELEYTO; AZCONA, 2010, p. 130, informação oral, tradução minha)

Iñárritu ponderou sobre os riscos em se adotar uma estrutura fragmentada para o fil-

me:

No entanto, neste tipo de experimento com a estrutura narrativa, sempre há um problema em potencial. Quando uma estrutura narrativa embaralhada não está a serviço da história, torna-se apenas um ornamento, que limita, em vez de destacar seu conteúdo. [...] No caso de 21 gramas, a forma é essencial para o conteúdo e os temas do filme. Eu estava com medo que os espectadores vissem o filme como um quebra-cabeças a ser resolvido. Eu não queria que eles pensassem muito sobre a estrutura. Eu estava buscando uma estrutu-

\footnotetext{
${ }^{81}$ No original: "Everything seemed quite predictable. I immediately realized that the history would benefit from a scrambled narrative structure, because that way predicability would become inevitability. And inevitability, as opposed to predicability, can be a very interesting when telling a story." (IÑ̂́RRITU, apud, DELEYTO; AZCONA, 2010, p. 130)

${ }^{82}$ A leitura das cenas do filme encadeadas em sua ordem temporal e causal no Apêndice D, confirmam que o diagnóstico precoce de Iñárritu quanto à necessidade de se narrar a história de 21 gramas de forma fragmentada e não-linear para evitar sua previsibilidade e vocação melodramática estava correto.

${ }^{83}$ No original: "21 grams had a potential radioactive problem: it deals with pure melodramatic elements that can be found one way or another in the soap-opera world. I knew I was dealing with something that needed a radically different approach and execution. The structure was crucial to it, not to mention the register and the performances.” (IÑÁRRITU, apud, DELEYTO; AZCONA, 2010, p. 130)apud
} 
ra emocional de uma história completamente atemporal. ${ }^{84}$ (IÑÁRRITU, 2009, apud DELEYTO; AZCONA, 2010, p. 130, informação oral, tradução minha)

A estratégia narrativa estruturante adotada por Iñárritu, Arriaga e o montador Stephen Mirrione ${ }^{85}$ em 21 gramas foi a de romper o encadeamento causal e temporal da história de um jeito que o espectador não consiga esboçar seu padrão de ordenação, deixando-o envolvido em um fluxo sistematizado emocionalmente e não logicamente. A forma narrativa do filme se explicita logo em sua sequência de abertura. A tessitura da sequência inicial de 21 gramas é bem distinta e mais complexa do que a de Amores brutos, mas apresenta o mesmo efeito de instigar o espectador em vez de explicar quem são os protagonistas e qual o conflito matriz que vai movê-los na trama.

O filme começa com a imagem de um casal nu em uma cama com som ambiente bastante silencioso. Paul está sentado fumando enquanto observa Cristina que dorme de bruços, conforme frame abaixo. ${ }^{86} 87$

\footnotetext{
${ }^{84}$ No original: "Yet in this type of experiment with narrative structure there is always a potential problem. When a scrambled narrative structure is not at the service of the story, it becomes just an ornament, and it limits rather than enhances the content. [...] In the case of 21 grams the form is essential to the content and the themes of the film. I was afraid that spectators would see the movie as a puzzle to be solved. I didn't want them to think too much about the structure. I was looking for an emotional structure in a completely atemporal storyline." (IÑÁRRITU, apud, DELEYTO; AZCONA, 2010, p. 130)

${ }^{85}$ Iñárritu declarou em entrevista que " 21 gramas foi provavelmente o filme que mais tenha reescrito na sala de montagem." No original: "21 grams is probably the movie that I've rewritten most times in the editing room." (apud DELEYTO e AZCONA, 2010, p. 130)

${ }^{86}$ Todas as Figuras deste capítulo são frames do filme 21 gramas. Fonte: 21 gramas. Direção: Alejandro Gonzales Iñárritu, EUA: Focus Features, 2003. 1 DVD (125 min).

${ }^{87}$ A composição dessa cena é uma citação assumida por Iñárritu da série fotográfica The ballad of sexual Dependency, especificamente "Nan and Brian in Bed", da fotógrafa novaiorquina Nan Goldin (WOOD, 2006, p. 78). A cena transmite a sensação de que o sexo não trouxe só prazer, mas também, tensão, ansiedade e sofrimento. Nas séries de Goldin, há ênfase na impossibilidade de comunicação entre seres humanos e a fragilidade que a tensão sexual produz em um dos parceiros.
} 


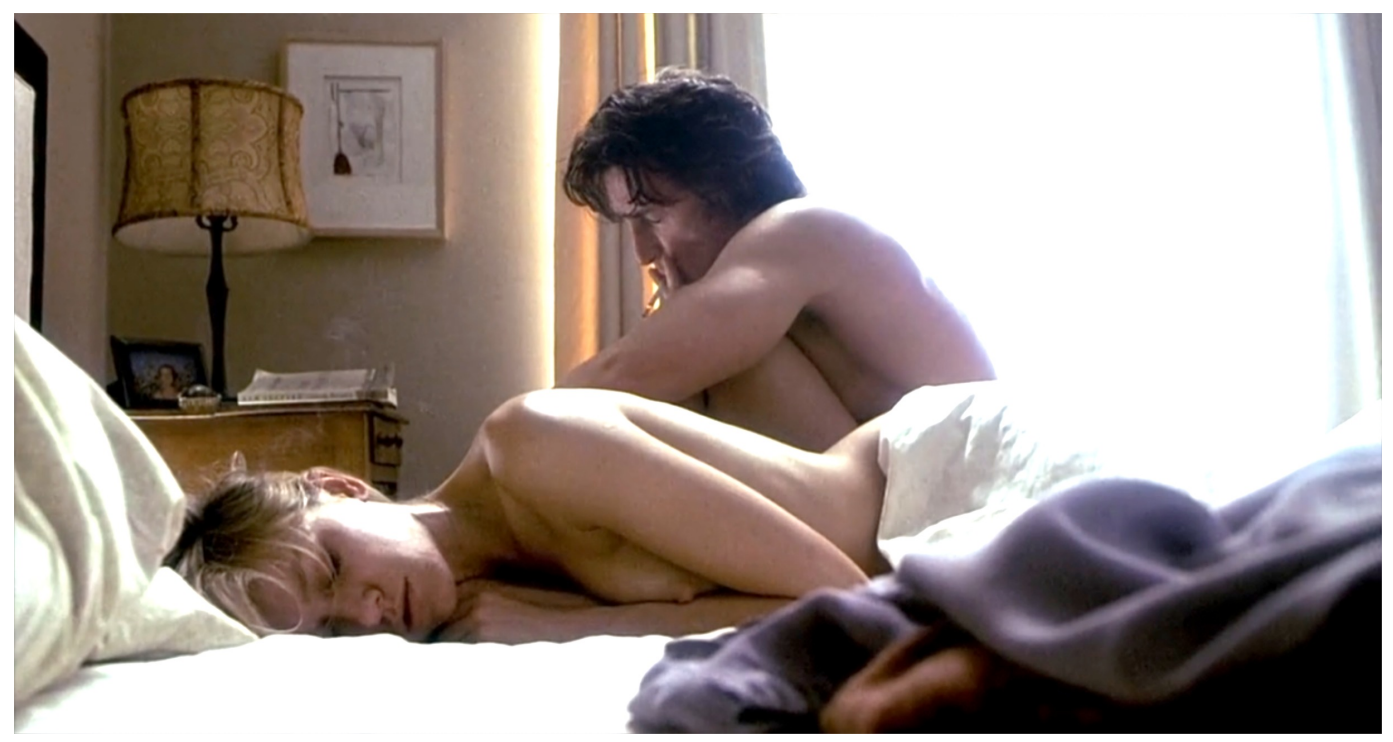

Figura 4.1 - A primeira imagem do filme mostra Paul tenso em momento pós-coito com Cristina

Entra o título do filme.

Michael aparece terminando de fazer uma refeição com suas duas filhas numa lanchonete. Em seguida, Cristina aparece dando um depoimento numa sessão de grupo de apoio, na qual destaca a importância da família, especialmente o apoio do marido, em seu processo de reabilitação como viciada em drogas.

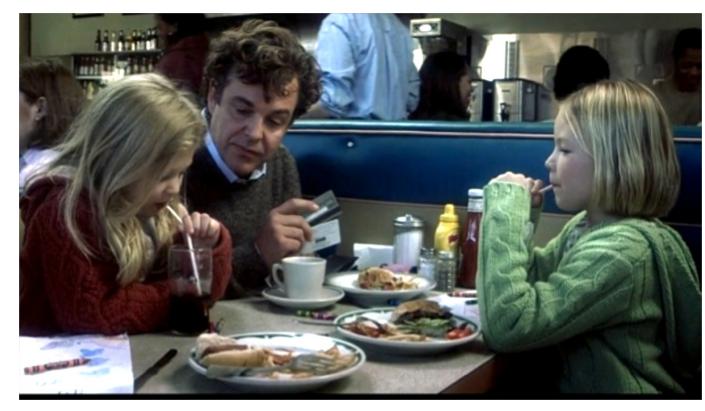

Figura 4.2 - Michael lancha com as filhas

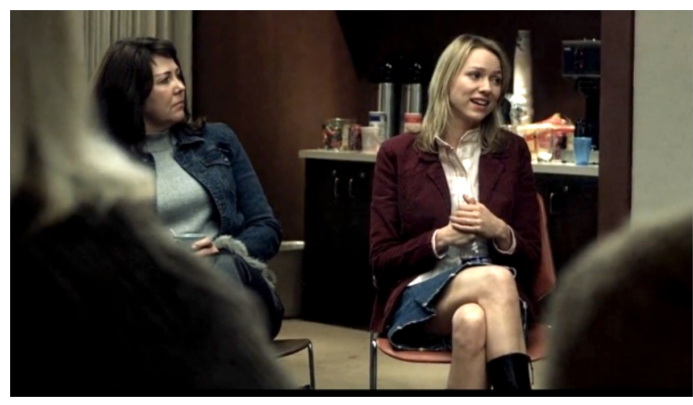

Figura 4.3 - Cristina em grupo de ajuda

Jack inaugura sua participação no filme tentando doutrinar um jovem descrente e mostrando a camionete que "ganhou" de Jesus por meio de uma rifa. A tela é tomada pela imagem lírica de uma revoada de pássaros ao poente. 


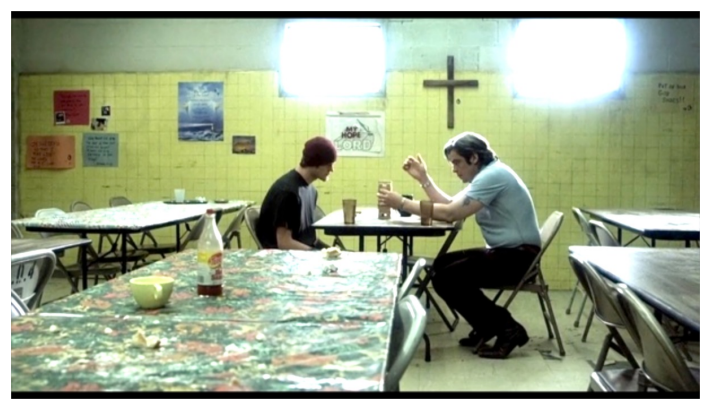

Figura 4.4 - Jack prega para jovem

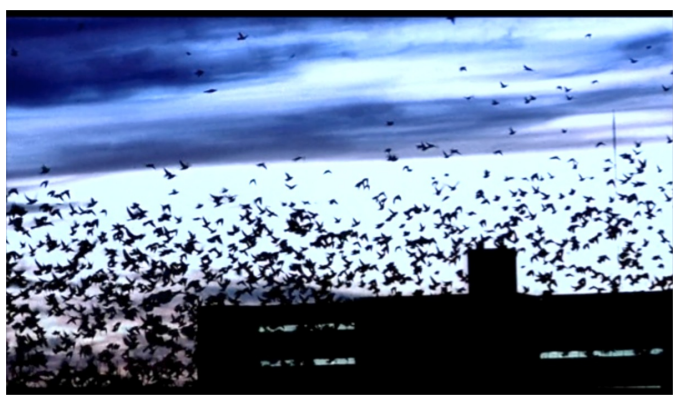

Figura 4.5 - Voo de pássaros

Paul aparece entubado em uma Unidade de Terapia Intensiva (UTI) e ouvem-se suas reflexões. Surge Mary em um exame ginecológico dizendo ao médico que o marido só tem um mês de vida.

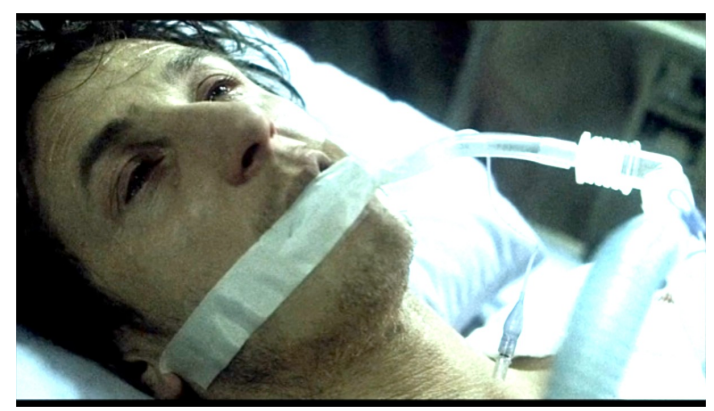

Figura 4.6 - Plano que estabelece monólogo interior de Paul

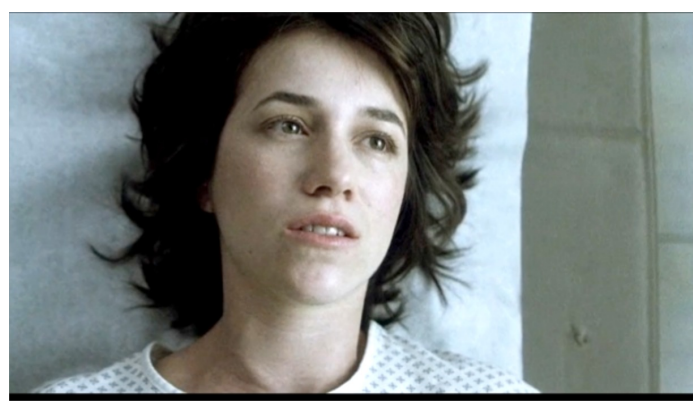

Figura 4.7 - Mary, mulher de Paul

Jack coloca bíblias sobre cadeiras na igreja, conversa com o reverendo sobre o jovem que estava tentando orientar. Eles saem para a rua e ao apartar desentendimento entre jovens no basquete, Jack perde a cabeça e se atraca com o jovem descrente para o qual pregava na cena anterior. Jack dirige sua camionete ouvindo rádio religiosa, chega em casa e interage carinhosamente com mulher e casal de filhos pequenos.

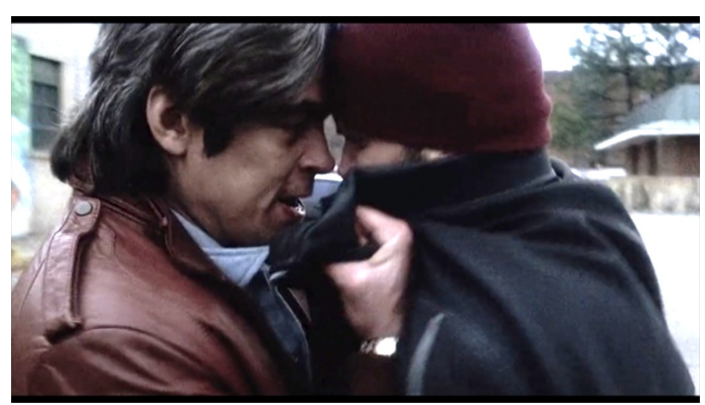

Figura 4.8 - Jack descontrola-se

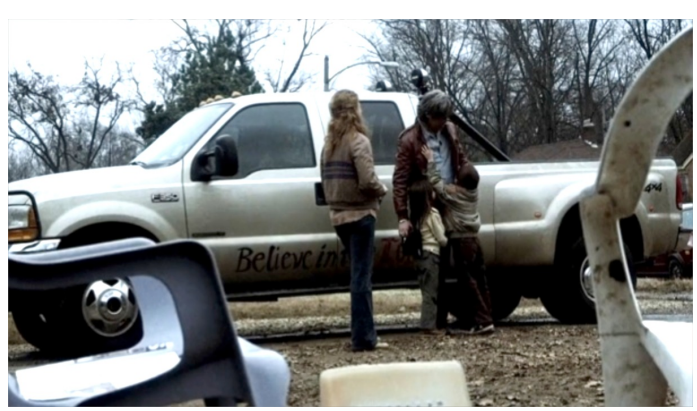

Figura 4.9 - Jack em família e a camionete que "ganhou de Jesus" ao fundo 
Paul, visivelmente debilitado, manipula um revólver sentado ao lado de uma piscina vazia e entulhada. Jack é colocado numa cela e o vizinho comenta que o lobo está de volta.

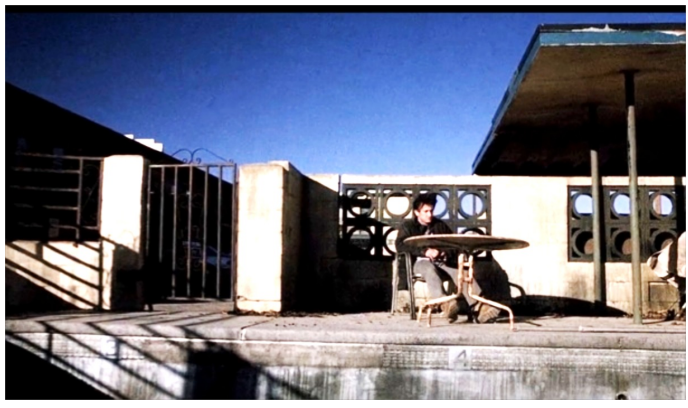

Figura 4.10 - Paul debilitado

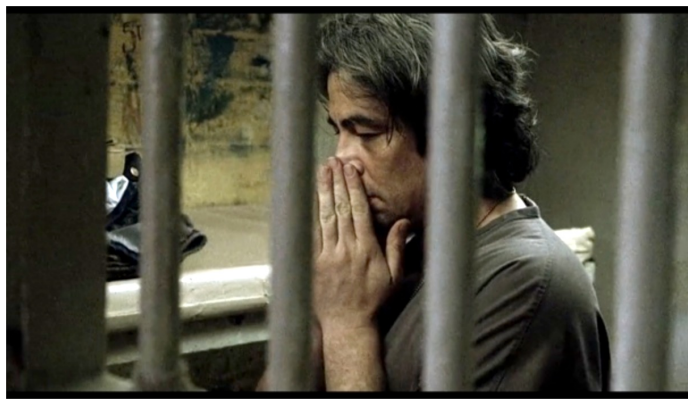

Figura 4.11 - Jack enclausurado

Iñárritu repete a estratégia aplicada em Amores brutos de apresentar personagens secundárias - Michael, marido de Cristina, e Mary, esposa de Paul - intercaladas com os protagonistas, e como há uma manipulação radical do encadeamento causal e da ordenação temporal em 21 gramas, Iñárritu demanda, assim, um esforço ainda maior do espectador na apreensão da função das personagens na história. A ordenação cronológica e causal não são completamente abolidas, mas são permeadas de discrepâncias que sugerem conexões de outras ordens e levantam enigmas. Por exemplo, a passagem direta da cena de Michael com as crianças para a de Cristina na terapia falando do marido induz à dedução de que essas personagens constituem uma família.

Raciocínio similar pode ser desenvolvido em relação à Mary, que diz que o marido está morrendo, e a associação direta com Paul na UTI, mas, então, o que ele está fazendo na cama com Cristina? A primeira vez que vemos Cristina, ela está nua na cama com outro homem, Paul, o que leva o espectador a levantar mais hipóteses - a grata Cristina trai o marido? - e a precisar de mais pistas para confirmá-las ou refutá-las. As diferenças na aparência do estado de saúde de Paul entre suas cenas levam a entender que existe uma variação de tempo entre elas, mas não é possível identificar exatamente qual sua progressão. Qual a relação entre Paul na cama com Cristina e ele no leito do hospital?

A apresentação de Jack começa com um desenvolvimento lógico - trabalho, saída do trabalho, caminho de casa, lar - para, em seguida, dar um salto para ele sendo preso. O encarceramento é anterior ou posterior à sua conversão? Um pouco mais à frente, Cristina aparece cheirando cocaína e não há informação disponível que permita aferir se isso acontece antes, na mesma época ou depois da sessão de reabilitação, se é uma recaída ou sua vida pregressa. 
Da mesma forma, não dá para ter certeza se a prisão de Jack é um salto para trás (flashback ou para a frente (flashforward) da história.

A organização narrativa errática em termos causais e temporais examinada da sequência inicial de 21 gramas se estende por todo o filme, levando Jonathan Romney a propor a seguinte síntese da forma do filme:

$\mathrm{Na}$ estrutura narrativa pouco convencional do filme, passado, presente e futuro se misturam e se fundem entre eles por meio de uma complexa teia que enfatiza as conexões emocionais entre as personagens e situações sobre as ligações cronológicas e causais. ${ }^{88}$ (ROMNEY, 2004, p. 12, tradução nossa)

Em entrevista ao próprio Romney, Iñárritu explicitou o princípio ordenador da narrativa do filme e sua expectativa de como a audiência iria recebê-la:

Tentei estabelecer um código de linguagem e, uma vez que as pessoas entendem esse código - no minuto 25 , ou por aí -, tudo se junta. Depois, não há problema se eu saltar ao redor, porque as pessoas entendem as regras do jogo. [...] O princípio era estar consciente da ordem emocional dos fatos. A ordem em que as cenas são apresentadas é subserviente a isso. ${ }^{89}$ (IÑÁRRITU, apud ROMNEY, 2004, p. 15, informação oral, tradução nossa)

Em Amores brutos, a ênfase é na simultaneidade das vidas e ações para mostrar quão multifacetada, complexa e contraditória é a vida em um espaço urbano. A ordem cronológica em 21 gramas é subordinada a outro tipo de ligadura entre os segmentos. O filme não está interessado em destacar as relações temporais entre os eventos de diferentes linhas narrativas. Entretanto, a falta de continuidade entre cenas contíguas não implica em desordem ou arbitrariedade. As vinculações são arquitetadas cena a cena, por meio de padrões de similaridade e contrastes, ligando personagens e tramas sem priorizar a coerência causal ou temporal. O sentimento de uma personagem ecoa nas demais e é magnificado pela sua reverberação neles. Deleyto e Azcona (2010, p. 40, tradução nossa) apontaram como a tessitura do enredo, por meio das emoções e sua reverberações, exalta as ligações entre as personagens:

\footnotetext{
${ }^{88}$ No original: "In the film's unconventional narrative structure, past, present and future are mixed and merge into one another through a complex web which emphasizes the emotional connections between characters and situations over chronological and causal links." (ROMNEY, 2004, p. 15)

${ }^{89}$ No original: "I try to establish a code of language and once people get the code - at minute 25, or something like it - everything comes together. Then there's no problem if I jump around because people understand the rules of the game. [...] The principle was to be aware of the emotional order of the facts. The order in which the scenes are presented is subservient to that." (IÑ̃́RRITU, 2004, apud ROMNEY, 2004, p. 15, informação oral)
} 
Por meio dessas reverberações, o filme enfatiza e amplifica as emoções das personagens, mas também sugere que não importa quão dolorosamente as pessoas pareçam isoladas no mundo imaginário de Iñárritu, elas são, em última análise, profundamente ligadas: nossas paixões são reveladas como partes de uma rede complexa, que é precisamente o que nos faz humanos. ${ }^{90}$

Apesar de a narrativa do filme ser tão imprevisível e oferecer poucas dicas temporais que ajudem o espectador na localização dos eventos na linha do tempo, é possível ir, gradualmente, identificando se os eventos acontecem antes, durante ou depois do atropelamento, que é o acontecimento que serve de entroncamento causal e temporal da trama. Durante a projeção do filme, a audiência vai acumulando e processando informações e compensando a falta de sentido imediata de seu encadeamento. À medida que a trama vai evoluindo, o espectador vai encontrando menos dificuldade de encaixar as diferentes partes do quebra-cabeça da narrativa multiplexa e consegue conformar, ao final, seu sentido integral e fechado.

No início, a audiência conhece o sofrimento de seus protagonistas, mas não sabe a causa dele. A busca pelo entendimento do porquê as personagens estão sofrendo promove uma forma específica de engajamento do espectador. A inversão da ordem lógica ao expor consequências antes das causas vincula-se naturalmente com a exposição não-linear dos eventos da trama. A trama explora as conexões, paralelos, transferências e mediações entre fortes experiências traumáticas relacionadas às consequências do atropelamento trágico. A narrativa, por meio de ligações emocionais entre personagens, estejam no mesmo quadro ou não, articula um tipo particular de universo ficcional dominado por sentimentos intensos.

As personagens de 21 gramas são muito frágeis, contraditórias e vulneráveis a algo ou alguém que nada tenha a ver com eles e que traga a desordem a suas vidas, seja por obra da sorte, do azar ou, simplesmente, uma coincidência. Imersas em um emaranhado de trajetórias pretendidas e atalhos inesperados, as personagens sofrem mudanças, procuram encontrar um caminho que lhes possibilite seguir adiante. A morte está sempre à espreita e a construção das personagens está baseada na consciência delas da efemeridade da vida. A proximidade com a morte deixa os desejos das personagens mais intensos e seus impulsos em encontrar afeto nos outros menos controláveis.

\footnotetext{
${ }^{90}$ No original: "Through these reverberations, the film emphasizes and amplifies characters' emotions but also suggests that, no matter how painfully isolated people appear to be in Iñárritu's fictional world, they are ultimately deeply connected: our passions are revealed to be part of a complex web, which is precisely what makes us human." (DELEYTO; AZCONA, 2010, p. 40)
} 
Paul, Cristina e Jack passam o filme tentando encontrar um sentido para suas "novas" vidas que ganharam depois que o atropelamento rompeu a estabilidade de suas existências. Cristina havia encontrado equilíbrio e constância na vida em família, que é dizimada no acidente, enterrando-a em um processo de autodestruição no qual ela volta às drogas. Em um primeiro momento, Cristina resiste, mas, depois, entrega-se à paixão louca por Paul. Jack tinha achado salvação na religião para estruturar-se e sair da prisão. O fundamentalismo religioso de Jack o coloca, o tempo todo, em contato com sua própria finitude. Ironicamente, é na direção da camionete que Jesus havia lhe "dado", que Jack atropela e mata a família de Cristina. Paul começa o filme à beira da morte, renasce com o transplante, vive uma tórrida paixão e volta para a morte.

Apesar de não ser apresentado na ordem causal pela trama, o atropelamento institui o primeiro ponto de virada (turning point) do filme que tira os protagonistas do equilíbrio de suas rotinas cotidianas, de seus modus vivendi, e os lançam em uma jornada de aventura (ver cena 71 no Apêndice C e XXI no Apêndice D). O episódio seria o "incidente incitante" "91 que coloca a história em movimento e marca a passagem do primeiro para o segundo ato.

A trama mescla materiais contrastantes provenientes das trajetórias dos protagonistas. De um lado têm-se as convicções abstratas de Paul, como a aceitação do caos, da aleatoriedade e do acaso como princípios de funcionamento do universo; do outro, apresentam-se as crenças de Jack em Deus como responsável por tudo, o poder da fé e a força do destino. Esse contraste fica explícito em algumas falas chave das personagens. Jack fala e repete que aprendeu com seu pastor que "Deus sabe até quando um fio de cabelo move-se em sua cabeça". Por sua vez, Paul recita um poema em seu almoço romântico conjugando sua visão de mundo como professor de matemática com sua atração por Cristina: “A Terra girou para nos deixar mais próximos/ela girou sobre ela mesma e sobre nós/até que, finalmente, nos trouxe juntos a este sonho". 92

Robert Philpin (2007, tradução nossa) também identificou um embate contrastante entre traços das personalidades de Cristina e Jack que também nutrem a trama:

\footnotetext{
${ }^{91} \mathrm{O}$ termo "incidente incitante" foi proposto por Robert Mckee (2006, p. 176) para designar "o primeiro grande evento da narrativa, é a causa primária de tudo o que segue, colocando os outros quatro elementos complicações progressivas, crise, clímax e resolução - em movimento." Trata-se, portanto, do episódio que emite a centelha que deflagra o conflito matriz que repercute em toda a história.

${ }^{92} \mathrm{O}$ poema do venezuelano Eugenio Montejo: "The Earth turned to bring us closer/it turned on itself and in us, /until it finally brought us together in this dream".
} 
É o choque de tais antagonismos - pragmatismo intelectual irritado de Watts em conflito profundo com autoilusão suicida de Del Toro - que impulsiona 21 Gramas. A necessidade obsessiva de vingança dela e a compulsão para absorver o autosacrifício dele resultam na morte do professor de ciências relativamente inocente. ${ }^{93}$

Além do traço contrastante entre as personagens, vale apontar também a presença da "situação trágica por excelência" aristotélica nas trajetórias de Jack e Cristina, que não se distinguem pela virtude e caem em desgraça, não por serem abomináveis, mas por força de um acidente ao acaso. Em mais uma camada na construção das personagens, o roteirista Arriaga destaca sua crença na contradição como a essência da natureza humana e expôs suas intenções ao utilizar esse atributo na concepção das personagens do filme:

Paul pode parecer egoísta em seu relacionamento com Mary e absolutamente generoso com Cristina. Jack está falando de amor o tempo todo e maltrata seu filho. [...] Eu acredito no vilão e no herói que todo mundo tem dentro de si. Eu queria que o público sentisse compaixão por Jack, o "cara mau" que mata uma família e foge. Eu queria que eles entendessem um personagem infiel como Paul e descobrissem que uma ex-viciada em drogas pode ser uma boa mãe. ${ }^{94}$ (ARRIAGA, 2003, apud WOOD, 2006, p. 148, informação oral, tradução nossa)

Há uma cena terrível de Jack jantando com a família que exemplifica bem o teor de contradição na compleição de sua obsessão religiosa. Após a tradicional prece de agradecimento antes da refeição, o filho agride a irmã, Jack força a filha a "oferecer a outra face" e ordena ao garoto que bata novamente. O menino hesita e Jack fala para ele não ter medo e bater, o que o garoto acaba fazendo. Marianne, mulher de Jack, protesta contra a inadequação com que o marido aplicou a lição de pacifismo cristão e sai da mesa para confortar a filha que chora. Jack dá um tapa na cabeça do filho e o coloca de castigo de frente para a parede dizendo que "não é admitido agressão naquela casa".

Seguindo essa linha de composição de personagens, utilizando-se contrastes, contradições e o componente trágico, a narrativa emprega personagens secundários, os três cônjuges dos protagonistas - Michael, Mary e Marianne - como agentes promotores da estabilidade, do

\footnotetext{
${ }^{93}$ No original: "It is the clash of such antagonisms - Watts' angry intellectual pragmatism in deep conflict with Del Toro's suicidal self delusion - that drives 21 Grams. Her obsessive need for vengeance, his compulsion for absolving self-sacrifice, results in the death of the relatively innocent science professor. (PHILPIN, 2007, s.p.)

${ }^{94}$ No original: "Paul can look selfish in his relationship with Mary and absolutely generous with Cristina. Jack is speaking of love all the time, and he mistreats his son. [...] I believe in the villain and the hero that everybody has inside. I wanted the audience to feel compassion with Jack, the 'bad guy' that kills a family and runs away. I wanted them to understand an unfaithful character, as Paul, and to find out that a former drug addict can be a good mother." (ARRIAGA, 2003 apud WOOD, 2006, p. 148).
} 
bem estar e do equilíbrio. Logo no início do filme, Michael surge alimentando as filhas em uma lanchonete. A cena é justaposta à de Cristina dando um depoimento em grupo de apoio falando da importância de sua família e da contribuição de seu marido em sua reabilitação.

Marianne fica o tempo todo cuidando de Jack e dos filhos. Ela está atenta aos exageros de Jack em seu apego aos dogmas religiosos e cobra dele suas responsabilidades como pai quando ele entra em processo de descrença e autopunição. Marianne faz de tudo para manter a união da família, algumas vezes até assumindo posturas eticamente questionáveis para atingir seu objetivo maior. Marianne aconselha Jack a não se entregar como autor do atropelamento, paga um advogado para tirá-lo da prisão e lembra-o que a vida segue em frente e que ele tem uma família para cuidar.

E ainda há Mary, que luta obsessivamente contra suas limitações físicas e o estado moribundo de Paul para dar uma perspectiva para a relação deles por meio da tentativa de uma gravidez por inseminação artificial. $\mathrm{O}$ casamento já não vai bem há muito tempo e eles vivem uma relação de conveniência. Segundo Arriaga "o lado triste é que eles permaneciam juntos porque ambos estavam doentes. Ele tem uma doença cardíaca que limita sua vida e ela tem aquela solidão que a está consumindo. Ele precisa de ajuda e ela, de alguém para fazerlhe companhia" (ARRIAGA, 2003, apud WOOD, 2006, p. 146, informação oral, tradução nossa). ${ }^{95}$ Paul sente-se inadequado em seu casamento e, como está prestes a morrer, sente-se mais apto a assumir seus ímpetos e deixa Mary para ligar-se a Cristina. O ideal romântico do amor estável, do "felizes sempre e para sempre", que move os cônjuges, personagens secundárias, é colocado em cheque, no desenrolar da trama, seja por incapacidade própria seja pela intervenção do acaso ou da combinação de ambos.

Existe, em 21 gramas, mais uma manipulação da instância narrativa das personagens que é singular na obra de Iñárritu e tem o objetivo de dar amarração à história como um todo: o monólogo interior de Paul. ${ }^{96}$ A narração de Paul aparece apenas no início e ao final do filme, quando ele está à beira da morte no hospital. Nas duas vezes que essa voiceover é empregada, vem precedida da imagem dos pássaros voando e acompanhada de música melancólica e minimalista. A imagem poética dos pássaros apresenta uma movimentação ascendente na

\footnotetext{
${ }^{95}$ No original: "The sad thing is was that they were together because both of them were sick. He has the heart disease that limited his life, and she had this loneliness that is consuming her. He needs care and she needs someone to be with her." (ARRIAGA, 2003, apud WOOD, 2006, p. 146, informação oral)

${ }^{96}$ No abertura do filme, ouve-se o seguinte pensamento de Paul: "Então, essa é a sala de espera da morte. Esses tubos ridículos, essas agulhas dilatando meus braços. O que estou fazendo nesse clube pré-cadáver? O que tenho a ver com eles? Eu não sei quando tudo isso aconteceu e nem quando vai acabar. Quem vai ser o primeiro a perder a vida? Ele que está em coma? Ou eu?" E, ao final, escuta-se o texto da epígrafe.
} 
primeira aparição e descendente na segunda funcionando como uma espécie de indexador que chama atenção para sua aparição e função de enlaçar a história.

A voz interna de Paul traz reflexões sobre os temas do filme: o sentido da vida, o poder do acaso em atrelar pessoas que não têm nada que ver umas com as outras e o peso da morte. $\mathrm{O}$ tom pausado e filosófico dessa narração, associado à música e aos ruídos dos aparelhos médicos ao redor de Paul, é fundamental para instituir o enfoque existencialista do filme. A posição das duas intervenções do monólogo interior na trama ao estabelecer e fechar a história também oferece a possibilidade de interpretar a narrativa fragmentada e embaralhada do filme como sendo a fabulação de Paul em seu derradeiro esforço de dar sentido à passagem da vida para a morte.

Ademais, a utilização de um monólogo interior no início e ao final dos filmes é uma prática comum na contemporaneidade que pode ser interpretada como uma articulação que visa garantir a legibilidade do mesmo. Essa estratégia pode ser encontrada tanto para tornar a imersão facilitada em uma narrativa mais convencional quanto para viabilizar o entendimento de uma construção fílmica urdida com multiplicidade e não-linearidade. Visto sob esse prisma, a opção de dar unidade à história, começando e findando com um monólogo interior, configura uma espécie de "concessão" do cinema multiplex em prol da comunicabilidade do filme. O uso desse dispositivo nutre sua narrativa com os atributos da clareza e do final fechado tão valorizados pelo cinema clássico. A diferença é que, em um viés mais clássico, o emprego do diálogo interior, estabelecendo e fechando filmes, opta por narrar priorizando as conexões causais e temporais no encadeamento das cenas. ${ }^{97}$ Por sua vez, o cinema multiplex, como o de Iñárritu, lança mão dessa estratégia como alternativa para dar liame a uma organização narrativa que se oferece como fluxo de conexões lógicas e temporais peculiares.

A ocorrência de acesso à subjetividade de apenas um dos protagonistas do filme por meio do diálogo interno, aliado à função que suas reflexões desempenham na estruturação do enredo, coloca Paul em uma posição destacada pela focalização da história em sua perspectiva. Iñárritu explicou sua opção pelo relevo de Paul da seguinte maneira: "Senti que era importante ao final do filme apresentar muito claramente um ponto de vista. No final, o filme é como se fosse a memória de Paul a se lembrar dos eventos. Eu precisava de um líder, aquele que

\footnotetext{
${ }^{97}$ Guardadas as proporções e distinções estéticas com o filme em estudo, pode-se identificar essa mesma estratégia de dar consistência à narração por meio de um monólogo no blockbuster Titanic (James Cameron, 1997). Nesse sucesso de bilheteria, o relato de Rose, no início e ao final, deflagra e arremata a história de seu caso de amor perdido como um grande flashback, tendo o naufrágio do navio como pano de fundo.
} 
redimiria os outros dois" (IÑÁRRITU, 2003, apud WOOD, 2006, p. 146, informação oral, tradução nossa). ${ }^{98}$

O multiprotagonismo, com sua vocação para criar representações das emaranhadas interações humanas, em associação com a narração não linear, imprime uma sensação de que o mundo está além da nossa capacidade de compreensão. A tessitura da narrativa do filme explora justamente essa dificuldade de entendimento do significado da vida. A amarração da história é astuciosamente tecida por meio de um duplo enlace da perda de sentido em níveis distintos - narração e personagens - que utiliza uma série de estratégias tanto macro como microestruturantes das cenas que serão examinadas na seção seguinte.

\subsection{O sentido da trama e a perda de sentido das personagens}

O duplo enlace de perda de sentido no filme é instituído no transcorrer da trama pelo entrelaçamento da perda de rumo nas vidas das personagens pela forma fragmentada e embaralhada com que o espectador recebe as informações da narração, dificultando sua compreensão da história. Por um lado, a desorientação causal e temporal do espectador o deixa mais receptivo ao drama das personagens. Por outro, a confusão que as personagens atravessam em seus dramas particulares ganha maior impacto e estimula uma atitude mais ativa do espectador quando narradas rompendo com a ordem causal e temporal. Como se não fosse suficientemente desafiador o entrelaçamento da dupla perda da coerência nos níveis da narração e das personagens, o filme ardilosamente elege como evento que proporciona ao espectador a base para elucidar a sua lógica causal e temporal justamente o acontecimento que faz a vida das personagens perderem o sentido: o atropelamento.

Assim como em Amores brutos, um acidente de carro é o entroncamento de 21 gramas. Trata-se do momento em que as vidas dos protagonistas se cruzam, de uma maneira direta ou indireta, proporcionando ao espectador a chance de encaixar suas trajetórias e dar nexo à narrativa como um todo. Enquanto, em Amores brutos, a colisão de automóveis é reapresentada quatro vezes de pontos de vista distintos, explorando as amplas possibilidades visuais de acrescentar informações à trama; em 21 gramas, o atropelamento apesar de invocado algumas vezes, nunca é explicitado visualmente. O momento exato da colisão é apresentado

\footnotetext{
${ }^{98}$ No original: "I felt that it was important at the end of the film to present very clearly one point of view. At the end the film is like a memory for Paul and how he remembers events. I needed one leader, the one who would redeemed the other two." (IÑÁRRITU, 2003, apud WOOD, 2006, p. 146, informação oral)
} 
apenas por meio do áudio. A camionete de Jack atropelando a família de Cristina não é vista por ninguém no universo diegético e nem pelo espectador. Vê-se segundos antes e depois, mas nunca no momento do choque, somente se pode escutar os ruídos do carro acertando os corpos.

O momento trágico de 21 gramas acontece no lusco-fusco, e é parcialmente testemunhado por um rapaz latino que cuida de um jardim nas imediações do acidente (cena 71). $\mathrm{O}$ rapaz está trabalhando quando escuta o baque da colisão, larga o que está fazendo e corre em direção ao acidente saindo de quadro. A montagem sustenta o plano vazio no qual a máquina de ar fica caída ligada com som estridente soprando as folhas secas do outono. A composição do plano final dessa cena invoca a ideia do caos produzido pelo acaso em muitos níveis e vai reverberar em todo o filme. $\mathrm{O}$ fato do atropelamento não ser explicitamente mostrado passa a sensação etérea de que a morte está à espreita em qualquer esquina. Não a vemos, mas ela está lá preparada para ceifar vidas ao acaso. $\mathrm{O}$ acidente representado dessa forma aguça no espectador o senso de mortalidade intrínseco à vida e materializa a fragilidade humana ao tentar manter a estabilidade das coisas.

O momento do atropelamento é aludido outras vezes de maneira indireta por meio da repetição da última mensagem de Michael deixada no celular de Cristina segundos antes do acidente e da ida de Cristina ao local da colisão. O celular de Cristina toca quando ela está saindo da piscina onde nadava com sua irmã, mas ela não atende a tempo ao que inferimos mais tarde ter sido a chamada de Michael (cena 14).

A primeira vez que ouvimos a mensagem de Michael é quando Cristina chega em casa de volta da natação, sua vida está em ordem e ainda não sabe do desastre (cena 28). Somente depois que o espectador sabe de toda desgraça, é que é mostrada a cena de Michael caminhando com as filhas, deixando a mensagem para Cristina e dirigindo-se para a colisão fatal. $\mathrm{Na}$ fase em que Cristina está deprimida e visita o lugar da tragédia, conversa com o jardineiro latino que viu sua família viva pela última vez (cena 99), a montagem destaca a importância do momento com a preferência por planos fechados, circulando em torno de Cristina, e a banda sonora é embalada por um tango triste de Santaolalla.

Cristina senta-se no meio fio da esquina do atropelamento desolada tentando entender o ocorrido. A câmera faz uma panorâmica para a esquerda tirando-a de quadro e emoldurando a rua vazia. O deslocamento tradicional do movimento de câmera panorâmico é da esquerda para a direita, como o sentido da leitura no mundo ocidental. Quando se faz o movimento no sentido inverso, da direita para a esquerda, convencionalmente deve haver algo expressivo que justifique a inversão. Quando a câmera faz a panorâmica invertida nesse ponto do filme, 
encontra uma esquina vazia enfatizando a ausência e insinuando que há algo ali que não vemos, a morte.

A mensagem de Michael é mixada ao tango fazendo a ponte de passagem para a cena de Cristina prostrada em sua cama ouvindo repetidas vezes as últimas palavras de seu finado marido. Cristina se agarra na tentativa de comunicação corriqueira de Michael como se ela pudesse vir a ser um fio de Ariadne capaz de tirá-la do labirinto de sofrimento e solidão em que o acaso a lançou. $\mathrm{O}$ empenho de Cristina em buscar sentido para o que aconteceu em sua vida tem eco no esforço do espectador para compreender a trama.

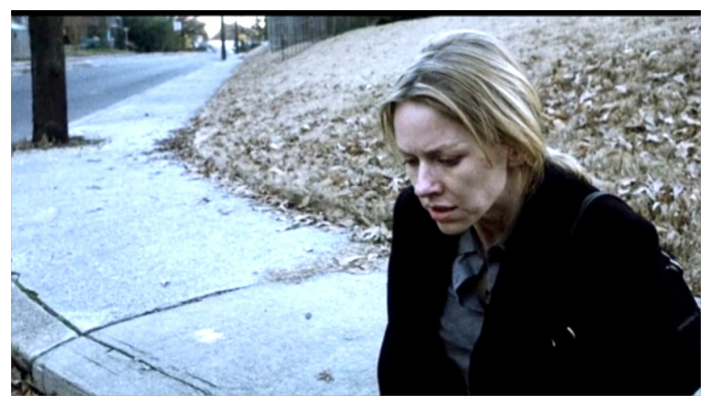

Figura 7.12 - Cristina visita o cruzamento em que sua família foi atropelada

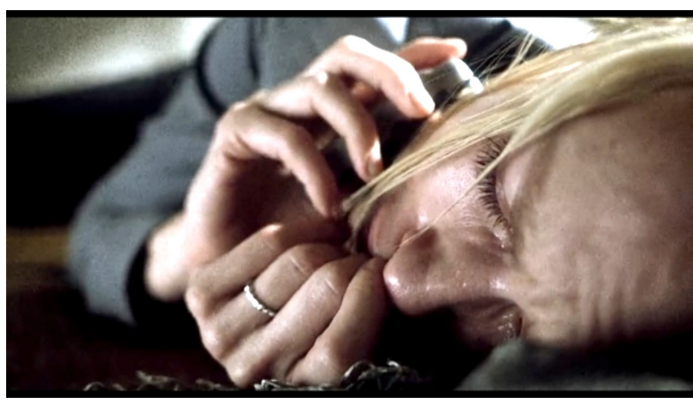

Figura 7.13 - Cristina ouve repetidas vezes a última mensagem deixada por seu marido

A articulação do tempo não-linear ordenado pelas emoções de protagonistas, que perdem o sentido da vida quando se cruzam em um atropelamento apresentado com sutileza, ganha uma camada extra de indefinição em sua composição desafiadora na falta de demarcação da cidade que prevalece como cenário da história. O filme acontece quase que totalmente em uma cidade americana qualquer, não identificada, que deixa no ar a dúvida se é real ou não. Trata-se de Memphis, Tennessee, mas sua identidade não tem nenhuma relevância para a trama e ela funciona como um genérico de cidade americana. A cidade foi escolhida como locação por sua atmosfera favorável à dramaturgia do filme, conforme explica Iñárritu (2009, apud DELEITO; AZCONA, 2010, p. 134, informação oral, tradução nossa):

Eu pensei que o elemento da culpa poderia ser melhor retratado nos Estados Unidos, especialmente no sul, onde as comunidades religiosas como a que aparece no filme abundam. [...] Em Memphis, encontrei um toque de decadência e tristeza. Ela retém um certo sabor. Gostei de sua aparência no outono, quando fomos filmar lá. [...] Eu queria o sentimento de uma cidade cinzenta, que os espectadores não identificassem imediatamente. [...] Rodei o 
filme em Memphis por causa das texturas e da permeante sensação de melancolia que inunda a cidade. ${ }^{99}$

O outro espaço do filme é o deserto para onde Jack se exila de sua família em autopenitência e é perseguido por Cristina e Paul na tentativa de matá-lo. Essa parte da história na qual aparecem o motel da piscina vazia, estradas, hospital e ermos foi filmada no estado do Novo México, que também não é designado na película. A indeterminação do espaço no qual a trama se desenrola coloca essa instância narrativa em sintonia com as demais - tempo, personagens e narração - funcionando como mais um fio na tessitura da teia imbricada do filme.

O jogo que o filme estabelece com o espectador ao nível da macroestrutura da narrativa ao disponibilizar informações desordenadas, cobrando-lhe um empenho mais intenso do que o convencional na apreensão da história, guarda uma relação com as estratégias de micro estruturação das cenas. O estilo realista de mise-en-scène, comum aos filmes de Iñárritu, ganha variações particulares nos enquadramentos e tratamento das imagens em 21 gramas. Assim como em seu filme de estreia, há predomínio do uso da câmera na mão transmitindo a sensação de instabilidade do universo diegético que é amplificada em 21 gramas pelo incremento da quantidade de planos fechados.

Em comparação com Amores brutos, é perceptível um aumento proporcional de close ups, superclose ups e planos de detalhe conformando uma decupagem alinhada com o princípio organizativo da narrativa, que destaca as emoções em detrimento das informações causais e temporais. A predominância dos planos fechados decorre de seu potencial expressivo em transmitir os sentimentos das personagens, linha mestra do filme. Por sua vez, os planos abertos aparecem com muita parcimônia em função de sua capacidade em transmitir informações espaço-temporais que não favorecem a amarração proposta pelo modo narrativo do filme.

O incremento da proporção de planos fechados em 21 gramas ganha ainda maior ênfase expressiva porque são captados com pouca profundidade de campo. A utilização do foco seletivo tem dois efeitos que ajudam a destacar as emoções das personagens. O primeiro é a separação visual que promove entre as personagens e o fundo, destacando seus sentimentos e não as informações físicas do cenário em que estão imersos. O segundo efeito desse recurso

\footnotetext{
${ }^{99}$ No original: "I thought that the element of guilt would be better portrayed in the United States, specially in the South, where religious communities like the one that appears in the film abound. [...] In Memphis I found a touch of decadence and sadness. It retains a certain flavor. I liked the way it looked in the fall, when we went to shoot there. [...] I wanted a feeling of a grey city, one that the spectators wouldn't immediately identify [...] I shot the film in Memphis because of the textures and the pervading sense of melancholy that inundates the city." (IÑÁRRITU, 2009, apud DELEITO; AZCONA, 2010, p. 134, informação oral)
} 
fotográfico é o da materialização da falta de sentido da vida das personagens por meio da indefinição do mundo desfocado, como que reproduzindo seu turbilhão caótico interno, plasmando, dessa forma, o estado subjetivo das personagens com o espaço em que estão inseridas.

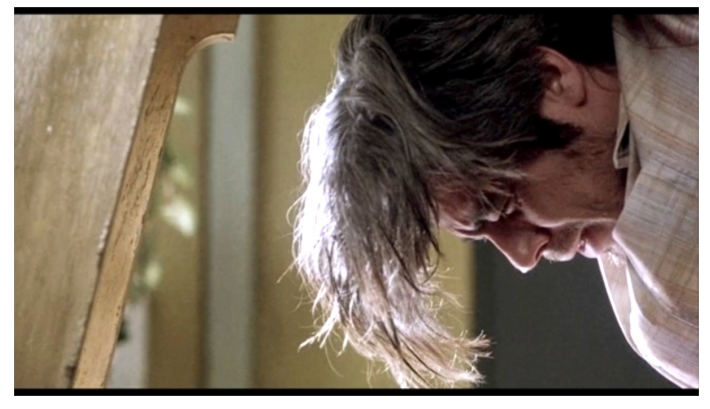

Figura 7.14 - Jack destacado do fundo pelo foco

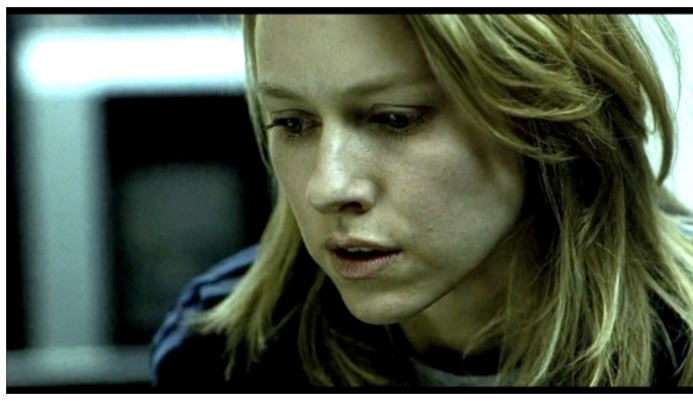

Figura 7.15 - Subjetividade da falta de sentido da vida de Cristina expressa no desfoque do fundo

Em vários momentos a montagem conjuga planos fechados com a indexação de um ponto de vista (point of view, POV) associado a uma personagem. A associação do enquadramento fechado com a subjetividade do POV aguça a percepção emocional das personagens. A decupagem fica ainda mais instigante do que a utilizada em Amores brutos, porque, além de provocar o choque da descontextualização entre planos consecutivos não pertencentes à mesma locação, também levanta a questão do pertencimento do olhar. Por exemplo, logo na abertura do filme (cena 7) aparece uma luminária fluorescente retangular que é justaposta ao olhar de Paul moribundo e reflexivo no hospital, possibilitando uma associação imediata entre plano e ponto de vista.

O uso recorrente na montagem de planos vinculados pela relação subjetiva de ponto de vista cria a expectativa de repetição dessa conexão abrindo a possibilidade de satisfazer ou frustrar esse atrelamento. Como acontece, logo na cena que segue a supracitada, em que surge o plano de detalhe de outra luminária, dessa vez, redonda e incandescente, seguida de Cristina cheirando cocaína no banheiro (cena 8). A segunda luminária não estabelece um ponto de vista de Cristina, mas como o espectador recém associou uma luminária com o olhar de outra personagem, por frações de segundo, tende a repetir a conexão anterior, precisando reconfigurá-la. A variação da existência ou não de vinculação de planos de detalhe com a perspectiva de personagens atiça um pouco mais a atenção do espectador provocando um microestímulo cognitivo na mesma direção dos choques promovidos entre as cenas embaralhadas na macroestrutura da trama. 
A justaposição incessante por corte direto de cenas fora da ordem temporal e causal com predominância de enquadramentos fechados com pouca profundidade de campo impõe ao espectador um engajamento muito mais alerta e ativo do que em uma narração mais convencional. A cada corte, ocorre uma quantidade elevada de mudanças de personagens, espaço, tempo, ações, ritmos, cores, entre outros. As mudanças são o estopim da renovação do nível de atenção do espectador no esforço de compreender as informações que lhe são apresentadas.

Em 21 gramas, o nível de demanda da participação ativa do espectador na compreensão da história por meio da trama é radical porque as elevadas possibilidades de conexões promovidas pelo multiprotagonismo são exponencialmente ampliadas pela fragmentação e embaralhamento desordenado da lógica das cenas. A cada plano do filme que bate na tela, o espectador é cobrado a responder um número muito maior de perguntas do que na fruição do cinema com montagem em continuidade sem multiplicidade. $\mathrm{O}$ andamento de 21 gramas reflete a complexidade do universo aleatório e caótico do protagonista detentor do ponto de vista geral da história, o matemático Paul.

A montagem de 21 gramas não tem pudores em, repentinamente e sem motivação causal, mudar o encaminhamento temporal da trama desrespeitando o tradicional encadeamento das ações em continuidade consagrado pelo código do cinema clássico. É recorrente, na montagem do filme, relacionar cenas por antítese, principalmente entrecortando momentos de estabilidade e intimidade com contextos pesados de violência, perda, desespero e depressão. A exemplo disso, podemos focalizar a grande eloquência na associação de cenas por antítese que constrói a seguinte sequência: Paul e Cristina têm almoço romântico (cena 76) e caminham para a casa de Cristina (cena 77); Paul com Cristina em motel e Paul tenta matar Jack (cenas 78 e 79); Marianne e Jack não conseguem transar em sua volta da prisão (cena 80); e volta para Paul e Cristina dentro da casa dela depois do almoço (cena 81).

O encontro de Paul e Cristina no restaurante tem uma luminosidade clara incomum no filme. O ambiente está vazio e a intensidade clara da luz parece suspender o casal de suas rotinas existenciais, passando a sensação de bem estar e serenidade. O transplante de Paul até esse momento vai sendo bem absorvido pelo seu corpo e ele sente gratidão pela nova vida que ganhou. Cristina está, pela primeira vez, tentando se relacionar com uma pessoa nova que possa oferecer alguma perspectiva para que saia do estado de fragilidade pela perda de sua família. Apesar do realismo da representação do encontro existe uma certa aura mágica que revela a paixão latente do casal. Paul fala poeticamente de como a matemática pode ajudar a entender a complexidade da vida e explicar o mistério por trás dos encontros entre pessoas 
que se gostam. Após o almoço, eles caminham conversando afetuosamente em direção à casa de Cristina que convida Paul a entrar. Corta para...

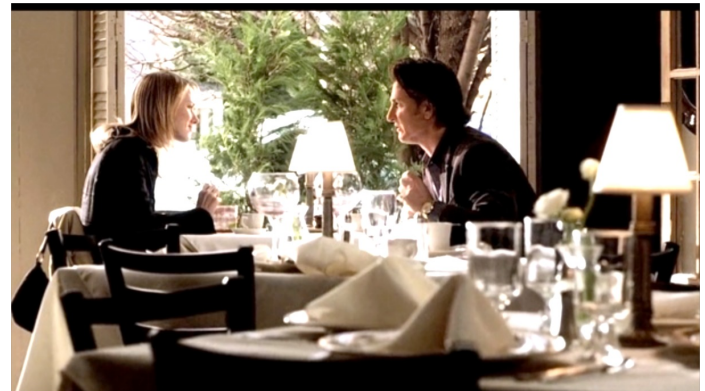

Figura 4.16 - Almoço romântico de Paul e Cristina

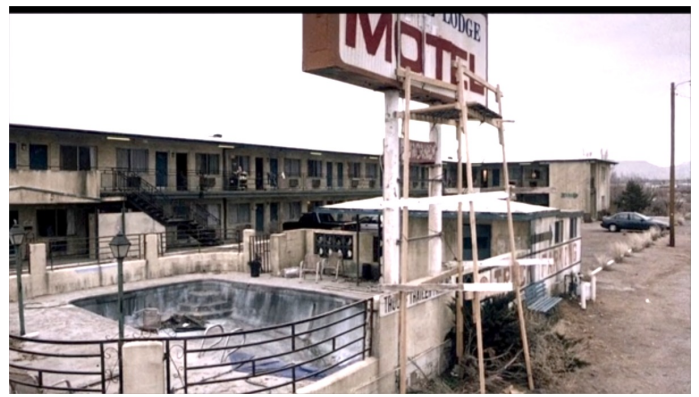

Figura 4.17 - Motel à beira de estrada filmado no Novo México

Em uma rara abertura de cena com plano geral, a tela é tomada por menos de três segundos pela imagem de um motel decadente de beira de estrada com piscina vazia e suja. Segue uma tomada interna do quarto do motel com Cristina adormecida em primeiro plano desfocada e Paul sentado ao fundo visivelmente ansioso e fumando desconcertantemente, pois está com muita dificuldade em respirar devido à rejeição do transplante. Ele levanta, guarda a arma e sai para atocaiar Jack na saída do motel. Apesar de muito debilitado, Paul rende Jack, leva-o para um terreno baldio, coloca-o de joelhos e dispara três vezes. Corte abrupto para...

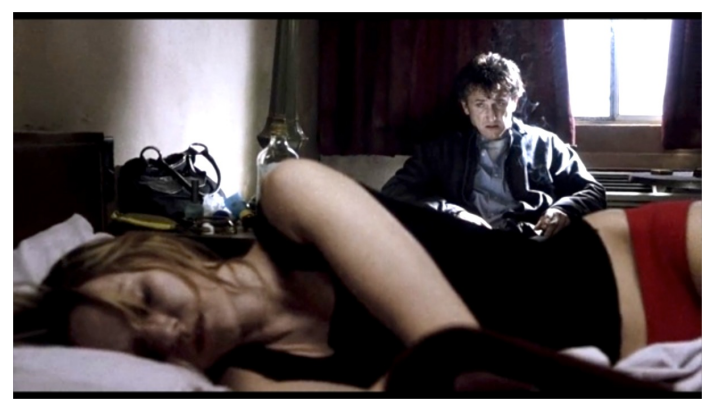

Figura 4.18 - Paul e Cristina em quarto de motel decadente

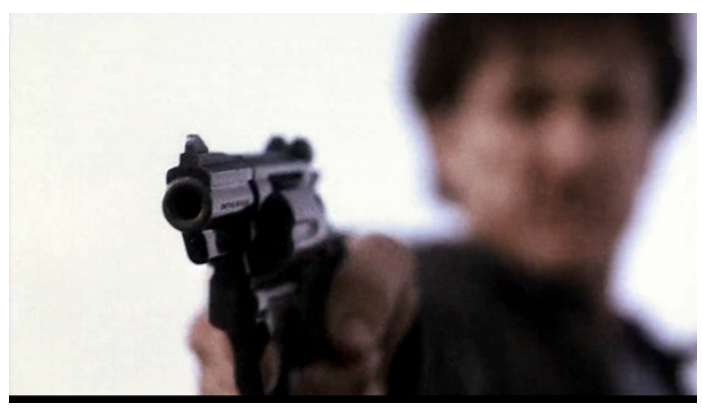

Figura 4.20 - Paul dispara contra Jack

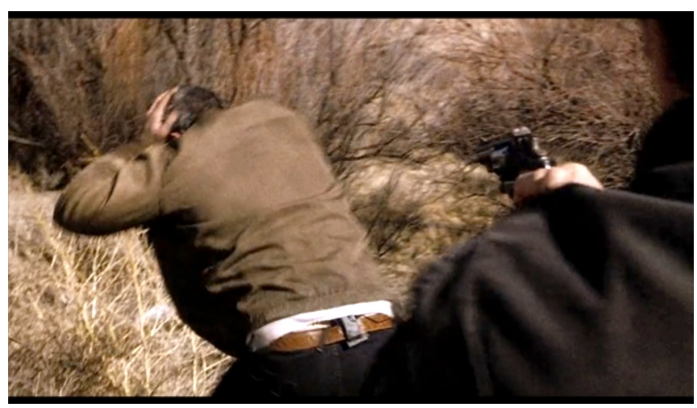

Figura 4.19 - Paul rende Jack

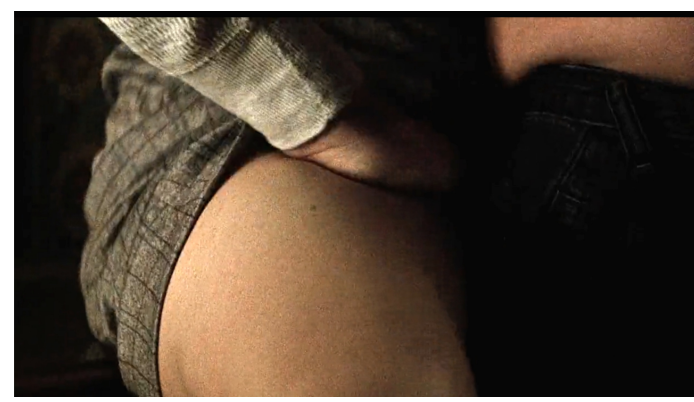

Figura 4.21 - Jack acaricia Marianne 
Plano de detalhe de coxas femininas e região pubiana sendo tocada por debaixo do vestido. Conforme outros planos vão se sucedendo, percebe-se que são Marianne e Jack tentando transar assim que ele sai da prisão. Existe muito desejo sexual nos carinhos, mas Jack perde a motivação e conta que não se esquece do olhar da filha de Cristina que ainda estava viva depois do atropelamento. Ele manifesta seu arrependimento por ter deixado a garota sem prestar socorro.

A passagem em corte seco de planos fechados de Paul atirando para matar Jack direto para o plano fechado do próprio Jack apalpando a genitália da esposa provoca um choque que vai muito além da descontextualização entre planos consecutivos. A montagem entre essas cenas estabelece uma antítese entre morte e vida - pulsão sexual. A junção de planos e cenas por antítese é recorrente no filme não apenas em cenas consecutivas, mas também dentro de uma mesma cena ou por meio de associações de imagens e ações que se encontram mais espaçadas no enredo. A antítese está presente internamente na cena em que Marianne está em casa com vários convidados da festa de aniversário de Jack e ele chega atrasado e conta que atropelou, matou uma família e fugiu (cena 32). ${ }^{100}$ Há vida na celebração dentro da casa e o aniversariante chega acompanhado da morte. A transição do interior em festa para o exterior com Jack chegando com o carro ensanguentado é feita em plano sequência, sem cortes, evidenciando que é fluida a passagem da vida para a morte.

Como exemplo de antítese entre cenas distantes, pode-se citar a que contrasta com a do coito interrompido da cena descrita acima, na qual Jack não consegue ter prazer por causa do seu remorso (cena 80), e a cena de sexo apaixonado entre Paul e Cristina (cena 92). Ou então, a oposição que se estabelece no confronto entre as imagens da piscina azul, limpa e asséptica na qual Cristina nada, antes do atropelamento e durante a aproximação de Paul, e a vazia e suja do motel parte do cenário da vingança.

\footnotetext{
${ }^{100}$ A outra festa do filme também acaba mal. Trata-se da comemoração do sucesso do transplante de coração, em que Mary anuncia a todos os convidados que decidiu, à revelia de Paul, que vai ter um filho dele por meio de inseminação artificial. O pronunciamento de Mary desagrada profundamente Paul e prenuncia a separação do casal (cena 47).
} 


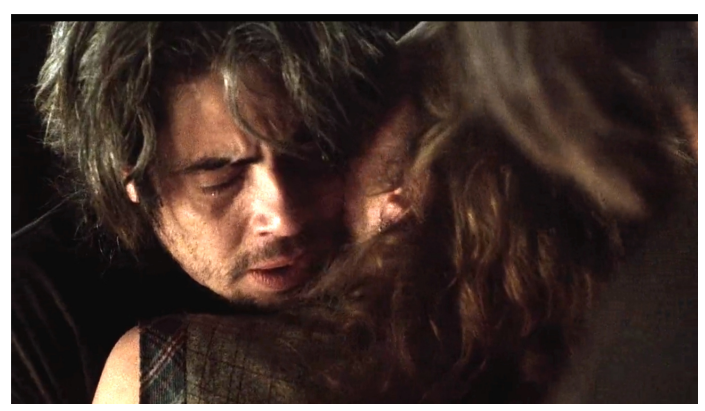

Figura 4.22 - Jack não consegue transar com Marianne

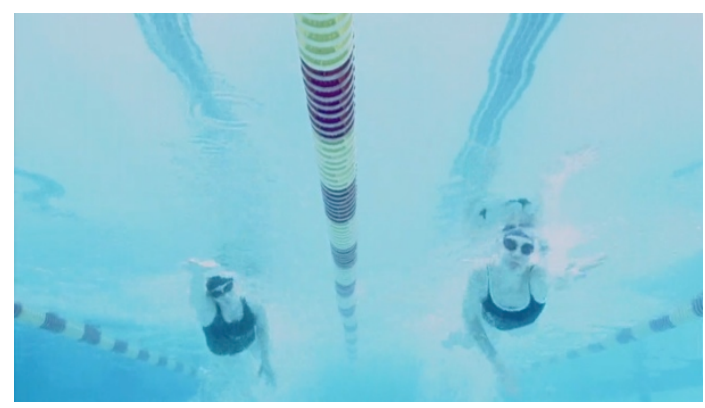

Figura 4.24 - Cristina nada com sua irmã

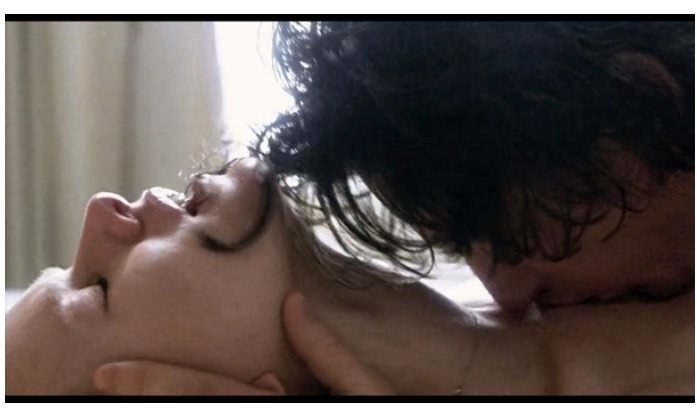

Figura 4.23 - Paul e Cristina consumam sua paixão

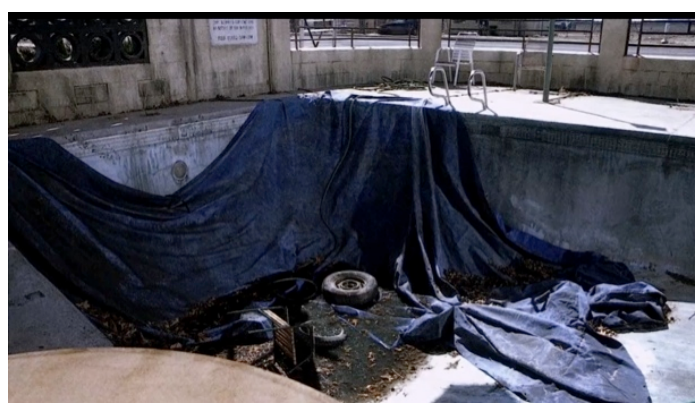

Figura 4.25 - Piscina entulhada do motel

Voltando à análise da sequência ligada por antítese, finalmente, a trama retoma o prosseguimento da aproximação amorosa entre Paul e Cristina dentro da casa dela depois do almoço. Enquanto Cristina vai pegar mais uma taça de vinho, Paul vê fotos de Michael com as meninas e sente-se tonto. Ao se despedir de Cristina na porta da casa, declara que há muito tempo não gostava de alguém como estava gostando dela. Paul tenta beijar os lábios de Cristina, que vira o rosto e fala que é casada.

A sequência descrita acima segue a ordenação denominada por Iñárritu como "emocional". A progressão inicial da relação de intimidade amorosa para Paul e Cristina com sua atmosfera leve e promissora é afrontada pelo clima pesado de mal-estar e tentativa de assassinato envolvendo o próprio casal em um futuro próximo. A esperança do começo promissor da relação afetiva do casal - restaurante/caminhada - muda drasticamente, ao ser contrastada com a deterioração dos sentimentos entre eles, quando empenhados na vingança da morte acidental da família de Cristina - motel/tentativa de matar Jack. O contraste visual entre essas cenas consecutivas com as mesmas personagens é bem marcado, da luz da bem-aventurança para as sombras do sórdido, do amor para a morte. A mudança é súbita e torna a felicidade efêmera ao ser cortada cruelmente por seu próprio futuro.

A primeira parte da sequência examinada termina com Cristina convidando Paul a entrar em sua casa (cena 77), o que evoluiria em uma narrativa mais convencional para os dois transando ou uma cena de pós-coito. A narrativa, em vez de saciar os desejos dos apaixonados 
e do público, entrega uma espécie de pesadelo. O espectador, atiçado a fazer conexões independentemente da ordem de apresentação, pode associar o encadeamento almoço/caminhada/convite para entrar com a primeiríssima imagem do filme na qual Paul e Cristina aparecem na cama sem roupa (cena 1) e inferir que, após o primeiro encontro, eles tiveram relações sexuais.

A semelhança da composição da cena do casal no quarto do motel com a inicial do filme estimula a audiência a relacioná-las (ver Figuras 4.1 e 4.18). Entretanto, essa conexão não é garantida porque esses planos se encontram muito distantes e o espectador foi solicitado a fazer dezenas de outras junções de pistas nesse ínterim. Caso a memória do espectador funcione bem e conecte as cenas (76 e 77 com a 1), ele vai notar que o clima de paz e felicidade do encontro romântico não se encaixa tão bem com a tensão e agonia presentes na imagem de abertura do filme. Então, o espectador vai deduzir que não se trata do mesmo momento, seguindo indefinida a cronologia da primeira cena até esse ponto. A narrativa, nesse ponto, lançou uma pista falsa estimulando a audiência a levantar uma hipótese e, mesmo ao considerá-la improcedente, assimilar um pouco melhor o jogo de atrelamentos proposto pela narração do filme.

A montagem da sequência examinada conforma uma elipse entre as duas cenas justapostas de Paul e Cristina, suprimindo o período em que a relação entre eles se estabelece, no qual há a exposição do motivo pelo qual Paul tenta matar Jack. Somente cerca de vinte e cinco minutos adiante no filme (cena 101, 1h44min33s), mostra-se Cristina manifestando seu desejo de vingança e conclamando Paul a ajudá-la a matar Jack.

Paul oferece comida para Cristina, percebe que ela está cheirando cocaína, derruba a droga e diz que ela não precisa daquilo. Cristina retruca nervosa para ele não dizer o que ela precisa. Ela manifesta sua indignação e inconformismo com a situação: “Aquele desgraçado está solto e eu nem consigo entrar no quarto delas. Eu não consigo mais viver". Paul tenta acalmá-la sem sucesso. A viúva sentencia: "Você está vivendo na casa dele, fodendo a mulher dele, vivendo com o coração dele. Aquele homem matou ele e as duas filhas e está livre. Você tem que matá-lo". Paul a abraça e ela, chorando, continua lamentando e conclamando Paul ao crime de vingança.

Destaco essa cena devido a sua função estrutural e seu significado profundo. Embora deslocado no enredo, o episódio redireciona o andamento da trama e estabelece o segundo ponto de virada (turning point) do filme que marca a passagem do segundo para o terceiro ato. Apesar de ambientada em uma casa de classe média americana contemporânea, a essência dramática da cena remete a um chamado de ritual de sacrifício para restituir o equilíbrio 
da vida que remonta à cultura ancestral mexicana. Em princípio, Cristina cobra de Paul a execução de Jack por vingança, para apaziguar seu sofrimento. Paul é apto para encarar a morte e até findar com a própria vida, mas é incapaz de matar. Contudo, ele é impelido a sacrificar a vida de Jack e a sua em troca da oferenda que recebeu, o coração de Michael. É olho por olho, coração por coração, vida por vida e morte por morte. No desenrolar da jornada de vingar a família da viúva, Paul e Cristina seguem juntos e acabam por gerar uma nova vida que abre perspectivas de redenção na conclusão do filme. Uma vez mais, vida e morte se entrelaçam na narrativa. $^{101}$

Conforme mostrado acima, a antítese como princípio aglutinador de cenas e planos, assim como as opções fotográficas de câmera na mão com predomínio de enquadramentos fechados com pouca profundidade de campo e ocasional POV, são estratégias macro e micronarrativas que se sobrepõem, suturando as fraturas causais e temporais da trama. Outro recurso muito valioso na costura da história é a utilização de repetições. Na análise de Amores brutos, foi citada a observação de David Bordwell (2008, p. 197) de que quanto mais complexa é uma narrativa maior é a necessidade de repetir algumas informações ou mesmo cenas para viabilizar a compreensão do todo. 21 gramas faz uso de diversos tipos de repetições, desde cenas até diálogos.

Como exemplo de recorrência de informação por meio do áudio, vale lembrar a já mencionada derradeira mensagem de celular de Michael para Cristina momentos antes do atropelamento. Outra repetição sonora que também merece ser aludida é a tripla inserção da mesma frase de diálogo no universo de cada protagonista. Primeiro, quando Paul está em consulta em uma clínica de inseminação artificial com Mary (cena 30), o médico adverte Paul que "com sua saúde talvez não chegue a conhecer seu filho". Paul pondera que: "bem, a vida continua, não?” A segunda vez, a frase surge no funeral de Michael (cena 50), quando o pai de Cristina sussurra confortando-a: "querida, a vida continua"; ao que ela discorda com veemência quase gritando: "isso é mentira, a vida não segue como se nada tivesse acontecido". E, pela terceira vez, de forma arrebatadora, quando Marianne visita Jack na cadeia e pergunta se ele "quer que os filhos passem mais anos sem ele" e Jack responde resignado que "é a vontade de Deus". Marianne fica enfurecida e lança a frase: "a vida continua, com ou sem Deus."

Nesse caso, a repetição foi utilizada para colocar o mote do filme diretamente na boca ou nos ouvidos dos protagonistas. Paul profere a frase com naturalidade e leveza de acordo

\footnotetext{
${ }^{101}$ É relevante apontar que somente após essa cena 101 do pedido de sacrifício de Jack por Cristina é justaposta a que revela que Paul atirou para o lado e não atingiu Jack conforme insinuava a cena 79, evidenciando como é ardilosa a articulação de causa e efeito nessa trama imbricada.
} 
com sua visão matemática da constante transformação da vida. Cristina reage com o inconformismo que vai nutrir seu desejo de vingança. E Marianne usa a frase de forma contundente para tentar convencer seu marido a se libertar de fanatismo religioso e a cuidar da família. Para o roteirista Arriaga (2003, apud WOOD, 2006, p. 147, informação oral, tradução nossa) "a vida continua" é o motif do filme: "21 gramas é sobre o poder da vida sobre o poder da morte. A vida tem uma força enorme e continua mesmo nas piores circunstâncias". ${ }^{102}$

A repetição de cenas, normalmente, acontece com acréscimo de informação ou mudança de ponto de vista, como acontece na já citada reapresentação da cena em que Paul dispara contra Jack. Na primeira vez que a ação é mostrada, não se sabe seu desfecho (cena 70), que só é revelado na sua reapresentação, na qual Paul atira para o lado (cena 102). Outra cena vital reiterada no filme é a que mostra o embate entre Jack, Paul e Cristina no quarto do motel, constituindo o momento de maior crise que projeta o enredo para seu clímax final.

\subsection{Da crise ao clímax}

No caso do embate físico entre os três protagonistas, ao contrário do exemplo anterior, o fragmento do evento apresentado no começo do filme (cena 17, 13min47s a 14min30s) mostra apenas a parte final de sua ação. A imagem de abertura da cena é um plano de detalhe da sola de um pé sangrando, uma imagem choque descontextualizada. A série de jump cuts (cortes com pulo) que se justapõem revelam que há sangue nas roupas de Paul e na parede e Cristina chora desesperada. Ela manda Jack chamar uma ambulância duas vezes com progressão de agressividade e, em seguida, muda de tom, revela sua fragilidade e passa a implorar para que ele faça alguma coisa. Jack está combalido, mas levanta-se com dificuldade, aproxima-se do corpo de Paul e, novamente, uma série de jump cuts passa a ideia de que em vez de chamar uma ambulância, vão carregar o ferido em busca de ajuda. Mais uma vez, a trama do filme exibe as consequências antes da ação que as provocou.

\footnotetext{
${ }^{102}$ No original: "21 grams is about the power of the life over the power of death. Life has an enormous strength and goes on even in the worst circumstances." (ARRIAGA, 2003, WOOD, 2006, p. 147, informação oral)
} 


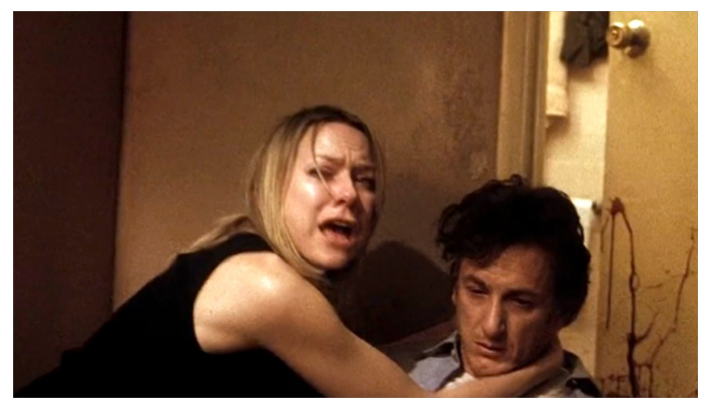

Figura 4.26 - Cristina desespera-se com Paul ferido

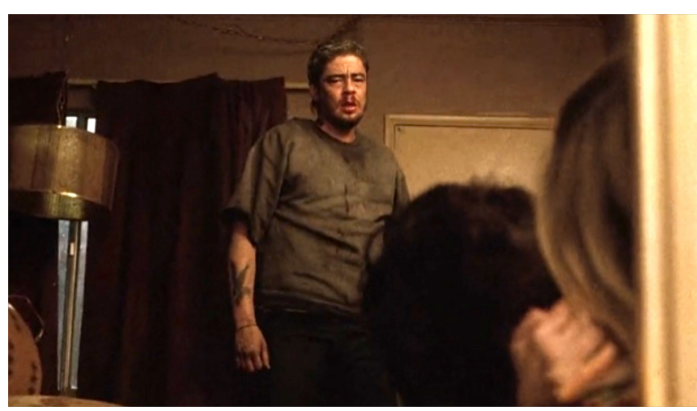

Figura 4.27 - Jack levanta-se para socorrer Paul

O entendimento pleno desse fragmento será alcançado somente quando a cena reaparecer ao final do filme mostrando a ação completa desse episódio (cena 105, 1h52min43s). A reapresentação da cena começa de maneira bem mais convencional, abrindo com um plano geral noturno do motel, seguido de uma série de planos da movimentação de Jack no corredor do motel intercalados com planos internos do quarto de Paul e Cristina, criando suspense para o eminente encontro dos três protagonistas. Cristina acorda Paul e alerta que há alguém do lado de fora. Paul levanta-se, pega a arma, olha através da janela e, ao destrancar a porta, Jack invade o quarto e suplica para que atirem nele. O som direto com os diálogos é suprimido pela mixagem, restando apenas um sutil ruído grave. Cristina grita, mas não ouvimos nada. Jack pega a mão de Paul e posiciona a arma em sua própria garganta. Paul hesita em atirar, os dois lutam pelo controle da arma. Paul pisa descalço em cima de um copo. Cristina golpeia violenta e sucessivamente Jack com um abajur. Paul se estica, pega o revolver e atira no próprio peito. O som direto é restabelecido com o estampido do disparo e volta-se a ouvir a respiração ofegante e as falas das personagens. Em seguida, exibe-se uma versão semelhante ao trecho antecipado na primeira apresentação dessa ação (cena 17), no qual Cristina abraça Paul e implora para que Jack a ajude a socorrê-lo, com o diferencial marcante da entrada de um crescente som de trem se aproximando. A estética hiperrealista da edição de som e mixagem da cena, ao suprimir, por um tempo, as vozes das personagens e o som ambiente e inserir o contundente ruído do trem, cria um efeito de amplificação das percepções subjetivas de desorientação e desespero da imersão na luta. 


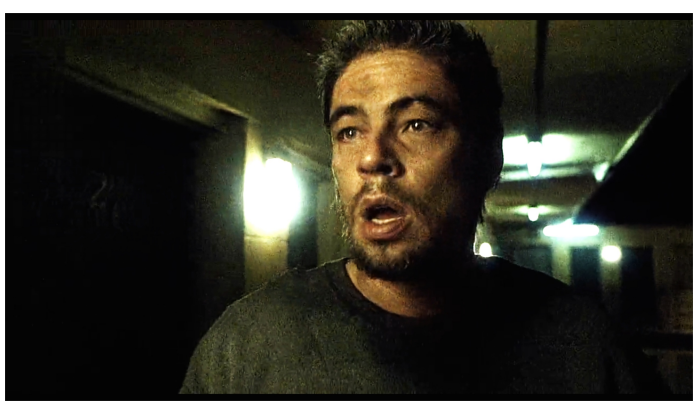

Figura 4.28 - Jack, no corredor do motel, procura por Paul

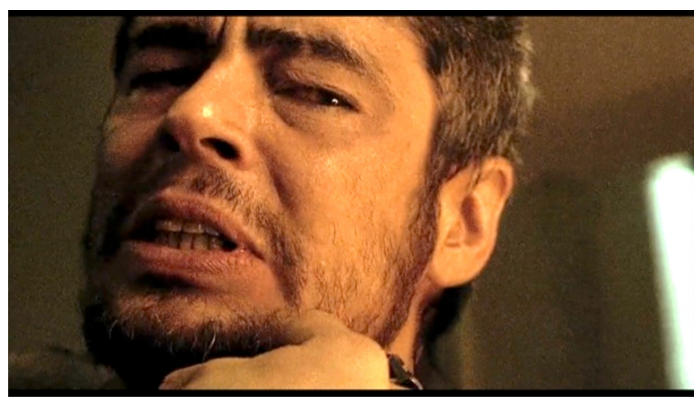

Figura 4.30 - Jack pede que Paul o mate

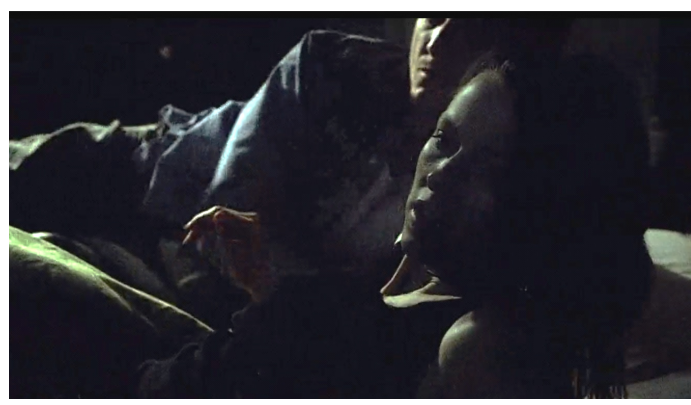

Figura 4.29 - Cristina e Paul despertam com ruídos de Jack no corredor

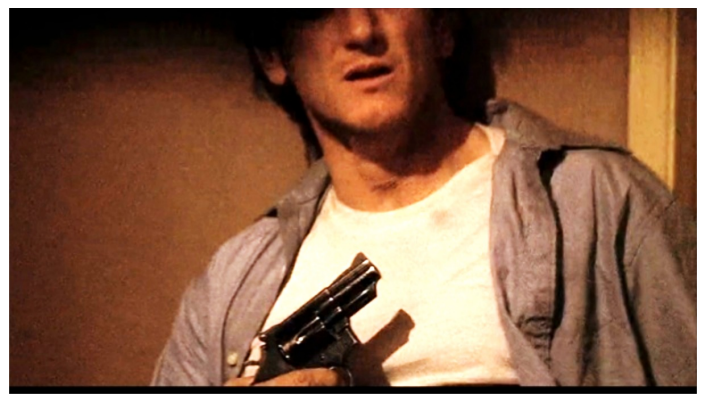

Figura 4.31 - Paul atira no próprio peito

A cena, em sua forma completa, constitui a "crise" do filme, o momento em que é tomada a decisão suprema da história. Robert MacKee (2006, p. 288) aponta que:

O ideograma chinês para crise significa dois conceitos: perigo/oportunidade - "perigo" porque uma decisão errada nesse momento, faz com que nós percamos para sempre o que queremos, e "oportunidade" porque a escolha certa permite-nos alcançar nosso desejo.

A jornada de Paul atravessando obstáculos progressivos chegou ao fim da linha, conforme prenunciava o som extradiegético do trem se aproximando, resta apenas essa última oportunidade. MacKee (2006, p. 288) alerta que essa oportunidade perigosa é "o ponto de maior tensão da estória" e, em 21 gramas, não é diferente. Paul enfrenta seu verdadeiro dilema e precisa decidir entre o menor de dois males irreconciliáveis: matar Jack ou se matar. A escolha de Paul revela seu eu profundo e a amplitude de sua humanidade. Ele já havia dado alguns passos significativos na direção de seu lance final. O primeiro, quando optou por não ficar internado no hospital aguardando uma nova doação quando o transplante começou a ser rejeitado. E em outros dois, quando não atirou em Jack nas vezes que esteve sob sua mira.

Em sua derradeira chance, Paul não titubeia em disparar contra seu próprio peito não deixando para o acaso resolver seu destino, embora ele não tenha o controle sobre tudo. Há um atenuante moral ao atentado de Paul contra a própria vida, o fato de estar desenganado. $\mathrm{E}$ 
quem tem menos a perder, tem mais a ganhar. A tentativa de suicídio de Paul é quase uma auto-eutanásia, mas ele não sabe como seu gesto de arruinar-se vai repercutir nos outros. Ao contemplar, com sua decisão, o desejo de suspender o próprio sofrimento, Paul acaba abrindo perspectivas para a suspensão das amarguras de Jack e Cristina. Por meio de uma ação letal, Paul incorpora o arquétipo do herói que se sacrifica em prol do bem estar coletivo. Contudo, apesar da contundência com que Paul perigosamente age para materializar sua decisão na “crise", sua ação abre uma brecha para o espectador se perguntar - "no que isso vai dar?" - e encaminha a trama imediatamente ao seu clímax final.

A cena da crise do embate entre os três protagonistas no quarto do motel é cortada para o plano de uma revoada de pássaros em movimento descendente, com a banda sonora tomada por um vertiginoso silêncio absoluto por alguns segundos, até que vem entrando gradualmente uma música minimalista, quase etérea, acompanhada pela narração final em off de Paul. A cena da crise, que já contava com alto grau de subjetividade instigado principalmente pelas manipulações sonoras, ganha uma dimensão ainda mais profunda em sua passagem para a imagem do voo dos pássaros em silêncio, que evoca um outro nível de consciência ao ser mixada com a música e as reflexões de Paul na montagem de planos do clímax final do filme. $\mathrm{O}$ arranjo de todos os elementos visuais e sonoros arquiteta uma mudança de valores súbita na transição da crise para o clímax, do negativo para o positivo, um amplo salto imaginativo, como uma ascese.

A trilha sonora misturada com as últimas reflexões de Paul sobre o sentido da vida e da morte encadeia momentos do passado e do presente reescrevendo as histórias dos protagonistas, para trás e para a frente. A montagem mostra Cristina passando a mão no rosto de Paul ferido a caminho do hospital e corta para ele entubado na UTI, vinculando a narração (voice over). Em câmera lenta, surgem três instantes felizes anteriores ao fatídico atropelamento que ainda não haviam sido desvendados: a saída alegre da lanchonete da última refeição de Michael com suas filhas; Jack acenando sorridente para o chefe que o despediu e entrando na camionete; e a irmã de Cristina dando o dedo do meio e fazendo Cristina sorrir na saída da natação. 


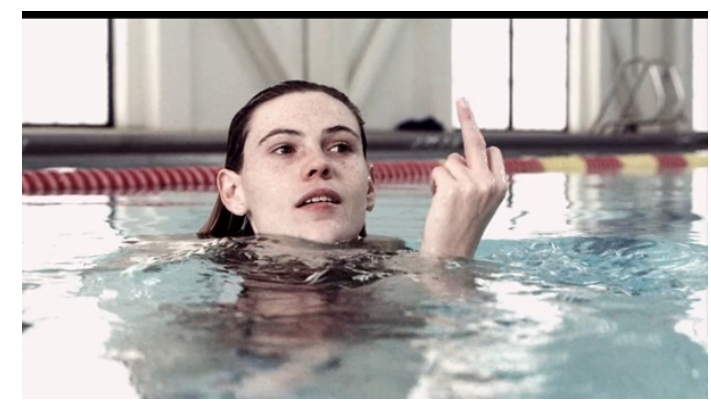

Figura 4.32 - Irmã de Cristina

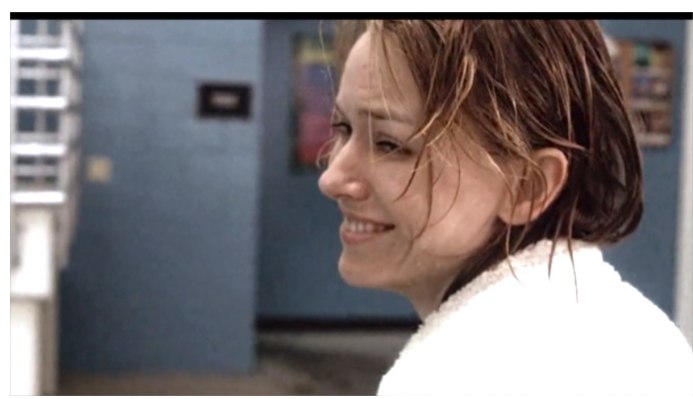

Figura 4.33 - Último momento de felicidade de Cristina antes do acidente

A revelação desses lampejos de felicidade instantes antes do acontecimento traumático evidencia a fragilidade e efemeridade da vida e a necessidade de se valorizar os fugazes bons momentos, enquanto durem. Há também uma ironia encoberta, pois o ex-chefe de Jack convidou-o e insistiu para tomarem uma cerveja, mas Jack resistiu abstêmio. Se Jack tivesse caído em tentação, afinal de contas, era dia do seu aniversário, ele teria perdido o emprego, e, provavelmente, não teria atropelado a família de Cristina.

Na sequência, Cristina aparece na sala de espera do hospital aflita pelo estado de saúde de Paul, e Jack se aproxima dela. Na simples troca de olhares dos dois, Cristina perdoa Jack, que, absolvido, absolve-se. Em dois planos, Jack está redimido entrando em sua casa e encontrando sua mulher. Cristina redimida pela concessão do perdão também volta para casa para começar vida nova com o filho de Paul em seu ventre. Os aparelhos médicos mostram que os batimentos cardíacos de Paul cessaram. Paul está morto.

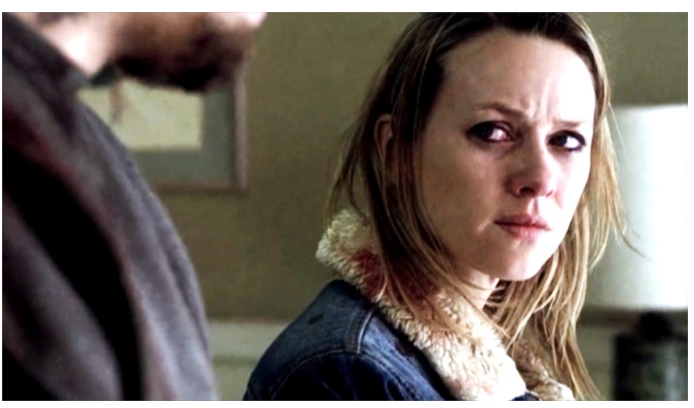

Figura 4.34 - Cristina perdoa Jack com o olhar

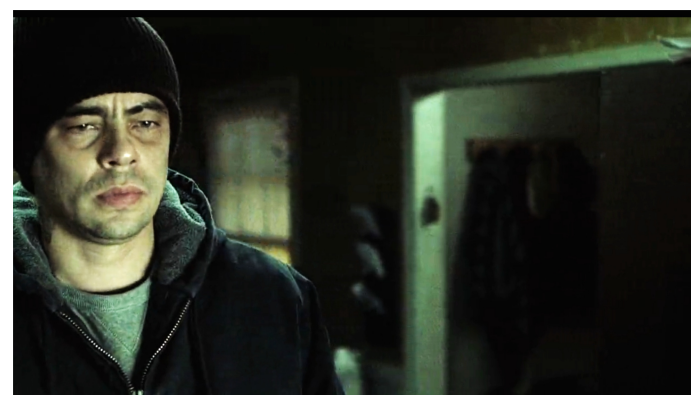

Figura 4.35 - Jack redimido volta para seu lar

A imagem da neve caindo na piscina do motel tem a força de sintetizar o significado e emoção que estava implícito em todas as cenas do filme e provocar arrebatamento. A piscina do cenário da vingança, que estava vazia e entulhada, acabada, recebe a neve, que vai derreter e virar água, vida. Uma imagem em transformação que remete à piscina azul e limpa onde Cristina nadava antes do atropelamento, que, posteriormente, ela continuou frequentando para 
se sentir normal e, à beira da qual, Paul foi se aproximar da então viúva e acabou gerando uma nova existência.

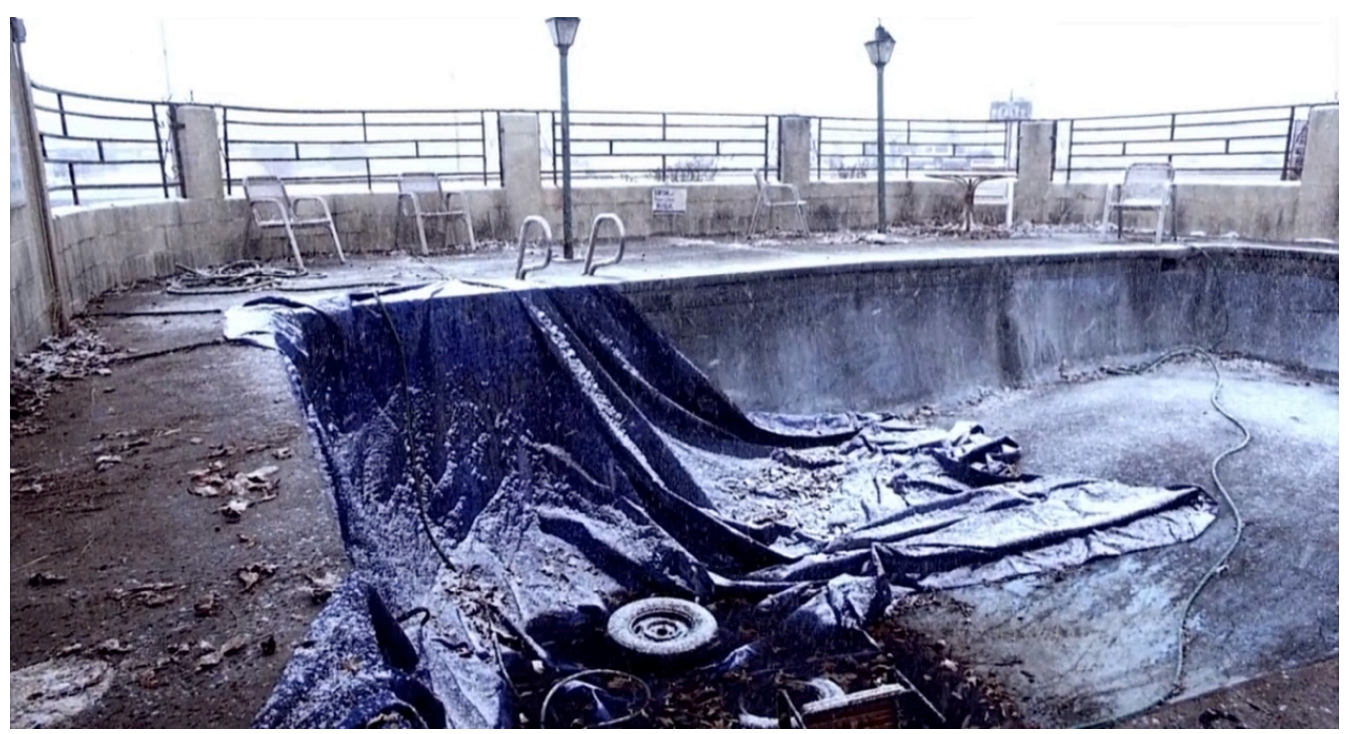

Figura 4.36 - Neve na piscina remete ao ciclo de transformação da vida

O ápice da crise deflagrou mais um ponto de virada que desembocou no clímax final, oferecendo a satisfação emocional desejada pelo público, só que de forma inesperada. A imagem chave da piscina somada ao conceito do título do filme explicado por Paul - a insignificante perda de 21 gramas de peso no momento da passagem da vida para a morte de qualquer ser humano - ressaltam a falta de barreiras entre esses polos tratados por muitas culturas ocidentais como opostos.

\subsection{O ciclo da redenção}

Iñárritu (2009), conforme citado no início do capítulo, argumentou que optou por uma estrutura narrativa fragmentada e não-linear para evitar a previsibilidade e destrinchar o teor melodramático intrínsecos ao argumento original do filme. A escolha por narrar a história em uma ordem que denominou de emocional engendrou a ruptura da lógica causal e temporal. A estrutura radical da narrativa, incomum em filmes mainstream, cobra um engajamento bastante ativo do espectador na conformação da história, por meio de uma trama da qual não se consegue apreender um padrão claro de desenvolvimento. Não é como em Amores brutos, em que logo é possível captar a proposta da estrutura com divisão em capítulos por história de 
cada protagonista permeados por episódios dos outros em simultaneidade. A evolução do enredo, em 21 gramas, tende a apresentar as consequências antes das causas das ações, estimulando a curiosidade e gerando expectativa. Essa ordenação causal invertida gera choques a cada corte de uma cena para outra, subvertendo as expectativas de relação de causa e efeito e continuidade entre ações consecutivas e lançando o espectador em busca de outras conexões entre as partes apresentadas. A predominância do uso de planos fechados com pouca profundidade de campo e, por vezes, vinculado ao ponto de vista de uma personagem, potencializa o efeito de descontextualização na passagem de um cena para a outra.

A imprevisibilidade da trama testa ao limite a capacidade do espectador em lembrar-se de eventos, fazer associações, deduções e inferências para entender o significado e as funções das partes na conformação de um todo coeso. Potencialmente, o espectador vai acumulando e processando as informações e, em um determinado ponto, começa a não se sentir tão perdido no curso narrativo e vai encontrando o encaixe entre as peças desse quebra-cabeças dramático. Como a causalidade e a temporalidade são fragmentadas e embaralhadas, a legibilidade da trama é garantida por uma série de estratégias fundamentadas no virtuosismo e sagacidade da narração e no arco de transformação das personagens.

O roteirista Arriaga indica com muita clareza como o tema do filme está entranhado na jornada das personagens:

Eu vejo este filme como a jornada de três personagens do inferno para o paraíso e de volta para o inferno e, em seguida, seus esforços para voltar. Jack vem do inferno da prisão e do abuso, Cristina, do inferno da dependência de drogas, e Paul, do inferno da saúde ruim. Quando eles pensam que o paraíso chegou, Jack por meio de Jesus, Cristina por meio de sua família e de Paul com seu novo coração, circunstâncias jogam-nos novamente em um inferno ainda mais profundo. Este é o tema de 21 gramas: como essas personagens encontram esperança dentro da escuridão; como alguém pode lutar pela vida em um momento em que a morte está golpeando com toda a sua força. ${ }^{103}$ (ARRIAGA, 2003, apud WOOD, 2006, p. 152, informação oral, tradução nossa)

O estado de saúde e de espírito das personagens é fundamental para a ordenação temporal da história a partir da trama. O espectador recebe informações que lhe permitem deduzir se uma determinada ação acontece antes, no dia fatídico, ou, depois do acidente, por meio de

${ }^{103}$ No original: "I see this movie as the journey of three characters from hell to heaven and back to hell and then their struggle to come back. Jack comes from the hell of goal and abuse, Christina from the hell of drug addiction and Paul from the hell of bad health. When they think that heaven has arrived, Jack through Jesus, Cristina through her family and Paul with his new heart, circumstances throw them again to an even deeper hell. This is the theme of 21 grams: how can these characters find hope inside darkness; how can someone fight for life in a moment when death is striking with all its strength?" (ARRIAGA, 2003, apud WOOD, 2006, p. 152, informação oral) 
indícios oriundos da aparência física das personagens, auxiliado pelo figurino que usam. Cristina e Jack ficam abatidos em distintos níveis depois do atropelamento, mas é o aspecto de Paul que opera como principal indexador que facilita o entendimento da disposição das ações na linha do tempo. Paul está mal de saúde antes do transplante, revitaliza-se após a cirurgia, piora com a rejeição e agoniza depois da tentativa de suicídio.

A narração eloquente do filme mescla algumas táticas que visam compensar a complexidade de sua ordenação, sendo que as de maior impacto estruturante são: a circularidade, a adoção de um narrador intradiegético e as repetições de episódios ou fragmentos de sons e imagens. O filme começa e termina com Paul morrendo e refletindo sobre a vida. Ao dar acesso aos pensamentos de Paul, a narração o institui como um mediador intradiegético e a trama se constitui como um fluxo de consciência do ponto de vista dele elucubrando sobre o que ocorreu. Além de proferir o monólogo interior que amarra o filme, Paul ainda é muito ativo na película e suas atitudes contundentes provocam guinadas no desenrolar da trama. Durante a primeira parte da história, Paul tem um nível de conhecimento maior do que o de Cristina, pois sabe que o doador do coração que lhe deu uma sobrevida foi o falecido marido dela. Paul vai se valer dessa informação para orientar suas ações. É ele quem observa, aborda e insiste no romance com Cristina, delibera não matar Jack e atira contra si mesmo.

A exposição da subjetividade de Paul, integrada com seu nível de conhecimento da história, e a força de suas ações colocam-no em posição de destaque em relação aos outros dois personagens principais de uma forma tal, que não seria forçar muito na interpretação considerar Jack, e quiçá Cristina, como coadjuvantes. ${ }^{104}$ Uma revisão convencional do peso relativo das personagens principais no filme, levando em consideração isoladamente aspectos dessa instância narrativa - acesso à subjetividade e impacto de suas ações na trama -, colocaria em cheque a classificação do filme como detentor de multiplicidade de personagens principais. Entretanto, as manipulações radicais da causalidade e da temporalidade reconfiguram a percepção das personagens por parte do espectador, realinhando seus pesos e funções e, dessa forma, colocando-os em patamares muito próximos de importância, dando sustentação ao seu multiprotagonismo.

A abordagem do desejo como uma força incontrolável está presente nas artes desde a Antiguidade, atravessou a Idade Média, ganhou destaque no Renascimento e continua muito presente nos dias de hoje. No audiovisual, há dois gêneros muito populares que dedicam ao tema especial atenção utilizando convenções narrativas do cinema clássico: a comédia român-

\footnotetext{
${ }^{104}$ Benicio Del Toro foi inclusive indicado ao Oscar na categoria de Melhor Ator Coadjuvante. A outra indicação do filme ao Oscar foi a de Naomi Watts como Melhor Atriz.
} 
tica e o melodrama. Ambos são normalmente articulados por meio de narrativas de casal que superam adversidades para consolidarem suas relações com finais felizes para sempre. Por sua vez, tramas multiplex, como a de 21 gramas, tendem a representar as relações articuladas pelo desejo destacando aspectos proeminentes na contemporaneidade como a multiplicidade, fragmentação, efemeridade e finitude.

Maria Azcona (2009, p. 112, tradução nossa) aponta que, "nesses filmes, o papel do desejo na vida das pessoas também é afetado pela subordinação dos indivíduos a uma estrutura abrangente, onde a aleatoriedade e a serendipidade reinam e encontros acidentais controlam os caminhos das personagens". ${ }^{105} \mathrm{O}$ multiprotagonismo e as narrativas de rede, com sua vocação em comum de expor as conexões entre os seres humanos, estariam mais aptas a criar representações que contemplem as pulsões do desejo nos dias de hoje, investigando as alternativas diversificadas de como contar os encontros e desencontros amorosos.

A hibridização de gêneros cinematográficos, comum no cinema hipermoderno, permite que Iñárritu flerte perigosamente com esquemas narrativos da comédia romântica sem perder sua mão na condução do drama de 21 gramas. Na longa parte do filme em que Paul se aproxima e seduz Cristina, ele é claramente movido pelo desejo, tem como objetivo ficar com ela e vai encontrar vários obstáculos pela frente. Há uma série de tentativas de abordagem de Paul que não dá certo - ele tenta lanchar com Cristina, mas é rejeitado; Paul leva Cristina bêbada para casa, ela dorme no carro, ele a deixa dormindo na garagem e depois ela nem se lembra que foi Paul que a levou pra casa - e que contém um potencial cômico explorado com muita parcimônia, mas que poderia muito facilmente fazer o sorriso do espectador virar gargalhada. Paul chega mesmo a tentar umas piadinhas hilárias de tão sem graça, como em "comer sozinha faz mal para os rins" (cena 62).

Contudo, tanto esses esquemas narrativos típicos da comédia romântica quanto o teor melodramático inerente ao filme estão envoltos e destrinchados por uma narração alternativa que dilui esses componentes de um cinema mais popular em uma estrutura de filme de arte, resultando um híbrido afinado com seu tempo cultural. O rompimento do encadeamento causal e temporal é um dos elementos que diferencia nitidamente a forma do filme das telenovelas, sejam mexicanas ou brasileiras, que também são melodramas multiprotagonistas que empregam esquemas de comédia romântica.

\footnotetext{
${ }^{105}$ No original: "In these movies, the role of desire in people's lives is also affected by the subordination of individuals to an overarching structure where randomness and serendipity reign and accidental encounters control characters' paths." (AZCONA, 2009, 112)
} 


\subsection{Apontamentos sobre Amores brutos e 21 gramas}

Conforme analisado neste capítulo e no anterior, as repetições de variações de cenas, ações, imagens, frases e diálogos colaboram na sutura das fraturas temporais e causais da narrativa. Mais uma vez, no caso de 21 gramas, utilizou-se o recurso de um objeto circulante - o coração de Michael - para juntar as linhas narrativas do filme. O curioso é que o elemento que sai do universo de uma personagem e vai para o de outra não é autônomo, como o cachorro Cofi em Amores brutos, mas o órgão humano que simboliza o amor e a emoção.

Outra situação presente em Amores brutos que surge ressignificada em 21 gramas é a da perseguição. Após o embate dos três protagonistas no quarto do motel (cena 105), Cristina e Jack, ironicamente, compartilham o mesmo objetivo, salvar Paul que está baleado no peito. A ação é exibida com Jack dirigindo em alta velocidade e Cristina amparando Paul ensanguentado no banco de trás (cena 33). O estilo de mise-en-scène, filmagem e montagem dessa correria se assemelha muito com o da perseguição de Octavio, Jorge e Cofi baleado na abertura de Amores brutos. Só que, em 21 gramas, a montagem vertiginosa da cena com ultrapassagens perigosas, freadas e gritos estabelece não um oponente, mas a própria morte como perseguidora.

O enredo de 21 gramas explora as instabilidades do desejo em uma história de solidão, sofrimento, morte e redenção. O desejo continua vital no desenvolvimento das personagens do cinema multiplex, mas sua função já não é a mesma que tinha no cinema clássico como norteador absoluto do desenrolar da história. Nota-se, nos filmes em análise, bem como em outras narrativas cinematográficas contemporâneas, uma redução do poder do desejo como energia que fortalece as personagens para vencerem obstáculos ao perseguirem seus objetivos e definirem o rumo dos acontecimentos. Por outro lado, assiste-se a uma valorização realista da participação de forças externas, aleatórias e inesperadas que movem as personagens para territórios distantes e divergentes de seus planos e vontades, especialmente na filmografia de Iñárritu. O conflito entre a capacidade do desejo e a tirania do acaso é materializado no arco de transformação das personagens em forma de contraste entre o que elas querem e o que o mundo lhes oferece. Diversamente da abordagem do cinema clássico, o embate não é resolvido por meio da imposição da vontade das personagens contra as adversidades, mas pela investigação da fragilidade, do sofrimento que leva ao isolamento e ratifica a solidão como a essência da condição humana.

Evidencia-se uma mudança significativa na concepção das personagens do cinema multiplex. Saem de cena os heróis poderosos, que transpõem obstáculos em série, para sacia- 
rem seus desejos e atingirem seus objetivos, e dá-se lugar a seres humanos passando por transformações que tentam entender melhor o mundo e a si mesmos. Não só o desenvolvimento das personagens mas também os pontos de virada da narrativa não são mais exclusivamente gerados pelo determinismo humano e sim, por intervenções aleatórias do acaso ou cruzamento acidental entre trajetórias de personagens.

A estrutura de 21 gramas fragmenta, inverte e mistura os eventos da história para ressaltar a força das coincidências e a inutilidade em se buscar entender as motivações por trás de ocorrências aleatórias na vida. As idas e vindas das personagens entre o paraíso e o inferno, como definiu Arriaga (2003), são induzidas por um acontecimento traumático que deflagra situações limítrofes repletas de emoções intensas e absorve bem a estética do exagero mexicano. Os sentimentos das personagens destacados pelos planos fechados reverberam uns nos outros por meio da montagem que conforma uma teia, entrelaçando vida e morte, como sintetizaram Deleyto e Azcona (2010, p. 48, tradução nossa):

A cronologia embaralhada do filme une personagens em sua humanidade comum, e a intensidade do vínculo que o filme evoca, apesar de não poderoso o suficiente para vencer a morte, dá-nos a força para continuar vivendo. Assim, manipulando o tempo cronológico de um modo tão ostensivo, o texto não só enfatiza contingência e mortalidade, mas também apresenta sua fé inquebrável no poder do relacionamento humano e da capacidade resiliente do ser humano em sua busca de felicidade e harmonia, mesmo nas piores circunstâncias. ${ }^{106}$

Além da aleatoriedade, paira sobre o filme o poder de uma outra força, a tecnociência. Conforme apontaram Gilles Lipovetsky e Jean Serroy (2009, p. 49), a presença da tecnociência no cotidiano é uma das características definidoras dos tempos hipermodernos e possui a mesma magnitude da ordem democrática individualista e da dinâmica do mercado (para mais, ver Capítulo I), No filme, a tecnociência aparece interferindo diretamente em seus polos temáticos, tanto na morte, por meio de um transplante de coração, como na vida, por meio da inseminação artificial. O fato de o filme ser ambientado nos Estados Unidos ressalta que as técnicas e procedimentos médicos ali mostrados são semelhantes aos praticados em diversos cantos da Terra.

\footnotetext{
106 No original: “The film's scrambled chronology links characters in their common humanity, and the intensity of the bond, the film claims, though not powerful enough to overcome death, gives us the strength to go living. Thus, by manipulating chronological time in such an ostentatious way, the text not only emphasizes contingency and mortality but also puts forward its unbreakable faith in the power of human relationship and the resilience of human beings in their search of happiness and harmony even in the direst of circumstances." (DELEYTO; AZCONA, 2010, p. 48)
} 
O conhecimento científico, assim como a cultura, é disseminado pelo processo de globalização midiatizado, repercutindo nas relações humanas. Ambos os procedimentos médicos sofisticados presentes no filme têm impacto relevante na trama, pois intervêm diretamente nos rumos das personagens. A história só existe porque Paul ganha uma sobrevida com o coração do finado marido de Cristina. Entretanto, apesar de a narrativa mostrar a interferência da tecnociência nas relações amorosas, prevalecem as forças naturais, pois o transplante não salva Paul da morte e ele acaba engravidando Cristina espontaneamente. A mensagem que fica é a de que, mesmo com todo o poder disseminado da tecnociência em intrometer-se na existência humana, ainda prevalecem os desígnios naturais da vida e da morte.

A morte é um tema recorrente na obra de Iñárritu e central em 21 gramas. Quando Iñárrritu atravessou a fronteira com os Estados Unidos, a morte o acompanhou como uma sombra. O filme explora a fronteira difícil de mapear da vida com a morte. Enrique Krause (2004), crítico do Los Angeles Times, creditou o maior sucesso de 21 Gramas no México e na Europa do que nos EUA, entre outras razões, às diferenças de percepção dessas culturas em relação a representações do perecimento. ${ }^{107}$ Enquanto os mexicanos teriam uma reação mais receptiva e naturalista diante da morte, os americanos preferem evitar a sua presença no cotidiano. Krause (2004) identificou, nesse filme, a ambição artística do diretor em explorar a confrontação entre essas diferenças em relação à morte existente entre as culturas desses dois países:

Gonzalez Iñárritu decidiu entrar no ventre da besta mais uma vez e aborda, com a mesma franqueza, o tema da morte. Apesar de não ser a morte da maneira que geralmente é tratada em Hollywood (como o desfecho da história, com a sua música de fundo, suas tonalidades sentimentais e sua lição de moral previsível), mas sim a morte como começo e raiz da história. ${ }^{108}$ (KRAUSE, 2004, p. 1)

\footnotetext{
107 “O público mexicano recebeu o filme com grande entusiasmo. É apenas natural. A cultura indígena mexicana e a cultura hispânica ambas enfrentam a morte com uma familiaridade estoica que, de certa forma, ainda colore a vida mexicana contemporânea. Na Europa, 21 Gramas teve uma excelente recepção do público. Na Itália, é um sucesso de bilheteria. 'Surpreendente, tão brutal como um soco', declarou o Libération em Paris. Na Inglaterra, 21 Gramas recebeu cinco indicações para o British Academy of Film and Television Arts Awards.
}

No original: "Mexican audiences received the movie with great enthusiasm. It is only natural. Indigenous Mexican culture and Hispanic culture both face death with a stoic familiarity that in some ways still colors contemporary Mexican life. In Europe, $21 \mathrm{Grams}$ has had an excellent reception from the public. In Italy it is a box-office success. 'Surprising, as brutal as a punch' declared Libération in Paris. In England, 21 Grams received five nominations for the British Academy of Film and Television Arts Awards." (KRAUSE, 2004, p. 1)

${ }^{108}$ No original: "Gonzalez Iñárritu once again decided to enter the belly of the beast and approach, with the same bluntness, the theme of death. Though not death in the way that it is usually dealt with in Hollywood (as the outcome of the story, with its background music, its sentimental tonalities and its predictable moral lesson), but rather death as a beginning and root of the story." (KRAUSE, 2004, p. 1) 
A ceifadora sinistra está na esquina e cruza vidas inesperadamente, detonando a estabilidade emocional de Paul, Cristina e Jack. Em um primeiro momento, eles sucumbem às suas fraquezas. Em seguida, gradualmente, as personagens vão se ajeitando como podem e encontrando uma maneira de seguir em frente. Cada um a sua maneira é um resiliente guiado por sua capacidade de reinventar suas relações afetivas e, refeitos, seguem momentaneamente suas jornadas vulneráveis a surpresas aleatórias da vida e da morte.

As personagens de 21 gramas encontram-se, por diversas vezes, em profundo estado de isolamento. A consciência de estarem desamparadas lançam-nas em tortuosos caminhos para abolirem a solidão, "que é a própria condição humana", segundo Octavio Paz (2014, p. 189). Elas buscam a redenção da solidão movidas pelo desejo "que é fome de comunhão, fome de cair e morrer tanto como de renascer” (PAZ, 2014, p. 190). Cristina, Paul, Mary, Jack e Marianne, ao constatarem que seus mundos estão arrasados, agarram-se ao instinto de sobrevivência, que não deixa de ser amor à vida, e tentam reconstruir suas existências por meio do afeto. Entretanto, como Paz (2014, p. 191) adverte, "criação e destruição se fundem no ato amoroso". É justamente esse conceito de vida e morte como movimentos antagônicos e complementares que parece nortear Iñárritu, Arriaga e Mirrione ao enredarem suas personagens em uma cíclica transposição da fronteira fluida entre esses dois estados existenciais.

Iñárritu (2003, apud WOOD, 2006, p. 153, informação oral) reforça sua visão de conexão circular entre princípios e finais ao vislumbrar que a redenção "não é o fim ou um estado infinito, uma vez que você o alcança, como muitas pessoas acreditam. Eu acho que é apenas um estado temporário, a partir do qual começa o ciclo estranho de vida". ${ }^{109}$ Assim como Paul, Cristina e Jack começam novos ciclos ao experimentarem diferentes formas de morte e renascimento, a travessia de fronteira para os Estados Unidos vai impelir Iñárritu a alçar voo ainda mais ousado com suas asas leves. Em seu projeto seguinte, Babel, o diretor mexicano vai transpor outros limites ao urdir mais uma narrativa de rede inovadora investigando as junções entre suas raízes e as realidades de quatro países em três continentes, o que será abordado no próximo capítulo.

\footnotetext{
${ }^{109}$ No original: "it is not the end or an infinite state once you reach it, as many people believe. I think that it is just a temporary state, from which to begin the strange cycle of life." (INÁRRITU, 2003, apud WOOD, 2006, p. 153 , informação oral)
} 


\title{
CAPítulo V
}

\section{BABEL: A REDE EXPANDIDA}

\begin{abstract}
"Acho que ninguém escuta com atenção o som de um relógio. Não é necessário. É possível esquecer-se do som por um bom tempo, e então um único tique-taque é capaz de criar na mente toda a longa sequência de tempo, ininterrupta e descendente, que não foi ouvida."110
\end{abstract}

William Faulkner (2002, p. 83)

pós cruzar a fronteira entre México e Estados Unidos na realização de 21
gramas (21 grams, 2003), Alejandro González Iñárritu alça um voo ainda
mais amplo para fechar sua trilogia da morte. Em vez de três linhas narrativas, como nos filmes anteriores, Babel (2006) entrelaça quatro enredos filmados em locações no Marrocos, Japão, Estados Unidos e, novamente, México. Trata-se de mais uma narrativa de rede entrelaçando relações familiares, só que, dessa vez, além de multiprotagonista, também é multicultural e multilinguística. ${ }^{111}$

Um tiro acidental disparado por um pré-adolescente urde uma teia de junções entre África, América e Ásia. O filme aborda travessias de fronteiras de diversas ordens - geográficas, políticas, culturais, étnicas, sociais e econômicas - ressaltando as conexões entre realidades contrastantes e evidenciando a preservação das identidades nacionais em um mundo globalizado ligado em rede. Em Babel, Iñárritu materializa, na tela, a travessia que ele e seus compatriotas diretores transnacionais de sucesso - Alfonso Cúaron e Guillermo del Toro empreenderam ao filmar o cruzamento da fronteira justamente em um de seus pontos mais

\footnotetext{
${ }^{110}$ FAULKNER, William. O Som e a fúria. São Paulo: Ed. Cosacnaify, 2002, p. 83.

${ }^{111}$ Babel é falado principalmente em quatro idiomas: inglês, espanhol, árabe e japonês. Isso significa que os espectadores, mundo afora, provavelmente não vão entender ao menos duas das línguas do filme. Há também, no filme, o emprego de Língua Japonesa de Sinais e a Internet Movies Database (Disponível em: < http://www.imdb.com/title/tt0449467/?ref_=nv_sr_1>. Acesso em $12 \mathrm{dez} 2014$.) menciona ainda a presença de alguns diálogos em francês e berbere.
} 
tensos, Tijuana, confrontando as desigualdades entre os dois sentidos: facilidade de entrada no México e rígido controle de ingresso nos Estados Unidos (ver Capítulo II).

Iñárritu e o núcleo duro de sua equipe criativa - Guillermo Arriaga, ${ }^{112}$ Rodrigo Prieto, Stefhen Mirrione e Gustavo Santaolalla - encontram outra forma alternativa de entrelaçar os múltiplos enredos distintos da estrutura dividida em capítulos permeáveis de Amores brutos e da ordenação emocional de 21 gramas. A trama de Babel é organizada em 24 Sequências, intercalando suas quatro linhas narrativas em aparente simultaneidade com algumas rupturas evidentes. A ordenação temporal não-linear engendrada entre as linhas narrativas é abrandada pelo predomínio do encadeamento lógico e cronológico entre as Sequências da mesma história, e pelo curto prazo em que todas as ações acontecem, cinco dias.

A estrutura do filme valoriza a expressividade das passagens entre os blocos de sequências de suas quatro linhas narrativas. As transições entre os blocos operam como fronteiras entre seus universos diegéticos com potencial tanto de separá-los por contraste como de aproximá-los por emoção e intelecção. Sentimentos e ideias cruzam enormes distâncias em cortes secos, destacando as personagens do contexto geográfico e tecendo uma teia de significados. As passagens entre as diferentes histórias vão acumulando amarrações que se proliferam constituindo um jogo incessante que seduz o espectador na compreensão de um todo interligado.

Babel é o filme de Iñárritu de maior bilheteria - arrecadação de 135 milhões de dólares $-{ }^{113}$ e maior reconhecimento pela indústria dos Estados Unidos com sete indicações ao Oscar. ${ }^{114}$ Trata-se, portanto, de um filme de grande audiência em um mercado globalizado. O

\footnotetext{
${ }^{112}$ Ironicamente o filme que trata da necessidade de respeito a diferenças marca o fim da parceria criativa entre o roteirista e o diretor. Arriaga reivindicou assinar como coautor de Babel e promoveu uma campanha pessoal defendendo que os roteiristas e diretores deveriam compartilhar o crédito da autoria dos filmes. Iñárritu negou veementemente a reivindicação de Arriaga e "desconvidou-o" para a estreia do filme no Festival de Cannes 2006, sendo muito criticado por sua represália apesar do apoio público que recebeu do compositor Santaolalla, autor da trilha sonora do filme, e dos atores Gael Garcia Bernal e Adriana Barraza.

${ }^{113}$ Pouco mais de um quarto do faturamento global de Babel (25.3\%) ocorreu nos Estados Unidos, somando mais de trinta e quatro milhões de dólares (US\$ 34.302.837,00). Três quartos da arrecadação do filme foram contabilizados, em diversos países, nos cinco continentes, com destaques para: quase quinze milhões de dólares no Japão, treze milhões e meio na Espanha, quase oito milhões na Alemanha, mais de sete milhões no México, quase 5 milhões e meio na Austrália, cinco milhões no Reino Unido e dois milhões e setecentos mil dólares no Brasil. BOX OFFICE MOJO $\quad$ (Net). Disponível $\quad$ em: http://boxofficemojo.com/movies/?page=intl\&id=babel.htm >. Acesso em: 12 dez 2014.

${ }^{114}$ As sete indicações ao Oscar de Babel ocorreram nas seguintes categorias: Melhor Filme, Melhor Diretor (primeira indicação da história de um mexicano), Melhor Roteiro Original (Guillermo Arriaga), Melhor Montagem (Stephen Mirrione e Douglas Crise), Melhor Trilha Sonora (Gustavo Santaolalla) e duas indicações em Melhor Atriz Coadjuvante (Adriana Barazza e Rinko Kikuchi). Apesar do número expressivo de indicações, em apenas uma, Melhor Trilha Sonora, consagrou-se ganhador. A dupla indicação de protagonistas do filme como atrizes coadjuvantes expõe a percepção da Academia acerca da participação de atores estrangeiros em filmes multiprotagonistas e levantam questões como: Por que Cate Blanchett e Brad Pitt também não foram indicados
} 
filme só alcançou uma gama tão ampla e diversificada de espectadores no mundo porque sua narrativa puxa os limites convencionais do padrão hollywoodiano, contudo, sem transcendêlos, estabelecendo um diferencial como produto cultural sem comprometer sua comunicabilidade. A forma do filme combina estratégias narrativas do cinema de arte com outras mais convencionais, que garantem a compreensão e prazer de um público amplo.

Marina Hassapopoulou (2008, p. 2, tradução nossa), crítica da revista Jump Cut, ao analisar Babel, menciona a combinação entre inovação e convenção narrativa:

Na minha opinião, excentricidade estilística e narrativa em sucessos de bilheteria geralmente não passa de um artifício para atrair o público, prometendo-lhe algo diferente (e estabelecendo a diferenciação do produto), enquanto, ao mesmo tempo, recicla práticas cinematográficas familiares para assegurar aos espectadores que "diferente" não significa incompreensível. ${ }^{115}$

Concordo com o argumento da crítica da revista inglesa de que Iñárritu consegue, por meio de abordagem íntima das relações interpessoais, tecer as múltiplas tramas de Babel ao redor do mundo em um arranjo não-linear diferenciado. Na obra, o diretor concilia boa comunicação com ousadia estilística ao tratar de temas pouco usuais em filmes voltados para grandes audiências, como as assimetrias e tensões nas relações entre países ricos e pobres e os dilemas sexuais da passagem da infância para a adolescência. Como nos filmes anteriores, Iñárritu encontra formas originais para tratar de assuntos relevantes e delicados valendo-se de articulações sagazes entre múltiplos personagens e não-linearidade temporal. No filme, o diretor ainda inova seu próprio repertório narrativo explorando as passagens entre os espaços geográficos dos enredos da trama e variadas maneiras de empregar a expressividade da banda sonora.

Em Babel, a instância narrativa do espaço geográfico ganha uma relevância diferenciada em comparação aos filmes anteriores de Iñárritu. Enquanto tinha-se apenas uma ou duas localidades em Amores brutos e 21 gramas - Cidade do México, no primeiro, e Memphis e Novo México, no segundo, - em Babel os espaços físicos são diversificados, como a metrópole Tóquio em contraste com aldeia e área rural no Marrocos ou a pequena cidade no México onde acontece o casamento. Há também, no terceiro filme, a abordagem do espaço como

como melhores atores coadjuvantes? Ou, por que Barraza e Kikuchi não receberam indicações como Melhores Atrizes já que seus papéis (Amelia e Chieko) são protagonistas e não coadjuvantes no filme?

${ }^{115}$ No original: "In my opinion, stylistic and narrative eccentricity in box office hits is usually nothing but a gimmick to lure audiences by promising them something different (and establishing product differentiation), while at the same time recycling familiar cinematic practices to reassure viewers that 'different' does not mean incomprehensible." (HASSAPOPOULOU, 2008, p. 2) 
fluxo tanto na fronteira entre México e Estados Unidos, como no Marrocos visitado pelos turistas. Devido à sua importância distinta na trama de Babel, o espaço recebe um tratamento formal inédito na obra de Iñárritu com grande ocorrência de planos abertos, inclusive grandes planos gerais, que são montados preferencialmente em contraponto com planos fechados provocando choque e incrementando a expressividade pela quase ausência de planos intermediários.

A banda sonora ganha realce na organização narrativa de Babel pelo ecletismo, funcionalidade e radicalismo de seus elementos e combinações. A diversidade cultural dos contextos do filme ecoa em sua escolha musical, que vai da sonoridade de instrumentos ancestrais aos timbres eletrônicos, passando pelos gêneros pop e regionais. A trilha sonora desempenha um papel articulador proeminente, fazendo pontes variadas, pontuando ou adicionando novas camadas de sentido nas transições entre os blocos das histórias. Algumas músicas solam em segmentos do filme, nos quais a edição de som suprime os ruídos ambiente e diálogos, produzindo autênticos videoclipes, o que marca uma hibridização de gêneros audiovisuais, algo que já havia sido tangenciado nos filmes anteriores de Iñárritu. A edição de som radicaliza na articulação de elementos aurais com trechos em silêncio absoluto justificados pela percepção subjetiva de uma personagem surda-muda.

A análise de $\mathrm{Babel}$, a seguir, visa investigar as estratégias diferenciadas utilizadas por Iñárritu ao urdir uma narrativa com maior grau de multiplicidade e complexidade ao completar sua trilogia iniciada com Amores brutos e 21 gramas. Acerca da opção por unir trios de filmes de diretores do cinema de arte, Bordwell e Thompson (2006, s.p., tradução e acréscimos nossos) observam que:

O cinema de festivais descobriu a trilogia antes que Hollywood o fizesse (Guerra nas estrelas [Star wars, George Lucas, 1977], O poderoso chefão [The godfather, Francis Ford Coppola, 1972] e Piratas do Caribe: a maldição da pérola negra [Pirates of the Carebbean: the course of the black pearl, 2003]), sendo que o agrupamento de três filmes pode muito bem ser a resposta dos filmes de arte para as franquias. ${ }^{116}$

Cito essa reflexão de Bordwell e Thompson (2006) sobre trilogias com o objetivo de trazer à tona outro nível de diálogo entre inovação e convenção na história recente do cinema, por meio de práticas distintas, modernas e contemporâneas, no âmbito de festivais e no mer-

\footnotetext{
${ }^{116}$ No original: "Festival cinema discovered the trilogy before Hollywood did (Star Wars, The Godfather, Pirates of the Caribbean), and the three-movie cluster may well be the art movies' answer to a franchise." (BORWELL; THOMPSON, 2006. Disponível em: < http://www.davidbordwell.net/blog/2006/11/27/lessons-from-babel/s.p.>. Acesso em: $12 \mathrm{dez} 2014$.)
} 
cado, com o objetivo de facilitar a circulação de filmes por meio de agrupamento de títulos com similaridades temáticas e estéticas. ${ }^{117}$ Pretende-se examinar as peculiaridades temáticas e de forma desse filme, que fecha a trilogia da morte de Iñárritu, e explicitar como sua articulação dos materiais expressivos instiga e recompensa o espectador em sua fruição, ao abordar a diversidade e conectividade da vida contemporânea de maneira tão abrangente.

\subsection{A orquestração da trama}

O resumo da história (fabula) do filme em sua ordem cronológica e causal é o seguinte: No Marrocos, o camponês Hassan (Abdelkader Bara) vende um rifle para seu vizinho Abdullah (Mustapha Rachidi), que, imediatamente, coloca a arma poderosa nas mãos de seus incautos filhos Yussef (Boubker Ait El Caid), o caçula, e Ahmed (Said Tarchani), o mais velho, para eles atirarem nos chacais e protegerem o rebanho de cabras. O caçula Yussef, insensatamente, dispara na direção de um ônibus de turistas ao longe para testar o alcance do rifle. O ônibus acusa o tiro e para na estrada.

A bala atinge o ombro da americana Susan (Cate Blanchett) que viaja de férias com o marido Richard (Brad Pitt) na tentativa de se reconciliarem de crise conjugal devido à perda de um filho. O incidente gera uma série de desdobramentos políticos, porque é interpretado como um ato terrorista. O imbróglio político dificulta o resgate de Susan que é levada para a pequena aldeia do guia turístico Anwar (Mohamed Akhzam) junto com todo o grupo turístico apavorado. Susan é atendida na casa de Anwar por um veterinário e é dopada com haxixe pela mãe de seu anfitrião, enquanto o resgate não chega para levá-la à Casablanca. As forças policiais investigam o caso, rastreiam o rifle, torturam Hassan, perseguem Abdullah e seus filhos e matam Ahmed.

\footnotetext{
117 David Bordwell e Kristin Thompson (2006, Disponível em: <http://www .davidbordwell.net/blog/2006/11/27/lessons-from-babel/>. Acesso em: 12 dez 2014.), no artigo do seu site "Lessons from Babel", aponta a importância em se rotular um trio de filmes de trilogia no circuito de cinema de arte (arthouse), tanto para alavancar financiamento para projetos de diretores com ambição autoral como também para facilitar sua penetração no circuito de festivais. Bordwell e Thompson no mesmo artigo destacam a anterioridade da relevância das trilogias no circuito de arte em relação ao cinema de grande público. O teórico cita como alguns exemplos, no cinema moderno , a trilogia da incomunicabilidade e da solidão de Michelangelo Antonioni - A aventura (L'avventura, 1960), A noite (La notte, 1961) e Eclipse (L'eclisse, 1962) - e a da crise da fé de Ingmar Bergman - Através de um espelho (Through a Glass Darkly, 1961), Luz de inverno, (Winter Light, 1963) e $O$ silêncio (The Silence, 1963). Os autores mencionam também exemplos do cinema contemporâneo: a trilogia das cores de Krzysztof Kieslowski - A liberdade é azul (Trois couleurs: bleu, 1993), A igualdade é branca (Trois couleurs: blanc, 1994) e A fraternidade é vermelha (Trois couleurs: rouge, 1994) ; e a "sobre os EUA sem nunca ter estado lá" de Lars von Trier - Dançando no Escuro (Dancer in the dark, 2000), Dogville (2003) e Manderlay (2005).
} 
O incidente retarda o retorno de Richard e Susan para casa em San Diego, Califórnia. O atraso da volta do casal de Marrocos leva a babá Amelia (Adriana Barraza) a atravessar a fronteira com o México em Tijuana para ir ao casamento do filho Luis (Robert 'Benie' Esquivel) levando consigo, sem autorização, as crianças do casal americano, Debbie (Elle Faning) e Mike (Nathan Gamble). Amelia e as crianças são conduzidas de carro nas travessias de fronteira pelo seu animado sobrinho Santiago (Gael García Bernal), que, inconsequentemente, vai contribuir para a deportação de Amelia na atabalhoada tentativa de retorno da festa para os Estados Unidos. ${ }^{118}$

A polícia japonesa vai ao encontro de Yasujiro (Kôji Yakusho) para confirmar se foi ele mesmo quem doou o rifle para seu outrora guia de caça de carneiros selvagens no Marrocos, Hassan. Yasujiro é viúvo e mora sozinho com sua filha adolescente surda-muda, Chieko (Rinko Kikuchi), em um sofisticado apartamento com ampla vista de Tóquio. Chieko está ambientada na "ecranosfera" definida por Gilles Lipovestsky (2009, ver Capitulo II), com telas por todos os lados e munida de um hiperativo celular. A adolescente está ávida para perder a virgindade, mas sua iniciação sexual é conturbada por suas limitações comunicativas e pelo trauma em razão do suicídio da mãe. A investigação sobre o rifle coloca Chieko em contato com o detetive Kenji. Chieko tenta seduzir Kenji sem sucesso, mas encontra ao menos compreensão no policial.

Os temas da solidão e da morte são novamente abordados em famílias incompletas que se interligam ao acaso por meio de um ato violento irresponsável. A "situação trágica por excelência" na acepção aristotélica se faz presente de maneira variada nas trajetórias de Yussef, Richard e Susan, Chieko e Amelia. Todos os protagonistas, embora não se sobressaiam pela virtude, acabam caindo em infortúnio, não por serem detestáveis, mas por força de uma eventualidade aleatória. Yussef e Ahmed, embora ainda estejam começando a adolescência, participam ativamente do trabalho duro rural da família e ficam expostos a uma situação de risco ao terem que manusear precocemente uma arma de fogo para proteger as cabras de animais selvagens. A tragédia vai ceifar a vida de Ahmed sob os olhos impotentes do pai, justamente o filho inocente.

O casal Richard e Susan viaja para muito longe de casa, deixando seus filhos com a empregada mexicana com o objetivo de se acertarem depois da perda de um filho recém-

\footnotetext{
${ }^{118}$ Iñárritu afirma que a personagem Amelia é livremente baseada em Julia, empregada mexicana que trabalha para a família de Iñárritu, que apesar de sentir muita falta do México prefere trabalhar nos Estados Unidos. (IÑÁRRITU, 2009, apud DELEYTO; AZCONA, 2010, p. 136, informação oral)
} 
nascido. ${ }^{119}$ As crianças do casal, Debbie e Mike, têm suas existências ameaçadas ao serem abandonadas no deserto. A deficiente Chieko tenta, atrapalhadamente, dar vazão aos seus impulsos sexuais debaixo da sombra da morte da mãe. Amelia é uma trabalhadora ilegal que vive sozinha em terra estrangeira e transfere sua afetividade latina para os filhos dos patrões, que trata como se fossem dela. Durante a trama, não há nenhuma menção ao marido ausente de Amelia. Ao atravessar a fronteira de seu país natal para o casamento do filho na companhia do sobrinho e das crianças "gringas", Amelia termina deportada com a roupa do corpo em farrapos, uma espécie de morte de sua existência de dezesseis anos nos Estados Unidos.

O liame entre as histórias é urdido pelo emprego do rifle como objeto circulante entre três dos quatro enredos. O trânsito da arma alinhava as histórias ao tecer uma sucessão circular de transações: o rifle doado por Yasujiro a Hassan; vendido a Abdullah; cedido aos meninos Yussef e Ahmed; cuja bala atinge Susan; sendo truculentamente rastreado por policiais marroquinos; e sendo checada sua origem pelo detetive japonês Kenji, que se envolve afetivamente na solidão desesperada de Chieko. O objeto circulante da história produz morte e dinamiza a vida.

A trama conta a história do filme em vinte e quatro sequências, variando entre suas quatro linhas narrativas (ver Apêndice E). As duas histórias que se passam no Marrocos, somam cinco sequências da tragédia de Yussef e Ahmed com mais seis do drama de Richard e Susan. As histórias de Amelia na fronteira entre Estados Unidos e México e de Chieko em Tóquio contabilizam seis sequências cada uma. $\mathrm{O}$ equilíbrio entre o número de sequências dedicados a cada história se reflete no tratamento homogêneo das principais personagens dos enredos. A alternância entre as histórias repete a seguinte ordem durante todo o filme: irmãos marroquinos, empregada mexicana, casal estadunidense e adolescente japonesa.

O encadeamento das sequências da mesma história respeita a ordem causal e temporal das ações. Entretanto, o entrelaçamento entre as quatro linhas narrativas dá a impressão de que as histórias acontecem simultaneamente, mas existem leves discrepâncias na ordenação temporal explicitada com sutileza por indícios no desenrolar do enredo. As discrepâncias temporais entre as histórias são atenuadas pelos fatos de que todas as ações acontecem em

\footnotetext{
${ }^{119}$ Iñárritu conta em entrevista a Rodrigo García que no roteiro original o conflito entre Richard e Susan havia surgido de uma infidelidade dele no passado e que apenas algumas semanas antes da filmagem sugeriu aprofundar o drama pela morte prematura de um filho. Brad Pitt só ficou sabendo da mudança do roteiro quando chegou ao Marrocos para as filmagens (GARCÍA, 2007, p. 260-261). A escolha do tema provocador do desentendimento do casal de personagens tem vinculação direta com a experiência de vida do diretor. Iñárritu e sua mulher, Maria Eladia, perderam um filho, Luciano, dois dias após seu nascimento. Iñárritu dedicou Amores brutos a Luciano e 21 gramas a sua esposa (WOOD, 2006, p. 152-153). Os sentimentos de culpa do casal pela morte súbita do filho proporcionaram uma base dramática consistente para a construção da tensão entre eles e uma comoção catártica quando se reconciliam.
} 
poucos dias, cinco, e de que há grande diferença de fusos horários entre as localidades dos eventos. As informações ocasionais com potencial de permitir ao espectador localizar as histórias na linha do tempo, indexadores temporais, são suficientes para se perceber que a ordenação é não-linear, não permitindo que se apreenda exatamente a relação temporal que estabelecem entre si. Indexador temporal é o "tique-taque" a que se refere Faulkner (2002, p. 83) na epígrafe como elemento "capaz de criar na mente toda a longa sequência de tempo, ininterrupta" que não foi oferecida linearmente pela trama ao espectador.

A configuração temporal singular entre as linhas narrativas de Babel só fica evidente por meio da análise comparativa entre as posições dos acontecimentos na trama com suas disposições na história (fabula) durante os cinco dias em que tudo acontece (ver Apêndices F e G). No primeiro dia da história, ocorre a transação do rifle entre os vizinhos e o tiro acidental (Sequências 1 - “O Rifle" - e 3 - "O acidente”); a ida do ônibus de turistas para a aldeia Tazarine onde Susan é atendida por um médico veterinário (Sequências 7 - "A necessidade de um médico" - e 11 - "Medicina local"); e a noite de remorso silencioso de Yussef e Ahmed (Sequência 5 - "Doentes de culpa").

No segundo dia, amanhece em Tazarine, e Richard depara-se com as dificuldades de resgate de Susan - a ambulância não vem, o ônibus turístico parte sem o casal e vão ter que esperar por um helicóptero (Sequência 15 - "Sem transporte"). Acontece a investigação policial, no local do incidente, pelas autoridades marroquinas, que logo encontram os cartuchos do disparo e rastreiam armas daquele calibre (.270) na área, chegando a Hassan. Interrogado com espancamento e arma apontada para sua cabeça, Hassan conta que vendeu o rifle para o vizinho no dia anterior. Os policiais vão em busca de Abdullah, mas encontram Yussef e Ahmed no meio do caminho que dão direções erradas, despistando o comboio policial. Os irmãos correm apavorados para casa e confessam ao pai a verdade sobre o tiro na americana. Ahmed delata a relação incestuosa de Yussef com a irmã e os garotos brigam (Sequência 9 "Rastreamento da arma").

Ocorre a delação de Hassan de que o rifle foi um presente de um caçador japonês, Yasujiro, e a perseguição e tiroteio da polícia com a família de Yussef (Sequência 13 - "Na correria”). Importante reparar que somente nessa sequência se estabelece tardiamente a conexão da parte japonesa da história já com uma hora e dezesseis minutos de filme. Para marcar bem esse elo, a mulher de Hassan apresenta uma foto de Yasujiro com Hassan e um carneiro morto 
para comprovar a confissão do marido, outra cópia da mesma foto será vista pelo detetive Kenji na parede da sala de estar do apartamento de Yasujiro (Sequência 16 - "Sedução"). ${ }^{120}$

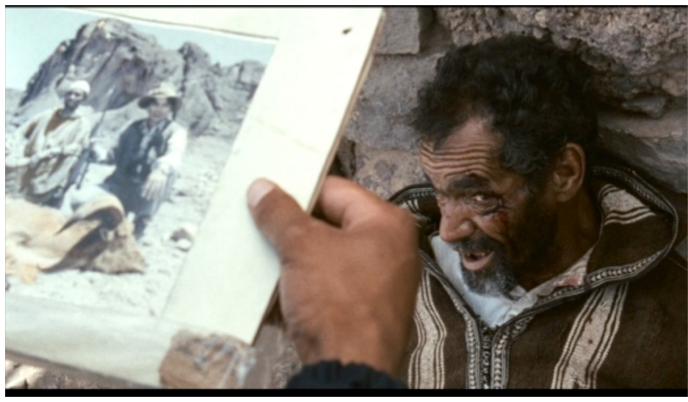

Figura 5.1 - Mulher de Hassan entrega para a polícia marroquina foto de caçada com Yasujiro

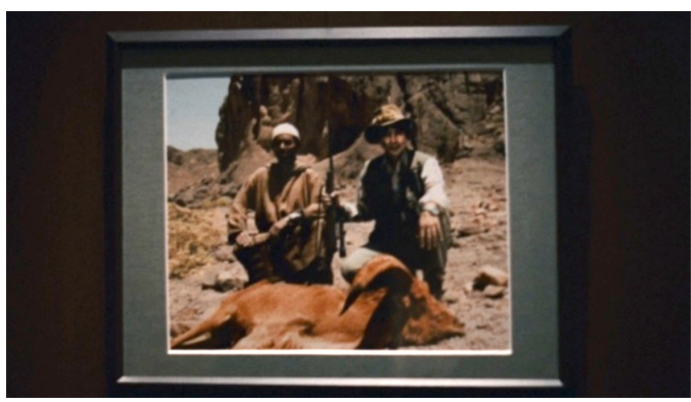

Figura 5.2 - O detetive Kenji encontra cópia da mesma foto no apartamento de Yasujiro

O filme dedica uma sequência ao desfecho trágico do cerco dos policiais à família de Abdullah na emocionante rendição de Yussef assumindo a autoria dos disparos em Susan e nos policiais, inocentando Ahmed e clamando de joelhos para que façam o que quiserem com ele, mas salvem seu irmão, que morre nos braços do pai (Sequência 17 - "O cerco”).

Nesse segundo dia da história do filme, sucede também a comovente reconciliação entre Richard e Susan (ver Sequência 19 - "Reconectando"); e a remoção em helicóptero de Susan para um hospital em Casablanca (ver Sequência 22 - "Deixando a vila"). Somente nessa penúltima sequência do filme, mostra-se a ligação de Richard para sua casa, falando com Amelia e seu filho Mike (ver Figura 5.4). A ligação repete integralmente os diálogos do segundo fragmento de história apresentado pela trama (ver Sequência 2 - "A procura por babá" e Figura 5.3). Na primeira apresentação da ligação, a cena é percebida apenas pela perspectiva da casa da família americana em San Diego, onde se veem Amelia e Mike ao telefone e apenas ouve-se a voz de Richard distante. Em sua reapresentação, a cena é invertida e mostra todo o diálogo do ponto de vista de Richard todo sujo em um telefone público no corredor do hospital falando muito fragilizado, enquanto o futuro de Susan está incerto na sala de cirurgia.

\footnotetext{
${ }^{120}$ Quase todas as Figuras deste capítulo são frames do filme Babel. Fonte: BABEL. Direção: Alejandro González Iñárritu, EUA, México: Paramount, 2006. 1 DVD (143 min).
} 


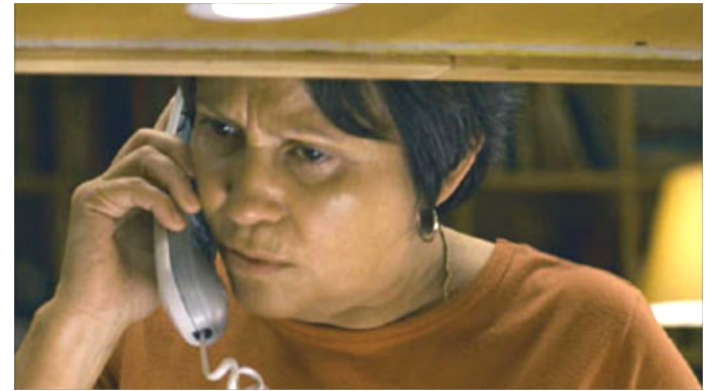

Figura 5.3 - Amelia recebe ligação de Richard no início do filme

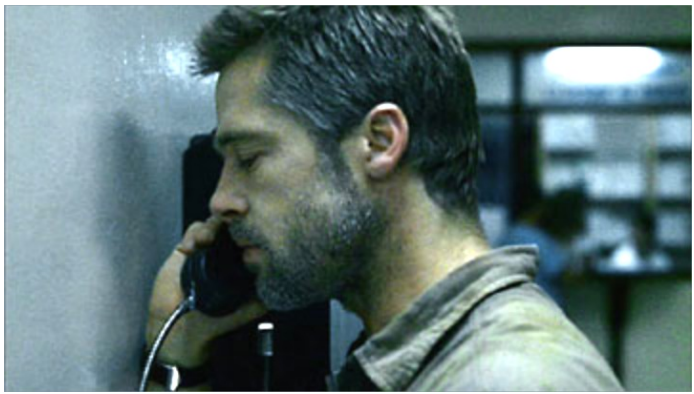

Figura 5.4 - A mesma ligação com Amelia se repete na perspectiva de Richard ao final do filme

O telefonema de Richard, quase ao final do filme, além dos sentimentos intensos que expõe acerca da reconexão familiar, funciona como um indexador temporal inquestionável. A ligação assinala claramente que toda a história de Amelia que a trama apresentou como desenvolvendo-se em paralelo aos acontecimentos no Marrocos, em sua ordem temporal correta só tem início após o resgate e a internação de Susan em Casablanca. Portanto, desde a segunda sequência do filme, antes da ida de Amelia ao casamento do filho, passando pelas sequências de travessias de fronteira e casamento (Sequências 6 - "Travessia de fronteira" -, 10 "Casamento mexicano" - e 14 - "Patrulha de fronteira") até sua deportação (Sequência 21 "Deportada"), todos esses eventos acontecem a partir do final do segundo dia da história, em um período de dois dias - ida para casamento, festa, retorno complicado e desenlace com a expulsão por oficial de fronteira.

A revelação do atrelamento causal do enredo japonês com o restante do filme é tardia por meio da confissão de Hassan da doação do rifle (Sequência 13), contudo, um pouco antes, surge uma informação que o posiciona temporalmente em relação aos demais. O detetive Kenji e um colega procuram por Yasujiro em seu prédio, encontram Chieko no hall, mas não dizem o motivo da visita e deixam um cartão para o pai entrar em contato com eles. Depois, Chieko está entediada zapeando a televisão, enquanto espera por uma amiga em casa, quando surge uma notícia do incidente marroquino com as fotos de Yussef e Abdullah (Sequência 8 "Visita da polícia"). 


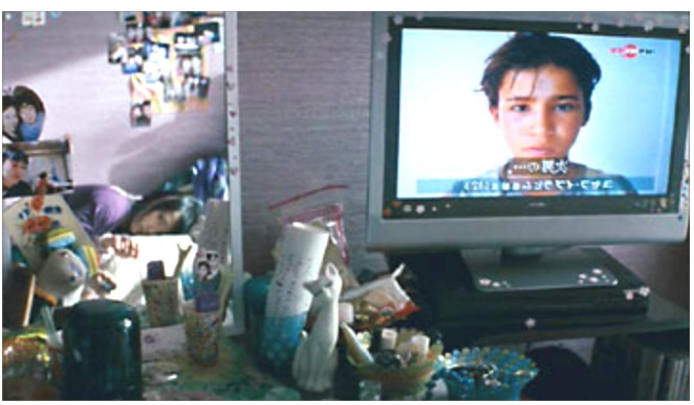

Figura 5.5 - Chieko assiste TV em seu quarto quando aparece o rosto de Yussef em matéria sobre o incidente com Susan

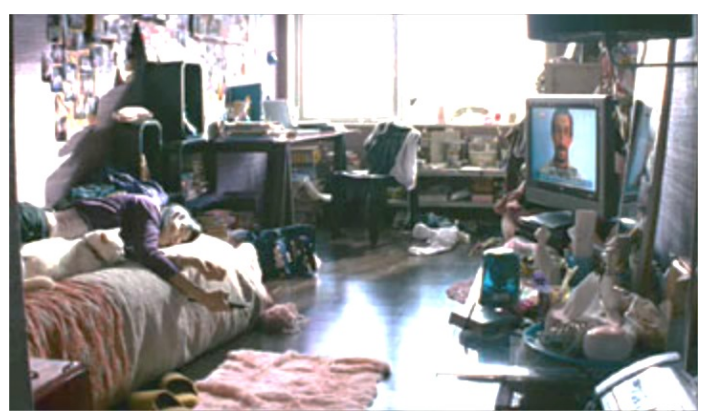

Figura 5.6 - Aparece também foto de Abdullah no telejornal japonês

As aparições das fotos de Abdullah e de Yussef marcam que a história japonesa está alguns dias à frente do drama dos meninos pastores, porque, até então, o conhecimento do envolvimento deles no incidente estava restrito a eles mesmos e ao espectador, por meio do olhar que a narração permite. Portanto, há claramente uma discrepância entre essa informação e a aparição mais recente dessas personagens na trama quando nem seus pais sabem ainda o que aconteceu, quiçá a polícia e o noticiário japonês (ver Sequência 5 - "Doentes de culpa").

Há uma outra informação temporal na cena em que Chieko chega em casa depois de se divertir com os amigos na rua e em boate e pede ao porteiro para ligar para o detetive Kenji (ver Sequência 12 - "Noite de Tóquio"). O porteiro fala ao telefone com o detetive que "a garota surda-muda que encontrou à tarde pediu para ligar”. A informação permite deduzir que as sequências anteriores desse enredo (ver Sequências 4 - "Vôlei/Restaurante" - e 8 - "Visita da polícia") acontecem nesse mesmo dia, assim como as sequências que estão por vir (ver Sequências 16 - "Sedução" -, 20 - "O grito silencioso" - e 23 - "Pai e filha").

Existe um terceiro indexador temporal no enredo japonês, em uma das últimas cenas do filme (ver Sequência 23), quando o detetive Kenji está sozinho em um bar e, novamente, em um telejornal, a apresentadora anuncia que Susan teve alta em Casablanca e "americanos tiveram final feliz depois de cinco dias de telefonemas e nervosismo". A matéria mostra Susan saindo do hospital com boa aparência e o braço em uma tipoia.

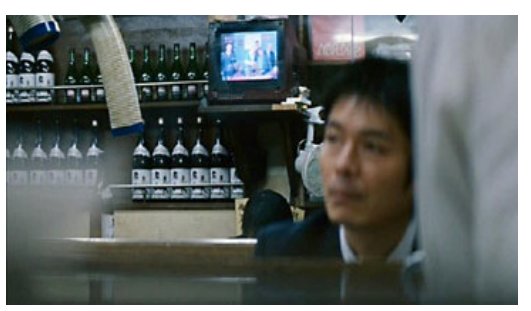

Figura 5.7 - Detetive Kenji está em bar onde passa telejornal

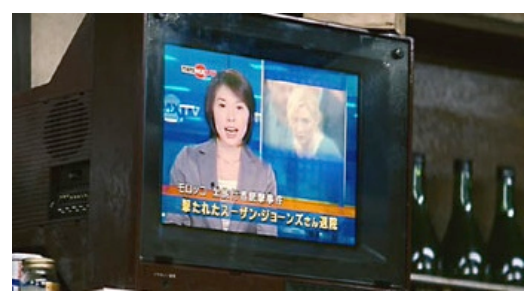

Figura 5.8 - TV atualiza matéria sobre incidente de Susan

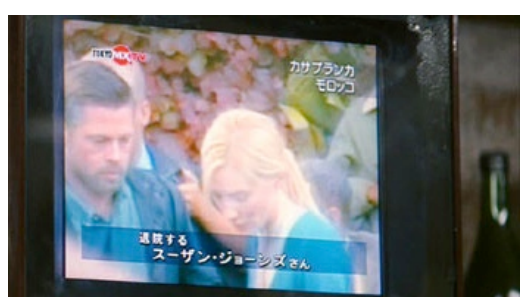

Figura 5.9 - Telejornal apresenta conclusão do drama de Susan 
O trecho da matéria que Chieko assiste de tarde aponta os investigados pela autoria do tiro - Yussef e seu pai - e, já à noite, o detetive Kenji vê uma evolução da apuração da notícia com o desfecho bem-aventurado da história de Susan. Baseado nas notícias da televisão japonesa e nos demais indexadores temporais do filme, é possível demarcar que todas as histórias se passam em um período de cinco dias. Nos dois primeiros dias, acontecem as histórias de Richard e Susan e de Yussef e Ahmed no Marrocos; nos dois seguintes, sucede o périplo de Amelia com Santiago, Debbie e Mike na fronteira entre Estados Unidos e México; e, no derradeiro dia, acompanha-se o movimentada jornada de Chieko em Tóquio.

A trama embaralha a ordem temporal das quatro histórias de tal forma, que demanda um esforço do espectador na compreensão de sua organização de difícil execução durante a fruição do filme. Os poucos indexadores temporais dispersos nas cenas funcionam mais no sentido de explicitar as discrepâncias temporais entre as sequências do que para efetivamente garantir ao espectador a percepção clara de seu ordenamento. Entretanto, a dificuldade em se estabelecer a ordem temporal entre as histórias não constitui um obstáculo para a compreensão da narrativa como um todo. Pelo contrário, a não-linearidade opera como um recurso para tirar o espectador de uma espécie de "zona de conforto cognitivo" promovida pela falsa simultaneidade. As fraturas temporais denunciadas pelos indexadores temporais renovam o nível de interesse e atenção do espectador, ao engajá-lo em uma postura mais ativa na busca de conexões que lhe possibilitem encaixar as diferentes histórias na linha do tempo.

Conforme analisado acima, a tessitura temporal de Babel é composta por uma dupla camada heterogênea: a narração encadeia linearmente as sequências das mesmas histórias e, paralelamente, embaralha não-linearmente suas quatro linhas narrativas. Por meio dessa composição temporal miscigenada, a montagem do filme expande as possibilidades expressivas dos acoplamentos entre as sequências das histórias, tornando as transições entre os blocos do filme em fronteiras explosivas de significado.

\subsection{Significados e sonoridade das transições entre as histórias}

As transições entre as vinte e quatro sequências da estrutura narrativa de Babel funcionam como fronteiras que, simultaneamente, separam e conectam os universos de suas quatro histórias, criando uma experiência cognitiva-emocional envolvente por meio de variadas estratégias visuais e sonoras. Iñárritu se diz muito interessado nas transições entre diferentes 
locações geográficas desde a escritura do roteiro. Segundo ele: "O espectador deve mover-se sem emendas nas transições entre uma cena e outra. E o som é uma parte crucial disso"121 (IÑÁRRITU, 2009, apud DELEYTO; AZCONA, 2010, p. 132).

As passagens entre os blocos narrativos trazem muitos significados, enfatizam as ligações entre realidades contrastantes e dão relevo ao fluxo de pessoas e informações transpassando fronteiras geopolíticas. À medida que as transições se sucedem, engatilham um jogo de múltiplas conexões incessantes que conformam uma teia interligando os universos diegéticos dos quatro países, nos quais as histórias se desenrolam. O repertório das conexões é amplo, tende, em um primeiro momento, a destacar as personagens do contexto geográfico, e, logo em seguida, institui afinidades existenciais mesmo em situações díspares. Sons ambientes e músicas desempenham um papel relevante na articulação entre os blocos narrativos. Os significados que emanam de cada emenda das sequências se sobrepõem enredando os dramas das personagens. A teia conectiva que se forma revela o impacto da dinâmica da sociedade de rede nas interações pessoais, especialmente nas relações de poder, que expõem a vulnerabilidade e efemeridade da existência humana e seus afetos. Conforme aponta Iñárritu, o que dá a liga da narrativa de Babel é sua teia conectiva:

Este filme é sobre como o mundo pode impactar nossa vida diária, como podemos ser definidos pelos outros - nós somos o que os outros influenciam em nós. Nós somos definidos pelos nossos pais, nossos irmãos - é sobre como as pessoas e eventos conectam e transformam as pessoas. ${ }^{122}$ (IÑÁRRITU, 2007, apud PHILPIN, 2007, informação oral, tradução nossa)

A amarração entre as fábulas familiares de intimidade e os grandes esquemas sócioeconômico-políticos em Babel é tecida pelas passagens entre as sequências de suas quatro histórias. Logo na primeira transição, corta-se dos irmãos pré-adolescentes pastores Yussef e Ahmed, correndo apavorados após atirarem no ônibus turístico, para as crianças americanas Debbie e Mike, brincando dentro de casa em San Diego, Califórnia (ver Sequência 1 para 2, e Figuras 5.10 e 5.11).

\footnotetext{
${ }^{121}$ No original: "The spectator has to move seamlessly in the transitions from one scene to another. And the sound is a crucial part of that." (IÑŃRRITU, DATA, apud DELEYTO; AZCONA, 2010, p. 132, informação oral)

${ }^{122}$ No original: "This film is about how the world can impact in our lives everyday, how can we be defined by others - we are what the others influence in us. We are defined by our parents, our brothers - this is about how people and events connect and transform people.” (IÑÁRRITU, DATA, apud PHILPIN, 2007, informação oral)
} 


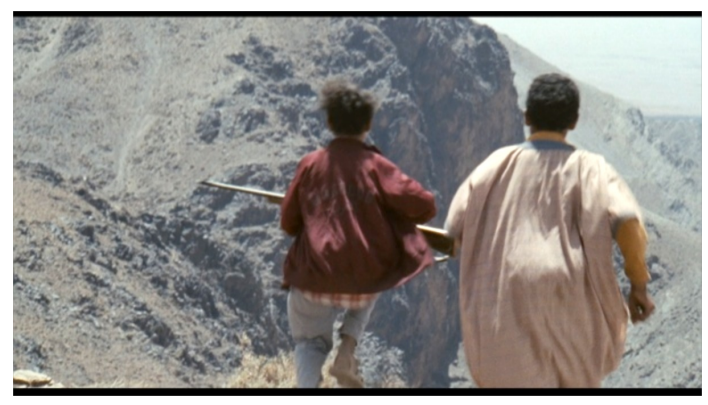

Figura 5.10 - Irmãos marroquinos correm com rifle nas montanhas

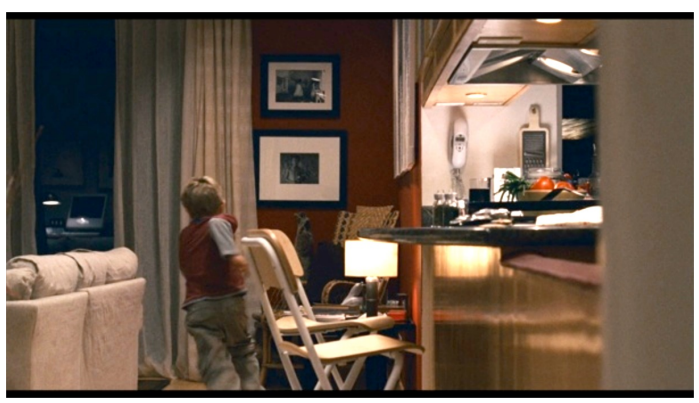

Figura 5.11 - Mike brinca na sua casa em San Diego

A justaposição de planos com a mesma ação, jovens correndo, é repleta de contrastes que geram vários significados. De imediato, revelam-se situações díspares da condição infantil entre uma sociedade rural marroquina pobre e outra, urbana estadunidense de classe média alta. De um lado, o trabalho infantil, os meninos pastoreando em espaço aberto árido - atividade econômica ancestral -, com o agravante do uso do artefato que coloca os garotos em situação de risco - o rifle. Do outro, o conforto e proteção de um espaço fechado para o exercício saudável e natural da brincadeira. O corte entre esses dois planos situa o distanciamento dos níveis civilizatórios das duas sociedades representadas por meio da comparação da condição de um de seus elos mais frágeis, a infância. Ao mesmo tempo em que essa passagem ressalta a profunda cisão entre esses dois mundos, também atrela-os. $\mathrm{O}$ ato inconsequente dos garotos marroquinos, precocemente expostos a situações adversas, terá graves consequências na vida das crianças protegidas californianas, podendo levar até à aniquilação de quase toda sua família. O forte contraste expressivo do corte seco entre as imagens e sons ambientes da primeira transição do filme é potencializado por ser inaugural do padrão organizador da narrativa, o que deixa o espectador mais atento e sensível ao seu traçado.

No decorrer do filme, o desenho das "fronteiras" entre as sequências das histórias apresenta grande variedade de modos de distinguir, concomitantemente, unindo sentimentos e ideias. Em duas delas, a montagem acopla planos, sugerindo uma relação de plano/ponto de vista, falaciosa mas instigante. A primeira fronteira ocorre na saída de Amelia para viajar para o casamento do filho, em que se justapõe um olhar de seu sobrinho Santiago através do parabrisa do carro com o grupo de turistas do ônibus de Richard e Susan caminhando em uma aldeia marroquina (Sequência 2 para 3). No carro de Santiago toca uma música regional mexicana e, no Marrocos, ouve-se o som ambiente de lá.

A junção dos planos, inicialmente, provoca um choque devido ao efeito da falsa continuidade entre eles, pois, por frações de segundos, não é possível saber, ao certo, se os frag- 
mentos pertencem à mesma história ou não. Visualmente se insinua a continuidade entre os planos das duas realidades que é negada pela ruptura do áudio. Superado o baque do desencaixe entre os planos da transição, sua justaposição denota que a transposição de fronteiras nacionais, atualmente, não é um privilégio das classes mais abastadas, mas também uma imposição ocasional aos necessitados que migram, mesmo ilegalmente, em busca de melhores condições de trabalho e vida.

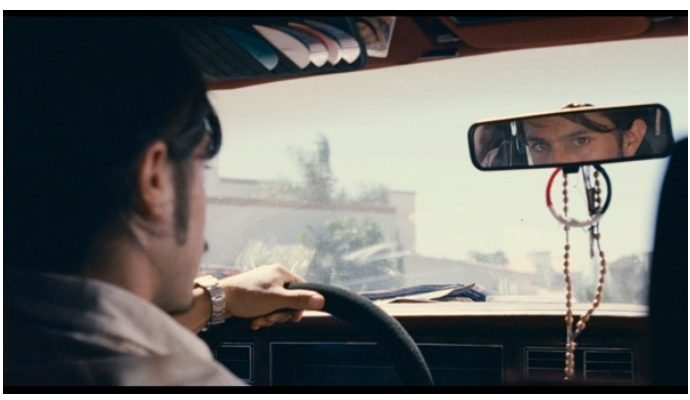

Figura 5.12 - Santiago parte de San Diego rumo ao México, levando sua tia Amelia, Mike e Debbie

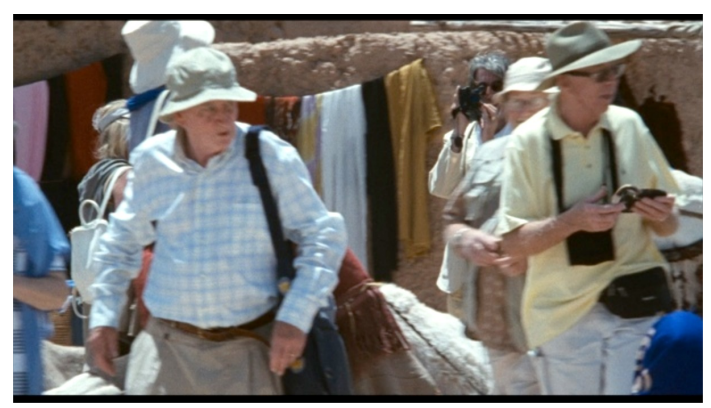

Figura 5.13 - Turistas no Marrocos

A mesma articulação dissimulada de plano/ponto de vista é utilizada na passagem do olhar do garoto Mike, aterrorizado com a decapitação de uma galinha feita por Santiago durante as preliminares do casamento mexicano (ver Figuras 5.14 e 5.15), para a imagem de sua mãe, Susan, sendo carregada dentro do ônibus no Marrocos (Sequência 6 para 7). Nesse caso, a junta tenciona mais as emoções. A expressão do olhar de Mike tem outra motivação, mas, ao ser acoplada ao sofrimento da mãe ferida, ganha outra dimensão, é como se o garoto reagisse ao atentado à vida de sua mãe. Essa passagem se aproxima do conceito de "ordem emocional” aplicado por Iñárritu para explicar a estrutura de 21 gramas.

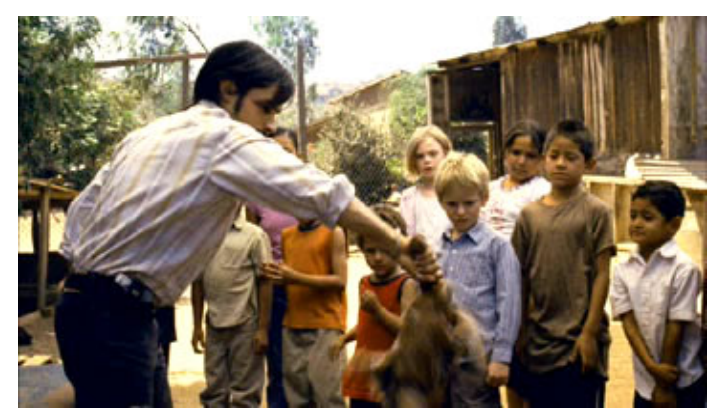

Figura 5.14 - Santiago arranca cabeça de galinha

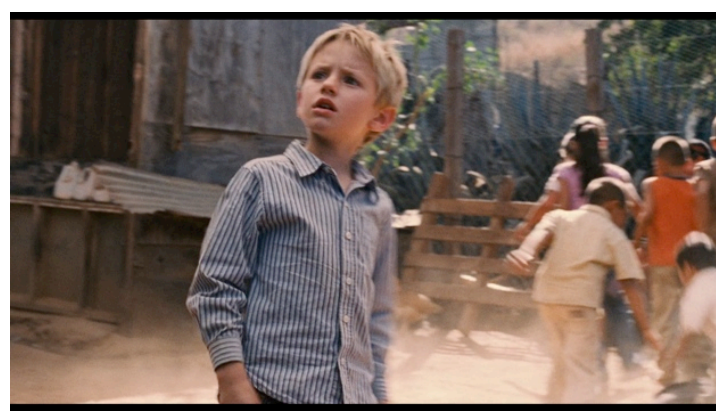

Figura 5.15 - Mike fica chocado 
Algumas transições utilizam as semelhanças do grafismo da composição da imagem e da movimentação da cena para promover uma passagem visualmente suave, mas desconcertante na colisão de seus conteúdos. Este é o caso da transição entre um policial marroquino sendo baleado por Yussef e um casal dançando na festa do casamento do filho de Amelia (Sequência 13 para 14). A junção de corpos balançando contrapõe desentendimento e harmonia, violência e paz, agressividade e afeto, uma via de mão dupla com sentidos antagônicos, um rumo à morte e o outro, à vida.

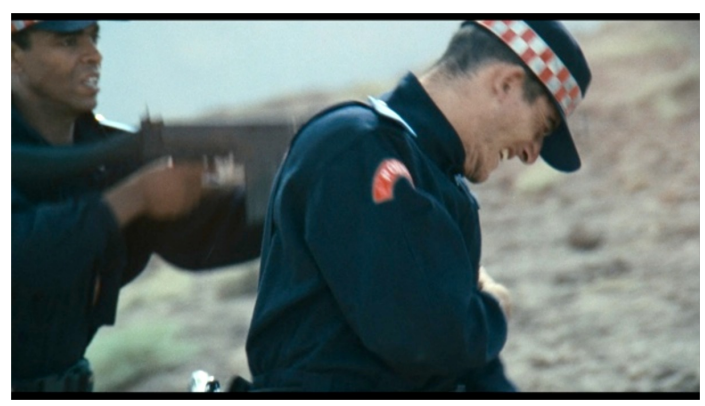

Figura 5.16 - Policial marroquino é baleado por Yussef

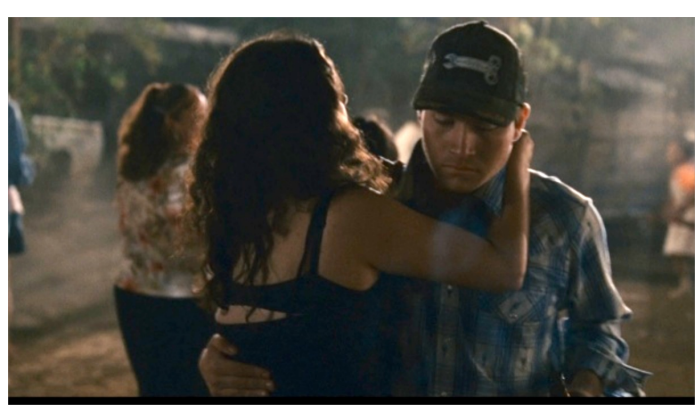

Figura 5.17 - Casal mexicano dança no casamento do filho de Amelia

Sucedem passagens entre sequências que operam como distensões de momentos muito intensos, propiciando um relaxamento em que o espectador tem a oportunidade de processar as informações que recebeu da trama. Como a que acontece no começo do filme, quando corta-se de Richard desesperado com o tiro que feriu Susan e o ônibus em polvorosa para o jogo de vôlei de Chieko (Sequência 3 para 4).

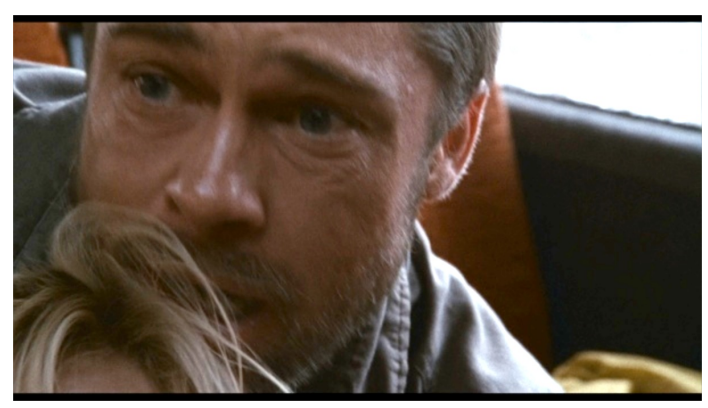

Figura 5.18 - Richard desespera-se ao perceber que Susan foi baleada

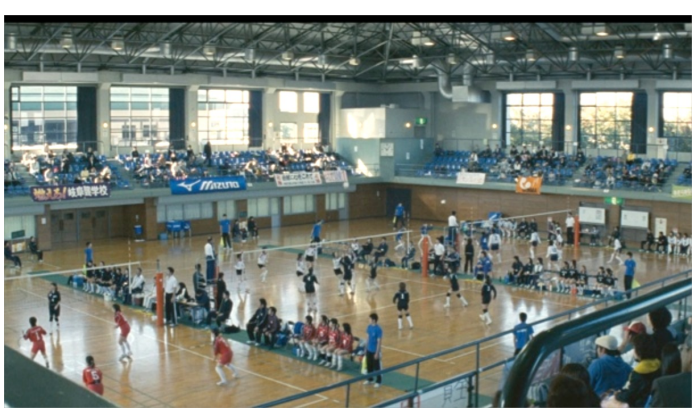

Figura 5.19 - Japão entra no filme em plano geral de jogo de vôlei

As três primeiras sequências do filme estabelecem seu "incidente incitante" na perspectiva do atirador (Sequência 1) e da vítima (Sequência 3), e, ainda, relaciona, fora da ordem linear, o ocorrido com Amelia e as crianças nos Estados Unidos (Sequência 2). Além da mu- 
dança do foco narrativo entre as três histórias, a narração também joga com a ordenação temporal, com uma elipse à frente, na passagem da sequência dos garotos marroquinos para a de Amelia com as crianças em San Diego, e um recuo para horas antes do tiro. Apesar da ordenação não-linear do tempo a causalidade é mantida, mostra-se, primeiro, o disparo do rifle e depois suas consequências. Quando o Japão aparece na tela, o espectador não recebe nenhuma pista sobre sua vinculação com as demais histórias, que só se configura tardiamente (Sequência 13), gerando suspense pelo retardamento dessa informação.

Chama atenção a pouca duração da sustentação da intensidade dramática do pânico no ônibus e desespero de Richard. Nos dois primeiros filmes de Iñárritu, situações com alto teor dramático, como a descrita acima, eram abordadas como oportunidades para se alongar esses momentos de sofrimento intenso e não oferecer um alívio rápido ao espectador. Nota-se, nesse ponto, e em outros de Babel, um certo arrefecimento da estética do excesso, característica do cinema mexicano, que é acentuada tanto em Amores brutos quanto em 21 gramas.

Outra transição que corrobora o abrandamento da estética do excesso acontece quando Susan está gritando de dor ao ter seu ferimento à bala costurado sem anestesia por um veterinário e corta-se para um superclose de uma japonesa desconhecida falando e não se ouve nada (Sequência 7 para 8). As duas transições mencionadas acima, a dos garotos e a das personagens femininas, ao provocarem a suspensão de tensão e pouparem o espectador do exagero de aflição das personagens, assinalam uma mudança no estilo da montagem em relação aos filmes anteriores, marcados pela valorização da intensidade dramática, ao estenderem cenas de sofrimento. A mudança na sustentação de cenas de sofrimento pode ser interpretada como a busca de uma montagem mais palatável, que evite provocar a rejeição de audiências mais amplas, principalmente no volumoso mercado dos Estados Unidos.

O corte interrompe a agonia de Susan e colide com a angústia de Chieko no dentista. A passagem entre sequências de histórias diferentes, dessa vez, explicita o desnível econômico entre Marrocos e Japão, contrastando o sujo, cheio de moscas e improvisado atendimento domiciliar por um "médico veterinário", com o asséptico e bem equipado consultório. A junção distingue e associa o sofrimento das duas mulheres. A dor física de Susan sendo costurada é relacionada com os transtornos psicológicos de carência e descontrole sexual de Chieko. A cena mostra a jovem japonesa tentando desajeitadamente seduzir o dentista, lambendo o rosto dele e levando sua mão à sua genitália por duas vezes. $\mathrm{O}$ dentista fica transtornado com o comportamento inadequado da paciente e a expulsa do consultório demonstrando uma intolerância. O sentimento de solidão que emana dos olhos puxados de Chieko é comovente. 
A junção das cenas das duas histórias também apresenta forte contraste auditivo. Os gritos de Susan deparam-se com o silêncio absoluto do plano da atendente do dentista movendo os lábios sem que se ouça nada. O desenho de som radicalmente assume o ponto de escuta subjetivo de Chieko durante quase vinte segundos, até que a atendente chama sua atenção com os braços para que entre no consultório. Desde que o cinema se tornou sonoro, o uso de silêncio absoluto é uma opção estética que foge completamente das convenções do cinema clássico e é incomum até mesmo em filmes modernistas mais experimentais.

A projeção de um filme sem nem mesmo uma suave camada de som ambiente pode ser facilmente interpretada pela audiência como um defeito. A montagem do filme foi bastante cuidadosa para evitar esse equívoco de interpretação ao estabelecer o silêncio absoluto claramente como a percepção acústica subjetiva da personagem, apesar do estranhamento que seu uso provoca na transição das cenas. A compreensão da subjetividade auditiva de Chieko é alcançada pelo encadeamento simples de planos de ponto de vista vinculados a closes dela na sala de espera. A vinculação do silêncio com Chieko se viabiliza, porque conta com o embasamento criado pela forma com que suas limitações auditivas foram apresentadas na primeira sequência dessa história (4 - "Vôlei/restaurante").

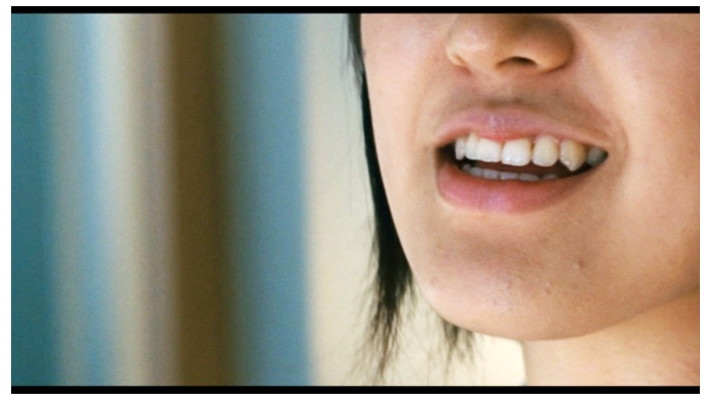

Figura 5.20 - Recepcionista aparece em cena com silêncio absoluto

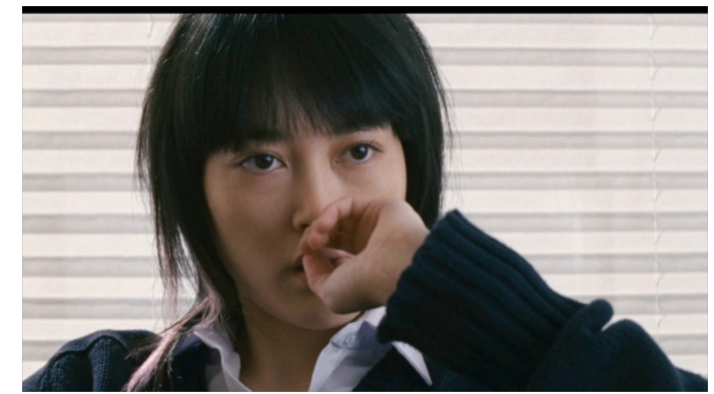

Figura 5.21 - A radicalidade do silêncio absoluto é vinculado à subjetividade de Chieko

O estabelecimento nítido do silêncio absoluto como subjetividade de Chieko no dentista é fundamental para o entendimento da mesma articulação sonora na boate (sequência 12. Noite de Tóquio). Na casa noturna, oscila-se entre o som do ambiente misturado com a música alegre September/The fever (sucesso remixado de Earth, Wind and Fire e Fatboy Slim ${ }^{123}$ ) em alto volume, conflitando com momentos do mundo surdo de Chieko. A utilização do silêncio absoluto subjetivo com moderação, de forma pontual, faz com que configure-se como

\footnotetext{
${ }^{123}$ Fatboy Slim (Quentin Leo Cook) é um músico do Reino Unido especializado em mixagens e faz muito sucesso nos Estados Unidos.
} 
um recurso expressivo que, apesar da radicalidade, colabora na imersão no universo da personagem puxando os limites convencionais sem comprometer a compreensão e engajamento do público. Na cena da boate, a radicalidade não convencional do silêncio absoluto é compensada pela combinação com música pop de alta circulação e fácil receptividade. Essa articulação de áudio é uma entre muitas em que o silêncio também é uma forma de marcar o isolamento da personagem e a música possui função de destaque no filme.

Iñárritu se assume como um músico frustrado, uma pessoa mais focada no sentido auditivo do que no visual. Para ele, a música não deve enfatizar o que já se pode ver: "Eu gosto quando a música acrescenta algo novo ou diferente do que já está sendo mostrado."124 (citado por DELEYTO e AZCONA, 2010, p. 132) Em Babel, a música comparece em maior quantidade e diversidade e desempenha funções mais variadas do que em seus filmes anteriores, assumindo papel proeminente entre os materiais expressivos cinematográficos.

O amplo espectro de tipos musicais em Babel se justifica pela variedade dos ambientes sonoros das quatro linhas narrativas que vai das rancheras ${ }^{125}$ mexicanas à sonoridade do oud $^{126}$, passando pelo pop e eletrônico da noite de neon japonesa. A volumosa presença decorre de seu emprego também em longos trechos nos quais se suspendem os diálogos e o sons ambientes das cenas e a música extradiegética reina absoluta como se fossem videoclipes internos ao filme. Outra parcela significativa da música de Babel advém de seu uso recorrente e articulador nas transições entre as sequências, seja para distinguir ou plasmar os universos das histórias por meio de técnicas variadas que adicionam camadas de significado e renovam o interesse e atenção do espectador. Nos primeiros noventa minutos do filme, há o predomínio do uso de sons ambientes e músicas diegéticas para marcar os contrastes entre as locações. Gradativamente, os sons de umas histórias começam a penetrar um pouco as outras, contribuindo na construção de espaços de fluxo. Nos quarenta minutos finais, o filme emprega fartamente músicas extradiegéticas para conectar as histórias.

A parte mexicana do filme é ricamente preenchida por música. Quando o sobrinho de Amelia, Santiago, entra em quadro, em sua primeira aparição, para levá-la de carro para o

\footnotetext{
${ }^{124}$ No original: "I like it when the music adds something new or different to what's being shown." (IÑÁRRITU, 2009, apud DELEYTO e AZCONA, 2010, p. 132, informação oral).

${ }^{125}$ A ranchera é um gênero da música mexicana tradicional. Ainda que intimamente associada aos mariachi, que evoluiram em Jalisco no período pós-revolução mexicana, as rancheras também são executadas por grupos chamados conjunto norteño ou banda duranguense. A ranchera, emanada do meio rural, foi considerada como reação ao gosto aristocrático, tornando-se um símbolo de nacionalidade mexicana. (Disponível em: < http://pt.wikipedia.org/wiki/Ranchera >. Acesso em: $12 \mathrm{dez} 2014$.)

${ }^{126} \mathrm{O}$ oud ou ud é um instrumento de cordas ancestral árabe em forma de meia pêra ou gota, similar ao alaúde mas sem os trastes e que é tocado com uma espécie de palheta, comumente usado em músicas do Oriente Médio.
} 
casamento, traz consigo música regional mexicana em alto volume no rádio do carro (final da Sequência 2). O som do carro de Octavio será a fonte da música que invade o final da cena silenciosa dos irmãos marroquinos sem conseguir dormir apreensivos pelas consequências do tiro (final da Sequência 5), e faz a ponte para a travessia de fronteira da entrada no México de Amelia, Santiago, Mike e Debbie.

A música segue embalando o acesso livre ao território latino, sem nenhum controle ou burocracia, e ganha forma de uma espécie de videoclipe do ponto de vista das crianças americanas que nunca haviam cruzado para o outro lado. Acompanhando a música, veem-se imagens típicas da fronteira mexicana: cruzes, imagens de Nossa Senhora de Guadalupe, prostitutas fazendo ponto à luz do dia, cores e mais cores, moscas e até um burrico pintado de zebra. Octavio ironiza para as crianças a falta de controle na entrada de seu país: "Viram como é fácil entrar no paraíso?”. Mike fala que a mãe disse que o México é um lugar perigoso e Santiago responde que é porque está cheio de mexicanos.

A festa de casamento mexicano conta com um vasto repertório de músicas diegéticas, com bandas tocando ao vivo e DJ animando os convidados (Sequência 10). Em um determinado ponto, a mixagem vai gradualmente suprimindo o som ambiente da algazarra e a música mecânica da festa e aumentando o volume da canção "Tu me acostumbraste" na voz intensa e chorosa de Chavela Vargas. ${ }^{127}$ A tocante canção extradiegética combinada com imagens levemente desaceleradas (rodadas a trinta quadros por segundo) intercala os recém-casados dançando e trocando carinhos na festa com o namoro de Amelia com um velho conhecido viúvo. O longo trecho instaura uma atmosfera idílica na festividade que promove um efeito de suspensão, em que a felicidade amorosa parece possível. Até que a música vai caindo, o som ambiente crescendo e Santiago saca seu revólver e dispara para o alto trazendo a festa de volta para a realidade com os ruídos e música locais. A sequência evoca a importância de se usufruir dos fugazes momentos de felicidade enquanto durem, e relembra o tiro em Susan no Marrocos, por meio da reação de seu filho Mike ao disparo de Santiago para o alto. Na transição dessa sequência para a seguinte, o som da festa mexicana é cortado na emenda, dando lugar ao som da locução de uma rádio árabe acompanhada de imagens da movimentação na aldeia de Tazarine.

\footnotetext{
${ }^{127}$ Chavela Vargas foi uma cantora da tradição ranchera mexicana, cuja trajetória também é marcada por travessias de fronteiras. Nasceu na Costa Rica (1919), mudou-se para o México aos quinze anos em busca de paz e de uma carreira. Teve grande evidência nos anos 1950 e posterior decadência devido ao consumo excessivo de álcool, foi redescoberta em 1992 pelo cineasta Pedro Almodóvar, que resgatou seu talento apresentando-a em seus filmes Kika (1992), A flor do meu desejo (La flor de mi secreto, 1995) e Carne trêmula (Carne trémula, 1997). (WIKIPÉDIA (Net). Disponível em: < http://pt.wikipedia.org/wiki/Chavela_Vargas >. Acesso em: $12 \mathrm{dez}$ 2014. IMDB (Net). Disponível em: < http://www.imdb.com/name/nm0889805/ > . Acesso em: $12 \mathrm{dez} 2014$.)
} 


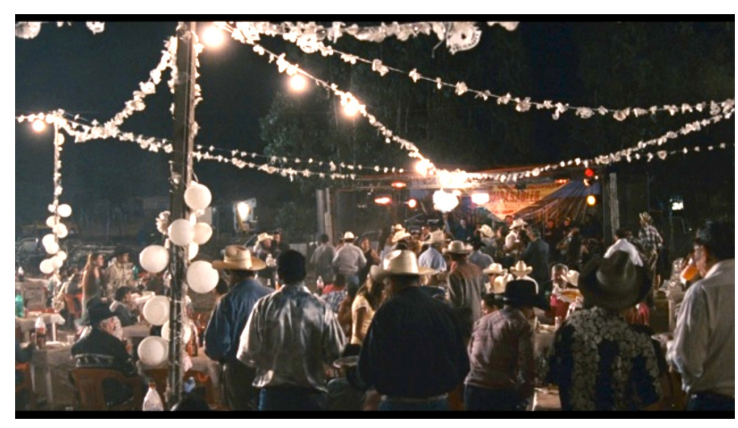

Figura 5.22 - Festa do casamento mexicano tem atmosfera de suspensão da realidade

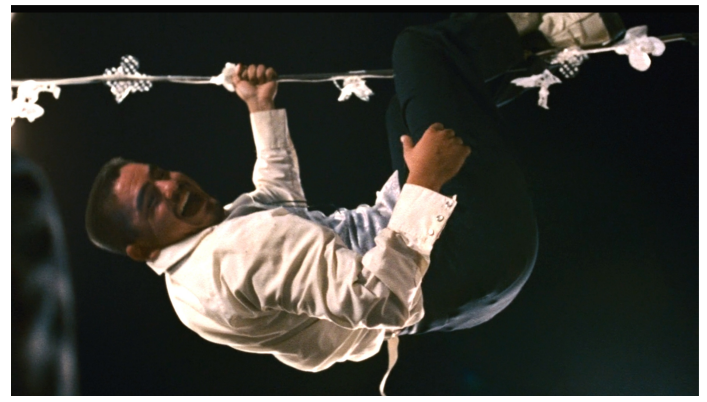

Figura 5.24 - Luis fica pendurado em fio quando é jogado para o alto nas brincadeiras da festa

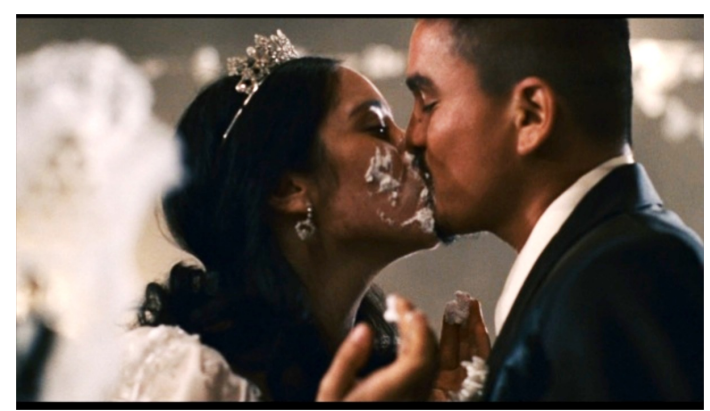

Figura 5.23 - Recém casados se lambuzam de bolo ludicamente ao som de Chavela Vargas

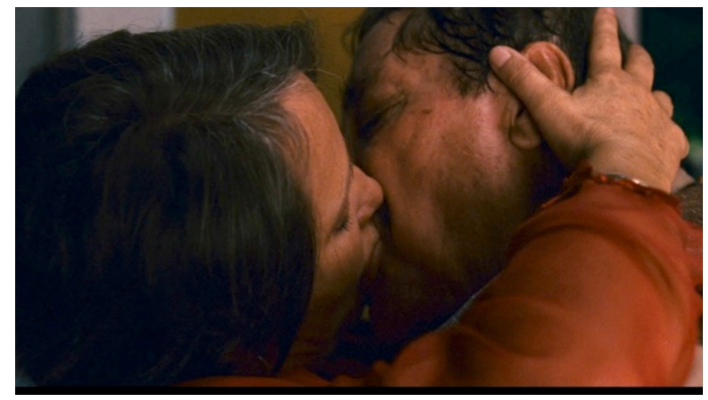

Figura 5.25 - Durante a festa, Amelia tem encontro romântico casual com velho conhecido

As transições entre os blocos do filme vão se sucedendo com variações de cortes secos ou interpenetrações sutis de alguns elementos sonoros diegéticos entre uma história e outra, até que assume outro padrão com músicas extradiegéticas semelhantes estabelecendo longas pontes sonoras a partir da transição entre a sequência do Japão na qual Chieko tenta seduzir o detetive Kenji (16 - "Sedução") e a de Marrocos com pai e filhos sobre tiroteio policial (17 “Cerco", à 1h42min28s). As músicas passam a fazer longas pontes sonoras que entrelaçam as histórias com variações do mesmo tema e marcante presença das cordas do oud em muitas delas.

Além das semelhanças entre elas, as músicas extradiegéticas se distinguem das sonoridades regionais das linhas narrativas tanto pelos arranjos quanto pela função que exercem na trama. A homogeneidade das músicas, na parte final do filme, estimula a percepção das amarrações entre as várias histórias. Enquanto canções populares regionais, diegéticas e extradiegéticas tratam de sentimentos específicos, a trilha sonora original imprime também uma força emocional de transnacionalidade. Iñárritu destacou que a sonoridade do oud, apesar de afromediterrânea, tem a capacidade de evocar o violão flamenco e mexicano com um toque do 
koto $^{128}$ japonês e que "a genialidade de Santaolalla tornou possível juntar as três culturas sem a necessidade de se recorrer aos instrumentos folclóricos de cada país, o que seria terrível" (GARCÍA, 2007, p. 259, tradução nossa). ${ }^{129}$

A primeira inserção da musicalidade transnacional emotiva, operando ponte sonora na transição de sequências, acontece entre um plano de Chieko sendo abraçada pelo detetive Kenji e Abdullah abraçando seu filho, Ahmed, baleado pela polícia (entre as Sequências 16 e 17). Visualmente, o corte tem o mesmo padrão das transições já analisadas entre as Sequências 1 e 2 - de garotos correndo no Marrocos para crianças correndo em casa na Califórnia - e entre as Sequências 13 e 14 - de policial marroquino sendo baleado, para casal dançando no casamento mexicano -, nas quais as semelhanças de composição e movimentação dos planos suavizam a passagem entre imagens consecutivas. A diferença ocorre na composição da banda sonora causando efeitos perceptivos bem caracterizados. Nas duas primeiras transições citadas (1 para 2 e 13 para 14), os sons ambientes dos planos são cortados na emenda, ressaltando a fratura entre os mundos das histórias, enquanto que na terceira transição (16 para 17) a música extradiegética atravessa a junção dos planos, suavizando a passagem e ressaltando a comunicação emocional entre os universos entrelaçados.

A música funciona como um amálgama, juntando a compreensão do detetive japonês, confortando a desiquilibrada Chieko, com o desespero do pai, abraçando o filho ferido. Os sofrimentos entrelaçados são muito distintos - psicológico de Chieko e físico de Ahmed assim como a vinculação entre os envolvidos - a adolescente é uma desconhecida para Kenji e a outra relação é de pai e filho. Há também, nessa emenda, o contraste entre a pulsão sexual de vida e a ameaça da morte, tema recorrente na obra de Iñárritu de forma explícita ou nas entrelinhas. A música unificadora original extradiegética ressalta a conexão da solidariedade paternal com a sensibilidade de Kenji que, mesmo não correspondendo ao desejo sexual da estranha nua, que insiste em levar a mão dele ao seu seio, consola afetuosamente a consternação da garota.

As pontes musicais servindo-se das músicas extradiegéticas originais vão ficando cada vez mais longas na trilha sonora de Babel, como na passagem associando o desespero de Abdullah ao desfecho do cerco marroquino, como o de Amelia, vagando abandonada no deserto, carregando as crianças americanas (entre as Sequências 17 e 18). Nesta transição, a monta-

\footnotetext{
${ }^{128} \mathrm{O}$ koto é um instrumento musical de cordas dedilhadas, composto de uma caixa de ressonância com diversas cordas, semelhante a uma grande cítara. Atualmente é o mais popular dentre os instrumentos musicais tradicionais japoneses. Tanto quanto piano ou violino, meninas em idade escolar aprendem o koto.

${ }^{129}$ No original: "Santaolalla genius made it possible to bring the three cultures together with no need to resorting to the folkloric instruments of each country, which would have been dreadful.” (GARCÍA, 2007, p. 259)
} 
gem optou por abrir a nova sequência com uma imagem desoladora do cenário do casamento mexicano no dia seguinte da festa, com som de ganidos de cachorros misturados à música extradiegética, para, só em seguida, mostrar a ação principal de Amelia caminhando perdida já do outro lado da fronteira. A intromissão de um espaço distinto da ação principal da sequência torna a passagem ainda menos previsível e acrescenta outra camada de informação mais intuitiva no encadeamento dos planos, apontando para o desencantamento da realidade depois da euforia da festa.

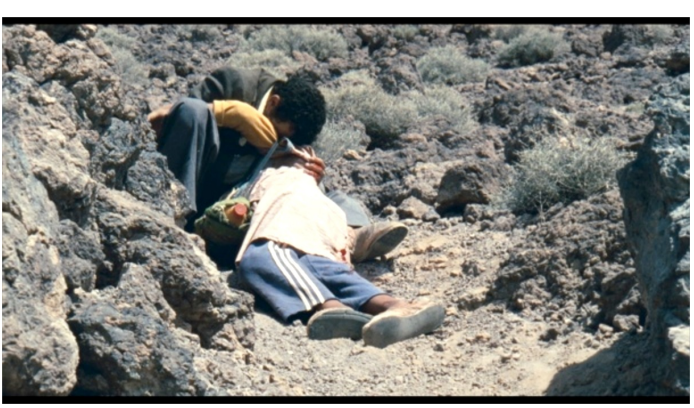

Figura 5.26 - Abdullah agarra seu filho Ahmed que foi mortalmente baleado pela polícia

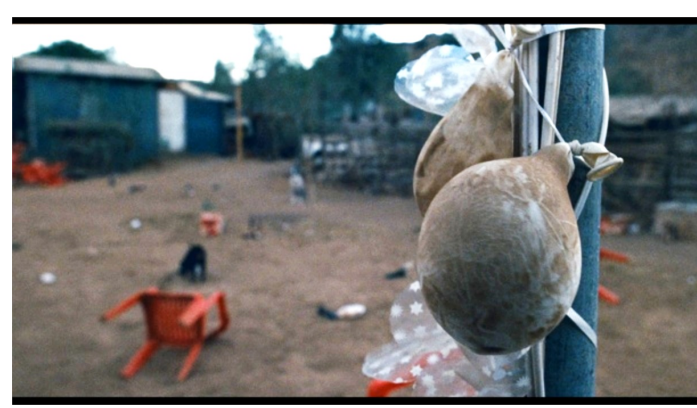

Figura 5.27 - Local da festa do casamento desolado ao amanhecer do dia seguinte

A transição seguinte, de Amelia perdida no deserto para Richard e Susan se perdoando e reatando, traz outras surpresas articulatórias (entre as Sequências 18 e 19). A primeira novidade é uma falsa passagem de bloco. Ao final da sequência 18, Amelia está desesperada procurando as crianças no deserto com a patrulha de fronteira. Em um primeiro momento, a música extradiegética ganha proeminência em relação aos diálogos e sons ambientes da cena atingindo níveis similares aos das pontes sonoras das transições anteriores. Em seguida, quando surge um helicóptero, a mixagem recua a música para segundo plano e dá volume para o som direto. Na sequência anterior de Richard e Susan, foi dada a informação de que um helicóptero estaria a caminho para o resgate. A informação, antecipando a vinda da aeronave, em associação com a presença da ponte sonora, que se estabeleceu como padrão recente das transições do filme, induz o espectador a acreditar que se trata do helicóptero que veio resgatar Susan e que teria se sucedido a passagem de uma história para a outra. Entretanto, a câmera desce do céu para o chão e mostra que segue a cena de Amelia no deserto, sendo a aeronave da patrulha de fronteira.

A construção configura um drible na expectativa da audiência e diminui a previsibilidade da montagem. A música volta a subir para primeiro plano e parece que a sequência vai continuar sua progressão quando, em uma nova surpresa, poucos segundos à frente, a voz de 
Susan chamando pelo nome de Richard se sobrepõe à imagem de Amelia, desesperada pelo sumiço das crianças, sendo colocada dentro do carro da patrulha. Só então, ocorre a transição para Susan pedindo a Richard para cuidar das crianças se ela morrer. Primeiro, a montagem insinuou que iria fazer a passagem entre essas histórias e, depois, antecipou a voz de Susan na transição, recurso utilizado exclusivamente nesse ponto do filme, associando a preocupação maternal com as crianças de ambas as cuidadoras, a biológica e a funcional.

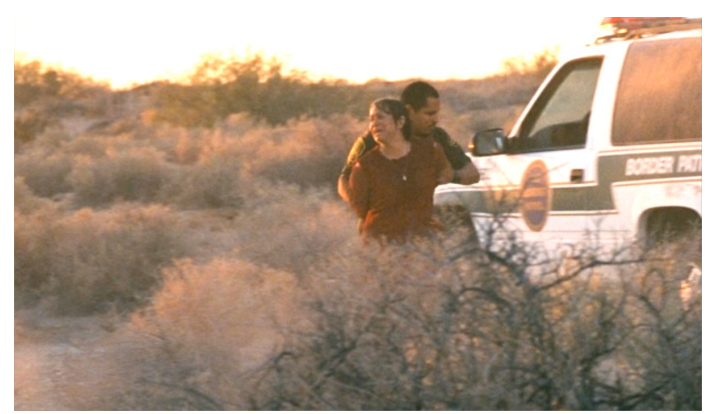

Figura 5.28 - Amelia é colocada no camburão da patrulha de fronteira sem encontrar as crianças no deserto

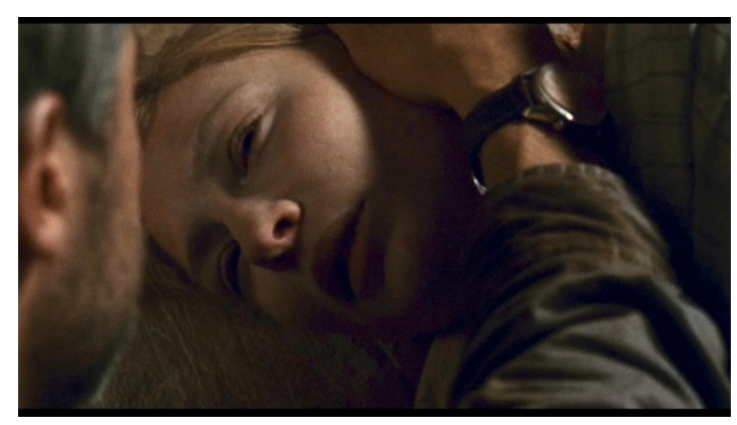

Figura 5.29 - Richard e Susan se reconciliam com muita emoção

As pontes sonoras continuam oferecendo formas mutantes e trazendo novas surpresas ao final do filme. Ao término da sequência da deportação de Amelia, a música transnacional emotiva toma a banda sonora e corta-se do rosto sofrido da mexicana coberto com as mãos para uma imagem sem foco de luzes em movimento de um lugar não identificável. Novamente, a construção insinua que seja uma passagem para outra história, mesmo porque o diálogo de Amelia com o oficial de fronteira foi conclusivo, não havendo mais nenhuma informação lógica necessária para a compreensão da situação. Mais uma vez, a montagem surpreende quando a imagem indefinida ganha foco e mostra Luis acolhendo sua mãe, na divisa, com as vestes que usou em seu casamento em farrapos.

A cadeia causal da sequência estava completa, mas faltava seu ápice emocional após tantas perdas, Amelia é repatriada e ganha sua família de volta. O espectador teve a oportunidade de contemplar como sua comunidade vive no México, e pode imaginar o quanto ela deve sentir falta do convívio com os entes queridos de seu país de origem. A música segue reinando absoluta, acontece a transição para um grande plano geral do deserto pedregoso do Marrocos com um barco misterioso ao fundo que deflagra uma montagem de planos de Ahmed sen- 
do carregado desfalecido nos braços do pai, seguido de um close up virtuoso de Yussef ${ }^{130} \mathrm{e}$ imagens dos irmãos brincando ao vento (Sequência 22).

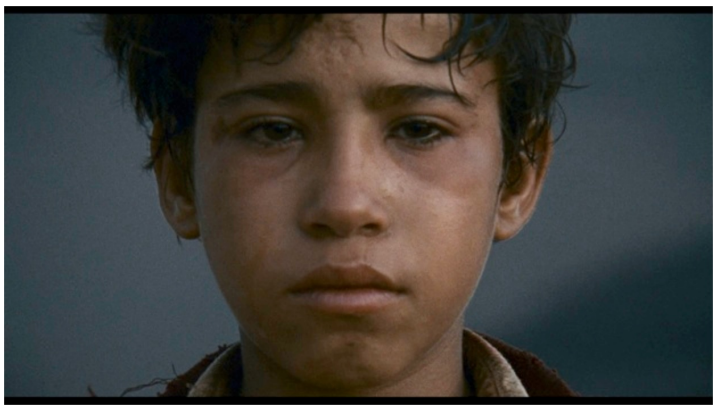

Figura 5.30 - O movimento de câmera ao redor do rosto de Yussef encadeia sua subjetividade

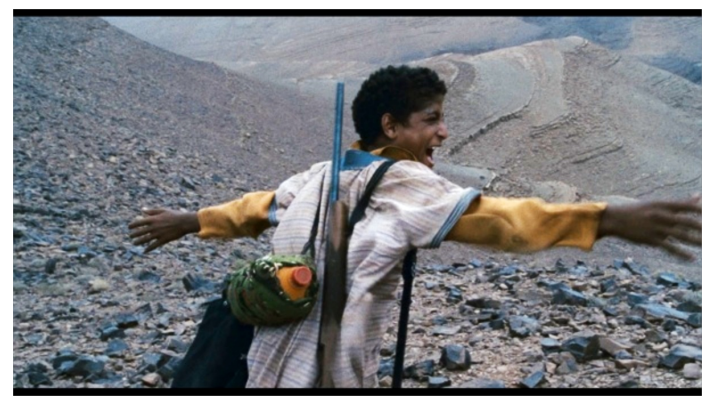

Figura 5.31 - Ahmed morto reaparece brincando ao vento como uma lembrança de Yussef

Não há som ambiente algum acompanhando a música na brevíssima aparição de uma cena do passado dos irmãos pastores, a de menor duração no filme (trinta e três segundos). Do plano de Ahmed brincando com o vento de braços abertos, corta-se para o helicóptero finalmente chegando para resgatar Susan. A música segue solando durante toda remoção de Susan da aldeia, a comovente recusa do punhado de dólares oferecido por Richard ao seu guia em gratidão, o voo do helicóptero sobre o deserto até sua chegada em um heliporto em Casablanca. No pouso, a música ganha a companhia do som ambiente com o burburinho dos repórteres cobrindo a chegada e segue até a entrada de Susan na área restrita do hospital. A música só cessa quando um médico vem explicar para Richard que vão ter que operar emergencialmente Susan, porque houve uma hemorragia e ela corre o risco de perder o braço. Os extensos quatro minutos em que a música tocou incessante estabelecem, com muito lirismo, interconexões entre os fechamentos de três das quatro histórias do filme. Amelia perde sua vida nos Estados Unidos e volta ao México só com os documentos e a roupa do corpo suja e esgarçada. Yussef perde seu irmão. Susan é resgatada, mas seu estado de saúde é incerto e, somente na última sequência da história japonesa, saber-se-á de seu destino.

\footnotetext{
${ }^{130} \mathrm{O}$ close up de Yussef na sequência 22 é um dos três planos nos quais se usou câmera sobre trilhos (dolly) na filmagem de Babel. O uso do carrinho, nesse caso, justifica-se devido à necessidade narrativa de trazer uma imagem de natureza diferenciada das demais para encadear a subjetividade de Yussef no momento da morte de seu irmão. Outro plano feito com uso de carrinho digno de nota é o último do filme com a câmera se afastando de Yasujiro abraçando sua filha Chieko nua, abandonando-os na varanda do apartamento em Tóquio, e que insinuaque aquela é apenas uma dentre a infinidade de histórias que se sucedem naquela metrópole e no mundo (Figura 5.46). O terceiro plano feito com carrinho é o travelling da abertura do filme, que mostra Hassan caminhando nas montanhas a caminho da casa de Abdullah. Como a câmera estava na mão, nesse plano, em vez de em um tripé, a instabilidade da imagem quase não permite que se note que se trata de movimento feito com carrinho em trilhos, exceto pela movimentação do fundo.
} 
Como analisado em minúcia nesta seção, as junções entre as sequências das linhas narrativas de Babel constituem-se como fronteiras deflagradoras de criação de significados ao distinguir e conectar as histórias por meio de estratégias articulatórias com expressiva participação da banda sonora. Em um primeiro momento, a montagem ressalta os contrastes entre as realidades abordadas, valendo-se principalmente da separação em corte seco de músicas e sons ambientes diegéticos, valorizando os contrastes. Gradualmente, a trama vai implementando variações de interpenetrações comedidas dessas sonoridades internas das cenas, para começar a tecer a amarração entre os universos das histórias. No terço final do filme, enfatizam-se as conexões entre as vidas de suas personagens, principalmente por meio da utilização consistente de música extradiegética. A unidade estética do filme é alcançada pela miscigenação entre estratégias articulatórias de montagem e edição de som que combinam alguns recursos com feitios mais convencionais, com outros, mais experimentais, tornando a narrativa menos previsível e estimulando o espectador a ficar mais alerta.

Após o detalhado exame da estrutura narrativa de Babel, torna-se oportuno aprofundar a reflexão sobre a proeminência do drama estadunidense no cômputo geral da trama, as relações de poder entre as fronteiras e investigar outras estratégias utilizadas para dar alcance maior a uma narrativa autoral com traços experimentais.

\subsection{Sutura de diferenças contrastantes}

As amarrações formais engendradas pelas estratégias descritas no item anterior estão vinculadas a uma situação histórica que propicia uma sustentação lógica para toda a trama. A teia expandida da narrativa fragmentada de Babel, com multiplicidade de etnias e culturas, em diversos continentes, embaralhada não-linearmente, consegue obter unidade por meio da verossimilhança de seu conflito matriz. A trama funciona, é crível que qualquer incidente envolvendo americanos no mundo árabe é facilmente interpretado como um ato terrorista, muito em função das consequências do atentado de 11 de setembro de 2001 no cenário internacional. A teia de conexões do filme só se sustenta porque a vítima do incidente do tiro é uma cidadã estadunidense, o que provoca o envolvimento de instâncias governamentais nacionais e internacionais em seu desenlace e ampla repercussão na mídia internacional.

A proeminência do drama do casal estadunidense no cômputo geral da trama foi reforçado ao se elencar para interpretá-lo dois atores hollywoodianos conhecidos mundialmente. Os papéis de Richard e Susan na estrutura do filme têm pesos semelhantes aos de Amelia e 
Chieko e Yussef, todos protagonistas de suas histórias. Entretanto, ter atores famosos como Cate Blanchett e, principalmente, Brad Pitt no elenco afeta a percepção da trama e constitui-se em mais uma estratégia que contribui para tornar os aspectos experimentais da narrativa do filme acessíveis para uma extensa audiência. Se, por um lado, a direção de atores precisa se esforçar para fazer as estrelas desaparecerem por trás das personagens para que se possa acreditar em seus dramas, por outro, a presença de atores dessa magnitude no filme oferece dois pontos de contato familiares que facilitam a promoção, receptividade e identificação não só para o público do opulento mercado estadunidense, mas em todo o planeta. A presença da dupla de estrelas também opera como uma chancela de produto mainstream ${ }^{131} \mathrm{em}$ um filme falado em muitas línguas, com atores pouco conhecidos do grande público (Gael Garcia Bernal, Adriana Barraza e Rinko Kikuchi) e até a atuação de não profissionais em papéis importantes em todo o núcleo marroquino. ${ }^{132}$

Pitt e Blanchett oferecem uma espécie de compensação de fácil assimilação ao espectador para reparar os desgastes gerados pelo estranhamento das diversas línguas, lugares e pessoas, superar o desconforto das legendas e suavizar a assimilação das rupturas das convenções empreendidas na tessitura de sua narrativa. Apesar da participação em tela da dupla hollywoodiana ser similar à dos demais protagonistas, ela incrementa o alcance do filme a um público mais vasto, aspecto assaz explorado na promoção de Babel.

\footnotetext{
131 “Mainstream - literalmente, 'dominante' ou 'grande público'. Diz-se, por exemplo, de um produto cultural voltado para o público em geral. 'Mainstream culture' pode ter uma conotação positiva, no sentido de 'cultura para todos', mas também, negativa, no sentido de 'cultura dominante'. (MARTEL, 2012, p. 479)

${ }^{132}$ Iñárritu conta, em conversa com Rodrigo García, que após tentativa frustrada de arrumar atores profissionais no Marrocos e em comunidades muçulmanas de Paris para os papéis dos meninos pastores, suas famílias e vizinhos, bem como para as personagens da história de Richard e Susan, decidiu-se por empreender uma desesperada pesquisa por não profissionais nas vilas pobres próximas de Tamnolgalt e Quarzazate. Dezessete dias antes de começarem as filmagens no Marrocos, a produção do filme não tinha nenhum ator além de Brad Pitt e Cate Blanchett. O processo de atração e seleção de atores não profissionais foi realizado com anúncios em autofalantes de minaretes, torres das mesquitas, testes em vídeo e exercícios com os selecionados por apresentarem compleição física adequada para os papéis. Para atenuar as dificuldades de direção de pessoas comuns em uma língua desconhecida (árabe e berbere), Iñárritu contou com a preciosa colaboração da atriz Hiam Abbas como coach de diálogos. O diretor defende que, apesar das limitações técnicas de se trabalhar com atores não profissionais, a "inocência é e sempre será mais poderosa que a experiência. A virgindade, pureza e honestidade em se fazer o papel de si mesmo não pode ser igualado." Iñárritu diz ter aprendido que "se a pessoa tem uma característica por meio da qual é possível se identificar com a personagem, quando o diretor a encontra e comunica seus objetivos dramáticos claramente, de uma forma simples, ele pode fazer qualquer ser humano do planeta atuar". (GARCÍA, 2007, p. 259-260)
} 


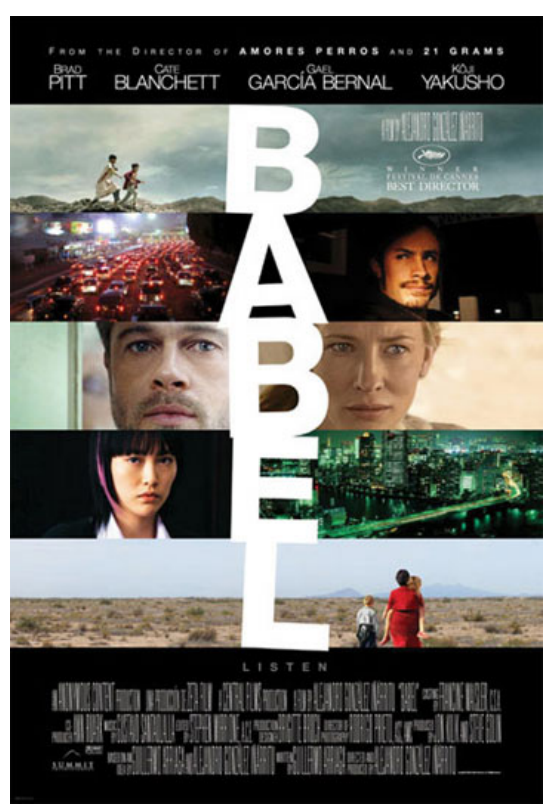

Figura 5.32 - Cartaz de Babel

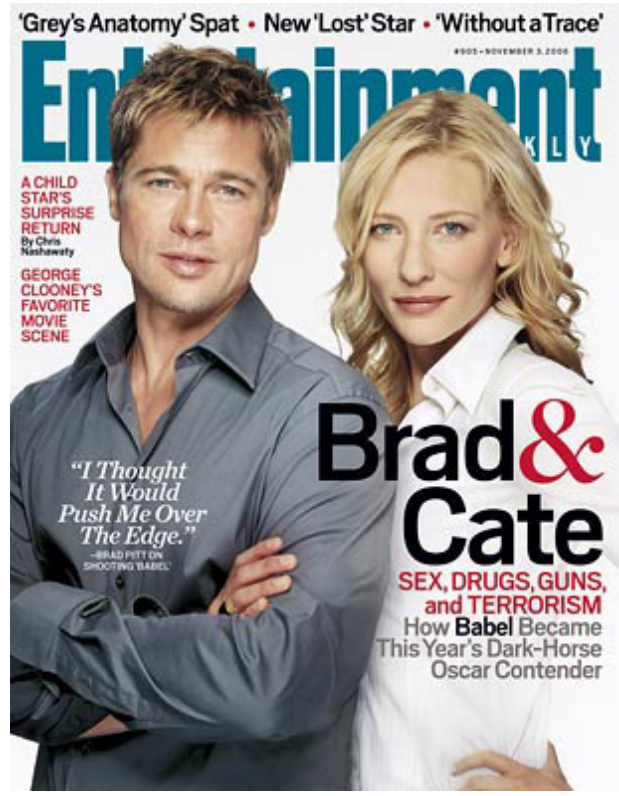

Figura 5.33 - Capa da revista Entertainment

$\mathrm{O}$ arte do cartaz (Figura 5.32) explicita a estratégia promocional do filme ao destacar Pitt e Blanchett, colocando seus rostos em enquadramentos mais fechados e em escala maior que os demais atores e bem ao centro da peça. ${ }^{133}$ A revista Entertainment, além de estampar as estrelas de Babel na capa de sua edição de novembro de 2006 (Figura 5.33), coloca o filme como candidato a azarão no Oscar, abordando suas temáticas por um viés que ressalta aspectos que seriam melhor absorvidos pelo grande público. O matéria fala de sexo, drogas, armas e terrorismo, quando, de fato, no filme, esses motes são tratados de forma bem diferenciada do padrão corriqueiro hollywoodiano. De início, a indução da associação das imagens e nomes do casal de estrelas com a primeira palavra do título, sexo (sex), não acontece no filme. Ao invés disso, as questões sexuais estão presentes em situações pouco convencionais em encontro casual entre casal de mais idade - Amelia e velho conhecido em meio a festa de casamento - e nas vivências conturbadas dos adolescentes Yussef e Chieko, assunto que será aprofundado mais à frente nesta mesma seção. Nas cenas do filme, pouco aparecem drogas ilícitas e nem armas - apenas duas ocorrências de cada - e o que é interpretado inicialmente como um ato terrorista, na verdade, não passa de um incidente sem nenhuma motivação política.

\footnotetext{
${ }^{133}$ A estratégia promocional de destacar Brad Pitt e Cate Blanchett induz à percepção de que eles sejam os únicos protagonistas de Babel, o que explicaria o fato de Adriana Barazza (Amelia) e Rinko Kikuchi (Chieko) terem sido indicadas ao Oscar na categoria de Melhor Atriz Coadjuvante, mesmo sendo também personagens principais da multitrama do filme.
} 
Apesar de Iñárritu insistir que seus filmes sejam sobre relacionamentos entre pais e filhos, Babel explora constantemente os contrastes sociais, econômicos e culturais entre os países abastados, Estados Unidos e Japão, e os despojados México e Marrocos. O mundo globalizado é conectado por movimentos populacionais e pela mídia, onde os ricos movem-se por prazer e os pobres por necessidade. Os movimentos populacionais constituem espaços de fluxo seja pelo turismo ou pela migração em busca de trabalho e melhores condições de vida. As desigualdades nas relações de poder entre países de poderios econômicos díspares fícam evidentes nas representações das implicações do incidente e na relação das polícias das várias nações com os envolvidos na trama.

A situação do tiro acidental configurou-se devido à atividade de turismo internacional, tanto na disponibilização do artefato letal quanto na aparição da vítima. O rifle só foi parar nas mãos do jovem Yusssef, porque Yasujiro deslocou-se de sua requintada Tóquio para uma área rudimentar do Marrocos para caçar animais selvagens. O turismo de caça transnacional, geralmente, provoca o contato entre pessoas que vivem em realidades muito díspares. De um lado, turistas com alto poder aquisitivo oriundos de sociedades sofisticadas, do outro, guias e serviçais muito simples que ganham seu sustento em atividades vinculadas à natureza, como agricultura, pesca e criação de animais. O gesto de Yasujiro ao doar a arma ao guia Hassan, deve ter sido motivado pela melhor das intenções e gratidão pela experiência que o marroquino lhe ofereceu. Hassan proporcionou a Yasujiro algo quase impossível de ele usufruir em seu país natal, abater um belo espécime silvestre. Em retribuição, ofereceu-lhe de presente algo igualmente raro no universo de Hassan, um instrumento requintado tecnologicamente. O trânsito do rifle articula a conexão circular da narrativa.

Um artefato de uma sociedade, quando inserido em outra, pode ganhar diferentes significados e funções. O rifle de alta tecnologia acaba trocado por um punhado de dinheiro e uma cabra e cai nas mãos de jovens imaturos. Pré-adolescentes dificilmente teriam acesso ao mesmo rifle no Japão. O uso da arma é ressignificado ao sair de uma sociedade pós-industrial e inserida em outra que vive um estágio civilizatório pré-industrial. De artefato de lazer de luxo, o rifle passa a ser objeto de trabalho para defesa de rebanho de criação contra animais selvagens, chacais. A arma é superdimensionada para sua nova função, seus operadores desqualificados para sua operação e o resultado, nefasto. A transferência de um único artefato entre culturas em diferentes níveis de desenvolvimento socioeconômico é capaz de provocar uma tragédia.

O turismo transnacional também é o agente que vai colocar Susan na alçada do tiro de Yussef com o rifle que foi de Yasujiro. Os dois estadunidense estão no Marrocos "para fica- 
rem sozinhos", como afirma ironicamente Richard na primeira sequência dessa história no filme. Da conversa do casal no almoço antes do incidente, o espectador apreende que estão viajando com uma motivação terapêutica, revitalizar a relação que passa por uma crise devido à perda de um filho recém-nascido. Para tanto, deixaram para trás em San Diego seu casal de crianças sob o cuidados da empregada ilegal mexicana Amelia. Como visto, o incidente atrasa o retorno de Richard e Susan para os Estados Unidos, induzindo Amelia a atravessar a fronteira com o México, levando as crianças Mike e Debbie para o casamento de seu filho. A travessia de fronteira de volta é complicada pelo comportamento inadequado de Santiago e a clandestinidade com que a empregada levou as crianças para o outro lado coloca Mike e Debbie em risco de morrer no deserto.

A viagem terapêutica do casal para superar a crise da perda de um filho quase acarreta a morte dos outros dois. Se Amelia foi irresponsável e inconsequente em levar as crianças para o México, Richard e Susan foram imprudentes em deixá-las com a empregada sem ter outra pessoa de confiança para intervir em caso de imprevistos. As pessoas a quem os patrões recorrem desconsideraram a relevância do casamento do filho para Amelia - chegam a sugerir que se adie o casamento - em uma atitude autoritária ao exigir a sujeição à prioridade dos empregadores sem sensibilidade para com a situação do empregado. Não é oferecida à Amelia outra alternativa para conciliar o zelo com as crianças dos patrões e o compromisso inadiável com seu próprio fillho. A situação expõe a disparidade nas relações de poder entre empregadores e trabalhadores ilegais, conforme aponta Hassapopoulou: "A deportação de Amelia, uma mexicana trabalhando como doméstica nos EUA, mostra como algumas partes do mundo (ou, nesse caso, algumas etnias) não se beneficiam da conexão global tanto quanto outras" (HASSAPOPOULOU, 2008). ${ }^{134}$

Richard e Susan penam muito no Marrocos, mas se reconciliam em uma das cenas mais tocantes do filme, a salvação acaba chegando na forma de helicóptero da cruz vermelha para resgatá-los na aldeia, e também como patrulha de fronteira no aludido salvamento de Debbie e Mike no deserto. Por sua vez, os filhos das nações desprovidas não têm a mesma sorte. O irmão inocente de Yussef, Ahmed, é morto pela polícia marroquina e Amelia é deportada. Chieko não resolve seu trauma pelo suicídio da mãe e nem sua ansiedade sexual, mas nada de mais grave lhe acontece - apenas o rapaz que ela estava desejando na boate fica com sua melhor amiga - e termina confortada pelo detetive Kenji e acolhida nos braços do pai.

\footnotetext{
${ }^{134}$ No original: "The deportation of Amelia, a Mexican working as a domestic in the U.S., shows how some parts of the world (or, in this case, some ethnicities) do not benefit from global networking as much as others." (HASSAPOPOULOU, 2008)
} 
Durante as interações, os menos favorecidos financeiramente têm perdas muito mais contundentes do que os endinheirados. Se Debbie e Mike tivessem padecido no deserto devido à ferocidade da política de patrulhamento da fronteira de seu próprio país, a história de Richard e Susan não teria tido o "final feliz" que anunciou a apresentadora do telejornal japonês em seu desfecho. A assimetria das perdas humanas entre os protagonistas do filme favorece o casal estadunidense, inclusive, com contornos de redenção e bem-aventurança.

As desigualdades das relações de poder entre ricos e pobres também ficam evidentes nas travessias de fronteiras e nas intervenções policiais. Ao ingressar no México, não há nenhum controle, levando Santiago a ridicularizar a situação, comentando jocosamente a facilidade de se "entrar no paraíso". No sentido inverso, mostra-se a assimetria no tratamento dos que vêm do México para os Estados Unidos com tratamento rude e invasivo, sem pudores em literalmente meter a mão nos pertences dos revistados e humilhá-los (Sequências 14 - "Patrulha de fronteira" -, 18 - "Perdidos no deserto" - e 21 - "Deportada"). ${ }^{135}$

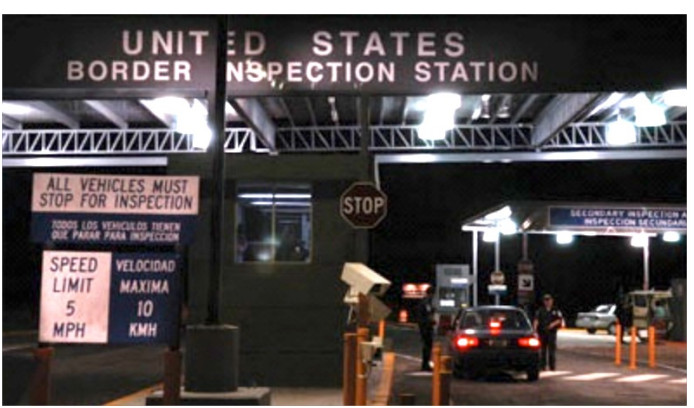

Figura 5.34 - Fronteira estadunidense

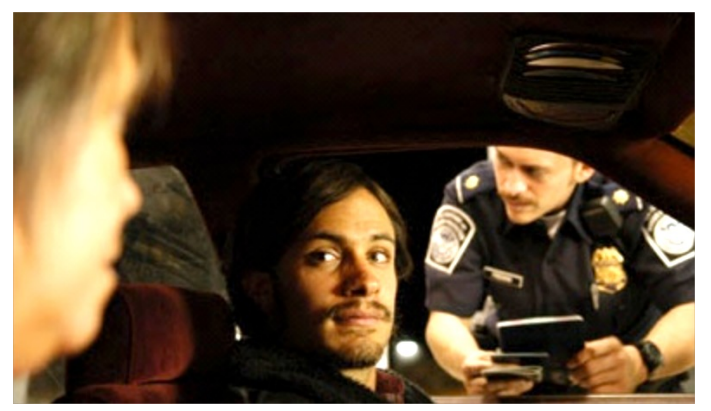

Figura 5.35 - Oficial de fronteira estadunidense impõe seu poder ao questionar Amelia e Santiago

Os policiais marroquinos são extremamente truculentos ao abordar Hassan, ainda na condição de suspeito, interrogá-lo sob espancamento, e também ao chegar já atirando em Abdullah e seus filhos nas montanhas, sem, ao menos, dar voz de prisão. Entretanto, quando guardas marroquinos são afrontados por Richard desesperado pela demora do socorro - "é seu país fodido, faça alguma coisa!" (Richard para policial marroquino na Sequência 15 - "Sem

\footnotetext{
${ }^{135}$ A representação das travessias de fronteira entre México e Estados Unidos, em Babel, contem influências da experiência pessoal de Iñarritu que passou a cruzá-la periodicamente, a cada seis meses, para renovar os vistos de sua família depois da mudança para Los Angeles. Iñárritu considera aquela fronteira abusiva e lembra que os EUA têm, lá, o maior muro jamais construído entre países vizinhos. Ele critica a desigualdade no acesso entre os dois sentidos e ironiza a falta de controle na entrada do México para quem vem dos EUA: "Você pode atravessar com seu carro com gente sequestrada em seu porta-malas ou uma bomba atômica. Ninguém vai te parar. [...] No sentido contrário, quando você volta é um questionamento sem fim e um ritual de humilhação.”
}

No original: "You can drive through in your car, you can have people kidnapped in your trunk or an atomic bomb. Nobody will stop you. [...] On the other hand, when you return it's neverending queues and a ritual of humiliation." (IÑÁRRITU, 2009, apud DELEYTO; AZCONA, 2010, p. 126, informação oral, tradução nossa) 
transporte". Tradução nossa). ${ }^{136}$ - reagem com passividade diante do estrangeiro, empoderado pela força de sua nação de origem. Por sua vez, os policiais japoneses são bastante educados ao abordar Yasujiro para questionar sobre o rifle, e o Tenente Kenji chega a ser sensível e delicado ao confortar Chieko após ser assediado inapropriadamente por ela. As interações das forças mantenedoras da ordem de diferentes nacionalidades com os envolvidos no incidente explicitam as assimetrias dos direitos dos cidadãos pertencentes a diferentes classes sociais.

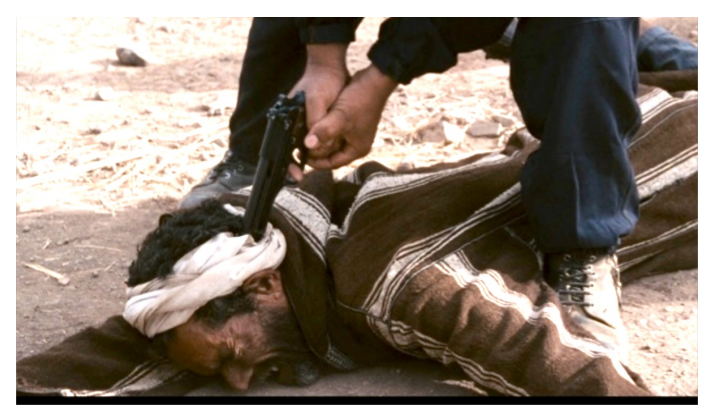

Figura 5.36 - Polícia marroquina é violenta ao abordar Hassan como suspeito

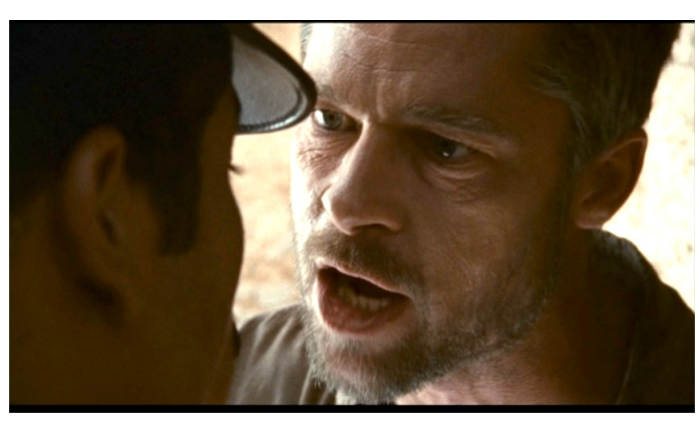

Figura 5.37 - Richard destrata policial marroquino, que não reage

Há, em Babel, outra fronteira, não menos turbulenta, a passagem da infância para a fase adulta, abordada por meio das experiências de iniciação sexual de Yussef e Chieko. Em contextos muito distintos, ambos os adolescentes atravessam limites impostos pelas convenções sociais ao darem vazão a seus desejos. A opção de tratamento do tema universal da iniciação sexual em Babel conta com aspectos delicados de serem endereçados para uma audiência ampla. Dentro de uma família tradicional islâmica, Iñárritu mostra Yussef espiando sua irmã se despir conivente com seu prazer incestuoso voyeurístico e, em seguida, masturbandose. Cheiko está desesperada para ter relações sexuais. Em um único dia, ela tira a calcinha e exibe sua genitália em um restaurante, lambe o dentista no consultório e coloca a mão dele em sua região erógena e, como se não bastasse, despe-se e tenta seduzir o detetive Kenji. Yussef e Chieko, apesar de todas as diferenças em suas vidas, têm em comum a manifestação de suas pulsões em desacordo com as normas vigentes das sociedades em que estão inseridos, são iniciantes divergentes. Ambos seguem seus instintos, quebrando regras, entretanto, suas inadequações comportamentais terão consequências muito díspares determinadas pelo nível civilizatório das comunidades em que vivem.

\footnotetext{
${ }^{136}$ No original: "This is your fucked up country, do something!"
} 


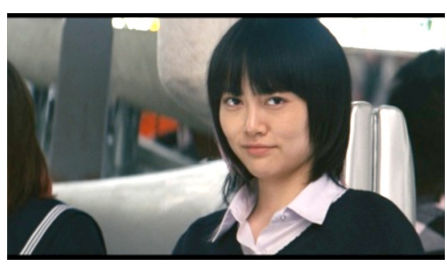

Figura 5.38 - Chieko decide vingar-se do preconceito de garotos

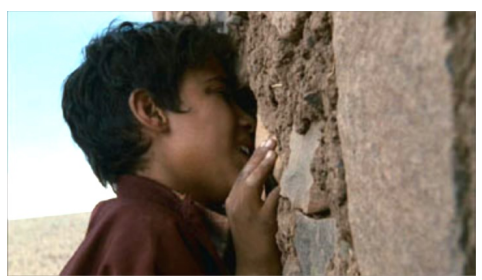

Figura 5.41 - Yuseff observa incestuosamente a irmã

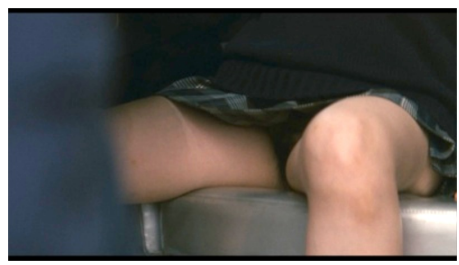

Figura 5.39 - Chieko expõe sua genitália por baixo da mesa

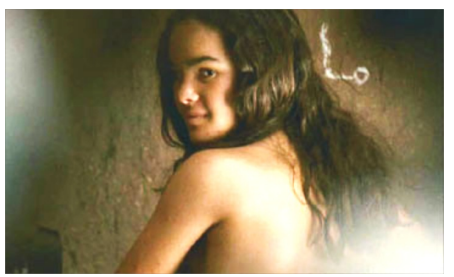

Figura 5.42 - Irmã se exibe para Yussef

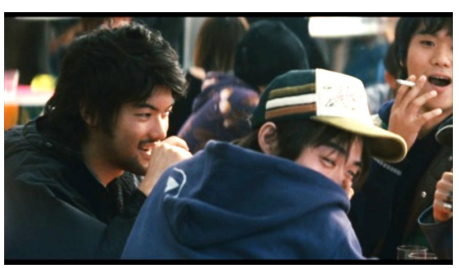

Figura 5.40 - Garotos reagem com risos tensos

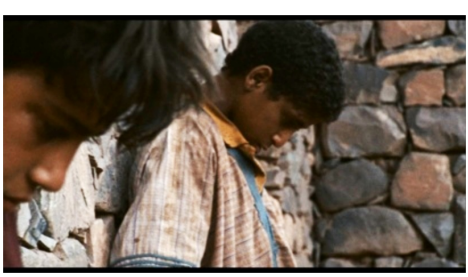

Figura 5.43 - Yussef e Ahmed são repreendidos pelo pai

As exposições e tentativas de sedução atabalhoadas de Chieko não têm maiores consequências além de sua própria frustração em não conseguir consumar suas vontades. Os garotos do restaurante apenas riem - de nervoso, talvez - do exibicionismo de Chieko; o dentista coloca a garota para fora do consultório com um misto de espanto e firmeza depois de três investidas inapropriadas; e o detetive Kenji chega a ser afetuoso após a adolescente ter se oferecido nua para ele em um apartamento vazio - até cobre-lhe carinhosamente com seu sobretudo. Por sua vez, Yussef apanha e é fortemente repreendido por seu pai, quando este fica sabendo do comportamento inadmissível entre os irmãos. Abdullah fala que Yussef desgraçou a família e dá a entender que o ocorrido entre os irmãos foi mais grave do que o tiro na americana. Chieko e Yussef são atrelados na narrativa pelo desejo e inadequação e distinguidos pelos contrastes das conjunturas nas quais procuram consumar seus ímpetos.

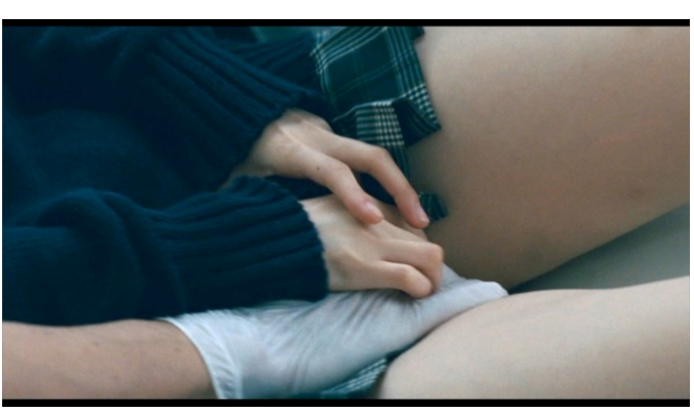

Figura 5.44 - Chieko leva a mão do dentista à sua genitália

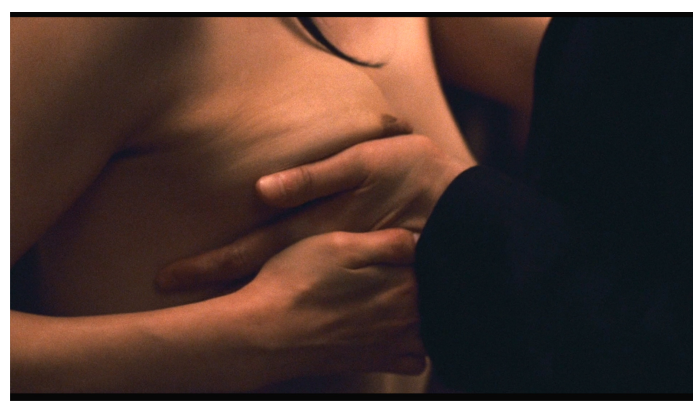

Figura 5.45 - Chieko conduz a mão do detetive Kenji ao seu seio 
Nesta seção, analisou-se a tessitura da sutura das assimetrias e contrastes presentes no elenco e no cerne da dramaturgia do filme. No tópico a seguir, examina-se como a estrutura multiplex de Babel encontra sustentação na mistura de articulações narrativas formais e temáticas experimentais, pouco comuns no cinema mainstream, com outras mais convencionais, que viabilizam uma composição que goza das benesses do engajamento imprevisível aportado pela multiplicidade e não-linearidade, sem, contudo, comprometer seu entendimento por uma larga audiência.

\subsection{Tessitura entre o convencional e o inovador}

É de amplo conhecimento e aceitação a premissa causal da trama de que qualquer acidente no mundo islâmico envolvendo um estadunidense é interpretado como um ato terrorista, assim como os efeitos sobre as pessoas e países envolvidos em um episódio dessa natureza. A consistência da premissa causal do filme garante, de partida, a verossimilhança da obra e facilita a imersão do público em sua fruição. Apesar de o filme abordar temas polêmicos, normalmente não retratados em filmes direcionados ao grande público - o comportamento sexual de adolescentes divergentes das normas sociais e as relações de poder desiguais entre forças policiais de países ricos e pobres -, eles são atenuados por uma amarração humanista que dá relevo à interconexão entre as pessoas em diferentes realidades. A demanda por um engajamento mais ativo do espectador na compreensão da imprevisibilidade do entrelaçamento nãolinear das vinte e quatro sequências de seus enredos é contrabalanceada pela linearidade interna de cada história. Além disso, as estratégias macroestruturantes da narrativa do filme são acrescidas de manipulações de seus materiais expressivos, sons e imagens, corroborando seu diferencial estético conciliador de elementos oriundos tanto do cinema de arte como do mainstream.

A montagem do filme integra duas formas articulatórias distintas ao entrelaçar a nãolinearidade entre as sequências dos diferentes enredos com a linearidade do encadeamento dos seguimentos da mesma história. Há predomínio da montagem "narrativa", na acepção de Marcel Martin (2007, p. 132, acréscimos nossos), no interior das sequências, com o encadeamento lógico e cronológico de "planos que possuem individualmente um conteúdo factual, e [essa montagem] contribui para que a ação progrida do ponto de vista dramático [...] e psicológico", promovendo a compreensão da trama pelo espectador por meio da causalidade 
$\mathrm{Na}$ justaposição de planos das transições entre as sequências das quatro histórias do filme, a montagem adquire a forma "expressiva", ao privilegiar o choque ou também o espelhamento de situações, entre sons e imagens, criando efeitos de ruptura na percepção do espectador ao exprimir ideias e sentimentos em vez de priorizar a passagem suave em continuidade. A montagem expressiva promove a aliciação do espectador ao "fazê-lo saltar intelectualmente para que seja mais viva nele a influência de uma ideia expressa pelo diretor e traduzida pelo confronto de planos" (MARTIN, 2007, p. 132-133).

Conforme analisado, durante os dois terços iniciais do filme, a montagem expressiva das transições intersequenciais serviu-se de sons ambientes e músicas diegéticas para valorizar os contrastes e potencializar os choques gerando significados cognitivos e sensoriais. No terço final do filme, há uma mudança de estratégia na edição do som, quando passa-se a empregar música extradiegética original unificadora visando suavizar as transições e integrar os múltiplos enredos. A ousadia da adoção de silêncio absoluto em alguns pontos do filme, assumindo a percepção subjetiva surda de Chieko, é contrabalançada por sua combinação com música pop de fácil absorção na cena da boate. Essa articulação de áudio é uma, entre tantas, em que a música possui função de realce no filme, ao equilibrar experimentalismo com convenção.

A escolha do elenco do filme também combina estratégias tradicionais e experimentais. A escalação das estrelas hollywoodianas de fama internacional da envergadura de Brad Pitt e Cate Blanchett compensam o grande público com familiaridade e facilidade de identificação, em oposição ao estranhamento de atores pouco conhecidos e a ousadia da participação destacada de atores não profissionais, principalmente nas histórias que acontecem no Marro$\cos$.

Babel explora os contatos e conflitos entre diferentes culturas, classes sociais e gêneros agenciados pela mídia e os movimentos populacionais de turismo e migrações entre países. A desterritorialização é representada como condição permanente da transnacionalidade tanto em espaços tradicionais definidos pelos lugares físicos como pelos virtuais articulados pela sociedade de rede. Iñarritu trata dos espaços de fluxos em fronteiras geopolíticas e culturais, dos perigos, injustiças e discriminações, envolvendo pessoas em trânsito e seus impactos nas relações afetivas. Novas identidades miscigenadas e mutantes estão sendo urdidas nesses espaços de fluxo de pessoas e informações, paradoxalmente dependentes da continuidade da existência de especificidades nacionais que se transcendem, negam-se e se transformam em processo dinâmico incessante e interconectado. 


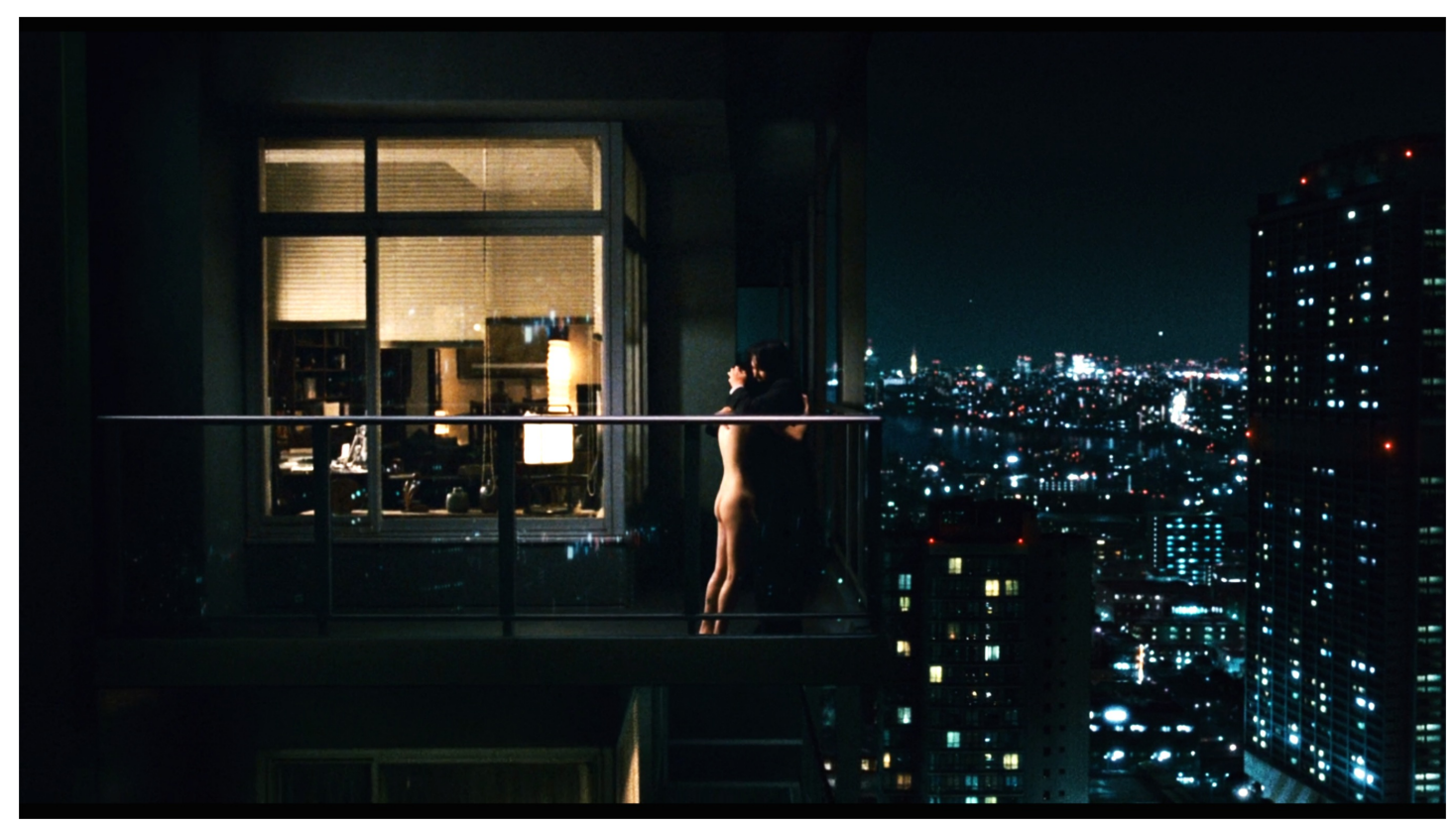

Figura 5.46 - Câmera se afasta em travelling inserindo pai e fillha na imensidão da noite de Tóquio

Na estreia de Babel no Festival de Cannes de 2006, Iñárritu declarou que seria seu último título que contaria com multiplicidade de tramas e protagonistas e não-linearidade, o que se cumpriu em sua realização seguinte, Biutiful (2010), que será analisada no próximo capítulo. 


\title{
CApítulo Vi
}

\section{BIUTIFUL: OS EXTREMOS DA VIDA}

\author{
"Alguien me habló todos los días de mi vida \\ al oido, despacio, lentamente. \\ Me dijo: ivive, vive, vive! \\ Era la muerte".
}

Jaime Sabines (in "Del mito", 1950) ${ }^{137}$

lejandro González Iñárritu, depois de bem sucedido com suas narrativas
fragmentadas caracterizadas por multiplicidade de tramas e protagonistas,
manifestou interesse em filmar uma história com um único personagem principal, de preferência que ocorresse na mesma cidade e falada predominantemente em sua língua mãe. A vontade do realizador se concretizou na realização de Biutiful (2010), ${ }^{138}$ que inova em suas manipulações não-lineares com a utilização de um flashforward estruturante e a transferência da ênfase de sua experimentação narrativa para o desenvolvimento das personagens e aprofundamento das questões temáticas relacionadas ao impacto das macro políticas socioeconômicas globalizantes nas relações interpessoais.

O quarto filme de Iñárritu preserva vários aspectos temáticos e formais em comum com suas realizações anteriores, mas também apresenta diferenciais marcantes na negociação narrativa que o diretor promove em sua obra entre o tradicional e o experimental. Solidão e morte seguem como motes proeminentes e ganham novos contornos com um único enredo (uniplot) e apenas um protagonista (uniprotagonista). Pluralidade e complexidade são entranhadas na tessitura da trama principalmente por meio da ramificação do enredo, da variedade

\footnotetext{
${ }^{137}$ Iñárritu pensou em usar esse poema no começo do filme, mas, depois, achou que ficaria muito óbvio. "Para mim ele [o poema] diz tudo. Você pode abraçar melhor a vida, pode apreciá-la mais, quando tem a consciência de que ela vai ter um fim. Você morde a vida." No original: "For me it says it all. You can better embrace life, you can enjoy it more, when you are conscious that it will end. You bite life." (IÑÁRRITU, DATA, apud SECHER, 2011, s.p.). Tradução nossa.

${ }^{138} \mathrm{O}$ título do filme é grafado conforme uma aproximação à língua espanhola dos fonemas da palavra em inglês beautiful.
} 
de camadas na construção das personagens, pelo impacto de um flashforward em sua estrutura e pela ruptura no realismo da representação. Iñárritu reconheceu que subestimou o quanto Biutiful demandaria dele na articulação de sua narrativa, que acabou ficando "bem mais complexo do que Babel”. (IÑÁRRITU, 2009, DELEITO; AZCONA, 2010, p. 138-139)

O cineasta, que já havia cruzado para o "outro lado", para viver em Los Angeles e realizar 21 gramas, filmado a travessia da fronteira entre Estados Unidos e México na história de Amelia em Babel, dessa vez, desloca-se com sua fiel trupe criativa - com exceção do dissidente roteirista Guillermo Arriaga - para Barcelona, Espanha, movido por um novo desafio: representar a passagem da vida para a morte. A diversidade se faz presente mais uma vez por meio das etnias, nacionalidades e línguas faladas em uma Barcelona marcada pelos impactos cruéis das relações de trabalho globalizadas nas interações afetivas entre nativos e migrantes ilegais africanos e chineses.

Em Biutiful, a não-linearidade ganha nova forma e função com a antecipação da última cena do filme como a primeira apresentada pela trama. A cena antecipada é justamente a da passagem da vida à morte de seu protagonista Uxbal (Javier Bardem). Apesar de ser a única articulação não-linear do filme, o flashforward tem profundo impacto na percepção da trama como um todo e é destacado do restante da narrativa por um escurecimento de tela (fade in), constituindo-se claramente como um prelúdio. Entre a primeira cena antecipada e sua reapresentação dentro da última sequência, a narrativa do filme é ordenada com linearidade causal e temporal.

Em comparação com os filmes anteriores de Iñárritu, Biutiful apresenta redução na pluralidade de enredos e protagonistas, predomínio da linearidade e nitidez na distinção de sua única manipulação temporal não-linear. $\mathrm{O}$ foco de sua experimentação narrativa concentra-se no entrelaçamento de ramificações do enredos e subplots nos quais as personagens se envolvem em situações limites. Em entrevista na época do lançamento do filme, Iñárritu justificou sua motivação em abordar personagens em ocasiões complicadas:

Nesse filme, assim como em cada um dos que fiz, tento explorar a natureza humana e as decisões tomadas por personagens nas circunstâncias mais duras. Estes são os momentos em que você é mais você mesmo - quando está em circunstâncias limítrofes, você se expressa de maneira mais ampla. ${ }^{139}$ (IÑÁRRITU, 2011, apud SECHER, 2011, s.p., informação oral, tradução nossa)

\footnotetext{
${ }^{139}$ No original: "In this film, as in every film I have done, I try to explore human nature and the decisions made by a character under the toughest circumstances. Those are the times you are most who you are - when you are in limited circumstances, you express yourself in a major way." (IÑ̃́RRITU, 2011, apud SECHER, 2011, http://www.telegraph.co.uk/culture/film/filmmakersonfilm/8288951/Alejandro-Gonzalez-Inarritu-interview-forBuitiful.html, s.p., informação oral)
} 
A escolha mais convencional na articulação das instâncias da narração e do tempo abre novas perspectivas para Iñárritu aprofundar a construção das ambiguidades e contradições das personagens, principalmente no traçado do arco de transformação trágico da personagem principal, Uxbal. Em filmes com apenas um protagonista existe a disponibilidade de um número bem maior de páginas e de tempo de tela para seu desenvolvimento, bem como, das personagens secundárias. Iñárritu aproveita essa disponibilidade para tecer uma densa teia afetiva entre seu anti-herói solitário e vulnerável, e as pessoas com as quais se relaciona. Não por acaso, a interpretação do protagonista por Javier Bardem foi consagrada no Festival de Cannes com o prêmio de Melhor Ator e recebeu indicação ao Oscar na mesma categoria. ${ }^{140}$

O filme apresenta também novidades estilísticas, como a ruptura inédita na filmografia de Iñárritu com o realismo por meio de elementos de fantasmagoria e flerte com o surrealismo. A fantasmagoria surge em representações de espíritos de mortos e visão de fora do corpo. Os lampejos de surrealismo se manifestam em imagens perturbadoras de corpos femininos com mamilos nas nádegas. Outras duas inovações imagéticas dignas de nota são a proliferação de planos-sequência e a inclusão de planos de detalhe pontuais de insetos entre as cenas, assumindo função simbólica provocativa.

A análise a seguir pretende investigar o diferencial da tessitura da narrativa de Biutiful ao abordar temáticas semelhantes aos filmes anteriores de Iñárritu, entretanto, adotando estratégias distintas com maior ênfase no entrelaçamento de ramificações do enredo e na evolução das personagens na trama do que em manipulações no encadeamento temporal e causal das cenas. Sem, contudo, deixar de examinar também o impacto dinamizador que o flashforward pode produzir na estrutura da narrativa ao engajar o espectador no desafio de ordenar os acontecimentos para compreender a história.

\subsection{Entrelaçamento de ramificações e profundidade de personagens}

Biutiful conta a história de um solitário pai separado, Uxbal (Javier Bardem), que não mede esforços para prover seus dois filhos, Ana (Hanna Bouchaid) e Mateo (Guillermo Estrella). Sua ex-mulher, Marambra (Maricel Alvarez), é bipolar e tem um caso amoroso com o cunhado, Tito (Eduard Fernandéz). Uxbal é espanhol e trabalha na informalidade intermedi-

\footnotetext{
${ }^{140}$ Além da indicação de Bardem para o Oscar de Melhor Performance de Ator em Papel Principal (Best Performance by an Actor in a Leading Role), Babel também recebeu indicação como Melhor Filme em Língua Estrangeira na Academia de Artes e Ciências Cinematográficas americana. Bardem ganhou o Goya da Espanha como Melhor Ator e Rodrigo Prieto foi laureado com o mexicano Ariel pela Melhor Fotografia.
} 
ando mão-de-obra clandestina de africanos e chineses em Barcelona. Uxbal, supostamente, tem uma capacidade mediúnica que lhe permite a comunicação com os mortos, rendendo-lhe uns trocados extras ao confortar pessoas que perderam entes queridos. Uxbal é diagnosticado com câncer de próstata em metástase e expectativa de apenas mais dois meses de vida. O antiherói do filme é traumatizado pela perda prematura da mãe e por não ter conhecido o pai, cujo cadáver vai ser exumado porque o cemitério em que está sepultado será demolido para dar lugar a um shopping center. Com a morte à espreita, Uxbal tem pouco tempo para resolver seus negócios e arrumar alguém para cuidar de seus filhos. ${ }^{141}$

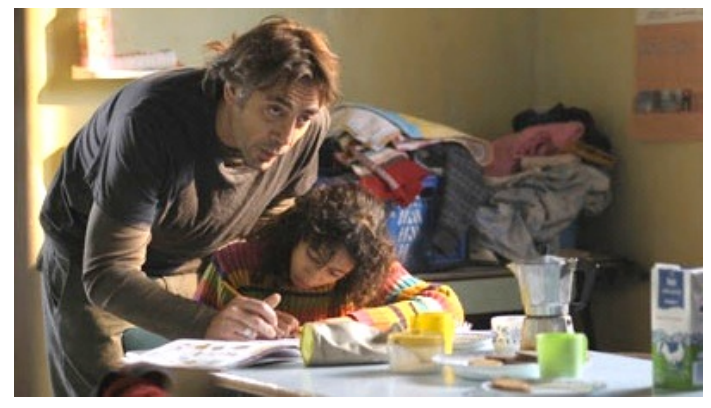

Figura 6.1 - Uxbal é responsável pela criação dos filhos

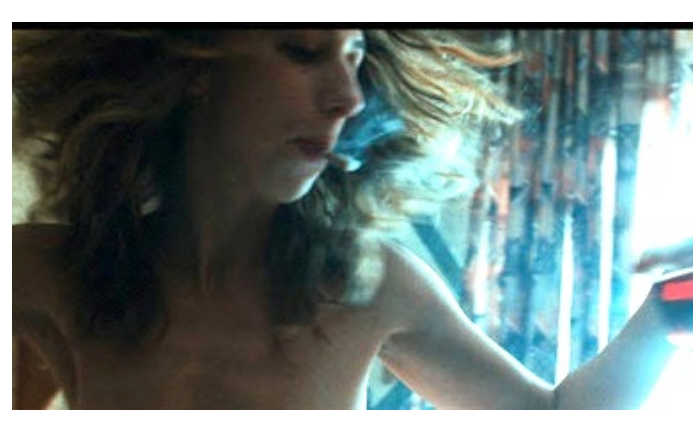

Figura 6.2 - Marambra é bipolar não consegue cuidar dos filhos

Uxbal tenta reconstituir a família com Marambra e vai com as crianças morar no apartamento dela. Os negócios se complicam quando a polícia, mesmo recebendo propina, prende em uma batida policial e deporta o senegalês Ekweme (Cheikh Ndiaye), deixando sua mulher Ige (Diaryatou Daff) e seu bebê aos cuidados de Uxbal, que os coloca para viver em sua casa. A ação da polícia desmancha o esquema de Uxbal que usava os africanos para comercializar produtos falsificados e DVDs piratas produzidos por um grupo de trabalhadores escravos chineses explorado por Hai (Taisheng Chen) e Liwei (Jin Luo).

Hai é um homem de negócios com uma numerosa família que mantém relação homossexual sigilosa com Liwei. Uxbal, com a cumplicidade de Tito e a concordância de Hai e Liwei, arma plano alternativo para explorar a mão-de-obra escrava chinesa na construção civil. A instabilidade emocional e as ausências de Marambra colocam as crianças em situação de risco e ela bate em Mateo, forçando Uxbal a voltar para seu apartamento levando as crianças consigo, passando a coabitar com Ige e seu bebê.

\footnotetext{
${ }^{141}$ Todas as Figuras deste capítulo são frames do filme Biutiful. Fonte: BIUTIFUL. Direção: Alejandro González Iñárritu, EUA, México, Espanha: Focus Features e Universal Pictures, 2010. 1 DVD (146 min).
} 
A trama assume feições trágicas quando Uxbal compra aquecedores baratos, na melhor das intenções, para aliviar o frio do grupo de chineses trabalhadores escravos de Hai confinados em um porão. A economia de Uxbal nos aquecedores visando guardar mais dinheiro para seus filhos acaba provocando a morte dos vinte e cinco semiescravos de Hai por vazamento de gás tóxico. Entre as vítimas estão inclusive Lili, a mulher que cuidava de Ana e Mateo enquanto Uxbal se virava para levantar o sustento de sua família.

A sequência da morte do grupo chinês no porão apresenta uma configuração que se encaixa na definição aristotélica da "situação trágica por excelência" (ver Capítulos II, p. 149, e Capítulo V, p. 182). A piedade surge da desgraça do herói que é infeliz sem o merecer. Aristóteles destaca o potencial trágico de personagens como Uxbal, sem consciência de seus atos, principalmente quando cometem algo terrível por ignorância. Assim, muito transtornado e se sentindo culpado pela morte dos chineses, o estado de saúde do protagonista piora. Ige passa, gradualmente, a cuidar dele e de seus filhos. Uxbal entrega todas as suas economias para Ige e pede que assuma os cuidados das crianças. Ige quase parte com seu bebê para o Senegal levando o dinheiro confiado pelo doente terminal, mas retorna para cuidar do acamado e sua família. Uxbal morre conversando com a filha e encontra o pai que nunca havia conhecido em um bosque nevado.

A única história do filme, apesar de ter um protagonista claramente movido pelo objetivo de arrumar as coisas antes de morrer, não é urdida de maneira tão simples e contém aspectos de multiplicidade e complexidade em seu bojo. O conflito matriz do protagonista é desenvolvido em duas linhas dramáticas - família e trabalho - que além de se entrelaçarem com pesos semelhantes também se ramificam (ver Apêndice H).

As relações de trabalho informais de Uxbal são imbricadas em rede com alto grau de ambiguidade. A principal atividade econômica de Uxbal, a que lhe dá maior rendimento, é a intermediação de mão de obra ilegal envolvendo etnias distintas na produção e distribuição de mercadorias ilegais. Na parte chinesa, o grupo de vinte e cinco pessoas exploradas em regime de semiescravidão por Hai e Liwei se encarrega da produção de cópias piratas de DVD e falsificação de roupas e acessórios de marcas conhecidas. 


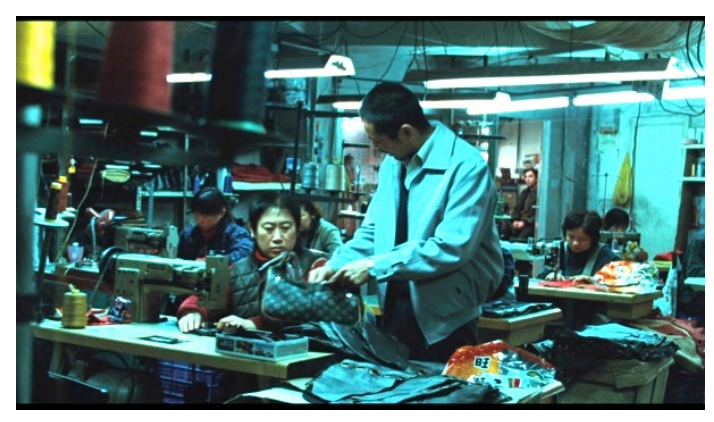

Figura 6.3 - Hai explora mão-de-obra chinesa em regime de semiescravidão na confecção de imitações de objetos de marca e pirataria de DVDs

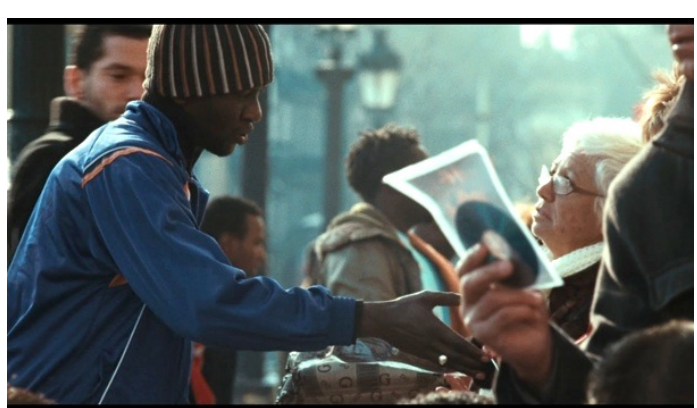

Figura 6.4 - Africanos vendem a produção chinesa e drogas nas ruas

Os africanos parecem operar como uma cooperativa, na qual existe um líder, Ekweme, que coordena a ação de um grupo de vendedores de rua que partilha os riscos e ônus da venda direta de produtos pirateados aos consumidores sem pagamento de impostos. Uxbal é uma espécie de intermediário, elo que articula as relações entre a produção chinesa e a comercialização das mercadorias pelos africanos. Uxbal se encarrega também das relações "institucionais" com as forças de manutenção da ordem, negociando e pagando propina para a polícia fazer vista grossa e permitir a continuidade de todo o esquema clandestino.

A função de Uxbal nas transações retrata a inserção de um espanhol sem oportunidade de atividade formal legal em um país europeu com um dos maiores índices de desemprego na última década. ${ }^{142}$ A trama faz uma crítica ao processo de globalização econômica mostrando as condições deploráveis da exploração de trabalho ilegal na Europa e faz alusão ao fato de que, mesmo assim, apresenta oportunidades mais atraentes do que as encontradas pelos migrantes em seus países de origem.

Em princípio, a atividade de Uxbal de intermediário nativo que viabiliza o funcionamento de todo o esquema de exploração de trabalhadores ilegais seria inadequada devido ao potencial de provocar reações de rejeição da audiência, comprometendo a identificação com o protagonista do filme. Entretanto, essa potencialidade é mitigada ao se apresentar Uxbal tratando os ilegais com respeito, lealdade e afetividade, e fazendo tudo que está ao seu alcance pelo bem dos filhos. Ele chega a apanhar e ser preso ao tentar proteger Ekweme da polícia e nunca abusa das mulheres migrantes que estão em situação vulnerável. A trama aponta a crueldade da economia globalizada nas relações trabalhistas e não julga os indivíduos envolvidos como algozes do processo, mas como participantes em conflito com as imposições das circunstâncias opressivas do capitalismo transnacional.

${ }^{142}$ A Espanha foi um dos países da região do Euro nos quais a crise econômica mundial gerou altos índices de desemprego que atingiu $20 \%$ em 2010, ano de lançamento de Biutiful. 
Uxbal é um anti-herói trágico e ambíguo, um solitário que vive à margem da sociedade e cativa a audiência por ter qualidades admiráveis, mesmo tendo atividades repugnantes à sombra da lei. Ele não se vê como um explorador de mão de obra ilegal, mas como um protetor que está "ajudando eles a terem o trabalho que podem ter" (BIUTIFUL, 2010). Por meio desse viés, Uxbal promove a identificação com o público para que acompanhe com fascínio sua queda, tendo em vista que no fundo ele é como muita gente, que, apesar de não pactuar com vários aspectos do esquema de trabalho no qual está inserido, segue sem opção, participando do jogo de forma honrada para garantir o sustento da família. Uxbal sofre também do dilema universal da dificuldade de discernir entre as coisas da vida com as quais temos que nos resignar e as que devemos lutar para transformar.

Como se não bastasse toda a complexidade e dilemas éticos presentes no submundo da exploração de trabalho ilegal, Uxbal tem uma segunda fonte de renda, não menos polêmica, atuando como médium que conforta parentes que perderam pessoas próximas. A atividade complementar de médium do protagonista é apresentada na trama antes da principal de intermediário de trabalho ilegal. A apresentação da ocupação auxiliar de Uxbal em primeiro lugar acompanha tendência organizativa do cinema hipermoderno, e também dos filmes anteriores de Iñárritu, de privilegiar informações secundárias visando incrementar a imprevisibilidade da trama.

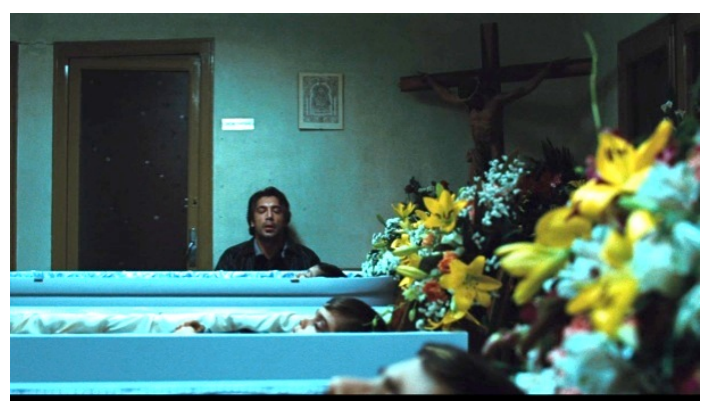

Figura 6.5 - Uxbal vê e se comunica com mortos

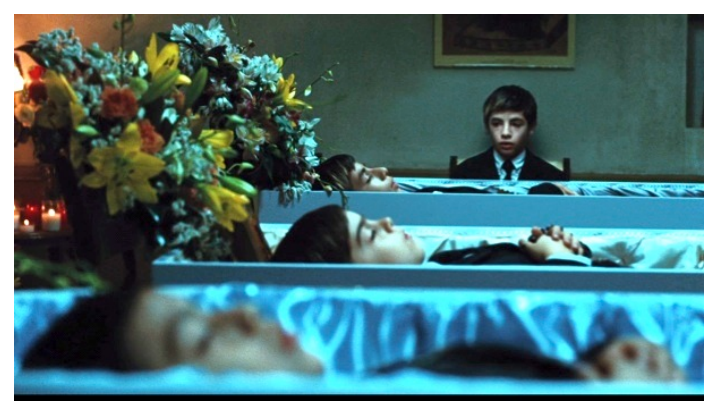

Figura 6.6 - Uxbal ganha um dinheiro extra com sua capacidade mediúnica, confortando quem perdeu entes queridos

O trabalho de Uxbal como intermediário de mão de obra ilegal é ramificado nas transações com africanos, chineses e policiais e envolve muitas personagens, ações e uma maior duração em tela. Por sua vez, a atividade de médium, apesar de ser menos subdividida e gerar menos cenas do que a de intermediação de mão de obra, tem vinculação direta com a abertura e o encerramento do filme: o desenvolvimento do conflito principal do protagonista e o tema de fundo da morte. Ironicamente, as duas ocupações de Uxbal são de intermediário ilícito, de 
força de trabalho e de comunicação entre mortos e vivos. Na primeira das duas visitas que Uxbal faz à Bea, sua mentora espiritual, ela menciona que não se deve cobrar para exercer o dom da mediunidade. Nas entrelinhas das conversas de Uxbal com Bea, fica sugerido que a sua doença esteja associada às energias decorrentes de suas ocupações ilícitas.

O enlace das linhas dramáticas do trabalho e da família é oriundo da interdependência inexorável entre elas para a realização do objetivo primordial do anti-herói de encaminhar a vida de seus filhos. Uxbal precisa obter os recursos financeiros necessários e alguém para geri-los e cuidar das crianças. A amarração da interdependência das linhas dramáticas para a viabilização do objetivo do protagonista se materializa na migração da personagem Ige de um universo para o outro. Originalmente na trama, Ige está vinculada ao mundo do trabalho de Uxbal - provisão de recursos financeiros - e migra para compor um novo arranjo familiar provisão de bem-estar emocional -, plasmando as duas vertentes da trama de forma inusitada.

Primeiramente, Uxbal tenta refazer seu lar com Marambra, mas constata que não é uma alternativa viável devido às suas condições psicológicas. A mentora espiritual de Uxbal, Bea, age também como arauto predizendo que Uxbal está enganado se acredita que é ele quem cuida das crianças, mas sim "o universo". Ao que Uxbal rebate pragmaticamente, lembrando que "o universo não paga o aluguel" (BIUTIFUL, 2010). A opção que se apresenta como cuidadora confiável das crianças advém, ao acaso, do universo do trabalho de Uxbal. A deportação de Ekweme propicia a ida de Ige e seu filho para a casa de Uxbal, em princípio, para serem protegidos pelo enfermo, situação que experimenta uma reviravolta. $O$ arranjo familiar alternativo que se configura no filme - mãe separada pela deportação de outro marido cuidando do esposo doente terminal e seus filhos, com mulher incapaz -, aborda outro tema recorrente na obra de Iñárritu: os atrelamentos entre determinação e acaso.

Vale ressaltar que, no começo do filme, quando Uxbal está vivendo sozinho com as crianças, é Lili, uma jovem mãe chinesa que tem um bebê novinho e faz parte do grupo de operários escravos de Hai e Liwei, que recebe para tomar conta de Ana e Mateo. Nas duas ocorrências de babás em Biutiful, Ige e Lili, assim como Amelia em Babel, tratam-se de mães migrantes, trabalhando ilegalmente em países estrangeiros cuidando de crianças nativas. É recorrente na obra de Iñárritu o interesse em tratar da questão do cuidado com as crianças por meio de uma abordagem que explicita uma contradição do sistema econômico globalizado, na qual é imputado ao trabalho ilegal justamente o zelo pelo que as sociedades têm de mais valioso, suas proles. A sensibilidade de Iñárritu para o tema pode ser associada a sua origem latina de país em desenvolvimento, de onde muitas mães migram para cuidar das crianças dos 
outros em países distantes, muitas vezes, tendo que abrir mão da criação de seus próprios filhos. ${ }^{143}$

O nível de complexidade da construção da personagem principal também se manifesta na constituição das secundárias, às quais, a trama dedica um bom tempo de apresentação e aprofundamento. Assim como em Amores brutos, os vínculos entre as personagens não são todos explicitados na primeira oportunidade. Marambra, por exemplo, surge no filme como amante enlouquecida, ouvindo música alto, dançando seminua, jogando vinho e pisando em Tito, que deitado na cama fala ao telefone com seu irmão Uxbal. Um pouco à frente do filme, qual não é a surpresa do público quando Marambra é apresentada como a mãe dos filhos de Uxbal. O fato de o espectador ter um nível de conhecimento maior do que o protagonista com relação ao romance de sua ex-mulher com o cunhado gera o suspense de quando Uxbal vai confirmar suas suspeitas de que ela mantém um relacionando amoroso com seu irmão.

A bipolaridade de Marambra é trabalhada em várias cenas, traçando a complicação de sua personalidade doente. A construção da personagem resultante distancia-se do estereótipo e compõe material dramático humano e contraditório suficiente para que a audiência acredite que, apesar de Marambra amar Uxbal e seus filhos, seu desequilíbrio psicológico não lhe dá condições de cuidar de sua família. A complexidade com que essa personagem é exposta, assim como Uxbal e várias outras do filme, dá credibilidade a suas dores existenciais, promovendo o engajamento do espectador, apesar de conter traços detestáveis em suas individualidades.

A densidade na construção das personagens afasta-as de representações planas tipificadas, aumentando a dramaticidade e complexidade da trama. Não só os membros da família de Uxbal recebem camadas de informações ambíguas que lhes conferem profundidade, como também, personagens do mundo do trabalho de Uxbal. A trama mostra as pessoas no batente e em casa, entrelaçando suas vidas públicas e privadas, seus dramas existenciais e aflições advindas de suas inserções sociais. Ekweme é mostrado se relacionando com sua família e outros africanos, coordenando a venda de mercadorias ilegais nas ruas e também envolvido com tráfico de drogas. Principalmente por meio da energia dos olhares entre Ekweme e Ige, apreende-se a intensidade da relação afetiva entre eles.

\footnotetext{
${ }^{143}$ A sensibilidade na construção de representação de babá migrante ilegal cuidando do filho dos outros está presente em filmes de diretores latino-americanos como, por exemplo, no episódio "Loin du16e", dirigido por Walter Salles em Paris, eu te amo (Paris je t'aime, 2006).
} 


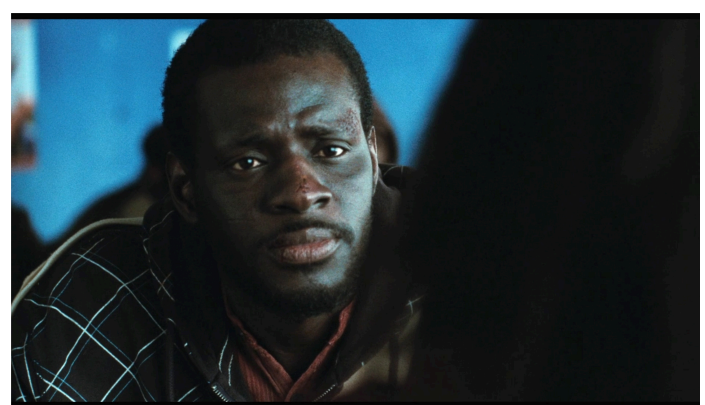

Figura 6.7 - Ekweme é preso, deportado e separado de sua mulher Ige e de seu bebê

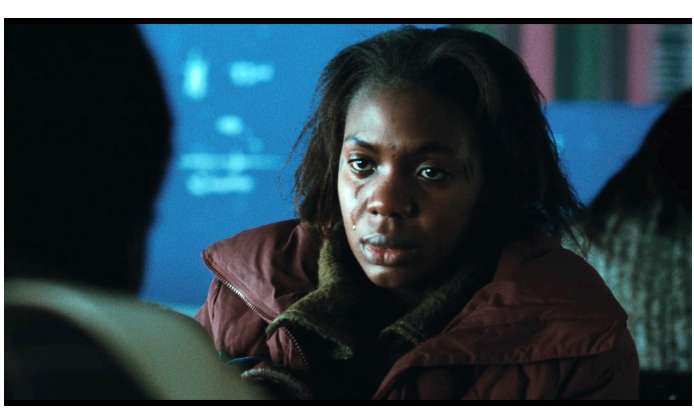

Figura 6.8 - Ige fica com o bebê em Barcelona aos cuidados de Uxbal

O adensamento das personagens é tão absorvente que dá sustentação a enredos periféricos como o romance homossexual acobertado entre o jovem Liwei e o homem de família Hai, que termina em assassinato (Figuras 6.9 e 6.10). E, até mesmo, personagens com poucas aparições na tela, como a jovem mãe chinesa Lili, têm características suficientes para promover uma empatia significativa junto ao espectador no desenrolar de seus destinos. Lili não é apenas mais uma chinesa trabalhadora escrava anódina, ela é prestativa, doce e carinhosa com as crianças, o que torna sua morte trágica mais emocionante.

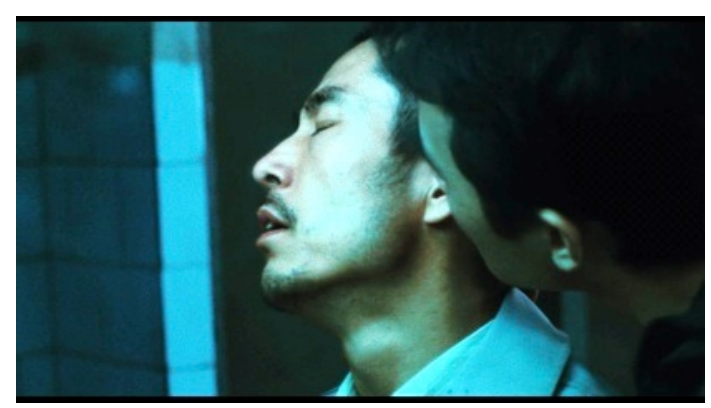

Figura 6.9 - Hai tem romance homossexual velado com Liwei

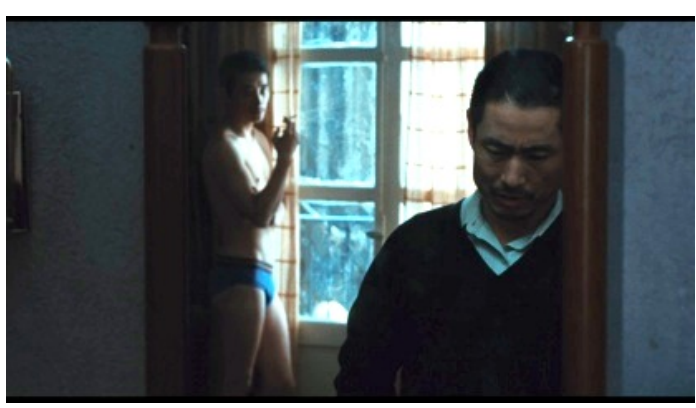

Figura 6.10 - Hai e Liwei também são mostrados em intimidade fora do trabalho

Biutiful tem cinco minutos a mais de duração do que Babel, que conta quatro histórias; e consideráveis vinte e quatro minutos adicionais em comparação com 21 gramas, que tem três protagonistas. ${ }^{144} \mathrm{~A}$ maior disponibilidade de tempo para contar somente uma história, com um protagonista, permite ao diretor trabalhar as personagens com multiplicidade de facetas e em ritmo mais brando. A cadência de Biutiful é determinada pela evolução das personagens (character-driven), apesar de sua estrutura conter pontos de viradas em suas distintas linhas. A predominância da progressão das personagens sobre a ocorrência de eventos na dinâmica do enredo advém da forma com que as informações da história são disponibilizadas

\footnotetext{
${ }^{144}$ Biutiful tem 148 minutos de duração, enquanto Babel, 143, e 21 gramas, 124.
} 
pela trama. No andamento geral de Biutiful, a lenta, realista e densa transformação das personagens é mais determinante no desenvolvimento da trama do que as ações. Apesar de contar com cenas movimentadas, como as de perseguição de africanos pela polícia (Cena 23) e a da ida de Uxbal a uma boate onde dançam mulheres com mamilos nas nádegas (Cena 52, ver Figuras 6.35 e 6.36), elas não prevalecem como determinantes do ritmo da trama.

O acontecimento que põe a história em movimento, seu "incidente incitante", é o diagnóstico terminal de Uxbal. O diagnóstico, entretanto, é urdido gradativamente em vários eventos e demora a se consumar. O filme conta com cinco minutos quando Uxbal faz seus primeiros exames (Figura 6.11). Aos dezoito minutos, mostra-se Uxbal sentindo dores ao urinar. A cor avermelhada da sua urina é um indício da gravidade de sua moléstia (Figura 6.12). Somente aos trinta e cinco minutos do filme, Uxbal faz exames mais sofisticados de ressonância magnética e, finalmente, o médico apresenta o diagnóstico tardio de câncer de próstata com metástase nos ossos e fígado, com prognóstico de apenas mais dois meses de vida. Sua reação inicial é de natural dificuldade em aceitar a situação, mas, gradualmente, ele vai passando por fases de perplexidade e busca de adaptação ao grave quadro. Uxbal inclusive vai recorrer ao parecer da sua mentora mística, Bea, em busca de orientação e apoio, já que não tem amigo ou membros da família com o qual possa contar (Cena 35).

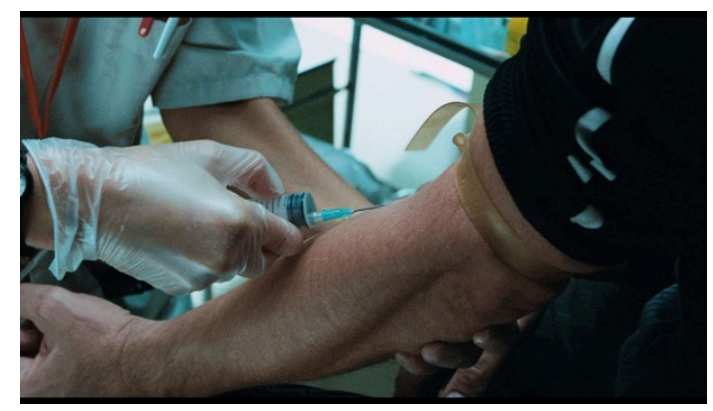

Figura 6.11 - Em plano-sequência Uxbal coleta seu próprio sangue após duas tentativas fracassadas da enfermeira

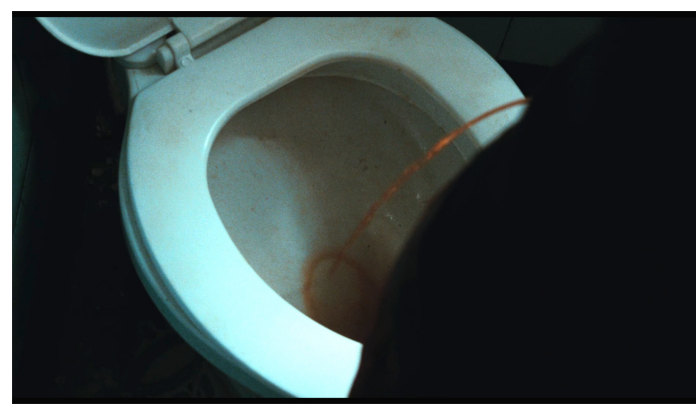

Figura 6.12 - A urina escura de Uxbal

Depois que Uxbal aceita a iminência da morte, sua movimentação para atingir o objetivo de organizar a vida para que os filhos fiquem bem é desenvolvida como uma jornada ramificada e cheia de percalços, surpresas e decepções. As linhas da família e do trabalho evoluem tortuosamente até que se enlaçam ao final. Para se ter uma noção clara do compasso lento da evolução das linhas dramáticas, basta assinalar seus avanços na linha do tempo. Ekweme é preso na batida policial aos 41 minutos do filme (Cena 23). Somente dezenove minutos depois (1h01min), Uxbal vai à casa de Ige levar dinheiro e tratar do assunto da prisão 
(cena 33). Doze minutos mais tarde (1h13min), Ekweme, confinado, conversa com Ige sobre sua deportação e a orienta a ficar na Espanha aos cuidados de Uxbal (Cena 39). Vão se passar mais dez minutos de filme (1h23min), até que Uxbal coloca Ige em sua casa e ela percebe que ele está doente (Cena 45). Vinte e quatro minutos mais tarde (1h47min), Uxbal volta a morar na sua casa com as crianças após sair do apartamento de Marambra, passando a coabitar com Ige e seu bebê, Samuel (Cena 55). Ou seja, entre o evento da prisão de Ekweme, que marca o início do processo de separação de Ige do marido, até a conformação do arranjo familiar inusitado junto com Uxbal e seus filhos, transcorrem-se uma hora e seis minutos de filme.

Iñárritu aponta que a cadência de Biutiful é constituída pela acumulação gradual de eventos bem pequenos, quase insignificantes, que, ao final, conformam uma força poderosa:

É uma pequena rajada que acaba como um tsunami. Diferente do tumulto dos filmes anteriores, do barulho ostensivo, esse filme era fascinante porque era como umidade: te molha gradualmente, de forma quase imperceptível, e quando você se dá conta está completamente molhado e se pergunta "quando eu me encharquei?" ${ }^{145}$ (IÑÁRRITU, 2009, apud DELEYTO; AZCONA, 2010, p. 138, informação oral, tradução nossa)

A análise acima evidenciou que, mesmo na tessitura de apenas uma história com um único protagonista em Biutiful, existe multiplicidade na variedade das linhas narrativas ramificadas que abordam as relações de trabalho e familiares, e complexidade promovida pelos enlaces dessas linhas em evolução cadenciada, valorizando a profundidade das personagens. Nos próximos itens, investiga-se o impacto na estrutura narrativa como um todo provocado pela única manipulação temporal não-linear do filme, a antecipação do final na abertura.

\subsection{O fim no começo}

Após os créditos iniciais em silêncio absoluto, Biutiful começa suavemente e, de maneira enigmática, com um som ambiente sutil conectado a um plano de detalhe de mão de criança tocando em anel que está no dedo mindinho da mão esquerda de um homem. Uma voz de menina sussurra: "É de verdade?" O homem, também sussurrando, responde que sim. Ele, então, conta que seu pai deu o anel à sua mãe antes de sair da Espanha, quando ela estava grá-

\footnotetext{
145 "No original: "It's a little gust that ends as a tsunami. Unlike the tumult of the previous ones, the ostensible noise, this film was fascinating because it was like dampness: it wets you gradually, almost imperceptibly, and when you realize it you are soaking wet and asking yourself 'When I got drenched?'” (IÑÁRRITU, 2009, apud DELEYTO; AZCONA, 2010, p. 138, informação oral)
} 
vida dele. A menina quer saber por que o anel está com ele. A voz masculina responde que sua mãe não voltou mais a ver seu pai. A menina diz que o anel é bonito e que achava que nunca tocaria em um brilhante de verdade. Ela pede para colocar o anel e ele consente. As mãos infantis retiram o anel do dedo do homem e o colocam em seu dedo anelar da mão esquerda. A mão masculina acaricia a mão infantil e o pai diz à filha que o anel agora é dela. A mão direita infantil envolve a mão dele e a retira de quadro, restando apenas a mão da criança com o anel em quadro. Ela diz que viu a mãe sempre colocar o anel "neste dedo", enquanto vemos o dedão infantil balançar (Figura 6.13).

Após a menina falar que a mãe sempre dizia que o anel era de mentira, a imagem da mão corta para uma paisagem externa de uma floresta gelada. O som ambiente é quase suprimido na emenda dos planos. A câmera faz um lento movimento panorâmico pelos troncos das árvores, enquanto a voz masculina confidencia que a mãe da menina nunca ouviu o ruído do mar e conta que, quando era pequeno, havia uma emissora de rádio que tocava o ruído do mar e de suas ondas gigantes. O homem imita o som do mar. O final da panorâmica revela uma coruja caída na neve quando (Figura 6.14) ele confessa que o ruído do mar lhe dava medo.

Quando a filha lhe pergunta por que o som do mar lhe dava medo, corta-se para um plano de detalhe da coruja e ouvimos o vento mexendo suas penas. Em seguida, corta-se para a primeira aparição de Uxbal no filme, enquanto a voz masculina segreda que lhe dava medo o fundo do mar e as coisas que vivem lá embaixo. Nesse ponto, entra o som direto de passos na neve fofa. Uxbal vira a cabeça de um lado para outro buscando a origem do ruído. Corta-se para uma série de três planos com enquadramentos diferentes em que um jovem aproxima-se fumando, ao mesmo tempo em que a voz da menina chama: "papa, papa".

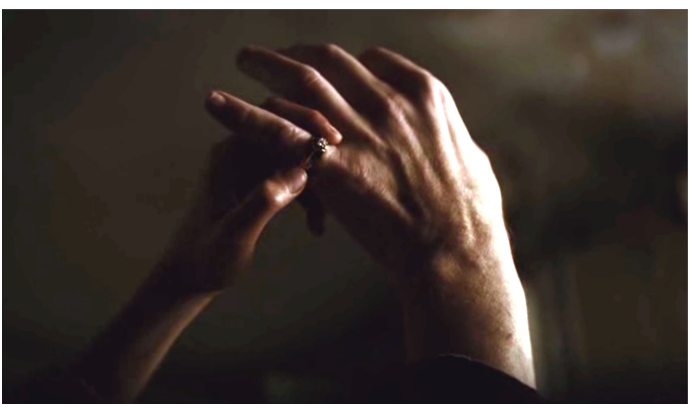

Figura 6.13 - Mão masculina passa anel para a de uma menina

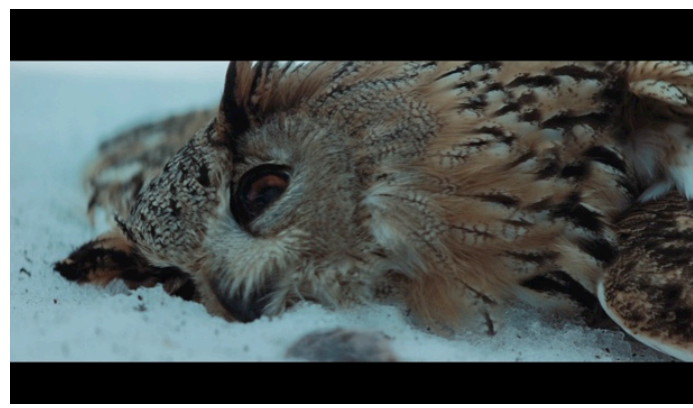

Figura 6.14 - Imagem simbólica 
O jovem pergunta à Uxbal se ele sabia que quando as corujas morrem soltam uma bola de pelos pelo bico. Uxbal sorri timidamente sem mostrar os dentes. O jovem então adverte que é melhor não ir ali com rabo-de-cavalo porque fica parecendo com uma raposa e pode espantar as corujas. Uxbal passa a mão em seus cabelos presos em um rabo-de-cavalo e responde que já viu esse filme. O jovem questiona se Uxbal não acredita nele, afirma que antes não havia nada lá, só água salgada e pergunta se ele sabe qual era o ruído que fazia. Uxbal balança a cabeça negativamente. Mexendo a boca, o jovem imita o ruído do mar. Em seguida, faz o mesmo para imitar o ruído do vento. Os dois trocam sorrisos abertos. Uxbal pergunta como seriam os dois sons juntos. O jovem mistura suas imitações de mar e vento (Figura 6.15). Os dois gargalham moderadamente.

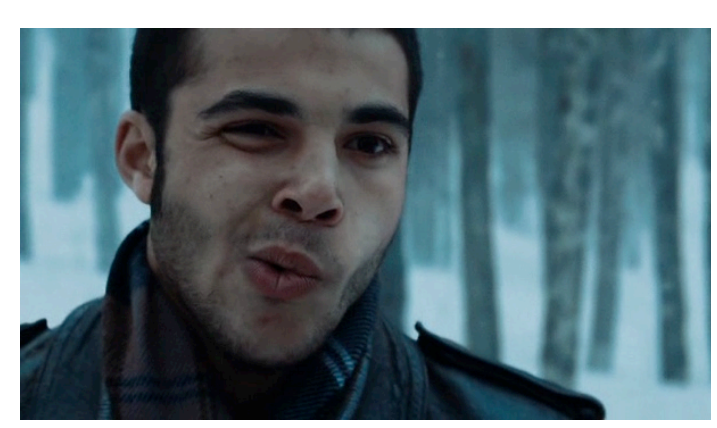

Figura 6.15 - Jovem imita ruídos do mar e do vento

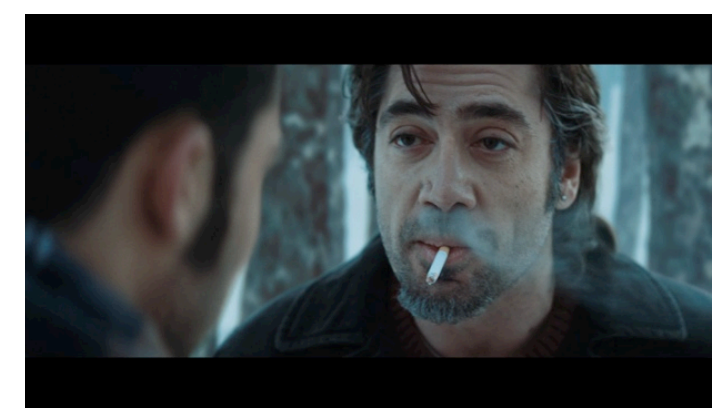

Figura 6.16 - Uxbal fuma com jovem

O jovem se aproxima mais de Uxbal e abre sua carteira de cigarros. Uxbal pega um, acende e solta fumaça pelas narinas. O jovem traga profundamente, dá uns passos, deixando o outro um pouco para trás, traga novamente e olha ao longe. Uxbal indaga o que há. O jovem dá mais um passo e sai de quadro. A cena escurece (fade out), ouve-se o som de um novo ambiente e surge o título do filme na tela. Em seguida, a trama revela que o pai da menina, Uxbal, é o protagonista do filme e passa a nos apresentar, linearmente, seu drama e seus desdobramentos.

Trata-se de uma abertura de filme pouco convencional. Os manuais de roteiro recomendam iniciar a narrativa apresentando as personagens principais e estabelecendo o conflitomatriz da história. Em outras palavras, aconselha-se promover a identificação do espectador com o protagonista e colocá-lo dentro da intriga logo nos primeiros minutos da película (COMPARATO, 2009. FIELD, 1982. DANCYGER; RUSH, 1991). A estratégia utilizada neste caso, um preâmbulo misterioso, ao invés de facilitar a entrada na história, adota uma postura de desafiar o espectador a entender o que está acontecendo, exigindo uma postura mais ativa durante todo o filme. 
Ao começar com um plano fechado, com cinquenta segundos de duração, que tem, em quadro, apenas mãos, associadas a um diálogo sussurrado, o filme cobra, desde o início, um esforço do espectador para tentar decifrar as conexões entre os sons e imagens que lhe são mostrados. O filme estabelece um silêncio inicial absoluto para que, posteriormente, possa ser percebida a entrada de um som ambiente baixo.

Primeiramente, cabe analisar se a relação entre as imagens e falas é sincrônica, pois não se mostra o rosto de quem fala. Gradualmente, por meio da correspondência entre o que é dito e o que é visto no gestual, vai se confirmando que vemos as mãos de um pai e de sua filha, enquanto o diálogo entre eles acontece. Há, portanto, sincronismo. O diálogo entre pai e filha ultrapassa o corte e adentra a imagem seguinte da floresta gelada. A montagem colocou o plano sonoro do diálogo mais longo do que o visual, unindo os planos e suavizando, assim, a passagem de um plano para outro.

No entanto, apesar de o diálogo ter prosseguido após a mudança da imagem, a edição de som substituiu o som ambiente do quarto, em que o diálogo acontecia, pela ambiência da floresta. Esse procedimento de edição foi intensificado por uma mixagem em um nível muito baixo, quase inaudível, na entrada da nova ambiência sonora em sincronia com a nova imagem, a floresta. A dissociação do diálogo de seu respectivo som ambiente original, mixado com desnível de volume na transição entre um plano e outro, promove uma explicitação do corte e cria uma atmosfera antinatural e de estranhamento para marcar a passagem entre diferentes níveis de realidade. Essa articulação sonora das ambiências combinada com o contraste entre o conteúdo das falas sobre o mar e a imagem de uma floresta nevada compõem um clima sobrenatural.

A aparente singeleza da imagem das mãos de pai e filha trocando um anel de dedos está impregnada de simbolismo e ganha complexidade na relação com o que é dito por eles. $\mathrm{O}$ pai conta que não conheceu o avô da menina, porque ele morreu durante sua gestação. Fica também explícita a falta de sintonia do pai com a mãe da menina. E essas informações carregadas de emotividade são passadas, enquanto o anel passa do pai para o dedo anelar da mão esquerda da filha, justamente o dedo que acomoda o anel do matrimônio na sociedade cristã ocidental.

As duas cenas descritas, que se interpenetram por meio do som na abertura de Biutiful, configuram a ocorrência de um acontecimento antes de seu lugar normal na história. A antecipação das cenas explicita uma intervenção externa direta na narração, "esquentando" a interação do espectador. A natureza enigmática e onírica das cenas antecipadas, conjugada com as relações que se estabelecem no meio da trama e de sua reapresentação em versão diferenci- 
ada, justamente na conclusão do filme, possui forte impacto na conformação da narrativa como um todo, por isso, nomeei a articulação de flashforward estruturante. Nos próximos itens será analisado o impacto da antecipação nas complicações progressivas e resolução da trama.

\subsection{Conexões da antecipação com o meio e o fim}

Aristóteles, em A Poética (2003), assinala a relevância do conceito de unidade na narrativa, no qual a ordem das partes constitui o todo. As partes são dispostas em conexões tais que, se movida ou eliminada uma delas, também se transforma o todo. Os eventos não estão soltos ou gratuitamente distribuídos na narrativa, todos os fragmentos e amarrações têm uma função no todo. Sob inspiração dessa explanação aristotélica, examinam-se alguns aspectos relacionais da abertura em flashforward com outras partes do filme. Sabendo que o elemento mais importante da narrativa é a trama dos fatos ordenada conforme a verossimilhança e que as ações são executadas pelas personagens conforme suas características e pensamentos, analisamos, também, as conexões entre a escolha da antecipação e a constituição da personagem principal da história.

$\mathrm{Na}$ fase de tentativa de reconciliação, quando Uxbal está morando com as crianças na casa de Marambra, ele está deitado no sofá com sua filha Ana, enquanto o filho Mateo estuda na mesa de jantar ao lado (Cena 41). Há uma ilustração de uma coruja no livro que Mateo lê. Uxbal olha documentos e fotos antigas (Figura 6.17). Mateo pergunta: você sabia que as corujas soltam uma bola de pelos pelo bico quando morrem? As fotos nas mãos de Uxbal são mostradas em detalhe. O jovem que aparece nas fotos é o mesmo da cena da floresta da sequência inicial do filme (Figura 6.18). Os filhos se interessam em saber quem está nas fotos. Uxbal conta que aquele jovem é o avô deles, que escapou para o México com vinte anos, porque, na época de Franco, perseguiam e matavam os que não se calavam, e que o avô morreu semanas depois de pneumonia. Ana pergunta se ele gostava muito do pai. Ele diz que não sabe dizer, pois não o conheceu. Mateo fala que é feio não ter pai. 


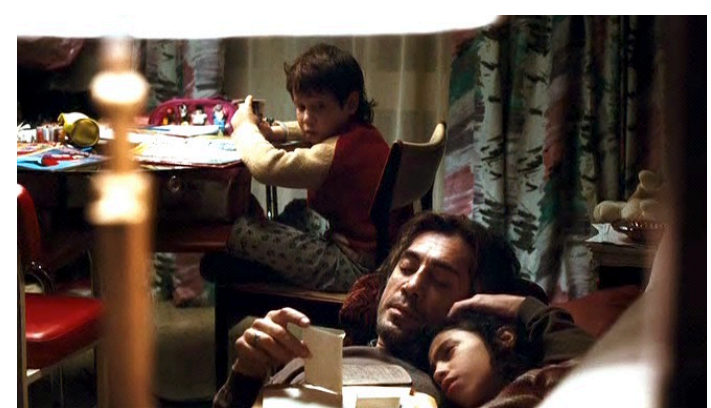

Figura 6.17 - Uxbal vê fotos antigas com os filhos e conta histórias sobre seu pai

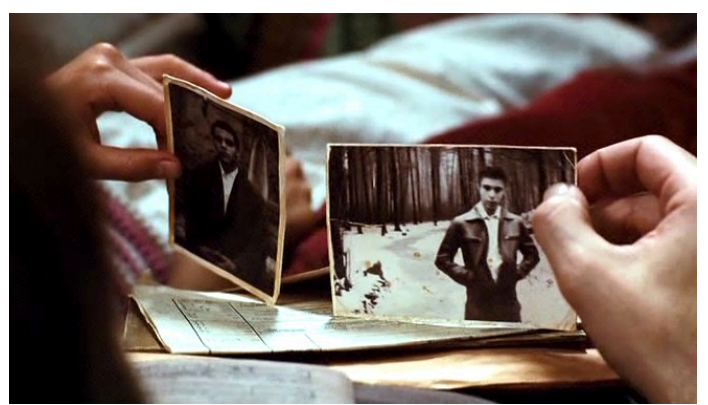

Figura 6.18 - Vê-se que o pai de Uxbal é o jovem que aparece na floresta nevada no início do filme

A reaparição de uma imagem de coruja, seguida da repetição da mesma frase que o jovem disse para Uxbal na cena da floresta, deflagra um processo associativo no espectador que evoca a memória das cenas iniciais. Essa conexão prepara e facilita o reconhecimento, por meio das fotos antigas, do pai de Uxbal, moço retratado, como sendo o jovem que vimos na floresta com ele no início do filme. Vale ressaltar que, em uma das fotos, o pai de Uxbal está numa floresta nevada muito parecida com a da sequência inicial.

Somente depois de mais de uma hora de fruição do filme, sabe-se quem estava conversando e fumando com o protagonista na abertura do filme. Essa articulação da narrativa é urdida por meio de uma técnica de roteiro que consiste em plantar pistas para o espectador recuperar mais tarde e sentir-se, assim, gratificado por conseguir fazer associações que o ajudam a compreender a trama (DANCYGER; RUSH, 1991, p. 182). Apenas um aspecto da sequência inicial foi explicado pela conexão com as fotos: a identidade do jovem que interagia com Uxbal, levando o espectador a se perguntar como pode o filho estar fumando com o pai morto? Será que foi um sonho? Ou será que é uma premonição? Há, também, o aspecto intrigante surreal da inversão entre as idades de pai e filho. O entendimento pleno da sequência inicial só será alcançado quando ela for reapresentada novamente, desta vez, em sua ordem cronológica normal ao final da narrativa.

Na cena seguinte à de Uxbal mostrando as fotos para seus filhos, durante a exumação do cadáver de seu pai, o público é surpreendido com a possibilidade de se ver o rosto do morto há tantos anos, que foi bem conservado por um embalsamento no México para resistir ao translado do corpo entre continentes. Caso algum espectador não tenha feito a associação das fotos do pai de Uxbal com o jovem do início do filme, ou tenha ficado em dúvida, com essa nova exposição da imagem dele, praticamente se elimina a possibilidade de o espectador não realizar essa conexão. 


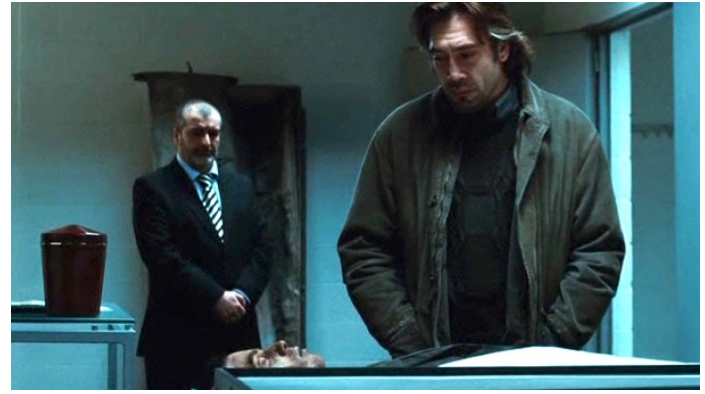

Figura 6.19 - Uxbal contempla o corpo exumado do pai que não chegou a conhecer em vida

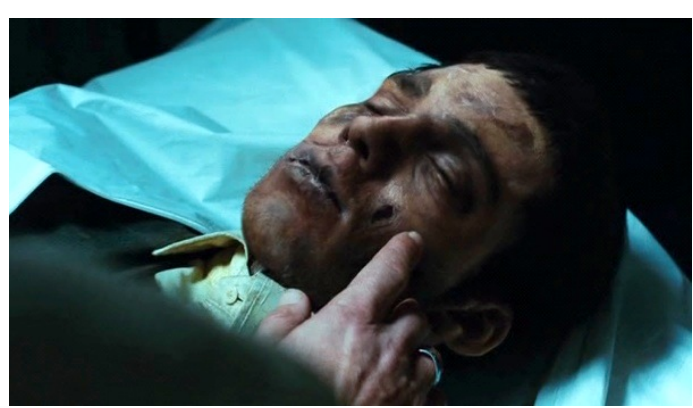

Figura 6.20 - O defunto surpreendentemente está em ótimas condições

Na penúltima cena do filme, Uxbal entra no quarto e senta-se na cama onde Ana está deitada. O anti-herói do filme está muito mal de saúde, sob efeito de fortes medicamentos, pega um anel que está na mesinha de cabeceira e o coloca em seu dedo mindinho da mão esquerda. O mal-estar dele é tão forte que a menina não consegue dormir ao seu lado. Ana pergunta se ele está sentindo dor e ele diz que não. Ela pede para acender a luz e ele liga o abajur. Ela diz que o anel na mão dele é especial, pede para vê-lo, pega a mão do pai e a traz para perto de seu rosto.

Ana pergunta se o anel é de verdade, retomando o diálogo da abertura em flashforward do filme. As falas que se seguem nas cenas são as mesmas, mas a interpretação das linhas do pai é diferente. Ao final, ele fala com dificuldade em respirar e ritmo mais lento do que no início do filme. O novo tom de interpretação é realista e compatível com o seu estado de saúde precário. A cena final é predominantemente enquadrada com vários planos em close up frontal, que oscilam entre os rostos e mãos do pai e da filha. A profundidade de campo é bem restrita gerando áreas de desfoque. Os enquadramentos (Figuras 6.21 e 6.24) estabelecem uma relação de contra-planos em relação ao plano de detalhe contínuo das mãos da primeira cena do filme (Figura 6.13), complementando-o ao mostrar o que a sequência inicial não revelava, as faces de Uxbal e Ana.

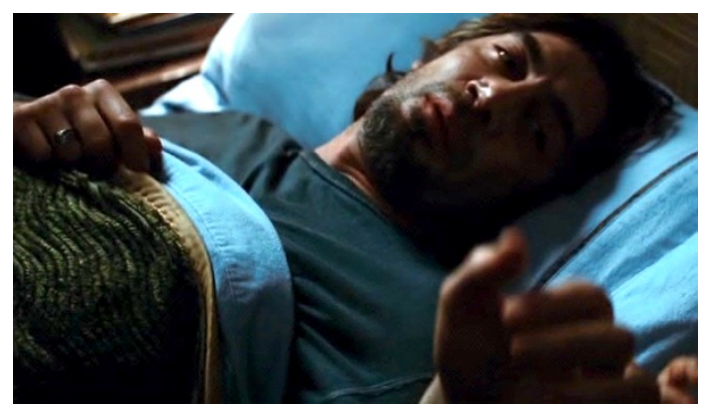

Figura 6.21 - Cena da passagem de anel de pai para filha antecipada na abertura do filme é reapresentada como contra-plano de sua primeira aparição

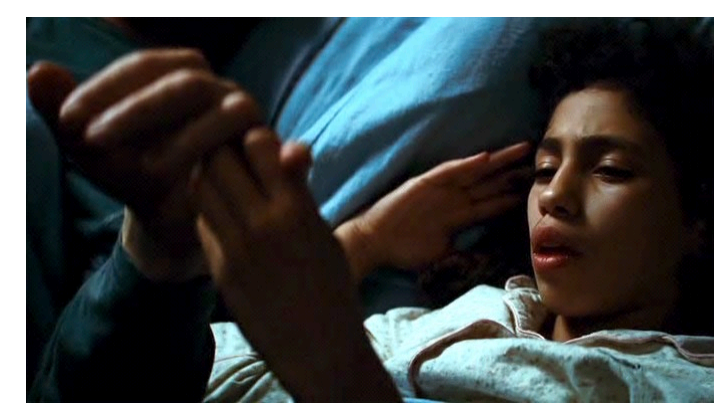

Figura 6.22 - Há ênfase nos rostos quando a cena reaparece em sua posição lógica e causal 
Quando Ana conta que a mãe sempre dizia que o anel era de mentira, e vemos, em quadro, apenas a mão direita da menina pousar a mão do pai na cama, é feita uma dissociação entre o som e a imagem. Continua-se a ouvir Uxbal falando que Marambra "nunca ouviu esse som”, enquanto o que vemos é a imagem dele de boca fechada e imóvel. Uxbal não mais respira. Fica, então, estabelecida uma relação destoante entre o som e a imagem. A atmosfera de estranhamento é adensada pelo acréscimo de um som envolvente de mar. Vale notar que, após deixar de ser sincrônica, a voz de Uxbal muda de tom de interpretação, assumindo uma compleição que denota alívio de sofrimento.

O enquadramento desloca-se lentamente em panorâmica, tira o pai e a filha de quadro e os recupera no espelho. No reflexo, continuamos a ouvir as falas assincrônicas de Uxbal, com seu corpo inerte, em contraste com o de sua filha, que fala em sincronismo. O clima sobrenatural produzido por essa sincronia divergente no mesmo plano é amplificado pela presença de um "outro" Uxbal, seu espírito fora do corpo, que aparece em cena sentado ao lado da cama (Figura 6.23). Enquanto um movimento de zoom vai trazendo o enquadramento desse "outro" Uxbal para um plano de detalhe de seus olhos, a voz do jovem pai de Uxbal faz, pela terceira vez no filme, a pergunta sobre a bola de pelos e a coruja. Dessa vez, a pergunta é encaixada entre as falas do final do diálogo entre pai e filha. Os olhos fixos no nada de Uxbal se iluminam (Figuras 6.25 e 6.26), imersos em uma mixagem com várias camadas de ruídos vento, mar, piados de pássaros, passos na neve, estampidos de tiros ao longe - e a voz de Ana a chamar pelo pai.

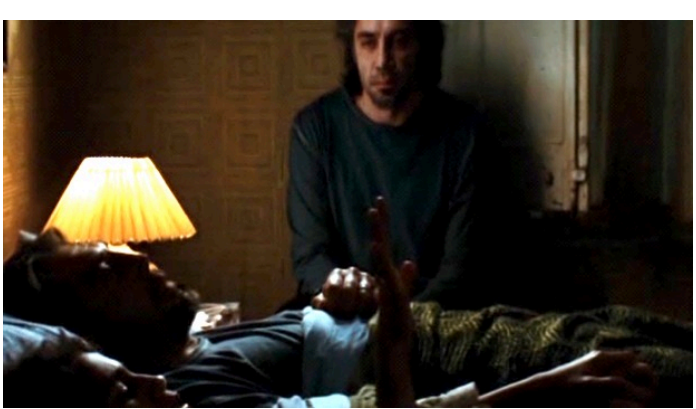

Figura 6.23 - No momento da morte de Uxbal, surge um duplo dele

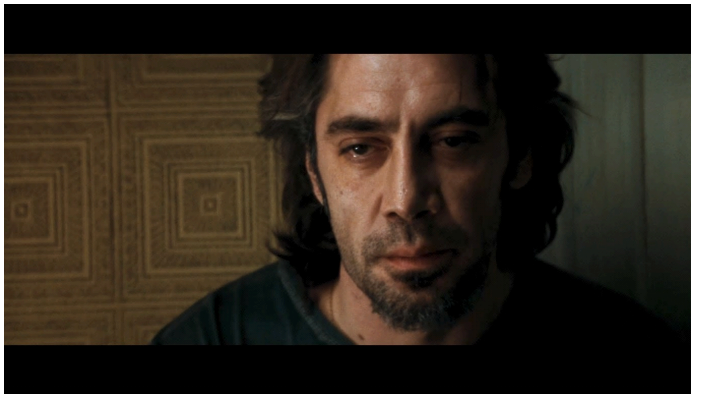

Figura 6.24 - A câmera se aproxima em zoom 


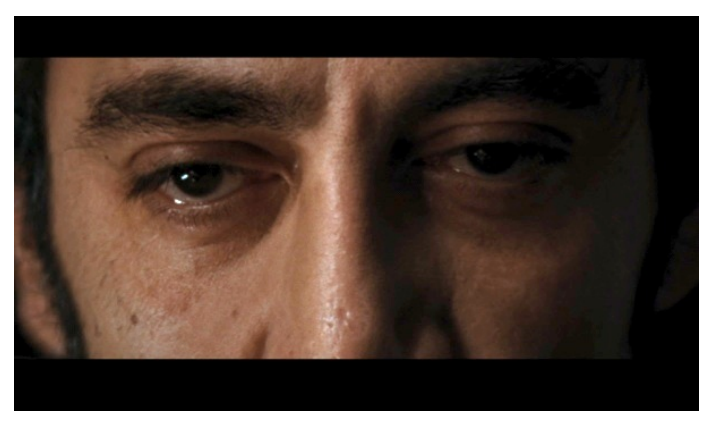

Figura 6.25 - A passagem do quarto de Uxbal para a floresta nevada é feita por mudança de luz com mesmo enquadramento

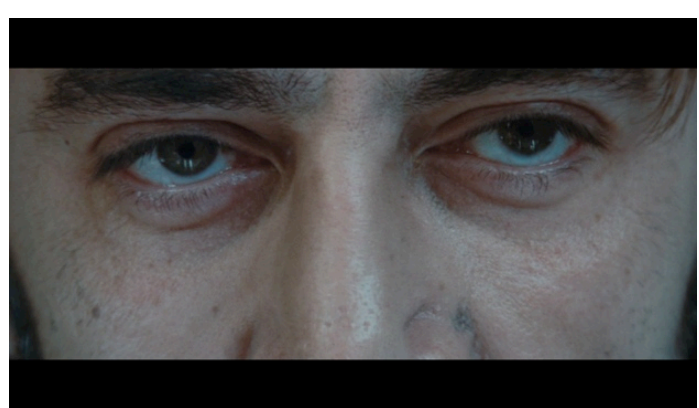

Figura 6.26 - Em plano de detalhe dos olhos é feita a passagem da morte para o além

Todos ruídos vão cessando, os olhos de Uxbal movem-se, ouve-se o som direto de seu pai, com a idade que morreu, aproximando-se dele na floresta nevada. Corta-se para um plano de detalhe da coruja caída na neve. Volta o som do mar ao fundo, enquanto vemos Uxbal, em super close de perfil, sorrir e gargalhar ao ouvir seu pai imitando o mar, o vento e os dois ao mesmo tempo (Figura 6.27). Soa uma música de piano, eles se aproximam, o pai dá um cigarro ao filho. Eles tragam, o pai jovem dá uns passos deixando para trás o filho de meia idade. O pai traga novamente e olha ao longe. Uxbal indaga o que há, seu pai dá mais um passo à frente e sai de quadro, alguns flocos de neve caem na floresta gelada.

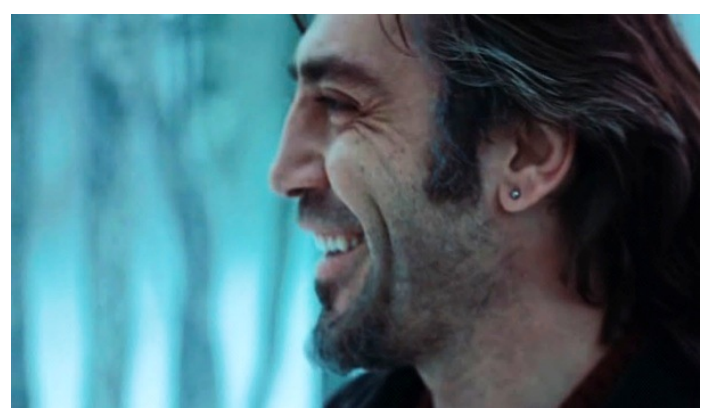

Figura 6.27 - Uxbal ri dos das imitações de ruídos feitas por seu pai

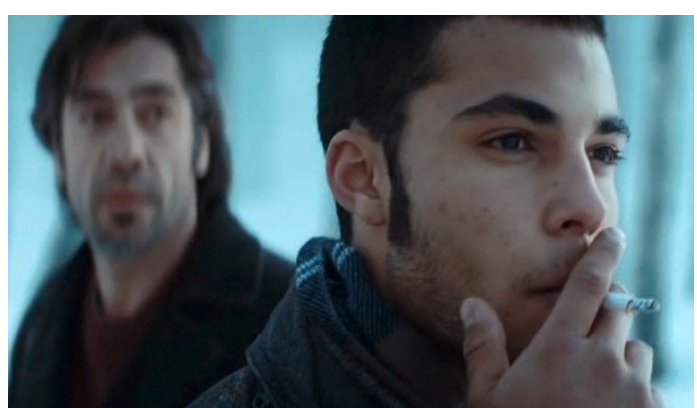

Figura 6.28 - O encontro de Uxbal com seu pai, ainda jovem, emociona e desconcerta a espectador

A análise mostra como o flashforward, ao permitir o vislumbre de um evento antes da compreensão de toda a cadeia causal que leva até ele, engaja a audiência no esforço de relacioná-lo e ordená-lo, na busca do entendimento da história. A estratégia de deslocar uma sequência tenciona a dupla temporalidade da narrativa: o tempo do discurso (enredo, plot) e o tempo da história (story).

As duas cenas que se interpenetram na abertura e no encerramento do filme compartilham o mesmo material dramático, mas são editadas e sonorizadas de forma diferente por 
possuírem funções distintas na trama como um todo. Tanto a apresentação quanto a reapresentação da cena mostram a transição de uma realidade à outra e a mixagem do som lembra o processo de cair no sono ou acordar com os sons ambiente, gradualmente, invadindo um sonho. As sutilezas da montagem e mixagem das duas versões desta sequência são experimentadas pelo espectador, sem que ele tenha condições de comparar os detalhes que as diferenciam, mesmo porque elas estão localizadas nas extremidades do filme. Somente por meio de uma análise fílmica minuciosa, é possível identificar as sutis técnicas de manipulação dos materiais expressivos audiovisuais, sons e imagens, na composição dessas cenas.

$\mathrm{Na}$ abertura, a opção por mostrar a singeleza de mãos trocando um anel e ocultar os rostos dos personagens que cochicham, torna a cena leve e enigmática. Não há indícios da gravidade do estado de saúde do pai. Inclusive as falas dele têm uma interpretação isenta de sofrimento. A forma com que a montagem escolheu, ordenou e determinou a duração dos planos visuais e sonoros não deixa claro o que aconteceu. A sequência possui lógica e aparência onírica. A ausência de apresentação de personagens e o estabelecimento do conflito matriz da trama privam o espectador dos elementos básicos iniciais para começar a entender a história na primeira sequência do filme.

A linearidade assume a trama após o título do filme e as cenas vão se justapondo relacionadas por causa e efeito. Gradativamente, conhecemos o protagonista, sua família e seus conflitos. À medida que a trama se desenrola, o espectador movido por curiosidade, suspense e surpresa, apreende pistas, relaciona-as com informações anteriores e conjectura sobre o que está por vir na trama, participando ativamente da recriação da forma do filme. Dessa maneira, ficamos sabendo que Uxbal está desenganado, como ele ganha a vida, que tem um pretenso dom mediúnico, como são suas relações afetivas e tantas outras coisas.

Somente na metade do filme, é estabelecida uma conexão direta com sua abertura, quando se revela, de maneira surpreendente, que o jovem que vimos conversando e fumando com Uxbal na floresta é seu finado pai, que ele nunca havia conhecido. O preâmbulo enigmático do filme que já estava quase esquecido pelo espectador é reativado por essa revelação. Nesse ponto da trama, no meio do filme, o espectador já sabe muito da vida do protagonista e traz, consigo, esse conhecimento em seu retorno à sequência inicial. O desvelamento tardio da identidade de uma personagem presente na abertura do filme deflagra um processo de revisão do significado da sequência inicial. Assim, o espectador, além de analisar as consequências desse novo dado, também leva em consideração todas as demais informações da intriga transmitidas até aquele ponto. 
A revelação funciona como um catalisador que promove a revisão e engendra um reengajamento do espectador com a trama. A orquestração de quando e qual informação é revelada projeta o espectador para trás e, depois, para frente, em seu esforço de compreensão da história. Primeiro, ele é remetido à abertura do filme, por meio de uma memória revisionista, que resulta em mais questionamentos do que desvendamento do nexo do enigma inicial. $\mathrm{O}$ novo patamar de entendimento da história leva-o, em seguida, a fazer novas inferências, a elaborar outras hipóteses e a remodelar suas expectativas, projetando-se no porvir.

No encerramento do filme, a sequência inicial reaparece em um novo arranjo, com as mesmas personagens, locações, ações e diálogos. Entretanto, a sequência ressurge em sua posição cronológica na história e após ter sido percorrida toda a cadeia de causa e efeito da trama. A reapresentação da mesma situação dramática, só que em um novo patamar de conhecimento das personagens e da história, impinge-lhe uma nova função e cobra-lhe uma nova forma. Apesar da complexidade da montagem na construção de uma atmosfera sobrenatural, narra-se com clareza o último diálogo de Uxbal com sua filha, sua passagem para o mundo dos mortos e o encontro com seu pai. Somente após a última cena do filme, é possível compreender completamente o sentido da sequência inicial.

O flashforward possui aspecto "mediúnico", já que anuncia um acontecimento vindouro de maneira mais ou menos explícita. Observa-se, em Biutiful, que a antecipação da sequência da morte do protagonista, utilizada na estruturação da narrativa, está relacionada com a capacidade de Uxbal em se comunicar com os mortos. Ou seja, a estratégia narrativa de antecipação compartilha o mesmo aspecto "mediúnico" que caracteriza a personagem principal, estabelecendo uma conexão entre instâncias distintas: narração e personagem. O enlace de níveis narrativos diferentes, por meio de um aspecto em comum - capacidade mediúnica -, promove a integração da maneira como se conta a história com uma característica marcante da personagem principal, dando consistência estética ao filme. A tessitura da repetição da cena envolve outras duplicidades: os dois níveis de realidade, o passado dos pais/avós e o presente pai/filha, o quarto e a floresta.

\subsection{Alternativas formais e aprofundamento temático}

Além das estratégias narrativas examinadas nos itens anteriores, Biutiful apresenta outras alternativas formais para alcançar aprofundamento temático, algumas delas focadas na visualidade das cenas. As imagens contrastadas de Biutiful mantêm a instabilidade da câmera na mão, a granulação e a sutileza na colorização dos filmes anteriores de Iñárritu. No geral, há 
um predomínio de imagens com menos luminosidade que os títulos pregressos, com muitas cenas internas e externas filmadas no crepúsculo. Uma novidade visual chamativa é a adoção de uma edição menos fragmentada com o uso inédito pelo diretor de diversos planossequência espalhados pelo filme.

O primeiro plano-sequência surge, logo na cena depois do título, e mostra o final de exame de toque retal em Uxbal, seguido de duas tentativas mal sucedidas de coleta de sangue feitas por uma enfermeira inábil e culmina com o próprio protagonista manuseando a seringa e retirando seu sangue (Figura 6.11). A ausência de corte potencializa o realismo da cena e provoca desconforto em boa parte da audiência. É como se Iñárritu, não satisfeito em provocar o espectador com o flashforward, o espetasse por meio das agulhadas do plano-sequência inicial.

Biutiful apresenta outra inovação visual que, apesar de seu arrojo experimental, passa despercebida por boa parte do público. Trata-se de uma alteração no formato da imagem (aspect ratio), na proporção entre a altura e o comprimento da imagem que muda de 1:85 para 1:2.40 durante o filme (1h51min). A mudança no formato do enquadramento acontece na emenda entre a cena em que Uxbal está deitado com seu filho Mateo e a que os corpos dos chineses aparecem na praia (Cenas 56 e 57). Na cena anterior, Uxbal foi à boate das nádegas com mamilos e, quando chega na casa de Marambra, surpreende-se ao encontrar seu filho deixado para trás pela mãe que viajou com a filha, Ana, para as montanhas. O plano da praia com os corpos foi feito com uso de uma grua e parte da imagem de uma lua contra um céu claro ao amanhecer, seguido por uma revoada de pássaros antes de revelar os cadáveres na praia. O ponto de transição entre os formatos de tela acontece no ápice da fragilidade do protagonista, no qual ele percebe que não consegue controlar os rumos de seus negócios e nem o destino de seus filhos.

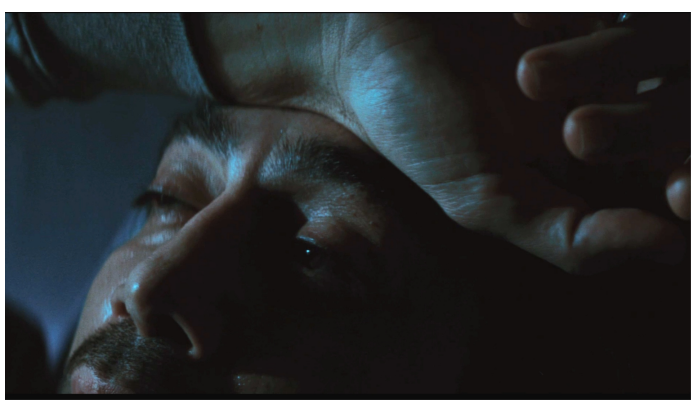

Figura 6.29 - Super close up de Uxbal na proporção (aspect ratio) 1:85

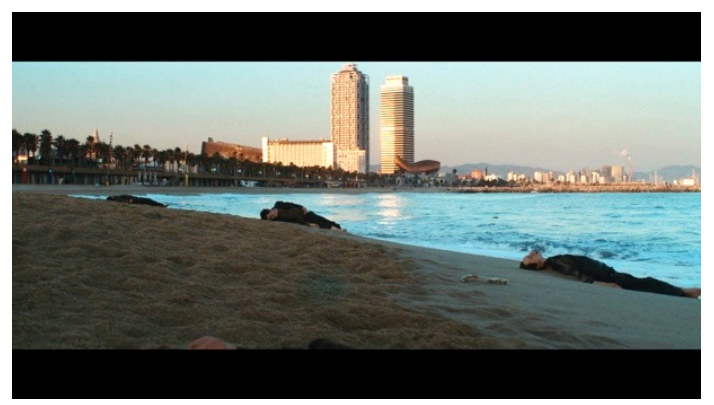

Figura 6.30 - Corpos dos chineses mortos asfixiados no porão surgem na praia, enquadrados na proporção (aspect ratio) 1:2.40. 
O diretor de fotografia Rodrigo Prieto justificou a ousadia da utilização do artifício no curso do filme, contando para o repórter da revista American Cinematographer Benjamin B. que, desde as primeiras discussões, Iñárritu descrevia Uxbal "como alguém tenso e controlado no começo do filme, e depois, quando forçado pelas circunstâncias a aceitar seu destino, ele finalmente é capaz de se deixar levar" (PRIETO, 2011, apud B., 2011, p. 1, informação oral, tradução nossa). ${ }^{146} \mathrm{O}$ diretor queria arrumar uma forma de representar visualmente a transição psicológica da personagem e o fotógrafo propôs a alteração do formato da imagem, que foi acolhida com entusiasmo.

Vale ressaltar que Iñárritu já havia utilizado imagem de bando de pássaros em voo errático ao entardecer como presságio de passagem de vida para morte em seu segundo filme. Quando a câmera aponta para o céu no plano-sequência lusco-fusco da cena em que Uxbal perturbado atravessa uma ponte, o movimento das aves remete a um similar de 21 gramas, evocando a memória do falecimento de Paul, constituindo-se como uma autocitação.

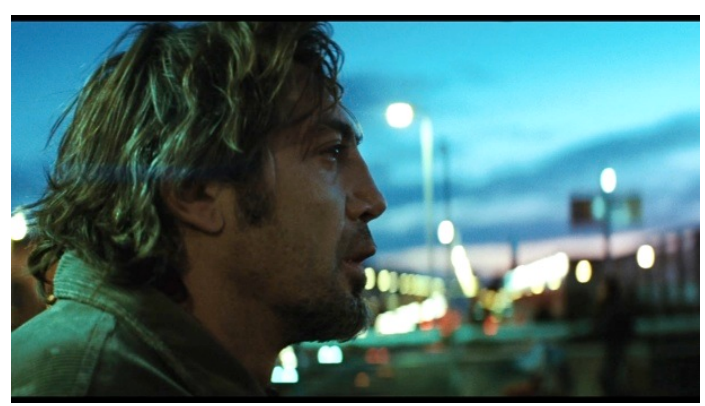

Figura 6.31 - Uxbal tem epifania ao cruzar ponte no lusco-fusco após morte de chineses

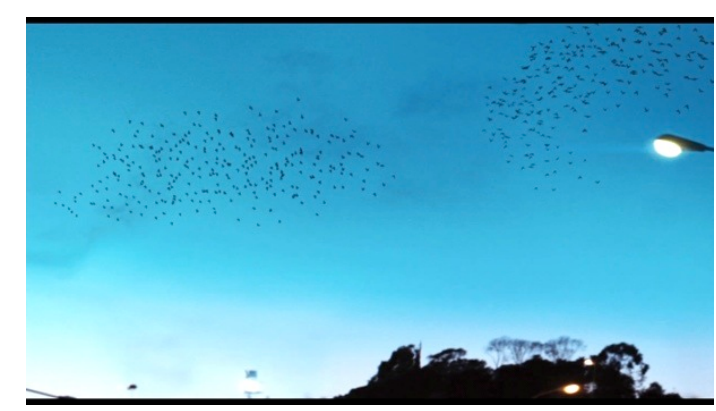

Figura 6.32 - Revoada de pássaros ao entardecer é uma auto referência de Iñárritu à plano semelhante de 21 gramas (ver Figura 4.5)

As alternativas formais de concepção visual, na composição das cenas analisadas acima, combinadas com as estratégias narrativas de entrelaçamento de ramificações do enredo, adensamento das personagens e do uso de flashforward estruturante proporcionaram a verticalidade na abordagem temática do filme. Biutiful expõe a problemática da ilegalidade do trabalho gerada pelos fluxos de populações em busca de melhores condições de vida na Europa e a fragmentação das famílias envolvidas nesse negócio. A unicidade da história ganha múltiplas ramificações em subplots que exploram os atrelamentos das macro relações entre capital e trabalho com a intimidade das relações pessoais por uma ótica crítica. A trama expõe as re-

\footnotetext{
${ }^{146}$ No original: "In one of the first discussions I had with Alejandro, he described Uxbal as someone who is uptight and controlling at the beginning of the film, and then, as he is forced by his circumstances to accept his fate, he is finally able to let go. Alejandro wanted to find a way to represent this transition visually." (PRIETO, 2011, apud B., 2011, http://www.theasc.com/ac_magazine/January2011/Biutiful/page1.php p. 1, informação oral)
} 
lações sórdidas na exploração de mão de obra ilegal e aponta a interdependência entre os membros do esquema que gera e faz circular recursos na economia informal, em que famílias são desagregadas por doenças e pela força da lei.

A tecnociência é até capaz de diagnosticar e oferecer paliativos, mas não de curar o câncer em metástase de Uxbal e nem a bipolaridade de Marambra. A deportação de Ekweme impõe sua separação de Ige e de seu bebê, e abre perspectivas para a formação de um arranjo familiar alternativo junto à família de Uxbal. $\mathrm{O}$ inusitado acomodamento doméstico de remanescentes de uniões tradicionais concilia compatibilidade de necessidades e afetividade ética, apesar de todas as adversidades nas quais seus participantes estão imersos. Nesse contexto, Iñárritu encontra brecha para, novamente, abordar um tema que lhe é caro e recorrente em toda a sua obra: o embate entre destino e acaso na determinação dos rumos das vidas das pessoas.

O fato de o filme contar apenas uma história de forma predominantemente linear, sem privilegiar os acontecimentos no desenrolar da trama, transfere boa parte do peso da narração para a construção de personagens consistentes e multifacetadas que se transformam gradualmente. A força dramática que as personagens tinham no roteiro é potencializada pela estratégia estabelecida pelo diretor em filmar em ordem cronológica, permitindo ao elenco e à equipe urdirem, com sutileza e controle, o arco de transformação das personagens.

Visando imprimir mais verdade à interpretação, Iñárritu recorre também, e mais uma vez, à escalação de atores não profissionais para papéis importantes como os senegaleses Cheikh Ndiaye (Ekweme) e Diaryatou Daff (Ige), e a espanhola de ascendência marroquina Hanna Bouchaid para fazer a filha de Uxbal, Ana. O diretor já havia tido êxito com essa estratégia em Babel, ao elencar pessoas comuns para interpretarem dramas muitos próximos aos de suas próprias realidades (ver Capítulo V, p. 203). Trabalhar com atores não profissionais é uma prática que tem precedentes no cinema de ficção moderno da escola soviética da década de 1920 e do neorrealismo italiano dos anos 1940. A composição do elenco misturando atores consagrados como Javier Bardem, com outros menos conhecidos, como Maricel Alvarez, da Argentina, que faz Marambra, e até não profissionais completamente inéditos para o público, conformam um painel humano altamente crível e atenuam os maneirismos dos atores mais tarimbados ao trazer espontaneidade e imprevisibilidade nas interações entre eles no set de filmagem.

Iñárritu, que já havia experimentado um flashforward na abertura de Amores brutos, fez uso mais radical desse recurso narrativo ao abrir Biutiful de forma enigmática e antecipando nada menos que sua sequência final. Por meio desse artifício, o diretor acirra a curiosidade 
do espectador e engaja-o mais ativamente no entendimento da trama. Exceto a sequência manejada no flashforward, todos os demais acontecimentos são apresentados linearmente, na ordem cronológica em que acontecem na história. A análise evidenciou como esse único deslocamento da ordem em que uma sequência aparece no enredo (plot) em relação a sua posição na história (story) foi suficiente para influenciar a maneira com que todo o filme é apreendido pelo espectador. Essa verificação confirma o princípio de unidade aristotélico no qual a relação das partes conforma o todo e corrobora o poder provocador da antecipação na narrativa.

A tessitura da narrativa de Biutiful, ao atrelar a capacidade do flashforward em antever lampejos do futuro com a característica mediúnica do protagonista, abriu perspectivas para a inclusão de imaginário surreal no universo, até então, marcado pelo realismo da obra de Iñárritu. A fantasmagoria surge na representação dos espíritos dos mortos que Uxbal é capaz de ver (Cenas 47 e 68). O diretor optou por composição híbrida dos fantasmas, na qual eles mantêm a aparência realista em contraste com ações irreais, levitando junto ao teto.

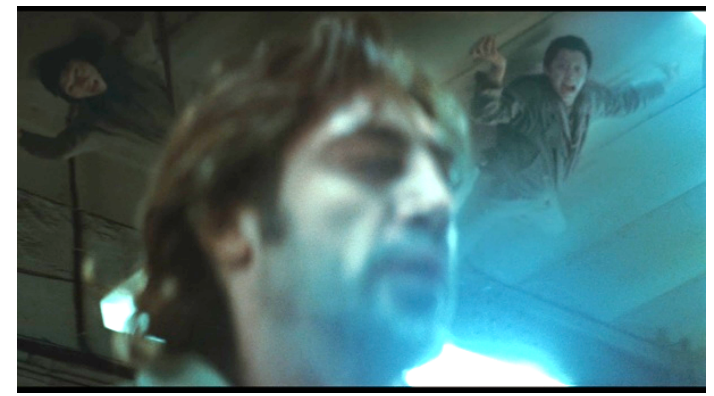

Figura 6.33 - Espíritos de chineses pairam no teto do porão onde morreram sufocados pelos gases dos aquecedores baratos comprados por Uxbal

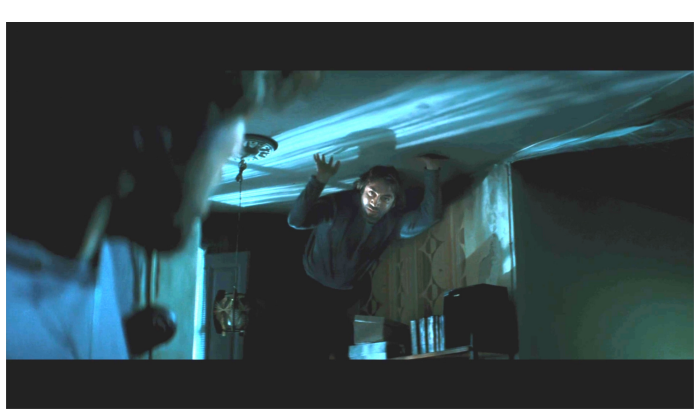

Figura 6.34 - Ao ir do banheiro para seu leito de morte, Uxbal vê seu espírito no teto

Outra variante de quebra do realismo no filme ocorre na boate (Cena 52) em que a direção de arte metamorfoseou seios nas nádegas das dançarinas. No making of, incluído no DVD do filme, Iñárritu diz que concebeu a ida de Uxbal à boate como se fosse uma viagem ao Inferno de Dante, uma representação extrema de Eros e Tânatos. Um espaço que misturasse desejo, proibição, morte, vida, carne, sexo e risada. "Um lugar onde Uxbal pudesse se perder facilmente, e também escapar, mesmo que por um momento. [...] Um lugar em que, enfim, ele pudesse dizer aos outros que está morrendo, mesmo que seja a uma puta." ${ }^{147}$

\footnotetext{
${ }^{147}$ Iñárritu citado no vídeo making of do filme: Behind Biutiful - directors flip notes (Por trás de Biutiful - as anotações do diretor).
} 


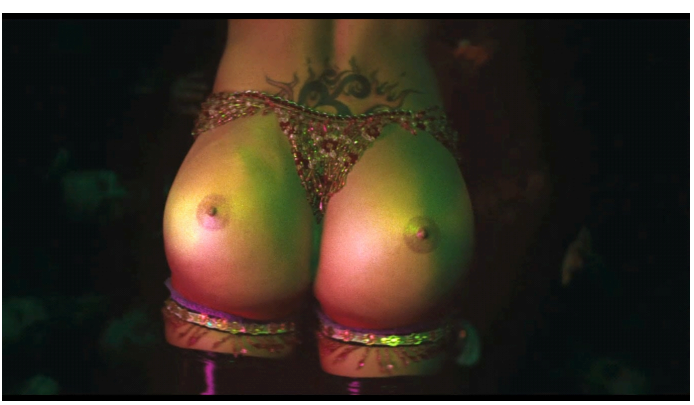

Figura 6.35. Flerte com o surrealismo

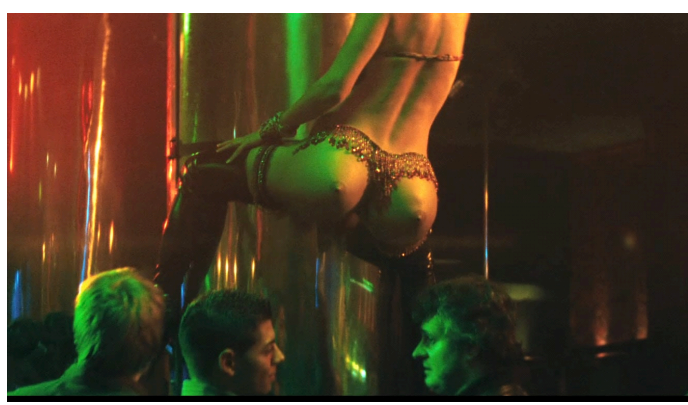

Figura 6.36. Uxbal vai ao "Inferno de Dante"

Durante o desenrolar da trama, a persistência do diretor em manter na tela momentos abjetos de Uxbal urinando (Figura 6.11), vomitando e sendo penetrado por agulhas (Figura 6.12) durante seu padecimento, assim como quando explora a textura do rosto do cadáver embalsamado de seu pai, podem ser interpretados como momentos de erupção de elementos que se alinham à retórica mexicana. As manifestações características da retórica do excesso, que eram vistosas em Amores brutos e 21 gramas e haviam sido atenuadas em Babel, retornam pujantes em Biutiful.

A análise empreendida neste capítulo da única história com apenas um protagonista de Biutiful, evidencia que, apesar da ruptura com o padrão de narrativas de rede multitramas e multiprotagonistas anteriores de Iñárritu, é possível identificar, no filme, a continuidade na utilização de estratégias formais e escolhas temáticas que caracterizam o estilo autoral do diretor em conciliar aspectos do cinema de arte com boa comunicabilidade de ideias e emoções para um público amplo. A tessitura da multiplexidade é, portanto, engendrada na unitrama predominantemente linear do filme por meio da ramificação e entrelaçamento de linhas narrativas que tratam de relações familiares e de trabalho, transição entre a vida e a morte, adensamento da construção das personagens, cadência parcimoniosa na evolução do enredo e impacto do flashforward na estrutura da trama.

Quando a filha de Uxbal, Ana, lhe pede ajuda nas tarefas escolares quanto a grafia da palavra em inglês "beautiful", e o pai responde que se escreve como se fala, "biutiful", o título do filme é mencionado durante seu andamento, causando um frisson pontual no espectador. Iñárritu, ao nomear o filme com uma palavra que significa bonito/bonita, belo/bela, grafada como fonemas do espanhol, parece estar querendo nos dizer que existe beleza na vida cotidiana, apesar de todas as mazelas, só que ela não se manifesta da forma que a idealizamos. 


\section{CONSIDERAÇÕES FINAIS}

$\mathrm{O}$ estudo da narrativa cinematográfica de Alejandro González Iñárritu, sob a óptica neoformalista-cognitivista na acepção de Bordwell (1985; 1993; 2005; 2006; 2008;), complementada pela crítica da cultura aportada principalmente por Lipovetsky (2010), Paz (2014) e Canclini (2008; 2011), proporcionou uma visão das vinculações existentes entre a experimentação estética desse cineasta e características da sociedade globalizada da primeira década do século XXI. As análises dos quatro primeiros filmes do diretor evidenciam que suas diversificadas combinações entre multiplicidade de narrações - multiplots e multiprotagonismo - com distintas maneiras de ordenação não-linear do tempo são capazes de enredar tramas hábeis na representação de questões pujantes da contemporaneidade.

Embora tenha realizado filmes de ampla circulação mundial, tanto em festivais como no circuito comercial, produzidos em diversos países e alicerçados em acordos com empresas midiáticas transnacionais, o diretor mexicano foi capaz de manter sua independência autoral e manter a unidade artística da sua filmografia. Ao tratar de temas banalizados no cinema mainstream, como relações familiares, sexo e violência, oferecendo, porém, uma peculiar abordagem humanista marcada por sua identidade cultural original, o cinema multiplex de Iñárritu destaca-se no panorama mundial ao expor contrastes e conflitos universais de um mundo caótico interligado por fluxos de informações e pessoas.

O exame minucioso das narrativas dos filmes em questão aponta para a busca de uma harmonia entre forma e conteúdo, na qual, questões políticas e sociais cruciais dos dias de hoje são tratadas com densidade sem, contudo, menosprezar a necessidade de encontrar maneiras criativas de contar histórias que despertem e renovem o interesse do espectador durante a fruição do filme. Visando aumentar a imprevisibilidade e provocar um engajamento mais ativo do espectador na compreensão dos filmes, Iñárritu explora as discrepâncias advindas da dupla temporalidade da narrativa, as diferenças entre a ordem em que os acontecimentos aparecem na trama (plot, syuzhet) e seu lugar na história (story, fabula).

Para tanto, embaralha o tempo dos eventos, fazendo com que a narrativa evolua em ramificações e círculos com conexões inesperadas. Conforme evidenciado nas análises dos filmes de Iñárritu contemplados nesta tese, cada um apresenta uma forma diferente de com- 
binar multiplicidade de enredos e protagonistas com ordenação temporal não-linear, que será sinteticamente resumida a seguir. Este resumo sintético é realizado sob três eixos analíticos: o primeiro destaca as amarrações formais, o segundo trata das principais questões temáticas dos filmes e o terceiro foca os atrelamentos entre os temas dos filmes e a globalização.

\section{O formato da teia - como narram}

O exame da primeira narrativa de rede do diretor, o multiplot e multiprotagonista Amores brutos (2000), destaca a força aglutinadora suscitada pela expectativa de que situações, ações e personagens tendam ao paralelismo entre elas, o que estimula o espectador a estabelecer conexões e preencher algumas lacunas deixadas pelo afrouxamento da causalidade no encadeamento da trama. Conforme verificou-se na análise da estrutura do filme dividida em capítulos permeados, a coesão do paralelismo é dinamizada pela combinação tanto de estratégias narrativas que conformam a macroestrutura da trama, como outras que operam na microcomposição das cenas, compondo um arranjo em que seus efeitos se potencializam.

A investigação mostrou, portanto, que abrir uma cena em plano de detalhe, assim como começar o filme com um flashforward, são estratégias narrativas provocadoras, que levantam perguntas, ao invés de prover informações explicativas, incitando uma postura mais ativa da audiência. Essas duas estratégias também operam em consonância com a de postergar a apresentação das personagens principais, já que estimula o espectador a fazer inferências, elaborar e testar hipóteses no esforço de apreender quem são os protagonistas e como se relacionam com as personagens secundárias. Tais estratégias formais são mais do que meros artifícios para prender a atenção do espectador, pois urdem uma teia narrativa coesa que revela um cenário urbano multifacetado marcado pelas experiências de personagens contraditórios, complexos, pertencentes a diversos extratos sociais.

Por sua vez, a estratégia narrativa radical adotada por Iñárritu na tessitura de seu segundo filme, 21 gramas (2003) - também multiprotagonista, mas com apenas um enredo -, rompe o encadeamento causal e temporal de um jeito tal que o espectador tem dificuldades em decifrar seu padrão de ordenação e adota a emoção como principal fio condutor de sua organização aparentemente aleatória. A evolução da trama tende a apresentar as consequências antes das causas das ações, gerando choques a cada corte de uma cena para outra, subvertendo as expectativas de relação de causa e efeito e continuidade entre ações consecutivas. As emoções das personagens, destacadas pela predominância de planos fechados com pouca profundidade de campo, reverberam uns nos outros por meio da montagem. 
Com o objetivo de viabilizar a absorção da complexidade da estrutura do filme, o diretor lançou mão de recurso articulatório inédito em sua obra, a adoção de um narrador intradiegético. As reflexões de Paul no leito de morte estabelecem o ponto de vista do fluxo de consciência que elucubra a história do filme, sem comprometer a imprevisibilidade da trama. Gradualmente, o espectador vai identificando se os eventos acontecem antes, durante ou depois do atropelamento, que é o acontecimento que serve de entroncamento causal e temporal da trama, como se fossem os devaneios de Paul semiconsciente, tal qual ele surge no início do filme. Durante a projeção do filme, a audiência vai acumulando e processando informações, compensando a falta de sentido imediata de seu encadeamento, e, ao final, consegue conformar seu sentido integral e fechado, suscitando uma reflexão sobre solidão, acaso, questões morais e, mais uma vez, o cruzamento de destinos aparentemente desencontrados. Iñárritu justificou a adoção dos sentimentos como principal fio condutor da ordenação aparentemente aleatória do filme, para evitar a previsibilidade e destrinchar o teor melodramático intrínseco ao argumento original do filme.

Após a travessia real da fronteira entre México e Estados Unidos para realizar 21 gramas, Iñárritu alça um voo ainda mais amplo para fechar sua trilogia da morte com Babel (2006), filmado em três continentes. A análise revelou que a ordenação temporal não-linear engendrada entre as quatro linhas narrativas do filme é abrandada pelo predomínio do encadeamento lógico e cronológico entre as sequências da mesma história. As transições entre os blocos de sequências das histórias do filme operam como fronteiras entre seus universos diegéticos com potencial tanto de separá-los por contraste como aproximá-los por intelecção e emoção.

As passagens entre as diferentes histórias vão acumulando amarrações constituindo um jogo incessante que estimula o espectador na compreensão de um todo interligado. Além das estratégias macro estruturantes aplicadas na urdidura de Babel, a trilha sonora desempenha um papel articulador proeminente no filme, pelo ecletismo e radicalismo na combinação de seus elementos. A sonoridade do filme chama a atenção, tanto pelo virtuosismo com que realiza pontes musicais adicionando novas camadas de sentido nas transições entre os blocos das histórias, como também pelo arrojo com que a edição de som estabelece trechos em silêncio absoluto, associados à percepção de uma personagem surda-muda, Chieko.

Mesmo com sua narrativa puxando os limites convencionais do padrão mainstream, Babel estabelece seu diferencial como produto cultural e consagra-se, por enquanto, como o filme de maior bilheteria feito por Iñárritu. Apesar da abordagem de temas pouco usuais para filmes de grande circulação, como as assimetrias e tensões nas relações entre países ricos e 
pobres, o filme combina habilmente estratégias narrativas do cinema de arte com outras mais clássicas, que garantem a compreensão e prazer de uma ampla audiência. Um exemplo claro dessa combinação entre o convencional e o alternativo está na configuração do elenco do filme, que escala as estrelas hollywoodianas Brad Pitt e Cate Blanchett, facilitando a receptividade do grande público, e compensando o estranhamento causado pela atribuição de papéis de destaque a atores não profissionais, principalmente no enredo marroquino.

Apesar da ruptura com o padrão de narrativas de rede anteriores de Iñárritu, foi possível identificar, na análise do único enredo com apenas um protagonista de Biutiful (2010), o prosseguimento coerente do estilo autoral característico do diretor, tanto na utilização de estratégias formais, como em suas escolhas temáticas. No filme, a antecipação da derradeira cena como a primeira exibida pela trama repercute em toda a estrutura da narrativa. Solidão e morte seguem como motes proeminentes e a complexidade faz-se presente, principalmente, por meio da ramificação e entrelaçamento de linhas narrativas que tratam de relações familiares e de trabalho e do adensamento da construção e evolução das personagens. A diversidade comparece mais uma vez nas etnias, nacionalidades e línguas faladas em uma Barcelona marcada pelos impactos cruéis das relações de trabalho globalizadas em meio às interações afetivas entre nativos espanhóis e migrantes ilegais africanos e chineses.

A investigação constatou também que o engenhoso atrelamento da capacidade do flashforward em antever lampejos do futuro com a característica mediúnica do protagonista possibilitou a abertura para a inclusão de imaginário surreal inédito no universo narrativo de Iñárritu, até então, calcado exclusivamente no realismo. A fantasmagoria surge na representação dos espíritos dos mortos que Uxbal é capaz de ver e o flerte com o surrealismo corporifica-se na inserção de mamilos nas nádegas de dançarinas de boate.

Além das estratégias narrativas específicas utilizadas na orquestração de cada filme descritas acima, notou-se a aplicação de alguns outros recursos articulatórios importantes permeando a filmografia estudada, entre os quais vale ressaltar o uso de repetições e de objetos circulantes. Ao analisar o emprego de objetos circulantes, observou-se que eles incrementam a dinâmica entre enredo e personagem. Em Amores brutos, o cachorro Cofi deixa de pertencer a Octavio e passa para El Chivo. O coração de Michael é transplantado para Paul em 21 gramas. O liame entre as histórias de Babel é fortalecido pelo trânsito circular de um rifle.

Outro recurso usado em todos os filmes de Iñárritu analisados foi o da repetição de variações de cenas, ações, imagens, frases e diálogos, que colaboram na sutura das fraturas temporais e causais comuns a suas tramas. $\mathrm{O}$ uso de repetições, também frequente na narrativa clássica, ganha destaque no cinema multiplex pela relevância das conexões que promovem ao 
assumir a função de indexador temporal e liame de causalidade. Algumas das repetições têm impacto marcante na organização da narrativa como as quatro apresentações da colisão de carros em Amores brutos, a repetição da cena do embate físico dos três protagonistas no motel em 21 gramas, o reprise do telefonema de Richard quando liga do hospital de Casablanca para sua casa em Babel e a duplicidade da passagem de Uxbal da vida para a morte no início e final de Biutiful.

\section{Temáticas enredadas - o que narram}

No início da pesquisa, supunha-se que haveria certa proeminência do tempo sobre as demais instâncias narrativas na tessitura das tramas, mas, no decorrer das análises fílmicas, constatei que a construção das personagens tem relevância similar na constituição das histórias. Nos filmes de Iñárritu, o alto grau de ambiguidade e contradição que suas personagens revelam em seus arcos de transformação, imersos em situações críticas e, por vezes, trágicas, exercem tanta influência no desenrolar das tramas como as manipulações temporais.

As personagens de Iñárritu são contraditórias e vulneráveis a algo ou alguém que nada tenha a ver com eles e que traga a desordem a suas vidas. Presas a um emaranhado de trajetórias deliberadas e atalhos inesperados, as personagens sofrem mudanças, procuram encontrar um caminho que lhes possibilite seguir adiante. A morte está sempre à espreita e a construção das personagens é baseada na consciência deles da efemeridade da vida. A proximidade com a morte deixa os desejos das personagens mais intensos e seus impulsos em encontrar afeto nos outros menos controláveis.

Assiste-se, nas narrativas cinematográficas contemporâneas e, em especial, nas de Iñárritu, a uma valorização realista da participação de forças externas, aleatórias e inesperadas que movem as personagens para territórios distantes e divergentes de seus planos e vontades. O conflito entre a força do desejo e a tirania do acaso é materializado no arco de transformação das personagens em forma de contraste entre o que elas querem e o que o mundo lhes provê. Diversamente da abordagem do cinema clássico, o embate não é resolvido por meio da imposição da vontade dos protagonistas diante dos infortúnios, mas pela verificação da fragilidade, do sofrimento que leva ao isolamento e corrobora a solidão, âmago da condição humana.

Evidencia-se uma mudança significativa na concepção dos protagonistas do cinema multiplex, na qual, perdem espaço os heróis poderosos, vencedores de obstáculos em série que 
buscam a satisfação de seus desejos e a realização de seus objetivos, e proliferam, nas telas, seres mais humanos, passando por transformações, que se esforçam para compreender melhor ao mundo e a si mesmos. Assim como o desenvolvimento das personagens, os pontos de virada das narrativas não são mais suscitados predominantemente pela determinação humana, mas sim por interferências aleatórias do acaso ou cruzamentos fortuitos entre trajetórias de personagens.

O exame da construção e desenvolvimento dos protagonistas dos filmes de Iñárritu também constatou que boa parte deles apresenta variações em suas gêneses, que se enquadram na acepção aristotélica de "situação trágica por excelência", na qual pessoas que não se distinguem pela virtude e nem pela justiça caem em infortúnio não por serem abomináveis, mas por força de algum erro ou eventualidade. Na obra estudada, a piedade surge da desgraça de personagens que sofrem devido ao acaso, tais como: Valeria em Amores brutos, que tem uma perna amputada em consequência de uma batida de carros na qual não teve nenhuma culpa; Cristina, que perde o marido e as filhas em um atropelamento em 21 gramas; Susan, que leva um tiro acidental em Babel, quando está em turismo com o marido no Marrocos; e Uxbal, que provoca a morte de um grupo de chineses ao economizar na compra de aquecedores, em Biutiful. Nessas situações limítrofes, Iñárritu investiga a natureza humana, enquanto suas personagens sofrem e se expressam intensamente.

Outra concepção grega a pairar como um princípio norteador do arco de transformação de alguns protagonistas e indutor da evolução de enredos é a da nemesis, que explicaria o ônus a ser coberto quando se infringe um princípio moral. Analisando as tramas sob essa óptica, Valeria, por exemplo, teria perdido uma perna e sido condenada ao ostracismo por seduzir seu amante Daniel a largar sua esposa mais velha e filhas para viver com ela; e Uxbal estaria morrendo de câncer por viver explorando trabalhadores ilegais e aferir ganhos indevidamente com seu dom mediúnico. Esse princípio mitológico grego tem afinidades com a moral predominantemente católica mexicana, na qual as noções de pecado e culpa explicam o preço a ser pago por se dar vazão aos impulsos contrários às normas éticas vigentes na sociedade. Nos filmes, essas violações de princípios morais têm consequências terríveis e destroem famílias.

Solidão, amor e morte são os temas proeminentes nos filmes estudados e são abordados por um viés em que fica nítida a influência da identidade cultural mexicana de Iñárritu. Provavelmente, na análise desse componente marcante da obra em foco, a pesquisa tenha encontrado sua maior limitação por falta de conhecimento mais profundo e, principalmente, de uma vivência no México por parte do pesquisador. Um aporte fundamental para mitigar essa carência foi oferecido por Octavio Paz em seu livro O labirinto da solidão (2014), que, embo- 
ra não seja citado na mesma proporção em que contribuiu para o entendimento da narrativa de Iñáritu, permeia todo o estudo.

Nele, Paz (2014, p. 31, 155, 189, 190 e 191) defende que a solidão seria a principal característica da mexicanidade, assim como a vontade de transcendê-la. Ele chama a atenção quanto à dualidade da solidão que envolve ruptura com um mundo e tentativa de criar um outro, ou seja, a consciência de sermos sós e a constante busca de comunhão que nos una novamente à vida. O desejo de sair de si e obter redenção e plenitude encontra vazão por meio da experiência quase inacessível do ato "mais humano": o amor.

A solidão é definidora da dor existencial que molda o estado de espírito dos principais personagens dos filmes de Iñárritu, que moram sozinhos ou fazem parte de famílias incompletas e são mostrados vagando pelas cidades ou isolados em suas casas. A maior parte dos enredos dos filmes estudados mostram tentativas de rupturas com a solidão e criação de novos mundos por meio de relações amorosas. Em Amores brutos, El Chivo suspende sua carreira de matador de aluguel e tenta reaproximar-se da filha que o tem como morto. Paul larga sua mulher e entrega-se à paixão por Cristina, viúva do doador de seu coração transplantado, em 21 gramas. A adolescente surda-muda de Babel, Chieko, tenta, atrapalhadamente, estabelecer contatos sexuais com vários homens que cruzam seu cotidiano. Em Biutiful, Uxbal rompe com sua mulher bipolar e tenta convencer uma mãe africana a cuidar de seus filhos. Todavia, diferentemente da narrativa do cinema clássico, o objetivo desses personagens de criar novos mundos não é plenamente alcançado pois encontram obstáculos, imprevistos e acasos, que redirecionam suas trajetórias.

Ocorre também nas histórias de Iñárritu que a ambição de constituição de um novo mundo cheio de vida traz a destruição e a morte. O desejo de Octavio em fugir com a cunhada, em Amores brutos, leva à morte de seu irmão e à destruição de sua família. Ao se lançar em sua paixão por Cristina, em 21 gramas, Paul é intimado a assassinar o homem que matou o marido e as filhas dela em um acidente. Aliás, essa relação entre vida e morte é outro traço da cultura mexicana que também estabelece um diferencial na obra de Iñárritu, levando, inclusive, seus três primeiros filmes a serem denominados de trilogia da morte.

Em Amores brutos, além do extermínio de vários cães de briga e da matilha de viralatas, que são a "família" de El Chivo, há, também, o falecimento violento de seres humanos em batida de automóveis, tiros e facadas. A morte é o tema central em 21 gramas com o perecimento do doente cardíaco Paul e do atropelamento fatal de um pai e duas filhas. Babel mostra a polícia assassinando brutalmente o filho inocente, Ahmed, diante de seu pai Abdulah. Biutiful apresenta o padecimento de Uxbal, acometido de câncer, sua comunicação com os 
espíritos dos que já se foram e a morte de dezenas de chineses clandestinos por asfixia. Apesar de decorridos séculos de colonização, Paz (PAZ, 2014, p. 57-58) defende que a naturalidade diferenciada com a qual os mexicanos encaram a vida e a morte como prolongamentos uma da outra é oriunda das culturas indígenas que viviam no México antes da chegada dos espanhóis. Essa visão peculiar da relação entre vida e morte permaneceria ativa na cultura mexicana ainda nos dias de hoje e está entranhada na dramaturgia de Iñárritu.

\section{Conexões - a obra em seu contexto}

Outro aspecto temático que contribui significativamente para conferir unidade e diferencial à obra do diretor mexicano é seu interesse em tratar das conexões existentes entre as transações socioeconômicas e as relações afetivas, principalmente no tocante aos efeitos da globalização nas tramas familiares. A identificação e interpretação dessas conexões no corpus da pesquisa só se viabilizaram a partir de ideias trazidas por Nestor Canclini $(2008 ; 2011)$, pouco citadas ao longo da tese, mas fundamentais para a compreensão dessa questão, não apenas nos filmes em que as implicações da globalização aparecem de maneira visceral, mas principalmente naqueles em que essas conexões figuram de maneira indireta e são abordadas com maior sutileza.

Uma das principais consequências da globalização a ter impacto nas relações interpessoais seria a tendência ao incremento da concentração de renda. Na análise de Amores brutos, apontam-se ligações traiçoeiras entre o mundo glamourizado dos ricos e as mazelas a que os menos favorecidos precisam se submeter para ganhar seu sustento. A narrativa do filme entrelaça, ao acaso, a futilidade do universo da modelo famosa Valeria com o mundo cão de Octavio. A perversidade de transações entre pessoas em situações sociais e financeiras muito contrastantes fica exposta na trajetória de El Chivo, que é contratado por um empresário endinheirado para matar seu sócio meio-irmão, ironicamente, com a intermediação corrompida de um policial.

Há duas outras vinculações menos evidentes de Amores brutos com o processo de globalização relacionadas à implementação do acordo do NAFTA (North American Free Trade Agreement), que tinha como objetivo estimular a circulação de capitais, bens e serviços entre Estados Unidos e México. A primeira vinculação seria positiva, diz respeito não ao enredo, e sim à mudança da forma de financiamento da produção de cinema no México, que deixou de ser predominantemente estatal e passou a ser majoritariamente privada, sob in- 
fluência do tratado. Essa mudança na origem dos recursos teria incrementado a competitividade comercial não apenas do primeiro filme de Iñárritu, como também dos de outros jovens diretores como Guillermo del Toro e Alfonso Cuarón.

A segunda associação de Amores brutos com o NAFTA diz respeito às consequências negativas que o processo de globalização, engendrado por meio de acordo de cooperação regional, teria sobre a vida na Cidade do México. No filme, as consequência negativas surgem de forma indireta por meio do aumento da pressão demográfica na capital, causado pela emigração massiva das áreas rurais empobrecidas devido à concorrência desleal com a produção agrícola subsidiada estadunidense. A pressão demográfica migrante rural desqualificada para centros urbanos acarretaria o aumento da violência associada a atividades econômicas informais ou ilícitas, como as rinhas de cães que Octavio participa e a ocupação de El Chivo como matador de aluguel. O movimento migratório de trabalhadores em busca de melhores condições de vida, característico da globalização, estaria presente no subtexto do filme dando sustentação à verossimilhança do universo representado. Em Babel e em Biutiful, a problemática das migrações relacionadas à globalização são abordadas de forma direta e com maior diversidade e amplitude transnacional.

Em 21 gramas, a globalização interfere na temática do filme mediada pela presença da tecnociência, cuja constância no cotidiano é uma das características definidoras dos tempos hipermodernos (LIPOVETSKY; SERROY, 2009, p. 49). Ambientado nos Estados Unidos, o filme mostra técnicas de transplante de coração e inseminação artificial que são semelhantes às praticadas em diversos cantos da planeta. Dessa forma, fica subentendido, que o conhecimento científico, assim como a cultura, é disseminado pelo processo de globalização e repercute nas relações humanas. Ambos os procedimentos médicos sofisticados presentes no filme têm impacto relevante na trama, pois intervêm diretamente nos rumos das personagens.

Já em Babel e em Biutiful, vários aspectos do impacto da globalização nas relações interpessoais são abordados de forma explícita e foram amplamente contemplados nas análises. Os dois filmes versam sobre os contatos e conflitos entre diferentes culturas e classes sociais, que são agenciados pela mídia e impulsionados por movimentos populacionais turísticos e migratórios de pessoas em busca de melhores condições de vida. Tanto em espaços tradicionais definidos por fronteiras geográficas como nos virtuais constituídos pela sociedade de rede, a desterritorialização é apresentada como condição permanente de transnacionalidade. Nos filmes, Iñarritu aborda os dramas de pessoas transitando em espaços de fluxos entre fronteiras geopolíticas e culturais, expondo os riscos, tensões e extradições - Amelia, em Babel, e Ekweme, em Biutiful, - que ocorrem nessas travessias. Os filmes apontam a formação de no- 
vas identidades miscigenadas e mutantes nesses espaços de fluxo de pessoas e informações, simultaneamente dependentes da continuidade e da superação de suas identidades nacionais imersos em processo dinâmico interconectado.

\section{A pesquisa - desdobramentos possíveis}

Portanto, concluo que a pesquisa empreendida constatou que Iñárritu promove um diálogo fecundo entre inovação e tradição no cinema contemporâneo, ao combinar aspectos formais de multiplicidade e complexidade, com alguns traços proeminentes do tempo no qual vivemos, tais como fragmentação e hibridização. Ao abordar criticamente temáticas envolvendo movimentos populacionais, multiculturalismo, desterritorialização e presença da mídia e da tecnociência no cotidiano, o diretor tece narrativas nas quais a clara diferenciação da ação principal das complementares é estilhaçada e embaralhada de maneira instigante.

O que se vê na tela é uma mistura de padrões de narração convencionais com outros mais experimentais, alguns oriundos de movimentos cinematográficos vanguardistas da modernidade, sem perder a comunicabilidade com um público amplo. A análise da tessitura das narrativas fílmicas de Iñárritu evidencia a especial sensibilidade do diretor para com os atrelamentos entre o macro universo das transações socioeconômicas com o micro das relações afetivas entre as pessoas, que é expressa por meio de personagens vivendo à margem do poder instituído e mais vulneráveis aos efeitos do processo civilizatório globalizante.

Já que o estudo debruçou-se sobre a análise da narrativa fílmica da obra de diretor vivo e em atividade, com, inclusive, filme recém finalizado, Birdman (2014), lançado no mercado estadunidense em dezembro passado e com estreia comercial no Brasil prevista para janeiro de 2015, a investigação tem como primeira perspectiva de continuidade a análise das próximas realizações de Iñárritu. Um outro desdobramento possível, e até mesmo desejável, da pesquisa seria o aperfeiçoamento do ferramental analítico cognitivista-neoformalista complementado pela crítica da cultura utilizado nesta investigação, por meio do desafiador exame de outras filmografias da contemporaneidade nas quais diretores se destacam por suas inovações narrativas, tais como Michael Haneke, Lars Von Trier, Fernando Meirelles e Ang Lee.

De certo e imediato, o conteúdo e a metodologia da pesquisa serão transpostos para dentro de sala de aula como base da disciplina de análise fílmica que começo a ministrar no primeiro semestre de 2015 e os conhecimentos narrativos adquiridos nessa jornada serão aproveitados como instrumental criativo nos próximos filmes que pretendo realizar. 


\section{REFERÊNCIAS BIBLIOGRÁFICAS}

AMIEL, Vincent. A estética da montagem. Lisboa: Texto \& Grafia, 2007.

APPADURAI, Arjun. Modernity at large: cultural dimensions of globalization. Minneapolis: University of Minnesota Press, 1996.

ARISTÓTELES. Poética. Tradução, prefácio, introdução, comentário e apêndices de Eudoro de Sousa. Brasil: Imprensa Nacional - Casa da Moeda, 2003.

AUMONT, Jacques ET AL. A estética do Filme. 3 ed. Campinas: Papirus, 2005.

AUMONT, Jacques; MARIE, Michel. A Análise do Filme. Lisboa: Texto \& Grafia, 2009.

AUMONT, Jacques. Dicionário teórico e crítico de cinema. Campinas: Papirus, 2003.

AZCONA, María del Mar. The multi-protagonist film. Wiley-Backwell: Chichester, West Sussex - UK, 2010.

MONTOLIÚ [AZCONA, María del Mar]. "A Time to Love and a Time to Die: Desire and Narrative Structure in 21 Grams". ATLANTIS. Journal of the Spanish Association of Anglo-American Studies. 31.2 (December 2009): 111-123 ISSN 0210-6124

B., Benjamin. "Letting go". The American Society of Cinematographers, 2011, Disponível em: <http://www.theasc.com/ac magazine/January2011/Biutiful/page1.php>. Acesso em: 27 set. 2013.

BAL, Mieke. Narratology: introduction to the theory of narrative. Toronto: University of Toronto Press Incorporated, third edition, 2009.

BAPTISTA, Mauro; MASCARELLO, Fernando (ORG.). Cinema mundial contemporâneo. Campinas - SP: Papirus, 2 ed., 2011.

. O cinema de Quentin Tarantino. Campinas - SP: Papirus, 2013.

BARTHES, Roland R. et al. Análise estrutural da narrativa. Petrópolis - RJ: Vozes, 2009. 
BAUDRILLARD, Jean; MACHADO, Juremir. Tela total: mito-ironias da era do virtual e da imagem. Porto Alegre: Sulina, 2005.

BAUMAN, Zigmunt. Globalização. Rio de Janeiro: Zahar, 1999.

. Modernidade Líquida. Rio de Janeiro: Zahar, 2001.

BAZIN, André. O cinema - ensaios. São Paulo: Brasiliense, 1991.

. O que é o cinema. São Paulo: Cosac Naify, 2014.

BORDWELL, David. Figuras traçadas na luz. Campinas: Papirus, 2008.

. Making meaning: inference and rhetoric in the interpretation of cinema. Cambridge-USA: Harward Univ. Press, 1989.

. Narration in the fiction film. Madison: The University of Wisconsin Press, 1985.

. O cinema clássico hollywoodiano: normas e princípios narrativos. In: RAMOS, Fernão Pessoa (org.). Teoria Contemporânea de cinema: volume 2 - documentário e narrativa ficcional. São Paulo: Senac, 2005, p. 227-301.

Poetics of cinema. New York: Routledge, 2008.

. The way Hollywood tells it: story and style in modern movies. Berkley: University of California Press, 2006.

BORDWELL, David; CARROL, Noel (orgs.). Post-theory: reconstructing film studies. Madison - USA: The University of Wisconsin Press, 1996.

BORDWELL, David; THOMPSON, Kristin. Film art: an introduction. New York: MaGrawHill, 1993.

"Lessons from Babel". 2006. Disponível em: $<$ http://www.davidbordwell.net/blog/2006/11/27/lessons-from-babel $>$. consultado em 7 nov. 2013.

BOSLEY, Rachael. "Forging Connections". The American Society of Cinematographers, novembro de 2006. Disponível em: <http://www.theasc.com/ac_magazine/November2006/Babel/page1.php> Acesso em: 3 nov. 2014.

CALHOUN, John. Heartbreak and loss. The American Society of Cinematographers, Dez 2003. Disponível em: <http://www.theasc.com/magazine/dec03/cover/>. Acesso em: 23 jul. 2014. 
CALVINO, Italo. Seis propostas para o próximo milênio: lições americanas. 3 ed., 5 reimpressão. São Paulo: Companhia das Letras, 1997.

CAMPBELL, Joseph. O herói de mil faces. São Paulo: Pensamento, 2007.

CANCLINI, Néstor Garcia. Culturas híbridas: estratégias para entrar e sair da modernidade. São Paulo: EDUSP, 2011.

. Leitores, espectadores e internautas. São Paulo: Iluminuras, 2008.

Will there be Latin American cinema in the year 2000? Visual culture in a Postnactional era. In: Framing Latin American Cinema: contemporary critical perspectives. Ed. Ann Marie Stock. Minneapolis: University of Minnesota Press, 1997.

CAROLL, Amy. Global Mexican coproduction: Babel, Pans Labyrinth and Childrem of Man. The Journal of Transnational American Studies. v. 4 n. 2, 2012. Disponível em: <https://escholarship.org/uc/item/4bp4x1sg>. Acesso em: 11 mar. 2014.

CASTEllanOS, Vicente. Tendencias en el cine contemporáneo. Revista Digital Universitaria, v. 7 n. 6. UAM- Cuajimalpa, p. 3, 7-8, 2006.

Chklovski, V; EICHenbaum, B; TYNIAnOV, I. Poetika Kino. Berkeley-USA: Berkeley Slavic Specialties, 1984.

COMPARATO, Doc. Da Criação ao Roteiro: teoria e prática. São Paulo: Sumus, 2009.

COOK, David A. A history of narrative film. New York: W.W. Norton \& Company, 1990.

CRAWFORD, Travis. Humane Society. Revista Filmmaker Magazine, 2001. Disponível em:

<http://filmmakermagazine.com/archives/issues/winter2001/features/humane_society. php>. Acesso em: 28 set. 2014.

DANCYGER, Ken. Técnicas de edição para cinema e vídeo. Rio de Janeiro: Elsevier, 2003.

DANCYGER, Ken; RUSH, Jeff. Alternative scriptwriting: writing beyond the rules. Boston - USA: Focal Press, 1991.

DELEYTO, Celestino; AZCONA, María del Mar. Alejandro Gonzáles Iñárritu: contemporary film directors. Illinois: University of Illinois Press, 2010. 
DELEUZE, Gilles. A imagem-movimento: cinema I. São Paulo: Brasiliense, 1983.

. A imagem-tempo: cinema II. São Paulo: Brasiliense, 2007.

DENBY, David. The new disorder: adventures in film narrative. New Yorker, 05 de março de 2007, p. 80-85. Disponível em: <http://www.newyorker.com/magazine/2007/03/05/the-new-disorder >. Acesso em: 16 mar. 2011.EDUARDO, Cleber. Diretores transnacionais latino-americanos. In:. BAPTISTA, Mauro e MASCARELLO, Fernando (orgs.). Cinema mundial contemporâneo. 2 ed. Campinas - SP: Papirus, 2011. p. 193-211.

EISENSTEIN, Sergei. A forma do filme. Rio de Janeiro: Jorge Zahar, 1990.

O sentido do filme. Rio de Janeiro: Jorge Zahar, 1990.

FELINTO, Erick. Cinema e tecnologias digitais. In: MASCARELLO, Fernando. (ORG.) História do Cinema Mundial. 2 ed. Campinas - SP: Papirus, 2011. p. 413-428.

FAULKNER, William. O Som e a fúria. São Paulo: Ed. Cosacnaify, 2002.

FIELD, Syd. Manual do Roteiro. Rio de Janeiro: Objetiva, 1982.

FRANÇA, Andréa. Cinema de Terras e Fronteiras. In: MASCARELLO, Fernando (ORG.). História do Cinema Mundial. Campinas-SP: Papirus 2006. p. 395-412.

GARCÍA, Rodrigo. The Foundations of Babel: a conversation between Rodrigo García and Alejandro González Iñárritu. In: Babel: a film by Alejandro González Iñárritu. Ed. María Hargerman. Hong Kong: Tashen, 2007. 256-63.

GAUDREUALT, André; JOST, François. A narrativa cinematográfica. Brasília: Editora UnB, 2009.

GENETTE, G. Narrative discourse: an essay in method. Ithaca: Cornell University Press, 1980.

. Narrative Discourse Revisited. Ithaca: Cornell University Press, 1988.

. Figuras. São Paulo: Perspectiva, 1972.

GIUNTINI, Mauro. Tiempo "Biultiful": la antecipación en la narrativa cinematográfica. In: SÁNCHES, Javier Sierra; ORMAECHEA, Sheila Liberal (orgs.) Reflexiones científicas sobre publicidade y género desde la óptica audiovisual. Madrid: Editora Fragua, 2011, p. 143-158. 
GREIMAS, A. J. Elementos para uma teoria da interpretação da narrative mítica. In: BARTHES, R. et al. Análise estrutural da narrativa. Petrópolis - RJ: Vozes, 2009.

HARGERMAN, María (ed.). Babel: a film by Alejandro González Iñárritu. Hong Kong: Tashen, 2007.

HASSAPOPOULOU, Marina. "Babel: Pushing and reaffirming mainstream cinema's boundaries". Jump Cut: a review of contemporary media. N. 50, 2008. Disponível em: <http://www.ejumpcut.org/archive/jc50.2008/Babel/index.html>. Acesso em: 6 out. 2013.

HOWARD, David; MABLE, Edward. Teoria e prática do roteiro. São Paulo: Globo, 1993. JAMESON, Fredric. As marcas do visível. Rio de Janeiro: Graal, 1995. 1996.

Pós-modernismo, a lógica cultural do capitalismo tardio. São Paulo: Ática,

KEER, Paul. Babel's network narrative: packaging a globalized art cinema. Transnacional Cinemas. v. 1, n. 1, p. 37-51, 2010.

KRAUSE, Enrique. Hollywood deaths: an American Dream. Los Angeles Times. 22 jan 2004. Disponível em: <http://articles.latimes.com/2004/feb/22/entertainment/cakrauze22>. Acesso em: 23 nov. 2014.

LYOTARD, Jean-François. A condição pós-moderna. Rio de Janeiro: José Olímpio, 1998.

LIPOVETSKY, Gilles; SERROY, Jean. A Tela Global: mídias culturais e cinema na era hipermoderna. Porto Alegre: Sulina, 2009.

LIPOVETSKY, Gilles; CHARLES, Sébastien. Os tempos hipermodernos. São Paulo: Barcarolla, 2004.

LITTGER, Stephan. The Director's Cut: picturing Hollywood in the $21^{\text {st }}$ century. Nova Iorque: Continuum, 2006.

LOPES, Denilson (org.). Cinema dos Anos 90. Argos: Chapecó, 2005.

LOPES, Maria Immacolata. Pesquisa em comunicação. São Paulo: Loyola, 2005.

MACCARTHY, Todd. Review: Babel. Variety, 23 mai 2006. Disponível em: <http://variety.com/2006/film/reviews/babel-3-1200516004/>. Acesso em: 7 jul. 2014.

MACHADO, Arlindo. O sujeito na tela: modos de enunciação no cinema e no ciberespaço. São Paulo: Paulus, 2007. 
. Pré-cinemas e pós-cinemas. 5 ed. Campinas-SP: Papirus, 2008.

MACKEE, Robert. Story: substância, estrutura, estilo e os princípios da escrita de roteiro. Curitiba: Arte \& Letras, 2006.

MCLUHAN, H.; FIORE, Q. War and Peace in the global village. Nova Iorque: Bantam Books, 1968.

MANEVY, Alfredo. Hollywood: a versatilidade do gênio do sistema. In:. BAPTISTA, Mauro; MASCARELLO, Fernando (orgs.). Cinema mundial contemporâneo. 2 ed. Campinas - SP: Papirus, 2011. p. 253-269.

MANOVICH, Lev. The language of new mídia. Massachusetts: MIT Press, 2002.

MARTEL, Frédéric. Mainstream: a guerra global das mídias e das culturas. Rio de Janeiro: Civilização Brasileira, 2012.

MARTIN, Marcel. A linguagem cinematográfica. São Paulo: Brasiliense, 2007.

MASCARELlO, Fernando. (org.) História do Cinema Mundial. Campinas - SP: Papirus, 2 ed., 2011.

Reinventando o conceito de cinema nacional. In: BAPTISTA, Mauro; MASCARELLO, Fernando (org.). Cinema mundial contemporâneo. 2 ed. Campinas - SP : Papirus, 2011. p. 25-55.

METZ, Christian. A grande sintagmática do filme narrativo. In: BARTHES, Roland. et al. Análise estrutural da narrativa. Petrópolis - RJ: Vozes, 2009.

A significação do cinema. $2^{\mathrm{a}}$ ed. São Paulo: Perspectiva, 2004.

MITRY, Jean, The aesthetics and psychology of the cinema.: Bloomington: Indiana University Press, 1997.

MOLINA, Sandra; et al. "21 Grams de narrativas postclásicas". Disponível em: <www.bocc.ubi.pt>. Acesso em: 12 jul. 2014.

MORA, Carl J. Mexican Cinema: reflections of a society 1896-2004. 3 ed. Jefferson, N.C.: McFarland \& Company, 2005.

MORALES, Ed. "Pulp nonfiction - Amores perros leads a Mexican revival". The Village Voice, 27 mar 2001. Disponível em: <http://www.villagevoice.com/2001-0327/film/pulp-nonfiction/>. Acesso em: 20 jan 2014.

Cultura de Massas no Século XX: o espírito do tempo - Neurose. Rio de Janeiro: Forense Universitária, 1987. 
MOTTA, Leda e PENAFIERI, Vânia. "O cinema de Alfred Hitchcock e Alejandro Iñárritu: convergência e geração de sentidos”. Revista Líbero - São Paulo - v. 16, n. 32, p. 5360, jul/dez de 2013.

MOTTA, Luiz Gonzaga. Análise crítica da narrativa. Brasília: Universidade de Brasília, 2013.

MUNOZ, Lorenza. "Modern Mexico unleashed". Los Angeles Times. 8 abr 2001. Disponível em: <http://articles.latimes.com/2001/apr/08/entertainment/ca-48253>. Acesso em: 15 jan 2014.

NUNES, Benedito. O tempo na narrativa. São Paulo Ática, 1988.

PARENTE, André. Narrativa e modernidade: os cinemas não-narrativos do pós-guerra. Campinas: Papirus, 2000.

PAZ, Octavio. O labirinto da solidão. São Paulo: Cosac Naify, 2014.

PARSHAL, Peter. Altman and after: multiple narratives in film. Plymouth: The Scarecrow Press, 2012.

PHILBIN, Robert. Globalism and the films of Alejandro González Iñárritu. Nthposition online magazine, 2007. Disponível em: <http://www.nthposition.com/globalismandthefilms.php\#note 2>. Acesso em: 24 nov 2014.

POND, Steve. Will somebody please nominate Javier Bardem?. The Wrap. 16/12/2010. Disponível em: <http://www.thewrap.com/awards/column-post/javier-bardemsnubbed-proud-23295/>. Acesso em: 11 nov 2014.

PROPP, Vladmir. Morfologia do conto maravilhoso. Rio de Janeiro: Forense, 1984.

PUCCI, Renato. Cinema pós-moderno. In: MASCARELLO, Fernando. (org.) História do Cinema Mundial. 2 ed. Campinas - SP: Papirus, 2011. p. 361-370.

RAMOS, Fernão Pessoa. (org.) Teoria contemporânea do cinema. vol. I e II. São Paulo: SENAC, 2005.

RICOUER, Paul. Tempo e narrativa - tomo I. Papirus: Campinas - SP, 1994.

Tempo e narrativa: a configuração do tempo na narrativa de ficção, vol. 2. São Paulo: Martins Fontes, 2010. 
ROMNEY, Jonathan. "Enigma Variation”. Sigth and Sound. ISSN 0037-4806, v. 14 n 3 , 2004, p. 12-16.

. "Going to the dogs". The Guardian. 22 ago 2000. Disponível em: $<$ http://www.theguardian.com/film/interview/interviewpages/0,6737,357271,00.html $>$. Acesso em: 13 jan. 2014.

ROTHLISBERGER, Leisa. "Babel's national frames in global Hollywood". Jump Cut - a review of contemporary media, $\mathrm{n}^{\mathrm{o}}$ 54, fall 2012. Disponível em: <http://www.ejumpcut.org/archive/jc54.2012/RothlisbergerBabel// >. Acesso em: 6 nov. 2013.

SABINES, Jaime. Del mito. In SABINES, Jaime. Antología Poetica. São Paulo: Martins Fontes, 1950. p. 120.

SANTOS, Milton. Por uma outra globalização: do pensamento único à consciência universal. 19 ed. Rio de Janeiro: Record, 2010.

SCOTT, Kevin. Lições de roteiristas. Rio de Janeiro: Civilização Brasileira, 2008.

SECHER, Benjamin. "Alejandro Gonzealez Iñárritu Interview for Biutiful”. The Telegraph. 29 de janeiro de 2011. Disponível em: $<$ http://www.telegraph.co.uk/culture/film/filmmakersonfilm/8288951/Alejandro-

Gonzalez-Inarritu-interview-for-Buitiful.html>. Acesso em: 27 set. 2013.

SHAW, Deborah. Babel and the global Hollywood gaze. Situations: project of the radical imagination. V. 4, n. 1, 2011. Disponível em: $<$ http://ojs.gc.cuny.edu/index.php/situations/article/view/742/1203>. Acesso em: 21 mar 2014.

SMITH, Paul Julian. Amores Perros. London: Britsh Film Institute, 2003.

SPERLING, Nicole. "The dark is just 'Biutiful' to Alejandro González Iñárritu e Javier Bardem". Los Angeles Times, 30 dez. 2010. Disponível em: $<$ http://www.latimes.com/entertainment/la-et-bardem-inarritu-20101230story.html\#page=1>. Acesso em: 11 nov. 2014.

SPINES, Christine. "Lost in translation”. Entertainment Week. 27 out 2006. Disponível em: <http://www.ew.com/ew/article/0,1551081,00.html>. Acesso em: 10 set. 2014.

STAM, Robert. Introdução à teoria do cinema. 2 ed. Campinas: Papirus, 2006. 
STOCK, Ann Marie (org). Framing Latin American Cinema: contemporary critical perspectives. Minneapolis: University of Minnesota Press, 1997.

SUPIA, Alfredo, PIEDADE, Lúcio; FERRARAZ, Rogério. O cinema independente americano. In:. BAPTISTA, Mauro; MASCARELLO, Fernando (orgs.). $2^{\mathrm{a}}$ ed Cinema mundial contemporâneo. Campinas - SP: Papirus, 2011, p. 235-252.

TERÁN, Juan. "Las mixtificaciones narrativas en el cine de Alejandro González Iñárritu". Revista Comunicación. v.1, n. 10. 2012, p. 1157-1171.

TIERNEY, Dolores. Alejandro González Iñárritu: director without borders. New Cinemas 7:2, p. 101-117, 2009. Disponível em: $<$ http://www.academia.edu/1065538/Alejandro_Gonzalez_Inarritu_Director_without_ Borders >. Acesso em: 6 nov. 203.

TODOROV, Tzvetan. As estruturas narrativas. 5 ed. São Paulo: Perspectiva, 2008.

TOMACHEVSKI, B. Temática, in EIKHENBAUM, B. Teoria da Literatura: formalistas russos. Porto Alegre: Globo, 1970.

VANOYE, Francis; GOLIOT-LÉTÉ, Anne. Ensaio sobre a análise fílmica. Campinas: Papirus, 1994.

VOGLER, Christopher. A jornada do escritor: estruturas míticas para escritores. Rio de Janeiro: Nova Fronteira, 1998.

XAVIER, Ismail. O discurso cinematográfico: a opacidade e a transparência. $4^{\mathrm{a}}$ ed. São Paulo: Paz e Terra, 2008.

. (org.) A experiência do cinema. Rio de Janeiro: Graal, 1998.

. O olhar e a cena. São Paulo: Cossac \& Naify, 2003.

WOOD, Jason. The faber book of Mexican Cinema. London: Faber and Faber, 2006.

AMORES brutos. IMDb (Net). Disponível em:

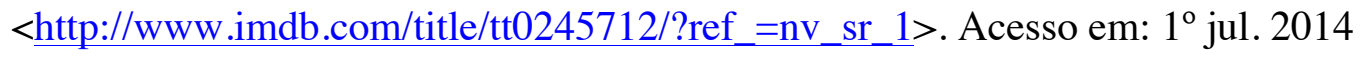

21 gramas. $\quad \mathrm{IMDb} \quad(\mathrm{Net})$.

Disponível

em:: <http://www.imdb.com/title/tt0315733/?ref_=fn_al_tt_1>.Acesso em: $1^{\text {o }}$ ago. 2014

BABEL. IMDb (Net). Disponível em: $<$ http://www.imdb.com/title/tt0449467/?ref_=nv_sr_1 $>$. Acesso em: $1^{\text {o }}$ set. 2014 
BIUTIFUL. IMDb (Net). Disponível em: $<$ http://www.imdb.com/title/tt0449467/?ref_=nv_sr_1 1 . Acesso em: $1^{\circ}$ nov. 2014

21 gramas. (Net) Disponível em: < http://www.21-grams.com/index.php>. Acesso em: 15 nov. 2014 


\section{REFERÊNCIAS FILMOGRÁFICAS}

21 gramas (21 grams, Alejandro Gonzales Iñárritu, 2003)

Acossado (À bout de souffle, Jean-Luc Godard, França, 1960)

A balada do pistoleiro (Desperado, Robert Rodriguez, 1995)

A espinha do diabo (El espinazo del diablo, Guillermo del Toro, 2001)

A estrada perdida (The lost highway, David Lynch, 1997)

Além da linha vermelha (The thin red line, Terrence Malick, 1998)

Amnésia (Amnesia, Christopher Nolan, 2000)

Amores brutos (Amores perros, Alejandro Gonzales Iñárritu, 2000)

Antes da chuva (Before de Rain, Milcho Manchevisk, 1994)

A princezinha (The little princess, Alfonso Cuáron, 1995)

A origem (Inception, Christopher Nolan, 2010)

A perdição dos homens (La perdición de los hombres, Arturo Ripstein, 2000)

Arroz amargo (Riso amaro, Giuseppe De Santis, 1949)

As mulheres (The women, George Cukor, 1939)

Assassinos por natureza (Natural born killers, Oliver Stone, 1994)

A separação (Jodaeiye Nader az Simin, Asghar Farhadi, 2011)

Babel (Alejandro Gonzales Iñárritu, 2006) 
Blade II - o caçador de vampiros (Blade II, Guillermo del Toro, 2002)

Birdman (Alejandro Gonzales Iñárritu, 2014)

Biutiful (Alejandro Gonzales Iñárritu, 2010)

Canoa (Felipe Cazals, 1977)

Cidadão Kane (Citzen Kane, Orson Welles, 1941)

Cidade dos sonhos (Mulholland Drive, David Lynch, 2001)

Cobrador - in God we trust (Paul Leduc, 2006)

Como água para chocolate (Alfonso Arau, 1992)

Coisas insignificantes (Cosas insignificantes, Andrea Martínez, 2008)

Corazones rotos (Rafael Montero, 2001)

Cortina de fumaça (Smoke, Wayne Wang, 1995)

Crash - no limite (Crash, Paul Haggis, 2005)

Cronos (Guillermo del Toro, 1993)

De noche vienes, Esmeralda (Jaime Humberto Hermosillo, 1997)

Diários de motocicleta (Walter Salles, 2004)

El jardin del Edén (María Novaro, 1994)

El santo oficio (Arturo Ripstein, 1974)

Ensaio de um crime (Ensaio de um crimen, Luis Buñuel, 1955)

E sua mãe também (Y tu mamá también, Alfonso Cuarón, 2001)

Faça a coisa certa (Do the right thing, Spike Lee, 1989).

Felicidade (Happiness, Todd Sodondz, 1998)

Filhos da esperança (Children of men, Alfonso Cuarón, 2006)

Frida (Julie Taymor, 2002) 
Frida naturaleza viva (Paul Ledúc, 1983)

Grand Canyon - ansiedade de uma geração (Grand Canyon, Lawrence Kasdan, 1991)

Grandes esperanças (Great Expectations, Alfonso Cuarón, 1998)

Gravidade (Gravity, Alfonso Cuarón, 2013)

Gangues de Nova York (Gangs of New York, Martin Scorsese, 2002)

Guerra nas estrelas (Star wars, George Lucas, 1977)

Grande hotel (Grand hotel, Edmund Goulding, 1932)

Hannah e suas irmãs (Hannah and her sisters, Woody Allen, 1986)

Harry Potter e o prisioneiro de Azkaban (Harry Potter and the prisoner of Azkaban Alfonso Cuarón, 2004)

Hellboy (Guillermo del Toro, 2004)

Hellboy II - o exército dourado (Hellboy II - the golden army, Guillermo del Toro, 2008)

Hiroshima mon amour (Alain Resnais, 1959)

Império dos sonhos (Inland Empire, David Lynch, 2006)

Indiana Jones e os caçadores da arca perdida (Raiders of the lost arc, Steven Spielberg, 1981)

Intolerância (Intolerance, D.W. Griffith, 1916)

Irreversível (Irreversible, Gaspar Noé, 2002)

Jantar às oito (Dinner at eight, George Cukor, 1933)

Juno (Jason Reitman, 2007)

Kill Bill: volumes 1 e 2 (Quentin Tarantino, 2003 e 2004)

Ladrões de bicicleta (Ladri di biciclette, Vittorio de Sica, 1948)

La reina de la noche (Arturo Ripstein, 1994) 
La virgem de la luxuria (Arturo Ripstein, 2002)

Las vueltas del citrillo (Felipe Cazals, 2006)

Magnólia (Magnolia, Paul Anderson, 1999)

Mecánica Nacional (Luis Alcoriza, 1971)

Muriel (Murriel ou le tems d'un retour, Alain Resnais, 1963)

Mutação (Mimic, Guillermo del Toro, 1997)

Nashville (Robert Altman, 1975)

Na linha vermelha (Thin red line, Terence Malick, 1998)

Nicotina (Hugo Rodríguez, 2003)

Ninguém escreve ao coronel (El coronel no tiene quien le escriba, Arturo Ripstein, 1999)

O alucinado (Él, Luis Buñuel ,1953).

O bruto (El Bruto, Luis Buñuel, 1952)

Obsessão (Ossessione, Luchino Visconti, 1943)

O anjo exterminador (El ángel exterminador, Luis Buñuel, 1962)

O ano passado em Marienbad (L'Année dernière à Marienbad, Alain Resnais, 1961)

O beco dos milagres (El callejón de los milagros, Jorge Fons, 1995)

O búfalo da noite (El búfalo de la noche, Jorge Hernandez Adana, 2007).

O caminho (Yol, Serif Gören e Ylma Güney, 1982)

O cão andaluz (Un chien d'Andalou, Luís Buñuel e Salvador Dali, 1929)

O céu sobre os ombros (The sky above, Sérgio Borges, Brasil, 2009)

O Grande Golpe (The killing, Stanley Kubrick, 1956)

O jardineiro fiel (The constant gardener, Fernando Meirelles 2005) 
O homem com a câmera (The cameraman, Dziga Vertov, 1929)

O labirinto do fauno (El labirinto del fauno, Guillermo del Toro, 2006)

O nascimento de uma nação (The birth of a nation, D.W. Griffith, 1915)

Onde os fracos não têm vez (No country for the old man, Ethan e Joel Cohen, 2007)

O segredo de Brokeback Mountain (Brokeback mountain, Ang Lee, 2005)

O segredo dos seus olhos (El secreto de tu ojos, Juan José Campanella, 2009)

Os esquecidos (Los olvidados, Luis Buñuel,1950)

O primeiro ano do resto de nossas vidas (St. Elmo's fire, Joel Shumacher, 1985)

O vento levou (Gone with the Wind, Victor Fleming, 1939)

Pequena miss sunshine (Little miss sunhine, Jonathan Dayton e Valerie Faris, 2006)

Poderosa Afrodite (Mighty Aphrodity, Woody Allen 1995)

Pulp fiction - tempo de violência (Pulp ficcion, Quentin Tarantino, 1994)

Roma cidade aberta (Roma, cittá aperta, Roberto Rosellini, 1945)

Rashomon (Rashomon, Akira Kursawa, 1950)

Reportaje (Emilio Fernández, 1953)

Rio 40 Graus (Nelson Pereira dos Santos, 1955)

Rio eu te amo (vários diretores, 2014)

Sem destino (Easy rider, Dennis Hoper, 1969)

Short Cuts - cenas da vida (Short Cuts, Robert Altman, 1993)

Sideways - entre umas e outras (Sideways, Alexander Payne, 2004)

Simples Mortais (Mauro Giuntini, 2007)

Smoking e No smoking (Smoking/Non-smoking, Alain Resnais, 1993) 
Sólo com tu pareja (Alfonso Cuarón, 1991).

Sonhos eróticos de uma noite de verão (A midsummer night's sex comedy, Woody Allen, 1980)

Tempestade de gelo (The ice storm, Ang Lee, 1997)

Time Code (Mike Figgis, 2010)

Titanic (James Cameron, 1997)

Traffic - ninguém sai limpo (Traffic, Steven Soderberg, 2000)

Tropa de elite 2 - o inimigo agora é outro (José Padilha, 2010).

Tubarão (Jaw, Steven Spielberg, 1975)

Quem quer ser um milionário (Slumdog millionaire, Danny Boyle e Loveleen Tanda, 2008)

Vidas que se cruzam (The burning plain, Guillermo Arriaga, 2008)

Wonderland (Wonderland, Michael Winterbotton, Inglaterra, 1999)

Words with gods (vários diretores, 2014) 


\section{APÊNDICES}

\section{ESTRUTURAS E ESCALETAS DOS FILMES}


APÊNDICE A

ESTRUTURA DE AMORES BRUTOS

Divisão de capítulos, repetição da batida de carros e entrelaçamento das histórias

El Chivo e Maru

Octavio e Susana

Daniel e Valeria

Abertura em flashforward

$1^{\text {a }}$ colisão de carros (cena 1,0 min51s)

Intertítulo do capítulo 1: Octavio e Susana

Sete inserções da história de El Chivo no capítulo 1:

a. El Chivo recolhe o resto de uma cama acompanhado de sua matilha à beira de uma pista (cena 4, 5min44s)

b. El Chivo parte com facão em punho na defesa de seus cachorros sob ameaça do cão de rinha de El Jarozo (cena 7, 9min20s)

c. El Chivo observa foto de um senhor de terno e coloca balas em um pistola (cena 9, $11 \min 29 \mathrm{~s})$

d. El Chivo mata a tiros o senhor de terno em um restaurante (cena 12, 15min27s)

e. El Chivo lê matéria de jornal sobre o homem que assassinou e encontra anúncio do enterro de sua ex-mulher (cena 17, 20min02)

f. El Chivo vai escamoteado ao enterro de sua ex-mulher e vê sua filha (cena 27, 34min01s)

g. El Chivo observa sua filha sair de casa e ela não o reconhece (cena 31, 44min46s) 


\section{Quatro inserções da história de Daniel e Valeria no capítulo 1:}

a. Daniel dirige entediado com sua mulher que com as filhas e vê outdoor de Valeria (cena 13, 16min12s)

b. Família chega em casa, esposa atende ao telefone e ninguém responde do outro lado da linha (cena 14, 16min37s)

c. Daniel está no quarto assistindo TV com a esposa e sai para atender telefonema da amante (cena 24, 30min44s)

d. Daniel cobre e beija as filhas que dormem (cena 34,43 min02s)

\section{$2^{\mathrm{a}}$ colisão de carros (cena $\left.41,57 \mathrm{~min} 20 \mathrm{~s}\right)$}

$3^{\mathrm{a}}$ colisão de carros (cena 45, 1 h01 min53s)

Intertítulo Capítulo 2: Daniel e Valeria

\section{Duas inserções da história de El Chivo no capítulo 2:}

a. El Chivo entra na casa de sua filha e rouba fotos dela. (cena 52, 1h08min18s)

b. El Chivo faz curativo no ferimento de bala de Cofi. (cena 56, 1h14min16s)

\section{$4^{\mathrm{a}}$ colisão de carros (cena $\left.82,1 \mathrm{~h} 45 \mathrm{~min} 25 \mathrm{~s}\right)$}

Intertítulo capítulo 3: El Chivo e Maru

Quatro inserções no capítulo 3 da história de Octavio - referente ao seu Terceiro Ato:

a. Ramiro, todo machucado da surra que Octavio encomendou para ele, acompanhado de Susana e do bebê cruza com El Chivo numa rua. (cena 77, 1h40min43s)

b. Ramiro tenta assaltar um banco e é morto pelo segurança. (cena 86, 1h50min11s)

c. No velório de Ramiro, Octavio, inconvenientemente, insiste para que Susana fuja para viver com ele em outra cidade. (cena 89, 1h56min25s)

d. Octavio aguarda Susana na rodoviária, não embarca no ônibus e sai caminhando desolado. (cena 100, 2h17min06s)

\section{Uma menção à história de Valeria no capítulo 3:}

a. Outdoor do perfume Enchant sendo retirado, enquanto El Chivo passa de carro. (cena $103,2 \mathrm{~h} 22 \mathrm{~min} 34 \mathrm{~s})$ 


\section{APÊNDICE B}

\section{ESCALETA DE AMORES BRUTOS}

\section{Créditos iniciais}

\section{Título: Amores Perros}

1. Octavio e Jorge, com um cão ferido e ensanguentado no banco de trás, são perseguidos com tiros por uma caminhonete. Octavio ultrapassa o sinal vermelho e provoca uma violenta colisão com outro carro.

\section{Intertítulo: Octavio y Susana}

2. Em um local de rinha de cães, Jarocho leva seu cão até a luta, enquanto cães feridos são retirados do local. Sob o comando de Maurício, Jarocho e o outro dono atiçam seus cães e a briga começa.

3. Susana chega em casa e, ao abrir a porta, Cofi foge. Ao entrar, Susana encontra a mãe de Octavio e Ramiro, que cuida de seu filho e falam sobre quem deve cuidar da criança no dia seguinte.

4. El Chivo, acompanhado de um grupo de cães, recolhe pedaços de lixo e os coloca em um carrinho.

5. De volta à rinha, os cães brigam e o cão de Jarocho está vencendo.

6. Octavio chega em casa, brinca e conversa com Susana e seu filho. Ramiro, marido de Susana e pai do menino, entra já sendo agressivo com Susana. Octavio entra na discussão para defendê-la e assume ter deixado Cofi fugir.

7. Mauricio paga Jarocho pela vitória. Na saída, Jarocho vê alguns vira-latas e leva seu cão até eles para "se divertir", mas El Chivo aparece segurando um facão, e defende os cães. Cofi passa por ali e Jarocho leva seu cão até ele para atacá-lo.

8. Susana vai até o quarto de Octavio, que assiste à filme do Corcunda de Notre Dame, e agradece-lhe por defendê-la. Ele vê um machucado em Susana e se mostra indignado com a forma como Ramiro a trata.

9. Em sua morada, El Chivo tira de uma gaveta uma foto e uma arma, e a carrega.

10. A mãe de Octavio o chama em seu quarto e diz que não gosta que Susana fique lá. Octavio vai até a porta da casa e vê Jorge que diz que Cofi matou o cão de Jarocho. Jarocho chega, em seguida, pra tirar satisfação. Após discutirem, Jarocho sai. 
11. Octavio e Ramiro almoçam. Sua mãe pede dinheiro a Ramiro, que diz que não tem. Durante o almoço, Octavio fala sobre ganhar dinheiro em farmácias a Ramiro, que se irrita e o ameaça.

12. El Chivo espreita, do lado de fora, um homem comendo em um restaurante. Ele tira uma arma debaixo do paletó e atira no homem, matando-o, e foge.

13. Daniel, suas filhas e esposa estão em um carro. As filhas brigam e sua esposa as manda parar. Daniel vê um grande outdoor com a imagem de Valeria.

14. Daniel e sua família chegam em casa e o telefone está tocando. Suas filhas atendem e dizem que não houve resposta. Sua esposa implica com a ligação, acreditando ser uma amante. $\mathrm{O}$ telefone toca novamente e a esposa atende. Ninguém responde. A esposa fica desconfiada.

15. Susana entra no quarto de Octavio e o conta que está grávida novamente, que não quer o bebê e não sabe o que fazer. Octavio a chama para fugir com ele e a beija. Susana se irrita e sai.

16. Ramiro e um amigo, dentro de um carro, conversam sobre um roubo. Eles pegam armas, colocam máscaras, saem do carro e assaltam uma farmácia.

17. El Chivo come enquanto lê o jornal e vê a notícia da morte do homem que matou no restaurante. Na seção de obituários, ele vê que sua ex-mulher morreu. Ele se emociona e recorta o pedaço de jornal.

18. Ramiro chega em casa e dá a Susana um aparelho de som de presente. Eles trocam beijos. Ramiro acorda o bebê, Susana se irrita e Ramiro discute com ela, fazendo o bebê chorar. Octavio ouve a cena de seu quarto.

19. Octavio fala com Jorge sobre seu amor por Susana, enquanto dá banho em Cofi, e diz a Jorge que pretende colocá-lo para lutar nas rinhas para ganhar dinheiro.

20. Em seu quarto, irritado, Octavio escuta Susana e Ramiro transando. Ele mente dizendo que há um telefonema para Susana, que vai até o telefone, mas ninguém responde. Octavio tenta beijá-la, mas ela recusa.

21. Mauricio explica para Octavio e Jorge como funcionam os negócios da rinha e propõe uma parceria. Mauricio pede que Cofi enfrente seu melhor cão para testá-lo, Octavio aprova e marca uma luta.

22. Ramiro trabalha como caixa em uma loja. Octavio aparece comprando fraldas para o filho de Susana. Eles discutem, Octavio dá uma cabeçada em Ramiro e sai.

23. Octavio chega em casa e entrega a Susana, que está com seu bebê, fraldas e dinheiro e diz que irá sustentar os dois filhos dela. Octavio sobe e Cofi vai atrás dele.

24. Daniel está deitado com sua esposa assistindo TV. O telefone toca e Daniel atende. Ele sai do quarto com o telefone, conversando com a amante, e lhe pede para que não fique ligando para ele e desligando a chamada, pois sua esposa desconfia. 
25. Ramiro entra no banheiro, lava o rosto e, com uma barra de ferro, bate em Octavio, que toma banho. Ramiro diz a ele para não se meter em suas coisas e sai.

26. No local de lutas de rinha, o "ringue" e os cães são lavados. Mauricio dá a Octavio uma cerveja. Jarocho chega e conversa com Mauricio, provocando Octavio e propondo apostas. Os cães são atiçados e a luta começa.

27. El Chivo observa de longe sua filha no enterro de sua ex-mulher. Sua cunhada o identifica e vai até ele. Ela lhe pede para ficar longe de sua filha, que acredita que ele está morto, mas ele ignora.

28. Jarocho, nervoso, coloca seu cão, morto, na caçamba da caminhonete. Mauricio tenta acalmá-lo, enquanto Jorge, Octavio e Cofi saem ao fundo.

29. Octavio chega em casa e encontra Susana dormindo. Ele a acorda e lhe dá mais dinheiro. Eles combinam de guardar o dinheiro em uma maleta. Octavio fala sobre seus planos a Susana e a tenta convencê-la de fugir com ele.

30. Montagem de planos: Ramiro rouba lojas - Octavio e Cofi ganham lutas - Octavio compra carro - Octavio e Susana contam e guardam dinheiro - Ramiro transa com atendente da loja em que trabalha - Octavio recebe seu dinheiro nas lutas - Octavio, Ramiro e Susana almoçam juntos - Jarocho discute com Mauricio

31. Octavio assiste TV. Ramiro chega e diz que quer metade do dinheiro que ganha com Cofi e ameaça matá-lo em caso contrário.

32. El Chivo observa, de longe, sua filha saindo de casa.

33. Octavio chega em casa e encontra Susana brincando com seu bebê. Ele interage com a criança e volta a insistir para que Susana fique com ele. Eles se olham, Octavio toca a virilha de Susana e a beija. Os dois trocam beijos e carícias.

34. Daniel entra no quarto de suas filhas, dá- lhes beijos de boa noite e apaga a luz.

35. Octavio e Jorge comem com Mauricio, que propõe uma luta com Jarocho, mas diz que Octavio deve entrar por conta própria. Octavio aceita e pede um favor a Mauricio.

36. Montagem de planos: Ramiro trabalha como caixa - Carro chega em mercado e homens saem dele - Octavio e Susana trocam carícias na máquina de lavar roupas Homens esperam fora do mercado - Octavio e Susana transam - Ramiro sai do mercado e se despede de atendente beijando-a - Homens do lado do mercado colocam Ramiro à força dentro do carro - Em local escuro e vazio, os homens espancam Ramiro

37. Octavio e Susana conversam. Octavio lhe diz que está com tudo pronto para irem embora e que só falta uma última luta de Cofi. Susana diz que o horário da saída está marcado. Octavio diz que Ramiro não os incomodará mais.

38. Susan busca seu filho na casa de sua mãe, que está completamente embriagada.

39. Octavio chega em casa e sua mãe lhe conta que Ramiro fugiu com Susana e o bebê. Octavio vai até o quarto de Susana e vê que levaram todo o dinheiro. 
40. Valeria está em programa na TV de Octavio. Ele conta dinheiro e Jorge lhe diz que Susana o sacaneou. Jorge assiste TV e repara na beleza de Valeria.

41. Octavio e Jorge chegam ao local da rinha. A luta começa e, quando Jarocho vê que vai perder, atira em Cofi. Jorge e Octavio saem com Cofi ferido, Octavio volta, esfaqueia Jarocho e foge com Jorge, sendo seguido pela gangue de Jarocho. Durante a perseguição, Octavio colide com outro carro.

42. No término da gravação de um programa, Valeria, sai junto com famoso ator com quem dividiu o programa. Ele a chama para almoçar.

43. Valeria e o ator chegam em um apartamento e lá ele finge estar obcecado por ela, até que Daniel surge e os dois revelam que aquele é o novo apartamento dela e de Daniel. Quando vai cumprimentá-lo, Valeria, acidentalmente, quebra o piso, abrindo um buraco. Daniel diz que se divorciou para poderem ficar juntos.

44. El Chivo vê o empresário Luis andar pela rua com uma mulher e o segue.

45. Susana deixa Daniel e sai de carro com Richie, ela vê El Chivo passando pela rua. Valeria espera o sinal abrir e segue, sendo atingida por um carro.

\section{Intertítulo: Daniel y Valeria}

46. Daniel aguarda em sala de espera de hospital. O médico diz que houve ferimentos graves e que ela está viva por um milagre.

47. Daniel fala com Valeria, que está em uma maca. Ele lhe diz que Richie está bem.

48. Valeria acorda durante a noite no hospital, chamando por Daniel, que está lá. Ela diz estar com medo.

49. Daniel chega em casa com Valeria na cadeira de rodas, ela cumprimenta Richie carinhosamente.

50. Daniel brinca com Valeria na cama e tenta excitá-la com as mãos.

51. Daniel se arruma pro trabalho e demonstra preocupação com Valeria. Ela lhe diz para não se preocupar e ele sai. Valeria vai até a janela e vê seu outdoor do lado de fora.

52. A filha de El Chivo sai de casa. Ele a observa e após ela sair, entra na casa arrombando o portão. Ele vê as fotos de sua filha e leva uma de sua graduação em que uma outra figura masculina aparece.

53. Valeria brinca de jogar a bola com Richie, e quando a bola cai no buraco do piso, Richie vai atrás. Valeria o chama mas ele continua lá.

54. Daniel chega em casa e Valeria lhe conta o que houve com Richie. Daniel tenta atrair Richie com chocolate, mas ele não aparece. Valeria continua preocupada. 
55. Durante a noite, Valeria ouve Richie e acorda Daniel, que o procura com uma lanterna no buraco mas não o acha. O telefone toca, Daniel atende, mas ninguém responde. Daniel chama Richie, mas ele não aparece.

56. El Chivo cuida de Cofi em sua morada.

57. Valeria fala no telefone com seu agente, que diz que seu contrato com a Enchant foi cancelado.

58. Valeria folheia um revista e começa a chamar por Richie. Ela o procura com uma lanterna embaixo do piso, vê um rato passando e se assusta.

59. Daniel está no trabalho e a secretária lhe diz que há um telefonema de sua esposa. Daniel atende e chama pelo nome de sua esposa, Julieta. É Valeria, que se irrita com a confusão. Ela lhe diz que Richie foi comido pelos ratos.

60. Daniel chega em casa e vê Valeria na sala, chorando, e dizendo que os ratos comeram Richie. Daniel não se preocupa e tenta acalmá-la, mas os dois se irritam. Eles ouvem Richie e Daniel busca um martelo para tirá-lo. O telefone toca, Valeria atende e ninguém responde. Valeria se irrita e os dois discutem.

61. À noite, Daniel acorda e vê que Valeria não está na cama. Ele a vê na sala, e ela diz que sente muita dor. Daniel a abraça.

62. Valeria mexe em fotos e papeis antigos.

63. Valeria assiste TV deitada.

64. Médico retira curativo da perna de Valeria. Ele pergunta se ela andou e ela diz que sim. Ele examina radiografias.

65. Daniel e Valeria voltam pra casa. Daniel tenta acalmar Valeria, mas ela se irrita.

66. À noite, Valeria ouve Richie e pede que Daniel tire Richie do buraco. Daniel diz que não tem dinheiro para consertar o chão depois, os dois discutem e Daniel sai

67. Daniel vê o outdoor de Valeria no prédio em frente ao seu

68. Valeria folheia uma revista. Daniel se despede e Valeria lhe diz que ela não precisa voltar.

69. No trabalho, Daniel liga para Julieta. Ela atende, mas Daniel não responde e desliga.

70. Daniel chega em casa e vê o piso danificado. Ele bate na porta do quarto chamando Valeria, mas ninguém responde. Ele se deita em outro quarto.

71. Daniel pede que Valeria abra a porta, mas não há resposta. Ele derruba a porta e vê Valéria inconsciente no chão. Ele tenta socorrê-la desesperadamente.

72. No hospital, Daniel aguarda na sala de espera. O médico o diz que precisou amputar a perna de Valeria. Daniel se emociona.

73. Em casa, Daniel ouve Richie. Ele pega ferramentas e começa a abrir o chão, até que o encontra, fraco. Daniel abraça Richie. 
74. Daniel chega em casa com Valeria, em uma cadeira de rodas e sem uma perna. Valeria vai à janela e vê que seu outdoor foi retirado. Daniel a abraça.

\section{Intertítulo: El Chivo y Maru}

75. Em um carro, Leonardo fala a Gustavo sobre seu amigo que irão visitar e que irá fazer um trabalho para Gustavo. Leonardo se irrita com Gustavo falando o tempo todo no telefone e joga seu telefone pela janela.

76. Gustavo e Leonardo chegam à morada de El Chivo, lhe dão um saco de pãezinhos e entram. Na sala eles explicam a El Chivo o que querem dele. Ele diz que parou, mas Gustavo diz que seu sócio lhe está passando a perna e que o quer morto. Acertam os preços e El Chivo aceita. Os três saem da sala.

77. El Chivo passa pela rua e vê Ramiro com rosto ferido, Susana e seu filho andando por lá. El Chivo entra em uma cabine de fotos, e tira algumas.

78. Em seu quarto, El Chivo vê fotos antigas dele com sua filha, e cola uma foto sua que tirou na rua sobre a imagem do possível padrasto da foto de sua filha.

79. El Chivo, deitado, recebe carinho de seus cães.

80. El Chivo anda pela rua com seus cães e seu carrinho. Ele vê Luis e Gustavo interagindo.

81. El Chivo vê Luis saindo da empresa com uma mulher, e os segue. Valeria passa com Richie de carro por El Chivo na rua.

82. Do lado de fora, El Chivo vê Luis em restaurante. Ocorre o acidente de carro. El Chivo vai até o carro de Octavio, pega seu dinheiro, retira Cofi do carro, coloca-o em seu carrinho e o leva pra casa. Uma ambulância chega, paramédicos atendem Jorge, Octavio e Valeria,

83. El Chivo chega com Cofi em casa e cuida de sua ferida. Ele mexe na carteira de Octavio, que roubou mais cedo e vê suas fotos.

84. El Chivo observa sua filha no trabalho do lado de fora. Ele acena para ela, mas ela o ignora.

85. El Chivo encara a lápide de sua ex-esposa falecida.

86. Ramiro e seu amigo assaltam banco. Ramiro rouba a carteira de Luciano e quando percebe que ele é policial, a polícia chega e atira em Ramiro e prende seu amigo.

87. El Chivo cuida de Cofi e retira seus curativos. Ele sai e deixa seus cães em casa.

88. El Chivo está esperando Luis sair do trabalho. Luciano aparece e lhe cobra o serviço. Luis sai e El Chivo o segue até uma loja e quando se prepara para matá-lo, garotos vão falar com ele, fazendo El Chivo recuar. 
89. No velório de Ramiro, Octavio aborda Susana e insiste em falar de seus planos de fugir com ela. Ela diz que não é possível, mas ele diz que ainda quer e que vai esperar por ela, no domingo, para fugirem juntos.

90. El Chivo chega em casa e vê Cofi cheio de sangue. Ele entra e vê que Cofi matou os seus cães. Ele aponta a arma para Cofi, mas não tem coragem de atirar. Uma cadela ainda vive. Ele a leva até o carro, mas ela logo morre.

91. El Chivo queima os corpos dos cães mortos.

92. El Chivo, deitado, encara o teto de seu quarto. Ele coloca seus antigos óculos.

93. El Chivo tira de uma gaveta uma arma e, de um armário, um par de algemas.

94. El Chivo sequestra Luis quando este sai de uma locadora e o faz dirigir.

95. Em sua casa, El Chivo prende Luis e conversa com ele sobre a pessoa que lhe pagou para matá-lo. El Chivo revela que foi Gustavo. Luis diz que é seu sócio e meio-irmão. El Chivo amordaça Luis e sai.

96. De manhã, El Chivo coloca uma música para tocar, tira a mordaça de Luis e lhe dá uma banana para comer. Luis lhe pede para soltá-lo e para matar Gustavo, mas El Chivo mostra que já tem dinheiro, e sai deixando Cofi com Luis.

97. El Chivo vai até uma oficina, conversa com um mecânico e lhe dá a chave de um carro.

98. El Chivo liga para Gustavo de um orelhão e o pede para ir para à sua casa com o dinheiro, pois o trabalho já havia sido feito.

99. Gustavo chega à morada de El Chivo, que recebe o dinheiro e lhe pede para entrar. Ele leva Gustavo até a "sala", onde encontra Luis, preso. El Chivo manda Gustavo matá-lo ele mesmo, depois oferece a um irmão que mate o outro, mas ambos estão em choque. Ele bate em Gustavo, deixando-o inconsciente.

100. Octavio espera sozinho em frente a um ônibus em uma rodoviária. O motorista do ônibus sai e diz que o ônibus já vai sair. Octavio vai embora, chorando.

101. Montagem de planos: El Chivo toma banho, faz a barba, corta o cabelo, coloca os óculos e se encara no espelho, corta as unhas, coloca um anel, veste-se, pega dinheiro e fotos e guarda em uma bolsa.

102. El Chivo vai até a cozinha e conversa com Gustavo e Luis, que estão amarrados e amordaçados. Ele lhes diz para resolverem suas diferenças, deixa a arma entre os dois e sai com Cofi.

103. El Chivo pega fotos que acabou tirar em uma cabine e cola uma delas em cima do rosto do possível padrasto em foto com a filha e a ex-esposa. Ele sai com o carro, enquanto outdoor da Enchant é retirado do prédio.

104. El Chivo arromba o portão da casa da filha. Ele entra no quarto dela, deixa dinheiro embaixo de seu travesseiro e devolve foto que roubou, agora com sua foto atual 
colada. Ele liga para ela e deixa uma mensagem de voz contando sua verdadeira história. Ele diz que a ama e que, um dia, irá atrás dela.

105. El Chivo chega na oficina e recebe dinheiro do mecânico, que pergunta o nome do cão. El Chivo dá um novo nome: Negro. Ele se despede e sai com Negro por um ambiente deserto.

\section{Dedicatória}

\section{Créditos finais}




\section{APÊNDICE C \\ ESCALETA DE 21 GRAMAS \\ CONFORME APRESENTADA PELA TRAMA}

Em cada cena apontam-se quais os protagonistas que participam das ações. A anotação "outros" indica que se trata de créditos, letreiro ou cena sem a presença de nenhum personagem principal.

\section{CENA DESCRIÇÃO}

\begin{tabular}{lll}
\hline 1. & Paul fuma, enquanto observa Cristina dormindo seminua. & Paul + Cristina \\
2. & Título "21 Gramas" & Outros \\
3. & Michael, marido de Cristina, termina lanche com filhas numa lanchonete. & Cristina
\end{tabular}

4. Cristina em depoimento numa sessão de terapia de grupo de ex-viciados. Cristina

5. Jack prega a jovem descrente e mostra a camionete que "ganhou" de Jesus. Jack

6. Revoada de pássaros ao poente em movimento ascendente.

Outros

7.

8. Cristina, deprimida, cheira cocaína em um banheiro.

\begin{tabular}{|c|c|c|}
\hline 9. & $\begin{array}{l}\text { Mary, mulher de Paul, em um exame ginecológico diz ao médico que o } \\
\text { marido só tem um mês de vida. }\end{array}$ & Paul \\
\hline 10. & $\begin{array}{l}\text { Jack conversa com reverendo na igreja, colega confirma a festa de } \\
\text { aniversário na casa de Jack e saem para o pátio. Jack se atraca com o } \\
\text { jovem descrente, ao apartar um desentendimento no basquete. }\end{array}$ & Jack \\
\hline 11. & $\begin{array}{l}\text { Jack dirige sua camionete ouvindo rádio religiosa, chega em casa e } \\
\text { interage carinhosamente com mulher e casal de filhos pequenos. }\end{array}$ & Jack \\
\hline 12. & $\begin{array}{l}\text { Paul, debilitado, manipula revólver, sentado ao lado de piscina vazia e } \\
\text { entulhada. }\end{array}$ & Paul \\
\hline 13. & $\begin{array}{l}\text { Jack é colocado numa cela e o vizinho, em off, comenta que o Lobo está de } \\
\text { volta. }\end{array}$ & Jack \\
\hline
\end{tabular}
Cristina ganha tiro de natação com a irmã mais jovem. Sai da piscina, seu

14. celular toca, ela não consegue atender a tempo e sai dizendo que vai Cristina encontrar a família.

15. Jack reza com firmeza em culto, acompanhado pela família e observado
pela mulher. $\begin{aligned} & \text { Paul está em casa de roupão e respirando com balão de oxigênio. Apesar } \\ & \text { 16. debilitado vai fumar escondido no banheiro. É flagrado pela esposa que } \\ & \text { o repreende e joga seus cigarros fora. }\end{aligned}$


18. Paul, com boa aparência, toca a campainha de uma casa e ninguém atende. Paul

$\begin{array}{lll}\text { 19. Jack é demitido como caddy por causa de suas tatuagens. } & \text { Jack } \\ \text { 20. } & \begin{array}{l}\text { Cristina, atormentada, fuma e bebe enquanto põe roupas de criança na } \\ \text { máquina de lavar. }\end{array} & \text { Cristina } \\ \text { 21. } & \text { Paul está hospitalizado e recebe um pote do médico com seu coração. } & \text { Paul } \\ & \begin{array}{l}\text { Paul e Cristina passam de carro ao lado da cerca de uma fábrica e } \\ \text { observam Jack todo sujo carregando sacos. Ela fica nervosa e diz que } \\ \text { 22. }\end{array} & \text { Paul + Jack + Cristina matá-lo. } \\ & \begin{array}{l}\text { Jack ora em agradecimento pela refeição e avisa que perdeu o emprego no } \\ \text { clube. A mulher diz que a culpa é do amigo dele. As crianças brigam, Jack } \\ \text { interfere equivocadamente ao repreendê-los e a mulher tira a filha da mesa. }\end{array} & \text { Jack } \\ \text { 23. }\end{array}$

24. Cristina se diverte fazendo um bolo com suas duas filhas. Cristina

25.
engravidar após uma cirurgia. Ele não concorda.

26. Paul, com boa aparência, segue Cristina da casa dela até uma loja de Paul + Cristina

27. Há uma festa na casa de Jack que ainda não chegou. Sua mulher cozinha Jack

Cristina chega em casa (depois da natação), chama as filhas e ouve a

28. mensagem de seu marido no seu celular avisando que já estão no caminho. Cristina Ela recebe um telefonema informando algo grave.

Reverendo dirige com a mulher de Jack ao seu lado. Passam por um

29. acidente com corpos ensanguentados cobertos no chão. Ela fica Jack emocionada, ele para e avisa que vai ver e já volta.

Paul e a esposa recebem informações do especialista em fertilidade em seu consultório. O médico alerta que mesmo que a cirurgia dela dê certo, pode

30. Ser que a inseminação artificial não seja bem sucedida e questiona Paul,

Paul alertando-o pois provavelmente não vai conhecer o filho. Paul prepara-se para fazer um espermograma.

31. Cristina chega ao hospital e pede informações sobre seu marido e filhas
que sofreram um acidente. A recepcionista pede para ela esperar e Cristina Cristina
encontra seu pai e sua irmã. Jack chega atrasado na festa em sua casa. Sua mulher sai pela cozinha para

32. conversar com ele no carro. Ele conta que atropelou um homem e duas Jack meninas.

\begin{tabular}{lll} 
33. & $\begin{array}{l}\text { Jack dirige afobadamente numa estrada. Cristina está no banco de trás } \\
\text { segurando Paul ensanguentado e pede para Jack ir mais rápido. }\end{array}$ & Paul + Jack + Cristina \\
34. & $\begin{array}{l}\text { Médico faz um exame pós-operatório em Paul que quer saber quem foi o } \\
\text { doador do coração que foi lhe transplantado. }\end{array}$ & Paul \\
35. & $\begin{array}{l}\text { Cristina recebe dos médicos a notícia da morte de suas duas filhas e do } \\
\text { estado crítico do marido com graves danos cerebrais. }\end{array}$ & Cristina \\
36. & Partane consola Jack e pede para a cunhada mandar todos embora da & Jack \\
37. & $\begin{array}{l}\text { Jack foi pegar suas coisas no clube de golfe de que foi demitido, encontra } \\
\text { o amigo que o demitiu e que o convida para beber, diz-lhe que está se } \\
\text { sentindo mal pelo que aconteceu e que está tentando arrumar serviço para } \\
\text { ele }\end{array}$ & Jack \\
\hline
\end{tabular}




\begin{tabular}{lll}
\hline 39. & $\begin{array}{l}\text { Funcionária do hospital fala com Cristina sobre a doação do coração de } \\
\text { seu marido. }\end{array}$ & Cristina \\
40. & $\begin{array}{l}\text { Paul e sua mulher recebem a notícia de que surgiu um coração para } \\
\text { doação. }\end{array}$ & Paul \\
41. & $\begin{array}{l}\text { Paul é preparado para a cirurgia e sua mulher vê Cristina saindo do } \\
\text { hospital amparada por seu pai e sua irmã. }\end{array}$ & Paul + Cristina \\
42. & $\begin{array}{l}\text { Paul aborda Cristina na lanchonete da academia e ela não aceita que ele se } \\
\text { sente com ela. }\end{array}$ & Paul + Cristina \\
43. & $\begin{array}{l}\text { Cristina bebe uísque sozinha em casa, liga para uma amiga num bar, mas } \\
\text { não fala com ela }\end{array}$ & Cristina
\end{tabular}
Jardineiro aspira folhas, enquanto Michael caminha na calçada, deixa

44. recado no celular de Cristina avisando que está a caminho de casa Cristina enquanto adverte as filhas.

Jack está em casa, sua mulher chega e conta que as vítimas morreram no

45. atropelamento. Jack diz que vai se entregar. Sua mulher tenta convencê-lo Jack do contrário sem sucesso. Ele sai.

46. Cristina junta brinquedos das filhas numa caixa na garagem, abre a porta, espia o quarto das meninas intocado, fecha a porta e chora.

Cristina

Paul celebra a volta ao lar com a mulher e amigos num almoço em casa.

47. Eles brindam à nova vida após a cirurgia. Sua mulher anuncia que eles vão

47. ser pais (operação, inseminação artificial, etc.) ele demonstra contrariedade

Paul no olhar.

48. Paul vai a um encontro num boliche. Paul

49. Marianne lava o sangue do para-choque da camionete de Jack e chora. Jack

50. Pai de Cristina conforta-a no velório da família. Cristina

51. Mary lava a louça após a festa de boas-vindas dele do hospital e discutem Paul

51. sobre o anúncio que ela fez de que seriam pais. Paul

A irmã de Cristina cobra dela ir à delegacia prestar queixa e menciona que

52. o atropelador é um ex-presidiário. Cristina diz que nada trará sua família Cristina de volta.

53. quem doou o coração a ele, como morreu e quem era o atropelador. Paul Paul sente-se mal.

54. Paul conta para sua mulher as informações que recebeu do detetive. Ela pede para ele parar de olhar para trás e buscarem juntos o novo, e o beija. Jack despede-se do amigo que o demitiu na frente de um bar. O amigo

55. insiste que ele deveria tomar uma cerveja no dia de seu aniversário. Jack recusa novamente a bebida, convida-o para a festa na sua casa e parte na sua camionete pintada com a palavra 'fé' bem grande.

Paul caminha num terreno árido com muita dificuldade em respirar e com

56. um revólver na mão. Ele piora, encosta-se e guarda a arma no bolso do Paul casaco.

57. Obstetra consulta Mary sobre marcação de sua cirurgia e revela sem querer para Paul que ela já havia feito um aborto.

Paul

Paul e Mary discutem no hall do elevador da clínica sobre a relação e ele

58. $\quad$ diz que acabou.

59. Jack recebe o reverendo em sua cela. Eles discutem. Jack sente-se traído Jack por Deus, que acredita ser o responsável pelo que está vivendo.

Jack

Cristina entra num bar. Paul a segue. Ela encontra a amiga para a qual

60. telefonou antes e não falou nada. Elas vão para o banheiro e ela lhe fornece Paul + Cristina drogas.

61. Jack tenta enforcar-se mas o cano onde pendurou-se quebra e é salvo por Jack 
um colega de cela.

Cristina sai do bar entorpecida e bate ao tentar sair com o carro. Paul

62. convence-a a deixar ele dirigir. Ele a leva para a casa dela e a deixa

Paul + Cristina dormindo dentro do carro na garagem.

\begin{tabular}{lll} 
63. & $\begin{array}{l}\text { Marianne visita Jack na cadeia e diz que vendeu a camionete para pagar o } \\
\text { advogado. Ela diz que tem dois anos que ele está na cadeia. }\end{array}$ & Jack \\
\hline 64. & Jack trabalha duro em uma fábrica insalubre. & Jack \\
\hline 65. & Cristina está num motel barato de beira de estrada com Paul. & Paul + Cristina \\
\hline 66. & Paul encontra o detetive no carro dele que lhe entrega o endereço do motel & Paul \\
\hline
\end{tabular}
Cristina está boiando na piscina da academia. Na saída, chove bastante e

67. ela está sem carro. Paul lhe oferece carona e ela recusa. Paul diz que foi ele que a levou em seu carro para casa na semana anterior. Ela aceita sua

Paul + Cristina carona.

68. Jack chega do trabalho na caçamba de uma pick-up. Quando Jack caminha Paul + Jack

68. para seu quarto, cruza com Paul que entra em outro quarto do motel.

69. Paul deixa Cristina em casa, convida-a para almoçar no dia seguinte e ela

69. aceita.

Paul + Cristina

70. Paul dirige seu carro, passa mal e vomita.

Paul

Michael caminha pela calçada, deixa recado para sua mulher no celular, enquanto diz para suas filhas não pegarem num pombo. Ele cumprimenta o

71. jardineiro. A camionete de Jack passa, ouvimos uma freada e o

Jack + Cristina atropelamento e o jardineiro corre na direção do acidente. (INCIDENTE INCITANTE)

Marianne e o reverendo aguardam Jack sair da prisão. Jack os vê, mas sai

72. andando sem falar com eles. Marianne fica chateada e o reverendo vai

Jack falar com ele.

Paul está no consultório de seu médico que diz que ele precisa voltar para

73. o hospital porque precisa de um outro coração. Paul pergunta se será salvo Paul se ficar. Sem a garantia do médico, ele diz que prefere morrer ao ar livre. Jack está no banco de trás no carro do reverendo, pergunta quanto o

74. advogado cobrou para botá-lo em liberdade e Marianne diz que o Jack suficiente para que os filhos lembrem da cara dele.

75. Jack chega em casa com Marianne. A filha é carinhosa com ele e o filho o

75. recebe com reservas. Fizeram bolo e desenhos para ele. A família se Jack abraça.

76. Paul almoça com Cristina num restaurante, fala de números, matemática e cita um poema. Ela sorri.

Paul + Cristina

77. Paul e Cristina caminham para casa depois do almoço. Ela o convida a entrar e ele aceita.

Paul + Cristina Paul respira com dificuldades, deixa Cristina dormindo no quarto do

78. motel, põe o revólver no bolso do casaco e sai.

79. Paul está num carro em frente ao motel, quando Jack passa, ele sai atrás dele, rende-o, coloca-o de joelhos e atira três vezes.

80. Jack e Marianne trocam carícias. Ele começa a falar sobre a menina que atropelou, corta o clima de romance e chora abraçado à mulher.

Paul + Cristina

Paul + Jack

Jack Paul entra na casa de Cristina que pergunta se ele vai continuar tomando

81. vinho tinto. Enquanto ela vai pegar a bebida, ele observa fotos da família pela casa. Ele passa mal, diz que há muito tempo não gosta de alguém

Paul + Cristina como dela, ela diz que é casada e ele vai embora.

82. Jack está num culto com a família e os fiéis cantam. Ele está abatido e deslocado e troca olhares com o jovem com o qual se desentendeu.

Jack 


\begin{tabular}{|c|c|c|}
\hline 83. & $\begin{array}{l}\text { Jack está em casa com a família assistindo TV. A filha pergunta se é } \\
\text { verdade que ele matou duas meninas e o pai delas. }\end{array}$ & Jack \\
\hline 84. & Jack reza desesperadamente sozinho na igreja. & Jack \\
\hline 85. & $\begin{array}{l}\text { Paul está na cama com sua mulher quando seu celular toca de madrugada. } \\
\text { Cristina o chama para sua casa. Sua mulher diz que achava que ele iria } \\
\text { mudar depois do transplante e ele responde que achava que ela mudaria se } \\
\text { ele mudasse, mas nenhum dos dois mudaram. }\end{array}$ & Paul + Cristina \\
\hline 86. & Jack olha a família dormindo, pega uma bolsa e sai. & Jack \\
\hline 87. & $\begin{array}{l}\text { Jack chega ao hospital afobado dirigindo o carro de Paul que está no banco } \\
\text { traseiro nos braços de Cristina. Jack diz que atirou no peito de Paul. }\end{array}$ & Paul + Jack + Cristina \\
\hline 88. & $\begin{array}{l}\text { Paul chega na casa de Cristina, eles se beijam, ele conta que tem o coração } \\
\text { do marido dela, ela fica enfurecida e o coloca para fora da sua casa. }\end{array}$ & Paul + Cristina \\
\hline 89. & Jack caminha no corredor do motel de noite olhando para os lados. & Jack \\
\hline 90. & $\begin{array}{l}\text { Cristina acorda em sua casa ao amanhecer, vê Paul dormindo em seu carro } \\
\text { em frente a sua casa e vai até ele. Dentro do carro ele se declara e eles se } \\
\text { beijam. }\end{array}$ & Paul + Cristina \\
\hline 91. & Mary caminha sozinha pela rua e depois senta-se cansada. & Paul \\
\hline 92. & Cristina e Paul transam. & Paul + Cristina \\
\hline 93. & $\begin{array}{l}\text { Jack fala ao telefone com Marianne que chora muito. Eles falam e não se } \\
\text { escutam, ele desliga. }\end{array}$ & Jack \\
\hline 94. & Cristina faz exame para doar sangue. & Cristina \\
\hline 95. & $\begin{array}{l}\text { Paul e Cristina estão nus na cama dela. Ela dorme, ele fuma e encontra } \\
\text { fotos dela com o marido e drogas na sua mesinha de cabeceira. }\end{array}$ & Paul + Cristina \\
\hline 96. & $\begin{array}{l}\text { Policial diz que a versão de Jack sobre o tiro em Paul não bate com as } \\
\text { investigações nem com os depoimentos do casal e lhe dá papéis para } \\
\text { assinar e ir. }\end{array}$ & Jack \\
\hline 97. & $\begin{array}{l}\text { Cristina e Paul estão nus no quarto dela. Ele dorme, ela vê as roupas de seu } \\
\text { marido no armário e veste uma blusa. }\end{array}$ & Paul + Cristina \\
\hline 98. & $\begin{array}{l}\text { Paul chega em casa e vê sua mulher arrumando as malas. Ela reclama por } \\
\text { ele estar sumido por muitos dias e fala que vai fazer a inseminação } \\
\text { artificial e voltar pra Londres. Paul vai contra em vão e ela vai embora. }\end{array}$ & Paul \\
\hline 99. & $\begin{array}{l}\text { Cristina conversa com o jardineiro que presenciou o atropelamento e vai } \\
\text { ao restaurante em que seu marido e suas filhas estavam antes do acidente e } \\
\text { do lado de fora vê o interior do restaurante. Cristina anda pela rua e senta } \\
\text { no meio fio, onde há um monte de folhas secas. Em casa, Cristina chora na } \\
\text { cama, ouvindo, nocelular, a mensagem de voz que seu marido lhe enviou } \\
\text { antes do atropelamento. }\end{array}$ & Cristina \\
\hline 100. & $\begin{array}{l}\text { Jack bebe e fuma em um quarto de hotel. Com uma faca, ele faz um corte } \\
\text { em seu antebraço e derrama álcool em cima. }\end{array}$ & Jack \\
\hline 101. & $\begin{array}{l}\text { Cristina fuma e cheira cocaína em um prato. Paul vê e derruba o prato. Ele } \\
\text { diz que ela não precisa daquilo, mas ela retruca nervosa. Cristina senta-se } \\
\text { nervosa à mesa da cozinha. Paul entra e se senta próximo a ela. Ela } \\
\text { lamenta a perda da família e a negligência de Jack, enfurece-se e diz que } \\
\text { quer matá-lo. Paul tenta acalmá-la sem sucesso. Ela diz que Paul precisa } \\
\text { ajudá-la a matá-lo, pois deve isso a Michael. Paul a abraça e ela lamenta } \\
\text { mais, chorando. }\end{array}$ & Paul + Cristina \\
\hline 102. & $\begin{array}{l}\text { Paul aponta uma arma para Jack, num terreno deserto. Paul manda Jack } \\
\text { fechar os olhos e atira, mas sem atingi-lo. Paul chama Jack de assassino e } \\
\text { o manda desaparecer. Ele deixa Jack lá e, indo embora, apoia-se em um } \\
\text { grande tubo de ferro e vomita. }\end{array}$ & Paul + Jack \\
\hline 103. & $\begin{array}{l}\text { Cristina aguarda na sala de espera do hospital. Uma enfermeira surge e diz } \\
\text { que não foi possível usar o sangue de Cristina para uma transfusão, devido }\end{array}$ & Cristina \\
\hline
\end{tabular}


à presença de drogas, e diz para não usá-las, pois está grávida. A enfermeira insiste que ela precisa se cuidar e entra em uma sala. Cristina chora.

Cristina se olha no espelho no banheiro. Ela se senta na privada e depois

104. sai do quarto. Ela vê Paul sentado próximo a uma piscina vazia e entulhada e pergunta se ele matou Jack. Ele diz que sim e que nunca encontrarão o corpo. Eles voltam pro quarto do motel e Cristina consola Paul. Jack vai até o quarto de Cristina e Paul. Paul vai até a porta e Jack invade e fala para eles o matarem. Paul hesita e Jack o empurra. Cristina bate em

105. Jack com um abajur, enquanto Paul, caído no chão, dá um tiro no próprio Paul + Jack + Cristina peito. Cristina desesperadamente pede para Jack chamar uma ambulância. (CRISE)

106. Pássaros voam no céu.

MONTAGEM DE

PLANOS - (CLIMAX

FINAL)

107. Cristina passa a mão na cabeça de Paul dentro de um carro.

108. Paul está deitado em uma maca, entubado.

Paul + Cristina

109. A família de Cristina sai de um restaurante

Paul

110. Jack se despede de seu chefe na rua e entra no carro

Cristina

111. A irmã de Cristina mostra o dedo para ela na piscina, enquanto Cristina vai embora sorrindo

Jack

Cristina aguarda aflita na sala de espera do hospital em frente à porta $\mathrm{e}$

112. Jack surge perto dela. Eles se olham.

Cristina

113. Jack fuma do lado de fora de sua casa. Ele entra e encontra sua família. Jack + Cristina

Cristina entra no quarto de suas filhas e, sentada na cama, encara uma

114. boneca.

Jack

115. Paul está deitado na maca de hospital e os aparelhos vão indicando que os batimentos cardíacos pararam. Paul morre.

Cristina

116. Neve cai dentro de uma piscina vazia e entulhada.

Paul

117. Dedicatória.

Outros

118. Créditos finais

Outros 


\section{APÊNDICE D}

ESCALETA DE 21 GRAMAS

CONFORME A ORDEM CAUSAL E TEMPORAL

Em cada cena apontam-se quais os protagonistas que participam das ações. A anotação "outros" indica que se trata de créditos, letreiro ou cena sem a presença de nenhum personagem principal.

PRIMEIRO ATO

\begin{tabular}{|c|c|c|c|}
\hline $\begin{array}{c}\text { Sequência } \\
\text { Causal/Temporal }\end{array}$ & $\begin{array}{l}\text { Sequência } \\
\text { original }\end{array}$ & Descrição & Protagonistas \\
\hline I. & 8 & $\begin{array}{l}\text { Cristina em depoimento numa sessão de terapia de } \\
\text { grupo de ex-viciados. }\end{array}$ & Cristina \\
\hline II. & 5 & $\begin{array}{l}\text { Jack prega à jovem descrente e mostra a camionete que } \\
\text { "ganhou" de Jesus. }\end{array}$ & Jack \\
\hline III. & 10 & $\begin{array}{l}\text { Jack conversa com reverendo na igreja, colega } \\
\text { confirma a festa de aniversário na casa de Jack e saem } \\
\text { para o pátio. Jack se atraca com o jovem descrente ao } \\
\text { apartar um desentendimento no basquete. }\end{array}$ & Jack \\
\hline IV. & 11 & $\begin{array}{l}\text { Jack dirige sua camionete ouvindo rádio religiosa, } \\
\text { chega em casa e interage carinhosamente com mulher } \\
\text { e casal de filhos pequenos. }\end{array}$ & Jack \\
\hline V. & 9 & $\begin{array}{l}\text { Mary, mulher do Paul, em um exame ginecológico diz } \\
\text { ao médico que o marido só tem um mês de vida. }\end{array}$ & Paul \\
\hline VI. & 15 & $\begin{array}{l}\text { Jack reza com firmeza em culto, acompanhado pela } \\
\text { família e observado pela mulher. }\end{array}$ & Jack \\
\hline VII. & 16 & $\begin{array}{l}\text { Paul está em casa de roupão, respirando com balão de } \\
\text { oxigênio. Apesar de debilitado vai fumar escondido no } \\
\text { banheiro. É flagrado pela esposa que o repreende e } \\
\text { joga seus cigarros fora. }\end{array}$ & Paul \\
\hline VIII. & 25 & $\begin{array}{l}\text { Mary diz a Paul, debilitado, que foi a um especialista e } \\
\text { que pode engravidar após uma cirurgia. Ele não } \\
\text { concorda. }\end{array}$ & Paul \\
\hline IX. & 19 & $\begin{array}{l}\text { Jack é demitido como caddy por causa de suas } \\
\text { tatuagens. }\end{array}$ & Jack \\
\hline $\mathbf{X}$. & 23 & $\begin{array}{l}\text { Jack ora em agradecimento pela refeição e avisa que } \\
\text { perdeu o emprego no clube. A mulher diz que a culpa } \\
\text { é do amigo dele. As crianças brigam, Jack interfere } \\
\text { equivocadamente ao repreendê-los e a mulher tira a } \\
\text { filha da mesa. }\end{array}$ & Jack \\
\hline XI. & 24 & $\begin{array}{l}\text { Cristina se diverte fazendo um bolo com suas duas } \\
\text { filhas. }\end{array}$ & Cristina \\
\hline XII. & 30 & $\begin{array}{l}\text { Paul e a esposa recebem informações do especialista } \\
\text { em fertilidade em seu consultório. O médico alerta que } \\
\text { mesmo que a cirurgia dela dê certo, pode ser que a } \\
\text { inseminação artificial não seja bem sucedida e alerta } \\
\text { Paul que pode não conhecer o filho. Paul prepara-se } \\
\text { para fazer um espermograma. }\end{array}$ & Paul \\
\hline XIII. & 38 & Jack pega suas coisas no clube de golfe, encontra seu & Jack \\
\hline
\end{tabular}


amigo que o demitiu e que o convida para beber. O

amigo está se sentindo mal pela demissão e diz para

Jack que está tentando arrumar serviço para ele.

\begin{tabular}{|c|c|c|c|}
\hline XIV. & 14 & $\begin{array}{l}\text { Cristina ganha tiro de natação com a irmã mais jovem. } \\
\text { Sai da piscina, seu celular toca e ela sai dizendo que } \\
\text { vai encontrar a família. }\end{array}$ & Cristina \\
\hline $\mathbf{X V}$. & 111 & $\begin{array}{l}\text { A irmã de Cristina mostra o dedo para ela na piscina, } \\
\text { enquanto Cristina vai embora sorrindo. }\end{array}$ & Cristina \\
\hline XVI. & 55 & $\begin{array}{l}\text { Jack despede-se do amigo que o demitiu na frente de } \\
\text { um bar. O amigo insiste que ele deveria tomar uma } \\
\text { cerveja no dia de seu aniversário. Jack recusa } \\
\text { novamente a bebida, convida-o para a festa na sua casa } \\
\text { e parte na sua camionete pintada com a palavra "fé" } \\
\text { bem grande. }\end{array}$ & Jack \\
\hline XVII. & 110 & Jack se despede de seu chefe na rua e entra no carro. & Jack \\
\hline XVIII. & 3 & $\begin{array}{l}\text { Michael, marido de Cristina, termina lanche com filhas } \\
\text { numa lanchonete. }\end{array}$ & Cristina \\
\hline XIX. & 109 & A família de Cristina sai de um restaurante. & Cristina \\
\hline $\mathbf{X X}$. & 44 & $\begin{array}{l}\text { Jardineiro aspira folhas, enquanto Michael caminha na } \\
\text { calçada, deixa recado no celular de Cristina avisando } \\
\text { que está a caminho de casa, enquanto adverte as filhas. }\end{array}$ & Cristina \\
\hline XXI. & 71 & $\begin{array}{l}\text { Marido de Cristina caminha pela calçada, deixa recado } \\
\text { para sua mulher no celular enquanto diz para suas } \\
\text { filhas não pegarem num pombo. Ele cumprimenta o } \\
\text { jardineiro. A camionete de Jack passa, ouvimos uma } \\
\text { freada e o atropelamento. O jardineiro larga o que está } \\
\text { fazendo e corre na direção do acidente. }\end{array}$ & Jack + Cristina \\
\hline
\end{tabular}


INCIDENTE INCITANTE - PRIMEIRO TURNING POINT

\begin{tabular}{|c|c|c|c|}
\hline \multicolumn{4}{|c|}{ SEGUNDO ATO } \\
\hline $\begin{array}{l}\text { Sequência } \\
\text { Causal/Temporal }\end{array}$ & $\begin{array}{l}\text { Sequência } \\
\text { original }\end{array}$ & Descrição & Composição \\
\hline XXII. & 27 & $\begin{array}{l}\text { É festa de aniversário de Jack e ele ainda não chegou. } \\
\text { Sua mulher cozinha com a cunhada e bebem cerveja } \\
\text { escondidas. }\end{array}$ & Jack \\
\hline XXIII. & 32 & $\begin{array}{l}\text { Jack chega atrasado em sua festa. Sua mulher sai pela } \\
\text { cozinha para conversar com ele no carro. Ele conta que } \\
\text { atropelou um homem e duas meninas. }\end{array}$ & Jack \\
\hline XXIV. & 36 & $\begin{array}{l}\text { Marianne consola Jack e pede para a cunhada mandar } \\
\text { todos embora da festa, exceto o reverendo. }\end{array}$ & Jack \\
\hline XXV. & 29 & $\begin{array}{l}\text { O reverendo dirige com Marianne ao seu lado. Passam } \\
\text { por um acidente com corpos ensanguentados cobertos no } \\
\text { chão. Ela fica emocionada, ele para, e diz vai ver e já } \\
\text { volta. }\end{array}$ & Jack \\
\hline XXVI. & 28 & $\begin{array}{l}\text { Cristina chega em casa (depois da natação), chama as } \\
\text { filhas e ouve a mensagem de seu marido no seu celular, } \\
\text { avisando que já estão no caminho. Ela recebe um } \\
\text { telefonema, avisando algo grave. }\end{array}$ & Cristina \\
\hline XXVII. & 31 & $\begin{array}{l}\text { Cristina chega ao hospital e pede informações sobre seu } \\
\text { marido e filhas que sofreram um acidente. A } \\
\text { recepcionista pede para ela esperar e Cristina encontra } \\
\text { seu pai e sua irmã. }\end{array}$ & Cristina \\
\hline XXVIII. & 45 & $\begin{array}{l}\text { Jack está em casa, sua mulher chega e conta que as } \\
\text { vítimas morreram no atropelamento. Jack diz que vai se } \\
\text { entregar. Sua mulher tenta convencê-lo do contrário sem } \\
\text { sucesso. Ele sai. }\end{array}$ & Jack \\
\hline XXIX. & 35 & $\begin{array}{l}\text { Cristina recebe dos médicos a notícia da morte de suas } \\
\text { duas filhas e do estado crítico do marido com graves } \\
\text { danos cerebrais. }\end{array}$ & Cristina \\
\hline XXX. & 39 & $\begin{array}{l}\text { Funcionária do hospital fala com Cristina sobre a doação } \\
\text { do coração de seu marido. }\end{array}$ & Cristina \\
\hline XXXI. & 40 & $\begin{array}{l}\text { Paul e sua mulher recebem a notícia de que surgiu um } \\
\text { coração para doação. }\end{array}$ & Paul \\
\hline XXXII. & 41 & $\begin{array}{l}\text { Paul é preparado para a cirurgia e sua mulher vê Cristina } \\
\text { saindo do hospital amparada por seu pai e sua irmã. }\end{array}$ & $\begin{array}{l}\text { Paul }+ \\
\text { Cristina }\end{array}$ \\
\hline XXXIII. & 49 & $\begin{array}{l}\text { Marianne lava o sangue do para-choque da camionete de } \\
\text { Jack e chora. }\end{array}$ & Jack \\
\hline XXXIV. & 21 & $\begin{array}{l}\text { Paul está hospitalizado e recebe um pote do médico com } \\
\text { seu coração. }\end{array}$ & Paul \\
\hline XXXV. & 50 & O pai de Cristina conforta-a no velório da família. & Cristina \\
\hline XXXVI. & 52 & $\begin{array}{l}\text { A irmã de Cristina cobra dela ir a delegacia prestar } \\
\text { queixa e menciona que o atropelador é um ex-presidiário. } \\
\text { Cristina diz que nada trará sua família de volta. }\end{array}$ & Cristina \\
\hline XXXVII. & 13 & $\begin{array}{l}\text { Jack é colocado numa cela e o vizinho, em off, comenta } \\
\text { que o Lobo está de volta. }\end{array}$ & Jack \\
\hline XXXVIII. & 34 & $\begin{array}{l}\text { Médico faz um exame pós-operatório em Paul que quer } \\
\text { saber quem foi o doador do coração que foi lhe } \\
\text { transplantado. }\end{array}$ & Paul \\
\hline XXXIX. & 59 & $\begin{array}{l}\text { Jack recebe o reverendo em sua cela. Eles discutem } \\
\text { fortemente. Jack sente-se traído por Deus que acredita } \\
\text { ser o responsável pelo que está vivendo. }\end{array}$ & Jack \\
\hline XL. & 61 & $\begin{array}{l}\text { Jack tenta enforcar-se mas o cano onde se pendurou } \\
\text { quebra-se e ele é salvo por um colega de cela. }\end{array}$ & Jack \\
\hline XLI. & 47 & $\begin{array}{l}\text { Paul celebra volta ao lar com a mulher e amigos num } \\
\text { almoço em casa. Eles brindam à nova vida após a }\end{array}$ & Paul \\
\hline
\end{tabular}




\begin{tabular}{|c|c|c|c|}
\hline & & $\begin{array}{l}\text { cirurgia. Sua mulher anuncia que eles vão ser pais } \\
\text { (operação, inseminação artificial, etc.) ele demonstra } \\
\text { contrariedade no olhar. }\end{array}$ & \\
\hline XLII. & 51 & $\begin{array}{l}\text { Mary lava a louça após a festa de boas-vindas dele do } \\
\text { hospital e discutem sobre o anúncio que ela fez de que } \\
\text { seriam pais. }\end{array}$ & Paul \\
\hline XLIII. & 48 & Paul vai a um encontro num boliche.*** & Paul \\
\hline XLIV. & 53 & $\begin{array}{l}\text { Paul encontra o mesmo sujeito do boliche que apresenta } \\
\text { informações sobre quem doou o coração a ele, como } \\
\text { morreu e quem é o atropelador. Paul sente-se mal. }\end{array}$ & Paul \\
\hline XLV. & 54 & $\begin{array}{l}\text { Paul conta para sua mulher as informações que recebeu } \\
\text { do detetive. Ela pede para ele parar de olhar para trás e } \\
\text { buscarem juntos o novo e o beija. }\end{array}$ & Paul \\
\hline XLVI. & 57 & $\begin{array}{l}\text { Obstetra consulta Mary sobre marcação de sua cirurgia e } \\
\text { revela, sem querer, para Paul que ela já havia feito um } \\
\text { aborto. }\end{array}$ & Paul \\
\hline XLVII. & 58 & $\begin{array}{l}\text { Paul e Mary discutem no hall do elevador da clínica } \\
\text { sobre a relação e ele diz que acabou. }\end{array}$ & Paul \\
\hline XLVIII. & 18 & $\begin{array}{l}\text { Paul, com boa aparência, toca a campainha de um casa e } \\
\text { ninguém atende. }\end{array}$ & Paul \\
\hline XLIX. & 26 & $\begin{array}{l}\text { Paul, com boa aparência, segue Cristina da casa dela até } \\
\text { uma loja de bebidas. }\end{array}$ & $\begin{array}{l}\text { Paul + } \\
\text { Cristina }\end{array}$ \\
\hline L. & 20 & $\begin{array}{l}\text { Cristina, atormentada, fuma e bebe, enquanto põe roupas } \\
\text { de criança na máquina de lavar. }\end{array}$ & Cristina \\
\hline LI. & 37 & Paul observa Cristina nadando na academia. & $\begin{array}{l}\text { Paul + } \\
\text { Cristina }\end{array}$ \\
\hline LII. & 42 & $\begin{array}{l}\text { Paul aborda Cristina na lanchonete da academia e ela não } \\
\text { aceita que ele se sente com ela. }\end{array}$ & $\begin{array}{l}\text { Paul + } \\
\text { Cristina }\end{array}$ \\
\hline LIII. & 46 & $\begin{array}{l}\text { Cristina junta brinquedos das filhas numa caixa na } \\
\text { garagem, abre a porta, espia o quarto das meninas } \\
\text { intocado, fecha a porta e chora. }\end{array}$ & Cristina \\
\hline LIV. & 43 & $\begin{array}{l}\text { Cristina bebe uísque sozinha em casa, liga para uma } \\
\text { amiga num bar, mas não fala com ela. }\end{array}$ & Cristina \\
\hline LV. & 60 & $\begin{array}{l}\text { Cristina entra num bar. Paul a segue. Ela encontra a } \\
\text { amiga para a qual telefonou antes e não falou nada. Elas } \\
\text { vão para o banheiro e ela lhe fornece drogas. }\end{array}$ & $\begin{array}{l}\text { Paul }+ \\
\text { Cristina }\end{array}$ \\
\hline LVI. & 62 & $\begin{array}{l}\text { Cristina sai do bar entorpecida e bate ao tentar sair com o } \\
\text { carro. Paul a convence a deixa-lo dirigir. Ele a leva para } \\
\text { a casa dela e a deixa dormindo dentro do carro na } \\
\text { garagem. }\end{array}$ & $\begin{array}{l}\text { Paul + } \\
\text { Cristina }\end{array}$ \\
\hline LVII. & 63 & $\begin{array}{l}\text { Marianne visita Jack na cadeia e diz que vendeu a } \\
\text { camionete para pagar o advogado. Ela diz que faz dois } \\
\text { anos que ele está na cadeia. }\end{array}$ & Jack \\
\hline LVIII. & 67 & $\begin{array}{l}\text { Cristina está boiando na piscina da academia. Na saída, } \\
\text { chove bastante e ela está sem carro. Paul lhe oferece uma } \\
\text { carona e ela recusa. Paul diz que foi ele quem a levou em } \\
\text { seu carro para casa na semana anterior. Ela aceita sua } \\
\text { carona. }\end{array}$ & $\begin{array}{l}\text { Paul + } \\
\text { Cristina }\end{array}$ \\
\hline LIX. & 69 & $\begin{array}{l}\text { Paul deixa Cristina em casa, convida-a para almoçar no } \\
\text { dia seguinte e ela aceita. }\end{array}$ & $\begin{array}{l}\text { Paul + } \\
\text { Cristina }\end{array}$ \\
\hline LX. & 70 & Paul dirige seu carro, passa mal e vomita. & Paul \\
\hline LXI. & 72 & $\begin{array}{l}\text { Marianne e o reverendo aguardam Jack sair da prisão. } \\
\text { Jack os vê mas sai andando sem falar com eles. Marianne } \\
\text { fica chateada e o reverendo vai falar com ele. }\end{array}$ & Jack \\
\hline LXII. & 74 & $\begin{array}{l}\text { Jack está no banco de trás no carro do reverendo, } \\
\text { pergunta quanto o advogado cobrou para botá-lo em } \\
\text { liberdade e Marianne diz que o suficiente para que os } \\
\text { filhos lembrem da cara dele. }\end{array}$ & Jack \\
\hline LXIII. & 75 & $\begin{array}{l}\text { Jack chega em casa com Marianne. A filha é carinhosa } \\
\text { com ele e o filho o recebe com reservas. Fizeram bolo e }\end{array}$ & Jack \\
\hline
\end{tabular}




\begin{tabular}{|c|c|c|c|}
\hline & & desenhos para ele. A família se abraça. & \\
\hline LXIV. & 76 & $\begin{array}{l}\text { Paul almoça com Cristina num restaurante, fala de } \\
\text { números, matemática e cita um poema. Ela sorri. }\end{array}$ & $\begin{array}{l}\text { Paul + } \\
\text { Cristina }\end{array}$ \\
\hline LXV. & 77 & $\begin{array}{l}\text { Paul e Cristina caminham para casa depois do almoço. } \\
\text { Ela a convida a entrar e ele aceita. }\end{array}$ & $\begin{array}{l}\text { Paul + } \\
\text { Cristina }\end{array}$ \\
\hline LXVI. & 81 & $\begin{array}{l}\text { Paul entra na casa de Cristina que pergunta se ele vai } \\
\text { continuar no vinho tinto. Enquanto ela vai pegar a } \\
\text { bebida, ele observa fotos da família pela casa. Ele passa } \\
\text { mal, diz que há muito tempo não gosta de alguém como } \\
\text { dela, ela diz que é casada e ele vai embora. }\end{array}$ & $\begin{array}{l}\text { Paul + } \\
\text { Cristina }\end{array}$ \\
\hline LXVII. & 80 & $\begin{array}{l}\text { Jack e Marianne trocam carícias. Ele começa a falar } \\
\text { sobre a menina que atropelou, corta o clima de romance } \\
\text { e chora abraçado a mulher. }\end{array}$ & Jack \\
\hline LXVIII. & 82 & $\begin{array}{l}\text { Jack está num culto com a família e os fiéis cantam. Ele } \\
\text { está abatido e deslocado e troca olhares com o jovem } \\
\text { com o qual se desentendeu. }\end{array}$ & Jack \\
\hline LXIX. & 83 & $\begin{array}{l}\text { Jack está em casa com a família, assistindo TV. A filha } \\
\text { pergunta se é verdade que ele matou duas meninas e o } \\
\text { pai delas. }\end{array}$ & Jack \\
\hline LXX. & 84 & Jack reza desesperadamente sozinho na igreja. & Jack \\
\hline LXXI. & 85 & $\begin{array}{l}\text { Paul está na cama com sua mulher, quando seu celular } \\
\text { toca de madrugada. Cristina o chama para sua casa. Sua } \\
\text { mulher diz que achava que ele iria mudar depois do } \\
\text { transplante e ele responde que achava que ela mudaria se } \\
\text { ele mudasse, mas nenhum dos dois mudaram. }\end{array}$ & $\begin{array}{l}\text { Paul + } \\
\text { Cristina }\end{array}$ \\
\hline LXXII. & 86 & Jack olha a família dormindo, pega uma bolsa e sai. & Jack \\
\hline LXXIII. & 88 & $\begin{array}{l}\text { Paul chega na casa de Cristina, eles se beijam, ele conta } \\
\text { que tem o coração do marido dela. Ela fica enfurecida e } \\
\text { o coloca para fora da sua casa. }\end{array}$ & $\begin{array}{l}\text { Paul + } \\
\text { Cristina }\end{array}$ \\
\hline LXXIV. & 93 & $\begin{array}{l}\text { Jack fala ao telefone com Marianne que chora muito. } \\
\text { Eles falam e não se escutam, ele desliga. }\end{array}$ & Jack \\
\hline LXXV. & 90 & $\begin{array}{l}\text { Cristina acorda em sua casa ao amanhecer, vê Paul } \\
\text { dormindo em seu carro em frente à casa e vai até ele. } \\
\text { Dentro do carro, ele se declara e eles se beijam. }\end{array}$ & $\begin{array}{l}\text { Paul + } \\
\text { Cristina }\end{array}$ \\
\hline LXXVI. & 91 & $\begin{array}{l}\text { Mary caminha sozinha pela rua e depois senta-se } \\
\text { cansada. }\end{array}$ & Paul \\
\hline LXXVII. & 92 & Cristina e Paul transam. & $\begin{array}{l}\text { Paul + } \\
\text { Cristina }\end{array}$ \\
\hline LXXVIII. & 95 & $\begin{array}{l}\text { Paul e Cristina estão nus na cama dela. Ela dorme, ele } \\
\text { fuma e encontra fotos dela com o marido e drogas na sua } \\
\text { mesinha de cabeceira. }\end{array}$ & $\begin{array}{l}\text { Paul + } \\
\text { Cristina }\end{array}$ \\
\hline LXXIX. & 1 & Paul fuma, enquanto observa Cristina dormindo seminua. & $\begin{array}{l}\text { Paul + } \\
\text { Cristina }\end{array}$ \\
\hline LXXX. & 97 & $\begin{array}{l}\text { Cristina e Paul estão nus no quarto dela. Ele dorme, ela } \\
\text { vê as roupas de seu marido no armário e veste uma blusa. }\end{array}$ & $\begin{array}{l}\text { Paul + } \\
\text { Cristina }\end{array}$ \\
\hline LXXXI. & 99 & $\begin{array}{l}\text { Cristina conversa com o jardineiro que presenciou o } \\
\text { atropelamento e vai ao restaurante em que seu marido e } \\
\text { suas filhas estavam antes do acidente, e, do lado de fora, } \\
\text { vê o interior do restaurante. Cristina anda pela rua e senta } \\
\text { no meio fio, onde há um monte de folhas secas. Em casa, } \\
\text { Cristina chora na cama, ouvindo no celular a mensagem } \\
\text { de voz que seu marido enviou-lhe antes do } \\
\text { atropelamento. }\end{array}$ & Cristina \\
\hline LXXXII. & 98 & $\begin{array}{l}\text { Paul chega em casa e vê sua mulher arrumando as malas. } \\
\text { Ela reclama por ele estar sumido por muitos dias e fala } \\
\text { que vai fazer a inseminação artificial e voltar pra } \\
\text { Londres. Paul vai contra em vão e ela vai embora. }\end{array}$ & Paul \\
\hline LXXXIII. & 101 & $\begin{array}{l}\text { Cristina fuma e cheira cocaína em um prato. Paul vê e } \\
\text { derruba o prato. Ele diz que ela não precisa daquilo, mas } \\
\text { ela retruca nervosa. Cristina senta-se nervosa à mesa da }\end{array}$ & $\begin{array}{l}\text { Paul + } \\
\text { Cristina }\end{array}$ \\
\hline
\end{tabular}


cozinha. Paul entra e se senta próximo a ela. Ela lamenta a perda da família e a negligência de Jack, enfurece-se e diz que quer matá-lo. Paul tenta acalmá-la sem sucesso. Ela diz que Paul precisa ajudá-la a matá-lo. pois deve isso a Michael. Paul a abraça e ela lamenta mais, chorando.

\begin{tabular}{|c|c|c|c|}
\hline LXXXIV. & 73 & $\begin{array}{l}\text { Paul está no consultório de seu médico que diz que ele } \\
\text { precisa voltar para o hospital, porque precisa de um outro } \\
\text { coração. Paul pergunta se será salvo se ficar. Sem a } \\
\text { garantia do médico, ele diz que prefere morrer ao ar } \\
\text { livre. }\end{array}$ & Paul \\
\hline LXXXV. & 66 & $\begin{array}{l}\text { Paul encontra o detetive no carro dele, que lhe entrega o } \\
\text { endereço do motel onde Jack está morando, um revólver } \\
\text { e mais informações. }\end{array}$ & Paul \\
\hline LXXXVI. & 64 & Jack trabalha duro em uma fábrica insalubre. & Jack \\
\hline LXXXVII. & 22 & $\begin{array}{l}\text { Paul e Cristina passam de carro ao lado da cerca de uma } \\
\text { fábrica e observam Jack todo sujo carregando sacos. Ela } \\
\text { fica nervosa e diz que precisam matá-lo. }\end{array}$ & $\begin{array}{l}\text { Paul }+ \text { Jack }+ \\
\text { Cristina }\end{array}$ \\
\hline LXXXVIII. & 68 & $\begin{array}{l}\text { Jack chega do trabalho na caçamba de uma pick-up. } \\
\text { Quando Jack caminha para seu quarto, cruza com Paul } \\
\text { que entra em outro quarto do motel. }\end{array}$ & Paul + Jack \\
\hline LXXXIX. & 65 & $\begin{array}{l}\text { Cristina está num motel barato de beira de estrada com } \\
\text { Paul. }\end{array}$ & $\begin{array}{l}\text { Paul }+ \\
\text { Cristina }\end{array}$ \\
\hline $\mathbf{X C}$. & 78 & $\begin{array}{l}\text { Paul respira com dificuldades, deixa Cristina dormindo } \\
\text { no quarto do motel, põe o revólver no bolso do casaco e } \\
\text { sai. }\end{array}$ & $\begin{array}{l}\text { Paul + } \\
\text { Cristina }\end{array}$ \\
\hline XCI. & 79 & $\begin{array}{l}\text { Paul está num carro em frente ao motel, quando Jack } \\
\text { passa, ele vai atrás, rende-o, coloca-o de joelhos e atira } \\
\text { três vezes. }\end{array}$ & Paul + Jack \\
\hline XCII. & 102 & $\begin{array}{l}\text { Paul aponta a arma para Jack num terreno deserto. Paul } \\
\text { manda Jack fechar os olhos e atira, mas sem atingi-lo. } \\
\text { Paul chama Jack de assassino e o manda desaparecer. } \\
\text { Paul deixa Jack lá, caído e, enquanto vai embora, guarda } \\
\text { uma arma em seu bolso, apoia-se em um grande tubo de } \\
\text { ferro e vomita. }\end{array}$ & Paul + Jack \\
\hline XCIII. & 56 & $\begin{array}{l}\text { Paul caminha num terreno árido com muita dificuldade } \\
\text { em respirar e com um revólver na mão. Ele piora, } \\
\text { encosta-se e guarda a arma no bolso do casaco. }\end{array}$ & Paul \\
\hline XCIV. & 12 & $\begin{array}{l}\text { Paul debilitado, manipula revólver sentado ao lado de } \\
\text { piscina vazia e entulhada. }\end{array}$ & Paul \\
\hline XCV. & 8 & Cristina deprimida cheira cocaína num banheiro. & Cristina \\
\hline XCVI. & 104 & $\begin{array}{l}\text { Cristina se olha no espelho no banheiro. Ela se senta na } \\
\text { privada e depois sai do quarto. Ela vê Paul sentado } \\
\text { próximo a uma piscina vazia e entulhada e pergunta se } \\
\text { ele matou Jack. Ele diz que sim e que nunca encontrarão } \\
\text { o corpo. Eles voltam pro quarto do motel e Cristina } \\
\text { consola Paul. }\end{array}$ & $\begin{array}{l}\text { Paul }+ \\
\text { Cristina }\end{array}$ \\
\hline XCVII. & 100 & $\begin{array}{l}\text { Jack bebe e fuma em um quarto de hotel. Com uma faca, } \\
\text { ele faz um corte em seu antebraço e derrama álcool em } \\
\text { cima. }\end{array}$ & Jack \\
\hline XCVIII. & 89 & $\begin{array}{l}\text { Jack caminha no corredor do motel de noite olhando para } \\
\text { os lados. }\end{array}$ & Jack \\
\hline XCIX. & 105 & $\begin{array}{l}\text { Jack vai até o quarto de Cristina e Paul. Paul vai até a } \\
\text { porta e Jack invade e pede que eles o matem. Paul hesita } \\
\text { e Jack o empurra. Cristina bate em Jack com um abajur, } \\
\text { enquanto Paul, caído no chão, dá um tiro no próprio } \\
\text { peito. Cristina desesperadamente pede para Jack chamar } \\
\text { uma ambulância. }\end{array}$ & $\begin{array}{l}\text { Paul }+ \text { Jack }+ \\
\text { Cristina }\end{array}$ \\
\hline
\end{tabular}


CRISE - SEGUNDO TURNING POINT

\section{TERCEIRO ATO}

\begin{tabular}{cclll}
$\begin{array}{c}\text { Sequência } \\
\text { Causal/Temporal }\end{array}$ & $\begin{array}{l}\text { Sequência } \\
\text { original }\end{array}$ & Descrição & Composição \\
C. & 17 & $\begin{array}{l}\text { Paul está ferido e sangrando num quarto de motel barato. } \\
\text { Cristina desesperada pede a Jack para chamar uma }\end{array}$ & $\begin{array}{l}\text { Paul + Jack + } \\
\text { Cristina }\end{array}$ \\
ambulância. & $\begin{array}{l}\text { Jack dirige afobadamente numa estrada. Cristina está no } \\
\text { banco de trás, segurando Paul ensanguentado e pede para }\end{array}$ & $\begin{array}{l}\text { Paul + Jack + } \\
\text { Cristina }\end{array}$ \\
CI. & 33 & 87 & $\begin{array}{l}\text { Jack ir mais rápido. } \\
\text { que está no banco traseiro nos braços de Cristina. Ele diz } \\
\text { que atirou no peito dele. }\end{array}$ & $\begin{array}{l}\text { Paul }+ \text { Jack }+ \\
\text { Cristina }\end{array}$ \\
\hline
\end{tabular}

\begin{tabular}{|c|c|c|c|}
\hline \multicolumn{4}{|c|}{ MONTAGEM DE PLANOS - CLÍMAX FINAL } \\
\hline CIII. & 107 & $\begin{array}{l}\text { Cristina passa a mão na cabeça de Paul ensanguentado dentro de um } \\
\text { carro. }\end{array}$ & $\begin{array}{l}\text { Paul + } \\
\text { Cristina }\end{array}$ \\
\hline CIV. & 94 & Cristina faz exame para doar sangue. & Cristina \\
\hline CV. & 103 & $\begin{array}{l}\text { Cristina aguarda na sala de espera do hospital. Uma enfermeira surge e } \\
\text { diz que não foi possível usar o sangue de Cristina para uma transfusão, } \\
\text { devido à presença de drogas, e diz para não usá-las, pois está grávida. A } \\
\text { enfermeira insiste que ela precisa se cuidar e entra em uma sala. Cristina } \\
\text { chora. }\end{array}$ & Cristina \\
\hline CVI. & 96 & $\begin{array}{l}\text { Policial diz que a versão de Jack sobre o tiro em Paul não bate com as } \\
\text { investigações nem com os depoimentos do casal e lhe dá papéis para } \\
\text { assinar e ir. }\end{array}$ & Jack \\
\hline CVII. & 108 & Paul está deitado em uma maca, entubado. & Paul \\
\hline CVIII. & 7 & Paul, em off, analisa sua situação, entubado numa UTI. & Paul \\
\hline CIX. & 113 & $\begin{array}{l}\text { Cristina aguarda aflita na sala de espera da UTI em frente à porta e Jack } \\
\text { surge perto dela. Eles se olham. }\end{array}$ & $\begin{array}{l}\text { Jack }+ \\
\text { Cristina }\end{array}$ \\
\hline CX. & 115 & $\begin{array}{l}\text { Paul está deitado na maca de hospital e os aparelhos vão indicando que } \\
\text { os batimentos cardíacos pararam. Paul morre. }\end{array}$ & Paul \\
\hline CXI. & 114 & $\begin{array}{l}\text { Cristina entra no quarto de suas filhas e, sentada na cama, encara uma } \\
\text { boneca. }\end{array}$ & Cristina \\
\hline CXII. & 113 & Jack fuma do lado de fora de sua casa. Ele entra e encontra sua família. & Jack \\
\hline
\end{tabular}




\title{
APÊNDICE E
}

\section{ESCALETA DE BABEL}

\section{Legenda:}

\author{
Enredo de Yussef (Boubker Ait El Caid) e Ahmed (Said Tarchani) \\ Enredo de Amélia (Adriana Barraza) e Santiago (Gael García Bernal) \\ Enredo de Richard Jones (Brad Pitt) e Susan (Cate Blanchett) \\ Enredo de Chieko (Rinko Kikuchi) e Yasujiro (Kôji Yakusho) \\ Descrições das transições entre as sequências das histórias.
}

\section{Créditos iniciais + Título}

\section{O RIFLE}

Hassan anda pelo deserto. Hassan vende rifle para Abdullah, no Marrocos e ensina Abdullah e seus filhos a usarem o rifle. Yussef vê sua irmã se trocando por um buraco na parede e Ahmed repreende o irmão por isso. Ahmed tenta atirar em um chacal, mas erra e assusta as cabras. Os irmãos discutem sobre Yussef ver a irmã nua. Yussef se masturba atrás de pedra. Ahmed e Yussef testam o alcance do rifle até Yussef atirar em um ônibus em movimento. $\mathrm{O}$ ônibus para e ambos saem correndo.

Transição de Yussef e Ahmed fugindo, com medo PARA filhos de Richard correndo brincando em seu apartamento nos EUA.

\section{A PROCURA POR BABÁ}

Os filhos de Richard brincam de esconder com a babá Amelia. O telefone toca e ela atende (0h03min10s). Richard fala com Amelia e depois lhe pede para passar o telefone para Mike, seu filho, e eles conversam. Amelia coloca as crianças para dormir. Amelia acorda com o telefone tocando. Ela atende e é Richard, dizendo que ela precisa ficar com as crianças o dia todo. Ela tenta arranjar alguém com quem deixar as crianças, sem sucesso. Amelia arruma suas roupas dentro de uma sacola. Santiago, seu sobrinho, chega de carro para levá-los ao casamento.

Transição de cena com Santiago em um carro tocando música tradicional mexicana PARA cena no Marrocos com música marroquina ao fundo.

\section{O ACIDENTE}

Richard e Susan discutem em um pequeno restaurante no Marrocos. Os dois passeiam com outros turistas em um ônibus. Um tiro atinge Susan no ombro. Richard se desespera e manda pararem o ônibus. 
Transição de cena caótica em um ônibus após Susan levar um tiro PARA calmo plano aberto de várias pessoas jogando vôlei.

\section{VÔLEI/RESTAURANTE}

Chieko joga uma competição de vôlei enquanto seu pai, Yasujiro, assiste. Chieko discute com o juiz e é expulsa. Chieko discute com amigas do time no vestiário. Ela e seu pai discutem no carro, até que ele a deixa em um shopping. Chieko entra no shopping e encontra suas amigas após falar com uma atendente. Elas flertam com rapazes da mesa ao lado. Em um fliperama, Chieko e uma amiga são abordadas por um rapaz, que as esnoba. Em um banheiro, Chieko reclama com a amiga da forma como os garotos as trataram. Ela tira a calcinha e, na mesa do refeitório com as amigas, mostra sua genitalha para os rapazes da mesa ao lado. Chieko recebe uma mensagem do pai e vai embora.

Transição de cena com garota japonesa rindo PARA cena no Marrocos, com cabras correndo e berrando.

\section{DOENTES DE CULPA}

Ahmed e Yussef levam as cabras para casa. Yussef e Ahmed estão no quarto, sua mãe entra e os manda trabalharem, mesmo eles insistindo que se sentem mal. Abdullah chega em casa em uma caminhonete. Abdullah e a família jantam e conversam sobre uma notícia de que terroristas mataram uma turista americana. Yussef e Ahmed estão deitados, porém acordados e pensativos em seu quarto.

Transição de cena quieta e melancólica de Yussef e Ahmed deitados em seu quarto PARA indivíduo sentado sob um muro vendo um automóvel passar, seguido de imagens animadas e coloridas, no México.

\section{TRAVESSIA DE FRONTEIRA}

Santiago dirige com Amelia e os filhos de Richard, que percebem a diferente cultura. Santiago e Amelia chegam ao local do casamento, cumprimentam a família e apresentam os filhos de Richard. As parentes de Amelia a ajudam a colocar um vestido. Santiago coloca as crianças para pegarem galinhas e arranca a cabeça de uma delas com as mãos, assustando os filhos de Richard.

Transição de cena sangrenta de galinha sendo decapitada com o choque de Mike PARA caos em um ônibus no Marrocos, em que Susan está ensanguentada e Richard, assustado.

\section{A NECESSIDDAE DE UM MÉDICO}

Susan sangra dentro do ônibus e há muito tumulto devido ao tiro. Richard pede ajuda médica, e um cidadão marroquino, Anwar, sugere irem para a aldeia dele. Ao chegarem lá, Susan fica sob os cuidados de uma senhora, enquanto Richard vai procurar ajuda. Os turistas sentem medo em esperar na aldeia. Um médico veterinário surge e dá pontos em Susan para parar o sangramento. 
Transição da dor de Susan ao ser costurada sem anestesia em um ambiente sujo e seu grito agonizante PARA a fala de uma calma atendente sob o silêncio absoluto da perspectiva aural de Chieko, que é surda, em um local limpo e claro.

\section{VISITA DA POLÍCIA}

Chieko vai ao dentista e, durante a consulta, ela tenta seduzi-lo. Ele se ofende e a manda sair. Chieko volta pra casa, onde estão dois policiais que querem falar com seu pai e deixam um recado para ele. Em seu apartamento, Chieko espera sua amiga chegar assistindo TV (0:48:50 - passa reportagem na TV mostrando que Yussef é culpado pelo tiro a Susan, o que mexe com a linearidade temporal pois ainda não havia sido mostrada a polícia investigando o caso. A amiga de Chieko chega e elas conversam. As duas mostram uma para a outra que estão sem calcinha e saem, rindo.

Transição das duas amigas japonesas juntas rindo indo se divertir PARA o reflexo de dois meninos sozinhos no deserto em uma poça, sendo deformado pelas ondas formadas na água por uma pedra jogada.

\section{RASTREAMENTO DA ARMA}

Yussef e Ahmed escondem o rifle atrás de uma grande pedra. A polícia investiga o caso na região, chegando ao lar de Hassan. Os policiais interrogam Hassan e sua esposa violentamente e ele diz a quem vendeu o rifle. Yussef e Ahmed veem a polícia passando por seu território e tentam despistá-los. Eles contam ao pai que são responsáveis pelo tiro e que a polícia está à procura deles. Ahmed conta da relação de Yussef com a irmã e os dois começam a brigar.

Transição da briga entre os irmãos e um momento muito desesperador e conflituoso para a família PARA uma festa familiar feliz e divertida de casamento.

\section{CASAMENTO MEXICANO}

Acontece o casamento do filho de Amelia, Luis. Amelia e Santiago se divertem e dançam com os filhos de Richard. Um viúvo conhecido de Amelia a tira para dançar. À noite, enquanto todos se divertem, Amelia e o tal conhecido se beijam e trocam carícias dentro de casa. A festa continua.

Transição de Santiago dançando na festa de casamento com a arma na cintura PARA a imagem de um gato pulando de uma pedra para outra no Marrocos.

\section{MEDICINA LOCAL}

No Marrocos, Susan sente muita dor, enquanto Richard a ampara. Uma velha senhora dá haxixe para Susan, o que a relaxa. No ônibus, os outros turistas se incomodam com o calor e o medo de estarem em uma aldeia marroquina, mas Richard os convence a esperar mais.

Transição da imagem de Richard e o marroquino entrando na casa dele, frustrados pela ausência de transporte rápido na cidade PARA uma imagem de um metro passando com velocidade, no Japão. 


\section{NOITE DE TÓQUIO}

Chieko e sua amiga encontram amigos em uma praça. Eles consomem álcool e ecstasy. Eles brincam na praça e em um metrô. Os jovens vão para uma boate. Chieko vê sua amiga beijando o rapaz em quem ela estava interessada e vai embora da boate. Chieko anda pela rua reparando nos homens que passam. Chegando em casa, Chieko pede ao porteiro que ligue para um dos policiais que estiveram lá mais cedo procurando pelo pai dela.

Transição da imagem do policial na rua, a caminho do apartamento de Chieko, PARA Yussef e Ahmed sendo repreendidos pelo pai, no Marrocos.

\section{NA CORRERIA}

Abdullah briga com seus filhos. Um policial interroga Hassan. Abdullah e os filhos pegam o rifle e vão se esconder na casa de um conhecido. Policial agride Hassan e leva sua esposa para chegar até Abdullah. Polícia encontra Abdullah e filhos fugindo e começam a atirar neles. Eles atingem Ahmed na perna e Yussef atira nos policiais com o rifle.

Transição do policial sendo atingido por um tiro PARA pessoas dançando na festa de casamento do filho de Amelia.

\section{PATRULHA DE FRONTEIRA}

Santiago, embriagado, leva Amelia e filhos de Richard de volta para os EUA após a festa. Eles chegam na fronteira e um policial os interroga, sob suspeição. Eles são revistados e um policial suspeita que Santiago esteja bêbado. Santiago ultrapassa a fronteira e foge. A polícia os persegue, Santiago larga Amelia e os filhos de Richard no deserto e vai embora. Amelia e as crianças andam pelo deserto.

Transição de cena de Amelia e os filhos de Richard andando no deserto PARA imagem com roupas e papéis ao vento presos em pedaços de pau e telhas, em um ambiente aparentemente árido.

\section{SEM TRANSPORTE}

No Marrocos, Richard e Anwar conversam, enquanto Susan dorme. Richard e Anwar brigam com um policial que diz que não há ambulâncias disponíveis para levar Susan. Richard briga com turistas, que querem ir embora. Richard fala com a embaixada, que diz que estão fazendo o possível, apesar de problemas políticos.

Transição da cena de Richard desesperado e angustiado PARA uma pacífica imagem de um incenso aceso.

\section{SEDUÇÃO}

Chieko chora deitada em seu apartamento. O policial chega e Chieko o convida para entrar. Os dois conversam sobre a morte da mãe dela e a necessidade da polícia de falar com Yasujiro. Antes que o policial possa ir embora, Chieko se despe e tenta seduzi-lo. O policial recusa, ela chora, ele a consola. 
Transição de Chieko sendo abraçada e consolada pelo detetive Kenji PARA Abdullah abraçando Ahmed ferido.

\section{O CERCO}

Abdullah e seus filhos continuam se escondendo dos tiros da polícia atrás das pedras, até que acertam novamente Ahmed e o matam. Yussef se rende.

Transição de Abdullah desesperadamente abraçando o corpo de Ahmed no deserto PARA o ambiente abandonado do que restou da festa de casamento do filho de Amelia, no México.

\section{PERDIDOS NO DESERTO}

Amelia dorme com os filhos de Richard no deserto, e, ao ver um carro passando à distância, acorda e tenta desesperadamente chamar sua atenção, sem sucesso. Amelia anda com as crianças pelo deserto, e as deixa sós para procurar ajuda. Ela anda sozinha pelo deserto até que encontra um policial de carro, que a prende e lhe pede para levá-lo até elas. Ela o leva até onde tinha deixado as crianças, mas elas não estão mais lá e o policial a prende no camburão.

Transição de Amelia desesperada pelo sumiço dos filhos de Richard PARA Richard e Susan em momento frágil juntos, falando sobre as crianças.

\section{RECONECTANDO}

Susan pede para Richard cuidar das crianças caso morra. Richard ajuda Susan a urinar. Os dois se beijam e desabafam sobre a morte de um filho dos dois. Finalmente a ajuda chega e Susan é tirada de lá por vários marroquinos.

Transição de um grande grupo de pessoas agitadas carregando Susan PARA o quieto apartamento de Chieko, que está sentada em silêncio com o policial.

\section{O GRITO SILÊNCIOSO}

O policial consola Chieko, que escreve um bilhete, dobra e entrega a ele. O policial vai embora.

Transição de imagens quietas das ruas do Japão PARA Amelia na delegacia.

\section{DEPORTADA}

Oficial de fronteira é duro, humilha e deporta Amelia. Ela insiste que criou toda uma vida nos EUA, mas não muda a opinião do oficial. O filho de Amelia, Luis, vai encontra-la na fronteira com o México.

Transição de Amélia abraçando seu filho PARA a imagem de um grande campo desértico. 


\section{YUSSEF LEMBRA-SE DO IRMÃO AO VENTO}

O corpo de Ahmed é retirado do deserto pela polícia. Yussef relembra um momento dos dois irmãos se divertindo com o vento no deserto.

Transição da imagem de Yussef e Ahmed sentindo o vento forte bater em seus corpos PARA a imagem de um helicóptero se aproximando.

\section{DEIXANDO A ALDEIA}

Um helicóptero pousa e Richard e outras pessoas carregam Susan para dentro dele. Richard oferece dinheiro a Anwar, que recusa. Richard entra no helicóptero e ele decola. $\mathrm{O}$ helicóptero chega ao hospital em Casablanca. Susan é levada para operação. Richard liga para casa e conversa com Amelia e depois com seu filho (2h07min15s - Mesma ligação que ocorre no início do filme, constituindo um indexador temporal que deixa claro que o enredo de Amelia acontece depois que Richard e Susan chegam à Casablanca).

Transição da imagem de Richard no telefone, no hospital PARA policial japonês no elevador.

\section{PAI E FILHA}

O policial japonês encontra com Yasujiro saindo do seu prédio. Eles conversam e o policial diz que sente muito pela esposa de Yasujiro e a sacada. Ele fica nervoso e diz que sua esposa se matou com um tiro e pede para a polícia nunca mais o incomodar com o assunto. Yasujiro vai para seu apartamento e o policial vai para um bar (2h13min $15 \mathrm{~s}$ - No bar, passa a notícia de que Susan saiu do hospital após cinco dias de angústia, mostrando que todos os acontecimentos do filme ocorreram nesse período). Ao entrar em seu apartamento, Yasujiro se depara com Chieko nua na sacada. Ele vai até ela, a abraça, a câmera afasta-se e pai e filha somem na imensidão da noite de Tóquio.

\section{Dedicatória}

Créditos finais 


\title{
APÊNDICE F
}

\section{SEQUÊNCIAS DE $B$ ABEL CONFORME APRESENTADAS PELA TRAMA}

\author{
Enredo de Yussef (Boubker Ait El Caid) e Ahmed (Said Tarchani) \\ Enredo de Amélia (Adriana Barraza) e Santiago (Gael García Bernal) \\ Enredo de Richard Jones (Brad Pitt) e Susan (Cate Blanchett) \\ Enredo de Chieko (Rinko Kikuchi) e Yasujiro (Kôji Yakusho)
}

I. O rifle

II. A procura por babá

III. O acidente

IV. Vôlei/restaurante

V. Doentes de culpa

VI. Travessia de fronteira

VII. A necessidade de um médico

VIII. Visita da polícia

IX. Rastreamento da arma

X. Casamento mexicano

XI. Medicina local

XII. Noite de Tóquio

XIII. Na correria
XIV. Patrulha de fronteira

XV. Sem transporte

XVI. Sedução

XVII. Cerco

XVIII. Perdidos no deserto

XIX. Reconectando

XX. O grito silencioso

XXI. Deportada

XXII. Yussef lembra-se do irmão ao vento

XXIII. Deixando a aldeia

XXIV. Pai e filha 


\title{
APÊNDICE G \\ SEQUÊNCIAS DE BABEL EM ORDEM CRONOLÓGICA COM DIVISÃO DE DIAS
}

\author{
Enredo de Yussef (Boubker Ait El Caid) e Ahmed (Said Tarchani) \\ Enredo de Amélia (Adriana Barraza) e Santiago (Gael García Bernal) \\ Enredo de Richard Jones (Brad Pitt) e Susan (Cate Blanchett) \\ Enredo de Chieko (Rinko Kikuchi) e Yasujiro (Kôji Yakusho)
}

$1^{\circ}$ Dia

XXV. O rifle (1)

XXVI. O acidente (3)

XXVII. A necessidade de um médico (7)

XXVIII. Medicina local (11)

XXIX. Doentes de culpa (5)

$2^{\circ}$ Dia

XXX. Sem transporte (15)

XXXI. Rastreamento da arma (9)

XXXII. Reconectando (19)

XXXIII. Na correria (13)

XXXIV.Cerco (17)

XXXV. Deixando a aldeia (22)

\section{$3^{\circ}$ Dia}

XXXVI. A procura por babá (2)

XXXVII. Travessia de fronteira (6)

XXXVIII. Casamento mexicano (10)

XXXIX. Patrulha de fronteira (14)

\section{$4^{0}$ Dia}

XL. Perdidos no deserto (18)

XLI. Deportada (21)

\section{$5^{\circ}$ Dia}

XLII. Vôlei/restaurante (4)

XLIII. Visita da polícia (8)

XLIV. Noite de Tóquio (12)

XLV. Sedução (16)

XLVI. O grito silencioso (20)

XLVII.Pai e filha (23) 


\section{APÊNDICE H}

\section{ESCALETA DE BIUTIFUL \\ COM IDENTIFICAÇÃO DO ENTRELAÇAMENTO DE RAMIFICAÇÕES DO ENREDO PRINCIPAL COM SUBPLOTS}

\section{LEGENDA}

\begin{tabular}{ll}
\hline CÓDIGO & LINHA NARRATIVA \\
\hline LN - Família & $\begin{array}{l}\text { Família original: relações de Uxbal com ex-mulher Marambra, irmão } \\
\text { Tito e filhos Ana e Mateo. }\end{array}$ \\
LN - Arranjo & $\begin{array}{l}\text { Linha narrativa do arranjo familiar alternativo: relações da senegalesa } \\
\text { Ige com a família de Uxbal constituindo novo arranjo familiar. }\end{array}$ \\
LN - Trabalho A & Linha narrativa do trabalho envolvendo mão-de-obra ilegal africana. \\
LN - Trabalho C & Linha narrativa do trabalho envolvendo mão-de-obra ilegal chinesa. \\
SP - Mediunidade & Subplot da mediunidade de Uxbal. \\
SP - Enfermidade & Subplot do padecimento físico e psicológico de Uxbal. \\
SP - Corrupção & Subplot da corrupção policial. \\
SP - Caso Hai/Liwei & Subplot da relação homoafetiva entre Hai e Liwei. \\
\hline
\end{tabular}

\section{CENA DESCRIÇÃO}

\section{LINHAS \\ NARRATIVAS E \\ SUBPLOTS}

\section{CRÉDITOS INICIAIS}

1. Uxbal fala sobre a história de seu anel com sua filha, LN - Família Ana.

2. Em uma floresta cheia de neve, Uxbal encontra seu SP - Mediunidade pai, porém mais novo do que ele. Eles conversam e brincam, acendem cigarros e o pai de Uxbal se afasta.

\section{TÍTULO}

3. Uxbal faz um exame de próstata. A enfermeira tenta $\mathrm{SP}$ - Enfermidade coletar seu sangue, mas não consegue e ele acaba manuseando a seringa sozinho. A enfermeira pergunta se Uxbal estava de jejum, ele se estressa e vai embora.

4. Uxbal desloca-se pensativo em uma estação de trem. SP - Enfermidade

5. Pássaros voam para longe de um grande quadro de $\mathrm{SP}$ - Mediunidade um barco. Uxbal anda pela rua em direção a uma igreja onde acontece um velório. Uxbal entra e passa 
por várias pessoas até chegar aos caixões com os corpos de garotos. Ele vê o espírito de um dos meninos e reza. Ao sair, Uxbal fala sobre a conversa que teve com um dos meninos com os pais do mesmo, que discutem com ele.

6. Uxbal está em um restaurante oriental e conversa LN - Trabalho C com o barman. Ele sai e anda pela rua, em direção a uma pequena loja asiática. Lá, busca seus filhos com a babá chinesa, Lili.

7. Uxbal cozinha peixe e os filhos reclamam que o

$$
\text { LN - Família }
$$
prato é sempre esse. Uxbal começa a brincar com os filhos de imaginar que a comida que têm é a que desejam. Uxbal briga erroneamente com Mateo e o manda ir para o quarto.

8. Uxbal acorda durante a noite e vê uma bruxa pousada no teto.

SP - Enfermidade

Uxbal vê Mateo, que diz que fez xixi na cama, $\quad$ LN - Família passando. Uxbal abraça o filho.

9. De manhã, Uxbal vê um mendigo na frente de sua $\quad \mathrm{SP}$ - Enfermidade casa, enquanto urina.

10. Uxbal deixa seus filhos na escola e

LN - Família

conversa com um africano na frente da escola. $\quad$ LN - Trabalho A

11. Tito acorda e fala no celular com seu irmão Uxbal e LN - Família pede a Marambra para abaixar a música que está tocando. Marambra aumenta, volta, sobe na cama e dança em cima de Tito, fumando e bebendo. Tito tenta beijá-la com força, mas ela não deixa, lhe dá dois tapas e vai embora.

12. Pessoas compram produtos na rua na frente de LN - Trabalho A grandes lojas. Uxbal conversa com um dos vendedores africanos, Ekweme. A polícia passa por perto e o vendedor manda os outros irem embora e eles vão. Ele diz que quer mostrar algo a Uxbal.

13. Na casa de Ekweme, discute com Uxbal acerca dos LN - Trabalho A negócios ilegais e fala que não vão bem. Ige, esposa de Ekweme tenta fazer seu filho dormir.

14. Hai reclama do trabalho de um dos vários chineses $\mathrm{LN}$ - Trabalho C ilegais fabricando produtos falsos. Uxbal, Hai e Liwei discutem os negócios dos empregados imigrantes e a má qualidade dos produtos. 
Hai entrega dinheiro para Uxbal subornar a polícia

SP - Corrupção para evitar que ela se meta nos negócios criminosos deles.

15. Hai lava as mãos, Liwei chega, eles conversam e SP - Caso Hai/Liwei trocam carícias.

16. Uxbal discute com o policial Zanc sobre a área de SP - Corrupção venda dos produtos ilegais e condições do acordo. Uxbal passa o dinheiro para Zanc.

17. Uxbal toca campainha, ninguém atende. Ele se LN - Família afasta, tira e conta dinheiro do bolso e vai embora.

18. Uxbal chega em casa e Ana está lavando a casa LN - Família enquanto Marambra cozinha. Ele se irrita com a forma como Marambra organizou suas camisas. Os dois e os filhos almoçam e conversam à mesa. Uxbal e Marambra discutem e ele a manda embora. Ela sai e ele vai atrás dela. Na rua eles discutem mais e ela lhe pede dinheiro e ele dá.

19. Uxbal faz um exame de ressonância magnética. Ele SP - Enfermidade aguarda o resultado do exame. Ele descobre que está com câncer e que está em um estágio avançado e que tem no máximo dois meses de vida.

\section{MONTAGEM DE PLANOS}

20. Uxbal pensa em um ônibus.

SP - Enfermidade

Uxbal busca os filhos na "creche" de Lili.

LN - Família

Uxbal fuma com frio na cobertura de seu bloco.

SP - Enfermidade

Uxbal, deitado em sua cama, vê um grupo de bruxas pousadas no seu teto.

21. Uxbal responde a uma charada de Mateo. Ana lhe

LN - Família pergunta como se escreve 'beautiful', e Uxbal diz que se escreve 'biutiful', origem do nome do filme.

22. Uxbal deixa filhos na escola.

LN - Família

23. Em uma praça grande da Barcelona, imigrantes LN - Trabalho A vendem produtos falsificados e Uxbal passa por perto. A polícia começa uma perseguição aos imigrantes, prendendo e agredindo-os. Uxbal vê policiais prendendo Ekweme e esses o agridem, e ele urina nas calças. SP - Enfermidade 
24. Na delegacia, Uxbal sai de sua cela e

conversa com Marambra no telefone. $\quad$ LN - Família

25. No quarto de Liwei, ele e Hai, após terem transado, SP - Caso Hai/Liwei conversam sobre negócios com os empregados imigrantes. Hai diz que vai pra casa e sai.

26. Tito busca Uxbal na delegacia. No carro eles LN - Família conversam sobre a herança do pai, sobre o trabalho dos imigrantes em uma obra e sobre Marambra.

27. No banheiro, Uxbal se despe e toma banho. $\mathrm{SP}$ - Enfermidade

28. Na rua, Uxbal encontra com o pai do garoto morto SP - Mediunidade com cujo espírito conversou no início do filme. Ele diz ao pai que o filho estava em paz e só estava assustado. O pai da algum dinheiro a Uxbal.

29. Uxbal toca a campainha da casa de Marambra e ela LN - Família abre. Uxbal vê as crianças dormindo em um quarto e fotos antigas dos quatro juntos em família. Marambra tenta convencê-lo de viverem juntos novamente mas ele desconversa falando da condição mental dela. Marambra o beija e tenta seduzi-lo, mas ele recusa. Eles relembram o passado juntos, Uxbal se emociona e eles se abraçam.

30. Os imigrantes chineses dormem em um quarto sujo e LN - Trabalho C um capataz os acorda para irem trabalhar. Eles entram em uma van e vão para o trabalho.

31. Em uma obra, imigrantes trabalham e Uxbal e Tito $\mathrm{LN}$ - Trabalho C discutem com Mendonza as condições e custos dos trabalhadores imigrantes chineses. Eles chegam a um acordo.

32. Uxbal e seus filhos sobem escadas para o LN - Família apartamento de Marambra. No apartamento, Marambra conversa com os filhos enquanto prepara a sobremesa. Uxbal se junta a eles na mesa. Eles planejam uma viagem juntos, riem e conversam sobre o passado de Uxbal e Marambra.

33. Uxbal chega à casa de Ige e Ekweme. Ige se LN - Trabalho A aborrece e responsabiliza Uxbal pela prisão de Ekweme e outros imigrantes. Eles discutem, ele a entrega algum dinheiro e sai. 


\section{MONTAGEM DE PLANOS}

34. Uxbal faz quimioterapia.

$\mathrm{SP}$ - Enfermidade

Uxbal conta dinheiro escondido em sua meia/Uxbal

LN - Trabalho C compra aquecedores baratos em loja de eletrônicos

(TV mostra peixes levados à areia da praia 1h04min20s).

Saindo da loja, Uxbal vomita na rua.

SP - Enfermidade

35. Bea, médium mentora de Uxbal, prepara um remédio SP - Mediunidade para ele. Eles conversam sobre a morte e o que deixar para a família. Uxbal não aceita a morte e Bea diz que a morte é inevitável e que ele deve resolver tudo antes disso e lhe da duas pedras para dar a seus filhos para protegê-los.

36. Uxbal fala com a esposa de um morto sobre a SP - Mediunidade conversa que teve com seu espírito e recebe dela algum dinheiro.

37. Marambra deixa filhos na escola, apressada.

LN - Família

38. Imigrantes chineses são acordados para irem LN - Trabalho C trabalhar. Uxbal vê funcionários instalarem aquecedores no claustro dos chineses ilegais. $\mathrm{Li}$ conversa com Uxbal sobre seus filhos. Uxbal é chamado para falar com Hai. Uxbal discute com Liwei seus ganhos e a exploração dos imigrantes. Uxbal o ataca, Hai para a briga e Uxbal sai. Hai vai atrás dele e lhe dá algum dinheiro.

39. Ige visita Ekweme, que será deportado, na prisão. LN - Trabalho A Ige quer ir com seu bebê junto com Ekweme mas ele insiste que fiquem na Espanha e que Uxbal cuidará deles.

40. O policial corrupto Zanc encontra Uxbal em um bar. SP - Corrupção Eles falam sobre o triste destino dos imigrantes africanos e uma tragédia que ocorreu com um domador de tigres.

Uxbal pede ajuda com a situação da família de $\quad$ LN - Trabalho A Ekweme mas Zanc diz que não pode ajudar. $\mathrm{SP}-$ Corrupção

41. Uxbal e sua família jantam. Uxbal descansa com os LN - Família filhos na sala, mostra fotos antigas e conta a história de seu pai e sua morte. Mateo e Ana falam sobre a 
viagem que combinaram e Uxbal os manda irem

dormir.

42. Uxbal e Tito veem o caixão de seu pai ser retirado. LN - Família

43. Em um escritório, um funcionário fala com os dois

LN - Família sobre o estado do corpo e sobre a cremação. Uxbal pede para ver o corpo. No necrotério, Uxbal vê e toca o rosto de seu pai morto. Uxbal e Tito andam de carro, emocionados.

44. Hai almoça com a família. Liwei chega na casa e o SP - Caso Hai/Liwei clima do almoço fica pesado. Hai sai da mesa e vai com Liwei mais para dentro de casa.

45. Uxbal leva Ige para morar na sua casa.

LN - Arranjo

Uxbal passa mal

$\mathrm{SP}$ - Enfermidade

e Ige percebe que ele está doente.

LN - Arranjo

46. Marambra vê colchão queimado ao chegar em casa.

LN - Família Uxbal a vê na porta de casa. Eles discutem a atitude dela ao ver os filhos fumando e ao ser ofendida por Mateo. Marambra admite que bateu em Mateo. Ela tenta mudar de assunto dizendo que já comprou as passagens para viajarem os quatro e que as crianças estão empolgadas. Uxbal não entra na conversa dela e deixa claro sua insatisfação com as atitudes de sua ex-mulher.

47. Capataz entra no quarto dos imigrantes chineses para LN - Trabalho C acordá-los e os encontra mortos e um fedor no ar. Liwei chora a morte dos trabalhadores. Uxbal chega e descobre que apenas um sobreviveu, vai ao quarto e percebe que é Lili, tenta levá-la para os hospital, mas ela morre no carro.

Uxbal volta ao quarto e vê espíritos no teto do local. SP - Mediunidade

48. Uxbal diz a Marambra para viajar com os filhos sem LN-Família ele, enquanto atravessa uma ponte.

Ele vê pássaros voando no poente e tem uma $\quad$ SP - Enfermidade epifania.

49. Uxbal chora e desabafa com Bea sobre a morte dos SP - Mediunidade imigrantes. Bea diz a Uxbal que foi um acidente e que ele deve procurar os espíritos das vítimas e pedir perdão. 
50. Uxbal bate furiosamente na porta do alojamento dos

LN - Trabalho C imigrantes chineses. Ninguém abre e ele pula o muro. Ele vê por uma janela que os corpos não estão mais lá. Seu celular toca, ele não atende e se desespera.

51. Uxbal anda pelas ruas da cidade. $\mathrm{SP}$ - Enfermidade

52. Uxbal encontra Tito em uma boate LN - Família

onde dançarinas seminuas tem mamilos nas nádegas. outro

Ele tenta contar ao irmão sobre o que aconteceu, mas LN - Família ele não ouve. Tito lhe oferece álcool, apresenta amigos e mulheres.

Uxbal cheira cocaína e conversa com uma garota da mesa.

53. Uxbal chega em casa embriagado, se despe no LN - Família banheiro, come um resto de comida num pote e vê um desenho de Ana colado na geladeira. Ao entrar, Uxbal vê Mateo sozinho no quarto, que fala que sua mãe o castigou não o levando na viagem. Uxbal vê um hematoma em seu rosto e chora.

54. Marambra tenta se explicar a Uxbal pelo que fez LN - Família com Mateo. Ela se desespera e o xinga. Uxbal se prepara para ir embora com os meninos e vê Marambra segurando Mateo. Uxbal o separa dela à força e sai com os filhos.

55. Ige, seu filho, Mateo e Ana jantam. Uxbal se junta à LN - Arranjo mesa e eles conversam.

56. De noite, Uxbal e os filhos têm dificuldade de dormir devido ao choro do bebê de Ige. Uxbal vê várias bruxas pousadas em seu teto.

57. Os corpos dos chineses mortos aparecem na areia da LN - Trabalho C praia.

58. Uxbal anda pela casa e pergunta pelos filhos. Ige diz LN - Arranjo que já é tarde e os levou à escola. O telefone toca e Uxbal atende.

59. A polícia invade a casa de Hai, aborda sua família LN - Trabalho C violentamente e os prende.

60. Hai fala com Uxbal dentro do carro que Liwei o LN - Trabalho C traiu. Hai diz a Uxbal que ele tem culpa e que 
precisa resolver a situação e silenciar qualquer um que saiba do que aconteceu e lhe dá algum dinheiro.

61. Na TV de Tito passam notícias sobre os corpos na $\quad$ LN - Trabalho C praia, enquanto este fala no telefone.

A campainha toca, é Uxbal, que vê a bolsa de LN - Família Marambra e se irrita, entra e vê a ex na cama de Tito. Uxbal agride o irmão e o ameaça de morte. Ele entra e conversa com Marambra, que está em péssimo estado e ambos lamentam. Uxbal relembra uma imagem de Marambra fumando.

\section{MONTAGEM DE PLANOS}

62. rotina e aproximação de Uxbal e seus filhos com Ige LN - Arranjo e seu filho, Samuel./Ige busca Mateo e Ana na escola. Eles andam separados na rua, mas se juntam./Uxbal guarda dinheiro em estojo. /Ige tira curativo de Mateo e Ana brinca com Samuel. /Uxbal toma remédio no banheiro e se despe, usando fralda geriátrica./ Ige abre janela no quarto de Uxbal (mostrado duas vezes) e o da café da manhã.

63. Uxbal fala com seus filhos sobre o estado de LN - Família Marambra na clínica.

Mateo vai à cozinha e ele e Ige voltam com um bolo LN - Arranjo de aniversário e todos cantam parabéns para Ana. Uxbal dá aos filhos as pedras que Bea o deu e os pede para guardá-las. Ana percebe que há algo estranho.

64. Ige aplica injeção em Uxbal, que a diz que pode ficar LN - Arranjo em sua casa, e que seus filhos gostam muito dela. Ela diz que vai voltar pra casa, mas ele insiste que ela fique, mostra dinheiro, pede que pegue o dinheiro e fique lá com as crianças.

65. Uxbal urina no banheiro, sentindo dor. A urina $\mathrm{SP}$ - Enfermidade contem sangue.

Ana entra e pergunta o que está acontecendo. Uxbal LN - Família percebe que Ana sabe que ele vai morrer, a pede para não esquecê-lo e a abraça.

66. Hai sai de um quarto, e o corpo de Liwei SP - Caso Hai/Liwei ensanguentado é mostrado em cima da cama. 
67. Ige pega o dinheiro que Uxbal the deu e o guarda em LN - Arranjo sua bolsa. Ela deixa Mateo na escola e vai até uma estação de trem.

68. Uxbal aplica em si mesmo uma injeção, no banheiro. SP - Enfermidade

Ele ouve Ige chegando em casa, $\mathrm{LN}$ - Arranjo

vê seu próprio espírito no espelho e outro de chinês SP - Mediunidade no teto. Ele coloca um anel e se deita ao lado de Ana, que acorda. Ele vê seu teto sem insetos. Ele e Ana conversam e ele dá seu anel a ela. Seu espírito aparece no espelho e vai para outra dimensão.

69. Em uma floresta cheia de neve, Uxbal encontra seu SP - Mediunidade pai, porém mais novo do que ele. Eles conversam, brincam e riem, acendem cigarros e o pai de Uxbal se afasta e vai embora. Uxbal o segue.

\section{DEDICATÓRIA}

\section{CRÉDITOS FINAIS}




\section{ANEXO}

FICHA TÉCNICA DOS FILMES ANALISADOS 


\section{AMORES BRUTOS (AMORES PERROS, 2000)}

Cor, 154 min. México

Produção: Zeta Film, Alta Vista Films

Produtor: Alejandro Gonzáles Iñárritu

Produtores associados: Raúl Olvera Ferrer, Guillermo Arriaga, Pelayo Gutiérrez, Mónica Lozano Serrano.

Produtores executivos: Martha Sosa Elizondo, Francisco González Compeán

Roteiro: Guillermo Arriaga

Diretor de fotografia: Rodrigo Prieto

Montagem: Alejandro González Iñárritu

Música: Gustavo Santaolalla

Direção de arte: Melo Melo Hinojosa

Decoradora de set: Julieta Álvarez

Designer de produção: Gabriela Diaque

Maquiagem: David Gameros, Marco Rosado

Som: Antonio Diego

Designer de som: Martín Hernández

Elenco: Emilio Echevarría (El Chivo), Gael Garcia Bernal (Octavio), Goya Toledo (Valeria), Álvaro Guerrero (Daniel), Vanessa Bauche (Susana), Jorge Salinas (Luis), Marco Péres (Ramiro), Rodrigo Murray (Gustavo), Humberto Busto (Jorge), Geraldo Campbell (Mauricio), Adriana Barraza (Laura Almeda (Julieta), Ricardo Dalmacci (Andrés Salgado), Gustavo Sánches Parra (Jarocho). 


\section{GRAMAS (21 GRAMS, 2003)}

Cor, 124 min. Estados Unidos, Alemanha

Produção: This Is That, Y Productions, Mediana Productions

Produtores: Alejandro González Iñárritu e Robert Salerno

Produtor associado: Guilhermo Arriaga

Produtor Executivo: Ted Hope

Roteiro: Guilherme Arriaga

Diretor de Fotografia: Rodrigo Prieto

Eidtor: Stephen Mirrione

Música: Gustavo Santaolalla

Diretor de arte: Deborah Riley

Designer de produção: Brigitte Broch

Designer de som: Martín Hernández, Roland Thai

Editores de som: Sergio Díaz, Michael Hertlein, Michael Mullane, Robert Getty

Elenco: Sean Penn (Paul Rivers), Namori Watts (Cristina Peck), Danny Juston

(Michael), Carly Nahon (Katie), Claire Pakis (Laura), Benício Del Toro (Jack

Jordan), Charlotte Gainsbourg (Mary Rivers), Eddie Marsan (Reverend John),

Melissa Leo (Marianne Jordan), Marc Thomas Musso (Freddy), Teresa Delgado

(Gina), Clea DuVall (Claudia), Jerry Chipman (pai de Cristina). 


\section{BABEL (2006)}

Cor, 143min. Estados Unidos, México, França

Produção: Anonymous Content, Zeta Filme, Central Filmes

Produtores: Alejandro González Iñárritu, Jon Kilik, Steve Golin

Coprodutor: Ann Ruark

Produtor associado: Corinne Golden Weber

Roteiro: Guillermo Arriaga

Diretor de fotografia: Rodrigo Prieto

Editores: Stephen Mirrione, Douglas Crise

Música: Gustavo Santaolalla

Diretores de arte: Claudia Vásquez Lostau (México), Rio Sujimoto (Japão)

Designer de produção: Brigitte Broch

Designer de som: Martín Hernãndez

Elenco: Brad Pitt (Richard Jones), Cate Blanchett (Susan), Mohamed Akhzam (Anwar), Sfia Ait Benboullah (avó de Anwar), Boubker Ait El Caid (Yussef), Said Tarchani (Ahmed), Mustapha Rachidi (Abdullah), Abdelkader Bara (Hassan), Adriana Barraza (Amelia), Elle Fanning (Debbie Jones), Nathan Gamble (Mike Jones), Gael García Benal (Santiago), Robert 'Bernie’ Esquivel (Luis), Rinko Kikuchi (Chieko Wataya), Kôji Yakusho (Yasujiro Wataya), Satoshi Nikaido (Detetive Kenji Mamiya). 


\section{BIUTIFUL (2010)}

Cor. Espanha, México

Produção: Cha Cha Cha, Focus Features, Mod Producciones, Universal Pictures

Produtores: Fernando Bovaira, Alfonso Cuarón, Alejandro González Iñárritu,

Guillermo del Toro

Roteiro: Alejandro González Iñárritu, Armando Bo, Nicolás Giacobone

Diretor de fotografia: Rodrigo Prieto

Editor: Stephen Mirrione

Música: Gustavo Santaolalla

Diretor de Arte: Marina Pozanco

Designer de produção: Brigitte Broch

Som: José Antonio Gárcía

Designer de som: Martín Hernãndez

Elenco: Javier Bardem (Uxbal), Blanca Portilho, Rubén Ochandiano, Eduard

Fernández, Ana Wagener, Maricel Álvarez, Jesús Puchol, Diana Aymerich 